ISSN 2082-064X

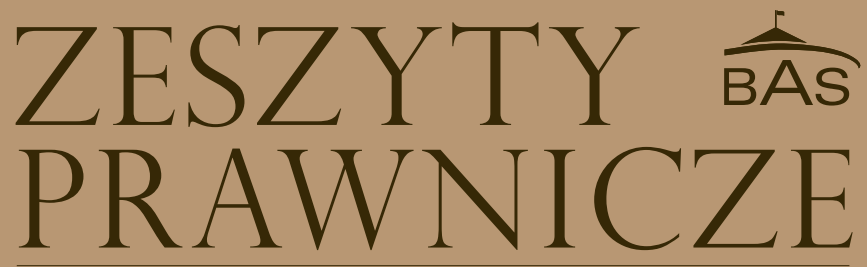

Biura Analiz Sejmowych Kancelarii Sejmu

Zielone finanse publiczne

Międzynarodowa harmonizacja prawa prywatnego

Możliwości łączenia mandatu posła z innymi funkcjami 


\section{ZESZYTY \\ PRAWNICZE}

BIURA ANALIZ SEJMOWYCH

ROK XVII • 1(62) • 2020

KANCELARIA SEJMU 


\section{Rada programowa}

dr Ziemowit Cieślik, Uniwersytet Kardynała Stefana Wyszyńskiego w Warszawie - przewodniczący - dr Piotr Czarny, Uniwersytet Jagielloński w Krakowie - prof. zw. dr hab. Cezary Mik, Uniwersytet Kardynała Stefana Wyszyńskiego w Warszawie - drhab. Adam Szafrański, Uniwersytet Warszawski - prof.zw. dr hab. Andrzej Szmyt, Uniwersytet Gdański - prof.zw. dr hab. Marek Szydło, Uniwersytet Wrocławski

\section{Zespół redakcyjny}

dr Przemysław Sobolewski, Uniwersytet Warszawski - redaktor naczelny - dr Wojciech Arndt, Akademia Ignatianum w Krakowie - dr Piotr Chybalski, Uniwersytet Kardynała Stefana Wyszyńskiego w Warszawie • dr Ewelina Gierach, Uniwersytet Kardynała Stefana Wyszyńskiego w Warszawie - dr hab. Robert Jastrzębski, prof. UW, Uniwersytet Warszawski - dr Adam Karczmarek, Uniwersytet Kardynała Stefana Wyszyńskiego w Warszawie - dr Krzysztof Kozłowski, Uniwersytet Jagielloński w Krakowie - Bartosz Pawłowski, Biuro Analiz Sejmowych Kancelarii Sejmu RP, Warszawa - dr hab. Jadwiga Potrzeszcz, prof. KUL, Katolicki Uniwersytet Lubelski im. Jana Pawła II w Lublinie - dr Zofia Szpringer, Biuro Analiz Sejmowych Kancelarii Sejmu RP, Warszawa - drhab. Michał Warciński, Uniwersytet Warszawski - Marta Kopeć - sekretarz redakcji

\section{Redakcja tematyczna}

dr Ewelina Gierach - prawo konstytucyjne - dr Adam Karczmarek - prawo administracyjne - dr Przemysław Sobolewski - prawo cywilne i handlowe - dr Zofia Szpringer - prawo finansowe

\section{Redakcja językowa i korekta}

Teresa Muś

\section{Skład}

Janusz Świnarski

\section{Fotografia na okładce}

„Sprawiedliwość" - płaskorzeźba Aleksandra Żurakowskiego w Sali Posiedzeń Sejmu, fot. Mariusz Wideryński

\section{Kontakt z redakcja}

e-mail: marta.kopec@sejm.gov.p

Biuro Analiz Sejmowych Kancelarii Sejmu

00-441 Warszawa, ul. Zagórna 3

tel. (+48 22) 6941845

faks (+48 22) 6941865

e-mail: punkt_konsultacyjny@sejm.gov.pl

e-mail:wydawnictwa_BAS@sejm.gov.pl

(C) Copyright by Kancelaria Sejmu

Warszawa 2020

Wszelkie prawa zastrzeżone. Żadna część ani całość opracowania nie może być bez zgody wydawcy Kancelarii Sejmu - reprodukowana, użyta do innej publikacji oraz przechowywana w jakiejkolwiek bazie danych.

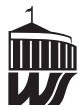

Wydawnictwo Sejmowe 


\section{SPIS TREŚCI}

1 ARTYKUŁY

Sebastian Skuza, Anna Modzelewska

Zielone finanse publiczne w Polsce. Stan obecny i autorskie propozycje zmian .

Alexander Martin Juranek

Międzynarodowa harmonizacja prawa prywatnego na przykładzie wybranych aktów modelowego prawa umów w zakresie regulacji kary umownej $\ldots \ldots$.

\section{OPINIE BAS}

A ZAGADNIENIA PRAWA KONSTYTUCYJNEGO

Piotr Chybalski

Kontynuowanie przez Komisję do Spraw Petycji postępowań w sprawie petycji, które zostały wszczęte w poprzedniej kadencji . . . . . . . . . . . . . .

Wojciech Odrowąż-Sypniewski

Szczegółowe rozpatrywanie projektu ustawy przez komisję (tryb modyfikacji tekstu rozpatrywanego projektu) $\ldots \ldots \ldots \ldots \ldots \ldots$

Piotr Czarny

Interpretacja art. 15 ust. 1 regulaminu Sejmu . . . . . . . . . . . . .

B ZAGADNIENIA PRAWA MIĘDZYNARODOWEGO I EUROPEJSKIEGO

\section{Marek Jaśkowski}

Analiza opracowania pt. „Polowania na ptaki. Zgodność z prawem międzynarodowym, unijnym i krajowym. Aspekt ochrony przyrody i humanitarno-prawny"

Marcin Fryźlewicz

Prawo do odprawy przejściowej przysługujące posłowi do Parlamentu Europejskiego po wygaśnięciu tego mandatu w przypadku objęcia mandatu posła na Sejm . .

C OPINIE LEGISLACYJNE

\section{Rafał Dubowski}

Ocena petycji w sprawie zniesienia instytucji ubezwłasnowolnienia . . . . . . .

Jolanta Waszczuk-Napiórkowska

Ocena petycji w sprawie zmiany ustawy o bezpieczeństwie żywności i żywienia

Beata Bińkowska-Artowicz

Ocena rządowego projektu ustawy o zmianie ustawy o Państwowej Inspekcji Sanitarnej . . . . . . . . . . . . . . . . . . . . . .

Magdalena Szczepańska

Ocena poselskiego projektu nowelizacji ustawy o emeryturach i rentach z Funduszu Ubezpieczeń Społecznych . . . . . . . . . . . . . . . . . . . . .

Robert Jastrzębski

Ocena projektu nowelizacji ustaw: o stosunku Państwa do Muzułmańskiego Związku Religijnego w RP oraz o stosunku Państwa do Karaimskiego Związku Religijnego $\mathrm{w} R \mathrm{RP} \ldots \ldots \ldots \ldots \ldots \ldots \ldots$ 


\section{Henryk Dzwonkowski}

Ocena skutków regulacji zawartych w poselskim projekcie ustawy Karta Praw Podatnika . . . . . . . . . . . . . . . . . . . . . .

Jacek Kulicki

Ocena zasad opodatkowania podatkiem od nieruchomości gruntów, budynków i budowli należących do spółdzielni mieszkaniowej $\ldots \ldots \ldots \ldots \ldots$

D WSPÓłPRACA MIĘDZYNARODOWA KANCELARII SEJMU

\section{Pawel Bachmat}

Wykonywanie pracy przez skazanego . . . . . . . . . . .

E SPRAWY POSELSKIE

Agnieszka Tomaszewska

Ocena możliwości łączenia mandatu posła ze statusem komandytariusza w spółce komandytowej . . . . . . . . . . . . . . . . . . . . . . .

Joanna M. Karolczak

Ocena możliwości łączenia mandatu posła z funkcją inkasenta podatkowego . .

Irena Galińska-Rączy

Ocena możliwości łączenia mandatu posła z funkcją dyrektora SP ZOZ Sanatorium Uzdrowiskowego MSWiA . . . . . . . . . . . . . . . . . . . .

Adam Karczmarek, Paweł Kościelny

Ocena możliwości łączenia mandatu posła $\mathrm{z}$ zatrudnieniem na stanowisku dyrektora Centrum Kultury i Bibliotek . . . . . . . . . . . . . . . .

F VARIA

\section{Ewelina Gierach}

Interpelacje i zapytania radnych $\ldots \ldots \ldots \ldots \ldots \ldots \ldots$

\section{Kamila Groszkowska}

Skład osobowy komisji rewizyjnej w sejmiku województwa, radzie powiatu i radzie gminy oraz konflikt interesów w samorządzie terytorialnym . . . . . . . . .

Małgorzata Bajor-Stachańczyk

Możliwość wyboru metody ustalania opłaty za gospodarowanie odpadami ko-

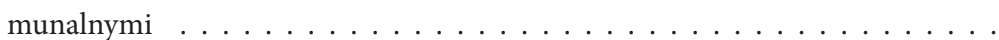

\section{STANOWISKA SEJMU W SPRAWACH} PRZED TRYBUNAŁEM KONSTYTUCYJNYM

\section{Dorota Lis-Staranowicz}

Ocena zgodności z Konstytucją przepisów ustawy - Kodeks cywilny (problem retroaktywności uchwał) $\ldots \ldots \ldots \ldots \ldots \ldots \ldots$

\section{Karol Dobrzeniecki}

Ocena zgodności z Konstytucją przepisów ustawy o gospodarce nieruchomościami oraz ustawy o szczególnych zasadach przygotowania i realizacji inwestycji w zakresie dróg publicznych . . . . . . . . . . . . . . . . . . . 


\section{CONTENTS}

1 ARTICLES

Sebastian Skuza, Anna Modzelewska

Green public finance in Poland. Current situation and proposals of changes . .

Alexander Martin Juranek

International harmonisation of private law on the example of selected acts of a model contract law regarding the regulation of contractual penalty $\ldots \ldots \ldots$

2 OPINIONS OF THE BUREAU OF RESEARCH (BAS)

A CONSTITUTIONAL LAW ISSUES

Piotr Chybalski

The continuation of proceedings by the Committee on Petitions regarding petitions that were submitted in the course of a previous term . . . . . . . . . .

Wojciech Odrowąż-Sypniewski

Detailed consideration of a bill by a committee (manner of modifying the text of the bill under consideration) $\ldots \ldots \ldots \ldots \ldots \ldots \ldots$

Piotr Czarny

Interpretation of Article 15 para. 1 of the Standing Orders of the Sejm . . . . . .

B EUROPEAN AND INTERNATIONAL LAW ISSUES

Marek Jaśkowski

Analysis of the study "Bird hunting. Compliance with international, EU and national law. Aspect of nature protection as well as a humanitarian and legal aspect"

Marcin Fryźlewicz

The entitlement to transitional allowance of a Member of the European Parliament after the expiry of their term of office in the event of becoming a Deputy to the Sejm

C LEGISLATIVE OPINIONS

\section{Rafał Dubowski}

Evaluation of a petition regarding the abolition of the institution of incapacitation

Jolanta Waszczuk-Napiórkowska

Evaluation of a petition regarding the amendment of the Act on Food Safety and Nutrition . . . . . . . . . . . . . . . . . . . . . . . .

Beata Bińkowska-Artowicz

Evaluation of the governmental Bill on Amending the Act on the State Sanitary

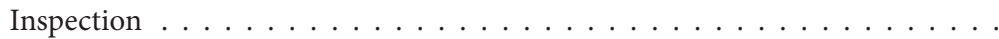

Magdalena Szczepańska

Assessment of the Deputies' Bill on Amending the Act on Pensions from the Social Insurance Fund . . . . . . . . . . . . . . . . . . . . . .

Robert Jastrzębski

Assessment of the Bill on Amending the Following Acts: on the State's Attitude Towards the Muslim Religious Union in the Republic of Poland and on the State's Attitude Towards the Karaim Religious Union in the Republic of Poland . . . . 


\section{Henryk Dzwonkowski}

Impact assessment of regulations contained in the Deputies' Bill on the Taxpayers' Rights Charter . . . . . . . . . . . . . . . .

Jacek Kulicki

Assessment of the principles of real estate tax on land, buildings and structures belonging to a housing cooperative . . . . . . . . . . .

D INTERNATIONAL COOPERATION OF THE CHANCELLERY OF THE SEJM OFFICE

\section{Paweł Bachmat}

Performance of labour by the convicted person $\ldots \ldots \ldots \ldots \ldots$

E DEPUTIES' AFFAIR

\section{Agnieszka Tomaszewska}

Assessment of the possibility of combining a Deputy's mandate with the status of a limited partner in a limited partnership $\ldots \ldots \ldots \ldots \ldots$

\section{Joanna M. Karolczak}

Assessment of the possibility of combining a Deputy's mandate with the function

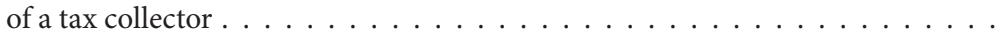

\section{Irena Galińska-Rączy}

Assessment of the possibility of combining the mandate of a Deputy with the function of a director of the SP ZOZ Sanatorium of the Ministry of the Internal Affairs and Administration . . . . . . . . . . . . . . . . .

Adam Karczmarek, Paweł Kościelny

Assessment of the possibility of combining the mandate of a Deputy with employment as the director of the Centre for Culture and Libraries . . . . . . . .

F MISCELLANEA

\section{Ewelina Gierach}

Interpellations and councillors' questions $\ldots \ldots \ldots \ldots \ldots$

\section{Kamila Groszkowska}

Composition of an audit committee in a voivodeship sejmik (regional parliament), district council and municipal council, as well as conflicts of interest in local government $\ldots \ldots \ldots \ldots \ldots \ldots \ldots \ldots$

Małgorzata Bajor-Stachańczyk

Choosing the method for determining the communal waste management fee . .

\section{THE SEJM'S POSITIONS ON CASES} BEFORE THE CONSTITUTIONAL TRIBUNAL

\section{Dorota Lis-Staranowicz}

Assessment of conformity to the Constitution of provisions of the Civil Code (issues related to the retroactivity of resolutions) $\ldots \ldots \ldots \ldots$

\section{Karol Dobrzeniecki}

Assessment of conformity to the Constitution of provisions of the Act on Real Estate Management and the Act on Specific Principles for the Preparation and Realisation of Investments Regarding Public Roads . . . . . . . . . . . . . . . 


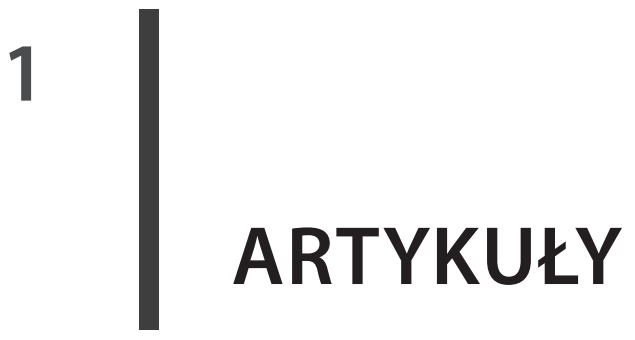



Sebastian Skuza*, Anna Modzelewska**

\title{
Zielone finanse publiczne w Polsce. Stan obecny i autorskie propozycje zmian
}

\author{
Green public finance in Poland. Current situation and proposals of changes
}

\begin{abstract}
The main aim of the article is to analyse the activities of the Polish government in the field of issuing green bonds. The authors attempted, on the basis of qualitative research (research desk, interview), to indicate the basic objectives and results of activities conducive to environmental protection, as well as to indicate the possibilities of developing financial instruments in the area of green finance.
\end{abstract}

Keywords: finances, treasury bonds, ecological investments, environmental protection

Głównym celem artykułu jest analiza działań polskiego rządu w zakresie emisji zielonych obligacji. Autorzy na podstawie badań z wykorzystaniem badań jakościowych (analiza danych zastanych, wywiad) podjęli próbę wskazania podstawowych celów i rezultatów działań sprzyjających ochronie środowiska oraz wskazania możliwości rozwoju instrumentów finansowych w obszarze zielonych finansów.

Słowa kluczowe: finanse, obligacje skarbowe, inwestycje ekologiczne, ochrona środowiska

* Doktor hab. nauk społecznych (dyscyplina: ekonomia i finanse) •

Uniwersytet Warszawski, Wydział Zarządzania, kierownik Katedry Systemów

Finansowych Gospodarki, WARSZAWA, POLSKA .

sskuza@wz.uw.edu.pl • https://orcid.org/0000-0002-9357-6791

** Doktor nauk humanistycznych (dyscyplina: nauki o zarządzaniu) •

Uniwersytet Jagielloński w Krakowie, Wydział Zarządzania i Komunikacji Społecznej,

Instytut Kultury, KRAKÓW, POLSKA •

anna.modzelewska@uj.edu.pl • https://orcid.org/0000-0003-1969-1836

\section{Wprowadzenie}

Polska jest światowym liderem w obszarze emisji tzw. zielonych obligacji rządowych. Chodzi o obligacje mające na celu finansowanie projektów korzystnie wpływających na środowisko, które były wyemitowane po raz pierwszy w grudniu 2016 r. Działania te zostały docenione na poziomie międzynarodowym, co przejawia się w decyzji Climate Bond Initiative (CBI) o przyznaniu polskiemu rządowi nagrody „Climate Bonds Award” w 2017 r. za pierwszą na świecie rządową emisję zielonych obligacji ${ }^{1}$.

1 Climate Bonds Annual Conference and Green Bond Awards, 2017, www.climatebonds.net/market/2017-awards [dostęp 17 sierpnia 2019 r.]. 
Ekologiczne zaangażowanie instytucji finansowych stanowi interdyscyplinarny przedmiot badań ${ }^{2}$ dlatego autorzy podejmują rozważania na gruncie nauk ekonomicznych, prawnych oraz nauk o zarządzaniu i jakości. Cel artykułu stanowi analiza działań polskiego rządu w zakresie emisji zielonych obligacji ze szczególnym uwzględnieniem założeń i rezultatów działań ukierunkowanych na ochronę środowiska, jak również wskazanie rozwiązań innych niż zielone obligacje umożliwiających finansowanie projektów proekologicznych.

Złożona i otwarta natura problemu badawczego wpłynęła na wybór metodologii jakościowej, posiadającej szczególne zastosowanie w eksploracji nowych zjawisk, które nie zostały wystarczająco przedstawione w literaturze przedmiotu. Podczas realizacji założonych celów poznawczych autorzy zastosowali następujące narzędzia oraz techniki badawcze: analizę danych zastanych (aktów prawnych, dokumentów Ministerstwa Finansów, literatury przedmiotu) oraz wywiad częściowo strukturyzowany przeprowadzony z Robertem Zimą, dyrektorem Departamentu Długu Publicznego w Ministerstwie Finansów. Dobór rozmówcy wynikał z faktu jego zaangażowania merytorycznego we wszystkie dotychczasowe emisje rządowych zielonych obligacji. Zgromadzony przez autorów materiał empiryczny został skonfrontowany z literaturą przedmiotu i obowiązującymi przepisami prawa.

\section{Zielone obligacje jako przedmiot badań}

Społeczna odpowiedzialność biznesu (Corporate Social Responsibility, CSR) stanowi ważną determinantę budowania strategii współczesnych organizacji, wdrażaną powszechnie przez organizacje różnej wielkości oraz obszernie opisywaną w literaturze ${ }^{3}$. Trend ten dotyczy również rynku finansowego, przejawiając się w emisji dłużnych papierów wartościowych, których celem jest zgromadzenie kapitału stanowiącego podstawę do pożyczkowego finansowania projektów proekologicznych. Jak zauważa Leszek Dziawgo, kryteria ekologiczne nabierają coraz większego znaczenia, stając się jednym z kluczowych wskaźników efektywności (obok wskaźników takich jak: przychód, koszt, zysk, bezpieczeństwo, płynność), tym sam wskazują na stale postępujący proces ekologicznej ewolucji rynku finansowego ${ }^{4}$. Zainteresowanie zielonymi obligacjami jest charakterystyczne zarówno dla sektora prywatnego, jak też publicznych uczestników rynku,

2 L. Dziawgo, Zielony rynek finansowy. Ekologiczna ewolucja rynku finansowego, Polskie Wydawnictwo Ekonomiczne, Warszawa 2010, s. 11.

3 P. Jedynak, CSR practices and competetiveness of the company in B2B market [w:] Competition and cooperation in the management theory and practice, red. P. Jedynak, Jagiellonian University Press, Kraków 2014, s. 11.

4 L. Dziawgo, Zielony rynek finansowy, op. cit., s. 9, s. 186. 
co wyraźnie wskazuje na istotne znaczenie kwestii ekologii ${ }^{5}$ Kryteria etyczne, społeczne i ekologiczne zyskują na znaczeniu w procesie alokacji kapitału i zarządzania portfelem inwestycji, co wpisuje się także w impact investment wywodzący się z koncepcji społecznie odpowiedzialnego inwestowania ${ }^{6}$.

Zielone obligacje są elementem szerszego obszaru zielonych finansów lub zielonych inwestycji, które to pojęcia w literaturze często stosuje się zamiennie ${ }^{7}$. Obejmują one wszystkie instrumenty rynkowe zaprojektowane w celu zapewnienia odpowiedniej jakości środowiska ${ }^{8}$, tworząc nowy model finansowy, który służy integracji ochrony środowiska z zyskami ekonomicznymi ${ }^{9}$. Zielone finanse obejmują ${ }^{10}$ :

- finansowanie publicznych i prywatnych zielonych inwestycji (w tym również koszty przygotowawcze), w tym towary i usługi środowiskowe (np. gospodarka wodna lub ochrona różnorodności biologicznej i krajobrazów),

- zapobieganie, minimalizacja i rekompensata szkód dla środowiska i klimatu (np. efektywność energetyczna lub zapory),

- finansowanie polityk publicznych (w tym koszty operacyjne), które zachęcają do wdrażania projektów i inicjatyw na rzecz łagodzenia szkód w środowisku lub dostosowywania się do nich (np. wprowadzenie taryf gwarantowanych na energię odnawialną),

- komponenty systemu finansowego, które dotyczą konkretnie zielonych inwestycji (np. zielone obligacje i zielone fundusze), w tym ich szczególne uwarunkowania prawne, ekonomiczne i instytucjonalne.

Motywacje do realizacji zielonych inwestycji mogą być różnorodne, w literaturze najczęściej wskazuje się cztery podstawowe typologie ${ }^{11}$ :

5 M.C. Voica, M. Panait, I. Radulescu, Green Investments - Between Necessity, Fiscal Constraints and Profit, „Procedia Economics and Finance” 2015, No 22, s. 72-79; M. Wiśniewski, J. Zieliński, Perspektywy finansowania zadań samorządu terytorialnego $w$ Polsce za pomoca obligacji zielonych, „INFOS. Zagadnienia Społeczno-gospodarcze” 2017, nr 15(238), s. 4.

6 W. Krawiec, Impact investment - istota i otoczenie rynku, „Annales Universitatis Mariae Curie-Skłodowska. Sectio H - Oeconomia” 2015, nr 4, s. 280.

7 S. Zadek, C. Flynn, South-Originating Green Finance: Exploring the Potential, UNEP Finance Initiative, Geneva 2013, s. 7.

$8 \quad$ S. Dörry, C. Schulz, Green financing, interrupted. Potential directions for sustainable finance in Luxembourg, "Journal Local Environment: The International Journal of Justice and Sustainability" 2018, No 7 (23), s. 718.

9 Y. Wang, Q. Zhi, The Role of Green Finance in Environmental Protection: Two Aspects of Market Mechanism and Policies, „Energy Procedia” 2016, No 104, s. 311.

10 N. Lindenberg, Definition of Green Finance, German Development Institute, Deutsches Institut für Entwicklungspolitik, Bonn 2014, s. 1-4.

11 M.C. Voica, M. Panait, I. Radulescu, Green Investments, op. cit., s. 73. 
- względy finansowe - zwrot, ryzyko, dywersyfikacja, długoterminowe uwzględnianie ryzyka, internalizacja efektów zewnętrznych,

- kwestie pozafinansowe - ekologiczne, naukowe, religijne, etyczne, polityczne,

- reputacja - reputacja inwestora, reputacja firmy, narzędzie marketingowe, presja ze strony mediów,

- zgodność i obowiązek powierniczy - prawo i regulacje krajowe, konwencje międzynarodowe.

Po raz pierwszy zielone obligacje zostały wprowadzone na rynek w $2007 \mathrm{r}$. i 2008 r. przez międzynarodowe instytucje finansowe, takie jak Europejski Bank Inwestycyjny oraz Bank Światowy, których sukces wykazał zainteresowanie inwestorów inwestycjami związanymi z łagodzeniem zmian klimatycznych oraz wsparciem dostosowania się do skutków tych zmian ${ }^{12}$. Publikacji krajowych dotyczących problematyki zielonych obligacji rządowych jest jednak niewiele. Wśród najważniejszych należy wskazać te prezentujące podstawowe cele, założenia i strukturę emisji zielonych obligacji rządowych ${ }^{13}$ oraz będące próbą opisu i oceny rentowności tych instrumentów w porównaniu z klasycznymi obligacjami o parametrach podobnych do zielonych obligacji emitowanych przez państwo polskie na rynkach zagranicznych ${ }^{14}$. Pozostałe publikacje z zakresu zielonych obligacji dotyczą struktury oraz tendencji na globalnym rynku obligacji klimatycznych ${ }^{15}$, rozwoju zielonych obligacji i idei zrównoważonego rozwoju ${ }^{16}$, identyfikacji czynników determinujących rozwój rynku zielonych obligacji w kontekście globalnego rynku długu ${ }^{17}$,

12 H. Reichelt, Green bonds: a model to mobilise private capital to fund climate change mitigation and adaptation projects [w:] The Euromoney Environmental Finance Handbook, World Bank, Washington 2010, s. 2-3.

13 M. Pawłowski, Zielone obligacje rządowe, „Ekonomiczne Problemy Usług” 2017, nr 4 (129), s. 219-227.

14 M. Mosionek-Schweda, M. Szmelter, Zielone obligacje - nowy instrument finansowania inwestycji polskiego rzadu, „Prace Naukowe Uniwersytetu Ekonomicznego we Wrocławiu" 2018, nr 532, s. 215-224.

15 J. Marszałek, K. Daszyńska-Żygadło, Charakterystyka globalnego rynku obligacji klimatycznych, „Finanse, Rynki Finansowe, Ubezpieczenia” 2016, nr 4, cz. 1, s. 945-955; M. Więckowska, Stan i perspektywy rozwoju rynku obligacji klimatycznych, „Zeszyty Naukowe Uniwersytetu Szczecińskiego. Finanse, Rynki Finansowe, Ubezpieczenia” 2013, nr 62, s. 455-465.

16 K. Brzozowska, Idea zrównoważonego rozwoju na rynku obligacji, „Prace Naukowe Uniwersytetu Ekonomicznego we Wrocławiu” 2017, nr 478, s. 70-80; J. Kłobukowska, Społecznie odpowiedzialne inwestowanie jako innowacja na rynku finansowym $w$ Polsce $w$ dobie finansjalizacji - stan obecny i perspektywy, „Folia Oeconomica. Acta Universitatis Lodziensis" 2018, nr 6 (339), s. 111-124.

17 A. Laskowska, The Green bond as a prospective instrument of the global debt market, "Copernican Journal of Finance \& Accounting” 2017, No 6(4), s. 69-83. 
zmian zachodzących na rynku zielonych obligacji ${ }^{18}$, perspektyw finansowania zadań samorządu terytorialnego w Polsce z wykorzystaniem instrumentu zielonych obligacji ${ }^{19}$, analizy potencjału rynku zielonych obligacji oraz najlepszych praktyk, które można wdrożyć w krajach Unii Europejskiej w celu wykorzystania potencjału rosnącego rynku zielonych obligacji ${ }^{20}$, wpływu preferencji proekologicznych na ceny obligacji ${ }^{21}$, analizy wpływu zielonych obligacji na wzrost wartości firmy i korzyści dla akcjonariuszy ${ }^{22}$.

Analiza literatury wykazuje niejednoznaczność w zdefiniowaniu terminu zielone obligacje. Najczęściej instrumenty te są przedstawiane jako dłużne papiery wartościowe emitowane w celu pozyskiwania kapitału do finansowania inwestycji niskoemisyjnych oraz inwestycji przyjaznych dla środowiska ${ }^{23}$. Zdaniem Roberta Zimy obecnie nie ma jednej definicji zielonych czy też klimatycznych obligacji ${ }^{24}$. Z kolei Anna Laskowska twierdzi, że zielone obligacje można zdefiniować jako papiery wartościowe o stałym dochodzie (fixed-income), wyemitowane w celu pozyskania kapitału na dalsze finansowanie lub refinansowanie przedsięwzięć przyczyniających się do poprawy stanu środowiska naturalnego ${ }^{25}$. W Unii Europejskiej trwają prace nad uporządkowaniem definicyjnym w obszarze zielonych finansów ${ }^{26}$. Obecnie bowiem pojęcia dotyczące tego zakresu są w praktyce definiowane każdorazowo przez samego emitenta. Zakres tematyczny projektów kwalifikujących się do finansowania zgodnie z ustalonymi ramami (framework)

18 A. Kuna-Marszałek, J. Marszałek, Green Bonds - Trends and Development Perspectives, „Annales Universitatis Mariae Curie-Skłodowska. Sectio H - Oeconomia” 2018, nr 4 (52), s. 39-47; M. Pawłowski, Diversification of the global green bond market, „European Journal of Service Management” 2018, nr 3(27/2), s. 331-337.

19 M. Wiśniewski, J. Zieliński, Perspektywy finansowania, op. cit., s. 1-4; M. Wiśniewski, J. Zieliński, Perspektywy finansowania zadań samorzadu terytorialnego w Polsce za pomoca obligacji zielonych, "Studia BAS” 2017, nr 4(52), s. 101-120 [Finansowanie zadań publicznych w Polsce, red. P. Russel].

20 T. Bieliński, M. Mosionek-Schweda, Green bonds as a financial instrument for environmental projects funding, „Unia Europejska.pl” 2018, nr 1(248), s. 13-21.

${ }_{21}$ O.D. Zerbib, The effect of pro-environmental preferences on bond prices: Evidence from green bonds, „Journal of Banking \& Finance” 2019, No 98, s. 39-60.

22 D.Y. Tang, Y. Zhang, Do shareholders benefit from green bonds?, „Journal of Corporate Finance" 2018, In Press, Corrected Proof, Available online, 8 December 2018.

23 E.S. Sartzetakis, Green Bonds as an instrument to finance low carbon transition, „Working Paper" Bank of Greece, Economic Analysis and Research Department - Special Studies Division 2019, No 258, s. 13-14; M. Baker, D. Bergstresser, G. Serafeim, J. Wurgler, Financing the Response to Climate Change: The Pricing and Ownership of U.S. Green Bonds, National Bureau of Economic Research, Cambridge 2018, s. 1.

24 Wywiad z R. Zimą przeprowadzony 27 sierpnia 2019 r.

25 A. Laskowska, The Green bond, op. cit., s. 69.

26 Report on EU Green Bond Standard, EU Technical Expert Group on Sustainable Finance, June 2019. 
będzie różnił się w przypadku Polski, Francji czy też Belgii. Emitenci korzystają z pewnych wytycznych (w szczególności zasad opracowanych przez International Capital Market Association), ale i tak każdy z inwestorów indywidualnie ocenia, czy dana oferta jest odpowiednia do prowadzonego przez niego portfela inwestycyjnego ${ }^{27}$. Kryteria kwalifikowalności zielonych obligacji zaproponowane przez Moody’s Green Bond Assessments opierają się na czterech elementach, które definiują instrument jako zieloną obligację, $\mathrm{tj}^{28}{ }^{28}$ :

- wykorzystanie środków pochodzących z emisji,

- zarządzanie pozyskanymi środkami,

- bieżące raportowanie,

- monitorowanie ex post.

Emisja zielonych obligacji wiąże się zarówno z korzyściami, jak i zagrożeniami dla emitenta oraz inwestora, co zostało ujęte w tabeli 1.

W literaturze funkcjonuje także termin obligacje klimatyczne, a granica między zielonymi i klimatycznymi obligacjami nie jest wyraźnie określona ${ }^{29}$. Wielu badaczy traktuje te pojęcia jako tożsame, używając ich synonimicznie ${ }^{30}$. Można przyjąć w uproszczeniu rozróżnienie, że obligacje klimatyczne mają węższy zakres znaczeniowy, oznaczając zasilenie kapitałowe projektów służących redukcji gazów cieplarnianych i adaptację gospodarki do zmian klimatycznych ${ }^{31}$. Marcin Wiśniewski i Jakub Zieliński zauważają, że nie można z góry zakładać, iż każda obligacja klimatyczna jest równocześnie zieloną obligacją, jak również, że nie wszystkie przedsięwzięcia realizowane ze środków pozyskiwanych z emisji zielonych obligacji kwalifikują je jako obligacje klimatyczne ${ }^{32}$. Przykładowo mogą być emitowane obligacje klimatyczne, z których pozyskane środki wykorzystywane są na sfinansowanie budowy murów morskich w miastach zagrożonych wzrastającym poziomem morza, nie będące instrumentami ekologicznymi, czy też do finansowania parków miejskich, co też nie jest bezpośrednio związane z zapobieganiem negatywnym skutkom zmian klimatycznych ${ }^{33}$.

Emitentów ekologicznych można podzielić na dwie grupy ze względu na uzyskiwany produkt, co zostało zaprezentowane na rysunku 1. Pierwsza grupa obejmuje podmioty niezależne od branży, jeśli się weźmie pod uwagę kryte-

27 Wywiad z R. Zimą.

28 M. Wiśniewski, J. Zieliński, Perspektywy finansowania, op. cit., s. 110.

29 M. Pawłowski, Zielone obligacje rządowe, op. cit., s. 220.

30 Zob. A. Laskowska, Polska światowym prekursorem zielonych obligacji skarbowych (Poland as the Global Precursor of Sovereign Green Bonds), „Profit Journal” 2017, nr 2(18), s. 5.

31 Zob. M. Pawłowski, Zielone obligacje rządowe, op. cit., s. 221; M. Wiśniewski, J. Zieliński, Perspektywy finansowania, op. cit., s. 111.

32 M. Wiśniewski, J. Zieliński, Perspektywy finansowania, op. cit., s. 111.

33 Ibidem. 
Tabela 1. Korzyści i zagrożenia związane z emisją obligacji zielonych z perspektywy emitenta $i$ inwestora

\begin{tabular}{|c|c|}
\hline \multicolumn{2}{|c|}{ Perspektywa emitenta } \\
\hline Korzyści & Zagrożenia \\
\hline $\begin{array}{l}\text { - zaprezentowanie i wdrożenie podejścia } \\
\text { ESG (Environment, Social i Governance - } \\
\text { środowisko, społeczeństwo, zarządzanie) } \\
\text { - dywersyfikacja bazy inwestorów } \\
\text { - zmniejszenie ryzyka zmian wahania popytu } \\
\text { na obligacje } \\
\text { - poprawa wizerunku emitenta } \\
\text { - wysoki popyt na zielone obligacje może } \\
\text { prowadzić do potencjalnego zwiększenia } \\
\text { wielkości emisji } \\
\text { - niższa zmienność cen obligacji na rynku } \\
\text { wtórnym } \\
\text { - wyartykułowanie i zwiększenie } \\
\text { wiarygodności strategii jednostki na rzecz } \\
\text { zrównoważonego rozwoju }\end{array}$ & $\begin{array}{l}\text { - ryzyko utraty reputacji przy } \\
\text { zakwestionowaniu „zieloności” } \\
\text { finansowanego projektu } \\
\text { - wysokie koszty związane z wymogami } \\
\text { certyfikacyjnymi, weryfikacyjnymi, } \\
\text { sprawozdawczymi oraz monitoringiem } \\
\text { wykorzystania środków } \\
\text { - inwestorzy mają możliwość nakładania kar } \\
\text { na emitenta w związku ze złamaniem tzw. } \\
\text { zielonych klauzul }\end{array}$ \\
\hline \multicolumn{2}{|c|}{ Perspektywa inwestora } \\
\hline Korzyści & Zagrożenia \\
\hline $\begin{array}{l}\text { - możliwość osiągnięcia zysku przy } \\
\text { jednoczesnym wspieraniu działań } \\
\text { proekologicznych } \\
\text { - poprawa wizerunku inwestora } \\
\text { (inwestowanie w zielone obligacje } \\
\text { uznane zostało przez ramową konwencję } \\
\text { Narodów Zjednoczonych w sprawie zmian } \\
\text { klimatu UNFCCC jako działanie osób } \\
\text { niepaństwowych na rzecz klimatu) } \\
\text { - możliwość wykorzystania „zielonych” } \\
\text { instrumentów do aktywnego zabezpieczania } \\
\text { się przez inwestorów przed ryzykiem polityki } \\
\text { klimatycznej } \\
\text { - poprawa oceny kredytowej „zielonych” } \\
\text { projektów wynikająca z dialogu } \\
\text { między inwestorem a emitentem i ich } \\
\text { ponadprzeciętnego zaangażowania w } \\
\text { sprawy ESG }\end{array}$ & $\begin{array}{l}\text { - brak ujednoliconych standardów może } \\
\text { skutkować ryzykiem naruszenia reputacji } \\
\text { inwestora, jeśli zakwestionowana zostanie } \\
\text { "zieloność" obligacji } \\
\text { - relatywnie niewielki rynek } \\
\text { - niska wartość emisji } \\
\text { - ograniczony zakres egzekwowania } \\
\text { uczciwości emitenta w zakresie „zielonych” } \\
\text { działań }\end{array}$ \\
\hline
\end{tabular}

Źródło: M. Wiśniewski, J. Zieliński, Perspektywy finansowania zadań samorządu terytorialnego w Polsce za pomoca obligacji zielonych, "Studia BAS" 2017, nr 4(52), s. 114 [Finansowanie zadań publicznych w Polsce, red. P. Russel]; OECD \& Bloomberg Philanthropies, Green Bonds. Mobilising the debt capital markets for a low-carbon transition. Policy perspectives, OECD Publishing, Paryż 2015, s. 1-28.

rium zachowania wysokich standardów ekologicznych w procesie produkcji lub świadczenia usług. Druga grupa to z kolei podmioty, które oprócz zachowywania wyżej wymienionych standardów oferują produkty i usługi powiązane bezpośrednio z ochroną środowiska.

Przedmiot badań w niniejszej publikacji stanowią obligacje rządowe, zatem z punktu widzenia uzyskiwanego produktu zaliczane będą do grupy pierwszej, tj. podmioty niezwiązane bezpośrednio z branżą proekologiczną. 


\section{Rysunek 1. Ekologiczni emitenci papierów wartościowych}

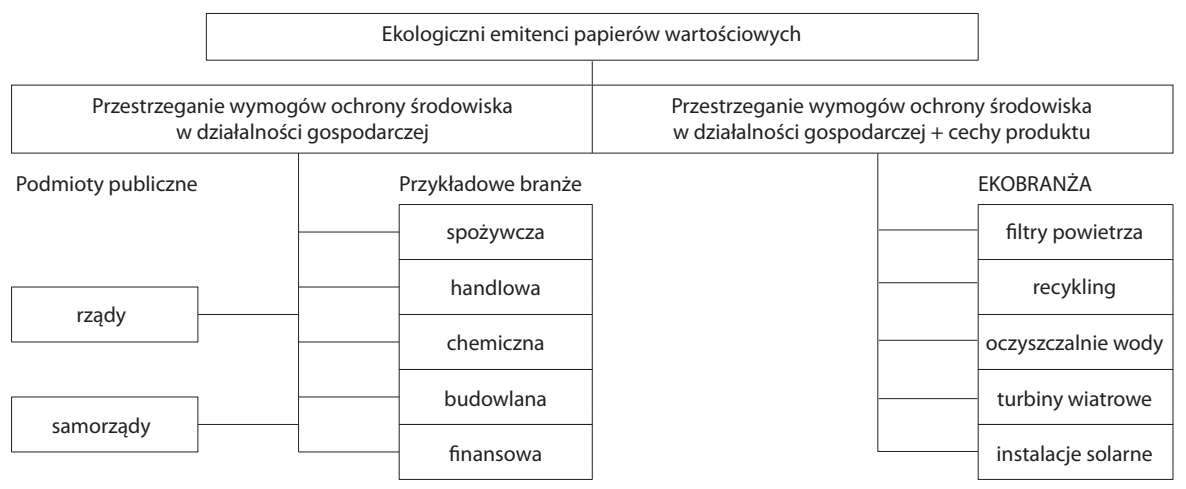

Źródło: L. Dziawgo, Zielony rynek finansowy. Ekologiczna ewolucja rynku finansowego, Polskie Wydawnictwo Ekonomiczne, Warszawa 2010, s. 45.

\section{Zielone obligacje rządowe w Polsce - wnioski z badań}

Jak już wykazano, problematyka zielonych obligacji rządowych jest wciąż wyzwaniem dla badaczy, a publikacji w tym zakresie jest niewiele. W artykule zastosowano jakościowe metody badawcze, wykorzystując techniki i narzędzia badawcze, takie jak: analiza danych zastanych (aktów prawnych, dokumentów Ministerstwa Finansów, literatury przedmiotu) oraz wywiad częściowo strukturyzowany, tj. wywiad oparty na zadawaniu opracowanych wcześniej pytań oraz pytań szczegółowych formułowanych do uzyskiwanych od interlokutora odpowiedzi. Wywiad został przeprowadzony w Ministerstwie Finansów w dniu 27 sierpnia 2019 r. Zgodnie z zasadami przeprowadzenia badań jakościowych $\mathrm{z}$ wykorzystaniem wywiadu rozmowa była nagrywana, następnie poddana transkrypcji zgodnie z zachowaniem formy i wyrażeń oryginalnej rozmowy ${ }^{34}$, jak również autoryzowana. Tak zgromadzony materiał empiryczny kodowano tradycyjnie ${ }^{35}$, zamieszczając cytaty z przeprowadzonego wywiadu, które w badaniu o charakterze jakościowym stanowią kluczowy materiał dowodowy, oddając złożoność badanej problematyki ${ }^{36}$. Wyniki badań zostały skonfrontowane z li-

34 D. Silverman, Interpretacja danych jakościowych, Wydawnictwo Naukowe PWN, Warszawa 2007, s. 250-251; T. Rapley, Analiza konwersacji, dyskursu i dokumentów, Wydawnictwo Naukowe PWN, Warszawa 2010, s. 104.

35 Zob. A. Strauss, J. Corbin, Basic of Qualitative Research, Newbury Park, CA Sage 1990, s. 61.

36 M. Kostera, Antropologia organizacji. Metodologia badań terenowych, Wydawnictwo Naukowe PWN, Warszawa 2010, s. 27; P. Krzyworzeka, Etnografia [w:] Metody badawcze w zarządzaniu humanistycznym, red. M. Kostera, Wydawnictwo Akademickie Sedno, Warszawa 2015, s. 34. 
teraturą przedmiotu i aktualnie obowiązującym stanem prawnym, na podstawie czego autorzy zaproponowali również wnioski de lege ferenda w obszarze zmian regulacji prawnych.

Przy pierwszej emisji zielonych obligacji z 2016 r. zainteresowanie inwestorów zagranicznych (91 inwestorów) oraz popyt na poziomie 1,5 mld euro pozwoliły na zwiększenie kwoty emisji do 750 mln euro z pierwotnie planowanej kwoty 500 mln euro ${ }^{37}$. Do chwili obecnej (sierpień 2019 r.) Ministerstwo Finansów dokonało trzech emisji zielonych obligacji (w tym jednej w dwóch transzach), których parametry zostały zaprezentowane w tabeli 2.

Tabela 2. Emisje zielonych obligacji rządowych w Polsce w latach 2016-2019

\begin{tabular}{|c|c|c|c|c|c|}
\hline Data emisji & $\begin{array}{c}\text { Data } \\
\text { zapadalności }\end{array}$ & Okres & $\begin{array}{c}\text { Kwota emisji } \\
\text { (w mln euro) }\end{array}$ & Kupon & Rentowność \\
\hline 20 grudnia 2016 & 20 grudnia 2021 & 5 lat & 750 & $0,500 \%$ & $0,634 \%$ \\
\hline 7 lutego 2018 & 7 sierpnia 2026 & 8 lat & 1000 & $1,125 \%$ & $1,153 \%$ \\
\hline 7 marca 2019 & 7 marca 2029 & 10 lat & 1500 & $1,000 \%$ & $1,057 \%$ \\
\hline 7 marca 2019 & 8 marca 2049 & 30 lat & 500 & $2,000 \%$ & $2,071 \%$ \\
\hline
\end{tabular}

Źródło: Ministerstwo Finansów.

Środki z wymienionych w tabeli 2 emisji mogą być przeznaczone na projekty określone w przygotowanym przez Ministerstwo Finansów Green Bond Framework ${ }^{38}$ :

1. Sektor „Energia odnawialna”:

- wytwarzanie energii ze źródeł odnawialnych (np. wiatr, energia słoneczna, pływy i biomasa),

- produkcja elementów technologii energii odnawialnej (np. turbiny wiatrowe, panele słoneczne),

- całościowa infrastruktura przesyłowa umożliwiająca dostarczanie energii ze źródeł odnawialnych do użytkowników.

2. Sektor „Bezemisyjny transport”:

- inwestycje w infrastrukturę kolejową (tabor elektryczny, linie kolejowe, przywracanie połączeń kolejowych, poprawa efektywności energetycznej systemu kolejowego),

- inwestycje związane z infrastrukturą kolejową (budowa i remonty stacji kolejowych oraz ich wyposażenia np. w automaty biletowe).

3. Sektor „Zrównoważone rolnictwo":

- wspieranie rozwoju rolnictwa ekologicznego.

37 Ministerstwo Finansów, Wycena obligacji Green Bond, https://finanse-arch.mf.gov.pl/.

38 The State Treasury of the Republic of Poland, represented by the Minister of Development and Finance Green Bond Framework 5 th December 2016, https://www.gov.pl/ web/finanse/emisje [dostęp 17 sierpnia 2019 r.]. 
4. Sektor „Zalesianie”:

- zrównoważona gospodarka leśna (zalesianie nowych obszarów, bieżące utrzymanie substancji leśnej oraz ochrona przeciwpożarowa).

5. Sektor „Parki narodowe”:

- zarządzanie parkami narodowymi (działania konserwatorskie i naprawcze, ochrona przeciwpożarowa, przywracanie równowagi przyrodniczej),

- organizacja i finansowanie działań w celu zwiększania świadomości oraz wiedzy na temat dziedzictwa narodowego.

6. Sektor „Rekultywacja gruntów”:

- rekultywacja skażonej gleby (usuwanie i rekultywacja gleby, odtwarzanie zniszczonego drzewostanu i innej roślinności).

Ustawa z 27 sierpnia 2009 r. o finansach publicznych (t.j. Dz.U. 2019, poz. 869, ze zm.; dalej: u.f.p.) zezwala na „znakowanie” środków w kilku przypadkach, np. jest to możliwe $\mathrm{w}$ odniesieniu do środków pozyskanych w ramach kredytów $\mathrm{z}$ międzynarodowych instytucji finansowych. Zgodnie z art. 42 ust. 2 u.f.p. środki publiczne pochodzące $\mathrm{z}$ poszczególnych tytułów nie mogą być przeznaczane na finansowanie imiennie wymienionych wydatków, chyba że odrębna ustawa stanowi inaczej. Powyższego ograniczenia nie stosuje się do:

- wydatków finansowanych z kredytów udzielonych przez międzynarodowe instytucje finansowe, o ile umowa tak stanowi,

- wydatków finansowanych ze środków europejskich,

- wydatków finansowanych ze środków na realizację:

a) programów w ramach celu „Europejska współpraca terytorialna”,

b) programów, o których mowa w rozporządzeniu Parlamentu Europejskiego i Rady (WE) nr 1638/2006 z 24 października 2006 r. określającym przepisy ogólne w sprawie ustanowienia Europejskiego Instrumentu Sąsiedztwa i Partnerstwa (Dz.Urz. UE L 310 z 9 listopada 2006 r., s. 1) oraz programów Europejskiego Instrumentu Sąsiedztwa,

c) Norweskiego Mechanizmu Finansowego 2004-2009,

d) Mechanizmu Finansowego Europejskiego Obszaru Gospodarczego 20042009 ,

- wydatków finansowanych $\mathrm{z}$ innych niż bezpośrednio wymienione w ustawie o finansach publicznych środków zagranicznych, niepodlegających zwrotowi,

- kosztów ponoszonych przez jednostki prowadzące działalność gospodarczą, agencje wykonawcze, instytucje gospodarki budżetowej oraz inne państwowe osoby prawne i samorządowe zakłady budżetowe.

Należy jednak zauważyć, że „znakowanie” środków początkowo nie odnosiło się do środków z emisji obligacji skarbowych. W celu przeprowadzenia emisji zielonych obligacji w 2016 r. niezbędna stała się nowelizacja zapisu ustawy o finansach publicznych. W trakcie prac sejmowych nad projektem ustawy o szcze- 
gólnych rozwiązaniach służących realizacji ustawy budżetowej na rok 2017 Klub Parlamentarny Prawa i Sprawiedliwości zgłosił podczas drugiego czytania poprawkę nowelizującą art. 84 u.f.p. Poprawka ta dotyczyła dodania do wyłączenia w wyżej wymienionym artykule reguły określonej w art. 42 ust. 2 u.f.p., rozszerzając wyłączenie z zasady braku możliwości imiennego finansowania wydatków publicznych m.in. na środki z emisji skarbowych papierów wartościowych.

Ustawa z 2 grudnia 2016 r. o szczególnych rozwiązaniach służących realizacji ustawy budżetowej na rok $2017^{39} \mathrm{w}$ art. 20 nadała art. 84 u.f.p. następujące brzmienie: Do zaciagania pożyczek i kredytów przez Skarb Państwa, emisji skarbowych papierów wartościowych oraz innych operacji zwiąanych bezpośrednio z zarządzaniem państwowym długiem publicznym nie stosuje się przepisów art. 35, art. 42 ust. 2 i art. 49, przepisów o zamówieniach publicznych oraz przepisów o grach hazardowych.

Środki pozyskane z obligacji przeznaczane są na finansowanie bądź refinansowanie „zielonych” wydatków budżetowych, tj. wydatków w obszarach zdefiniowanych w dokumencie regulującym wykorzystanie środków z tych emisji, tj. w opracowanym przez Ministerstwo Finansów Green Bond Framework.

Zielone wydatki budżetowe mogłyby zostać sfinansowane w ramach zwykłej realizacji budżetu państwa (zasada nieoznaczoności środków budżetowych i finansowanie zielonych wydatków w ramach limitu wydatków, w tym finansowania deficytu budżetowego z wykorzystaniem zwykłych obligacji budżetowych), jednak w tym wypadku zasadne jest stworzenie możliwości dedykowanego finansowania, które jednocześnie realizuje strategiczne cele zarządzania długiem, jak dalsza dywersyfikacja bazy inwestorów, oraz ma korzystny wpływ na postrzeganie kraju jako emitenta. Zielone obligacje nie są instrumentem kreującym politykę prośrodowiskową państwa, tylko środkiem finansowania działań realizowanych przez państwo ${ }^{40}$.

W obligacjach emitowanych przez jednostki samorządu terytorialnego w przeciwieństwie do obligacji skarbowych można określić wyraźny cel inwestycyjny wykorzystania środków. Standardowe obligacje skarbowe służą finansowaniu ogólnych potrzeb pożyczkowych budżetu państwa, na które składa się przede wszystkim refinansowanie zapadającego zadłużenia oraz potrzeby netto, czyli głównie deficyt budżetowy i deficyt budżetu środków europejskich, ale też np. kredyty udzielane przez Skarb Państwa. Jak zauważył R. Zima: określanie celu wykorzystania środków pozyskanych z obligacji skarbowych byłoby całkowicie nieracjonalne i niewykonalne. W odniesieniu do zielonych obligacji cele wykorzystania środków sa dokładnie określone we wspomnianym Green Bond Framework w postaci obszarów tematycznych spetniających odpowiednie kryteria ${ }^{41}$.

39 Ustawa z 2 grudnia 2016 r. o szczególnych rozwiązaniach służących realizacji ustawy budżetowej na rok 2017, Dz.U. poz. 1984, ze zm.

40 Wywiad z R. Zimą.

${ }^{41}$ Ibidem. 
Tabela 3. Struktura geograficzna i instytucjonalna nabywców zielonych obligacji w latach 2016-2019

\begin{tabular}{|c|c|c|c|}
\hline $\begin{array}{l}\text { Data } \\
\text { emisji }\end{array}$ & Struktura geograficzna & Struktura instytucjonalna & $\begin{array}{l}\text { Udział w emisji } \\
\text { podmiotów } \\
\text { zorientowanych } \\
\text { na „zielone” } \\
\text { inwestycje }\end{array}$ \\
\hline $\begin{array}{l}20 \text { grudnia } \\
2016\end{array}$ & $\begin{array}{l}\text { - } \text { Niemcy i Austria ( } 27 \%) \\
\text { - kraje Beneluksu (17\%) } \\
\text { - Wielka Brytania i Irlandia } \\
(16 \%) \\
\text { - kraje nordyckie (15\%), } \\
\text { - Francja ( } 13 \%) \\
\text { - Polska ( } 7 \%) \\
\text { - pozostałe kraje }(5 \%)\end{array}$ & $\begin{array}{l}\text { - fundusze inwestycyjne } \\
(49 \%) \\
\text { - banki ( } 22 \%) \\
\text { - instytucje ubezpieczeniowe } \\
\text { i fundusze emerytalne } \\
(16 \%) \\
\text { - banki centralne i instytucje } \\
\text { publiczne (12\%) } \\
\text { - inne (1\%) }\end{array}$ & $61 \%$ \\
\hline $\begin{array}{l}7 \text { lutego } \\
2018\end{array}$ & $\begin{array}{l}\text { - } \text { Francja }(23,5 \%) \\
\text { - } \text { Niemcy }(19,0 \%) \\
\text { - Wielka Brytania (13,9\%), } \\
\text { - Polska }(9,6 \%), \\
\text { - Szwajcaria }(5,0 \%), \\
\text { - } \text { kraje skandynawskie }(4,8 \%), \\
\text { - } \text { Austria }(3,9 \%) \\
\text { - } \text { kraje Beneluksu (1,9\%) } \\
\text { - pozostałe kraje europejskie } \\
\quad(8,1 \%) \\
\text { - } U S A(3,5 \%) \\
\text { - } \text { Bliski Wschód }(2,0 \%) \\
\text { - pozostałe kraje }(4,9 \%)\end{array}$ & $\begin{array}{l}\text { - } \text { fundusze inwestycyjne } \\
(66,5 \%) \\
\text { - banki }(15,9 \%) \\
\text { - banki centralne i instytucje } \\
\text { publiczne }(9,2 \%) \\
\text { - instytucje ubezpieczeniowe } \\
\text { i fundusze emerytalne } \\
(7,8 \%) \\
\text { - fundusze hedgingowe } \\
\text { (0,3\%) } \\
\text { - pozostałe podmioty }(0,2 \%)\end{array}$ & $41 \%$ \\
\hline $\begin{array}{l}7 \text { marca } \\
2019 \\
\text { (obligacje } \\
\text { 10-letnie) }\end{array}$ & 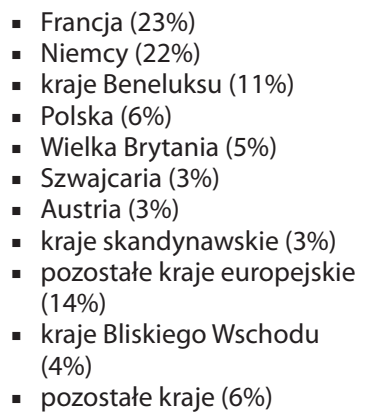 & $\begin{array}{l}\text { - fundusze inwestycyjne } \\
(38 \%) \\
\text { - banki ( } 36 \%) \\
\text { - instytucje ubezpieczeniowe } \\
\text { i fundusze emerytalne } \\
\text { ( } 12 \%) \\
\text { - banki centralne i instytucje } \\
\text { publiczne }(11 \%) \\
\text { - fundusze hedgingowe }(2 \%) \\
\text { - pozostałe podmioty }(1 \%)\end{array}$ & $47 \%$ \\
\hline $\begin{array}{l}7 \text { marca } \\
2019 \\
\text { (obligacje } \\
\text { 30-letnie) }\end{array}$ & $\begin{array}{l}\text { - } \text { Niemcy }(45 \%) \\
\text { - } \text { Francja }(15 \%) \\
\text { - } \text { Wielka Brytania (9\%) } \\
\text { - Szwajcaria (3\%) } \\
\text { - } \text { Austria }(3 \%) \\
\text { - kraje Beneluksu (3\%) } \\
\text { - pozostałe kraje europejskie } \\
(18 \%) \\
\text { - kraje Bliskiego Wschodu } \\
(2 \%) \\
\text { - } \text { pozostałe kraje }(2 \%)\end{array}$ & $\begin{array}{l}\text { - fundusze inwestycyjne } \\
(48 \%) \\
\text { - instytucje ubezpieczeniowe } \\
\text { i fundusze emerytalne } \\
(37 \%) \\
\text { - banki (6\%) } \\
\text { - banki centralne i instytucje } \\
\text { publiczne }(5 \%) \\
\text { - fundusze hedgingowe }(3 \%) \\
\text { - pozostałe podmioty }(1 \%)\end{array}$ & $43 \%$ \\
\hline
\end{tabular}

Źródło: Ministerstwo Finansów. 
Autorzy w pełni podzielają pogląd zapewnienia jak najszerszej konsolidacji finansów publicznych i braku konieczności określania w liście emisyjnym szczegółowego celu wykorzystania środków pozyskanych z tytułu sprzedaży obligacji skarbowych na konkretne projekty czy też programy. Odniesienie się do obszarów określonych w Green Bond Framework przygotowanym przez Ministerstwo Finansów należy uznać za wystarczające.

Ponadto Robert Zima zauważył, że: większość funduszy inwestycyjnych zorientowanych na tego typu inwestycje znajduje się właśnie w obszarze Unii Europejskiej, dlatego też wszystkie dotychczasowe emisje polskich zielonych obligacji były $w$ walucie euro. W Stanach Zjednoczonych popyt na tego typu instrumenty finansowe jest relatywnie ograniczony. Na polskim rynku brak jest również wystarczającego popytu ze strony dedykowanych „zielonych” funduszy. Ponadto, dokonując emisji zielonych obligacji, intencją rządu była również chęć dywersyfikacji nabywców skarbowych papierów wartościowych, zatem naturalnym wyborem był rynek europejski. Struktura geograficzna i instytucjonalna nabywców zielonych obligacji została przedstawiona w tabeli 3.

Obecnie w Ministerstwie Finansów prowadzone są prace nad ewentualnymi zmianami i aktualizacjami Framework (z uwzględnieniem wcześniej wspomnianych prac na forum unijnym) pod kątem możliwego rozszerzenia go i włączenia innych wydatków, które będą klasyfikowane zgodnie z europejskimi wytycznymi jako zielone ${ }^{42}$.

Zgodnie z zapowiedziami Ministerstwa Finansów zielone obligacje na rynku europejskim oferowane są z częstotliwością raz na rok. A więc kolejnej emisji spodziewać się można w pierwszym kwartale lub na przełomie pierwszego i drugiego kwartału 2020 r. Należy zauważyć, że większość potrzeb pożyczkowych Minister Finansów finansuje na rynku krajowym w złotych, a rynki zagraniczne stanowią jedynie uzupełniające źródło finansowania ${ }^{43}$.

\section{Zielone fundusze publiczne - propozycje rozwiązań}

W trakcie realizowanego procesu badawczego podczas wywiadu w odpowiedzi na pytanie o przyczyny braku emisji zielonych obligacji na rynek krajowy Robert Zima jako jeden z powodów wskazał brak rozwiniętego rynku zielonych fundu$\mathrm{szy}^{44}$. W okresie lipiec/sierpień 2019 można było zaobserwować pewien progres w tym obszarze. W dniu 30 lipca 2019 r. Zarząd PGE (spółki o istotnym znaczeniu

42 Ibidem.

43 Ministerstwo Finansów, Departament Długu Publicznego, Plan finansowania potrzeb pożyczkowych budżetu państwa i jego uwarunkowania - maj 2019, Warszawa 2019, s. 5.

44 Wywiad z R. Zimą. 
dla gospodarki) przekazał do wiadomości publicznej informację o podpisaniu wraz ze spółkami zależnymi (PGE Energia Ciepła, PGE Górnictwo i Energetyka Konwencjonalna oraz PGE Energia Odnawialna) umowy inwestycyjnej z TFI Energia (podmiot należący do Grupy PGE) mającej na celu utworzenie funduszu inwestycyjnego zamkniętego aktywów niepublicznych - „Fundusz Inwestycyjny Zamknięty Aktywów Niepublicznych Eko-Inwestycje”. PGE oraz spółki zależne zobowiązały się zainwestować w ten fundusz co najmniej 1,5 mld zł. Fundusz Eko-Inwestycje będzie inwestował m.in. w projekty związane $\mathrm{z}$ elektromobilnością, usługami efektywności energetycznej, ograniczaniem emisyjności oraz digitalizacją energetyki ${ }^{45}$. Ponadto w planowanym do utworzenia jesienią $2019 \mathrm{r}$. nowym funduszu parasolowym (z 11 subfunduszami) przez Amundi Polska TFI zakłada się funkcjonowanie zielonego subfunduszu inwestującego w zielone obligacje $^{46}$. Niemniej przewidywana skala działalności finansowej nowo tworzonych zielonych funduszy inwestycyjnych (na koniec lipca 2019 r. we wszystkich funduszach TFI Amundi było zgromadzonych 1,48 mld zł aktywów) nie będzie stanowić, zdaniem autorów, przełomu w źródłach pozyskiwania finansowania $\mathrm{z}$ wykorzystaniem instrumentu skarbowych zielonych obligacji.

W kontekście przeprowadzonych badań zasadne wydaje się przedstawienie wniosków de lege ferenda w zakresie możliwości stworzenia rozwiązań umożliwiających finansowanie zielonych projektów ze środków publicznych w sposób inny niż z wykorzystaniem zielonych obligacji. Poza instrumentem zielonych obligacji w rozwiniętych gospodarkach rynkowych można bowiem zaobserwować trend realizacji zadań publicznych $\mathrm{z}$ wykorzystaniem instytucji zbiorowego inwestowania (fundusze infrastrukturalne, fundusze tworzone przez instytucje międzynarodowe). Przykładowo takim narzędziem wsparcia inwestycji prorozwojowych, w tym proekologicznych, jest Europejski Fundusz Inwestycji Strategicznych ${ }^{47}$.

Należy jednak zauważyć, że art. 49 ust. 1 u.f.p. wyłącza możliwość nabywania i obejmowania przez jednostki sektora finansów publicznych (z wyjątkami podmiotowymi obejmującymi jednostki samorządu terytorialnego oraz ich związki) udziałów lub akcji w spółkach oraz obligacji emitowanych przez podmioty inne niż Skarb Państwa lub jednostki samorządu terytorialnego, a także udziałów w spółdzielniach, chyba że odrębna ustawa stanowi inaczej.

45 PAP, PGE tworzy fundusz $z$ 1,5 mld $z \nmid$ na „zielone” inwestycje, https://www.pb.pl/ pge-tworzy-fundusz-z-15-mld-zl-na-zielone-inwestycje-966975 [dostęp 8 września 2019 r.].

46 A. Pałasz, W. Potyra, Amundi Polska TFI: Ruszamy z nowymi funduszami, https:// www.parkiet.com/Ludzie-rynku/308209989-Wojciech-Potyra-Amundi-Polska-TFI-Ruszamy-z-nowymi-funduszami.html [dostęp 8 września 2019 r.].

47 S. Skuza, Analiza możliwości prawnych realizacji zadań publicznych z wykorzystaniem zasobów publicznych poprzez instytucje funduszu inwestycyjnego, „Zarządzanie i Finanse / Journal of Management and Finance" 2015, nr 3, cz. 2, s. 297-298. 
Przywołany powyżej przepis art. 49 ust. 1 u.f.p. zakazuje nabywania i posiadania przez jednostki sektora finansów publicznych wymienionych w tym przepisie rodzajów instrumentów, tj. udziałów, akcji, obligacji emitowanych przez inne podmioty niż Skarb Państwa lub jednostki samorządu terytorialnego.

Literalna wykładnia przepisu zdaje się odnosić do zakazu nabywania wyłącznie wymienionych w art. 49 ust. 1 u.f.p. określonych instrumentów finansowych oraz innych praw majątkowych. Jednak wykładnia rozszerzająca wydaje się interpretować powyższy przepis jako zakaz obejmujący również inne rodzaje instrumentów finansowych i traktowanie możliwości objęcia lub nabycia przez podmioty sektora finansów publicznych jako niedopuszczalne $e^{48}$.

Chcąc rozwiać wyżej wymienione wątpliwości, należałoby zmienić art. 49 ust. 1 u.f.p. Wraz ze zmianą art. 49 ust. 1 u.f.p. niezbędne jest dokonanie także zmiany w art. 124 ust. 4 pkt 1 u.f.p., polegającej na dodaniu do wskazanych w tym przepisie wydatków na zakup i objęcie akcji oraz wniesienie wkładów do spółek prawa handlowego wydatków na zakup certyfikatów inwestycyjnych lub jednostek uczestnictwa ${ }^{49}$.

Instytucja funduszu inwestycyjnego, zwłaszcza zamkniętego, umożliwiłaby zapewnienie stabilnego długoterminowego finansowania oraz umożliwiałaby pozyskanie mieszanego kapitału publiczno-prywatnego. Należy na przykład zwrócić uwagę na art. 14 ust. 1 i 2 ustawy z 19 grudnia 2008 r. o partnerstwie publiczno-prywatnym ${ }^{50}$, zgodnie z którymi umowa o partnerstwie publiczno-prywatnym może przewidywać, że w celu jej wykonania podmiot publiczny i partner prywatny zawiążą spółkę kapitałową, spółkę komandytową lub komandytowo-akcyjną; cel i przedmiot działalności spółki nie może wykraczać poza zakres określony umową o partnerstwie publiczno-prywatnym. W ocenie autorów zamknięty fundusz inwestycyjny mógłby być narzędziem dużo bardziej właściwym do łączenia ośrodków publicznych i prywatnych ${ }^{51}$.

W odniesieniu do zielonych funduszy autorzy proponują rozwiązanie powyższego problemu przez umożliwienie wykonywania zadań publicznych z wykorzystaniem instytucji funduszu inwestycyjnego ${ }^{52}$. Autorzy mają świadomość, że niecelowe i niezasadne byłoby tworzenie zielonych funduszy inwestycyjnych ze środków publicznych, których celem byłoby inwestowanie w zielone obligacje skarbowe. Instytucja funduszu inwestycyjnego umożliwiałaby jednak tworzenie mieszanego kapitału (publicznego i prywatnego); ponadto zaangażowanie na początkowym etapie rozwoju rynku ze strony państwa (działanie w tzw. luce rynko-

48 Taką możliwość zasugerował S. Skuza, ibidem, s. 303-304.

49 Ibidem, s. 305.

50 Ustawa z 19 grudnia 2008 r. o partnerstwie publiczno-prywatnym, Dz.U. 2019, poz. $1445,1572$.

51 S. Skuza, Analiza możliwości, op. cit., s. 307-308.

52 Zob. ibidem, s. 297-311. 
wej) mogłoby przyczynić się do przyspieszenia budowy tego rynku oraz redukcji niedoskonałości rynkowych.

„W ustawie z dnia 27 sierpnia 2009 r. o finansach publicznych (Dz. U. z 2019 r. poz. 869 , z późn. zm.) wprowadza się następujące zmiany:

1) w art. 49 ust. 1 otrzymuje brzmienie:

«1. Jednostki sektora finansów publicznych, z wyłączeniem jednostek, o których mowa w art. 9 pkt 2, nie mogą posiadać, obejmować lub nabywać udziałów lub akcji w spółkach ani nabywać obligacji oraz innych instrumentów finansowych emitowanych lub oferowanych przez podmioty inne niż Skarb Państwa lub jednostki samorządu terytorialnego, a także udziałów w spółdzielniach, chyba że przepisy niniejszej ustawy lub odrębnych ustaw stanowią inaczej, z zastrzeżeniem ust. 2.»;

2) w art. 124 ust. 4 po pkt 1 dodaje się pkt 1a w brzmieniu:

«1a) wydatki na nabycie lub objęcie jednostek uczestnictwa lub certyfikatów inwestycyjnych funduszy inwestycyjnych, o których mowa w art. 3 ust. 1 ustawy z dnia 27 maja 2004 r. o funduszach inwestycyjnych i zarządzaniu alternatywnymi funduszami inwestycyjnymi (Dz. U. z 2018 r. poz. 1355, z późn. zm.), w funduszach inwestycyjnych, których przedmiotem działalności jest lokowanie środków pieniężnych w określone papiery wartościowe, instrumenty rynku pieniężnego i inne prawa majątkowe w celu realizacji zadań publicznych związanych z ochroną środowiska;»" 53 .

Przyjęcie powyższych zmian umożliwiłoby, zdaniem autorów, likwidację prawnych ograniczeń wykonywania zadań publicznych w obszarze ochrony środowiska $z$ wykorzystaniem instytucji funduszu inwestycyjnego.

Należy również zauważyć, że możliwość zaangażowania środków publicznych $\mathrm{w}$ fundusze inwestycyjne w systemie polskiego prawa finansowego nie byłaby wyjątkiem. Prawna możliwość takich inwestycji ma bowiem jedna z agencji wykonawczych nadzorowanych przez Ministra Nauki i Szkolnictwa Wyższego - Narodowe Centrum Badań i Rozwoju. Do ustawowych zadań tej instytucji należy ${ }^{54}$ - pobudzanie inwestowania przez przedsiębiorców w działalność naukową, w szczególności przez:

a) współfinansowanie przedsięwzięć prowadzonych przez podmiot posiadający zdolność do zastosowania wyników projektu w praktyce,

b) wspieranie pozyskiwania przez podmioty, o których mowa w art. 7 ust. 1 pkt 1, 2 i 4-8 ustawy - Prawo o szkolnictwie wyższym i nauce, środków na działalność naukową pochodzących z innych źródeł niż budżet państwa,

c) wspieranie komercjalizacji wyników badań naukowych lub prac rozwojowych oraz innych form ich transferu do gospodarki,

53 Ibidem, s. 308.

54 Ustawa z 30 kwietnia 2010 r. o Narodowym Centrum Badań i Rozwoju, Dz.U. 2019, poz. 1770, 2020. 
- inicjowanie i realizacja programów obejmujących finansowanie badań naukowych lub prac rozwojowych oraz działań przygotowujących do wdrożenia wyniki badań naukowych lub prac rozwojowych,

- inicjowanie i realizacja programów obejmujących finansowanie badań aplikacyjnych, o których mowa w art. 4 ust. 2 pkt 2 ustawy - Prawo o szkolnictwie wyższym i nauce,

- udział w realizacji międzynarodowych programów badań naukowych lub prac rozwojowych, w tym programów współfinansowanych ze środków zagranicznych,

- finansowanie badań aplikacyjnych realizowanych w formie niepodlegających wspóffinansowaniu z zagranicznych środków finansowych projektów badawczych realizowanych w ramach programów lub inicjatyw międzynarodowych ogłaszanych we współpracy dwu- lub wielostronnej oraz projektów badawczych realizowanych przy wykorzystaniu przez polskie zespoły badawcze wielkich międzynarodowych urządzeń badawczych,

- upowszechnianie w środowisku naukowym i gospodarczym informacji o planowanych i ogłaszanych konkursach na wykonanie projektów finansowanych przez Centrum,

- popularyzowanie efektów zrealizowanych zadań,

- realizacja innych zadań zlecanych przez Ministra Nauki i Szkolnictwa Wyższego, przy zapewnieniu środków finansowych na te cele.

Ponadto Narodowe Centrum Badań i Rozwoju wspiera rozwój kadry naukowej, w szczególności przez finansowanie programów adresowanych do młodych naukowców w rozumieniu art. 360 ust. 2 ustawy - Prawo o szkolnictwie wyższym i nauce.

Zgodnie z art. 30a ust. 1 ustawy o Narodowym Centrum Badań i Rozwoju w celu realizacji wyżej wymienionych ustawowych zadań agencja ta może obejmować lub nabywać certyfikaty inwestycyjne, o których mowa w art. 117 ust. 1 ustawy o funduszach inwestycyjnych i zarządzaniu alternatywnymi funduszami inwestycyjnym.

\section{Podsumowanie}

Emisja zielonych obligacji czy też zaproponowane w niniejszym artykule inne sposoby finansowania zielonych wydatków publicznych zawsze wiązać się będą zarówno z korzyściami, jak i zagrożeniami dla emitenta i inwestora. Przeprowadzona analiza wykazała, że prawodawstwo krajowe zostało w odpowiedni sposób znowelizowane w celu umożliwienia emisji rządowych zielonych obligacji. Wobec powyższego dalsze nowelizacje ustawy o finansach publicznych w obszarze emisji zielonych obligacji nie są już wymagane. Ze względu na fakt, że 
w praktyce niezbędnym elementem emisji zielonych obligacji jest każdorazowa ocena agencji ratingowych frameworku, zgodności wydatkowania środków czy też jakości raportowania działań związanych z emisją zielonych obligacji oraz umiędzynarodowienia problematyki instrumentu zielonych obligacji, nie jest zasadne definiowanie zielonych obligacji w przepisach prawa krajowego. Bardziej właściwe wydaje się zdefiniowanie tych instrumentów na poziomie co najmniej soft law Unii Europejskiej. Nie jest konieczne odrębne definiowanie terminów zielone obligacje i obligacje klimatyczne, gdyż ich zakres znaczeniowy jest zbieżny, a zadania finansowane środkami pozyskanymi z zielonych obligacji określa framework przypisany danej emisji.

Niewątpliwie Polska za sprawą zielonych obligacji uatrakcyjniła swój wizerunek na arenie międzynarodowej, co ma wpływ na zainteresowanie inwestorów zagranicznych ${ }^{55}$. Obecnie obszar Unii Europejskiej wydaje się stanowić najbardziej odpowiedni cel dla kolejnych emisji zielonych obligacji rządowych. W przeprowadzonym badaniu nie było możliwe ustalenie korzyści finansowych wynikających z emisji zielonych obligacji w porównaniu z emisjami obligacji klasycznych, emitowanych na rynki zagraniczne w analogicznym okresie ze względu na ich brak. Skarb Państwa finansował bowiem większość potrzeb pożyczkowych na rynku krajowym. Dotychczasowe doświadczenia w obszarze emisji zielonych obligacji wskazują na potrzebę kontynuowania tego typu działań.

Autorom wydaje się zasadne rozważenie możliwości szerszego wykorzystania środków publicznych na finansowanie zadań publicznych w obszarze ochrony środowiska z wykorzystaniem instytucji funduszy. Wobec braku rynku zielonych funduszy wskazane byłoby wypełnienie takiej luki rynkowej przez fundusze tworzone ze środków publicznych. Obecny stan prawny uniemożliwia podejmowanie takich działań w odniesieniu do środków budżetowych. Przedstawiona przez autorów nowelizacja ustawy o finansach publicznych stworzyłaby możliwość powstawania funduszy o kapitale mieszanym (publicznym i prywatnym), co prowadziłoby do rozwoju tego segmentu rynku finansowego (zielone fundusze) oraz niwelowałoby niedoskonałości rynku.

Autorzy mają świadomość, że w artykule nie zostały przedstawione analizy dotyczące rentowności poszczególnych alternatywnych możliwości finansowania zielonych wydatków publicznych. Nie było to bowiem intencją autorów, zwłaszcza w odniesieniu do proponowanych przez autorów możliwości zaangażowania środków budżetowych w jednostki uczestnictwa lub certyfikaty inwestycyjne emitowane przez fundusze inwestycyjne. W ocenie autorów brak jest uzasadnienia utrzymywania takiego zakazu na poziomie przepisów ustawowych, ze względu na możliwość inwestowania środków budżetowych w akcje lub udziały spółek kapitałowych - niezależnie do profilu ich ryzyka, czy też ich

55 A. Laskowska, Polska światowym prekursorem zielonych obligacji skarbowych (Poland as the Global Precursor of Sovereign Green Bonds), „Profit Journal” 2017, nr 2(18), s. 6. 
angażowania - w celu zarządzania długiem - $\mathrm{w}$ instrumenty pochodne. Ponadto, w sposób pośredni, już obecnie można zauważyć zaangażowanie państwa w fundusze inwestycje. Autorzy mają na myśli podmioty: Polski Fundusz Rozwoju SA, Bank Gospodarstwa Krajowego czy też Narodowe Centrum Badań i Rozwoju, wykorzystujące jako źródło finansowania swoich zadań środki publiczne, w tym dotacje celowe. Ryzyko inwestycyjne, bezpośrednie lub pośrednie, angażowania środków publicznych w powyższe podmioty inwestujące w fundusze inwestycyjne czy też bezpośrednie zaangażowanie tych środków w instrumenty finansowe emitowane przez te fundusze wydaje się być, zdaniem autorów, de facto na takim samym poziomie. Autorzy w niniejszym artykule nie dokonują również analizy strony korzyści i kosztów budowy rynku zielonych obligacji w Polsce, za zasadne uważają natomiast tworzenie określonych możliwości prawnych aktywności państwa w obszarze zielonych finansów. W tym zakresie intencją autorów nie była analiza kosztów i korzyści umożliwienia inwestowania środków budżetowych w fundusze inwestycyjne, a wyłącznie zidentyfikowanie bariery prawnej, która, zdaniem autorów, jest nieuzasadniona, i zaproponowanie wniosków de lege ferenda.

\section{Bibliografia}

\section{Monografie}

Dziawgo L., Zielony rynek finansowy. Ekologiczna ewolucja rynku finansowego, Polskie Wydawnictwo Ekonomiczne, Warszawa 2010.

Jedynak P., CSR practices and competetiveness of the company in B2B market [w:] Competition and cooperation in the management theory and practice, red. P. Jedynak, Jagiellonian University Press, Kraków 2014.

Rapley T., Analiza konwersacji, dyskursu i dokumentów, Wydawnictwo Naukowe PWN, Warszawa 2010.

Reichelt H., Green bonds: a model to mobilise private capital to fund climate change mitigation and adaptation projects [w:] The Euromoney Environmental Finance Handbook, World Bank, Washington 2010.

Silverman D., Interpretacja danych jakościowych, Wydawnictwo Naukowe PWN, Warszawa 2007.

Strauss A., Corbin J., Basic of Qualitative Research, Newbury Park, CA Sage 1990.

Zadek S., Flynn C., South-Originating Green Finance: Exploring the Potential, UNEP Finance Initiative, Geneva 2013.

\section{Artykuły}

Baker M., Bergstresser D., Serafeim G., Wurgler J., Financing the Response to Climate Change: The Pricing and Ownership of U.S. Green Bonds, National Bureau of Economic Research, Cambridge 2018, https://doi.org/10.3386/w25194. 
Bieliński T., Mosionek-Schweda M., Green bonds as a financial instrument for environmental projects funding, „Unia Europejska.pl” 2018, nr 1(248).

Brzozowska K., Idea zrównoważonego rozwoju na rynku obligacji, „Prace Naukowe Uniwersytetu Ekonomicznego we Wrocławiu" 2017, nr 478.

Dörry S., Schulz C., Green financing, interrupted. Potential directions for sustainable finance in Luxembourg, „Journal Local Environment: The International Journal of Justice and Sustainability" 2018, No 7 (23), https://doi.org/10.1080/13549839.2018.1428792.

Kłobukowska J., Społecznie odpowiedzialne inwestowanie jako innowacja na rynku finansowym $w$ Polsce $w$ dobie finansjalizacji - stan obecny i perspektywy, „Folia Oeconomica. Acta Universitatis Lodziensis" 2018, nr 6(339), https://doi.org/10.18778/0208-6018.339.07.

Kuna-Marszałek A., Marszałek J., Green Bonds - Trends and Development Perspectives, „Annales Universitatis Mariae Curie-Skłodowska, Sectio H - Oeconomia” 2018, nr 4(52), https://doi.org/10.17951/h.2018.52.4.39-47.

Krawiec W., Impact investment - istota $i$ otoczenie rynku, „Annales Universitatis Mariae Curie-Skłodowska, Sectio H - Oeconomia” 2015, nr 4(49), https://doi. org/10.17951/h.2015.49.4.279.

Laskowska A., The Green bond as a prospective instrument of the global debt market, „Copernican Journal of Finance \& Accounting” 2017, No 6(4), https://doi.org/10.12775/ cjfa.2017.023.

Laskowska A., Polska światowym prekursorem zielonych obligacji skarbowych (Poland as the Global Precursor of Sovereign Green Bonds), „Profit Journal” 2017, nr 2(18).

Lindenberg N., Definition of Green Finance, German Development Institute, Deutsches Institut für Entwicklungspolitik, Bonn 2014.

Marszałek J., Daszyńska-Żygadło K., Charakterystyka globalnego rynku obligacji klimatycznych, „Finanse, Rynki Finansowe, Ubezpieczenia” 2016, nr 4, cz. 1, https://doi. org/10.18276/frfu.2016.4.82/1-78.

Mosionek-Schweda M., Szmelter M., Zielone obligacje - nowy instrument finansowania inwestycji polskiego rzadu, „Prace Naukowe Uniwersytetu Ekonomicznego we Wroclawiu" 2018, nr 532, https://doi.org/10.15611/pn.2018.532.21.

Pawłowski M., Diversification of the global green bond market, „European Journal of Service Management" 2018, No 3 (27/2), https://doi.org/10.18276/epu.2018.129-18.

Pawłowski M., Zielone obligacje rządowe, „Ekonomiczne Problemy Usług” 2017, nr 4(129), https://doi.org/10.18276/epu.2018.129-18.

Sartzetakis E.S., Green Bonds as an instrument to finance low carbon transition, „Working Paper” Bank of Greece, Economic Analysis and Research Department - Special Studies Division, 2019, nr 258, https://doi.org/10.1007/s10644-020-09266-9.

Skuza S., Analiza możliwości prawnych realizacji zadań publicznych $z$ wykorzystaniem zasobów publicznych poprzez instytucję funduszu inwestycyjnego, „Zarządzanie i Finanse / Journal of Management and Finance" 2015, nr 3, cz. 2.

Szymański D., To jest absolutny hit polskiego rządu. „Wszędzie nas pytają, jak tego dokonaliśmy", https://businessinsider.com.pl/finanse/makroekonomia/zielone-obligacje-okazaly-sie-hitem-polski/8fzfpyw. 
Tang D.Y., Zhang Y., Do shareholders benefit from green bonds?, „Journal of Corporate Finance" 2018, In Press, Corrected Proof, Available online 8 December 2018, https:// doi.org/10.2139/ssrn.3259555.

Voica M.C., Panait M., Radulescu I., Green Investments - Between Necessity, Fiscal Constraints and Profit, „Procedia Economics and Finance” 2015, No 22, https://doi. org/10.1016/s2212-5671(15)00228-2.

Więckowska M., Stan i perspektywy rozwoju rynku obligacji klimatycznych, „Zeszyty Naukowe Uniwersytetu Szczecińskiego. Finanse, Rynki Finansowe, Ubezpieczenia” 2013, nr 62.

Wang Y., Zhi Q., The Role of Green Finance in Environmental Protection: Two Aspects of Market Mechanism and Policies, „Energy Procedia” 2016, nr 104, https://doi. org/10.1016/j.egypro.2016.12.053.

Wiśniewski M., Zieliński J., Perspektywy finansowania zadań samorzadu terytorialnego $w$ Polsce za pomoca obligacji zielonych, „INFOS. Zagadnienia Społeczno-gospodarcze” 2017, nr 15(238).

Wiśniewski M., Zieliński J., Perspektywy finansowania zadań samorzadu terytorialnego w Polsce za pomoca obligacji zielonych, "Studia BAS” 2017, nr 4(52) [Finansowanie zadań publicznych $w$ Polsce, red. P. Russel].

Zerbib O.D., The effect of pro-environmental preferences on bond prices: Evidence from green bonds, „Journal of Banking \& Finance” 2019, No 98, https://doi.org/10.1016/j. jbankfin.2018.10.012.

\section{Źródła internetowe i inne źródła}

Climate Bonds Annual Conference and Green Bond Awards, 2017, https://www.climatebonds.net/market/2017-awards.

Ministerstwo Finansów, Wycena obligacji Green Bond, https://finanse-arch.mf.gov.pl.

Ministerstwo Finansów, Departament Długu Publicznego, Plan finansowania potrzeb pożyczkowych budżetu państwa i jego uwarunkowania - maj 2019, Warszawa 2019.

OECD \& Bloomberg Philanthropies, Green Bonds. Mobilising the debt capital markets for a low-carbon transition. Policy perspectives, OECD Publishing, Paryż 2015.

Pałasz A., Potyra W., Amundi Polska TFI: Ruszamy z nowymi funduszami, https://www. parkiet.com/Ludzie-rynku/308209989-Wojciech-Potyra-Amundi-Polska-TFI-Ruszamy-z-nowymi-funduszami.html.

PAP, PGE tworzy fundusz z 1,5 mld zł na „zielone” inwestycje, https://www.pb.pl/pge-tworzy-fundusz-z-15-mld-zl-na-zielone-inwestycje-966975.

Report on EU Green Bond Standard, EU Technical Expert Group on Sustainable Finance, June 2019.

The State Treasury of the Republic of Poland, represented by the Minister of Development and Finance Green Bond Framework 5 th December 2016, https://www.gov.pl/web/finanse/emisje.

Wywiad z Robertem Zimą, dyrektorem Departamentu Długu Publicznego w Ministerstwie Finansów, przeprowadzony 27 sierpnia 2019 r. 
Alexander Martin Juranek

\title{
Międzynarodowa harmonizacja prawa prywatnego na przykładzie wybranych aktów modelowego prawa umów w zakresie regulacji kary umownej
}

\author{
International harmonisation of private law on the example of selected \\ acts of a model contract law regarding the regulation of contractual \\ penalty
}

\begin{abstract}
The purpose of this article is to synthesize the basic acts of the so-called model contract law and the relations between the solutions adopted in them and the regulation of contractual penalty applicable in Polish law. Particular emphasis was puted on the analysis of conditions for a claim for payment of a contractual penalty and acceptable limits of modification of a debtor's liability in Polish and model law. On the basis of model law, it was proposed to resolve the most frequent doubts in Polish doctrine. The comparative conclusions drawn in relation to the contractual penalty are also an example of evaluation of the Polish regulation from the point of view of the progressing process of European private law harmonisation.
\end{abstract}

Keywords: harmonisation, private law, model law, civil law, stipulated payment, contractual penalties, contractual liability, breach of contract, limits of liability

Niniejszy artykuł ma na celu syntetyczne przybliżenie podstawowych aktów tzw. modelowego prawa umów oraz relacji pomiędzy przyjętymi w nich rozwiązaniami a obowiązującą w prawie polskim regulacją kary umownej. Szczególny nacisk położono na analizę przesłanek powstania roszczenia o zapłatę kary umownej i dopuszczalnych granic modyfikacji odpowiedzialności dłużnika w prawie polskim i modelowym. W oparciu o prawo modelowe zaproponowano rozstrzygnięcie najczęściej pojawiających się wątpliwości w polskiej doktrynie. Wyprowadzone wnioski komparatystyczne w odniesieniu do kary umownej stanowią nadto przykład oceny polskiej regulacji z punktu widzenia postępującego procesu europejskiej harmonizacji prawa prywatnego.

Słowa kluczowe: harmonizacja, prawo prywatne, prawo modelowe, prawo cywilne, kara umowna, odpowiedzialność kontraktowa, naruszenie umowy, granice odpowiedzialności

\section{Doktorant -}

Uniwersytet Warszawski, Wydział Prawa i Administracji, WARSZAWA, POLSKA •

Uniwersytet Śląski w Katowicach, Instytut Nauk Prawnych, Zespół badawczy ds. prawa

cywilnego i prawa prywatnego międzynarodowego, KATOWICE, POLSKA •

am.juranek@wpia.uw.edu.pl • https://orcid.org/0000-0002-4927-8252

\section{Uwagi wprowadzające}

Od wielu lat w europejskiej doktrynie toczy się dyskusja o potrzebie utworzenia kompleksowej jednolitej regulacji, która stanowiłaby spójne ramy współpracy między państwami europejskimi w obszarze prawa prywatnego, zapewniając 
możliwą jednolitość i spójność funkcjonujących mechanizmów i rozwiązań. Celem niniejszego artykułu jest, po pierwsze, wskazanie, o jakie regulacje akcentujące tę „jednolitość” chodzi, a po drugie - praktyczne przedstawienie relacji między konstrukcjami tego prawa (tzw. prawa modelowego) a ich funkcjonalnymi odpowiednikami w prawie krajowym.

Warto przypomnieć, że szczególnie doniosłe (i niejako pionierskie) znaczenie w płaszczyźnie wspólnotowych projektów kodyfikacji prawa prywatnego w szczególności prawa umów - odegrała Konwencja Narodów Zjednoczonych o umowach międzynarodowej sprzedaży towarów ${ }^{1}$, sporządzona w Wiedniu 11 kwietnia 1980 r. $^{2}$, a stosowana do dziś przez większość państw członkowskich UE. To właśnie jej rozwiązania zostały w większym lub mniejszym stopniu recypowane w procesie późniejszego konstruowania podwalin europejskiego prawa umów ${ }^{3}$, stanowiąc odpowiedź na wysnuwany przez praktyków postulat: przyjęcia jednolitych zasad regulujących umowy międzynarodowej sprzedaży towarów, uwzględniających różne systemy społeczne, gospodarcze i prawne ${ }^{4}$, które przyczynią się: do usunięcia przeszkód prawnych $w$ obrocie międzynarodowym ${ }^{5}$ oraz będą sprzyjały rozwojowi handlu międzynarodowego ${ }^{6}$.

Relewantne (w odniesieniu do tematyki artykułu) zasady ponadnarodowego prawa kontraktów zostały ujęte - chronologicznie względem powstania - w skali globalnej w 1994 r. jako Reguły Międzynarodowych Umów Handlowych UNIDROIT (UNIDROIT Principles of International Commercial Contracts) ${ }^{7}$, zaś w skali europejskiej jako Zasady Europejskiego Prawa Umów (Principles of European Contract Law) ${ }^{8}$. Warto przy tym nadmienić, że opracowywanie zarówno

1 Tak m.in. W. Popiołek, Obowiązek przyjęcia dostawy towaru w projekcie „Zasad europejskiego prawa umów” i w Konwencji ONZ o międzynarodowej sprzedaży towarów [w:] W kierunku europeizacji prawa prywatnego. Ksiega pamiątkowa dedykowana Profesorowi Jerzemu Rajskiemu, red. A. Brzozowski, W. Kocot, K. Michałowska, Warszawa 2007, s. 563.

2 W stosunku do Polski weszła w życie z dniem 1 czerwca 1996 r. (Dz.U. 1997, nr 45, poz. 286-287, s. 1538 i n.), http://prawo.sejm.gov.pl/isap.nsf/download.xsp/ WDU19970450286/O/D19970 286.pdf]; dalej: CISG, konwencja wiedeńska 1980.

3 Zob. W. Popiołek, Obowiązek przyjęcia dostawy towaru, op. cit., s. 563.

4 Zob. P. Drapała, A. Olejniczak, Dodatkowe zastrzeżenia umowne [w:] System prawa prywatnego, t. 5, Prawo zobowiązań - część ogólna, red. E. Łętowska, Warszawa 2013, s. 1539.

5 Ibidem.

6 Ibidem.

7 UNIDROIT Principles of International Commercial Contracts 2016, https://www. trans-lex.org/400120/highlight_unidroit/unidroit-principles-of-international-commerci al-contracts-2016/ [dostęp: 22 października 2019 r.]; dalej: Reguły UNIDROIT, UPICC.

8 The Principles of European Contract Law, https://www.trans-lex.org/400200/_/pecl/ [dostęp: 22 października 2019 r.], dalej: Zasady PECL, PECL. Zob. także O. Lando, 
UPICC, jak i PECL, było efektem przeprowadzonych wcześniej badań komparatystycznych, skondensowanych wokół niemal tożsamych materiałów źródłowych, tj. aktów prawnych krajowych i międzynarodowych ${ }^{9}$. Oba komentowane zbiory oparte są na podobnej aksjologii i filozofii co do funkcjonalności rozwiązań przyjętych w celu uwzględnienia potrzeb międzynarodowego obrotu handlowego, jak i w równej mierze czerpią z rozwiązań i terminologii CISG ${ }^{10}$. Z tego też względu, system wspólnych reguł wytworzony przez konwencję wiedeńską 1980 r., Reguły UNIDROIT i Zasady PECL bywa określany mianem „trojki”, stanowiącej podstawy nowoczesnego lex mercatoria ${ }^{11}$.

W dalszej kolejności należy zwrócić uwagę na najnowszą prywatnoprawną wspólnotową kodyfikację, będącą niejako sukcesorem Zasad PECL, a mianowicie Projekt Wspólnej Ramy Odniesienia (Draft Common Frame of Reference) ${ }^{12}$. W każdym wypadku wymaga jednak zaakcentowania, że normatywne fundamenty harmonizacji prawa prywatnego - kwalifikowane przez opinio communis doctorum jako lex mercatoria ${ }^{13}$ - nie mają co do zasady charakteru prawnie wiążącego (tzw. soft law) ${ }^{14}$.

Rozważania o praktycznym wpływie prawa modelowego na regulacje w systemach prawa krajowego zostaną przedstawione na przykładzie stipulated payment for non-performance, czyli prawnomodelowego odpowiednika kary umownej w prawie polskim (tj. art. 483-484 Kodeksu cywilnego ${ }^{15}$ ).

H. Beale, The Principles of European Contract Law. Part I: Performance, Non-Performance and Remedies, Dordrecht 1995. Kolejne wersje PECL zostały ogłoszone odpowiednio w roku 2000 (cz. I i II) oraz 2002 (cz. III).

9 Tak E. Rott-Pietrzyk, Interpretacja umów w prawie modelowym i wspólnym europejskim prawie sprzedaży (CESL), Warszawa 2013, s. 130.

10 Ibidem.

11 Podobnie O. Lando, CISG and Its Followers: A Proposal to Adopt Some International Principles of Contract Law, AJCL 2005, t. 53, s. 381-382; także E. Rott-Pietrzyk, Interpretacja umów, op. cit., s. 130.

12 Zob. Ch. von Bar, E. Clive, H. Schulte-Nölke, Principles, Definitions and Model Rules of European Private Law. Draft Common Frame of Reference (DCFR), Full Edition, t. I, Munich 2009, dalej: DCFR; zob. także P. Drapała, A. Olejniczak, Dodatkowe zastrzeżenia, op. cit., s. 1135 .

13 Szerzej co do pojęcia lex mercatoria zob. B. Fuchs, Lex mercatoria - pojęcie [w:] System prawa handlowego, t. 9, Międzynarodowe prawo handlowe, red. W. Popiołek, Warszawa 2013, s. 46 i n.

14 Zob. E. Rott-Pietrzyk, Interpretacja umów, op. cit., s. 105. Z kolei o charakterze przywołanych, jednolitych aktów prawnych w ramach harmonizacji międzynarodowego prawa handlowego - zob. eadem, s. 131-139.

15 Ustawa z 23 kwietnia 1964 r. - Kodeks cywilny, Dz.U. nr 16, poz. 93; t.j. Dz.U. 2019, poz. 1145; dalej: k.c. 


\section{Ogólna charakterystyka wybranych aktów prawa modelowego}

\section{UNIDROIT Principles of International Commercial Contracts (UPICC)}

Jak zostało zaznaczone, zarówno konwencja wiedeńska 1980 r., jak i UPICC mają, w odróżnieniu od PECL i DCFR, charakter aktów globalnych, stanowiących źródła regulacji w zakresie międzynarodowego obrotu handlowego. Istotne jednak, że zgodnie z pkt 8 preambuły Reguł UNIDROIT akt ten może zostać wykorzystany jako wzorzec nie tylko przez prawodawcę krajowego czy międzynarodowego, ale także jako zbiór materiałów kursowych w zakresie nauczania prawa umów na poziomie akademickim i faktyczna baza komparatystyczna ${ }^{16}$. UPICC stanowi więc zbiór reguł dla międzynarodowych umów handlowych, którego zakres zastosowania ma charakter otwarty ${ }^{17}$. Nie zdefiniowano jednak ani kryterium uznania umowy za „międzynarodową”, ani za „handlową”. Na ogół przyjmuje się - dla określania „międzynarodowości” - za czynnik decydujący siedzibę stron albo miejsce zwykłego pobytu w różnych państwach, choć oczywiście w omawianym przypadku tego wprost nie uczyniono. Nie określono też, kiedy dana czynność ma charakter "handlowy”, co presuponuje, że w braku profesjonalnego charakteru umowy można mówić o wyłączeniu możliwości zastosowania UPICC ${ }^{18}$.

Bezsporne jest również, że Reguły UNIDROIT mogą być stosowane wówczas, gdy strony uzgodnią, iż umowa podlega ogólnym zasadom prawa, lex mercatoria lub innym podobnym zasadom ${ }^{19}$. Daje to więc inter partes możliwość umówienia się, że mocą skutecznej klauzuli w łączącym je stosunku obligacyjnym wyłączają wszelkie wynikłe $\mathrm{z}$ tego stosunku spory spod właściwości prawa określonego państwa na rzecz zastosowania wzmiankowanego już lex mercatoria czy innych zasad $^{20}$. Tym samym w braku dokonania przez strony wyboru prawa dla zawartej między nimi umowy mogą w pełni znaleźć zastosowanie Reguły UNIDROIT, przy czym to, jakiemu prawu będzie podlegała umowa, zależy, po pierwsze, od tego, czy ustalenie prawa właściwego dla danej umowy będzie zawierało się

16 Por. UNIDROIT Principles. Preamble - 8. Other possible uses of the Principles: [...] The Principles may also be used as a substitute for the domestic law otherwise applicable. This is the case whenever it proves impossible or extremely difficult to establish the relevant rule of that particular domestic law with respect to a specific issue, i.e. it would entail disproportionate efforts and/or costs. The reasons for this generally lie in the special character of the legal sources of the domestic law in question and/or the cost of accessing them. Furthermore, the Principles may be used as course material in universities and law schools, thereby promoting the teaching of contract law on a truly comparative basis.

17 Zob. E. Rott-Pietrzyk, Interpretacja umów, op. cit., s. 136-137.

18 Por. B. Fuchs, Reguty, op. cit., s. 61.

19 Ibidem, nb. 85.

20 Ibidem, nb. 86. 
w gestii sądu powszechnego lub arbitrażowego ${ }^{21}$, po drugie, jaka w tej materii była wola stron ${ }^{22}$. Warto zaznaczyć, że UPICC mogą być wykorzystywane także w celu dokonywania wykładni i uzupełniania aktów międzynarodowego prawa jednolitego ${ }^{23}$ oraz prawa krajowego ${ }^{24}$, co pozwala być im prawem modelowym w tym sensie, że mogą stanowić wzorzec dla krajowego lub międzynarodowego prawodawcy.

Szczegółowo Reguły UNIDROIT zostaną jeszcze umówione w kontekście funkcjonalnego odpowiednika „kary umownej”, niemniej dużo istotniejsze znaczenie z punktu widzenia powszechnej już współcześnie koncepcji multicentryczności systemu prawa mają koncepcje przyjmowane na szczeblu wspólnotowym, omawiane w dalszej części artykułu².

\section{CECL Principles of European Contract Law}

Jak zaznaczono, Zasady PECL miały charakter prekursorski w zakresie utworzenia jednolitej europejskiej kodyfikacji obejmującej ogólne zasady unijnego

${ }^{21}$ W przypadku sądu arbitrażowego możliwość jego związania wskazaniem materialnoprawnym regulacji niemającej charakteru prawa krajowego lub międzynarodowego sensu stricto nie powinna budzić wątpliwości. Inaczej rzecz przedstawia się w kontekście związania sądu państwowego materialnoprawnym wskazaniem regulacji. Uznanie, czy sąd państwowy jest właściwy do rozpoznania sprawy z zobowiązania, dla którego strony zdecydowały się na wybór materialnoprawny, zależy od tego, czy właściwość taka przyznawana jest sądowi państwowemu przez przepisy prawa właściwego dla umowy. Podobnie zresztą o tym, czy w procesie wykładni umowy lub poszczególnych jej postanowień, dla których strony zdecydowały się sięgnąć do określonego systemu normatywnego (stosując materialnoprawne wskazanie), wolno czerpać z reguł wykładni w tym systemie, rozstrzygać będą dyrektywy wykładni umów zawarte w prawie właściwym dla umowy. Zob. w tym kontekście zwłaszcza rozważania P. Machnikowskiego i A. Brzozowskiego w zakresie mechanizmu stosowania PECL - P. Machnikowski, A. Brzozowski, Unifikacja europejskiego prawa umów. Zasady Europejskiego Prawa Umów (PECL) [w:] System prawa prywatnego, t. 5, Prawo zobowiązań - część ogólna, red. K. Osajda, Warszawa 2020, s. 496-498 i 523; M. Pazdan, Wybór prawa w świetle rozporządzenia Rzym I - analiza szczegółowa [w:] System prawa prywatnego, t. 20B, Prawo prywatne międzynarodowe, red. M. Pazdan, Warszawa 2015, s. 70 i n.; idem, Wybór kolizyjnoprawny, op. cit., s. 76.

B. Fuchs, Reguty, op. cit., nb. 86.

23 Tak M.J. Bonell, The UNIDROIT Principles Of International Commercial Contracts And CISG - Alternatives Or Complementary Instruments?, ULR 1996, t. 26, s. 33 i n.; a także B. Fuchs, Reguły, op. cit., nb. 87-88.

Zob. E. Rott-Pietrzyk, Interpretacja umów, op. cit., s. 137, oraz cytowani tam autorzy.

25 Szerzej o multicentryczności systemu zob. E. Łętowska, Multicentryczność współczesnego systemu prawa i jej konsekwencje, „Państwo i Prawo” 2005, z. 4, s. 3; a także eadem, Multicentryczność współczesnego systemu prawa i wykładnia jej przyjazna [w:] Rozprawy prawnicze: ksiega pamiątkowa Profesora Maksymiliana Pazdana, red. L. Ogiegło, W. Popiołek, M. Szpunar, Kraków 2005, s. 1127 i n. 
prawa umów, co zresztą wynika expressis verbis z art. 1:101 ust. 1 PECL ${ }^{26}$. Ich stosowanie dotyczy przede wszystkim wspólnotowych stosunków zobowiązaniowych, a więc wyłącznie tych podmiotów, o których można powiedzieć, że mają przynależność wspólnotową ${ }^{27}$. W przypadku osób fizycznych kryterium bez wątpliwości będzie łącznik miejsca ich zwykłego pobytu ${ }^{28}$. Większe trudności pojawiają się w przypadku przedsiębiorstw, wobec których w celu uzyskania statusu przedsiębiorstwa wspólnotowego wymaga się kumulatywnego spełnienia dwóch kryteriów: 1) założenia zgodnie z prawem któregokolwiek państwa UE oraz 2) posiadania statutowej siedziby, zarządu lub głównego przedsiębiorstwa w obrębie Unii ${ }^{29}$.

Nie budzi wątpliwości, że Zasady PECL będą najczęściej stosowane między uczestnikami obrotu profesjonalnego mającymi siedzibę na terytorium UE. Jednakże nie można wykluczać także ich międzynarodowego oddziaływania w sytuacji, kiedy tylko jedna ze stron umowy będzie miała przynależność wspólnotową, druga zaś wywodzić się będzie spoza granic Unii ${ }^{30}$. Podobnie zresztą nie można ograniczać ich zastosowania wyłącznie do umów zawieranych między uczestnikami obrotu profesjonalnego, delimitując zastosowanie w odniesieniu do umów o charakterze konsumenckim ${ }^{31}$.

Mimo zaklasyfikowania Zasad PECL jako soft law, nie można odmówić im mocy wiążącej w dwóch przypadkach: kiedy strony w ramach danego stosunku obligacyjnego zastrzegą, że poddają łączącą je umowę Zasadom PECL ${ }^{32}$, jak i w sytuacji, kiedy strony wyraziły zgodę na poddanie ich umowy general principles of law, lex mercatoria bądź innym podobnym zasadom ${ }^{33}$. W pierwszym wypadku chodzi więc o klauzulę materialnoprawnego wskazania regulacji, która w obrocie międzynarodowym ma charakter powszechnie stosowany (tzw. wariant podstawowy $)^{34}$. W drugim wypadku, rozważając pojęcie general principles

${ }^{26}$ Zgodnie $\mathrm{z}$ tym przepisem: These Principles are intended to be applied as general rules of contract law in the European Communities.

27 Tak E. Wieczorek, Zasady europejskiego prawa umów, Gdańsk 2005, s. 11.

28 Szerzej na ten temat zob. M. Pazdan, E. Rott-Pietrzyk, Łaczniki w normach kolizyjnych [w:] System prawa prywatnego, t. 20B, Prawo prywatne międzynarodowe, red. M. Pazdan, Warszawa 2015, s. 231 i n.

29 Tak E. Wieczorek, Zasady, op. cit., s. 11.

30 Ibidem, s. 12.

31 Ibidem.

32 Zob. art. 1:101 ust. 2 Zasad PECL.

33 Zob. art. 1:101 ust. 3 Zasad PECL.

34 Korzystając z przysługującej autonomii woli stron - również na gruncie kolizyjnym strony nie określają tutaj wzajemnych praw i obowiązków, ale dokonują wskazania oznaczonego porządku prawnego (niekoniecznie krajowego), według reguł którego ma być oceniane powstanie, treść i wykonanie danego zobowiązania; szerzej o problematyce wyboru prawa i kwestii ustalania prawa właściwego w braku wyboru prawa zob. M. Paz- 
of law (tzw. wariant alternatywny), należy mieć na względzie zwłaszcza orzecznictwo TSUE ${ }^{35}$, które bardzo często odwołuje się do tradycji prawnych poszczególnych państw członkowskich ${ }^{36}$. Przywołane tutaj wyliczenie ma charakter przykładowy ${ }^{37}$. Co istotne, poziom ogólności wymienionych zbiorów norm sprawia, że nie nadają się one do bezpośredniego stosowania i wymagają każdorazowej konkretyzacji $a c a s u^{38}$, zaś same strony mogą także wyłączyć zastosowanie którejkolwiek z norm PECL (w tym uchylić lub zmienić wynikające z tego aktu skutki), chyba że z określonej zasady wynika co innego ${ }^{39}$.

Zasady PECL mogą znaleźć zastosowanie również w tych stanach faktycznych, dla których wskazany system prawny lub przepisy prawa właściwego nie przewidują żadnego rozstrzygnięcia ${ }^{40}$. Nie stoi tutaj na przeszkodzie okoliczność, że umowa podlega określonemu porządkowi prawnemu bądź to na skutek wybranego dla niej prawa, bądź na skutek zastosowania określonych łączników ${ }^{41}$. Można wręcz syntetycznie przyjąć, że PECL znajdzie zastosowanie w razie konieczności wypełnienia luk występujących zarówno w regulacjach pochodzących od ustawodawcy krajowego, jak i w aktach legislacji międzynarodowej, w szczególności w międzynarodowych konwencjach branych pod uwagę na etapie ustalania prawa właściwego, np. konwencji wiedeńskiej $1980 \mathrm{r}^{42}$. We wskazanych tu okolicznościach o zastosowaniu Zasad PECL każdorazowo rozstrzygać będzie organ stosujący ${ }^{43}$.

Uwaga „techniczna” dotyczy tego, że Zasady PECL stanowią, co prawda, bazę dla harmonizacji prawa prywatnego w ramach Unii Europejskiej ${ }^{44}$, jednak sam

dan, Wybór prawa, op. cit., s. 70 i n.; szczegółowo kwestie te rozważają także B. Fuchs, M. Jagielska i in., Prawo właściwe w braku wyboru prawa [w:] System prawa prywatnego, t. 20B, Prawo prywatne międzynarodowe, red. M. Pazdan, Warszawa 2015, s. 95-353.

Zob. B. Fuchs, Reguty, op. cit., s. 61.

36 Pozwala to tym samym na wyodrębnienie pewnego niekwestionowanego w doktrynie katalogu zasad o fundamentalnym znaczeniu dla praktyki obrotu, do którego zalicza się m.in. zasady pacta sunt servanda, bona fides, clausula rebus sic stantibus, ochrony praw nabytych czy ochrony zaufania; szerzej zob. E. Wieczorek, Zasady, op. cit., s. 14.

37 Tak też E. Rott-Pietrzyk, Harmonizacja prawa prywatnego w aktach prawa modelowego (soft law) [w:] System prawa handlowego, t. 9, Międzynarodowe prawo handlowe, red. W. Popiołek, Warszawa 2013 s. 54.

38 Podobnie A. Szumański, Renegocjacje umów w międzynarodowym obrocie gospodarczym. Studium prawnoporównawcze, Kraków 1994, s. 75.

39 Zob. art. 1:102 ust. 2 PECL, który stanowi, że [...] the parties may exclude the application of any of the Principles or derogate from or vary their effects, except as otherwise provided by these Principles. Zob. art. 1:101 ust. 4 Zasad PECL.

${ }^{41}$ Zob. E. Wieczorek, Zasady, op. cit., s. 14.

42 Tak E. Rott-Pietrzyk, Interpretacja umów, op. cit., s. 132.

43 Ibidem, s. 132, a także cytowani tam autorzy.

44 Jest to jednak jeden z tzw. celów długoterminowych; tak też E. Rott-Pietrzyk, Harmonizacja umów, op. cit., s. 57. Autorka ta wskazuje również, że: [cel długoterminowy - 
proces harmonizacyjny należy odróżniać od ujednolicenia prawa w drodze formalnego instrumentu normatywnego ${ }^{45}$, za który uchodzi chociażby projektowane rozporządzenie $\mathrm{CESL}^{46}$. Ma to istotne znaczenie na etapie dokonywania oceny „siły związania” prawodawców krajowych normami ponadnarodowymi przyjętymi w ramach harmonizacji prawa prywatnego (odrębną sprawą jest kwestia podnoszenia jakości tzw. acquis communautaire ${ }^{47}$ ). Można wręcz przyjąć, że często ujednolicanie instrumentem normatywnym stanowi konkretyzację postulatu ogólnej harmonizacjii ${ }^{48}$, co pozostaje nie bez znaczenia dla dalszych rozważań, których przedmiot jest obecnie w fazie założeń ogólnych.

\section{Wspólny System Odniesienia (DCFR)}

Draft Common Frame of Reference (DCFR) ${ }^{49}$ ma stanowić, według zamysłu twórców, fundament $\mathrm{w}$ procesie opracowywania wspólnych "politycznych instrumentów" w ramach acquis communautaire. Został pomyślany jako następca Zasad PECL, będący kolejnym krokiem na drodze unifikacji europejskiego prawa umów i w rozwoju wspólnotowego prawa modelowego ${ }^{50}$.

Po dokonaniu porównania obu aktów nie trudno zauważyć, że Zasady PECL zostały całkowicie inkorporowane przez DCFR, stanowiący ich poszerzoną wersję. Zabieg ten objął księgi I, II oraz III, które zdają się tożsame w obu aktach. Poszerzenie objęło natomiast całkowicie oderwane od konstrukcji Zasad PECL księgi IV-X, które wykraczają poza zakres części ogólnej prawa umów oraz części ogólnej dotyczącej wykonania i niewykonania zobowiązań umownych ${ }^{51}$. Swoim zakresem odnoszą się do pozaumownych źródeł zobowiązań, w szczególności bezpodstawnego wzbogacenia, negotiorum gestio oraz deliktów, a także problematyki powiernictwa, przeniesienia własności nieruchomości czy zabezpiecze-

przyp. A.M.J.] jest również realizowany i znajduje obecnie odzwierciedlenie $w$ instrumencie opcjonalnym.

45 Ibidem.

46 Proposal for a Regulation of the European Parliament and the Council on a Common European Sales Law, https://eur-lex.europa.eu/legal-content/EN/ TXT/?uri=CELEX\%3A52011PC0635 [dostęp 6 kwietnia 2019 r.]; dalej: CESL.

47 Szerzej na temat pojęcia acquis communautaire zob. np. A. Dana, Miejsce „acquis communautaire” w Konstytucji Rzeczypospolitej Polskiej, „Doctrina. Studia Społeczno-polityczne" 2006-2007, nr 3-4, s. 205-219.

48 Tak zdaje się E. Rott-Pietrzyk, Harmonizacja prawa prywatnego, op. cit., s. 57.

49 Draft Common Frame of Reference (DCFR) jest tłumaczony albo jako Wspólny System Odniesienia, albo jako Wspólne Ramy Odniesienia. W niniejszej pracy oba zwroty będą stosowane zamiennie. Szerzej co do terminologii zob. E. Rott-Pietrzyk, Harmonizacja prawa prywatnego, op. cit., s. 69

50 Tak E. Rott-Pietrzyk, ibidem.

51 Por. Ch. von Bar, E. Clive, H. Schulte-Nölke, Principles, Definitions and Model Rules, op. cit., s. 131 i n. 
nia na rzeczach ruchomych ${ }^{52}$. Najbardziej uwage przykuwa fakt, że twórcy DCFR odstąpili od konstruowania jego założeń na podstawie umowy jako naczelnej instytucji Systemu, posługując się szerszym pojęciem „zobowiązania”" ${ }^{3}$. Co więcej, obok pojęcia „zobowiązania” istotna rola w DCFR jest przypisywana także „czynności prawnej” (art. II-1:101) ${ }^{54}$.

Co ciekawe, jedna z najczęściej przywoływanych wokół DCFR kontrowersji ma charakter formalno-merytoryczny w tym sensie, że odwołuje się do normatywnych podstaw struktury i funkcjonowania DCFR w prawie unijnym, a także wskazuje na brak w jego założeniach mocnej podstawy komparatystycznej ${ }^{55}$. Przytacza się wręcz, że System opiera się głównie na XIX-wiecznym modelu kontynentalnego prawa cywilnego (ze szczególnie silnymi rysami prawa germańskiego i romańskiego), wypaczając założenia modeli skandynawskiego i common law. Prowadzić to może w efekcie do wyraźnej bipolaryzacji między różniącymi się instytucjami przywołanych modeli, tym samym uniemożliwiając sprawowanie roli faktycznego „układu odniesienia”. W odpowiedzi na te zarzuty autorzy DCFR podają, że wybrana przezeń normatywna struktura daje maksymalną elastyczność, którą można zapewnić przy nie do końca sprecyzowanych dziś celach, którym jednolite DCFR ma sprostać w przyszłości. Zdaniem twórców łatwiej jest bowiem w razie konieczności wprowadzać zmiany do części ogólnej prawa zobowiązań (jak np. w związku z ewentualnym pojawieniem się rozporządzenia CESL), niż rozbudowując prawo umów tak, by jego reguły mogły objąć zobowiązania pozaumowne ${ }^{56}$. Ponadto, jak słusznie zauważono, regulacja części ogólnej prawa zobowiązań, a w szczególności relewantnych z punktu widzenia dalszej części artykułu skutków niewykonania zobowiązania w akcie takim jak DCFR, jest wysoce pożądana przez wzgląd na konieczność zapewnienia sankcji zawartym w tym akcie obowiązkom przedkontraktowym i antydyskryminacyjnym, których w prekursorskich Zasadach PECL próżno było szukać ${ }^{57}$.

Najpoważniejsze z zarzutów kierowanych przeciwko Systemowi dotyczą jednak jego prawnego charakteru, a ściślej rzecz ujmując - podstaw legitymacji twórców DCFR do kształtowania europejskiego prawa prywatnego, której

52 Zob. E. Rott-Pietrzyk, Harmonizacja prawa prywatnego, op. cit., s. 70

53 Zob. P. Machnikowski, T. Pajor, Prawo prywatne Unii Europejskiej i jego wplyw na prawo polskie [w:] System prawa prywatnego, t. 1, Prawo cywilne - część ogólna, red. M. Safjan, Warszawa 2012, s. 311.

54 Podobnie P. Machnikowski, T. Pajor, Prawo prywatne, op. cit., s. 312, oraz cytowani tam autorzy.

55 Ibidem.

56 Zob. Ch. von Bar, E. Clive, H. Schulte-Nölke, Principles, Definitions and Model Rules, op. cit., s. 38-41.

57 Zob. P. Machnikowski, T. Pajor, Prawo prywatne Unii Europejskiej, op. cit., s. 312 in fine. 
wprost zarzuca się brak demokratycznej proweniencji ${ }^{58}$. Przy czym i ten zbiór argumentów bywa kontrowany przez podniesienie braku należytej dyferencjacji między akademicką i polityczną stroną Systemu. Jednak z uwagi na wyłącznie naukowy „rodowód” DCFR nie można żądać od jego twórców wykazania demokratycznej legitymacji wynikającej z prawa wspólnotowego, zaś ewentualne działania wymagające tejże legitymacji będą podejmowane tylko przez uprawnione do tego organy Unii Europejskiej ${ }^{59}$.

$\mathrm{Z}$ punktu widzenia prawa polskiego stosowanie reguł wynikających z prawa modelowego jako reguł normatywnych możliwe będzie wyłącznie w przypadku, gdy podmiot rozstrzygający spór będzie miał możność niekierowania się wiążącym wskazaniem prawa właściwego przez reguły kolizyjne prawa polskiego. Nietrudno więc dostrzec tutaj „komfortową” w pewnym sensie pozycję sądów arbitrażowych. Z kolei w odniesieniu do sytuacji, gdzie przepisy prawa modelowego przewidują swoje zastosowanie w sytuacji włączenia ich do umowy czy też wprowadzenia przez strony klauzuli poddającej umowę ich kognicji, w doktrynie dostrzeżono ${ }^{60}$, że nie będzie to mimo wszystko wspomniany uprzednio kolizyjnoprawny wybór prawa, a raczej materialnoprawne wskazanie regulacji ${ }^{61}$. To pierwsze zawsze oznacza bowiem poddanie zobowiązania określonemu systemowi prawnemu (tj. prawu merytorycznemu określonego państwa ${ }^{62}$, którego prawo jako wybrane staje się prawem właściwym dla określonego stosunku obligacyjnego. Trudno zatem reguły vel zasady prawa modelowego utożsamiać z prawem merytorycznym państwa, zważywszy, że te pierwsze mają, jak już wielokrotnie wspomniano, charakter soft law.

Konstrukcja materialnoprawnego wskazania regulacji prawnej stanowi natomiast jeden z najbardziej światłych przejawów swobody kontraktowej stron, której granice określa prawo merytoryczne właściwe dla stosunku zobowiązaniowego. Co istotne, przy konstruowaniu skutecznej inter partes umowy strony mogą albo włączyć do umowy postanowienia, mechanizmy czy instytucje zaczerpnięte z wybranego systemu prawa czy zbioru norm (inkorporacja), albo też wprost odwołać się do konkretnej regulacji (interpolacja) ${ }^{63}$. Posłużenie się materialnoprawnym wskazaniem dopuszczalne jest jednak wyłącznie w granicach norm

$58 \quad$ Ibidem, s. 313.

59 Ibidem.

60 Ibidem, s. 314; także J. Skąpski, Autonomia woli w prawie prywatnym międzynarodowym w zakresie zobowiązań z umów, Kraków 1964, s. 31; J. Gołaczyński, Prawo prywatne międzynarodowe, Warszawa 2003, s. 126 i n.

${ }_{61}$ Szerzej na temat materialnoprawnego wskazania regulacji prawnej zob. M. Pazdan, Wybór kolizyjnoprawny, op. cit., s. 74-75. Co do związania sądu państwowego materialnoprawnym wskazaniem zob. przyp. 21.

62 Ibidem, s. 75.

63 Ibidem. 
ustanawiających swobodę kontraktową w rodzimym systemie prawa ${ }^{64}$. Prowadzi to do wniosku, że powołane w taki sposób normy nie będą mogły zastąpić norm imperatywnych lub semiimperatywnych prawa krajowego, w przeciwieństwie do norm o charakterze dyspozytywnym ${ }^{65}$.

\section{Kara umowna jako agreed payment for non-performance w UNIDROIT PICC}

Jak wspomniano, praktyczne działanie prawa modelowego zostanie przedstawione na przykładzie regulacji kary umownej zarówno w tym prawie, jak i w porównaniu z rozwiązaniami przyjętymi przez ustawodawcę polskiego. Z uwagi na szeroki zakres zastosowania Reguł UNIDROIT w skali globalnej ${ }^{66}$ zostaną one rozważone w pierwszej kolejności.

Już na wstępie warto sprostować, że Reguły UPICC nie określają interesującego nas dodatkowego zastrzeżenia umownego „karą umowną"67. Podobnie zresztą żaden akt europejskiego prawa modelowego nie posługuje się tym pojęciem wprost, wprowadzając właściwe sobie odpowiedniki ${ }^{68}$. I tak Reguły w art. 7.4.13 pkt 1 posługują się pojęciem agreed payment for non-performance, czyli „uzgodnionej płatności za niewykonanie" ${ }^{\text {" }}$. Zgodnie z treścią tego przepisu: jeżeli umowa przewiduje, że strona, która nie spełni swojego świadczenia, zapłaci $z$ tego tytułu określona sumę pieniężną, suma ta należy się wierzycielowi niezależnie od faktycznie poniesionej szkody [wyróżnienie - A.M.J.] ${ }^{70}$.

Odnosząc się do wykładni literalnej komentowanego przepisu, trzeba wziąć pod uwagę kilka okoliczności. Po pierwsze, nie budzi zastrzeżeń, że regulacja art. 7.4.13 pkt 1 UPICC ma charakter w wysokim stopniu syntetyczny. Jest to $\mathrm{z}$ pewnością pożądane $\mathrm{z}$ uwagi na dzisiejszy zintensyfikowany rozwój między-

64 Tak też J. Skąpski, Autonomia woli, op. cit., s. 31.

65 Podobnie o niemożności pozostawania w sprzeczności norm prawa obcego, powołanych w skutek materialnoprawnego wskazania regulacji względem przepisów kogentnych prawa krajowego - zob. M. Pazdan, Wybór kolizyjnoprawny, op. cit., s. 76 in fine; zob. także Prawo prywatne Unii Europejskiej, op. cit., s. 315.

${ }_{66}$ Tak M. Romanowski, Ogólne reguły wykładni kontraktów w świetle zasad europejskiego prawa kontraktów a reguly wykładni umów w prawie polskim, „Przegląd Prawa Handlowego" 2004, nr 8, s. 11.

67 Zob. Reguły UNIDROIT, art. 7.4.13, s. 339.

68 Por. art. 7.4.13 pkt. 1 UPICC, art. 9: 305 ust. 1 PECL, art. III-3:712 ust. 1 DCFR.

69 Zob. M. Jagielska, M. Szpunar, Polski przekład Reguł UNIDROIT, „Problemy Prawa Handlu Zagranicznego" 2000, t. 19/20, s. 358.

70 Ibidem; dla przejrzystości rozważań, aby uniknąć każdorazowego powtarzania formuły o „uzgodnionej płatności za niewykonanie”, posługiwał się będę zamiennie terminem agreed payment, kary umownej lub kary umownej w UPICC. 
narodowych stosunków handlowych i dywersyfikację podmiotów w nich uczestniczących. Taki zresztą był zamysł samych autorów przedmiotowej regulacji, tj. konstrukcja definicji na tyle modalnej, aby strony w zakresie łączącej je umowy mogły swobodnie konstruować klauzule o charakterze kompensacyjnym, symplifikacyjnym czy represyjno-prewencyjnym, w zależności od preferowanego przez nie celu, którego osiągnięcie to zastrzeżenie miałoby wspierać ${ }^{71}$. Konsekwencją tych założeń jest posługiwanie się przez UPICC pojęciem „ustalonej płatności”, które obejmować będzie zarówno świadczenia zastrzeżone tytułem odszkodowania, jak i te, które mają zapewnić realne wykonanie zobowiązania przez przymuszenie dłużnika do zaspokojenia wierzyciela zgodnie z treścią stosunku podstawowego.

Po drugie, Reguły odwołują się do istnienia oznaczonej „umowy”, z której wynikał będzie obowiązek dłużnika do zapłaty określonej sumy wierzycielowi na skutek niespełnienia swojego świadczenia. Ma to istotne znaczenie w odniesieniu zarówno do polskiej konstrukcji kary umownej, jak i w prospekcie rozważań o karze umownej w europejskim prawie modelowym. W pierwszym przypadku ustawodawca polski w treści art. $483 \$ 1$ in principio k.c. powiada, że: można zastrzec $\boldsymbol{w}$ umowie [wyróżnienie - A.M.J.], że naprawienie szkody [...]. Wskazuje to na zbieżność zarówno twórców Reguł UNIDROIT, jak i ustawodawcy polskiego co do „fundamentu”, na którym co do zasady możliwe jest konstruowanie kary umownej. W obu regulacjach expressis verbis przyjęto kontrakt. Z kolei drugi przypadek zostanie, co prawda, szczegółowo omówiony w punkcie poświęconym Zasadom PECL i prawu DCFR, to jednak warto już teraz zasygnalizować, że podstawy zastrzeżenia kary umownej w tych aktach są odmienne.

Po trzecie, przedmiot kary umownej w Regułach UNIDROIT został zawężony do specified sum ${ }^{72}$, czyli oznaczonej sumy należnej wierzycielowi. Zgodnie bowiem $\mathrm{z}$ art. $7.4 .13 \mathrm{pkt}$ 1: where the contract provides that a party who does not perform is to pay specified sum [wyróżnienie - A.M.J.] to the aggrieved party $[\ldots]^{73}$. W tym zakresie definicja ta pozostaje zbieżna $\mathrm{z}$ regulacją art. $483 \$ 1$ in fine k.c., w której ustawodawca rozstrzygnął, że naprawienie szkody wynikłej z niewykonania lub nienależytego wykonania zobowiązania niepieniężnego nastąpi przez „zapłatę określonej sumy”. Warto przy tym przypomnieć, że definicja agreed payment obejmuje klauzule ustalające ex ante zryczałtowane odszkodowanie $\mathrm{z}$ tytułu niewykonania zobowiązania zarówno w celu represyjnym, jak i kompensacyjnym ${ }^{74}$.

71 Zob. Reguły UNIDROIT, s. 284.

72 Tak też P. Drapała, A. Olejniczak, Dodatkowe zastrzeżenia, op. cit., s. 1136.

73 Zob. Reguły UNIDROIT, s. 289.

74 Tak P. Drapała, A. Olejniczak, Dodatkowe zastrzeżenia, op. cit., s. 1135. Zob. także A.M. Juranek, Kara umowna, wybrane klauzule quasipenalne oraz klauzule indemnifikacyjne $w$ prawie polskim i prawie modelowym. Rozważania de lege lata $i$ de lege ferenda, Katowice 2019, s. 15-17. 
Po czwarte, twórcy Reguł UNIDROIT zastrzegli, że roszczenie wierzyciela o zapłatę kary umownej powstaje bez względu na okoliczność poniesienia przez niego szkody (irrespective of its actual harm ${ }^{75}$ ), a więc tym bardziej irrelewantna jest jej wysokość. Ma to przemożne znaczenie wobec toczącej się w polskiej doktrynie dyskusji w kontekście związku między roszczeniem o zapłatę kary umownej a szkodą, której niewystąpienie w dalszym ciągu uznawane jest przez część piśmiennictwa za negatywną przesłankę dochodzenia komentowanego roszcze$\mathrm{nia}^{76}$. Co istotne, również analiza najnowszego orzecznictwa wskazuje na coraz częstsze odwoływanie się sądów krajowych do regulacji prawa modelowego, co de lege ferenda implikuje konieczność wzięcia pod uwagę przyjmowanych przez nie rozwiązań 77 .

\section{Zob. art. 7.4.13 pkt 1 in fine UPICC.}

76 Za możnością zwolnienia się przez dłużnika z obowiązku zapłaty kary umownej w razie wykazania, że wierzyciel w ogóle szkody nie poniósł, opowiedzieli się m.in. J. Dąbrowa, Kara umowna [w:] System prawa cywilnego, t. III, cz. 1, Prawo zobowiazań - część ogólna, red. Z. Radwański, Warszawa 1981, s. 831; K. Zagrobelny, Komentarz do art. 484 [w:] Kodeks cywilny. Komentarz, red. E. Gniewek, P. Machnikowski, Warszawa 2017, s. 1021; P. Drapała, A. Olejniczak, Dodatkowe zastrzeżenia, op. cit., s. 1149-1150; wcześniej także W. Warkałło, Wykonywanie zobowiązań i skutki ich niewykonania według Kodeksu cywilnego, „Państwo i Prawo” 1965, z. 8-9, s. 216. Odmiennie, a więc w obronie interesu wierzyciela m.in. Z. Radwański, A. Olejniczak, Zobowiązania - część ogólna, Warszawa 2014, s. 365-367; W. Borysiak, Glosa do uchw. SN (7) z 06.11.2003 r., sygn. akt III CZP 61/03, „Monitor Prawniczy” 2007, nr 6; F. Zoll, Pojęcie niewykonania i nienależytego wykonania zobowiązania oraz kwalifikowane postaci naruszenia zobowiazania i ich skutki [w:] System prawa prywatnego, t. 6, Prawo zobowiązań - czesść ogólna, red. A. Olejniczak, Warszawa 2018, s. 1219-1220; W. Popiołek, Komentarz do art. 483 [w:] Kodeks cywilny, t. II, Komentarz. Art. 450-1088, red. K. Pietrzykowski, Warszawa 2018, nb. 4; wcześniej także J. Szwaja, Kara umowna wedtug Kodeksu cywilnego, Warszawa 1967, s. 89.

77 Zob. uchwała SN (7) z 6 listopada 2003 r., sygn. akt III CZP 61/03, OSNC 2004, nr 5, poz. 69, w której stwierdzono, że: za wyrażonym $w$ uchwale stanowiskiem mogq przemawiać także rozwiązania prawne przyjmowane $w$ ramach regulacji prawa kontraktowego o charakterze międzynarodowym, dotyczące bezpośrednio instytucji kary umownej. W art. 7.4.13 przyjętych przez UNIDROIT zasad międzynarodowych umów handlowych z 5.1994 r. (Principles of International Commercial Contracts), stwierdzono, że jeżeli w umowie określono, iż strona, która jej nie wykona, zapłaci drugiej stronie określona kwotę $w$ razie niewykonania zobowiązania, to druga strona będzie uprawniona do żądania tej kwoty niezależnie od faktycznie poniesionej szkody. Jeżeli nie postanowiono inaczej, wspomniana kwota pieniężna może być obniżona do odpowiedniej wysokości, gdy jest rażąco wygórowana w relacji do szkody wynikajacej z niewykonania zobowiązania lub innych okoliczności. Podobna regulację zawarto $w$ art. $9.5 .09 \mathrm{za}$ sad europejskiego prawa kontraktowego (The Principles of European Contract Law $z 7.1998$ r., Europdische Vertagsrechts-vereinheitlichung unddeutsches Recht, Tubingen, 2000, s. 219 i nast.); a także wyrok SN z 24 czerwca 2014 r., sygn. akt I CSK 392/13, 
Piąte zastrzeżenie - zdaje się najistotniejsze z punktu widzenia konstrukcji kary wadialnej przyjętej w Kodeksie cywilnym - odnosi się do charakteru zobowiązania, którego niewykonanie lub wykonanie w sposób nienależyty wiąże się z powstaniem po stronie wierzyciela roszczenia o zapłatę kary umownej. W polskiej doktrynie przeważa stanowisko, że kara ta może zostać zastrzeżona wyłącznie względem świadczenia o charakterze niepieniężnym ${ }^{78}$. Niektórzy autorzy akcentują jednak, że nie jest niedopuszczalne zastrzeżenie w umowie obowiązku zapłaty oznaczonej sumy pieniężnej w związku z niewykonaniem lub nienależytym wykonaniem zobowiązania, jednak nie będzie to kara umowna w rozumieniu art. $483 \$ 1$ k.c. $^{79}$. Konsekwencją przyjęcia tego poglądu jest delimitacja możności zastrzegania kar umownych wyłącznie do zobowiązań o charakterze niepieniężnym, która nie występuje ani w Regułach UNIDROIT, ani w innych omawianych przeze mnie aktach prawa modelowego. Autorzy UPICC stoją na stanowisku, że dynamika współczesnego obrotu gospodarczego wymusza na prawodawstwie przyjmowanie takich założeń, które przyczynią się do uelastycznienia regulacji krajowych w zakresie, w jakim poprawi to płynność i rozwój stosunków w handlu, szczególnie międzynarodowym ${ }^{80}$. Wprowadzanie niemodalnych regulacji, ograniczających swobodę kontraktową stron w zakresie pożądanych przezeń zastrzeżeń przymuszających do realnego wykonania zobowiązania nie jest poglądem, który w ówczesnych realiach może zasługiwać na poparcie. Należałoby w zasadzie dopuścić każdą możliwość umówienia się stron co do tego, w jaki sposób chcą zabezpieczyć wykonanie istniejącego między nimi zobowiązania (o charakterze pieniężnym lub niepieniężnym), o ile tylko nie będzie to stanowiło naruszenia zasad rządzących swobodą kontraktowania, porządku publicznego państwa, którego prawu umowa jest poddana, czy w końcu jakichś innych reguł, honorowanych w handlu międzynarodowym (w postaci zarówno ogólnych zasad prawa, jak i lex mercatoria oraz innych) ${ }^{81}$.

Szósta uwaga dotyczy kwestii, która w Kodeksie cywilnym została expressis verbis rozstrzygnięta przez ustawodawcę, natomiast w Regułach UNIDROIT ma charakter niejednoznaczny. Próżno bowiem szukać w art. 7.4.13 pkt 1 i 2 UPICC odniesienia się do kwestii odpowiedzialności dłużnika, a konkretniej - zakresu tejże. W prawie polskim stosuje się w tym kontekście m.in. art. 473 k.c., mocą którego dłużnik może w drodze umowy przyjąć na siebie odpowiedzialność za

Legalis; uchwała SN z 19 listopada 2010 r., sygn. akt III CZP 70/10; wyrok SN z 5 października 2006 r., sygn. akt IV CSK 157/06; szczególnie także wyrok SA w Katowicach z 24 września 2014 r., sygn. akt I ACa 378/14, Legalis.

78 Szerzej nt. zob. A.M. Juranek, Kara umowna, op. cit., s. 15 i n.

79 Zob. F. Zoll, Pojęcie niewykonania, op. cit., s. 1225.

80 Zob. Reguły UNIDROIT, s. 289.

81 Można przyjąć, że w podobnym kierunku zmierza P. Widerski, Charakter prawny kary umownej wedtug prawa polskiego na tle ponadnarodowych uregulowań prawnych, „Studia Prawa Prywatnego” 2018, nr 2, s. 12-13. 
niewykonanie lub nienależyte wykonanie zobowiązania z powodu wskazanych w tej umowie okoliczności, za które na mocy przepisów ustawy odpowiedzialności by nie ponosił. W przypadku Reguł UNIDROIT, co prawda, nie wynika to z treści art. 7.4.13 pkt 1 i 2, natomiast w komentarzu do tego przepisu zaznaczono, że za niewykonanie zobowiązania dłużnik musi ponosić odpowiedzialność ${ }^{82}$. Nie stoi to jednak na przeszkodzie odmiennego umówienia się inter partes, a więc wprowadzenia do umowy klauzuli, która zakres odpowiedzialności dłużnika rozszerzy również na niewykonanie lub nienależyte wykonanie tych obowiązków umownych, za których niewykonanie lub nienależyte wykonanie „W wersji podstawowej” odpowiedzialności by nie poniósł³. Przyjęcie rozszerzonej odpowiedzialności przez dłużnika na podstawie prawa polskiego ma jednak ten skutek, że takie zastrzeżenie jest traktowane jako tzw. zobowiązanie typu gwarancyjnego $^{84}$, nie zaś jako kara umowna ${ }^{85}$. Może mieć charakter co najwyżej zbliżony do kary umownej ${ }^{86}$. Oczywiście - powołany art. 473 k.c. nie jest jedyną możliwością w zakresie modyfikacji zakresu ustawowej odpowiedzialności dłużnika; odpowiednie zastosowanie znajdzie chociażby art. $353^{1}$ k.c. ${ }^{87}$.

\section{Zob. Reguły UNIDROIT, s. 289.}

83 Ibidem; podobnie P. Widerski, Charakter prawny kary, op. cit., s. 13.

84 Kwestia ta jest wielorako rozumiana terminologicznie; także w postaci „klauzuli gwarancyjnej”, „kary gwarancyjnej”, „zobowiązania gwarancyjnego” itp.

85 Reperkusją przyjęcia takiego stanowiska może być to, że względem zobowiązań typu gwarancyjnego co do zasady nie stosuje się instrumentu miarkowania, który w kontekście kary umownej przewiduje art. 484 k.c. - szerzej nt. zob. A.M. Juranek, Kara umowna, op. cit., s. 93-96; także literaturę cytowaną w przypisie 88. Z kolei o różnicach między karą umowną i zobowiązaniem gwarancyjnym zob. także Z. Radwański, A. Olejniczak, Zobowiązania, op. cit., s. 335; J. Dąbrowa, Kara umowna, op. cit., s. 829; K. Zagrobelny, Komentarz do art. 483 [w:] Kodeks cywilny. Komentarz, red. E. Gniewek, P. Machnikowski, Warszawa 201 s. 902; E. Skowrońska-Bocian, Kara umowna kompensacja czy represja?, „Zeszyty Prawnicze UKSW” 2003, nr 3/2, s. 192. Niektórzy autorzy przyjmują, że nie można ustanowić kary umownej jako zobowiązania o charakterze wyłącznie gwarancyjnym w tym znaczeniu, że dłużnik byłby zobligowany do świadczenia kary, mimo że nie ponosi odpowiedzialności z tytułu niewykonania (nienależytego wykonania) zobowiązania - tak P. Drapała, A. Olejniczak, Dodatkowe zastrzeżenia, op. cit., s. 1152.

86 Tak SN w wyroku z 15 października 2008 r., sygn. akt I CSK 154/08, Legalis.

87 Szerzej zob. także K. Zagrobelny, Komentarz do art. 472 [w:] Kodeks cywilny. Komentarz, red. E. Gniewek, P. Machnikowski, Warszawa 2017, s. 904; W. Popiołek, Komentarz do art. 472 [w:] Kodeks cywilny, t. II, Komentarz. Art. 450-1088, red. K. Pietrzykowski, Warszawa 2018, nb. 2; M. Lemkowski, Kara umowna w przypadku odstapienia od umowy [w:] Kodeks cywilny, t. II, Komentarz do art. 353-626, red. M. Gutowski, Warszawa 2019, nb. 10, oraz cytowani tam autorzy; F. Zoll, Pojęcie niewykonania, op. cit., s. 1172. 
Ostatnia uwaga dotyczy relewantności wyboru dokonanego między stronami stosunku obligacyjnego co do tego, za pomocą jakiego „kształtu” klauzuli zabezpieczą wykonanie zobowiązania. Chodzi tutaj oczywiście o to, czy będzie to klasyczna kara umowna, o której mowa w art. 483 k.c. i art. 7.4.13 pkt 1 UPICC, z jednocześnie skorelowanym odpowiednio $\mathrm{w}$ art. $484 \$ 2$ k.c. i art. 7.4.13 pkt 2 UPICC instrumentem miarkowania, czy zobowiązanie typu gwarancyjnego, względem którego stosowanie tego mechanizmu pozostaje kwestią dyskusyjną ${ }^{88}$. Należy zważyć, że zarówno Reguły UNIDROIT ${ }^{89}$, jak i część przedstawicieli polskiej doktryny ${ }^{90}$ istnienie szkody słusznie uznaje za jedną z przesłanek, które winny zostać uwzględnione na etapie ewentualnego miarkowania kary wadialnej, nie zaś jako przesłankę negatywną co do powstania samego roszczenia o jej zapłatę.

\section{Kara umowna jako agreed payment for non-performance w Zasadach PECL i stipulated payment for non-performance w Systemie DCFR}

Mając na uwadze dokonane już omówienie zależności pomiędzy Zasadami PECL a prawem modelowym DCFR, ograniczę się wyłącznie do stwierdzenia, że w zakresie kary umownej oba komentowane akty są w dużej mierze zbieżne. Elementy dyferencjujące przyjęte w nich konstrukcje zostaną omówione poniżej.

Zachowuje swoją aktualność twierdzenie, że ani Zasady PECL, ani system DCFR - podobnie jak uprzednio rozważane Reguły UNIDROIT - nie posługują się pojęciem kary umownej. W pierwszej z powołanych regulacji odpowiednik jest $\mathrm{w}$ istocie terminologicznie tożsamy $\mathrm{z}$ tym występującym $\mathrm{w}$ art. 7.4 .13 pkt 1 UPICC, tzn. agreed payment for non-performance, a powinien być rozumiany

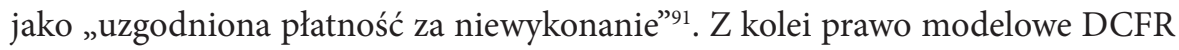
posługuje się terminem stipulated payment for non-performance ${ }^{92}$, tłumaczonym jako „zastrzeżona płatność za niewykonanie”. Podobnie zresztą jak w przypadku art. 7.4.13 UPICC, również względem regulacji z art. 9:509 PECL i art. III-3:712

88 Szerzej zob. J. Jastrzębski, Nietypowe kary umowne - swoboda sankcji kontraktowych i ochrona dtużnika, „Przegląd Prawa Handlowego” 2014, nr 6, s. 11 i n.

89 Zob. Reguły UNIDROIT, art. 7.4.13, s. 289.

90 Zob. w szczególności W. Popiołek, Komentarz do art. 484 [w:] Kodeks cywilny, t. II, Komentarz. Art. 450-1088, red. K. Pietrzykowski, Warszawa 2018, nb. 6.

91 Zob. art. 9:509 pkt 1 PECL; zgodnie z tym przepisem: Where the contract provides that a party who fails to perform is to pay a specified sum to the aggrieved party for such nonperformance, the aggrieved party shall be awarded that sum irrespective of its actual loss.

92 Zob. art. III-3:712 pkt 1 DCFR, zgodnie z którym: Where the terms regulating an obligation provide that a debtor who fails to perform the obligation is to pay a specified sum to the creditor for such non-performance, the creditor is entitled to that sum irrespective of the actual loss. 
DCFR zasadne jest twierdzenie, że syntetyczność tych regulacji w pełni odpowiada współczesnym wymogom wynikającym z realiów międzynarodowego obrotu handlowego.

Zgodnie z treścią art. 9:509 pkt 1 PECL: jeżeli zgodnie z umowa strona, która nie spełnia świadczenia, zobowiązana jest $z$ tego tytułu zapłacić określona sume poszkodowanemu, suma ta należy się wierzycielowi bez względu na wysokość faktycznie poniesionej szkody [wyróżnienie - A.M.J.] ${ }^{93}$. Komentowany przepis nie różni się więc znacząco od regulacji, która została wyrażona art. 7.4.13 pkt 1 UPICC. Można wręcz stwierdzić, że podstawowe założenia w skali globalnej (tj. Reguły UNIDROIT) zostały w tej materii recypowane na grunt europejskiego prawa modelowego. Większość komentarzy poczynionych w odniesieniu do art. 7.4.13 UPICC pozostaje więc aktualna także względem art. 9:509 PECL.

Odmiennie sytuacja przedstawia się w przypadku analizowania projektu Wspólnej Ramy Odniesienia. W treści art. III-3:712 ust. 1 DCFR zastrzeżono bowiem, że: jeżeli zgodnie z warunkami regulujacymi zobowiązanie dłużnik, który nie spetnia zobowiązania, zobowiązany jest z tego tytułu zapłacić określona sume wierzycielowi, wierzyciel jest uprawniony do tej sumy bez względu na wysokość faktycznie poniesionej szkody [wyróżnienie - A.M.J.] ${ }^{94}$. Warto zauważyć, że zasadniczym pojęciem, którym posługują się twórcy DCFR, nie jest już występująca w Regułach UNIDROIT i Zasadach PECL „umowa”, ale znacznie szersze

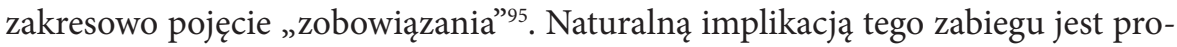
porcjonalne poszerzenie zakresu przedmiotowego DCFR w porównaniu z jego normatywnymi „poprzednikami”"96.

Z uwagi na leksykalną zbieżność występującą w odniesieniu do regulacji kary umownej we wszystkich trzech powołanych aktach prawa modelowego, brak jest

93 M.A. Zachariasiewicz, J. Bełdowski, Europejskie prawo umów. Principles of European Contract Law. Les principes du droit europeen des contrats. Zasady europejskiego prawa umów (tłum. z jęz. angielskiego i francuskiego), cz. I i II, „Kwartalnik Prawa Prywatnego" 2004, nr 3, s. 814 i n.; a także zob. J. Bełdowski, A. Kozioł, Principles of European Contract Law, part III. Les principes du droit europeen du contrat, partie III (Zasady europejskiego prawa umów, część III), „Kwartalnik Prawa Prywatnego”2006, nr 3, s. 860 i n.

Zob. P. Widerski, Charakter prawny kary, op. cit., s. 15.

95 Podobnie zob. P. Machnikowski, T. Pajor, Prawo prywatne w Unii Europejskiej, op. cit., s. 311-312.

96 Całość aktu liczy obecnie X Ksiąg, a więc o 7 więcej, niż było to w przypadku Zasad PECL. DCFR obejmuje bowiem nie tylko prawo kontraktów, ale także kwestie negotiorum gestio, czynów niedozwolonych, bezpodstawnego wzbogacenia, zabezpieczenia na ruchomościach, przeniesienia własności ruchomości czy powiernictwa. Zwraca się także uwagę na istotne znaczenie pojęcia „czynności prawnej” (art. II-1:101 DCFR). Dokonano wyraźnego oddzielenia części ogólnej od szczegółowej prawa zobowiązań - zob. szerzej P. Machnikowski, T. Pajor, Prawo prywatne w Unii Europejskiej, op. cit., s. 312. 
przeszkód do uznania, że komentarze autorów Reguł UNIDROIT znajdą zastosowanie również i w tych przypadkach ${ }^{97}$. Tym samym agreed/stipulated payment będzie - w zależności od przyjętego przez strony wariantu - realizowała albo funkcję surogatu odszkodowania z tytułu niewykonania (nienależytego wykonania) zobowiązania, albo będzie zastrzeżeniem represyjno-prewencyjnym, zmierzającym do zapewnienia realnego wykonania zobowiązania ${ }^{98}$. Zakres obu pojęć jest w tym wypadku szeroki.

Zarówno art. 9:509 PECL, jak i art. III-3:712 DCFR pozostają zbieżne z regulacją art. $483 \$ 2$ k.c. w zakresie przysługującego dłużnikowi facultas alternativa co do wyboru między zapłatą kary umownej a wykonaniem zobowiązania, nie przewidując takiej możliwości. Oba akty wypowiadają się w sprawie non-performance, tj. niewykonania, a nie alternative performance, $\mathrm{tj}$. alternatywnego wykonania zobowiązania99.

Różnica po raz kolejny pojawia się względem przedmiotu umowy - zarówno Reguły UNIDROIT, jak i Zasady PECL posługiwały się pojęciem „świadczenia”. Prawo modelowe DCFR posługuje się w tym zakresie terminem „zobowiązania”. Żaden z tych aktów nie wprowadza znanej w polskim prawie prywatnym delimitacji, o której mowa w art. $483 \$ 1$ k.c., który statuuje karę umową wyłącznie względem zobowiązań o charakterze niepieniężnym. Cechą spójną dla wszystkich powołanych wyżej regulacji jest z kolei modalne określenie przedmiotu kary konwencjonalnej jako specified sum. Nie ma więc przeszkód, by w „podstawowej” postaci agreed payment zostało wyrażone przez zryczałtowaną sumę, należną wierzycielowi na skutek niewykonania lub nienależytego wykonania tak zobowiązania, jak i pojedynczego obowiązku. W postaci „kwalifikowanej” określenie wysokości kary umownej może nastąpić przez odwołanie się do jakiegoś obiektywnego wskaźnika, pozwalającego na ustalenie określonej sumy w konkretnych okolicznościach ${ }^{100}$. Aktualne pozostają także poczynione względem Reguł UNIDROIT i Zasad PECL ustalenia co do określenia przez strony granic odpowiedzialności dłużnika, w tym w ramach umownego rozszerzenia tej odpowiedzialności ${ }^{101}$.

Również wyróżniane w polskiej doktrynie kary umowne alternatywne i zaliczalne zachowują znaczenie w przypadku sięgania do reguł europejskiego prawa modelowego. Zarówno bowiem PECL, jak i DCFR dopuszczają możliwość zastrzeżenia oznaczonej, minimalnej kwoty kary wadialnej. Wierzyciel będzie mógł oczywiście uzyskać większą kwotę zaspokojenia, jeśli tylko udowodni, że

97 Tak też P. Widerski, Charakter prawny kary, op. cit., s. 16.

98 Ibidem.

99 Tak też Ch. von Bar, E. Clive, H. Schulte-Nölke, Principles, Definitions and Model Rules, op. cit., s. 963.

100 Zob. P. Widerski, Charakter prawny kary, op. cit., s. 36.

101 Ibidem. 
poniesione przez niego straty przekraczają umówioną kwotę minimalną ${ }^{102}$. Pytanie można postawić odnośnie do tego, jaką formę powinno przyjąć „wyrównanie" wysokości kary umownej zastrzeżonej poniżej faktycznie doznanej straty w sytuacji, gdy umówiona między stronami kara konwencjonalna miałaby zostać oszacowana przez zastosowanie obiektywnych wskaźników, dozwalających na precyzyjne wskazanie jej wysokości. W takiej sytuacji można prima facie przyjąć, że nastąpi to albo przez dopłatę oznaczonej kwoty zmierzającej do pokrycia różnicy między sumą zastrzeżoną jako kara umowna przez zastosowanie wskaźnika obiektywnego a rzeczywiście poniesioną przez wierzyciela stratą. Drugim sposobem mógłby okazać się albo wybór innego wskaźnika, albo jednoczesne zastosowanie dodatkowego wskaźnika w celu wyrównania rzeczywiście poniesionej straty. Byłby to więc - utrzymując przyjętą przeze mnie konwencję terminologiczną - mechanizm odwróconego miarkowania. Wątpliwości te można jednak uczynić, w mojej ocenie, bezprzedmiotowymi, konstruując „wskaźnik kaskadowy", a więc następujący jeden po drugim aż do pokrycia straty, z jednoczesnym zachowaniem ogólnych ograniczeń swobody umów.

Kary umowne zastrzegane w zgodzie z „poszerzoną” wersją prawa modelowego DCFR mogą być także wprowadzane do kontraktu na wypadek niewykonania lub wykonania w sposób nienależyty przez dłużnika zobowiązania pozaumownego $^{103}$, co jest stanowiskiem powszechnie aprobowanym również w polskiej doktrynie i judykaturze względem art. 483-484 k.c. ${ }^{104}$.

\section{Podsumowanie}

W toku powyższych rozważań zbadano zjawisko postępującej harmonizacji prawa prywatnego, analizując w tym kontekście założenia wynikające $\mathrm{z}$ tzw. prawa modelowego, a następnie dokonano szczegółowego wskazania praktycznego oddziaływania tychże norm na reguły przyjęte w prawie krajowym (tu: polskim).

102 Zob. O. Lando, H. Beal, The Principles of European Contract Law. Part I: Performance, Non-Performance and Remedies, Dordrecht 1995, s. 454 (w odniesieniu do PECL); także Ch. von Bar, E. Clive, H. Schulte-Nölke, Principles, Definitions and Model Rules, op. cit., s. 962 (w odniesieniu do DCFR).

103 Zob. Ch. von Bar, E. Clive, H. Schulte-Nölke, Principles, Definitions and Model Rules, op. cit., s. 962.

104 Zob. w szczególności W. Borysiak, Komentarz do art. 483 KC [w:] Kodeks cywilny. Komentarz, t. IIIA, Zobowiązania. Czesść ogólna, red. K. Osajda, Warszawa 2017, nb. 31, 51; P. Drapała, A. Olejniczak, Dodatkowe zastrzeżenia, op. cit., s. 1140-1141; Z. Radwański, A. Olejniczak, Zobowiązania, op. cit., s. 334-335; A. Rzetecka-Gil, Komentarz do art. 483 KC [w:] Kodeks cywilny. Zobowiązania. Część ogólna. Komentarz, red. A. Rzetecka-Gil, Warszawa 2011, nb. 9; K. Zagrobelny, Komentarz do art. 483, op. cit., s. 902; zob. także wielokrotnie powoływaną uchwałę SN (7) z 6 listopada 2003 r., sygn. akt III CZP 61/03, Legalis. 
Przeprowadzone badania komparatystyczne doprowadziły do sformułowania kilku istotnych wniosków. Po pierwsze, współczesna legislatywa ustawodawstw krajowych w coraz mniejszym stopniu może istnieć „sama sobie”, a więc w oderwaniu od analogicznych regulacji występujących zarówno w prawie ponadnarodowym, jak i w ustawodawstwach państw obcych. Umiędzynarodowienie stosunków między podmiotami prawa prywatnego sprawia, że prawo krajowe musi przewidywać mechanizmy służące ochronie prawnej uczestników tych stosunków (zwłaszcza w płaszczyźnie zobowiązaniowej), a liczba sytuacji, w których dana sytuacja prawna jest „niezauważalna” przez optykę prawa forum, powinna zostać zdecydowanie zmarginalizowana, czemu, w moim przekonaniu, służy odwoływanie się przez judykaturę do prawa modelowego. Nie należy jednak wniosku tego utożsamiać z postulatem bezkrytycznego powielania instytucji istniejących $\mathrm{w}$ różnych systemach prawnych na potrzeby każdocześnie rozpatrywanej sprawy. Chodzi tu bowiem nie o „identycznośc” rozwiązań przyjętych w danym zakresie, ale o wyposażenie systemu prawa krajowego w „instrumentarium dostosowawcze”, które umożliwiłoby reakcję organu stosującego prawo na pojawienie się w rozpatrywanej przezeń sprawie sytuacji, dla której ramy instytucjonalne fori nie pozostają hermetycznie zamknięte. Po drugie, czerpanie z rozwiązań przyjętych w model law gwarantuje posługiwanie się instrumentarium, które wielokrotnie zostało poddane funkcjonalnej „ofensywie” w systemach prawnych państw, z których wywodzą się „konstruktorzy” rozwiązań iniekowanych do prawa modelowego. Po trzecie, wyposażenie systemu prawa krajowego w „mechanizmy dostosowawcze" znacznie usprawni i uwydatni intensyfikację obrotu gospodarczego przez brak konieczności szczegółowego analizowania postanowień umów czy treści czynności prawnych pod kątem zgodności z analogicznymi odpowiednikami funkcjonalnymi w prawie krajowym, koncentrując się jedynie na wspólnych ramach funkcjonalnych danej instytucji, które wynikałyby chociażby z aktów modelowych. Po czwarte, zawarte w prawie harmonizacyjnym ${ }^{105}$ zasady konstrukcyjne, sposób sformułowania określonych hipotez i dyspozycji normatywnych, związane $\mathrm{z}$ nimi skutki, a wreszcie powiązanie ich $\mathrm{z}$ wieloletnim dorobkiem i tradycją legislacyjną poszczególnych ustawodawstw krajowych i transponowanie do reguł prawa modelowego wyłącznie konsensualnie uzgodnionej treści przepisów - tworzy rozwiązania zdecydowanie bardziej podatne na późniejszą fluktuację stanu prawnego i upraszczające praktykę obrotu międzynarodowego (zwłaszcza handlowego). Rozwiązania te charakteryzować będzie kolokwialne „wszechstronne rozważenie” z uwagi na ich naukową proweniencję (walorem model law jest wszak jego akademicki charakter) i powiązanie ze znajomością przez autorów legistalive history ${ }^{106}$ każdej z rodzimych instytucji.

105 Terminem tym posługuję się synonimicznie względem pojęcia „prawa modelowego”.

106 O legislative history jako czynniku zwiększającym wartość funkcjonalną i poznawczą rozwiązań przyjętych w systemie prawnym zob. szerzej A. Bielska-Brodziak, Po co 
Po piąte i ostatnie - rozwiązania przyjęte w najnowszych projektach aktów modelowych w zakresie kary umownej spotykają się z coraz większą przychylnością zarówno polskiej doktryny prawa prywatnego [stąd wspomniana koncepcja zmiany przesłanek względnych i bezwzględnych powstania obowiązku zapłaty kary umownej, stosunku względem przedmiotu zabezpieczenia (już nie tylko umowa, ale bardziej ogólne „zobowiązanie”; w kontekście kary umownej przychylając się do rozwiązań model law - bez znaczenia powinien stać się także jego pieniężny lub niepieniężny charakter) czy granic miarkowania], jak również orzecznictwa (coraz częstsze odwoływanie się przez Sąd Najwyższy w judykatach do wspólnych europejskich projektów kodyfikacyjnych). Analogicznie wspomniane rozwiązania powinny nabrać także znaczenia dla polskiego prawodawcy w kontekście projektowanych zmian w obowiązującym prawie prywatnym. Przyjęte konstrukcje w zakresie prawa umów (i wciąż obowiązującej tu zasady swobody kontraktowej) nie powinny mieć charakteru nadmiernie usztywniającego (jak np. omówiona wcześniej delimitacja zawarta w art. $483 \$ 1$ k.c.), a pozwalać stronom na w pełni swobodne kształtowanie łączącego je stosunku zobowiązaniowego (w tym również konsekwencji związanych z jego naruszeniem), uwzględniając przy tym konieczność „zgodności” przyjętych inter partes rozwiązań z naturą danego zobowiązania (w zgodzie z art. $353^{1}$ k.c.), jak i zapewniając ochronę wynikającą wyłącznie z ogólnych zasad rządzących prawem cywilnym (o ile oczywiście strony postanowią w ten sposób ukształtować łączący je stosunek obligacyjny). Skoro bowiem współczesne tendencje harmonizacyjne, zmaterializowane w projektach prawa modelowego, zmierzają do zapewnienia stronom dużej swobody i modalności w zakresie kształtowania łączącego je stosunku (umożliwiając np. zastrzeżenie stipulated payment także w odniesieniu do zobowiązań pieniężnych), pożądane byłoby, w mojej ocenie, podejmowanie przez ustawodawcę krajowego działań zmierzających do wywołania tożsamego skutku również w prawie polskim (oczywiście w granicach domniemywanej racjonalności prawodawcy) ${ }^{107}$.

Wszystkie powołane okoliczności wskazują, że pogłębiona współpraca środowiska prawników-akademików europejskich, przyjmująca za cel opracowanie normatywnej odpowiedzi na postępujące tendencje harmonizacyjne i zdecydowanie wzmożoną ( $w$ porównaniu $z$ latami poprzednimi) wymianę międzynarodową (osobową, ekonomiczną, handlową itp.) jest szczególnie relewantna w czasach, w których granice państw coraz częściej postrzegane są wyłącznie z perspektywy geograficznej lub historycznej.

prawnikom materiały legislacyjne?, „Radca.pl - Kwartalnik Okręgowej Izby Radców Prawnych w Katowicach" 2017, nr 3(15), s. 23 i n.

107 Oczywiście, zastrzeżenia te zyskują cechę relewantności w tych stosunkach prawa prywatnego, które nie mają waloru stricte konsumenckich. Podzielam tu stanowisko, że z uwagi na specyfikę obrotu konsumenckiego - szeroka modalność stosunków zobowiązaniowych w tzw. formie B2C może mieć miejsce wyłącznie wówczas, gdy względem sytuacji prawnej i majątkowej konsumenta wywołuje skutek pozytywny, tzn. polepszający jego sytuację. 


\section{Bibliografia}

Bełdowski J., Kozioł A., Principles of European Contract Law, part III. Les principes du droit europeen du contrat, partie III (Zasady europejskiego prawa umów, cz. III), „Kwartalnik Prawa Prywatengo" 2006, z. 3.

Bielska-Brodziak A., Po co prawnikom materiały legislacyjne?, „Radca.pl - Kwartalnik Okręgowej Izby Radców Prawnych w Katowicach” 2017, nr 3(15).

Bonell M.J., The UNIDROIT Principles Of International Commercial Contracts And CISG - Alternatives Or Complementary Instruments?, ULR 1996, t. 26.

Borysiak W., Glosa do uchw. SN (7) z 06.11.2003 r., sygn. akt III CZP 61/03, „Monitor Prawniczy" 2007, nr 6.

Borysiak W., Komentarz do art. 483 [w:] Kodeks cywilny. Komentarz, t. IIIA, Zobowiązania. Część ogólna, red. K. Osajda, Warszawa 2017.

Dana A., Miejsce „acquis communautaire” w Konstytucji Rzeczypospolitej Polskiej, „Doctrina. Studia Społeczno-polityczne" 2006-2007, nr 3-4.

Dąbrowa J., Kara umowna [w:] System prawa cywilnego, t. III, cz. 1, Prawo zobowiązań część ogólna, red. Z. Radwański, Warszawa 1981.

Drapała P., Olejniczak A., Dodatkowe zastrzeżenia umowne [w:] System prawa prywatnego, t. 5, Prawo zobowiązań - część ogólna, red. E. Łętowska, Warszawa 2013.

Fuchs B., Lex mercatoria - pojęcie [w:] System prawa handlowego, t. 9, Międzynarodowe prawo handlowe, red. W. Popiołek, Warszawa 2013.

Fuchs B., Reguly Międzynarodowych Kontraktów Handlowych UNIDROIT (UPICC) [w:] System prawa handlowego, t. 9, Międzynarodowe prawo handlowe, red. W. Popiołek, Warszawa 2013.

Gołaczyński J., Prawo prywatne międzynarodowe, Warszawa 2003.

Jagielska M. i in., Prawo właściwe w braku wyboru prawa [w:] System prawa prywatnego, t. 20B, Prawo prywatne międzynarodowe, red. M. Pazdan, Warszawa 2015.

Jagielska M., Szpunar M., Polski przekład Reguł UNIDROIT, „Problemy Prawne Handlu Zagranicznego" 2000, t. 19/20.

Jastrzębski J., Nietypowe kary umowne - swoboda sankcji kontraktowych i ochrona dłużni$k a$, „Przegląd Prawa Handlowego” 2014, nr 6.

Juranek A.M., Kara umowna, wybrane klauzule quasipenalne oraz klauzule indemnifikacyjne w prawie polskim i prawie modelowym. Rozważania de lege lata i de lege ferenda, Katowice 2019.

Kodeks cywilny, t. II, Komentarz. Art. 450-1088, red. K. Pietrzykowski, Warszawa 2018.

Kodeks cywilny, t. II, Komentarz do art. 353-626, red. M. Gutowski, Warszawa 2019.

Kodeks cywilny. Komentarz, red. E. Gniewek, P. Machnikowski, Warszawa 2017.

Kodeks cywilny. Komentarz, t. III/A, Zobowiązania. Część ogólna, red. K. Osajda, Warszawa 2017.

Kodeks cywilny. Zobowiązania. Część ogólna. Komentarz, red. A. Rzetecka-Gil, Warszawa 2011.

Lando O., Beale H., The Principles of European Contract Law. Part I: Performance, Non-Performance and Remedies, Dordrecht 1995. 
Lando O., CISG and Its Followers: A Proposal to Adopt Some International Principles of Contract Law, AJCL 2005, t. 53.

Lemkowski M., Kara umowna w przypadku odstapienia od umowy [w:] Kodeks cywilny, t. II, Komentarz do art. 353-626, red. M. Gutowski, Warszawa 2019.

Łętowska E., Multicentryczność współczesnego systemu prawa i jej konsekwencje, „Państwo i Prawo" 2005, z. 4.

Łętowska E., Multicentryczność współczesnego systemu prawa i wykładnia jej przyjazna [w:] Rozprawy prawnicze: ksiega pamiątkowa Profesora Maksymiliana Pazdana, red. L. Ogiegło, W. Popiołek, M. Szpunar Kraków 2005.

Machnikowski P., Brzozowski A., Unifikacja europejskiego prawa umów. Zasady Europejskiego Prawa Umów (PECL) [w:] System prawa prywatnego, t. 5, Prawo zobowiązań część ogólna, red. K. Osajda, Warszawa 2020.

Machnikowski P., Pajor T., Prawo prywatne Unii Europejskiej i jego wplyw na prawo polskie [w:] System prawa prywatnego, t. 1, Prawo cywilne - część ogólna, red. M. Safjan, Warszawa 2012.

Pazdan M., Rott-Pietrzyk E., Łączniki w normach kolizyjnych [w:] System prawa prywatnego, t. 20B, Prawo prywatne międzynarodowe, red. M. Pazdan, Warszawa 2015.

Pazdan M., Wybór prawa w świetle rozporzązenia Rzym I - analiza szczegółowa [w:] System prawa prywatnego, t. 20B, Prawo prywatne międzynarodowe, red. M. Pazdan, Warszawa 2015.

Popiołek W., Komentarz do art. 472, art. 483, art. 484 [w:] Kodeks cywilny, t. II, Komentarz. Art. 450-1088, red. K. Pietrzykowski, Warszawa 2018.

Popiołek W., Obowiązek przyjęcia dostawy towaru w projekcie „Zasad europejskiego prawa umów" i w Konwencji ONZ o międzynarodowej sprzedaży towarów [w:] W kierunku europeizacji prawa prywatnego. Księga pamiątkowa dedykowana Profesorowi Jerzemu Rajskiemu, red. A. Brzozowski, W. Kocot, K. Michałowska,Warszawa 2007.

Radwański Z., Olejniczak A., Zobowiązania - część ogólna, Warszawa 2014.

Romanowski M., Ogólne reguły wykładni kontraktów w świetle zasad europejskiego prawa kontraktów a reguly wykładni umów w prawie polskim, „Przegląd Prawa Handlowego” 2004.

Rott-Pietrzyk E., Harmonizacja prawa prywatnego w aktach prawa modelowego (soft law) [w:] System prawa handlowego, t. 9, Międzynarodowe prawo handlowe, red. W. Popiołek, Warszawa 2013.

Rott-Pietrzyk E., Interpretacja umów w prawie modelowym i wspólnym europejskim prawie sprzedaży (CESL), Warszawa 2013.

Rozprawy prawnicze: ksiega pamiątkowa Profesora Maksymiliana Pazdana, red. L. Ogiegło, W. Popiołek, M. Szpunar, Kraków 2005.

Rzetecka-Gil A., Komentarz do art. 483 [w:] Kodeks cywilny. Zobowiązania. Część ogólna. Komentarz, red. A. Rzetecka-Gil, Warszawa 2011.

Skąpski J., Autonomia woli w prawie prywatnym międzynarodowym w zakresie zobowiqzań z umów, Kraków 1964.

Skowrońska-Bocian E., Kara umowna - kompensacja czy represja?, „Zeszyty Prawnicze UKSW" 2003, nr 3/2. 
System prawa cywilnego, t. III, cz. 1, Prawo zobowiązań - część ogólna, red. Z. Radwański, Warszawa 1981.

System prawa handlowego, t. 9, Międzynarodowe prawo handlowe, red. W. Popiołek, Warszawa 2013.

System prawa prywatnego, t. 1, Prawo cywilne - część ogólna, red. M. Safjan, Warszawa 2012.

System prawa prywatnego, t. 5, Prawo zobowiązań - część ogólna, red. E. Łętowska, Warszawa 2013.

System prawa prywatnego, t. 5, Prawo zobowiązań - część ogólna, red. K. Osajda, Warszawa 2020.

System prawa prywatnego, t. 6, Prawo zobowiązań - część ogólna, red. A. Olejniczak, Warszawa 2018.

System prawa prywatnego, t. 20B, Prawo prywatne międzynarodowe, red. M. Pazdan, Warszawa 2015.

Szumański A., Renegocjacje umów w międzynarodowym obrocie gospodarczym. Studium prawnoporównawcze, Kraków 1994.

Szwaja J., Kara umowna według Kodeksu cywilnego, Warszawa 1967.

Von Bar Ch., Clive E., Schulte-Nölke H., Principles, Definitions and Model Rules of European Private Law. Draft Common Frame of Reference (DCFR), Full Edition, t. I, Munich 2009.

Warkałło W., Wykonywanie zobowiązań i skutki ich niewykonania wedtug Kodeksu cywilnego, „Państwo i Prawo” 1965, z. 8-9.

Widerski P., Charakter prawny kary umownej wedtug prawa polskiego na tle ponadnarodowych uregulowań prawnych, „Studia Prawa Prywatnego” 2018, nr 2.

Wieczorek E., Zasady europejskiego prawa umów, Gdańsk 2005.

W kierunku europeizacji prawa prywatnego. Ksiega pamiątkowa dedykowana Profesorowi Jerzemu Rajskiemu, red. A. Brzozowski, W. Kocot, K. Michałowska, Warszawa 2007.

Zachariasiewicz M.A., Bełdowski J., Europejskie prawo umów. Principles of European Contract Law. Les principes du droit europeen des contrats. Zasady europejskiego prawa umów (tłum. z jęz. angielskiego i francuskiego), cz. I i II, „Kwartalnik Prawa Prywatnego" 2004, nr 3.

Zagrobelny K., Komentarz do art. 472, art. 483, art. 484 [w:] Kodeks cywilny. Komentarz, red. E. Gniewek, P. Machnikowski, Warszawa 2017.

Zoll F., Pojęcie niewykonania i nienależytego wykonania zobowiązania oraz kwalifikowane postaci naruszenia zobowiązania i ich skutki [w:] System prawa prywatnego, t. 6, Prawo zobowiązań - część ogólna, red. A. Olejniczak, Warszawa 2018. 

\begin{tabular}{l|l}
2 & OPINIE BAS
\end{tabular}

\begin{tabular}{l|l} 
A & ZAGADNIENIA PRAWA \\
KONSTYTUCYJNEGO
\end{tabular} 

Piotr Chybalski

\title{
Kontynuowanie przez Komisję do Spraw Petycji postępowań w sprawie petycji, które zostały wszczęte w poprzedniej kadencji ${ }^{1}$
}

\author{
The continuation of proceedings by the Committee on Petitions regarding \\ petitions that were submitted in the course of a previous term
}

In the opinion of the author, the principle of discontinunity in relation to "petition proceedings" does not apply to acts carried out as part of the work of the Committee on Petitions. This should also apply to those activities of the Commission that follow the choice of how to handle the petition, e.g. to prepare projects or desiderates as part of dealing with a given petition. Petitions that were considered in the previous term of office should be reconsidered, while the Commission in the current term is not bound by the arrangements made in the previous term of the Sejm. It is not permissible to renew the legislative initiative in the event of the draft submitted by the Committee on Petitions of the previous term was discontinued at the end of the term.

Keywords: discontinuation, petition, Standing Orders of the Sejm

W opinii autora zasada dyskontynuacji w stosunku do „postępowań w sprawie petycji” nie ma zastosowania do czynności podejmowanych w ramach prac Komisji do Spraw Petycji. Należy to także odnieść do tych czynności komisji, które następują po dokonaniu wyboru sposobu załatwienia petycji, np. do przygotowywania projektów czy dezyderatów w ramach załatwiania danej petycji. Petycje, których rozpatrywanie rozpoczęto w poprzedniej kadencji, powinny być rozpatrzone ponownie, przy czym komisja w obecnej kadencji nie jest związana ustaleniami poczynionymi w poprzedniej kadencji Sejmu. Nie jest dopuszczalne ponowienie komisyjnej inicjatywy ustawodawczej w przypadku, gdy projekt wniesiony przez Komisję do Spraw Petycji poprzedniej kadencji uległ dyskontynuacji wraz z zakończeniem kadencji.

Słowa kluczowe: dyskontynuacja, petycja, regulamin Sejmu

Doktor nauk prawnych, adiunkt -

Uniwersytet Kardynała Stefana Wyszyńskiego w Warszawie, Wydział Prawa i Administracji,

Katedra Prawa Konstytucyjnego, WARSZAWA, POLSKA •

piotr.chybalski@sejm.gov.pl • https://orcid.org/0000-0002-7703-1767

\section{Przedmiot opinii}

Przedmiotem niniejszej opinii jest ocena dopuszczalności kontynuowania przez Komisję do Spraw Petycji Sejmu IX kadencji postępowań w sprawie petycji, któ-

1 Opinia prawna w sprawie kontynuowania przez Komisję do Spraw Petycji postępowań w sprawie petycji, które zostały wszczęte w poprzedniej kadencji sporządzona 18 listopada 2019 r. na zlecenie dyrektora Biura Komunikacji Społecznej Kancelarii Sejmu; BAS-WAKiU 2202/19. 
re zostały wszczęte w toku VIII kadencji izby. Analizie zostaną poddane sytuacje, w których komisja „podjęła określone decyzje (np. przygotowanie projektów dezyderatów oraz przygotowanie projektów ustaw w wyniku rozpatrzenia poszczególnych petycji, jak również rozpatrzenie nadesłanych odpowiedzi na dezyderaty)”, lecz „nie zdołała wnieść wszystkich projektów ustaw ze względu na harmonogram i charakter jej prac oraz konieczność odbycia konsultacji i dokonania pogłębionych analiz problemu - w celu jak najlepszego przygotowania każdego projektu". Zostały też sformułowane pytania o charakterze szczegółowym, na które odpowiedź znajduje się w dalszej części opinii.

\section{Sejmowe postępowanie w sprawie petycji a zasada dyskontynuacji}

Prawne regulacje postępowania w sprawie petycji kierowanych do Sejmu zostały zawarte w ustawie z 11 lipca 2014 r. o petycjach (Dz.U. 2018, poz. 870) oraz w regulaminie Sejmu, w szczególności w dziale II rozdziale 9a „Postępowanie w sprawach petycji”. Jedną z cech charakterystycznych przepisów ustawowych jest jednolity model postępowania petycyjnego, bez uwzględnienia różnorodności (w szczególności ustrojowej) organów, do których petycje mogą być kierowane. Należy przy tym zauważyć, że krąg tych organów jest szeroki. Zgodnie z art. 63 Konstytucji, gwarantującym każdemu prawo do przedkładania petycji, skarg i wniosków, potencjalnymi adresatami tych wystąpień są organy władzy publicznej oraz organizacje i instytucje społeczne w związku z wykonywanymi przez nie zadaniami zleconymi z zakresu administracji publicznej. Ponadto analogicznie określono krąg adresatów petycji w art. 2 ust. 1 ustawy o petycjach.

Wyjątek od jednolitego charakteru postępowania petycyjnego został przewidziany w art. 9 ust. 1 ustawy, gdyż dopuszczono, aby w regulaminach Sejmu oraz Senatu wskazano odpowiednio organy wewnętrzne, które byłyby uprawnione do rozpatrywania petycji skierowanych do izb. Przepis ten umożliwił utworzenie szczególnego, sejmowego modelu postępowania petycyjnego, który charakteryzuje się tym, że w przebieg postępowania nie jest włączany Sejm in pleno, lecz jedynie organy izby, Marszałek Sejmu oraz Komisja do Spraw Petycji. Odnośnie do pozostałych kwestii ustawa nie uwzględnia specyfiki ustrojowej izby, co może prima facie prowadzić do wniosku, że postępowanie petycyjne w Sejmie powinno się toczyć według tych samych ram prawnych, co analogiczne postępowania prowadzone przez innych adresatów petycji. Wniosek taki byłby jednak błędny, gdyż pomija, jak się wydaje oczywisty, fakt, że przepisy określające tryb rozpatrywania petycji nie obowiązują w swego rodzaju "próżni normatywnej”, lecz w sytuacji obowiązywania innych regulacji ustrojowych, w szczególności konstytucyjnych, odnoszących się do wszelkich organów władzy publicznej. Oznacza to, w odniesieniu do Sejmu, że w postępowaniu petycyjnym per se nie 
zostało wyłączone stosowanie innych ustrojowych uregulowań dotyczących izby, w tym - co kluczowe w świetle przedmiotu niniejszej opinii - zasady dyskontynuacji. Należy przypomnieć, że zasada ta, choć nie została expressis verbis ustanowiona $\mathrm{w}$ Konstytucji, to zgodnie $\mathrm{z}$ jednolitym stanowiskiem doktryny prawa konstytucyjnego, wspartym orzecznictwem konstytucyjnym, w pełni obowiązuje w odniesieniu do Sejmu, w szczególności jako konsekwencja zasady kadencyjności (art. 98 ust. 1 Konstytucji). Zasada ta oznacza, że o ile przepisy prawa nie stanowią inaczej, to: wraz z końcem kadencji wszystkie sprawy, wnioski i przedłożenia, $w$ których nie doszło do zamknięcia prac parlamentarnych, uznaje się za ostatecznie załatwione $w$ sensie niedojścia do skutku. Nie sa więc one $w$ żadnej formie przekazywanie nowemu parlamentowi, który rozpoczyna nowa kadencje $z$ „czystym" niejako kontem².

Zarysowane wyżej tło normatywne uzasadnia celowość wprowadzenia do regulaminu Sejmu, nowelą regulaminu z 12 czerwca 2015 r., (M.P. poz. 550) art. 126g, który w odniesieniu do postępowania petycyjnego przełamuje zasadę dyskontynuacji, stanowiąc, że w przypadku, gdy postępowanie w sprawie petycji nie zostanie zakończone przed upływem kadencji Sejmu, jest ono prowadzone przez komisję w następnej kadencji Sejmu ${ }^{3}$. Wykładnia tego przepisu rzutuje na kierunek rozstrzygnięcia problemów przedstawionych do analizy w niniejszej opinii.

Kluczową kwestię stanowi fakt, że w przywołanym wyżej przepisie przedmiotem wyjątku od zasady dyskontynuacji uczynione zostało „postępowanie w sprawie petycji”, co koresponduje z zakresem rozdziału 9a działu II regulaminu Sejmu. A zatem, podtrzymując sformułowane wcześniej stanowisko ${ }^{4}$, należy stwierdzić, że ów wyjątek co do zasady odnosi się do wszelkich faz postępowania petycyjnego przewidzianych $\mathrm{w}$ tym rozdziale. Tym samym dopuszczalne jest kontynuowanie w następnej kadencji Sejmu postępowań petycyjnych, które w momencie zakończenia poprzedniej kadencji znajdowały się w toku merytorycznego rozpatrywania przez Komisję do Spraw Petycji bądź w fazie późniejszej. Należy przy tym podkreślić, że w świetle przepisów ustawy o petycjach, a także regulaminu Sejmu należy odróżnić rozpatrzenie petycji od jej załatwienia. Rozpatrzenie petycji, obwarowane ścisłymi ramami ustawowymi (w szczególności terminami, zob. art. 10 ustawy petycjach), obejmuje zapoznanie się adresata petycji z zawartym $\mathrm{w}$ niej żądaniem, a następnie poprzedzony merytoryczną analizą wybór sposobu załatwienia petycji. W odniesieniu do petycji kierowa-

2 L. Garlicki, Zasada dyskontynuacji prac parlamentarnych, „Studia Iuridica” 1995, t. XXVIII, s. 45, cyt. za L. Garlicki, Komentarz do art. 98 [w:] Konstytucja Rzeczypospolitej Polskiej. Komentarz, t. I, red. L. Garlicki, Warszawa 1999, s. 29.

3 Na temat zasadności wprowadzenia art. 126g regulaminu Sejmu szerzej wypowiedziałem się w innym opracowaniu, zob. P. Chybalski, Uwagi do art. 126g [w:] Komentarz do regulaminu Sejmu, red. A. Szmyt, Warszawa 2018, s. 586.

4 Ibidem. 
nych do Sejmu kwestię tę jednoznacznie przesądza art. 126c ust. 1 regulaminu Sejmu, zgodnie z którym rozpatrzenie petycji obejmuje przedstawienie petycji przez posła wyznaczonego przez prezydium komisji, dyskusję oraz rozstrzygnięcie w sprawie sposobu załatwienia petycji, przy czym listę (otwartą) sposobów załatwienia petycji określono w art. 126c ust. 3 regulaminu Sejmu. Owo rozstrzygnięcie, a także wykonanie kolejnych czynności przewidzianych ustawą (zwłaszcza poinformowanie wnioskodawcy petycji o sposobie jej załatwienia, art. 13 ustawy o petycjach), nie kończy jednak postępowania, gdyż Komisja do Spraw Petycji może przystąpić do „załatwiania” danej petycji, a więc np. podjąć prace nad projektem ustawy czy uchwały realizującym żądanie zawarte w petycji (zob. art. $126 \mathrm{c}$ ust. 3 pkt 1 regulaminu Sejmu) 5 . Tym samym, skoro przewidziany w art. $126 \mathrm{~g}$ regulaminu Sejmu wyjątek od zasady dyskontynuacji odnosi się do całego postępowania petycyjnego w komisji, to nie ma powodu, aby nie odnieść go również do tych czynności Komisji do Spraw Petycji, które następują po dokonaniu wyboru sposobu rozpatrzenia petycji.

Opowiadając się za objęciem wspomnianej wyżej fazy postępowania zakresem wyjątku od zasady dyskontynuacji, należy poczynić dwa zastrzeżenia. Po pierwsze, w praktyce możliwość kontynuacji w nowej kadencji postępowania w sprawie danej petycji kształtuje się w sposób zróżnicowany, co wymaga od komisji analizy każdego przypadku osobno, na zasadzie a casu ad casum. Niekiedy kontynuowanie prac nie będzie możliwe, np. w sytuacji, gdy komisja (poprzedniej kadencji), uwzględniając żądanie wnioskodawcy petycji, aby wnieść poprawkę do danego projektu ustawy, podejmie decyzję o opracowaniu poprawki, zaś przed jej wniesieniem dany projekt ulegnie dyskontynuacji wraz z końcem kadencji Sejmu. Po drugie, w moim przekonaniu, Komisja do Spraw Petycji nowej kadencji nie jest związana dokonanym przez swoją poprzedniczkę wyborem sposobu załatwienia danej petycji w tym sensie, że na komisji nowej kadencji ciąży obowiązek załatwienia petycji w sposób wybrany w kadencji wcześniejszej. Przeciwny wniosek stałby w sprzeczności z zasadą wolnego mandatu parlamentarnego (art. 104 ust. 1 Konstytucji), gdyż nakładałby na posłów - członków Komisji do Spraw Petycji prawne ograniczenia co do kierunku wykonywania przez nich funkcji członka komisji.

Odnośnie do ostatniej z zarysowanych kwestii, pojawia się wątpliwość, czy dopuszczalny byłby ponowny wybór sposobu załatwienia petycji przez Komisję

5 Pominąć należy fakt, że zgodnie z pkt la załącznika do regulaminu Sejmu przedmiotowy zakres działania Komisji do Spraw Petycji obejmuje wyłącznie „rozpatrywanie petycji złożonych do Sejmu”. Ścisła wykładnia tego przepisu, wykluczająca możliwość podejmowania przez komisję czynności mających na celu realizację wybranego sposobu załatwienia petycji, negowałaby sens normatywny art. 126c ust. 3 regulaminu Sejmu. Wybór sposobu załatwienia petycji stałby się bowiem czynnością bez znaczenia, skoro komisja nie byłaby w stanie podjąć jakichkolwiek czynności w celu jego realizacji. 
do Spraw Petycji nowej kadencji - w sytuacji, gdyby komisja ta nie podzieliła decyzji swojej poprzedniczki co do tej kwestii. Prima facie obowiązujące przepisy nie przewidują możliwości „powrotu” do fazy wyboru sposobu załatwienia danej petycji, lecz należy uznać, że byłoby to dopuszczalne. Gdyby bowiem przyjąć wniosek przeciwny, to wystąpiłaby sytuacja paradoksalna. Otóż, z jednej strony - jak już wspomniałem - Komisja do Spraw Petycji nowej kadencji nie byłaby związana wyborem sposobu załatwienia petycji przez komisję wcześniejszej kadencji. $Z$ drugiej zaś strony, gdyby opowiadała się za odmiennym sposobem niż wybrany przez jej poprzedniczkę, to jedyną możliwość stanowiłby brak podjęcia jakichkolwiek czynności mających na celu załatwienie takiej petycji. Taki stan rzeczy uniemożliwiłby, z powodów czysto formalnych, zakończenie postępowania petycyjnego, tj. podjęcia przez Komisję do Spraw Petycji (nowej kadencji) merytorycznej decyzji odnośnie do zasadności spełnienia żądania zawartego. Skutkowałby natomiast wstrzymaniem postępowania petycyjnego wszczętego we wcześniejszej kadencji Sejmu do upływu nowej kadencji izby - tylko po to, aby postępowanie formalnie zakończyć. Warto przy tym nadmienić, że przewidziane w art. 126g regulaminu Sejmu „przełamanie” dyskontynuacji postępowania petycyjnego obejmuje wyłącznie jedną („następną”) kadencję Sejmu6.

\section{Odpowiedź na pytania szczegółowe}

- Czy komisja nowej kadencji może uchwalić dezyderaty, co do których decyzję o ich przygotowaniu podjęła komisja poprzedniej kadencji?

$\mathrm{W}$ świetle powyższych uwag jest to dopuszczalne. $\mathrm{Z}$ drugiej strony Komisja do Spraw Petycji nowej kadencji nie jest obowiązana uchwalić dezyderat, tj. załatwić daną petycję w sposób wybrany przez Komisję do Spraw Petycji poprzedniej kadencji.

- Czy komisja nowej kadencji może rozpatrywać odpowiedzi na dezyderaty uchwalone przez komisję poprzedniej kadencji?

W świetle powyższych uwag jest to dopuszczalne.

- Czy komisja nowej kadencji może ponowić projekty ustaw wniesione przez komisję poprzedniej kadencji?

W moim przekonaniu z odpowiedzią na to pytanie wiążą się znaczne wątpliwości. Formalnie wniesienie projektu ustawy przez Komisję do Spraw Petycji stanowi realizację wybranego przez tę komisję sposobu załatwienia petycji, co finalizuje dane postępowanie petycyjne. $Z$ drugiej jednak strony, wnosząc projekt, Komisja

6 Zob. P. Chybalski, Uwagi do art. 126g, op. cit., s. 587. 
do Spraw Petycji staje się jego wnioskodawcą, a zatem uczestniczy w postępowaniu ustawodawczym, posiadając pełnię praw i obowiązków wnioskodawcy. Tym samym de facto nie kończy się zainteresowanie komisji daną petycją. Mimo to, mając na uwadze fakt, że przewidziane w art. 126g regulaminu Sejmu wyłączenie dyskontynuacji odnosi się wyłącznie do postępowania w sprawie petycji, a także, iż owo wyłącznie ma charakter wyjątku od zasady dyskontynuacji, opowiadam się przeciwko możliwości ponowienia komisyjnej inicjatywy ustawodawczej w przypadku, gdy projekt wniesiony przez Komisję do Spraw Petycji poprzedniej kadencji uległ dyskontynuacji wraz z zakończeniem kadencji (exceptiones non sunt extendendae).

- Czy Komisja nowej kadencji może kontynuować prace nad projektami ustaw, o których wniesieniu zdecydowała komisja poprzedniej kadencji, ale z uwagi na zakończenie kadencji nie zostały one wniesione?

W świetle powyższych uwag jest to dopuszczalne.

\section{Podsumowanie}

- Artykuł 126g regulaminu Sejmu wyłącza (na jedną kadencję Sejmu) zastosowanie zasady dyskontynuacji w odniesieniu do "postępowania w sprawie petycji”, a zatem w odniesieniu do wszystkich czynności podejmowanych przez Komisję do Spraw Petycji w ramach tego postępowania. Nie ma więc powodu, aby nie odnieść go również do tych czynności Komisji do Spraw Petycji, które następują po dokonaniu wyboru sposobu załatwienia petycji w trybie art. 126c ust. 3 regulaminu Sejmu, a więc np. do przygotowywania projektów czy dezyderatów w ramach załatwiania danej petycji.

- W praktyce możliwość kontynuacji w nowej kadencji postępowania w sprawie danej petycji kształtuje się w sposób zróżnicowany, co wymaga od komisji analizy każdego przypadku osobno, na zasadzie a casu ad casum. Niekiedy kontynuowanie prac nie będzie możliwe, np. w sytuacji, gdy Komisja do Spraw Petycji (wcześniejszej kadencji), uwzględniając żądanie wnioskodawcy petycji, aby wnieść poprawkę do danego projektu ustawy, podejmie decyzję o opracowaniu poprawki, zaś przed jej wniesieniem dany projekt ulegnie dyskontynuacji wraz z końcem kadencji Sejmu.

- W sytuacji, gdy Komisja do Spraw Petycji wcześniejszej kadencji wybierze sposób załatwienia danej petycji, lecz nie zdąży przed upływem kadencji zakończyć prac nad realizacją tego sposobu (np. wnieść projekt ustawy), komisja nowej kadencji nie jest związana dokonanym przez swoją poprzedniczkę wyborem sposobu załatwienia danej petycji. Dopuszczalny byłby „powrót” przez Komisję do Spraw Petycji nowej kadencji do fazy wyboru sposobu załatwienia danej petycji. Innymi słowy, gdy komisja nowej kadencji będzie opowiadać się za odmiennym 
sposobem niż wybrany przez jej poprzedniczkę, to możliwy będzie wybór innego sposobu.

- Odnośnie do przedstawionych pytań szczegółowych należy stwierdzić, że jest dopuszczalne dokonanie przez Komisję do Spraw Petycji „nowej kadencji” następujących czynności:

a) uchwalenie dezyderatów, co do których decyzję o ich przygotowaniu podjęła komisja poprzedniej kadencji,

b) rozpatrzenie odpowiedzi na dezyderaty uchwalone przez komisję poprzedniej kadencji,

c) kontynuowanie prac nad projektami ustaw, o których wniesieniu zdecydowała komisja poprzedniej kadencji, ale z uwagi na zakończenie kadencji nie zostały one wniesione.

- Nie jest dopuszczalne ponowienie komisyjnej inicjatywy ustawodawczej w przypadku, gdy projekt wniesiony przez Komisję do Spraw Petycji poprzedniej kadencji uległ dyskontynuacji wraz z zakończeniem kadencji

\section{Bibliografia}

Chybalski P., Uwagi do art. 126g [w:] Komentarz do regulaminu Sejmu, red. A. Szmyt, Warszawa 2018.

Garlicki L., Komentarz do art. 98 [w:] Konstytucja Rzeczypospolitej Polskiej. Komentarz, t. I, red. L. Garlicki, Warszawa 1999.

Garlicki L., Zasada dyskontynuacji prac parlamentarnych, „Studia Iuridica” 1995, t. XXVIII. 
Wojciech Odrowąż-Sypniewski

\title{
Szczegółowe rozpatrywanie projektu ustawy przez komisję (tryb modyfikacji tekstu rozpatrywanego projektu) ${ }^{1}$
}

\author{
Detailed consideration of a bill by a committee (manner of modifying \\ the text of the bill under consideration)
}

\begin{abstract}
In the author's opinion, the following provisions (sections) of a bill project referred to committee should not become subjects of voting by the committee, but the committee should vote only on motions aimed at their modification (substantive and editorial amendments and motions for deletion of a provision). A different manner of work of the committee may lead to the deletion of a given provision, if the provision is not approved in voting, even in case of the lack of motion to delete it. The Sejm should decide upon legislative motions and legislative postulates included in the committee's report on the bill, prepared in the form of a consolidated text.
\end{abstract}

Keywords: parliamentary committee, bill, Standing Orders of the Sejm

Zdaniem autora przedmiotem głosowania w komisji nie powinny być poszczególne jednostki redakcyjne skierowanego do komisji projektu, a jedynie wnioski zmierzające do ich modyfikacji (poprawki merytoryczne, redakcyjne i wnioski o skreślenie). Odmienny tryb prac komisji może prowadzić do wykreślenia danej jednostki redakcyjnej w razie nieprzyjęcia jej w głosowaniu, mimo braku wniosku o jej wykreślenie. Rozstrzygnięciu przez Sejm powinny podlegać wnioski i postulaty legislacyjne zamieszczone w sprawozdaniu do projektu w formie tekstu jednolitego.

Słowa kluczowe: komisja sejmowa, projekt ustawy, regulamin Sejmu

Ekspert ds. legislacji Biura Analiz Sejmowych •

Kancelaria Sejmu, Biuro Analiz Sejmowych, Wydział Analiz Prawnych, Zespół Prawa

Parlamentarnego, WARSZAWA, POLSKA •

wojciech.sypniewski@sejm.gov.pl • https://orcid.org/0000-0002-7704-5042

\section{Przedmiot opinii}

Przedmiotem opinii jest zagadnienie dotyczące ukształtowanej praktyki szczegółowego rozpatrywania projektu ustawy przez komisje sejmowe. Istota zagadnienia wiąże się z trybem wprowadzania zmian do tekstu rozpatrywanego projektu, który został opisany w następujący sposób:

„W praktyce parlamentarnej szczegółowe rozpatrzenie projektu ustawy przez komisję (podkomisję) sejmową polega na rozstrzyganiu o poszczególnych jednostkach redakcyjnych projektu tj. na poddaniu przez przewodniczącego pod głosowanie wniosku o przyjęcie danej jednostki redakcyjnej (ewentualnie zapy-

1 Opinia prawna na temat szczegółowego rozpatrywania projektu ustawy przez komisje (tryb modyfikacji tekstu rozpatrywanego projektu) sporządzona 21 listopada 2019 r. na zlecenie zastępcy Szefa Kancelarii; BAS-WAUIP 2251/19. 
taniu czy jest sprzeciw wobec przyjęcia danej jednostki redakcyjnej). Przy takim sposobie szczegółowego rozpatrywania projektu może dojść do sytuacji, w której dana jednostka redakcyjna nie zostanie przyjęta w głosowaniu, co jest traktowane jak skreślenie tej jednostki z tekstu projektu, pomimo tego, że w odniesieniu do niej nie została złożona poprawka zakładająca wykreślenie. Praktyka taka może więc budzić wątpliwości w świetle art. 43 ust. 2 pkt 2 regulaminu Sej$\mathrm{mu}$, zgodnie z którym w sprawozdaniu o projekcie komisja przedstawia wniosek o przyjęcie projektu z określonymi poprawkami w formie tekstu jednolitego projektu. Czy zatem, w związku z przedstawioną wątpliwością dotyczącą aktualnej praktyki szczegółowego rozpatrywania przez komisję (podkomisję) sejmową projektu ustawy, za właściwy sposób rozpatrywania nie należałoby uznać takiego, w którym w trakcie rozpatrywania projektu rozstrzyga się w głosowaniu jedynie o wniesionych poprawkach i wnioskach do poszczególnych jednostek redakcyjnych a następnie o całości projektu?".

\section{Model normatywny rozpatrywania projektów ustaw przez komisje sejmowe}

Regulamin Sejmu w bardzo ogólny sposób normuje zasady rozpatrywania projektów przez komisje sejmowe. Zasady te obejmują: (1) obowiązek wspólnych obrad komisji, do których skierowany został projekt ustawy (art. 40 ust. 2); (2) nakaz ustalenia toku prac nad projektem na wniosek prezydium komisji (art. 40 ust. 3); (3) możliwość podjęcia uchwały o wspólnym rozpatrzeniu projektów połączonych tematycznie i rozpatrywanych w tym samym postępowaniu (art. 40 ust. 4); (4) możliwość powołania podkomisji w celu szczegółowego rozpatrywania projektu, której prace wieńczyć winno sprawozdanie przedstawiane komisji (art. 41 ust. 1); (5) obowiązek wzięcia pod uwagę opinii przedstawionych przez inne komisje i posłów (art. 42 ust. 1); (6) obowiązek udziału w posiedzeniu komisji przedstawiciela wnioskodawcy (art. 42 ust. 2); (7) tryb zgłaszania poprawek do projektu (art. 42 ust. 2a); (8) możliwość redakcyjnego opracowania poprawek przez prezydium lub powołany w tym celu zespół poselski (art. 42 ust. 3); (9) możliwość zasięgnięcia opinii ministra właściwego do spraw członkostwa RP w UE w sprawie zgodności projektu z prawem UE (art. 42 ust. 4); (10) możliwość wystąpienia za pośrednictwem Marszałka Sejmu z wnioskiem do wnioskodawcy o przepracowanie projektu $\mathrm{z}$ uwzględnieniem zmian postulowanych przez komisję (art. 42 ust. 5); (11) obowiązek przedstawienia sprawozdania o projekcie zawierającego jeden $\mathrm{z}$ trzech wniosków: a) przyjęcie projektu bez poprawek, b) przyjęcie projektu $\mathrm{z}$ określonymi poprawkami $\mathrm{w}$ formie tekstu jednolitego projektu, c) odrzucenie projektu (art. 43 ust. 2).

Ze względu na wątpliwość stanowiącą temat opinii szczególnie istotny jest nakaz ustalenia przez komisję, na wniosek jej prezydium, toku prac nad projek- 
tem. Pozwala on organowi kierującemu pracami komisji na przedłożenie komisji propozycji (wniosku) określającej szczegółowe zasady rozpatrywania projektu („toku prac”), w tym m.in. kolejności rozpatrywania poszczególnych artykułów lub rozdziałów projektu, sugestii dotyczącej wyboru tzw. projektu bazowego (w przypadku rozpatrywania kilku projektów połączonych tematycznie) czy zakresu i kolejności korzystania z opinii doradców stałych komisji, ekspertów i przedstawicieli zainteresowanych organizacji społecznych. Pozornie można byłoby sądzić, że kompetencja w zakresie wyznaczania „toku prac” mieści w sobie także możliwość kształtowania sposobu rozstrzygania o poszczególnych jednostkach redakcyjnych projektu. Taka interpretacja pozwalałaby na wybór formuły rozstrzygania o kolejnych przepisach czy rozdziałach projektu, która w największym stopniu przysłużyłaby się efektywności działań komisji, a w konsekwencji ekonomii prac całej izby. Za wyborem konkretnych scenariuszy głosowań stać mogłyby względy prakseologiczne, czyli przekonanie, że pozwolą one w sprawny sposób przeprowadzić etap szczegółowego rozpatrzenia projektu.

Zakres uprawnienia wynikającego z art. 40 ust. 3 regulaminu Sejmu, a także zakres uprawnień przewodniczącego komisji prowadzącego obrady (w tym głosowania) postrzegać jednak należy z uwzględnieniem konstytucyjnych zasad rozpatrywania projektów ustaw przez Sejm. W świetle art. 119 ust. 2 Konstytucji należy przyjąć, że instytucja „poprawki” stanowi jedyną dopuszczalną formę ingerencji w tekst projektu w trakcie rozpatrywania go przez Sejm. Innymi słowy, modyfikacja treści projektu możliwa jest jedynie w wyniku zgłoszenia poprawki (czy wniosku o odrzucenie projektu). W świetle ograniczeń normatywnych wyznaczanych przepisami Konstytucji wykluczyć należy takie ukształtowanie procedury trzech czytań (art. 119 ust. 2), które zakładałoby, że wniesiona inicjatywa ustawodawcza stanowi jedynie inspirację dla prac komisji, podczas których $a b$ initio kreowany jest nowy tekst projektu. Przedmiotem postępowania w Sejmie na wszystkich jego etapach jest projekt wniesiony przez uprawnionego wnioskodawcę, a modyfikacja jego treści możliwa jest wyłącznie przez zgłoszenie poprawki odnoszącej się do konkretnej jednostki redakcyjnej (albo wniosku postulującego odrzucenie projektu) ${ }^{2}$. Wyrazem tych założeń są postanowienia regulaminu Sejmu nakazujące komisji rozpatrującej projekt ustawy przedstawienie sprawozdania obejmującego jeden $\mathrm{z}$ trzech dysjunktywnych wniosków (art. 43 ust. 2). Innymi słowy, sprawozdanie komisji, które nie zawiera wniosku o odrzucenie projektu lub przyjęcie go bez poprawek, nie może stanowić tekstu normatywnego pokrewnego jedynie tematycznie lub ideowo z rozpatrywanym tekstem, lecz powinno być rezultatem czynności polegających na przekształceniu projektu w wyniku przyjęcia lub odrzucenia przez komisję poprawek do poszcze-

2 Poza zakresem rozważań pozostawiam - wykraczające poza temat opinii - złożone zagadnienie wspólnego rozpatrywania projektów ustaw połączonych tematycznie na podstawie art. 40 ust. 4 oraz kwestię zgodności z Konstytucją tego rozwiązania proceduralnego. 
gólnych jednostek redakcyjnych projektu. Każdy z postulatów legislacyjnych rozpatrywanych przez komisję powinien zostać zgłoszony przez uprawnionego wnioskodawcę zgodnie z przewidzianą w tym zakresie procedurą (art. 42 ust. 2a).

Przepisy regulaminu Sejmu dotyczące poprawek postrzegać należy jako konkretyzację konstytucyjnego prawa wnioskodawcy projektu, posłów i Rady Ministrów do wnoszenia poprawek do projektu ustawy w czasie rozpatrywania go przez Sejm. Analiza konstytucyjnego pojęcia "poprawka” oraz wynikające z niej wnioski najszerzej przedstawione zostały w wyroku Trybunału Konstytucyjnego z 24 marca 2004 r., sygn. akt K 37/03. Zdaniem Trybunału wprawdzie ani Konstytucja, ani inne obowiązujące akty normatywne nie zawierają legalnej definicji poprawki do projektu ustawy, jednak nie oznacza to, że pojęcia poprawki nie można zrekonstruować w drodze wykładni przepisów Konstytucji. Rekapitulując przedstawione $\mathrm{w}$ omawianym wyroku ustalenia, można stwierdzić, że poprawką w rozumieniu art. 119 ust. 2 jest (1) propozycja [...] skreślenia pewnej części $w$ tekście projektu ustawy, uzupetnienia go przez dopisanie pewnych elementów lub zastapienia niektórych cześsi tekstu projektu, zwłaszcza określonych wyrazów, innym. Tego rodzaju postulat powinien (2) pozostawać w związku ze złożonym w Sejmie przez wnioskodawcę projektem (poprawkę można zgłosić tylko określając dokładnie, do którego projektu ustawy ma się ona odnosić), zaś (3) związek ten ma wymiar nie tylko formalny, ale i merytoryczny (konkretne poprawki [...] musza zmierzać do modyfikacji treści projektu, a nie do stworzenia nowego projektu). Tak rozumiane "poprawki” (4) maja z założenia charakter "punktowy" i zakładaja pozostawienie bez zmian tych części projektu ustawy, których nie dotycza ( $w$ sensie technicznym poprawki nie maja samodzielnego charakteru, ale z założenia maja charakter fragmentaryczny). Nawet gdy poprawki całkowicie zmieniają kierunki rozwiązań przyjęte przez podmiot realizujący inicjatywę ustawodawczą, to jednak (5) musza [...] - co do zasady - mieścić się w zakresie projektu wniesionego przez uprawniony podmiot i poddanego pierwszemu czytaniu, a ponadto powinny (6) pozostawać $\mathrm{w}$ „ramach finansowych” pierwotnego przedłożenia (sygn. akt $\mathrm{K}$ 37/03). W ocenie Trybunału Konstytucyjnego konsekwencją prawa do wnoszenia poprawek jest spoczywający na Sejmie obowiązek ich rozpatrzenia (ustosunkowania się do nich), a w szczególności ich przyjęcia albo odrzucenia w głosowaniu.

Powołane stanowisko Trybunału Konstytucyjnego wyjaśniające sens normatywny pojęcia „poprawki” z art. 119 ust. 2 Konstytucji wielokrotnie było przywołane w późniejszym orzecznictwie. Pozwala to na sformułowanie tezy o istnieniu konsekwentnej linii orzeczniczej w tym zakresie. Wnioski wynikające $\mathrm{z}$ analizy przeprowadzonej przez sąd konstytucyjny pozostają zbieżne z poglądami doktryny prawa konstytucyjnego ${ }^{3}$.

3 L. Garlicki, Uwagi 7-9 do art. 119 [w:] Konstytucja Rzeczypospolitej Polskiej. Komentarz, red. L. Garlicki, t. II, Warszawa 2001; P. Chybalski, Poprawka w postępowaniu ustawodawczym w świetle Konstytucji RP, Warszawa 2014, s. 91-101. 
Konsekwencją powyższych rozważań jest pogląd, że prawidłowy scenariusz rozpatrywania projektu ustawy przez komisję sejmową (podkomisję) powinien zakładać, że przedmiotem cząstkowych rozstrzygnięć poprzedzających przedstawienie całościowego sprawozdania są wyłącznie wnioski i postulaty legislacyjne zgłoszone w trybie określonym w art. 42 ust. 2a regulaminu Sejmu. Innymi słowy, przedmiotem głosowania nie powinny być poszczególne jednostki redakcyjne skierowanego do komisji projektu, a jedynie wnioski zmierzające do ich modyfikacji (poprawki merytoryczne, redakcyjne i wnioski o skreślenie). Opisana we wstępie opinii praktyka polegająca na poddawaniu pod głosowanie przez prowadzącego obrady kolejnych jednostek redakcyjnych prowadzić może do eliminacji konkretnych artykułów czy ustępów, mimo że żaden z uprawnionych wnioskodawców nie zgłosił poprawki o ich skreślenie. Wezwanie przewodniczącego komisji „kto jest za przyjęciem danej jednostki redakcyjnej?” (podobnie jak pytanie „czy jest sprzeciw wobec przyjęcia danej jednostki redakcyjnej?”) nie znajduje oparcia w przepisach Konstytucji i regulaminu Sejmu. Komisja nie rozstrzyga bowiem o przyjęciu poszczególnych przepisów tworzących projekt, a jedynie o przyjęciu poprawek do poszczególnych jednostek redakcyjnych (albo wniosku o przyjęciu projektu bez poprawek bądź wniosku o odrzucenie projektu).

Właściwy scenariusz powinien przewidywać - w miejsce dotychczasowego pytania - wezwanie do zgłaszania wniosków do określonego przepisu („czy są wnioski do art. XY?”). Zgłoszenie takich wniosków otwiera procedurę prowadzącą do ewentualnej modyfikacji danego przepisu, zaś ich brak umożliwia przejście do kolejnej jednostki redakcyjnej (w takim wypadku zbędna jest również formuła „stwierdzam, że komisja przyjęła art. XY”; w jej miejsce prowadzący obrady mógłby co najwyżej stwierdzić: „stwierdzam, że nie zostały zgłoszone żadne poprawki do art. XY”).

\section{Podsumowanie}

Przedstawiona w opinii analiza wskazuje, że dotychczasowa praktyka parlamentarna wyrażająca się w rozstrzyganiu przez komisję sejmową rozpatrującą projekt ustawy o poszczególnych jednostkach redakcyjnych projektu przez poddanie pod głosowanie przez przewodniczącego komisji wniosku o przyjęcie danej jednostki redakcyjnej nie znajduje oparcia w przepisach Konstytucji i regulaminu Sejmu. Prawidłowy scenariusz rozpatrywania projektu ustawy powinien zakładać, że przedmiotem cząstkowych rozstrzygnięć poprzedzających przedstawienie całościowego sprawozdania są wyłącznie wnioski i postulaty legislacyjne zgłoszone w trybie określonym w art. 42 ust. 2a regulaminu Sejmu. Innymi słowy, przedmiotem głosowania nie powinny być poszczególne jednostki redakcyjne skierowanego do komisji projektu, a jedynie wnioski zmierzające do ich modyfikacji (poprawki merytoryczne, redakcyjne i wnioski o skreślenie). 


\section{Bibliografia}

Chybalski P., Poprawka w postępowaniu ustawodawczym $w$ świetle Konstytucji RP, Warszawa 2014.

Garlicki L., Uwagi 7-9 do art. 119 [w:] Konstytucja Rzeczypospolitej Polskiej. Komentarz, t. II, red. L. Garlicki, Warszawa 2001. 
Piotr Czarny

\title{
Interpretacja art. 15 ust. 1 regulaminu Sejmu ${ }^{1}$
}

\author{
Interpretation of Article 15 para. 1 of the Standing Orders of the Sejm
}

The opinion presents the interpretation of the definition of "parliamentary group representing a separate electoral list on the day of the start of the Sejm's term". The conditions that all Deputies' associations have to meet in order to fall into this category have been indicated. Meeting such conditions is necessary for obtaining the right to participate of a representative of the group in sittings of the Council of Seniors. The need to amend the interpreted provision of the Standing Orders of the Sejm, in order to adapt it to relevant provisions of electoral law, has been also signalled.

Keywords: parliamentary group, Council of Seniors, Standing Orders of the Sejm

\begin{abstract}
W opinii przedstawiono interpretację definicji „koła parlamentarnego reprezentującego w dniu rozpoczęcia kadencji Sejmu osobną listę wyborczą". Wskazano warunki, jakie łącznie muszą spełnić zrzeszenia, aby podlegały tej kategorii. Spełnienie tych warunków jest konieczne dla udziału przedstawiciela określonego koła w posiedzeniach Konwentu Seniorów. Zasygnalizowano potrzebę dokonania nowelizacji interpretowanego przepisu regulaminu Sejmu w celu dostosowania go do obowiązujących przepisów prawa wyborczego.
\end{abstract}

Słowa kluczowe: koło poselskie, Konwent Seniorów, regulamin Sejmu

Doktor nauk prawnych, starszy wykładowca -

Uniwersytet Jagielloński w Krakowie, Wydział Prawa i Administracji, Katedra Prawa

Konstytucyjnego, KRAKÓW, POLSKA •

piotr.czarny@neostrada.pl • https://orcid.org/0000-0002-6558-1075

\section{Ustalenia wstępne}

Niniejsza opinia prawna dotyczy wykładni określonej części art. 15 ust. 1 regulaminu Sejmu oraz odpowiedzi na pytanie o interpretację pojęcia „koła parlamentarne reprezentujące w dniu rozpoczęcia kadencji Sejmu osobną listę wyborczą", a także ocenę - w kontekście członkostwa w Konwencie Seniorów - sytuacji, w której dany komitet wyborczy wprowadza do Sejmu mniej niż 15 posłów, a na początku kadencji (pytanie dodatkowe: kiedy, czy w dniu rozpoczęcia pierwszego posiedzenia, czy, jeśli to możliwe, wcześniej) posłowie ci informują Marszałka o utworzeniu dwóch (lub nawet więcej) kół. Problem praktyczny, jaki powstaje w takim wypadku, polega na tym, czy któreś z nich (a jeśli tak, to dlaczego) uważać można za uprawnione do udziału jego przedstawiciela w posiedzeniach Konwentu Seniorów.

1 Opinia prawna dotyczaca interpretacji art. 15 ust. 1 regulaminu Sejmu sporządzona 8 listopada 2019 r. na zlecenie zastępcy Szefa Kancelarii Sejmu; BAS-WAKiU 2252/19. 
Zgodnie $z$ art. 15 ust. 1 regulaminu Sejmu (t.j. M.P. 2012, poz. 32, ze zm.) w skład Konwentu Seniorów wchodzą: Marszałek, wicemarszałkowie, przewodniczący lub wiceprzewodniczący klubów oraz przedstawiciele porozumień, o których mowa w art. 8 ust. 5, a także klubów parlamentarnych, jeśli reprezentują co najmniej 15 posłów, oraz kół parlamentarnych reprezentujących w dniu rozpoczęcia kadencji Sejmu osobną listę wyborczą. Niniejsza opinia dotyczy wyłącznie ostatniej z wymienionych w tym przepisie kategorii członków Konwentu Seniorów. Oczywiste jest przy tym, że koło liczyć musi co najmniej trzech posłów (art. 8 ust. 3 regulaminu Sejmu).

Należy podkreślić, że końcowa część art. 15 ust. 1 została wprowadzona w uchwale Sejmu z 28 października 1997 r. w sprawie zmiany regulaminu Sejmu RP (M.P. nr 80, poz. 779), która weszła w życie z dniem jej podjęcia (art. 3). Można zwrócić uwagę, że postanowienia analogicznego do regulacji zawartej w art. 15 ust. 1 in fine regulaminu Sejmu nie ma w regulaminie Senatu.

\section{Uzasadnienie i ustalenia szczegółowe}

W pierwszej kolejności należy zauważyć, że wykładnia art. 15 ust. 1 in fine regulaminu Sejmu jest utrudniona z uwagi na wysoce niejednoznaczny sposób sformułowania, co podaje w wątpliwość wyniki wykładni językowej i systemowej. Świadczy o tym przede wszystkim użycie wyrażenia „koła parlamentarne”, co sugerowałoby, że chodzi o zrzeszenia parlamentarzystów, o których mówi art. 17 ust. 3 ustawy z 9 maja 1996 r. o wykonywaniu mandatu posła i senatora (t.j. Dz.U. 2018, poz. 1799, ze zm.). Zgodnie z tym przepisem posłowie wraz z senatorami mogą tworzyć wspólne kluby, koła lub zespoły parlamentarne. Natomiast posłowie (sami posłowie) tworzyć mogą m.in. koła poselskie (art. 17 ust. 1 ustawy o wykonywaniu mandatu, art. 8 ust. 1 i 3 regulaminu Sejmu), które są zatem formalnie pewnym odrębnym od kół parlamentarnych rodzajem zrzeszeń. Jednak ściśle logiczno-językowa interpretacja prowadziłaby do absurdalnych konsekwencji. Otóż w wyborach do Senatu komitety wyborcze zgłaszać mogą tylko jednego kandydata w okręgu wyborczym (art. 264 ustawy z 5 stycznia 2011 r. - Kodeks wyborczy, t.j. Dz.U. 2019, poz. 684, ze zm.). Stąd też senator z natury rzeczy nie może „reprezentować” żadnej listy wyborczej. Aby uniknąć w związku z tym sytuacji, w której art. 15 ust. 1 in fine regulaminu Sejmu jest tzw. normą pustą (tj. nie może znaleźć zastosowania do żadnej sytuacji faktycznej), przyjąć należy, że odnosi się on w istocie do kół poselskich, a więc formuły koła parlamentarne należy używać w specyficznym znaczeniu, innym niż wynikające $z$ ustawy o wykonywaniu mandatu. Założenie to nie oznacza, że również wspólne koła poselsko-senatorskie nie mogą korzystać z uprawnienia do wskazywania swojego przedstawiciela w Konwencie Seniorów. Będzie tak w sytuacji, gdy wszyscy posłowie członkowie określonego koła „reprezentują osobną listę 
wyborczą" i spełnione zostaną inne warunki, takie jak w przypadku kół poselskich. Dodać należy, że ukształtowana praktyka parlamentarna wskazuje, że do utworzenia koła parlamentarnego wystarczy przynależność do niego minimalnej liczby posłów lub senatorów koniecznej dla założenia koła poselskiego lub senatorskiego (oraz co najmniej jednego członka drugiej z izb). Niezależnie od tego, czy praktyka ta jest prawidłowa, oznacza to, że może powstać sytuacja, w której koło parlamentarne składa się tylko z 1 lub 2 posłów oraz z co najmniej trzech senatorów, choć przynajmniej na początku kadencji jest to mało prawdopodobne. W takiej szczególnej sytuacji zasada równego traktowania (art. 32 ust. 1 Konstytucji) wymaga jednak, aby członkostwo przedstawiciela takiego koła w Konwencie Seniorów ograniczone było do takich zrzeszeń, do których należy co najmniej 3 posłów.

Po drugie, formuła mówiąca o reprezentowaniu osobnej listy wyborczej jest również w sensie prawnym wysoce niejasna. Wydaje się oczywiste, że nawiązywać ona powinna do prawa wyborczego. Jednak Kodeks wyborczy posługuje się w odniesieniu do wyborów do Sejmu pojęciem listy kandydatów zgłoszonych przez komitety wyborcze w poszczególnych okręgach wyborczych (zob. art. 209 i nast. Kodeksu wyborczego). Należy też podkreślić, że pojęcia „lista wyborcza" nie używała obowiązująca w 1997 r. (a więc w czasie, kiedy weszła w życie analizowana zmiana regulaminu Sejmu) ustawa z 28 maja 1993 r. - Ordynacja wyborcza do Sejmu Rzeczypospolitej Polskiej (Dz.U. nr 45 poz. 205, ze zm.), która rozróżniała listy okręgowe i ogólnopolskie kandydatów na posłów (art. 2). Poza tym zgodnie z językowym znaczeniem słowa „reprezentować” oznacza ono (przynajmniej w podstawowym znaczeniu): występowanie $w$ imieniu i na rzecz jakiejś osoby, grupy osób, organizacji lub instytucji ${ }^{2}$. W tym dosłownym sensie koło poselskie (czy też koło parlamentarne) nie może reprezentować listy wyborczej, bo nie można bliżej ustalić podmiotu reprezentowanego. Nie wiadomo, czy chodzi tu o występowanie w imieniu wyborców, którzy oddali głos na określoną listę, ogółu kandydatów umieszczonych na liście, czy też może komitetu wyborczego, który ją zgłosił. Samą listę wyborczą można byłoby ewentualnie uważać za instytucję prawną, ale niemożliwe jest jej reprezentowanie w podanym wcześniej znaczeniu.

W tym kontekście zasygnalizować tylko należałoby potrzebę dokonania nowelizacji regulaminu Sejmu i dostosowania art. 15 ust. 1 w części końcowej do obowiązujących norm Kodeksu wyborczego. Inną możliwość sprecyzowania treści tego przepisu stanowi podjęcie przez Prezydium Sejmu uchwały interpretacyjnej na podstawie art. 12 pkt 3 regulaminu Sejmu.

Pewnych (aczkolwiek niepełnych) wskazań dla interpretacji art. 15 ust. 1 in fine regulaminu Sejmu dostarcza wykładnia historyczna. Przytoczyć tu należy dwie wypowiedzi, stanowiące uzasadnienie tej regulacji i obrazujące jej kontekst.

2 Słownik języka polskiego, t. 4, red. M. Bańko, Warszawa 2007, s. 419. 
Poseł D. Grabowski stwierdził na pierwszym posiedzeniu Sejmu III kadencji w dniu 21 października 1997 r., że: Ruch Odbudowy Polski jest kołem w parlamencie i jako koło nie ma swojego reprezentanta w Prezydium Sejmu. Nie ma także, zgodnie z regulaminem, który obowiązuje, swojego reprezentanta $w$ Konwencie Seniorów. Sądzę, że warto przypomnieć, że pomimo niewielkiej liczby posłów w parlamencie oddano na nas przeszło 5\% głosów. Zatem jest to duża liczba wyborców. Jeśli obecny parlament ma być reprezentatywny, a przecież o to nam wszystkim cho$d z i$, to uważam, że reprezentant koła Ruchu Odbudowy Polski winien być właczony do Konwentu Seniorów. Taki wniosek składamy dzisiaj i będziemy o to wnosili w czasie prac Komisji Nadzwyczajnej ${ }^{3}$. Z kolei poseł W. Włodarczyk na posiedzeniu Sejmu w dniu 28 października 1997 r. stwierdził, że: Artykuł 16 ust. 1 regulaminu mówi, że w skład Konwentu Seniorów wchodza przedstawiciele klubów oraz porozumień kół poselskich. Rozumiem, że taka regulacja jest potrzebna, że taka sytuacja podziału klubów i wyłonienia się z nich kót może nastąić w przyszłości. I rzeczywiście takie zabezpieczenie $w$ regulaminie wydaje się sensowne i konieczne. Chciałbym jednak zwrócić uwagę, że poprawka, którą chcemy w tej chwili zgłosić, dotyczy czegoś innego. Uważamy, że członkami Konwentu Seniorów powinni być przewodniczacy kół parlamentarnych, które reprezentują określona listę wyborczą. Tak właśnie jest w przypadku Ruchu Odbudowy Polski. Weszliśmy do Sejmu z listy Ruchu Odbudowy Polski. Reprezentujemy ponad pół miliona wyborców... ${ }^{4}$.

Co do praktyki parlamentarnej w zakresie stosowania analizowanej regulacji, to stwierdzić można, że nie jest ona bogata. Jedynie w III kadencji Sejmu w składzie Konwentu Seniorów zasiadał - na podstawie art. 15 ust. 1 in fine regulaminu Sejmu - przedstawiciel koła poselskiego ${ }^{5}$. W praktyce pojawił się problem, czy zmiany w składzie osobowym tego koła w trakcie kadencji wpływają na jego uprawnienie do „delegowania” przedstawiciela do Konwentu Seniorów. Co do zasady przyjęto, że wpływu takiego nie $\mathrm{ma}^{6}$.

Dla wykładni systemowej pewne znaczenie przyznać należy art. 14 regulaminu Sejmu, który określa ogólnie charakter i podstawową funkcję Konwentu Seniorów. Zgodnie z tym przepisem organ ten zapewniać ma współdziałanie klubów w sprawach związanych $z$ działalnościa i tokiem prac Sejmu. Uzasadnia to założenie, że podstawowy skład Konwentu tworzą przedstawiciele klubów, a zatem

$3 \quad$ Http://orka2.sejm.gov.pl/Debata3.nsf [dostęp 21 października 2019 r.].

4 Wypowiedź posła W. Włodarczyka na pierwszym posiedzeniu Sejmu III kadencji w dniu 28 października 1997 r., http://orka2.sejm.gov.pl/Debata3.nsf [dostęp 19 października 2019 r.].

5 Zob. M.A. Kamiński, Rola Konwentu Seniorów w Sejmie RP na tle porównawczym [w:] Ustrój państwa. Myśl polityczno-prawna. Wspótczesne systemy rząów. Prace ofiarowane prof. zw. nauk prawnych Adamowi Jamrozowi z okazji Jego Jubileuszu, red. S. Bożyk, A. Olechno, Białystok 2018, s. 133.

6 M. Zubik, Uwaga 6 do art. 15 [w:] Komentarz do regulaminu Sejmu, red. A. Szmyt, Warszawa 2018, s. 89. 
wynikające $\mathrm{z}$ analizowanej regulacji uprawnienie niektórych kół ma charakter wyjątkowy ${ }^{7}$, a wobec tego nie można interpretować go w sposób rozszerzający (również w aspekcie podmiotowym).

Aby rozwiązać problem opisany we wstępie opinii, potrzebne jest dokonanie wykładni łączących się z sobą dwóch sformułowań: „koło parlamentarne reprezentujące listę wyborczą” oraz „osobnej listy wyborczej”. Poza tym wyjaśnienia wymaga znaczenie odwołania się do dnia rozpoczęcia kadencji Sejmu.

Wspomniany wcześniej kontekst historyczny nakazuje przyjęcie, że pojęciu „reprezentowania osobnej listy wyborczej” nadać należy przede wszystkim znaczenie personalne, a nie programowo-polityczne. Powinno ono być rozumiane jako wymóg przynależności do danego koła wyłącznie posłów, którzy umieszczeni byli na listach kandydatów do Sejmu zgłoszonych przez ten sam komitet wyborczy (niezależnie od statusu tego komitetu, a więc od tego, czy został utworzony przez partię polityczną, koalicję partii politycznych czy też wyborców). Inaczej mówiąc, pojęcie listy wyborczej w rozumieniu art. 15 ust. 1 regulaminu Sejmu oznacza zbiorcze określenie wszystkich list kandydatów na posłów zgłoszonych przez jeden komitet wyborczy. Powoduje to w praktyce, że jeśli w składzie osobowym danego koła (w dniu rozpoczęcia kadencji Sejmu) znalazłaby się choćby jedna osoba, która znajdowała się na liście kandydatów do Sejmu zgłoszonych przez inny komitet wyborczy, to koło takie traci automatycznie uprawnienie do „przedstawicielstwa” w Konwencie Seniorów. Ustalenie to nawiązuje do językowego znaczenia przymiotnika osobny, który oznacza „rzeczy oddzielone od innych lub od siebie nawzajem” albo też „różne rzeczy, sprawy lub osoby”. Jeżeli koło skupia posłów, którzy wybrani zostali z list różnych komitetów wyborczych, to jako całość oczywiście nie może być ono traktowane jako reprezentacja osobnej listy wyborczej (w podanym wcześniej znaczeniu), niezależnie od relacji ilościowej między posłami wybranymi z list różnych komitetów wyborczych. Taki kierunek interpretacji potwierdza wykładnia historyczna. W przytoczonych wcześniej wypowiedziach zwracano bowiem wyraźnie na uwagę na to, że posłowie tworzący koło Ruchu Odbudowy Polski wybrani zostali do Sejmu z list kandydatów tylko jednego komitetu wyborczego.

Pojawia się jednak pytanie, czy zastosowanie art. 15 ust. 1 in fine regulaminu Sejmu wymaga przynależności do określonego koła wszystkich posłów wybranych z list określonego komitetu wyborczego, czy też wystarczający jest akces tylko pewnej ich części. W literaturze wyrażono pogląd, który stanowić może podstawę rozstrzygnięcia tej kwestii. Stwierdza się mianowicie, że koło reprezentuje osobną listę wyborczą, jeżeli: członkowie tego koła dostali się do Sejmu ze wspólnej listy wyborczej - odrębnej od list z których uzyskali mandat posłowie

M. Zubik, Uwaga 6 do art. 15, op. cit., s. 89.

8 Słownik języka polskiego, t. 3, op. cit., s. 395. 
tworzacy pozostałe kluby $i$ koła ${ }^{9}$ Z tak sformułowanych założeń wynika, że prawidłowy jest drugi z przedstawionych wcześniej wariantów, a więc również koło, do którego należą tylko niektórzy posłowie wybrani do Sejmu z list kandydatów jednego komitetu wyborczego, nabywa uprawnienie do udziału jego przedstawiciela w pracach (posiedzeniach) Konwentu Seniorów. Wobec wspomnianych wcześniej niejasności co do pojęcia „reprezentowania listy wyborczej” trudno na jego podstawie sformułować wymaganie zgodne z pierwszą z przedstawionych wcześniej alternatyw.

Powyższe ustalenia wymagają jednak pewnego uzupełnienia. W praktyce może wystąpić sytuacja, w której część posłów wybranych z list kandydatów jednego komitetu wyborczego tworzy na początku kadencji Sejmu koło poselskie, ale część przystępuje do klubów lub kół wraz z posłami wybranymi z list innych komitetów wyborczych. W świetle przytoczonego wcześniej poglądu doktrynalnego (a dokładnie drugiej jego części) należałoby przyjąć, że w takiej konkretnej sytuacji do koła poselskiego nie ma zastosowania art. 15 ust. 1 regulaminu Sejmu. Koło nie zrzesza bowiem posłów, którzy: dostali się do Sejmu z listy odrębnej od list, z których uzyskali mandat posłowie tworzacy pozostałe kluby $i$ koła.

Wydaje się jednak, że stanowisko takie nie jest trafne. Przytoczony wyżej pogląd (traktowany dosłownie) stanowi nadmierną generalizację i jest zbyt daleko idący. Jeżeli bowiem przyjąć kryterium „jednorodności personalnej” dla oceny reprezentatywności koła wobec konkretnej listy wyborczej, to logiczne byłoby założenie, że koła lub kluby, w skład których wchodzą posłowie wybrani z list kandydatów różnych komitetów wyborczych, nie reprezentują żadnej konkretnej „listy wyborczej”. Stąd też ich powstanie nie powinno co do zasady wpływać na kwalifikację z tego punktu widzenia koła poselskiego założonego przez innych posłów. Takie podejście nawiązuje też do zarysowanej wcześniej praktyki, która opierała się na założeniu, że zmiana „przynależności frakcyjnej” w toku kadencji nie wpływa na status koła (naturalnie z wyjątkiem sytuacji, gdy jego liczebność spadnie poniżej 3 posłów). Z uwagi jednak na ogólnikowość i niejasność regulacji cały problem trudno jednoznacznie rozstrzygnąć.

Niezależnie od powyższych wątpliwości, przyjąć należy, że jeśli niektórzy posłowie wybrani z list kandydatów danego komitetu wyborczego są (w dniu rozpoczęcia pierwszego posiedzenia Sejmu w nowej kadencji) tzw. posłami niezrzeszonymi, to pozostali członkowie izby poselskiej, którzy uzyskali mandat z tych list, mogą założyć koło ze skutkiem opisanym w art. 15 ust. 1 regulaminu Sejmu.

Odwołanie do rozpoczęcia kadencji Sejmu traktować należy jako nawiązanie do art. 98 ust. 1 Konstytucji. Zgodnie z tym przepisem kadencja Sejmu rozpoczyna się z dniem zebrania się Sejmu na pierwsze posiedzenie, zwołane przez

9 J.K. Sokołowski, Organizacja wewnętrzna, tryb i zasady funkcjonowania organów ustawodawczych [w:] Wybrane aspekty funkcjonowania Sejmu w latach 1997-2007, red. J.K. Sokołowski, P. Poznański, Kraków 2008, s. 49. 
Prezydenta RP. W kontekście praktyki wielodniowych pierwszych posiedzeń Sejmu zauważyć należy, że art. 15 ust. 1 in fine odnosi się do dnia oznaczonego w postanowieniu Prezydenta określającym datę pierwszego posiedzenia Sejmu, o ile - co jest raczej teoretyczne - z jakichś nadzwyczajnych przyczyn Sejm nie zebrałby się na posiedzenie w tym dniu. Znaczenie daty pierwszego posiedzenia Sejmu odnosi się do „reprezentacyjnego” charakteru danego koła wobec „listy wyborczej”. Łączy się ściśle z niedopuszczalnością: wprowadzenia do Konwentu przedstawicieli tzw. kół rozłamowych powstałych $w$ toku kadencji przez odejście kilku posłów z większego klubu (lub wyjątkowo koła), nawet jeśli zostali oni wybrani z list kandydatów jednego komitetu wyborczego. Czyni jednak: dopuszczalna praktykę polegająca na włączeniu do utworzonego na początku kadencji koła posłów, którzy należeli na początku kadencji do innych klubów lub kót, jak również posłów niezrzeszonych ${ }^{10}$. Należy jednak podkreślić, że niekiedy praktyka ta jest stawiana pod znakiem zapytania ${ }^{11}$.

Konsekwencją wyraźnego odwołania się w art. 15 ust. 1 regulaminu Sejmu do dnia rozpoczęcia kadencji Sejmu istotny jest - z „chronologicznego” punktu widzenia - wymóg istnienia (utworzenia) koła najpóźniej w tym dniu. Niezależnie od wspomnianych wcześniej wątpliwości co do rozumienia pojęcia reprezentowania, oczywiste jest, że koło, które powstało w terminie późniejszym, nie mogło nikogo reprezentować $\mathrm{w}$ dniu rozpoczęcia kadencji. Wymóg reprezentatywności odniesiony został przy tym wyraźnie do samego koła, a nie do posłów, którzy do niego należą. Jeśli chodzi o ustalenie daty powstania koła, to podzielić należy w pełni pogląd, że jest nią dzień ukonstytuowania się koła. Najczęściej będzie to dzień pierwszego posiedzenia jego członków ${ }^{12}$. Sama data złożenia zawiadomienia, o którym mowa w art. 8 ust. 7 regulaminu Sejmu, nie ma w tym wypadku rozstrzygającego znaczenia.

Nawiązując do dominującego w doktrynie prawa konstytucyjnego poglądu, w myśl którego datą nabycia mandatu parlamentarnego jest dzień ogłoszenia wyników wyborów ${ }^{13}$, stwierdzić należy, że koło poselskie (czy koło parlamentarne) powstać może przed dniem pierwszego posiedzenia Sejmu nowej kadencji. Co prawda, sprawowanie mandatu parlamentarnego zaczyna się od momentu złożenia ślubowania (art. 104 ust. 2 Konstytucji RP), ale zgodnie z utrwaloną praktykę pewne działania związane $\mathrm{z}$ wykonywaniem mandatu mogą być podejmowane przez posłów już wcześniej. Zalicza się do nich m.in. działalność we frakcjach

$10 \quad$ Ibidem, s. 49.

11 Zob. M. Zubik, Organizacja wewnętrzna Sejmu RP, Warszawa 2003, s. 257.

12 J.M. Karolczak, Data utworzenia klubu lub koła poselskiego [w:] Regulamin Sejmu w opiniach Biura Analiz Sejmowych, wybór i oprac. W. Odrowąż-Sypniewski, t. I, Warszawa 2010, s. 60.

13 K. Grajewski, J. Stelina, P. Uziębło, Komentarz do ustawy o wykonywaniu mandatu posła i senatora, Warszawa 2014, s. 33. 
parlamentarnych ${ }^{14}$. Granicą jest jednak dzień oficjalnego ogłoszenia wyników wyborów.

Odnosząc się do konkretnego problemu powstania dwóch (lub więcej) kół poselskich, które zrzeszają (wyłącznie) posłów wybranych z list jednego komitetu wyborczego, stwierdzić należy, że teoretycznie dopuszczalne wydają się cztery rozwiązania. Po pierwsze, przyjęcie, że koło reprezentuje osobną listę wówczas, gdy posłowie wybrani z list konkretnego komitetu są członkami jednego koła, a zatem w sytuacji utworzenia przez nich większej liczby kół żadne z nich nie jest uprawnione do wskazania przedstawiciela wchodzącego w skład Konwentu Seniorów. Po drugie, potencjalnie możliwe wydaje się zastosowanie wówczas kryterium ilościowego, tj. za reprezentatywne uznawać należałoby koło o większej liczbie członków (a dokładnie liczbie posłów wybranych z list kandydatów jednego komitetu wyborczego). Po trzecie, odwołać można się do kryterium „tożsamości politycznej”, co w praktyce oznacza, że należałoby ustalać, które z kół pozostaje w najbliższym związku z komitetem wyborczym, a w szczególności z partią polityczną, która go utworzyła. Po czwarte, można byłoby nawiązać do zasady prior tempore potior iure (pierwszeństwo w czasie daje lepsze prawa) i stwierdzić, że w analizowanej sytuacji decydować powinna data powstania poszczególnych kół poselskich (parlamentarnych).

W literaturze wyrażono pogląd, że w art. 15 ust. 1 regulaminu Sejmu: chodzi oczywiście o sytuacje, w której istnieje tylko jedno koło reprezentujące dana listę wyborcza $q^{15}$. Oznacza to wybór pierwszego z zarysowanych wcześniej wariantów. Pogląd ten opiera się, po pierwsze, na interpretacji pojęcia „osobnej listy wyborczej" i przyjęciu, że oznacza ono, iż w skład Konwentu nie może wchodzić więcej niż jeden przedstawiciel kół reprezentujących (w omówionym wcześniej aspekcie personalnym) tę samą „listę wyborczą”. Takie podejście wydaje się uzasadnione dążeniem do nadania sformułowaniu „osobna lista wyborcza” innego (szerszego) znaczenia niż określeniu „jedna lista wyborcza”. Po drugie, powołać się można na argumenty natury funkcjonalnej. Otóż przyjęcie, że posłowie wybrani z list jednego komitetu wyborczego w liczbie co najmniej 6 mogliby tworzyć dwa (a w przypadku wyboru więcej niż 8 posłów nawet trzy) koła, które reprezentowały jedną listę, prowadziłoby do tego, że mogłyby w ten sposób „sztucznie” zwiększać swoją reprezentację w Konwencje Seniorów. Byłoby to systemowo trudne do pogodzenia z założeniem „dominującej” roli klubów (poselskich i parlamentarnych) w Konwencie Seniorów. Stąd też przyjąć należy, że w sytuacji, gdy posłowie wybrani $z$ list kandydatów jednego komitetu wyborczego utworzyliby (według stanu na dzień zwołania pierwszego posiedzenia Sejmu) dwa koła poselskie (lub więcej), to art. 15 ust. 1 nie ma zastosowania do żadnego z nich.

14 Ibidem, s. 31.

15 J.K. Sokołowski, Organizacja wewnętrzna, op. cit., s. 49, przypis 60. 
Zwrócić można uwagę, że analogicznie ocenić należy sytuację, w której część posłów wybranych z list kandydatów określonego komitetu utworzyła klub (poselski lub parlamentarny), a część koło poselskie. Koła takiego nie można uznać za reprezentujące osobną „listę wyborczą”.

W kontekście przedstawionych wcześniej czterech wariantów rozwiązania analizowanego problemu stwierdzić należy przede wszystkim, że brak jest podstaw normatywnych, które jednoznacznie wskazywałyby na trafność któregoś z tych wariantów. Ocena z punktu widzenia liczebności kół może wpływać ewentualnie tylko na stopień reprezentatywności względem „listy wyborczej”, ale trudno byłoby tylko na tej podstawie odmówić zastosowania art. 15 ust. 1 regulaminu Sejmu. Poza tym ze względów praktycznych zastosowanie tego kryterium wymagałoby i tak przyjęcia dodatkowej reguły, która dotyczyłaby sytuacji równej liczebności konkretnych kół. Z kolei odwołanie się do „tożsamości politycznej” musiałoby obejmować wskazanie w miarę jednoznacznych kryteriów oceny, aby uniknąć zarzutu arbitralnej oceny. Oczywiście ich sformułowanie byłoby trudne, a w każdym razie nie można odnaleźć ich w przepisach regulaminu Sejmu. Wreszcie posłużenie się regułą prior tempore potior iure pozornie przyniosłoby jednoznaczne wyniki, ale i tak normatywnego sprecyzowania wymagałoby ustalenie, czy liczy się moment utworzenia koła (i co konkretnie pojęcie to oznacza), czy też moment wypełnienia przez koło obowiązku, o którym mówi art. 8 ust. 7 regulaminu Sejmu.

Wobec powyższego wspomniane wcześniej potencjalne sposoby rozwiązania analizowanego w tej części opinii problemu uznać można tylko za wskazówki dla ewentualnego jednoznacznego jego rozstrzygnięcia w drodze nowelizacji regulaminu Sejmu.

W końcowej części opinii należy zwrócić uwagę na najważniejsze zagadnienia proceduralne. Po pierwsze, nie ulega wątpliwości, że zastosowanie art. 15 ust. 1 in fine wymaga wykonania przez władze określonego koła obowiązku podania do wiadomości Marszałka Sejmu składu koła oraz jego statutu (regulaminu) wewnętrznego (art. 8 ust. 7 regulaminu Sejmu). Zawiadomienie takie może zostać złożone także po dniu, w którym rozpoczęła się kadencja Sejmu, jednak w takiej sytuacji wynikać z niego powinno, że koło istniało już w tym dniu. Władze koła nie muszą stawiać formalnego wniosku o włączenie jego przedstawiciela w skład Konwentu Seniorów, jednak względy pewności prawnej wymagały wyraźnego wskazania lub zawiadomienia (ewentualnie w statucie lub regulaminie koła), który konkretnie poseł ma być jego przedstawicielem w Konwencie Seniorów. W odróżnieniu od klubów poselskich Marszałek Sejmu nie podejmuje żadnego odrębnego rozstrzygnięcia w sprawie uznania kompetencji danego koła do „delegowania” przedstawiciela w Konwencie Seniorów lub też odmowy stwierdzenia tego uprawnienia. Jego ocena wyraża się przez tzw. czynności konkludentne, tj. zawiadamianie konkretnego posła (względnie samego koła) o zwołaniu posiedzenia Konwentu i dopuszczeniu go do udziału w nim. W sytuacjach wątpliwych 
Marszałek Sejmu może ewentualnie zapraszać przedstawiciela konkretnego koła na posiedzenia Konwentu na podstawie art. 15 ust. 3 regulaminu Sejmu. Przed rozstrzygnięciem kwestii reprezentacji Marszałek może zwrócić się o opinię do Prezydium Sejmu i Komisji Regulaminowej, Spraw Poselskich i Immunitetowych, do której należą sprawy wykładni i stosowania regulaminu Sejmu (pkt 28 załącznika do regulaminu Sejmu - Przedmiotowy zakres działania komisji sejmowych).

Gdy Marszałek Sejmu stwierdził, że przedstawiciel określonego koła nie ma prawa brania udziału w pracach Konwentu Seniorów, władzom tego koła lub jego członkom nie przysługują żadne formalne środki odwoławcze.

\section{Podsumowanie}

- Pojęcie „koła parlamentarnego reprezentującego w dniu rozpoczęcia kadencji Sejmu osobną listę wyborczą" (art. 15 ust. 1 regulaminu Sejmu) obejmuje zrzeszenia, które spełniać muszą łącznie następujące warunki:

a) zostały utworzone najpóźniej w dniu, w którym odbywa się pierwsze posiedzenie (a dokładniej w dniu, na który Prezydent RP zwołał pierwsze posiedzenie Sejmu); data powiadomienia Marszałka o składzie osobowym koła i jego statucie nie ma rozstrzygającego znaczenia,

b) składają się z co najmniej trzech posłów, członkostwo senatorów jest dopuszczalne,

c) wszyscy posłowie tworzący dane koło zostali wybrani z list kandydatów zgłoszonych przez ten sam komitet wyborczy,

d) pozostali posłowie, wybrani z list kandydatów zgłoszonych przez ten komitet wyborczy, nie utworzyli (do dnia zebrania się Sejmu na pierwsze posiedzenie) innego klubu lub koła poselskiego.

- Spełnienie powyższych warunków wynikać powinno z podanych do wiadomości Marszałka Sejmu informacji o składzie osobowym koła oraz jego regulaminu (statutu). Dopełnienie tego „obowiązku informacyjnego" jest konieczne dla udziału przedstawiciela określonego koła w posiedzeniach Konwentu Seniorów. Przedstawicielem koła nie musi być jego przewodniczący lub wiceprzewodniczący, chyba że statut (regulamin) koła ustanawia taki wymóg.

- W sytuacji, gdy posłowie wybrani z list kandydatów jednego komitetu wyborczego utworzą (według stanu na dzień zwołania pierwszego posiedzenia Sejmu) dwa lub więcej kół poselskich, to art. 15 ust. 1 nie ma zastosowania do żadnego z nich. Przyjąć należy, że nie reprezentują one wówczas osobnej „listy wyborczej”. - W kontekście poważnych wątpliwości interpretacyjnych zasygnalizować należy potrzebę dokonania nowelizacji art. 15 ust. 1 regulaminu Sejmu (w części końcowej) i dostosowania go do obowiązujących przepisów ustawowych z zakresu prawa wyborczego albo sprecyzowania jego treści w drodze uchwały interpretacyjnej Prezydium Sejmu (art. 12 pkt 3 regulaminu Sejmu). 


\section{Bibliografia}

Grajewski K., Stelina J., Uziębło P., Komentarz do ustawy o wykonywaniu mandatu posła i senatora, Warszawa 2014.

Kamiński M.A., Rola Konwentu Seniorów w Sejmie RP na tle porównawczym [w:] Ustrój państwa. Myśl polityczno-prawna. Wspótczesne systemy rzadów. Prace ofiarowane prof. zw. nauk prawnych Adamowi Jamrozowi z okazji Jego Jubileuszu, red. S. Bożyk, A. Olechno, Białystok 2018.

Karolczak J.M., Data utworzenia klubu lub koła poselskiego [w:] Regulamin Sejmu w opiniach Biura Analiz Sejmowych, wybór i oprac. W. Odrowąż-Sypniewski, t. I, Warszawa 2010.

Słownik języka polskiego, t. 3, t. 4, red. M. Bańko, Warszawa 2007.

Sokołowski J.K., Organizacja wewnętrzna, tryb i zasady funkcjonowania organów ustawodawczych [w:] Wybrane aspekty funkcjonowania Sejmu w latach 1997-2007, red. J.K. Sokołowski, P. Poznański, Kraków 2008.

Zubik M., Organizacja wewnętrzna Sejmu RP, Warszawa 2003.

Zubik M., Uwaga 6 do art. 15 [w:] Komentarz do regulaminu Sejmu, red. A. Szmyt, Warszawa 2018. 
\begin{tabular}{l|l}
2 & OPINIE BAS
\end{tabular}

B

ZAGADNIENIA PRAWA MIĘDZYNARODOWEGO I EUROPEJSKIEGO 

Marek Jaśkowski

\title{
Analiza opracowania pt. „Polowania na ptaki. Zgodność z prawem międzynarodowym, unijnym i krajowym. Aspekt ochrony przyrody i humanitarno-prawny"1
}

\author{
Analysis of the study "Bird hunting. Compliance with international, EU \\ and national law. Aspect of nature protection as well as a humanitarian \\ and legal aspect"
}

According to the author, in numerous aspects the assessment of the compliance with the Birds Directive can be carried out at the local level, taking into account elements such as habitat characteristics, the nature of the hunt or the degree of actual probability of the error due to the similarity of hunted and protected species. The thesis that pheasants and partridges can be considered as game only after the maturity of their own broods is too far-reaching. According to the author, the use of lead shot in areas of special protection may be considered incompatible with the protection requirements of these areas, and the practice of general exclusion of hunting plans from the requirement to undergo an impact assessment on a given area may be considered incompatible with the Habitats Directive.

Keywords: hunting, wildlife conservation, animal protection, Hunting Law, European Union

W ocenie autora, na wielu płaszczyznach ocena zgodności z dyrektywą ptasią może być przeprowadzana na poziomie lokalnym, z uwzględnieniem takich elementów jak cechy siedliska, charakter polowania czy rzeczywiste prawdopodobieństwo wystąpienia pomyłki wskutek podobieństwa gatunków łownych i chronionych. Teza, zgodnie z którą bażanty i kuropatwy mogą zostać uznane za zwierzynę łowną dopiero po okresie wyprowadzenia własnych lęgów, jest zbyt daleko idąca. Zdaniem autora, stosowanie śrutu ołowianego na obszarach szczególnej ochrony może zostać uznane za niezgodne z wymogami ochrony tych terenów, zaś praktyka polegająca na generalnym wyłączeniu planów łowieckich spod wymogu poddania ocenie wpływu na dany teren może zostać uznana za niezgodną z dyrektywą siedliskową.

Słowa kluczowe: łowiectwo, ochrona przyrody, ochrona zwierząt, prawo łowieckie, Unia Europejska

Doktor nauk prawnych, adiunkt Uniwersytet Kardynała Stefana Wyszyńskiego w Warszawie, Wydział Prawa i Administracji, Katedra Prawa Międzynarodowego i Europejskiego, WARSZAWA, POLSKA • marek.jaskowski@sejm.gov.pl • https://orcid.org/0000-0001-6598-810X

1 Opinia dotycząca opinii „Polowania na ptaki. Zgodność z prawem międzynarodowym, unijnym i krajowym. Aspekt ochrony przyrody i humanitarno-prawny" sporządzona 23 stycznia 2020 r. na zlecenie posła Klubu Parlamentarnego Platforma Obywatelska Koalicja Obywatelska; BAS-WAPM 162/19. 


\section{Przedmiot opinii}

Niniejsza opinia stanowi analizę zasadniczych tez zawartych w opinii „Polowania na ptaki. Zgodność z prawem międzynarodowym, unijnym i krajowym. Aspekt ochrony przyrody i humanitarno-prawny" dr Magdaleny Micińskiej (dalej: analizowania opinia).

Niniejsza opinia dotyczy aspektów prawnych powyższego zagadnienia, w szczególności oceny zgodności wskazanych przepisów i praktyk z normami prawa UE i prawa międzynarodowego. Poza zakresem opinii pozostają zwłaszcza uwagi, w których Autorka analizowanej opinii dokonuje oceny raczej o charakterze moralnym niż prawnym [(np. chociaż w ocenie Autorki na tle humanitarno-prawnego standardu uśmiercania kręgowców polowania na ptaki stanowia rażacy, demoralizujacy anachronizm prawniczy (s. 23 analizowanej opinii), to jednak przyznaje ona, że: prawo międzynarodowe, unijne i krajowe nie wprowadziło szczegółowych wymogów humanitarnych odnośnie polowań (s. 21 analizowanej opinii)].

Z uwagi na odwoływanie się przez Autorkę w znacznym stopniu do prawa UE i do konwencji berneńskiej², wstępna część opinii została poświęcona relacjom między tą konwencją a prawem UE, zwłaszcza dyrektywami 2009/147/WE oraz 92/43/EWG. Kolejne części niniejszej opinii stanowią odniesienie do poszczególnych tez zawartych w analizowanej opinii.

\section{Relacje między konwencją berneńską a dyrektywami 2009/147/WE oraz 92/43/EWG}

W analizowanej opinii zawarte zostały zarzuty niezgodności określonych regulacji polskich z konwencją berneńską i dyrektywami 2009/147/WE oraz 92/43/ EWG. Jednocześnie należy zauważyć daleko posunięte podobieństwo między niektórymi przepisami, z jednej strony konwencji berneńskiej, a z drugiej - obu wspomnianych dyrektyw. W związku z tym punktem wyjścia dla niniejszej opinii należy uczynić wyjaśnienie relacji między tymi aktami prawnymi, w szczególności w celu ustalenia zależności interpretacyjnych między nimi.

Konwencja o ochronie gatunków dzikiej flory i fauny europejskiej i ich siedlisk została zawarta 19 września 1979 r. i weszła w życie 1 czerwca 1982 r. po osiągnięciu wymaganego progu ratyfikacji (5). Zgodnie z art. 19 ust. 1 konwencji jej stroną mogły stać się nie tylko państwa, ale również Europejska Wspólnota Gospodarcza (obecnie: Unia Europejska). Ówczesna EWG przystąpiła do konwencji na mocy decyzji Rady z 3 grudnia 1981 r. dotyczącej zawarcia konwencji o ochronie gatunków dzikiej flory i fauny europejskiej oraz ich siedlisk

2 Konwencja o ochronie gatunków dzikiej flory i fauny europejskiej i ich siedlisk z 19 września 1979 r. 
(82/72/EWG, Dz.Urz. L 038 z 10 lutego1982 r., s. 1). Konwencja weszła w życie w stosunku do obszarów objętych stosowaniem prawa ówczesnej Europejskiej Wspólnoty Gospodarczej 1 września 1982 r. (Dz.Urz. L 150 z 8 czerwca 1983 r., s. 36). Niezależnie od tego należy zauważyć, że stronami konwencji są jednocześnie wszystkie państwa członkowskie UE.

Jeżeli chodzi o relacje między konwencją berneńską a dyrektywami 2009/147/WE oraz 92/43/EWG, to należy zauważyć, że żadna z tych dyrektyw nie odwołuje się do konwencji. Projekt dyrektywy 79/409/EWG przedłożono w roku 1976 (COM (76) 676), zaś sama dyrektywa została przyjęta 2 kwietnia 1979 r. Trudno więc oczekiwać, aby dokumenty te wprost odwoływały się do konwencji przyjętej we wrześniu 1979 r., która, co więcej, weszła w życie wobec EWG 1 września 1982 r., (jakkolwiek możemy zakładać, że autorzy dyrektywy brali pod uwagę prace nad późniejszą konwencją berneńskąa , które rozpoczęły się również w 1976 r. ${ }^{4}$. Trzeba jednak zauważyć, że mimo licznych nowelizacji dyrektywy 79/409/EWG, aż do jej uchylenia z mocą od 2010 r., nie zostało w niej zawarte odwołanie do konwencji berneńskiej. Również zastępująca ją dyrektywa 2009/147/WE (ani uzasadnienie towarzyszące jej projektowi) nie wskazuje w swojej treści, aby stanowiła ona akt wdrażający konwencję berneńską na poziomie UE. Podobnie konwencja berneńska jest wielkim nieobecnym w tekście dyrektywy 92/43/EWG.

Mimo to $\mathrm{w}$ praktyce unijnych organów wskazuje się na zależności między tymi dokumentami, aczkolwiek są one ujmowane w różny sposób. Przykładowo, w sprawozdaniu przedstawionym przez Komisję Europejską, zgodnie z wymogami art. 9 ust. 2 konwencji berneńskiej, stwierdza się, że dyrektywa 79/409/EWG (obecnie dyrektywa 2009/147/WE) wraz z dyrektywą 92/43/EWG stanowią unijne ramy wykonywania postanowień tej konwencji ${ }^{5}$. Z taką oceną zgadza się rzecznik generalna J. Kokott, według której: dyrektywa siedliskowa służy - łącznie z dyrektywa ptasia - implementacji konwencji berneńskiej ${ }^{6}$. Na marginesie warto zauważyć,

3 Opinia rzecznika generalnego w sprawie C-57/89, pkt 10.

4 J.P. Ribaut, How the Bern Convention Came into Being, „Naturopa” 2004, No (101), s. 4. 5 SEC/2001/0515 final.

6 Pkt 34 opinii rzecznika generalnego w sprawie C-221/04; pkt 10 opinii rzecznika generalnego w sprawie C-383/09, tak samo w odniesieniu do dyrektywy siedliskowej, acz z lekkim wahaniem, V. Koester, The Bern Convention and I, „Naturopa” 2004, No (101), s. 5; zob. również rezolucję Rady Wspólnot Europejskich i przedstawicieli rządów państw członkowskich zebranych w Radzie z 19 października 1987 r. w sprawie kontynuacji i implementacji polityki dotyczącej środowiska naturalnego i programu działania Wspólnot Europejskich w zakresie ochrony środowiska (1987-1992) (Dz.Urz. UE C 328, s. 1, pkt 5.1.4-5.1.6), gdzie zauważa się potrzebę przyjęcia aktu prawa wspólnotowego zmierzającego do ochrony gatunków fauny i flory, jak również siedlisk gatunków dzikich, m.in. z tego powodu, że wdrażanie konwencji berneńskiej jest wysoce niezadowalające w państwach członkowskich Wspólnoty, i że przyjęcie odpowiedniego instrumentu prawnego na poziomie EWG poprawiłoby tę sytuację. 
że w ramach procedury prowadzącej do przyjęcia dyrektywy siedliskowej Komitet Ekonomiczno-Społeczny wskazał, że celem przedłożonego projektu jest zapewnienie bardziej skutecznej realizacji zobowiązań wynikających z konwencji ${ }^{7}$.

W omawianym kontekście należy też zaznaczyć, że zgodnie $\mathrm{z}$ orzecznictwem TSUE akty prawa wtórnego UE należy - w miarę możliwości - interpretować „W świetle prawa międzynarodowego”, w szczególności jeśli są to przepisy, które mają właśnie na celu wprowadzenie w życie umowy międzynarodowej zawartej przez Wspólnotę , lub, jak stwierdził Trybunał przy innej okazji, „,W sposób zgodny” z wiążącymi Unię konwencjami międzynarodowymi ${ }^{9}$. Należy więc zgodzić się z opinią rzecznika generalnego H. Saugmandsgaarda Øe w sprawie C-674/17, zgodnie z którą dokumenty interpretacyjne wydawane na podstawie konwencji berneńskiej mogą stanowić dla TSUE wskazówkę w zakresie interpretacji dyrektywy siedliskowej, jako że dyrektywa ta w znacznym stopniu oparta jest na konwencji berneńskiej $^{10}$. Analogiczny wniosek należy wysnuć w odniesieniu do dyrektywy ptasiej.

Warto też zauważyć, że zgodnie z art. 12 konwencji jej strony mogą zastosować bardziej rygorystyczne środki w celu ochrony dzikiej flory i fauny oraz ich naturalnych siedlisk niż przewidziane w samej konwencji. W tym kontekście oczywisty jest wniosek rzecznika generalnego N. Fennelly’ego, że fakt, iż konwencja nie znajduje zastosowania do niektórych gatunków ptaków (objętych przepisami dyrektywy ptasiej), w żaden sposób nie zwalnia państw członkowskich z obowiązku pełnego wykonania tej dyrektywy, również więc w zakresie wykraczającym ponad standardy ochrony przewidziane w konwencji. Brak zakazu polowań na określone ptaki w konwencji nie może więc być traktowany jako dorozumiane upoważnienie do prowadzenia takich polowań.

\section{Opiniowana teza: „sprowadzanie wysokiego ryzyka zabicia ptaków objętych ochroną gatunkową, płoszenie i niepokojenie ich w siedliskach, koliduje z przepisami art. 6 lit. a, b, i c konwencji berneńskiej, art. 4 ust. 4 i art. 5 lit. a, b, d dyrektywy ptasiej"}

\section{Artykuł 4 ust. 4 dyrektywy 2009/147/WE}

Artykuł 4 ust. 4 dyrektywy 2009/147/WE ${ }^{11}$ (dalej również dyrektywa ptasia) wymaga, aby w odniesieniu do obszarów ochrony gatunków chronionych (określo-

7 Opinion on the proposal for a Council Directive on the protection of natural and seminatural habitats and of wild fauna and flora and on the Supplementary Annexes (91/C 31/01), pkt 1.2.

8 Wyrok TSUE w sprawie C-306/05, pkt 35.

$9 \quad$ Wyrok TSUE w sprawie C-161/08, pkt 38.

10 Opinia rzecznika generalnego w sprawie C-674/17, przypis 57.

11 Dyrektywa Parlamentu Europejskiego i Rady 2009/147/WE z 30 listopada 2009 r. w sprawie ochrony dzikiego ptactwa, Dz.Urz. UE L 20 z 26 stycznia 2010 r., s. 7. 
nych w załączniku I do dyrektywy) i gatunków migrujących państwa członkowskie podjęły właściwe kroki w celu uniknięcia powstawania zanieczyszczenia lub pogorszenia warunków naturalnych siedlisk lub jakichkolwiek zakłóceń wpływających na ptactwo, o ile mają one znaczenie w odniesieniu do celów tego artykułu. Należy przy tym zaznaczyć, że państwa członkowskie są zobowiązane przestrzegać obowiązków, które wynikają z tego przepisu, nawet jeżeli dane obszary nie zostały sklasyfikowane jako obszary specjalnej ochrony, jeżeli okaże się, że powinny były zostać tak sklasyfikowane ${ }^{12}$.

Zgodnie $\mathrm{z}$ analizowaną opinią pobyt myśliwych, psów myśliwskich i pojazdów w siedliskach i kontaminacja środowiska śrutem ołowianym stanowią naruszenie art. 4 ust. 4 dyrektywy ptasiej, ponieważ prowadzą do powstawania zanieczyszczenia lub pogorszenia warunków naturalnych siedlisk lub zakłóceń wpływających na ptactwo. Zagadnienie zanieczyszczenia środowiska śrutem ołowianym zostanie omówione osobno, w dalszej części opinii. Natomiast w odniesieniu do pobytu myśliwych, psów myśliwskich i pojazdów w siedliskach należy zauważyć, że, zgodnie z interpretacją Komisji Europejskiej, art. 4 dyrektywy ptasiej nie sprzeciwia się prowadzeniu polowań jako takich na obszarach szczególnej ochrony, co więcej - na podstawie dyrektyw o ochronie przyrody nie ma ogólnych przesłanek przeciwko polowaniu na terenach sieci Natura 2000. Powinny one jednak być właściwie zarządzane i kontrolowane, aby uniknąć powodowania poważnych zakłóceń na takich obszarach. Polowanie i inne działania człowieka mogą potencjalnie prowadzić do tymczasowego ograniczenia korzystania z siedlisk na danym terenie. Działania takie byłyby znaczące, gdyby prowadziły do wyraźnego zmniejszenia zdolności terenu do utrzymania gatunku, dla którego został on przeznaczony (co jednocześnie prowadziłoby do zmniejszenia możliwości prowadzenia tamże polowań $)^{13}$. Dokonując oceny powagi zakłócenia, należy wziąć pod uwagę takie czynniki, jak charakter i rozmiar terenu, charakter i rozmiar polowania, gatunki występujące na danym obszarze, a także powody, dla których teren jest istotny dla ochrony przyrody, a które doprowadziły do ujęcia go w sieci Natura 2000. W konsekwencji, działania związane z polowaniem na terenach należących do sieci Natura 2000 są zasadniczo kwestiami związanymi z zarządzaniem tymi obszarami, co powinno stanowić przedmiot ustaleń głównie na poziomie lokalnym, za pomocą planu zarządzania (wytyczne 2008, pkt 1.5.7).

Co istotne, $\mathrm{z}$ uwagi na stanowisko zawarte $\mathrm{w}$ analizowanej opinii, $\mathrm{w}$ ocenie Komisji Europejskiej sytuacja polegająca na występowaniu rzadkiego gatunku, który jest bardzo wrażliwy na zakłócenie, obok potencjalnej zwierzyny łownej,

12 Wyrok TSUE w sprawie C-141/14, pkt 67.

13 Wytyczne dotyczące polowania na podstawie dyrektywy Rady 79/409/EWG w sprawie ochrony dzikiego ptactwa, Komisja Europejska 2008 (dalej: wytyczne 2008), pkt 1.5.1, 1.5.3. 
może prowadzić do wniosku, że polowanie byłoby niezgodne z celami ochrony dla poszczególnych terenów. Jednakże Komisja podkreśla konieczność zniuansowanego podejścia, uznając, że przypadki takie mogą być ustalane tylko dla indywidualnych terenów (wytyczne 2008, pkt 1.5.4).

Wobec powyższego należy uznać, że zawarta w analizowanej opinii teza, jakoby pobyt myśliwych, psów myśliwskich i pojazdów w siedliskach stanowiły jako takie naruszenie art. 4 ust. 4 dyrektywy ptasiej jest zbyt daleko idąca. Oceny zgodności z dyrektywą należy bowiem dokonywać na poziomie lokalnym, z uwzględnieniem cech siedliska i charakteru polowania.

\section{Artykuł 5 lit. a, b i d dyrektywy 2009/147/WE}

Artykuł 5 dyrektywy 2009/147/WE nakazuje państwom członkowskim ustanowienie powszechnego systemu ochrony dla wszystkich gatunków dzikiego ptactwa (z wyjątkiem określonych w załączniku II do tej dyrektywy gatunków łownych). System ochrony ma w szczególności zabraniać w odniesieniu do dzikiego ptactwa (a) umyślnego zabijania lub chwytania jakimikolwiek metodami; (b) umyślnego niszczenia lub uszkadzania ich gniazd i jaj lub usuwania ich gniazd; (d) umyślnego płoszenia, szczególnie w okresie lęgowym i wychowu młodych, jeśli mogłoby to mieć znaczenie w odniesieniu do celów dyrektywy ptasiej. System ochrony $\mathrm{w}$ danym państwie członkowskim ma obejmować wszystkie gatunki ptactwa występujące naturalnie w stanie dzikim na europejskim terytorium państw członkowskich, nie ograniczając się do dzikiego ptactwa, którego siedlisko naturalne znajduje się na jego terytorium. System ochrony ma więc obejmować również gatunki posiadające siedliska na terytorium innego lub innych państw członkowskich (wyrok TSUE w sprawie C-192/11, pkt 23-24, 33-34). Zgodnie z orzecznictwem TSUE art. 5 dyrektywy ptasiej wymaga, by państwa członkowskie ustanowiły kompletne i skuteczne ramy prawne poprzez podjęcie - jak przewiduje art. 12 dyrektywy siedliskowej - konkretnych i specyficznych środków ochrony, które mają pozwolić na zapewnienie skutecznego poszanowania wspomnianych wyżej zakazów zmierzających zasadniczo do chronienia terenów rozrodu i odpoczynku ptaków objętych tą dyrektywą (wyrok TSUE w sprawie C-441/17, pkt 252). Ochrona przewidziana w art. 5 lit. b musi mieć charakter stały i nie może zostać wyłączona w danych okresach. Konieczność taka wynika z faktu, że niektóre gatunki ponownie wykorzystują gniazda zbudowane w poprzednich latach (wyrok TSUE w sprawie 252/85). Okoliczność, że populacje określonych gatunków ptaków pozostają na niezmienionym poziomie, a nawet zwiększają się, jest bez znaczenia dla stwierdzenia naruszenia dyrektywy ptasiej. Obowiązki ochrony istnieją bowiem, zanim zostanie stwierdzone zmniejszenie liczby ptaków lub zanim zmaterializuje się ryzyko wyginięcia danego gatunku chronionego ptaków (wyrok TSUE w sprawie C-441/17 213). Powyższa interpretacja dotycząca ogólnego systemu ochrony ptaków przewidzianego w art. 4 ust. 4 dyrektywy ptasiej znajduje zastosowanie 
tym bardziej w ramach ochrony specjalnej przewidzianej w art. 5 lit. b i d dyrektywy ptasiej.

Dla prawidłowej interpretacji powyższych przepisów kluczowe jest wyjaśnienie znaczenia zastosowanego tam pojęcia „umyślności”. W świetle orzecznictwa TSUE należy uznać, że dotyczy ono sytuacji, w której sprawca albo zamierzał zabić ptaki należące do gatunku objętego ochroną, albo przynajmniej godził się na taką ewentualność ${ }^{14}$. Na zasadzie analogii trzeba zinterpretować pojęcie „umyślności" użyte w art. 5 lit. b i d ${ }^{15}$.

2.1. Artykuł 5 lit. a. Według analizowanej opinii, mimo formalnego objęcia na mocy prawa polskiego ochroną występujących w Polsce gatunków ptaków wymienionych w załączniku I do dyrektywy, wysokie prawdopodobieństwo pomyłki w identyfikacji gatunków podczas polowania prowadzi do naruszenia zakazu zabijania gatunków chronionych. Jak wskazuje Autorka, w szczególności podgorzałka zwyczajna (Aythya nyroca) może być mylona z kaczka czernica (Aythya fuligula) i głowienka zwyczajna (Aythya ferina). Natomiast gęś mała (Anser erythropus), bernikla biatolica (Branta leucopsis), bernikla rdzawoszyja (Branta ruficollis) moga być [...] mylone z gatunkami gęsi townych.

Odnosząc się do powyższej tezy, należy zaznaczyć, że zgodnie z orzecznictwem TSUE przepisy dyrektywy muszą zostać wdrożone za pomocą instrumentów o niekwestionowanej mocy prawnej, a ponadto w sposób szczegółowy, precyzyjny i jasny, aby zapewnić poszanowanie zasady pewności prawa (wyrok TSUE w sprawie C-159/99, pkt 32). Sama tylko praktyka administracyjna, która może w ramach uznania zostać zmieniona przez organy krajowe, i która nie została w należyty sposób ogłoszona, nie może zostać uznana za prawidłowe wypełnienie obowiązków wynikających z dyrektyw (wyrok TSUE w sprawie C-75/01, pkt 28). W omawianym kontekście należy zwrócić uwagę na przepisy ustawy Prawo łowieckie, ustawy o ochronie przyrody i Kodeksu karnego. W myśl art. 42 Prawa łowieckiego uzyskanie uprawnień do wykonywania polowania wymaga spełnienia określonych warunków, w tym odbycia stażu, szkolenia i zdania egzaminu. Rozporządzenie Ministra Środowiska w sprawie uprawnień do wykonywania polowania (Dz.U. 2010, nr 3, poz. 19) przewiduje, że egzamin mający na celu uzyskanie podstawowych uprawnień do wykonywania polowania obejmuje sprawdzenie znajomości m.in. przepisów wskazanych w rozporządzeniu aktów prawnych, zasad i warunków wykonywania polowania, zasad ochrony przyrody i podstawowych gatunków zwierząt objętych ochroną gatunkową, listy gatunków zwierząt łownych, ich biologii oraz okresów polowań na te zwierzęta.

14 Wyrok TSUE w sprawie C-221/04, pkt 71 (interpretacja przyjęta na kanwie art. 12 ust. 1 lit. a dyrektywy siedliskowej).

15 Zob. przykładowo wyrok w sprawie C-103/00, gdzie TSUE uznał użytkowanie rowerów wodnych i małych łodzi za umyślne niepokojenie gatunków podczas okresu rozrodu (pkt 36). 
Prawo łowieckie określa również sankcje za naruszenie zawartych w nim zakazów, m.in. za wybieranie jaj, piskląt, niszczenie gniazd ptaków łownych lub ich lęgowisk (art. 51 ust. 1 pkt 2), jak również za polowanie w czasie ochronnym lub bez uprawnień do polowania (art. 53 pkt 3 i 4). Ponadto, zgodnie z art. 131 pkt 14 ustawy o ochronie przyrody: kto bez zezwolenia lub wbrew jego warunkom narusza zakazy w stosunku do roślin, zwierząt lub grzybów objętych ochrona gatunkowa podlega karze aresztu albo grzywny. Natomiast na mocy art. $181 \$ 3$ Kodeksu karnego grzywnie, karze ograniczenia wolności albo pozbawienia wolności do lat 2 podlega ten, kto niezależnie od miejsca czynu niszczy albo uszkadza rośliny lub zwierzęta pozostające pod ochroną gatunkową, powodując istotną szkodę. Należy zauważyć, że na mocy $\$ 5$ tego artykułu również sprawca działający nieumyślnie podlega karze, aczkolwiek w niższym wymiarze (grzywnie albo karze ograniczenia wolności). Wskazane przepisy mają na celu m.in. ochronę gatunków ptaków wskazanych w załączniku I dyrektywy ptasiej.

W świetle przywołanych przepisów należy uznać, że ustawodawca polski podjął działania zmierzające do zapewnienia ochrony wynikającej z art. 5 dyrektywy ptasiej poprzez wymóg poświadczenia znajomości gatunków chronionych i reguł ich ochrony, jak również poprzez ustanowienie sankcji o charakterze administracyjnym lub karnym za naruszenie tych reguł.

Analizowana opinia odnotowuje tę okoliczność, niemniej, w ocenie Autorki, zakazy te są nieskuteczne $z$ uwagi na prawdopodobieństwo pomyłki. W konsekwencji, celem uzyskania pełnej zgodności prawa łowieckiego z celami dyrektywy ptasiej należy wykreślić z listy ptaków łownych określone gatunki podobne do gatunków objętych ochroną.

W związku z tym należy zauważyć, że obowiązek wdrożenia (implementacji) dyrektywy nie ogranicza się do transpozycji, tj. przeniesienia norm dyrektywy do prawa krajowego. Obejmuje on bowiem konieczność podjęcia wszelkich innych działań, które zapewnią efektywne osiągnięcie celu określonego przez dyrektywę, w tym tzw. implementację konkretną, polegającą na efektywnym stosowaniu transponowanych norm w konkretnych przypadkach ${ }^{16}$. Dlatego też formalna transpozycja dyrektywy mogłaby istotnie zostać uznana za niewystarczającą, jeżeli w rzeczywistości cel dyrektywy nie mógłby w ten sposób zostać osiągnięty z powodów wskazanych w analizowanej opinii. W tym kontekście należy jednak zauważyć, że ustalając treść załącznika II do dyrektywy, uwzględnia takie czynniki, jak zagrożenie dla gatunków chronionych wynikające z ich podobieństwa do gatunków łownych. Przykładowo, na mocy dyrektywy 94/24/WE z 8 czerwca 1994 r. zmieniającej załącznik II do dyrektywy 74/409/EWG w sprawie ochrony dzikiego ptactwa Rada usunęła z załącznika II/2 gatunki Limosa limosa, Limosa lapponica oraz Numenius arquata w odniesieniu do Włoch w celu ochrony glo-

16 B. Kurcz, Dyrektywy Wspólnoty Europejskiej i ich implementacja do prawa krajowego, Kraków 2004, s. 46, 49. 
balnie zagrożonego gatunku Numenius tnuirostis, do którego wskazane gatunki są tak bardzo podobne, jeśli chodzi o ich zwyczaje i wygląd, że istnieje szczególne ryzyko ich pomylenia ${ }^{17}$. Wobec powyższego można więc uznać, że w przypadku gatunków nadal figurujących w załączniku II unijny prawodawca nie podziela wyrażonego w analizowanej opinii poglądu o konieczności usunięcia wskazanych gatunków z listy gatunków łownych w skali Polski.

Natomiast należy zgodzić się, że podnoszony w analizowanej opinii problem ma potencjalnie poważny charakter i prawidłowe wdrożenie dyrektywy może wymagać wprowadzenia postulowanych w niej ograniczeń w skali lokalnej, z uwzględnieniem takich czynników jak rzeczywiste podobieństwo danych gatunków, prawdopodobieństwo wystąpienia pomyłki czy względnie znaczne występowanie podobnych gatunków w tym samym czasie i miejscu objętym polowaniem. Trzeba też podkreślić, że wprowadzenie zakazu polowania nie zawsze stanowiłoby środek konieczny. W zależności bowiem od sytuacji dla zapewnienia zgodności z dyrektywą może okazać się wystarczające np. odpowiednie określenie godzin polowania, co poprawi widoczność i rozpoznawalność ptaków.

Na problem pomylenia gatunków łownych i gatunków objętych ochroną zwraca również uwagę Komisja Europejska, przy czym w jej wytycznych proponuje się rozwiązania o charakterze lokalnym: ryzyko pomyłki [...] może stanowić ryzyko dla ochrony niektórych narażonych lub zagrożonych gatunków [...] szczególnie na obszarach, gdzie odbywa się polowanie. Problemem tym należałoby się zajać w ogólnym kontekście gospodarki tymi terenami (wytyczne 2008, pkt 2.6.10).

2.2. Artykuł 5 lit. b. Analizowana opinia nie uzasadnia tezy o niezgodności $\mathrm{z}$ art. 5 lit. $\mathrm{b}$ dyrektywy.

2.3. Artykuł 5 lit. d. Odnosząc się do tezy, zgodnie z którą polowania odbywające się w siedliskach gatunków chronionych mogą stanowić naruszenie zakazu umyślnego płoszenia tych ptaków, szczególnie w okresie lęgowym i wychowu młodych, a w konsekwencji naruszenie art. 5 lit. d, należy odesłać do uwag dotyczących art. 4 ust. 4 dyrektywy ptasiej. Wynika z nich, że prowadzenie polowań (również w siedliskach gatunków chronionych) jest dopuszczalne, natomiast wprowadzenie zakazów lub ograniczeń w tym zakresie powinno odbywać się z uwzględnieniem okoliczności danego przypadku.

\section{Naruszenie art. 6 lit. a, b i c konwencji berneńskiej}

Artykuł 6 lit. a, b i c konwencji berneńskiej wymaga, aby państwa strony konwencji wprowadziły zakaz następujących działań w odniesieniu do gatunków dzikiej fauny, wymienionych w załączniku II do konwencji: (a) wszystkich form umyślnego chwytania, przetrzymywania i umyślnego zabijania; (b) umyślnego uszkadzania lub niszczenia miejsc rozrodu lub odpoczynku; (c) umyślnego nie-

17 Zob. preambuła dyrektywy 94/24/WE. 
pokojenia dzikich zwierząt, zwłaszcza w okresie rozrodu, wychowu młodych lub snu zimowego, jeżeli takie postępowanie będzie miało istotne skutki w odniesieniu do celów niniejszej konwencji.

Z uwagi na podobieństwo między art. 6 lit. a, b i c konwencji berneńskiej a art. 5 lit a, b, d dyrektywy ptasiej można uznać, że zawarte wyżej uwagi dotyczące w tym zakresie tej dyrektywy znajdują odniesienie również do odpowiednich przepisów konwencji berneńskiej.

\section{Opiniowana teza: „brak szacowania liczebności stanu większości gatunków ptaków łownych na obszarze obwodów łowieckich, na których następuje ich pozyskiwane, prowadzi do naruszenia art. 7 ust. 4 dyrektywy"}

Jak wskazuje się w analizowanej opinii, w odniesieniu do większości gatunków ptaków, w tym także gatunków niemigrujących, nie określa się ich liczebności, a jedynie pozyskanie, co stanowi naruszenie art. 7 ust. 4 dyrektywy ptasiej. Zgodnie $\mathrm{z}$ analizowaną opinią prowadzi to do naruszenia art. 7 ust. 4 dyrektywy (zasada rozsądnego wykorzystywania i ekologicznie zrównoważonej kontroli gatunków). Nie może być bowiem mowy o rozsądnym wykorzystywaniu i ekologicznie zrównoważonej kontroli gatunków bez znajomości elementarnych danych o ilości eksploatowanych zasobów.

Należy zgodzić się z Autorką, że: unijny wymóg rozsądnego wykorzystywania $i$ ekologicznie zrównoważonej kontroli zakłada posiadanie elementarnych danych odnośnie stanu zasobów, którymi sie gospodaruje. Znajduje to potwierdzenie m.in. w wytycznych KE z 2008 r., gdzie zauważa się, że: istnieje potrzeba solidnych, opartych na naukowych podstawach mechanizmów monitorowania w celu zapewnienia, aby wykorzystywanie było utrzymane na poziomach, które moga być znoszone przez populacje dzikich gatunków nie wpływając szkodliwie na rolę gatunków $w$ ekosystemie lub na sam ekosystem (wytyczne 2008, pkt 2.4.16), a także że: plany gospodarowania mające na celu przywrócenie właściwego stanu zachowania gatunków musza być poparte programami monitorowania zdolnymi do wykrycia zmian w stanie zachowania odnośnych gatunków. Monitorowanie to powinno obejmować ocenę odłowu w ramach polowania oraz roli, jaka petni on $w$ dynamice populacji (wytyczne 2008, pkt 2.4.28).

Jednocześnie jednak trzeba zauważyć, że zgodnie z art. 8a ust. 2 ustawy - Prawo łowieckie inwentaryzacja zwierzyny ma być sporządzana rokrocznie przez dzierżawców albo zarządców obwodów łowieckich i ma zawierać szacowaną liczebność występujących zwierząt łownych (z wyłączeniem łownych ptaków migrujących). Analizowana opinia uwzględnia treść tego przepisu, jednak zauważa się tam, że: $w$ odniesieniu do większości gatunków ptaków, w tym także gatunków nie migrujących, nie określa się ich liczebności a jedynie pozyskanie. Wynika 
to $z$ art. 8a. 2 ustawy - prawo łowieckie [który - M.J.] stanowi: „Inwentaryzacja zwierzyny [...] zawiera szacowana liczebność występujących zwierząt łownych, $z$ wyłaczeniem łownych ptaków migrujacych [...]" oraz $z$ zatwierdzonego przez Ministra Środowiska wzoru rocznego planu łowieckiego, który zawiera znaki X (nie należy wypełniać) w rubrykach dotyczacych szacowanej liczebności: gęsi gęgawy, gęsi zbożowej i gęsi białoczelnej, krzyżówki, cyraneczki, głowienki, czernicy, gołębia grzywacza, słonki i łyski.

Odnosząc się do powyższej tezy, należy uznać, że na poziomie ustawowym wymóg inwentaryzacji został zrealizowany, zaś wyłączenie spod niego ptaków migrujących wiąże się z brakiem praktycznej możliwości wiarygodnego oszacowania ich liczebności na potrzeby planowania gospodarki łowieckiej. Ocena wskazanego $\mathrm{w}$ analizowanej opinii formularza wykracza natomiast poza granice niniejszej opinii.

\section{Opiniowana teza: „zbyt krótkie okresy ochronne dla gatunków głowienki (Aythya ferina), czernicy (Aythya fuligula), łyski (Fulica atra), gołębia grzywacza (Columba palumbus) i gęsi gęgawy (Anser anser) stanowią naruszenie art. 7 ust. 4 dyrektywy ptasiej"}

Zgodnie z art. 7 ust. 4 dyrektywy ptasiej państwa członkowskie zapewniają, by na gatunki, do których stosuje się prawo łowieckie, nie były organizowane polowania w okresie wychowu młodych ani w czasie trwania poszczególnych faz reprodukcji (akapit 2), zaś w przypadku gatunków wędrownych - by na gatunki, do których mają zastosowanie przepisy łowieckie, nie były organizowane polowania w okresie ich reprodukcji lub ich powrotu do swoich miejsc wylęgu (akapit 3). Zgodnie $\mathrm{z}$ utrwalonym orzecznictwem TSUE przepisy te zmierzają do zapewnienia systemu całkowitej ochrony w okresach szczególnego narażenia ptaków. Niezgodne z art. 7 ust. 4 dyrektywy ptasiej byłoby więc wyznaczenie okresów ochronnych na podstawie okresów reprodukcji czy wędrówek typowych dla większości osobników danego gatunku. Prowadziłoby to bowiem do wyłączenia części populacji spod ochrony z uwagi na wariacje wynikające w szczególności ze zmiennych warunków meteorologicznych ${ }^{18}$.

Powołując się na opracowanie P. Wylegały i Ł. Ławickiego ${ }^{19}$, Autorka analizowanej opinii wskazuje, że: okres wychowu młodych u głowienki, czernicy, łyski i grzywacza kończy się między pierwsza dekadą września a końcem miesiąca, podczas gdy sezon polowania na te gatunki rozpoczyna sie już 15 sierpnia. W ocenie

18 Wyrok TSUE w sprawie C-157/89, pkt 14.

19 P. Wylegała, Ł. Ławicki, Głowienka, czernica, cyraneczka, łyska - stan populacji w Polsce $i$ wpływ gospodarki łowieckiej. Opinia na potrzeby Polskiego Komitetu Krajowego IUCN, PTOP Salamandra, Poznań 2019. 
Autorki sytuację taką należy w związku z tym uznać za naruszenie art. 7 ust. 4 dyrektywy ptasiej. Analiza fachowej literatury z zakresu ornitologii wykracza poza przedmiot niniejszej opinii. Należy jednak zauważyć, że zgodnie z materiałem „Key Concepts Document on Article 7(4)” dostępnym na stronie Komisji Europejskiej ${ }^{20}$, okres reprodukcji (z uwzględnieniem wychowu młodych) wskazanych gatunków na terytorium Polski kończy się w ostatniej dekadzie lipca (gołąb grzywacz, łyska), w drugiej dekadzie sierpnia (głowienka) lub w końcu sierpnia (czernica, gęgawa) ${ }^{21}$.

W analizowanej opinii wskazuje się również, że: na terenie województw dolnośląskiego, lubuskiego, wielkopolskiego i zachodniopomorskiego okres polowań na gessi zbożowe i białoczelne jest wydtużony do 31 stycznia, a na gegawy do 15 stycznia. Określone we wzmiankowanym rozporzadzeniu terminy narażaja więc gęsi gegawy na przypadkowe zastrzelenie $w$ drugiej połowie stycznia $w$ wyniku pomyłki z gęsia zbożowa lub białoczelną. W ocenie Autorki stanowi to naruszenie art. 7 ust. 4 dyrektywy ptasiej.

Odnosząc się do powyższej tezy, należy odwołać się do stanowiska TSUE wyrażonego w sprawie C-435/92. Komentując zagrożenie gatunków migrujących z uwagi na ich podobieństwo do gatunków, na które sezon polowań jeszcze się nie zakończył, TSUE uznał, że art. 7 ust. 4 (akapit 3) dyrektywy ptasiej ma służyć m.in. ochronie takich gatunków przed zagrożeniem związanym z polowaniami mającymi miejsce $\mathrm{w}$ trakcie ich migracji przedgodowych. Wymaga to więc ze strony państw członkowskich podjęcia wszelkich niezbędnych środków w celu zapobieżenia polowaniom w takim okresie (wyrok TSUE w sprawie C-435/92, pkt 18). Należy też zaznaczyć, że określenie różnych dat zakończenia okresu polowania dla różnych regionów danego państwa członkowskiego jest dopuszczalne, jednak pod warunkiem zapewnienia pełnej ochrony ptakom migrującym (wyrok TSUE w sprawie C-435/92, pkt 27).

Interpretując ten wyrok, Komisja Europejska zauważa m.in., że (a) jeżeli zróżnicowanie terminów polowań ma być dozwolone, to terminy otwarcia i zamknięcia muszą być ustalane dla każdej grupy „podobnych” gatunków w sposób uniemożliwiający ich częściowe pokrywanie się z okresami, w czasie których, zgodnie z dyrektywą, polowania są niedozwolone; (b) aby ryzyko było realne, gatunki łowne (lub ich grupy) muszą występować na obszarze objętym polowaniem w danych ramach czasowych, zaś obecność innych, „mylących” gatunków łownych, dla których okres polowań jest zamknięty, również powinna być przewidywalna i znaczna; (c) ryzyko pomyłki zwiększa fakt, że różne gatunki pta-

20 Https://ec.europa.eu/environment/nature/conservation/wildbirds/action_plans/guidance_en.htm.

21 Dane dla poszczególnych gatunków są ujęte zbiorczo dla całych państw członkowskich i nie uwzględniają ewentualnych rozbieżności na poziomie regionalnym. Opracowanie uwzględnia najpóźniejsze daty w danym państwie członkowskim (s. 7). 
ków często współistnieją, w związku z czym polowanie selektywne może stać się bardzo trudne. Komisja wskazuje też, że należy uwzględnić takie czynniki wpływające na ryzyko wystąpienia pomyłki, jak typ polowania i związana $\mathrm{z}$ tym przewidywana odległość ptaków od myśliwego, pora polowania, warunki atmosferyczne i wynikające $\mathrm{z}$ nich ograniczenia widoczności, a także kompetencje myśliwego. W konsekwencji Komisja widzi konieczność przeprowadzenia podziału na grupy „podobnych” gatunków łownych używających tych samych typów siedlisk w tym samym czasie oraz ustalenia tych samych terminów otwarcia i zamknięcia dla polowań na te grupy w taki sposób, aby uniknąć kolidowania ich z okresami, gdy polowanie jest niedozwolone. Wymaga to także ustalenia, czy warunki, w jakich odbywa się polowanie, nie stwarzają poważnego ryzyka pomyłki różnych gatunków łownych (wytyczne 2008, pkt 2.6.3-2.6.13, 2.6.24).

W odniesieniu do potencjalnego wpływu ludzkiego zakłócenia na populacje ptaków w okresie zróżnicowanych terminów polowań, Komisja Europejska preferuje podejście zniuansowane. Polega ono na uwzględnieniu potrzeby stworzenia dodatkowych niezakłóconych obszarów schronienia, które zapewnią ptakom narażonym na zakłócenia zarówno odpoczynek, jak i pożywienie. Projekt takich obszarów musi stwarzać możliwość dobrego jakościowo żerowania oraz innych rodzajów aktywności w ich obrębie. Należy to określić dla każdego obszaru z osobna w odniesieniu do ekologicznych, behawioralnych, żywieniowych i energetycznych potrzeb różnych gatunków łownych, na które mają wpływ zróżnicowane terminy polowań (wytyczne 2008, pkt 2.6.220).

Podsumowując, należy stwierdzić, że ocena zasadności tezy zawartej w analizowanej opinii powinna zostać przeprowadzona dla danego obszaru z uwzględnieniem wskazanych wyżej elementów szczegółowo określonych w wytycznych 2008.

\section{Opiniowana teza: „stosowanie śrutu ołowianego stanowi naruszenie art. 4 ust. 4 dyrektywy ptasiej oraz art. 6 lit. b i c konwencji berneńskiej"}

W analizowanej opinii wskazuje się, że stosowanie przez myśliwych śrutu ołowianego stanowi naruszenie art. 4 ust. 4 dyrektywy ptasiej (jako wywołujące powstawanie zanieczyszczenia lub pogorszenie warunków naturalnych siedlisk lub zakłócenie wpływające na ptactwo), a także art. 6 lit. b i c konwencji berneńskiej (umyślne uszkadzanie lub niszczenie miejsc rozrodu lub odpoczynku; umyślne niepokojenie dzikich zwierząt, zwłaszcza w okresie rozrodu, wychowu młodych lub snu zimowego), ponieważ jest to metal ciężki, który nie ulega biodegradacji, kumuluje się natomiast w tkankach organizmów żywych. Stosowanie tego rodzaju amunicji podczas polowań powoduje, że w siedlisku pozostawiany jest toksyczny śrut ołowiany, który przenika do środowiska wodnego, pogarszając warunki ekologiczne bytowania ptaków chronionych. 
Stosowanie amunicji ołowianej nie jest wprost uregulowane ani przez dyrektywę ptasią, ani przez konwencję berneńską ${ }^{22}$. Niemniej w zaleceniu przyjętym przez Stały Komitet w ramach tej konwencji wskazuje się na zwiększoną śmiertelność wśród ptactwa wodnego i drapieżników wywołaną zatruciem ołowiem, w większości pochodzącym z amunicji. W konsekwencji Stały Komitet zaleca podjęcie działań zmierzających do bezzwłocznego zakończenia stosowania śrutu ołowianego na terenach podmokłych, a także określenie harmonogramu zastąpienia śrutu ołowianego śrutem wytworzonym z materiałów nietoksycznych ${ }^{23}$.

Również w dokumentach KE zagadnienie toksyczności amunicji podnoszone jest od lat. Można tu wskazać na komunikat KE z 29 maja 1995 r. Wise use and conservation of wetlands (COM (95) 189 final), w którym zauważa się, że zasada wykorzystywania zasobów ptactwa wodnego w zrównoważony sposób może istotnie przyczyniać się do ochrony terenów wodno-błotnych, pod warunkiem że obejmuje używanie nietoksycznego śrutu (s. 15), oraz, że wysoce pożądane byłoby przyjęcie na poziomie UE aktu zmierzającego do eliminacji toksycznego śrutu (przypis 28 komunikatu). W wytycznych 2008 Komisja Europejska wskazuje, że coraz powszechniej uznaje się, iż używanie ołowianego śrutu stwarza istotne zagrożenie dla ptaków i ich siedlisk, zwłaszcza terenów wodno-błotnych. Jego stosowanie na obszarach szczególnej ochrony, które prowadzi do pogorszenia stanu siedlisk lub poważnego zakłócenia dla ptaków, jest niezgodne z wymogami ochrony tych terenów (wytyczne 2008, pkt 2.4.18-2.4.19).

Należy też zauważyć intensyfikację działań KE w tym zakresie od roku 2015. W szczególności trzeba zwrócić uwagę na następujące dokumenty sporządzone na wniosek KE przez Europejską Agencję Chemikaliów (ECHA):

- sprawozdanie z kwietnia 2017 r. zawierające projekt wprowadzenia ograniczenia możliwości stosowania śrutu ołowianego na terenach podmokłych. W czerwcu 2018 r. opinia komitetów naukowych ECHA została przedłożona Komisji Europejskiej i obecnie dokument ten jest przedmiotem jej prac,

- sprawozdanie z września 2018 r. (wersja skorygowana z listopada 2018 r.) ${ }^{24}$ zawierające m.in. propozycję ograniczenia możliwości stosowania amunicji ołowianej również na pozostałych terenach. Obecnie toczą się dalsze prace nad tym dokumentem (w okresie październik-grudzień 2019 r. trwało zgłaszanie uwag w ramach konsultacji prowadzonych przez Europejską Agencję

22 W odróżnieniu od porozumienia o ochronie afrykańsko-euroazjatyckich wędrownych ptaków wodnych, które przewiduje, że strony podejmą działania zmierzające do zaprzestania stosowania śrutu ołowianego na terenach podmokłych (załącznik 3, pkt 4.1.4). Stronami porozumienia są m.in. Unia Europejska oraz większość państw członkowskich UE, poza Austrią, Grecją, Maltą i Polską.

23 Zalecenie Stałego Komitetu z 6 grudnia 1991 r. w sprawie stosowania nietoksycznego śrutu na terenach podmokłych.

24 Annex XV Investigation Report $A$ review of the available information on lead in shot used in terrestrial environments, in ammunition and in fishing tackle. 
Chemikaliów). W ocenie ECHA akt prawny może zostać przyjęty do końca 2022 r., o ile uda się osiągnąć porozumienie $\mathrm{w}$ ramach procedury ustawodawczej ${ }^{25}$.

Odnosząc się do prawnej możliwości stosowania śrutu ołowianego w świetle obecnie obowiązujących przepisów, należy zauważyć, że zarówno konwencja berneńska, jak i dyrektywa ptasia dopuszczają prowadzenie polowań. W związku $\mathrm{z}$ tym należy rozważyć, czy w ten (dorozumiany) sposób oba akty prawne dopuszczają stosowanie amunicji ołowianej na chronionych obszarach. Konkluzje sprawozdań ECHA każą jednak zakwestionować taki argument. W dokumentach tych bowiem nie tylko wskazuje się, że wyniki badań potwierdzają szkodliwość ołowiu dla (m.in.) ptaków, zarówno na terenach podmokłych, jak i pozostałych ${ }^{26}$. Wynika z nich również, że w powszechnym użyciu w UE, jak i poza nią, jest śrut $\mathrm{z}$ innych materiałów (głównie stalowy i bizmutowy, ale również wolframowy). $\mathrm{W}$ sprawozdaniu wskazuje się, że stosowanie śrutu $\mathrm{z}$ alternatywnych materiałów jest technicznie wykonalne, porównywalne cenowo, a jednocześnie mniej szkodliwe dla środowiska ${ }^{27}$. Dopuszczalność prowadzenia polowań nie implikuje więc możliwości stosowania śrutu ołowianego. W świetle przywołanych wyników badań naukowych uzasadniona wydaje się teza, że stosowanie śrutu ołowianego na obszarach szczególnej ochrony może zostać uznane za niezgodne z wymogami ochrony tych terenów.

\section{Opiniowana teza: „polowania na bażanty i kuropatwy hodowane w ośrodkach hodowli zwierzyny stanowią naruszenie rozporządzenia Rady nr 1099/2009 z 24 września 2009 r. w sprawie ochrony zwierząt podczas ich uśmiercania"}

W analizowanej opinii wskazuje się, że bażanty i kuropatwy hodowane w ośrodkach hodowli zwierzyny (OHZ) traktowane są jak ptaki gospodarskie, w związku z czym objęte są wymogami, o których mowa w rozporządzeniu 1099/2009.

25 Https://echa.europa.eu/hot-topics/lead-in-shot-bullets-and-fishing-weights.

26 Sprawozdanie ECHA z września 2018, s. 7-9.

27 Sprawozdanie ECHA $\mathrm{z}$ kwietnia 2017 (ANNEX XV RESTRICTION REPORT PROPOSAL FOR A RESTRICTION SUBSTANCE NAME: Lead EC NUMBER: 231-1004 CAS NUMBER: 7439-92-1, s. 65). Jednocześnie należy jednak zauważyć, że w literaturze wskazuje się również na niedoszacowanie ryzyka ekologicznego związanego $\mathrm{z}$ uwalnianiem metali ze śrutu wytworzonego $\mathrm{z}$ alternatywnych wobec ołowiu materiałów i w konsekwencji postuluje się prowadzenie dalszych badań nad ich toksycznością [szerzej zob. J. Fäth i in., Leaching behavior and ecotoxicological effects of different game shot materials in freshwater, "Knowledge \& Management of Aquatic Ecosystems" 2018, No 419(24)]. 
W szczególności powinny one być uśmiercane wyłącznie po uprzednim ogłuszeniu, zgodnie z metodami określonymi dla drobiu w załączniku I rozporządzenia. W świetle analizowanej opinii bażanty i kuropatwy hodowane w OHZ stają się zwierzyną łowną dopiero po wypuszczeniu ich na wolność do docelowych siedlisk i łowisk, w których przetrwają do czasu wyprowadzenia własnych lęgów - stają się wówczas zwierzyną dziką i dopiero wtedy mogą zostać uznane za zwierzynę łowną. Autorka analizowanej opinii zwraca uwagę, że choć rozporządzenia nie stosuje się do polowań, to wyłączenie to należy rozumieć jako dotyczące polowań na zwierzynę wolno żyjącą, w stanie dzikim.

Istotnie, rozporządzenie 1099/2009 nie znajduje zastosowania podczas polowań (art. 3 lit. a pkt ii tego rozporządzenia), jednak samo pojęcie „polowania” nie zostało w nim zdefiniowane. W preambule wskazuje się jedynie uzasadnienie powyższego wyłączenia. Zgodnie z jej motywem (14) polowania odbywają się w kontekście, którego warunki w odniesieniu do uśmiercania znacznie się różnią od stosowanych wobec zwierząt utrzymywanych w warunkach fermowych, a łowiectwo podlega szczególnemu prawodawstwu.

W sytuacji, w której akt prawa UE nie definiuje określonego pojęcia w sposób autonomiczny, należy oprzeć się na definicji przyjętej w prawie państwa członkowskiego. Zgodnie z art. 4 ust. 2 ustawy - Prawo łowieckie, termin „polowanie” oznacza: tropienie, strzelanie z myśliwskiej broni palnej, łowienie sposobami dozwolonymi zwierzyny żywej, (a także, za zgodą ministra właściwego do spraw środowiska, łowienie zwierzyny przy pomocy ptaków łowczych) zmierzające do wejścia w jej posiadanie. Z kolei pojęcie „zwierzyna” oznacza zwierzęta łowne (art. 1 prawa łowieckiego). W literaturze wskazuje się, że pojęcie „zwierzyna łowna” zostało użyte we wskazanym przypisie w sensie prawnym, jest ono zmienne w czasie oraz w ogóle nie pokrywa się z pojęciem stosowanym w naukach łowieckich, biologii i naukach przyrodniczych ${ }^{28}$. Aktualnie wykaz gatunków zwierząt łownych jest zawarty w rozporządzeniu Ministra Środowiska z 11 marca 2005 r. w sprawie ustalenia listy gatunków zwierząt łownych (Dz.U. nr 45, poz. 433) i obejmuje m.in. bażanty i kuropatwy. Wskazuje się też, że w odróżnieniu od ustawy łowieckiej z 1959 r. obecna ustawa - Prawo łowieckie nie zastrzega, że termin „polowanie” nie obejmuje czynności zmierzających do pozyskania zwierzyny podejmowanych $\mathrm{w}$ ogrodzonych zwierzyńcach, bażantarniach, parkach narodowych i niektórych rezerwatach przyrody. Można z tego wysnuć wniosek, że w świetle obowiązujących przepisów czynności podejmowane na takich terenach są uważane za polowanie ${ }^{29}$.

Odnosząc powyższe ustalenia do zaprezentowanej w analizowanej opinii tezy, zgodnie z którą bażanty i kuropatwy mogą zostać uznane za zwierzynę

28 W. Radecki, Prawo łowieckie - komentarz, Warszawa 2014, s. 57-58; B. Rakoczy, R. Stec, A. Woźniak, Prawo łowieckie. Komentarz, 2014, LEX.

29 W. Radecki, Prawo łowieckie, op. cit., s. 69. 
łowną dopiero po okresie wyprowadzenia własnych lęgów, należy uznać, że jest ona zbyt daleko idąca i nadmiernie zawęża interpretację pojęcia "polowanie”, w konsekwencji bezpodstawnie poszerzając zakres stosowania rozporządzenia 1099/2009.

\section{Opiniowana teza: „brak przeprowadzania procedury strategicznej oceny oddziaływania na środowisko wieloletnich planów hodowlanych oraz rocznych planów łowieckich narusza art. 14 ust. 1 lit. a konwencji o różnorodności biologicznej, art. 6 ust. 3 dyrektywy siedliskowej, art. 46 pkt 3 ustawy o udostępnianiu informacji o środowisku i jego ochronie, udziale społeczeństwa w ochronie środowiska oraz o ocenach oddziaływania na środowisko oraz art. 33 ust. 3 ustawy o ochronie przyrody"}

Zgodnie z analizowaną opinią łowiectwo jest działalnością istotnie oddziałującą na środowisko i jako takie może być realizowane tylko na podstawie dokumentów planistycznych podlegających ocenie środowiskowej z uwzględnieniem czynnika udziału społecznego. Wieloletni plan hodowlany oraz roczne plany łowieckie są dokumentami, których realizacja może negatywnie wpływać na środowisko przyrodnicze, wymagającymi przeprowadzenia strategicznej oceny oddziaływania na środowisko. Tymczasem, mimo przyjęcia $\mathrm{w}$ ustawodawstwie polskim przepisów dotyczących ocen oddziaływania na obszary Natura 2000 (w szczególności art. 46 ust. 1 pkt 3 ustawy o udostępnianiu informacji o środowisku i jego ochronie, udziale społeczeństwa $\mathrm{w}$ ochronie środowiska oraz o ocenach oddziaływania na środowisko oraz art. 33 ust. 3 ustawy o ochronie przyrody), w analizowanej opinii wskazuje się, że w Polsce procedura zatwierdzania rocznych planów łowieckich i wieloletnich łowieckich planów hodowlanych nie uwzględnia tych przepisów.

Konwencja o różnorodności biologicznej została zawarta 5 czerwca 1992 r. i weszła w życie 29 grudnia 1993 r. Stronami tej konwencji są m.in. Polska oraz Unia Europejska. Artykuł 14 konwencji nakłada na strony - w miarę możliwości i potrzeb - obowiązek m.in. (a) wprowadzenia procedur wymagających wykonania oceny oddziaływania na środowisko proponowanych projektów, które mogą mieć istotne negatywne skutki dla różnorodności biologicznej, w celu uniknięcia lub zmniejszenia takich skutków, oraz tam, gdzie to jest właściwe, pozwala na udział społeczności w tych procedurach; (b) wprowadzenia uregulowań dla zapewnienia, że środowiskowe konsekwencje jej programów i polityk, które mogą mieć znacznie negatywne oddziaływanie na różnorodność biologiczną, są w sposób należyty brane pod uwagę. 
Jednym z instrumentów prawnych wdrażających konwencję o różnorodności biologicznej na poziomie UE jest dyrektywa siedliskowa ${ }^{30}$. Jej art. 6 ust. 3 przewiduje więc obowiązki podobne do tych wynikających $\mathrm{z}$ art. 14 konwencji o różnorodności biologicznej. Przepis ten wymaga, aby państwa członkowskie UE wprowadziły w życie regulacje przewidujące, że każdy plan lub przedsięwzięcie, które nie jest bezpośrednio związane lub konieczne do zagospodarowania terenu, ale które może na nie w istotny sposób oddziaływać, zarówno oddzielnie, jak i w połączeniu z innymi planami lub przedsięwzięciami, podlegało odpowiedniej ocenie jego skutków dla danego terenu z punktu widzenia założeń jego ochrony. Państwa członkowskie wyrażają zgodę na ten plan lub przedsięwzięcie dopiero po upewnieniu się, że nie wpłynie on niekorzystnie na dany teren oraz, w stosownych przypadkach, po uzyskaniu opinii całego społeczeństwa.

Dyrektywa siedliskowa nie definiuje pojęć „plan” ani „przedsięwzięcie”. W zawiadomieniu Komisji Europejskiej z 21 listopada 2018 r. „Zarządzanie obszarami Natura 2000. Przepisy art. 6 dyrektywy siedliskowej 92/43/EWG” (dalej: „zawiadomienie 2018”) sugerowane jest szerokie rozumienie tych pojęć, ponieważ dyrektywa siedliskowa nie ogranicza zakresu ani planu, ani przedsięwzięcia poprzez odwołanie się do konkretnych ich kategorii. Głównym czynnikiem ograniczającym jest natomiast to, czy mogą one w istotny sposób oddziaływać na obszar. W ocenie Komisji Europejskiej zakres art. 6 ust. 3 obejmuje również plany sektorowe, o ile mogą one oddziaływać w sposób istotny na obszary Natura 2000. Mogą to być na przykład plany sieci transportowych, plany energetyczne, plany gospodarki odpadami, plany gospodarki wodnej lub plany gospodarki leśnej (pkt 3.4 zawiadomienia 2018). Konieczność przeprowadzenia oceny skutków powstaje, jeżeli istnieje prawdopodobieństwo lub ryzyko, że ten plan lub przedsięwzięcie będzie oddziaływać na dany teren w istotny sposób. W orzecznictwie TSUE przyjęto szeroką interpretację obowiązku określonego w art. 6 ust. 3 dyrektywy siedliskowej: Mając w szczególności na uwadze zasadę ostrożności, będąca jedna z podstaw polityki Wspólnoty $w$ dziedzinie środowiska naturalnego, stawiajacej sobie za cel wysoki poziom ochrony zgodnie z art. 174 ust. 2 zdanie pierwsze WE, w świetle którego należy dokonywać wykładni dyrektywy siedliskowej, ryzyko takie ma miejsce wówczas, gdy na podstawie obiektywnych informacji nie można wykluczyć, że przedmiotowy plan lub przedsięwzięcie będzie oddziaływać na dany teren w istotny sposób (wyrok TSUE w sprawie C-127/02, pkt 44). Z kolei w odniesieniu do pojęcia „istotne oddziaływanie" TSUE podkreślił, że jest ono związane z założeniami ochrony danego terenu. Jeżeli plan wpływa na dany teren, jednakże nie niesie ze sobą ryzyka naruszenia założeń ochrony tego terenu, to nie należy tego planu lub przedsięwzięcia traktować jako mogącego oddziaływać na przedmiotowy teren w sposób istotny.

30 Zob. szerzej J.M. Verschuuren, Implementation of the Convention on Biodiversity in Europe: 10 Years of Experience with the Habitats Directive, „Journal of International Wildlife Law and Policy“ 2002, No 5, s. 251. 
Jeżeli natomiast niesie on ze sobą ryzyko naruszenia założeń ochrony tego terenu, należy go wówczas konsekwentnie uznać za mogący oddziaływać na przedmiotowy teren w sposób istotny (wyrok TSUE w sprawie C-127/02, pkt 46-48).

Zgodnie $\mathrm{z}$ orzecznictwem TSUE niezgodna $\mathrm{z}$ art. 6 ust. 2 i 3 dyrektywy siedliskowej jest możliwość całkowitego zwolnienia pewnych rodzajów działalności na podstawie obowiązujących przepisów z obowiązku oceny oddziaływania na dany teren. Takie zwolnienie nie może bowiem zagwarantować, że działalność tego rodzaju nie będzie miała niekorzystnego wpływu na ten obszar (wyrok TSUE w sprawie C-98/03 pkt 43, 44; wyrok TSUE w sprawie C-241/08, pkt 31). $\mathrm{Z}$ uwagi na przedmiot niniejszej opinii należy zwrócić uwagę na wyrok w sprawie C-241/08, w którym TSUE uznał, że francuski przepis apriorycznie przesądzający, że polowanie i inna działalność łowiecka, które są podejmowane na warunkach dopuszczalnych na podstawie obowiązujących ustaw i przepisów wykonawczych i na określonych $\mathrm{w}$ tych przepisach terenach, nie stanowią działalności będącej niepokojeniem lub oddziałującej w ten sposób ${ }^{31}$, był niezgodny z art. 6 ust. 2 i 3 dyrektywy siedliskowej (wyrok TSUE w sprawie C-241/08, pkt 30-39). W świetle przywołanego orzecznictwa za niezgodną z dyrektywą siedliskową należy uznać w szczególności interpretację (w tym wypadku ustawy o ochronie przyrody), zgodnie z którą działalność łowiecka nie może poważnie negatywnie oddziaływać na cele ochrony obszaru Natura 2000, ponieważ godziłoby to $\mathrm{w}$ podstawowe cele, jakim ma służyć łowiectwo ${ }^{32}$. Taka interpretacja koliduje bowiem $\mathrm{z}$ - wynikającym z art. 4 ust. 3 Traktatu o Unii Europejskiej wymogiem interpretacji prawa krajowego, w miarę możliwości, w sposób zgodny z prawem UE. Zgodnie $\mathrm{z}$ orzecznictwem TSUE, stosując prawo wewnętrzne, a w szczególności przepisy prawa krajowego wprowadzone w celu wykonania dyrektywy, sądy krajowe są zobowiązane do wykładni prawa krajowego zgodnie $\mathrm{z}$ treścią i celem dyrektywy, w celu osiągnięcia rezultatu, o którym mowa w art. 288 akapit trzeci TFUE (wyrok TSUE w sprawie 14/83, pkt 26).

Konkludując, należy stwierdzić, że praktyka polegająca na generalnym wyłączeniu planów łowieckich spod wymogu poddania ocenie wpływu na dany teren, o której mowa w art. 6 ust. 3 dyrektywy siedliskowej, może zostać uznana za niezgodną z tym przepisem.

31 Ówczesny art. L. 414-1 ust. V code de l'environnement (francuskiego kodeksu ochrony środowiska naturalnego).

32 Przyjęcie zgodnie $z$ ustawa Prawo Łowieckie, iż celem łowiectwa $w$ tym prowadzenie działań polegajacych na pozyskiwaniu zwierząt kopytnych $w$ ramach gospodarki łowieckiej, jest ochrona środowiska tj. zwierząt łownych (zwierzyny) i gospodarowanie ich zasobami w zgodzie z zasadami ekologii oraz zasadami racjonalnej gospodarki rolnej, leśnej i rybackiej, wyklucza uznanie tej działalności za mogaca znaczaco negatywnie oddziaływać na cele ochrony obszaru Natura 2000 lub obszar znajdujaccy się na liście, o której mowa w art. 27 ust. 3 pkt 1. Godzi to bowiem w podstawowe cele jakim ma służyć łowiectwo, wyrok WSA Warszawa, sygn. akt IV SA/Wa 217/14. 


\section{Podsumowanie}

- Teza, jakoby pobyt myśliwych, psów myśliwskich i pojazdów w siedliskach stanowił jako taki naruszenie art. 4 ust. 4 dyrektywy ptasiej jest zbyt daleko idąca. Oceny zgodności z dyrektywą należy bowiem dokonywać na poziomie lokalnym, $\mathrm{z}$ uwzględnieniem cech siedliska i charakteru polowania.

- Postulowane w analizowanej opinii ewentualne ograniczenia lub zakazy polowania na ptaki łowne określonych gatunków z uwagi na ich podobieństwo do gatunków objętych ochroną powinny być dokonywane w skali lokalnej, z uwzględnieniem takich czynników, jak rzeczywiste podobieństwo danych gatunków, prawdopodobieństwo wystąpienia pomyłki czy względnie znaczne występowanie podobnych gatunków w tym samym czasie i miejscu objętym polowaniem.

- Na poziomie ustawowym wymóg inwentaryzacji zwierzyny został zrealizowany, zaś wyłączenie spod niego ptaków migrujących wiąże się z brakiem praktycznej możliwości wiarygodnego oszacowania ich liczebności na potrzeby planowania gospodarki łowieckiej.

- Określenie różnych dat zakończenia okresu polowania dla różnych regionów danego państwa członkowskiego jest dopuszczalne, jednak pod warunkiem zapewnienia pełnej ochrony ptakom migrującym. Ocena zasadności tezy zawartej w analizowanej opinii, jakoby okresy ochronne dla wskazanych gatunków ptaków były zbyt krótkie, powinna zostać przeprowadzona dla danego obszaru, $\mathrm{z}$ uwzględnieniem elementów szczegółowo określonych w wytycznych Komisji Europejskiej z $2008 \mathrm{r}$.

- Należy zgodzić się z tezą, że stosowanie śrutu ołowianego na obszarach szczególnej ochrony może zostać uznane za niezgodne z wymogami ochrony tych terenów.

- Teza, zgodnie z którą bażanty i kuropatwy mogą zostać uznane za zwierzynę łowną dopiero po okresie wyprowadzenia własnych lęgów, jest zbyt daleko idąca i nadmiernie zawęża interpretację pojęcia „polowanie”, w konsekwencji bezpodstawnie poszerzając zakres stosowania rozporządzenia 1099/2009.

- Praktyka polegająca na generalnym wyłączeniu planów łowieckich spod wymogu poddania ocenie wpływu na dany teren, o której mowa w art. 6 ust. 3 dyrektywy siedliskowej, może zostać uznana za niezgodną z tym przepisem.

\section{Bibliografia}

Fäth J. i in., Leaching behavior and ecotoxicological effects of different game shot materials in freshwater, „Knowledge \& Management of Aquatic Ecosystems” 2018, No 419(24), https://doi.org/10.1051/kmae/2018009.

Kurcz B., Dyrektywy Wspólnoty Europejskiej i ich implementacja do prawa krajowego, Kraków 2004. 
Radecki W., Prawo łowieckie - komentarz, Warszawa 2014.

Rakoczy B., Stec R., Woźniak A., Prawo łowieckie. Komentarz, 2014, LEX.

Ribaut J.P., How the Bern Convention Came into Being, „Naturopa” 2004, nr 101.

Verschuuren J.M., Implementation of the Convention on Biodiversity in Europe: 10 Years of Experience with the Habitats Directive, „Journal of International Wildlife Law and Policy" 2002, No 5.

Wylegała P., Ławicki Ł., Głowienka, czernica, cyraneczka, łyska - stan populacji w Polsce i wpływ gospodarki łowieckiej. Opinia na potrzeby Polskiego Komitetu Krajowego IUCN, PTOP Salamandra, Poznań 2019. 
Marcin Fryźlewicz

\title{
Prawo do odprawy przejściowej przysługujące posłowi do Parlamentu Europejskiego po wygaśnięciu tego mandatu w przypadku objęcia mandatu posła na Sejm
}

\author{
The entitlement to transitional allowance of a Member of the European \\ Parliament after the expiry of their term of office in the event of becoming \\ a Deputy to the Sejm
}

\begin{abstract}
Members of the European Parliament are entitled to a transitional allowance in the amount of their salary for the period of one month for each year in which their mandate has been exercised. In case of exercising the mandate of a Deputy to the Sejm of the Republic of Poland, the allowance should be reduced by the amount of the Deputy's salary. Should a former MEP be entitled simultaneously to the payment of the transitional allowance and the old-age pension, he or she must choose one or the other. While exercising the mandate of a Deputy to the Sejm the European Parliament old-age pension is reduced by the amount of the Deputy's salary.
\end{abstract}

Keywords: pensions, parliamentary severance pay, European Parliament, Deputy

Posłowie do Parlamentu Europejskiego mają prawo do odprawy przejściowej w wysokości ich wynagrodzenia przez okres jednego miesiąca za każdy rok sprawowania mandatu. W przypadku pełnienia mandatu posła na Sejm RP odprawę pomniejsza się o przysługujące wynagrodzenie poselskie. Przy jednoczesnym prawie do odprawy przejściowej oraz do emerytury parlamentarnej były poseł ma obowiązek wybrać jedno z przysługujących mu świadczeń. Emerytura z PE podlega pomniejszeniu o wynagrodzenie poselskie w czasie pełnienia mandatu posła na Sejm RP.

Słowa kluczowe: emerytury i renty, odprawa parlamentarna, Parlament Europejski, poseł

Ekspert ds. legislacji Biura Analiz Sejmowych •

Kancelaria Sejmu, Biuro Analiz Sejmowych, Wydział Analiz Prawa Międzynarodowego

¡ Zagranicznych Systemów Prawnych, Zespół Prawa Unii Europejskiej, WARSZAWA, POLSKA •

marcin.fryzlewicz@sejm.gov.pl • https://orcid.org/0000-0003-4049-559X

\section{Przedmiot opinii}

Przedmiotem opinii jest odpowiedź na pytanie, jaki wpływ ma objęcie mandatu posła na Sejm na prawo do otrzymywania odprawy przejściowej przysługują-

1 Opinia prawna dotyczaca prawa do odprawy przejściowej przystugującego postowi do Parlamentu Europejskiego po wygaśnięciu mandatu posta do Parlamentu Europejskiego $w$ przypadku objęcia mandatu posła na Sejm sporządzona 28 stycznia 2020 r. na zlecenie posła Klubu Parlamentarnego Koalicja Polska - Polskie Stronnictwo Ludowe Kukiz15; BAS-WAPM 63/20. 
ce posłowi do Parlamentu Europejskiego po wygaśnięciu mandatu posła do PE, zwanej dalej odprawą przejściową².

Zasadnicza wątpliwość dotyczy zachowania prawa do odprawy przejściowej, przysługującego posłowi do PE po wygaśnięciu mandatu (tj. byłemu posłowi do $\mathrm{PE}), \mathrm{w}$ przypadku objęcia mandatu posła na Sejm. Można przedstawić następujące rozwiązania:

- możliwość otrzymywania odprawy przejściowej w pełnej kwocie przez posła na Sejm, który nie ma statusu tzw. posła zawodowego,

- istnienie wymogu uzyskania przez posła statusu tzw. posła zawodowego, co skutkowałoby pomniejszaniem kwoty odprawy przejściowej o kwotę otrzymywanego przez posła uposażenia poselskiego.

W opinii uwzględniono stan prawny na dzień 10 stycznia 2020 r. następujących aktów prawnych:

- decyzja Parlamentu Europejskiego z 28 września 2005 r. w sprawie przyjęcia statutu posła do Parlamentu Europejskiego (2005/684/WE, Euratom) ${ }^{3}$; dalej: statut,

- decyzja Prezydium Parlamentu Europejskiego z 19 maja i 9 lipca 2008 r. ustanawiająca przepisy wykonawcze do statutu posła do Parlamentu Europejskiego (2009/C 159/01) $)^{4}$ dalej: przepisy wykonawcze.

Opinię sporządzono z zastrzeżeniem, że stosowanie i wykładnia przepisów statutu oraz przepisów wykonawczych należy do właściwych służb Parlamentu Europejskiego. Poglądy wyrażone w opinii nie stanowią wiążącej wykładni przepisów prawa i mogą nie odpowiadać praktyce ich stosowania przez służby prawne PE. Zgodnie z przepisami wykonawczymi były poseł do PE, który uważa, że przepisy nie zostały wobec niego prawidłowo zastosowane przez właściwe służby, może skierować zażalenie na piśmie do sekretarza generalnego $\mathrm{PE}^{5}$.

2 Poza przedmiotem opinii leży zagadnienie, jaki wpływ na prawo do uposażenia poselskiego ma otrzymywanie z PE odprawy przejściowej. Kwestii tej dotyczy Opinia prawna dotyczaca wplywu odprawy z PE na uposażenie poselskie, sporządzona przez Biuro Analiz Sejmowych 7 listopada 2019 r. (sygn. BAS-WAP 2077/19). W opinii tej wyrażono pogląd, że zgodnie z art. 25 ust. 3 ustawy z 9 maja 1996 r. o wykonywaniu mandatu posła i senatora (Dz.U. 2018, poz. 1799) otrzymywanie odprawy z Parlamentu Europejskiego nie powoduje utraty prawa do uposażenia poselskiego w pełnej wysokości.

3 Dz.Urz. UE L 262 z 7 października 2005 r., s. 1.

4 Dz.Urz. UE C 159 z 13 lipca 2009 r., s. 1, ze zm.

5 Zob. art. 72 ust. 1 przepisów wykonawczych. Zgodnie z ust. 2-4 tego artykułu były poseł do PE, który nie zgadza się z decyzją sekretarza generalnego PE, może w terminie dwóch miesięcy od jej otrzymania wnieść o przekazanie sprawy kwestorom, którzy podejmują decyzję po zasięgnięciu opinii sekretarza generalnego. Strona pro- 
Poseł wyjaśnił, że od 2004 r. do 1 lipca 2019 r. był posłem do PE. W dniu 13 października został wybrany na posła na Sejm. Od 13 listopada 2019 r. jest członkiem sejmowych Komisji Finansów Publicznych oraz Komisji Spraw Zagranicznych. Poseł otrzymuje dodatek z tytułu członkostwa w Komisji Finansów Publicznych, o którym informuje Dział Finansowy Parlamentu Europejskiego, przesyłając na początku miesiąca odpowiednie zaświadczenie z Sejmu o pobranej z tego tytułu kwocie w miesiącu ubiegłym. Poseł nie otrzymuje uposażenia poselskiego i nie ma statusu tzw. posła zawodowego ${ }^{6}$. W pkt IX („Inne dochody...”) oświadczenia o stanie majątkowym sporządzonego 7 listopada 2019 r. ${ }^{7}$ poseł wskazał dochód osiągany z tytułu emerytury z ubezpieczenia dobrowolnego posłów do PE.

\section{Uzasadnienie}

Zgodnie z art. 9 ust. 2 statutu posłowie do Parlamentu Europejskiego po wygaśnięciu mandatu (dalej: byli posłowie do $\mathrm{PE}$ ) mają prawo do odprawy przejściowej. Prawo to przysługuje byłym posłom do PE przez okres jednego miesiąca za każdy rok sprawowania mandatu, jednak nie krócej niż sześć miesięcy i nie dłużej niż 24 miesiące (art. 13 ust. 2 statutu). Artykuł 45 przepisów wykonawczych stanowi, że prawo do odprawy przejściowej przysługuje od pierwszego miesiąca następującego po zaprzestaniu pełnienia funkcji poselskich.

Byłym posłom do PE przysługuje odprawa przejściowa w wysokości wynagrodzenia posła do PE, które wynosi 38,5\% poborów podstawowych sędziego Trybunału Sprawiedliwości Unii Europejskiej (art. 13 w związku z art. 10 statutu) ${ }^{8}$,

cedury zażalenia, która nie zgadza się z decyzją podjętą przez kwestorów, może w terminie dwóch miesięcy od jej otrzymania wnieść o przekazanie sprawy Prezydium PE, które podejmuje ostateczną decyzję.

6 Poseł zawodowy to poseł, który korzysta z urlopu bezpłatnego w swoim miejscu pracy lub w ogóle zrezygnował z pracy, nie prowadzi działalności gospodarczej i nie pobiera emerytury, z wyjątkami określonymi w art. 25 ust. 3a ustawy z o wykonywaniu mandatu posła i senatora. Ustawodawca nie posługuje się tym pojęciem, jest ono używane potocznie.

7 Zob. złożone przez posła na początku IX kadencji Sejmu oświadczenie majątkowe, http://orka.sejm.gov.pl/osw9.nsf/0/115C9EA41C4E31DAC12584AC00580B82/\%24F ile/OSW9P_340.pdf [dostęp 27 stycznia 2019 r.].

8 Zgodnie z art. 12 Statutu oraz art. 70 przepisów wykonawczych zarówno wynagrodzenie posłów do PE, jak odprawa przejściowa oraz emerytura przysługujące byłym posłom do PE podlegają podatkowi określonemu przepisami rozporządzenia Rady (EWG, Euratom, EWWiS) nr 260/68 z 29 lutego 1968 r. ustanawiającego warunki i procedurę stosowania podatku na rzecz Wspólnot Europejskich (Dz.Urz. WE L 56 z 4 marca 1968 r., s. 8, ze zm.; Dz.Urz. UE, polskie wydanie specjalne, rozdz. 1, t. 1, s. 33). 
zwana dalej „odprawą przejściową w pełnej wysokości”. Z przepisów statutu oraz przepisów wykonawczych wynika, że w przypadku objęcia mandatu w parlamencie narodowym (w tym mandatu posła na Sejm) odprawa przejściowa w pełnej wysokości przysługuje byłemu posłowi do PE wyłącznie w okresie poprzedzającym objęcie mandatu9. Zgodnie z zasadą zakazu kumulowania płatności pochodzących ze środków publicznych kwoty otrzymane przez byłego posła do PE w związku z pełnieniem przez niego mandatu w parlamencie narodowym, z wyłączeniem zwrotu kosztów faktycznie poniesionych do tego momentu, podlegają odjęciu od odprawy przejściowej wypłacanej przez $\mathrm{PE}^{10}$. Byłemu posłowi do PE w okresie wykonywania mandatu posła na Sejm przysługuje zatem odprawa przejściowa w kwocie pomniejszonej o przysługujące $\mathrm{w}$ danym miesiącu wynagrodzenie poselskie ${ }^{11}$. Odliczeniu mogą podlegać wyłącznie składniki wynagrodzenia, które poseł rzeczywiście otrzymuje z tytułu wykonywania mandatu ${ }^{12}$. W szczególności nie ma podstaw prawnych do odliczenia od odprawy przejściowej kwoty uposażenia poselskiego w odniesieniu do posła, który nie jest tzw. posłem zawodowym i nie otrzymuje uposażenia poselskiego. Jeżeli poseł otrzymuje wyłącznie dodatek z tytułu członkostwa w danej komisji sejmowej, to przysługuje mu odprawa przejściowa w wysokości zmniejszonej o kwotę tego dodatku.

Artykuł 48 ust. 1 przepisów wykonawczych stanowi, że w celu skorzystania z prawa do odprawy przejściowej były poseł do PE zwraca się z wnioskiem do sekretarza generalnego PE $\mathrm{w}$ terminie trzech miesięcy od wygaśnięcia mandatu, wraz z załączonym oświadczeniem, w którym zaświadcza, że nie sprawuje mandatu w parlamencie narodowym. Były poseł do PE ma obowiązek bezzwłocznie powiadomić sekretarza generalnego o wszelkich zmianach $\mathrm{w}$ występowaniu przesłanek przyznania prawa do odprawy przejściowej, które mogą spowodować zmianę tego prawa (art. 48 ust. 3 przepisów wykonawczych) ${ }^{13}$.

9 Wniosek ten wynika $\mathrm{z}$ łącznego odczytania norm prawnych zawartych w art. 13 Statutu oraz art. 46 przepisów wykonawczych.

10 Zob. motyw 13 preambuły decyzji Prezydium Parlamentu Europejskiego z 26 października 2015 r. zmieniającej przepisy wykonawcze do statutu posła do Parlamentu Europejskiego (2015/C 397/03; Dz.Urz. UE L 392 z 28 listopada 2015 r., s. 2; dalej: decyzja 2015/C 397/03) oraz wprowadzone na mocy tej decyzji brzmienie art. 46 przepisów wykonawczych.

11 Zgodnie z art. 2 ust. 3 w związku z art. 46 ust. 2 przepisów wykonawczych obliczenia przysługującego świadczenia dokonuje się wówczas na podstawie wysokości każdego ze świadczeń, tj. odprawy przejściowej oraz wynagrodzenia poselskiego, przed opodatkowaniem.

12 Zgodnie z motywem 13 preambuły decyzji 2015/C 397/03: kwoty otrzymane przez posła $w$ zwiazku z petnieniem przez niego mandatu w innym parlamencie [...] zostanq odjęte od odprawy przejściowej wypłacanej przez Parlament Europejski.

13 Naruszenie obowiązku powiadomienia sekretarza generalnego PE o objęciu przez byłego posła do PE mandatu w parlamencie narodowym może skutkować zawieszeniem 
Zgodnie $\mathrm{z}$ art. 9 Statutu oraz art. 49 ust. 1 akapit pierwszy przepisów wykonawczych po wygaśnięciu mandatu były poseł do PE, który sprawował mandat przez co najmniej pełny rok, ma prawo do dożywotniej emerytury, wypłacanej począwszy od pierwszego dnia miesiąca następującego po miesiącu, w którym osiągnął wiek 63 lat ${ }^{14}$. Prawo to (dalej: prawo do emerytury z PE) istnieje niezależnie od innych emerytur (np. emerytur krajowych; art. 14 ust. 3 statutu). Były poseł do PE, mający jednocześnie prawo do odprawy przejściowej i do emerytury z PE, ma obowiązek podjąć decyzję, z którego prawa chce skorzystać. Powiadamia on o swojej decyzji sekretarza generalnego PE w terminie trzech miesięcy od wygaśnięcia mandatu. Decyzja ta jest nieodwołalna (art. 47 ust. 1 przepisów wykonawczych). Jeżeli były poseł do PE wybrał wypłatę odprawy przejściowej, wypłata emerytury z PE podlega zawieszeniu przez cały okres wypłaty odprawy przejściowej. Po upływie tego okresu posłowi na Sejm, który uzyskał prawo do emerytury z PE, będzie wypłacane świadczenie emerytalne z PE w kwocie pomniejszonej o kwotę wynagrodzenia poselskiego ${ }^{15}$.

Analiza postanowień statutu oraz przepisów wykonawczych prowadzi do wniosku, że były poseł do PE ma prawo do odprawy przejściowej w pełnej kwocie wyłącznie w okresie poprzedzającym objęcie mandatu posła na Sejm. W okresie wykonywania mandatu posła na Sejm byłemu posłowi do PE przysługuje odprawa przejściowa w kwocie pomniejszanej o otrzymywane w danym miesiącu wynagrodzenie poselskie. Odprawa przejściowa przysługuje byłemu posłowi do PE bez względu na to, czy poseł ma status tzw. posła zawodowego i otrzymuje uposażenie poselskie. Odliczeniu mogą podlegać wyłącznie składniki wynagrodzenia, które poseł na Sejm rzeczywiście otrzymuje z tytułu wykonywania mandatu.

\section{Podsumowanie}

- Zgodnie z aktami prawnymi Parlamentu Europejskiego poseł do PE ma prawo do odprawy przejściowej począwszy od pierwszego dnia miesiąca następującego po wygaśnięciu mandatu posła do PE. Prawo do odprawy przejściowej w wysokości odpowiadającej wynagrodzeniu posła do PE przysługuje przez okres jed-

wypłaty odprawy przejściowej. Zgodnie z art. 48 ust. 4 przepisów wykonawczych, jeżeli na podstawie okoliczności faktycznych możliwych do zweryfikowania za pośrednictwem ogólnodostępnych źródeł sekretarz generalny otrzyma wiadomość, że były poseł sprawuje mandat $\mathrm{w}$ parlamencie narodowym, zawiesza on wypłatę odprawy przejściowej i powiadamia o tym zainteresowanego.

14 Emerytura wynosi 3,5\% wynagrodzenia posła do PE za każdy rok sprawowania mandatu i 1/12 tej kwoty za każdy następny pełen miesiąc, jednak łącznie nie więcej niż $70 \%$ (art. $14 \mathrm{w}$ związku z art. 10 statutu).

15 Wniosek ten wynika z dyspozycji art. 14 ust. 4 statutu, zgodnie z którym do emerytury z PE stosuje się odpowiednio postanowienia art. 11 statutu. 
nego miesiąca za każdy rok sprawowania mandatu, jednak nie krócej niż sześć miesięcy i nie dłużej niż 24 miesiące.

- W przypadku objęcia mandatu posła na Sejm odprawa przejściowa w pełnej wysokości przysługuje byłemu posłowi do PE wyłącznie w okresie poprzedzającym objęcie mandatu posła na Sejm. W okresie wykonywania mandatu posła na Sejm byłemu posłowi do PE przysługuje odprawa przejściowa w kwocie pomniejszonej o przysługujące mu $\mathrm{w}$ danym miesiącu wynagrodzenie poselskie. Odliczeniu mogą podlegać wyłącznie składniki wynagrodzenia, które poseł rzeczywiście otrzymuje z tytułu wykonywania mandatu. W szczególności nie ma podstaw prawnych, aby odprawa przejściowa była obniżana o kwotę uposażenia poselskiego w przypadku posła, który - nie mając statusu tzw. posła zawodowego - nie otrzymuje uposażenia poselskiego. Jeżeli poseł otrzymuje wyłącznie dodatek z tytułu członkostwa $\mathrm{w}$ danej komisji sejmowej, to przysługuje mu odprawa przejściowa w wysokości zmniejszonej o kwotę tego dodatku.

- Zgodnie z przepisami prawnymi przyjętymi przez PE, dotyczącymi kumulacji świadczeń, były poseł do PE, mający jednocześnie prawo do odprawy przejściowej oraz dożywotnej emerytury przysługującej byłym posłom do PE po ukończeniu 63. roku życia, ma obowiązek podjąć decyzję, z którego prawa chce skorzystać. Jeżeli były poseł do PE wybrał wypłatę odprawy przejściowej, wypłata emerytury podlega zawieszeniu przez cały okres wypłaty odprawy przejściowej. Po upływie tego okresu posłowi na Sejm, który uzyskał prawo do emerytury z PE, wypłaca się świadczenie emerytalne w kwocie pomniejszonej o kwotę wynagrodzenia poselskiego. 

2

OPINIE BAS

C

OPINIE LEGISLACYJNE 

Rafał Dubowski

\title{
Ocena petycji w sprawie zniesienia instytucji ubezwłasnowolnienia'
}

\author{
Evaluation of a petition regarding the abolition of the institution \\ of incapacitation
}

\begin{abstract}
The petition under review concerns the proposal to abolish the institution of total and partial incapacitation, to introduce the institution of assistant care and the care with a concurrent representation. In the opinion of the author, the reform of the institution of legal incapacitation is required to fulfil international obligations. However, the solution proposed in the petition may insufficiently protect the interests of the protected person, his/her family, relatives and other legal entities. The author suggests that in some cases legislation should enable the possibility to apply substitution measures and, moreover, it is worth to consider introducing a mandatory periodic verification of the existence of the reasons for the use of a guardianship measure, in case of commencing activities on amending the relevant provisions.
\end{abstract}

Keywords: petition, legal incapacitation

W ocenianej petycji zaproponowano zniesienie instytucji ubezwłasnowolnienia całkowitego i częściowego, wprowadzenie instytucji opieki asystencyjnej oraz opieki z reprezentacją równoległą. Zdaniem autora opinii reforma instytucji ubezwłasnowolnienia jest pożądana ze względu na potrzebę wypełnienia zobowiązań międzynarodowych. Jednak proponowane w petycji rozwiązanie może niedostatecznie chronić interesy osoby objętej opieką, jej rodziny, bliskich oraz innych uczestników obrotu prawnego. Jego zdaniem w niektórych przypadkach - oprócz tych środków - ustawodawstwo powinno przewidywać możliwość zastosowania środków substytucyjnych, a ponadto w razie podjęcia prac nad nowelizacją przepisów warto rozważyć wprowadzenie obligatoryjnej okresowej weryfikacji istnienia podstaw do stosowania środka opiekuńczego.

Słowa kluczowe: petycja, ubezwłasnowolnienie

Doktor nauk prawnych, ekspert ds. legislacji Biura Analiz Sejmowych •

Kancelaria Sejmu, Biuro Analiz Sejmowych, Wydział Analiz Prawnych, Zespół Prawa

Prywatnego, WARSZAWA, POLSKA -

rafal.dubowski@sejm.gov.pl • https://orcid.org/0000000178524275

\section{Treść i cel petycji}

Petycja została wniesiona $\mathrm{w}$ interesie publicznym. Postuluje się w niej zniesienie instytucji ubezwłasnowolnienia całkowitego i częściowego, a ponadto wprowadzenie instytucji opieki asystencyjnej, zakładającej pozostawienie pod-

1 Opinia prawna na temat petycji nr BKSP-145-553/19 w sprawie zniesienia instytucji ubezwłasnowolnienia sporządzona 5 sierpnia 2019 r. na zlecenie przewodniczącego Komisji do Spraw Petycji; BAS-WAP 1209/19. 
opiecznemu pełnej zdolności do czynności prawnych i udzielanie mu wsparcia w podejmowaniu decyzji przez opiekuna. Poza tym proponuje się wprowadzenie opieki z reprezentacją równoległą. Zgodnie z postulatem przedstawionym w petycji osobie podlegającej tego rodzaju opiece przysługiwałaby zdolność do czynności prawnych, przy czym opiekun posiadałby prawo do reprezentowania podopiecznego w określonym zakresie. Oprócz tego w petycji zaproponowano ustanowienie obowiązku przebadania podopiecznego, co 3 lata, w celu stwierdzenia (bez)zasadności dalszego stosowania środka opiekuńczego. Ponadto postuluje się wprowadzenie regulacji umożliwiających unieważnienie czynności prawnej przez sąd w przypadku, gdy: 1) czynność prawna pociąga za sobą rażące pokrzywdzenie danej osoby lub jej najbliższych; 2) osoba ta w chwili dokonywania czynności nie była zdolna do pokierowania swoim postępowaniem oraz rozpoznania jego znaczenia.

\section{Czy petycja mieści się w zakresie zadań i kompetencji adresata petycji (art. 2 ust. 3 ustawy o petycjach)?}

Petycja dotyczy zmiany ustawy przez Sejm. Zgodnie z art. 95 ust. 1 Konstytucji RP władzę ustawodawczą w Rzeczypospolitej Polskiej sprawują Sejm i Senat. Natomiast stosownie do art. 118 ust. 1 Konstytucji inicjatywa ustawodawcza przysługuje m.in. posłom. Artykuł 32 ust. 2 regulaminu Sejmu w związku z art. 112 Konstytucji precyzuje, że poselskie projekty ustaw mogą być wnoszone przez komisje sejmowe lub grupę co najmniej 15 posłów podpisujących projekt. Uwzględniając powyższe, należy uznać, że petycja mieści się w zakresie zadań i kompetencji Sejmu.

\section{Wymogi formalne (art. 4 ust. 1 i 2 ustawy o petycjach)}

Petycja spełnia wymogi formalne określone w art. 4 ust. 1 i 2 ustawy o petycjach.

\section{Kwestie, które ekspert uznaje za istotne w związku z petycją}

\section{Ubezwłasnowolnienie w świetle obowiązujących regulacji}

W prawie polskim występują dwa rodzaje ubezwłasnowolnienia, tj. ubezwłasnowolnienie całkowite oraz częściowe. Zgodnie z art. $13 \$ 1$ k.c. ${ }^{2}$ : [o]soba, która ukończyła lat trzynaście, może być ubezwłasnowolniona całkowicie, jeżeli wskutek choroby psychicznej, niedorozwoju umysłowego albo innego rodzaju zaburzeń psychicznych, $w$ szczególności pijaństwa lub narkomanii, nie jest $w$ stanie kierować swym postę-

2 Ustawa z 23 kwietnia 1964 r. - Kodeks cywilny, t.j. Dz.U. 2019, poz. 1145; dalej: k.c. 
powaniem. Jak dodaje $\$ 2$ tego artykułu: [d]la ubezwłasnowolnionego całkowicie ustanawia się opiekę, chyba że pozostaje on jeszcze pod władza rodzicielską. Osoby ubezwłasnowolnione całkowicie nie mają zdolności do czynności prawnych tak samo jak osoby, które nie ukończyły lat trzynastu (art. 12 k.c.). Natomiast czynność prawna (a więc np. umowa) dokonana (zawarta) przez osobę, która nie ma zdolności do czynności prawnych, jest nieważna (art. $14 \$ 1$ k.c.). Jednakże gdy osoba niezdolna do czynności prawnych zawarła umowę należącą do umów powszechnie zawieranych $\mathrm{w}$ drobnych bieżących sprawach życia codziennego, umowa taka staje się ważna z chwilą jej wykonania, chyba że pociąga za sobą rażące pokrzywdzenie osoby niezdolnej do czynności prawnych (art. $14 \$ 2$ k.c.). Do tej kategorii umów należy zakwalifikować np. umowy sprzedaży artykułów spożywczych, środków higieny, papierniczych, przewozu środkami komunikacji miejskiej, uczestniczenia w imprezie kulturalnej, sportowej lub rozrywkowej, o ile nie mają dużej wartości ${ }^{3}$.

Jak stanowi art. $16 \$ 1$ k.c.: [o] soba petnoletnia może być ubezwłasnowolniona częściowo z powodu choroby psychicznej, niedorozwoju umysłowego albo innego rodzaju zaburzeń psychicznych, w szczególności pijaństwa lub narkomanii, jeżeli stan tej osoby nie uzasadnia ubezwłasnowolnienia całkowitego, lecz potrzebna jest pomoc do prowadzenia jej spraw. Dla osoby ubezwłasnowolnionej częściowo ustanawiana jest kuratela (art. $16 \$ 2$ k.c.). Osoby ubezwłasnowolnione częściowo mają ograniczoną zdolność do czynności prawnych tak samo jak małoletni, którzy ukończyli lat trzynaście (art. 15 k.c.). Do ważności czynności prawnej, przez którą osoba ograniczona w zdolności do czynności prawnych (a więc także osoba ubezwłasnowolniona częściowo) zaciąga zobowiązanie lub rozporządza swoim prawem, potrzebna jest zgoda jej przedstawiciela ustawowego (art. 17 k.c.). Jednak w przypadku, gdy umowa została zawarta przez osobę ograniczoną w zdolności do czynności prawnych bez wymaganej zgody przedstawiciela ustawowego, ważność umowy zależy od potwierdzenia umowy przez tego przedstawiciela (art. $18 \$ 1$ k.c.). Przy czym: [o] soba ograniczona $w$ zdolności do czynności prawnych może sama potwierdzić umowę po uzyskaniu petnej zdolności do czynności prawnych (art. $18 \$ 2$ k.c.). Ponadto osoba posiadająca ograniczoną zdolność do czynności prawnych może bez zgody przedstawiciela ustawowego zawierać umowy należące do umów powszechnie zawieranych $\mathrm{w}$ drobnych bieżących sprawach życia codziennego (art. 20 k.c.). Czynność prawna jednostronna, do której ustawa wymaga zgody przedstawiciela ustawowego, dokonana przez osobę ograniczoną w zdolności do czynności prawnych jest nieważna i inaczej niż umowa - nie może być konwalidowana przez wyrażenie zgody przez przedstawiciela ustawowego po dokonaniu czynności (art. 19 k.c.). Trzeba dodać, że osoba posiadająca ograniczoną zdolności do czynności prawnych może bez zgody przedstawiciela ustawowego rozporządzać swoim zarobkiem, chyba że

3 Zob. P. Księżak, Art. 14 [w:] Kodeks cywilny. Komentarz, red. K. Osajda, 2019, Legalis, pkt 3. 4 Zob. P. Księżak, Art. 19 [w:] Kodeks cywilny. Komentarz, red. K. Osajda, 2019, Legalis. 
sąd opiekuńczy z ważnych powodów inaczej postanowi (art. 21 k.c.). A ponadto gdy: przedstawiciel ustawowy osoby ograniczonej $w$ zdolności do czynności prawnych oddał jej określone przedmioty majątkowe do swobodnego użytku, osoba ta uzyskuje pełna zdolność $w$ zakresie czynności prawnych, które tych przedmiotów dotycza. Wyjątek stanowią czynności prawne, do których dokonania nie wystarcza według ustawy zgoda przedstawiciela ustawowego (art. 22 k.c.).

Ubezwłasnowolnienie i wiążące się z nim ograniczenie praw publicznych wywiera istotne skutki w sferze konstytucyjnych praw politycznych. Na przykład osoby ubezwłasnowolnione nie mają czynnego prawa wyborczego oraz prawa udziału w referendum (art. 62 ust. 2 Konstytucji), a tym samym nie mogą kandydować do Sejmu i Senatu (art. 99 Konstytucji), na urząd Prezydenta (art. 127 ust. 3 Konstytucji), nie mogą również korzystać z prawa powszechnej inicjatywy ustawodawczej (art. 118 ust. 2 Konstytucji) ${ }^{5}$.

Ubezwłasnowolnienie wywiera skutki także w zakresie stosunków prawnorodzinnych. Na przykład osoba ubezwłasnowolniona całkowicie nie może zawrzeć małżeństwa ${ }^{6}$. Ubezwłasnowolnienie całkowite wpływa na zdolność do wytoczenia powództwa o zaprzeczenie ojcostwa (art. 64 k.r.o.; art. $69 \$ 3$ k.r.o. w związku $\mathrm{z}$ art. 64 k.r.o.), macierzyństwa (art. $61^{13} \$ 3$; art. $61^{14} \S 2 \mathrm{w}$ związku z art. 64 k.r.o.) czy też ustalenie bezskuteczności uznania ojcostwa (art. $78 \$ 2$ w związku z art. 64 k.r.o.; art. $81 \S 3$ w związku z art. 64 k.r.o.).

Osoba ubezwłasnowolniona całkowicie nie może nawiązać stosunku pracy ${ }^{7}$. Natomiast osoba ubezwłasnowolniona częściowo - zgodnie z art. $22 \$ 3$ k.p. ${ }^{8}$ : może bez zgody przedstawiciela ustawowego nawiąać stosunek pracy oraz dokonywać czynności prawnych, które dotycza tego stosunku. Jednakże gdy stosunek pracy sprzeciwia się dobru tej osoby, przedstawiciel ustawowy za zezwoleniem sądu opiekuńczego może stosunek pracy rozwiązać.

Osoba ubezwłasnowolniona - co do zasady - nie może być krwiodawcą ${ }^{9}$ Za życia nie może ona być również dawcą komórek, tkanek lub narządów ${ }^{10}$. Ponad-

5 Zob. pkt III.1. uzasadnienia wyroku TK z 7 marca 2007 r., sygn. akt K 28/05, OTK-A ZU 2007, nr 3, poz. 24; R. Rybski, Konstytucyjny status osób ubezwłasnowolnionych, Warszawa 2015, s. 88.

6 Zob. art. $11 \$ 1$ ustawy z 25 lutego 1964 r. - Kodeks rodzinny i opiekuńczy, t.j. Dz.U. 2017, poz. 682, ze zm.; dalej: k.r.o.

7 Zob. postanowienie SN z 22 listopada 1979 r., sygn. akt III PZ 7/79, LEX nr 12619; G. Goździewicz, T. Zieliński, Art. 22 [w:] Kodeks pracy. Komentarz, red. L. Florek, 2017, LEX, pkt 14.

8 Ustawa z 26 czerwca 1974 r. - Kodeks pracy, t.j. Dz.U. 2019, poz. 1040.

9 Zob. art. 15 ust. 1 pkt 2 oraz art. 15 ust. 2 ustawy z 22 sierpnia 1997 r. o publicznej służbie krwi, t.j. Dz.U. 2019, poz. 1222; R. Rybski, Konstytucyjny status, op. cit., s. 105.

10 Zob. art. 12 ust. 1 pkt 7 ustawy z 1 lipca 2005 r. o pobieraniu, przechowywaniu i przeszczepianiu komórek, tkanek i narządów, t.j. Dz.U. 2019, poz. 1405; R. Rybski, Konstytucyjny status, op. cit., s. 105-106. 
to osoba ubezwłasnowolniona nie może samodzielnie zdecydować o tym, czy będzie dawcą po śmierci (decyzję w tym przedmiocie podejmuje przedstawiciel ustawowy) ${ }^{11}$. Zgodę na przeprowadzenie badania lub udzielenie innych świadczeń zdrowotnych w przypadku osoby całkowicie ubezwłasnowolnionej wyraża przedstawiciel ustawowy tej osoby ${ }^{12}$. Jednakże jeżeli osoba taka jest w stanie $\mathrm{z}$ rozeznaniem wypowiedzieć opinię w sprawie badania, konieczne jest ponadto uzyskanie zgody tej osoby ${ }^{13}$. Jeżeli jednak osoba ubezwłasnowolniona sprzeciwia się czynnościom medycznym, poza zgodą jej przedstawiciela ustawowego albo w przypadku niewyrażenia przez niego zgody wymagane jest zezwolenie sądu opiekuńczego $^{14}$.

Powyższa charakterystyka instytucji ubezwłasnowolnienia i jej skutków, choć skrótowa i tym samym niewyczerpująca, pokazuje, że ubezwłasnowolnienie związane jest z licznymi ograniczeniami dotykającymi wielu sfer życia, w szczególności prywatnego, gospodarczego i społecznego. Na tym tle trzeba stwierdzić, że zdolność do czynności prawnych i jej zakres jest istotnym wyznacznikiem wolności przysługującej jednostce. Ponadto zaprezentowana charakterystyka wskazuje, iż z uwagi na to, że ubezwłasnowolnienie wywołuje skutki prawne nie tylko w zakresie prawa cywilnego, ale również w obszarze innych gałęzi prawa, ewentualna reforma tej instytucji wymagałaby zmian systemowych.

\section{Ubezwłasnowolnienie w świetle konwencji o prawach osób niepełnosprawnych}

Trybunał Konstytucyjny stwierdził, że: osoby ubezwłasnowolnione powinny być zasadniczo traktowane jako osoby niepełnosprawne, którym należy się pomoc $w$ zabezpieczaniu egzystencji, przysposobieniu do pracy oraz komunikacji społecznej (art. 69 Konstytucji). Opieka nad osobami, którym zaburzenia psychiczne nie pozwalaja kierować swoim postępowaniem, zarówno ze strony innych osób, jak $i$ władz publicznych jest szczególnym aspektem wspomnianego $w$ preambule do Konstytucji obowiązku solidarności międzyludzkiej, jak również poszanowania i ochrony godności człowieka ${ }^{15}$.

11 Zob. art. 5 ust. 1-2 ustawy o pobieraniu, przechowywaniu i przeszczepianiu komórek, tkanek i narządów; R. Rybski, Konstytucyjny status, op. cit., s. 105-106.

12 Zob. art. 32 ust. 4 zdanie 1 ustawy z 5 grudnia 1996 r. o zawodach lekarza i lekarza dentysty, t.j. Dz.U. 2019, poz. 537, ze zm.; R. Rybski, Konstytucyjny status, op. cit., s. 106.

13 Zob. art. 32 ust. 4 zdanie drugie ustawy o zawodach lekarza i lekarza dentysty; R. Rybski, Konstytucyjny status, op. cit., s. 106.

14 Zob. art. 32 ust. 6 ustawy o zawodach lekarza i lekarza dentysty; R. Rybski, Konstytucyjny status, op. cit., s. 106.

15 Zob. pkt III.1. uzasadnienia wyroku TK z 7 marca 2007 r., sygn. akt K 28/05, OTK-A ZU 2007, nr 3, poz. 24. 
W dniu 25 sierpnia 2012 r. Prezydent RP ratyfikował ${ }^{16}$ konwencję o prawach osób niepełnosprawnych, przyjętą 13 grudnia 2006 r. przez Zgromadzenie Ogólne Narodów Zjednoczonych w Nowym Jorku (Dz.U. 2012, poz. 1169). Zgodnie $\mathrm{z}$ art. 12 ust. 2 tej konwencji: Państwa Strony uznaja, że osoby niepełnosprawne maja zdolność prawna, na zasadzie równości z innymi osobami, we wszystkich aspektach życia. Natomiast ust. 3 tego artykułu zobowiązuje państwa strony do podjęcia odpowiednich środków w celu zapewnienia osobom niepełnosprawnym dostępu do wsparcia, którego mogą potrzebować przy korzystaniu ze zdolności prawnej. Z kolei, jak stanowi art. 12 ust. 4: Państwa Strony zagwarantują, że wszelkie środki związane z korzystaniem ze zdolności prawnej obejmować będa odpowiednie i skuteczne zabezpieczenia $w$ celu zapobiegania nadużyciom, zgodnie $z$ międzynarodowym prawem praw człowieka. Zabezpieczenia zapewnia, że środki związane z korzystaniem ze zdolności prawnej będa respektowały prawa, wole i preferencje osoby, będa wolne od konfliktu interesów i bezprawnych nacisków, będa proporcjonalne i dostosowane do sytuacji danej osoby, będa stosowane przez możliwie najkrótszy czas i będa podlegały regularnemu przeglądowi przez właściwe niezależne i bezstronne władze lub organ sadowy. Zabezpieczenia powinny być proporcjonalne do stopnia, w jakim takie środki wpływaja na prawa i interesy danej osoby.

Dostrzeżenie roli art. 12 konwencji o prawach osób niepełnosprawnych w kontekście ewentualnej reformy instytucji ubezwłasnowolnienia wymaga wyjaśnienia wątpliwości, które budzi występujące w nim określenie - zdolność prawna (legal capacity). Jak wskazuje się w piśmiennictwie prawniczym: [a]naliza założeń, celów oraz prac przygotowawczych prowadzi do wniosku, że celem art. $12 \mathrm{KPON}$ [Konwencji o prawach osób niepełnosprawnych - dopisek R.D.] było zagwarantowanie zdolności czynnej, a nie jedynie zdolności biernej (podmiotowości prawnej), której dotyczy bezpośrednio art. 12 ust. 1 KPON. Użycie sformułowania legal capacity wynika z braku ścisłego rozróżnienia pomiędzy zdolnościa prawną a zdolnościa do czynności prawnych w systemach prawnych państw common law ${ }^{17}$. Interpretację tę przyjął także Komitet ds. praw osób niepełno-

16 Ustawa o ratyfikacji Konwencji o prawach osób niepełnosprawnych, sporządzonej w Nowym Jorku 13 grudnia 2006 r., Dz.U. 2012, poz. 882; Convention on the Rights of Persons with Disabilities [w:] Status of treaties, https://treaties.un.org/Pages/ViewDetails. aspx?src=TREATY\&mtdsg_no=IV-15\&chapter=4\&lang=en [dostęp 31 lipca 2019 r.].

17 Cytat za: M. Domański, Ubezwłasnowolnienie w prawie polskim a wybrane standardy międzynarodowej ochrony praw człowieka, „Prawo w Działaniu. Sprawy Cywilne” 2014, 17, s. 30. Zob. P. Księżak, Art. 13 [w:] Kodeks cywilny. Komentarz, red. K. Osajda, 2019, Legalis, pkt 7, gdzie autor stwierdza: [w] polskiej wersji językowej niewatpliwie błędnie w art. 12 używa się terminu „zdolność prawna”, mimo że zarówno z przebiegu prac nad PrawNiepK, treści oryginalnej angielskiej wersji językowej (legal capacity), jak $i$ kontekstu wynika, że chodzi bardziej o zdolność do czynności prawnych. Tłumaczenie wypacza zatem sens przepisu w sposób niekorzystny dla osób z niepetnosprawnością. A ponadto zob. M. Balwicka-Szczyrba, A. Sylwestrzak, Instytucja ubezwłasnowolnienia 
sprawnych (ustanowiony na podstawie art. 34 konwencji o prawach osób niepełnosprawnych) w komentarzu do przepisów tej konwencji ${ }^{18}$. Podzielił ją również polski Sąd Najwyższy, stwierdzając w uzasadnieniu uchwały z 21 grudnia 2017 r.: [i]nterpretacja art. 12 Konwencji, prowadzona $z$ uwzględnieniem jej obcojęzycznych tekstów oraz oficjalnego komentarza do tego postanowienia (por. General comment No. 1 (2014), pkt 12, Committee on the Rights of Persons with Disabilities, (http://www.ohchr.org/EN/HRBodies/CRPD/Pages/GC.aspx)), prowadzi przy tym do wniosku, że postanowienie to dotyczy nie tylko zdolności prawnej, lecz także zdolności do czynności prawnych (legal capacity, capacité juridique, Rechts- und Handlungsfähigkeit). Taki sam wniosek wynika z polskiego tłumaczenia Konwencji opublikowanego w Dzienniku Urzędowym Unii Europejskiej, w którym mowa jest $w$ art. 12 ust. 2-4 o zdolności prawnej i zdolności do czynności prawnych, mając na względzie, że Konwencja, po jej zatwierdzeniu decyzja Rady 2010/48/WE z dnia 26 listopada 2009 r. (Dz.Urz. UE z 2010 r., L 23, s. 35), wiąże Rzeczpospolita Polska także jako integralny element prawa unijnego (por. wyrok Trybunału Sprawiedliwości Unii Europejskiej z dnia 11 kwietnia 2013 r., C-335/11 i C-337/11 (sprawy połaczone), HK Danmark przeciwko Dansk almennyttigt Boligselskab i HK Danmark przeciwko Dansk Arbejdsgiverforening, ECLI:EU:C:2013:222) ${ }^{19}$.

W związku z tym, że art. 12 ust. 4 konwencji o prawach osób niepełnosprawnych dotyczy także zdolności do czynności prawnych, trzeba stwierdzić, że regulacje dotyczące ubezwłasnowolnienia - zgodnie z tym przepisem - powinny:

- respektować prawa, wolę i preferencje osoby,

- eliminować konflikty interesów i bezprawne naciski,

- być proporcjonalne i dostosowane do sytuacji danej osoby,

w perspektywie unormowań Konstytucji RP oraz Konwencji ONZ o prawach osób niepełnosprawnych, „Gdańskie Studia Prawnicze” 2018, t. XL, s. 152, gdzie autorki wskazują, że: [u] żyte $w$ tym przepisie pojęcie legal capacity w polskim przekładzie zostało sformułowane, wedtug dosłownego tłumaczenia, jako „zdolność prawna”, co w doktrynie spotkało się z uzasadniona krytyką. Wywodzi się bowiem, że określenie to, biorac pod uwage petna treść art. 12 Konwencji ONZ, odnosi się nie tylko do płaszczyzny statycznej podmiotowości, obejmującej przysługiwanie praw, lecz także płaszczyzny dynamicznej - skoro $w$ dalszej części przepisu mowa jest o korzystaniu ze zdolności prawnej. Zamysł tkwiący u podstaw unormowań Konwencji ONZ lepiej odzwierciedlałoby więc określenie „zdolność w sferze prawa” obejmujące zarówno zdolność prawna, jak i zdolność do czynności prawnych. Podobnie na temat wykładni art. 12 konwencji zob. M. Szeroczyńska, Ubezwłasnowolnienie $i$ alternatywne formy pomocy $w$ realizowaniu zdolności do czynności prawnych osób z niepełnosprawnością intelektualną, w regulacjach międzynarodowych oraz w prawie obcym, na przykładzie Estonii, Niemiec, Szwecji, Wielkiej Brytanii i Kanady (stanu Manitoba) [w:] Jeśli nie ubezwłasnowolnienie, to co? Prawne formy wsparcia osób z niepełnosprawnością intelektualną, red. K. Kędziora, Warszawa 2012, s. 24-26.

18 Zob. M. Domański, Ubezwłasnowolnienie, op. cit., s. 31-33.

19 Uchwała SN z 21 grudnia 2017 r., sygn. akt III CZP 66/17, Legalis nr 1697215. 
- być stosowane przez możliwie najkrótszy czas,

- podlegać regularnemu przeglądowi przez właściwe niezależne i bezstronne władze lub organ sądowy.

Oceniając polskie regulacje w świetle wymogów konwencji, Małgorzata Balwicka-Szczyrba oraz Anna Sylwestrzak wskazały, że: [b]ez watpienia polska instytucja ubezwłasnowolnienia nie spełnia powyższych wymogów, choćby dlatego, że z uwagi na nieelastyczna formułę dwóch postaci ubezwłasnowolnienia nie jest dostosowana do sytuacji danej osoby [...], jak również dlatego, że zakres opieki nie uwzględnia aktywizacji osoby ubezwłasnowolnionej ${ }^{20}$. Z kolei M. Domański podniósł, że: polski system prawny oparty na instytucji ubezwłasnowolnienia całkowitego nie mieści się w modelu konwencyjnym, nawet przy bardziej „ostrożnej” jego interpretacji. Wątpliwości budzi z tego punktu widzenia również ubezwłasnowolnienie częściowe. Można doszukiwać się w tej instytucji pewnych elementów „wsparcia”, jednak orzeczenie ogranicza istotnie zdolność do czynności prawnych, może zostać ustanowione wbrew woli osoby niepetnosprawnej, ma charakter bezterminowy $i$, co chyba najistotniejsze, kurator powołany do reprezentowania osoby ubezwłasnowolnionej może działać jako przedstawiciel ustawowy, dokonując czynności z bezpośrednim skutkiem dla ubezwłasnowolnionego w zakresie takim, jak opiekun osoby ubezwłasnowolnionej całkowicie [...] nie ma przy tym obowiązku respektowania stanowiska ubezwłasnowolnionego ${ }^{21}$. Podobne oceny dotyczące niezgodności instytucji ubezwłasnowolnienia $\mathrm{z}$ konwencją przedstawiają także inni autorzy ${ }^{22}$.

W dniu 25 września 2012 r. zostało złożone oświadczenie rządowe w sprawie mocy obowiązującej konwencji o prawach osób niepełnosprawnych, sporządzonej w Nowym Jorku 13 grudnia 2006 r. (Dz.U. 2012, poz. 1170), w którym stwierdzono, że: Rzeczpospolita Polska oświadcza, że interpretuje art. 12 konwencji w sposób zezwalajacy na stosowanie ubezwłasnowolnienia, w okolicznościach $i$ w sposób określony w prawie krajowym, jako środka, o którym mowa w art. 12 ust. 4, w sytuacji, gdy wskutek choroby psychicznej, niedorozwoju umysłowego lub innego rodzaju zaburzeń psychicznych osoba nie jest $w$ stanie kierować swoim postępowaniem. Niemniej w literaturze prawniczej wskazuje się, że wbrew nazwie oświadczenie to należy uznawać za zastrzeżenie w rozumieniu art. 2 ust. 1 lit. d konwencji wiedeńskiej o prawie traktatów z 23 maja 1969 r. (Dz.U. 1990, nr 74, poz. 439), i to za zastrzeżenie niedopuszczalne, ze względu na to, iż jest ono

20 M. Balwicka-Szczyrba, A. Sylwestrzak, Instytucja ubezwłasnowolnienia, op. cit., s. 153.

Zob. M. Domański, Ubezwłasnowolnienie, op. cit., s. 44-45.

22 Zob. P. Księżak, Art. 13, op. cit., pkt 7; D. Mróz, Krytycznie wobec postulatu zniesienia ubezwłasnowolnienia $w$ kontekście harmonizacji polskiego prawa cywilnego $z$ Konwencją ONZ o prawach osób niepełnosprawnych, „Acta Iuris Stetinensis” 2018, nr 4, s. 16-17; M. Zima-Parjaszewska, Artykuł 12 Konwencji ONZ o prawach osób z niepetnosprawnościami a ubezwłasnowolnienie w Polsce, „Studia Prawnicze” 2013, nr 2, s. 99-100; R. Rybski, Konstytucyjny status, op. cit., s. 152. 
sprzeczne z celem konwencji (art. 19 lit. c konwencji wiedeńskiej o prawie traktatów oraz art. 46 konwencji o prawach osób niepełnosprawnych) ${ }^{23}$. W konsekwencji przyjmuje się, że Polska jest związana w całości art. 12 konwencji o prawach osób niepełnosprawnych ${ }^{24}$.

Mając powyższe na uwadze, trzeba wskazać, że reforma instytucji ubezwłasnowolnienia jest pożądana ze względu na potrzebę wypełnienia zobowiązań międzynarodowych. Tym samym zasadne jest postawienie pytania, o kierunki ewentualnych zmian.

\section{Modele prawne ochrony osób dorosłych}

W piśmiennictwie prawniczym wartościowe typologie środków ochrony dorosłych przedstawił L. Kociucki ${ }^{25}$. W ślad za nim ze względu na „źródło” danego środka można wyróżnić:

- środki władcze ustanawiane na podstawie orzeczenia sądu (np. orzeczenie o ubezwłasnowolnieniu, a następnie ustanowieniu opieki),

- środki ochrony przedsiębrane przez dorosłego we własnym zakresie (np. pełnomocnictwo opiekuńcze),

- środki ochrony skuteczne z mocy prawa (np. instytucje prawne umocowujące bliskich do reprezentacji podopiecznego bez konieczności wydawania orzeczenia przez sąd $)^{26}$.

Ze względu na zakres ochrony:

- środki pełne (obejmujące wszystkie sprawy podopiecznego),

- zakresowe (obejmujące określony zakres spraw),

- środki ad casum (dotyczące jednej lub kilku konkretnych spraw, dla których środek jest ustanawiany ${ }^{27}$.

Ze względu na czas, na jaki są ustanawiane:

- środki na czas nieokreślony,

- środki na czas określony,

- środki ad casum ustanawiane dla potrzeb jednej sprawy ${ }^{28}$.

23 Zob. P. Księżak, Art. 13, op. cit., pkt 7; M. Domański, Ubezwłasnowolnienie, op. cit., s. 38-41. Por. M. Balwicka-Szczyrba, A. Sylwestrzak, Instytucja ubezwłasnowolnienia, op. cit., s. 153; M. Zima-Parjaszewska, Artykut 12 Konwencji ONZ o prawach osób z niepetnosprawnościami, op. cit., s. 97-98.

24 Zob. M. Domański, Ubezwłasnowolnienie, op. cit., s. 41; P. Księżak, Art. 13, op. cit., pkt 7-8.

25 L. Kociucki, Niektóre problemy nowelizacji polskiego prawa o ubezwłasnowolnieniu, „Studia Prawnicze” 2013, nr 2, s. 111-112.

26 Ibidem.

27 Ibidem, s. 112.

28 Ibidem. 
Natomiast ze względu na rodzaj pieczy można wyodrębnić:

- środki substytucyjne (osoba sprawująca pieczę podejmuje czynności zamiast podopiecznego),

- środki asystencyjne (opiekun działa obok podopiecznego) ${ }^{29}$.

Ponadto środki ochrony dorosłych można podzielić (według zakresu swobody, którą dysponuje organ orzekający o ich zastosowaniu lub osoba podejmująca decyzję o skorzystaniu z nich) na tzw. środki „szyte na miarę” oraz środki, których treść jest ściśle zdefiniowana w ustawie ${ }^{30}$.

Przedstawione typologie pokazują, że ustawodawca dysponuje szerokim wachlarzem środków, za pomocą których może zapewnić ochronę osobom dorosłym, które z uwagi na różnego rodzaju zaburzenia psychiczne nie są w stanie kierować swoim postępowaniem. Możliwych rozwiązań jest wiele, zwłaszcza jeśli weźmiemy pod uwagę, że konkretne środki ochrony osób dorosłych łączą cechy poszczególnych typów. Konstrukcja prawna tych środków - jak się wydaje - powinna stanowić kompromis między potrzebą poszanowania godności i wolności osoby, która ze względu na różnego rodzaju zaburzenia psychiczne nie jest w stanie kierować swoim postępowaniem, a potrzebą ochrony interesów tej osoby, jej rodziny, bliskich oraz innych uczestników obrotu prawnego.

\section{Ubezwłasnowolnienie w świetle projektu założeń Komisji Kodyfikacyjnej Prawa Cywilnego}

Zagadnienie reformy instytucji ubezwłasnowolnienia było przedmiotem prac prowadzonych przez Komisję Kodyfikacyjną Prawa Cywilnego. Prace nad projektem założeń nowelizacji Kodeksu cywilnego, Kodeksu postępowania cywilnego, Kodeksu rodzinnego i opiekuńczego i innych ustaw Komisja zakończyła 22 marca 2013 r. ${ }^{31}$. Projekt założeń został przyjęty przez Radę Ministrów 10 marca 2015 r. $^{32}$. W projekcie tym zaproponowano wyeliminowanie odrębnych instytucji: ubezwłasnowolnienia częściowego i całkowitego, opieki nad ubezwłasnowolnionymi całkowicie, kurateli nad ubezwłasnowolnionymi częściowo, kurateli dla osoby niepełnosprawnej i zastąpienie ich instytucją opieki o zróżnicowanym zakresie i formie, dostosowanym do sytuacji poszczególnych osób ${ }^{33}$. Zgodnie

29 Ibidem.

30 Ibidem.

31 Komisja Kodyfikacyjna Prawa Cywilnego, https://arch-bip.ms.gov.pl/pl/dzialalnosc/ komisje-kodyfikacyjne/komisja-kodyfikacyjna-prawa-cywilnego/ [dostęp 31 lipca 2019 r.]. Zob. D. Mróz, Krytycznie wobec postulatu, op. cit., s. 18.

32 Zob. protokół ustaleń nr 10/2015 posiedzenia Rady Ministrów w dniu 10 marca 2015 r., https://legislacja.rcl.gov.pl/docs//1/208000/208041/208045/dokument165691. pdf [dostęp 31 lipca 2019 r.]; zob. D. Mróz, Krytycznie wobec postulatu, op. cit., s. 18.

33 Test regulacyjny do projektu założeń projektu ustawy o zmianie ustawy - Kodeks cywilny, ustawy - Kodeks rodzinny i opiekuńczy, ustawy - Kodeks postępowania cywil- 
z projektem założeń, orzekając o ustanowieniu opieki, sąd określałby zakres zadań opiekuna, przy czym mógłby, stosownie do potrzeb osoby korzystającej z ochrony, powierzyć mu określoną rolę w procesie realizacji zdolności do czynności prawnych przez podopiecznego. Możliwe to byłoby w jednej albo kilku $\mathrm{z}$ następujących form:

- opieka asystencyjna, pozostawiająca osobie korzystającej z ochrony pełną zdolność do czynności prawnych, a polegająca na udzielaniu podopiecznemu wsparcia w podejmowaniu decyzji,

- opieka z reprezentacją „równoległą”, pozostawiająca osobie korzystającej z ochrony zdolność do czynności prawnych, a jednocześnie nadająca opiekunowi upoważnienie do reprezentowania podopiecznego w oznaczonym zakresie,

- opieka z kompetencją do współdecydowania, polegająca na zastrzeżeniu zgody lub potwierdzenia opiekuna dla ważności oznaczonych rodzajów czynności prawnych osoby korzystającej z ochrony,

- opieka połączona z umocowaniem do wyłącznego zastępstwa, w której upoważnienie do podejmowania czynności prawnych w oznaczonym w orzeczeniu zakresie miałby tylko opiekun, a nie miałaby go osoba z niepełnosprawnością psychiczną ${ }^{34}$.

Decyzja o wyborze jednej albo kilku wymienionych form opieki (dla różnych zakresów czynności prawnych) należałaby do sądu ${ }^{35}$.

W projekcie założeń zaproponowano wprowadzenie tzw. pełnomocnictwa opiekuńczego. Jego sens polega na tym, że osoba dorosła i sprawna psychicznie może ustanowić pełnomocnika, który byłby upoważniony do dokonywania w jej imieniu określonych czynności, w tym także o charakterze osobistym, gdyby mocodawca doznał w przyszłości zaburzeń psychicznych ${ }^{36}$.

Z uwagi na rozwiązanie Komisji Kodyfikacyjnej Prawa Cywilnego z dniem 17 grudnia 2015 r. prace nad projektem zostały przerwane ${ }^{37}$.

nego, ustawy o wspieraniu rodziny i systemie pieczy zastępczej oraz niektórych innych ustaw, https://legislacja.rcl.gov.pl/docs//1/208000/208001/208002/dokument127276. pdf [dostęp 31 lipca 2019 r.], s. 1; projekt założeń projektu ustawy o zmianie ustawy - Kodeks cywilny, ustawy - Kodeks rodzinny i opiekuńczy, ustawy - Kodeks postępowania cywilnego, ustawy o wspieraniu rodziny i systemie pieczy zastępczej oraz niektórych innych ustaw, https://legislacja.rcl.gov.pl/docs//1/208000/208001/208002/ dokument104528.pdf [dostęp 31 lipca 2019 r.], s. 9; zob. D. Mróz, Krytycznie wobec postulatu, op. cit., s. 18-20.

34 Projekt założeń, op. cit., s. 11. Zob. D. Mróz, Krytycznie wobec postulatu, op. cit., s. 18-20.

35 Projekt założeń, op. cit., s. 11.

36 Projekt założeń, op. cit., s. 15; zob. D. Mróz, Krytycznie wobec postulatu, op. cit., s. 20; M. Balwicka-Szczyrba, A. Sylwestrzak, Instytucja ubezwłasnowolnienia, op. cit., s. 166.

37 Komisja Kodyfikacyjna Prawa Cywilnego, https://arch-bip.ms.gov.pl/pl/dzialalnosc/ komisje-kodyfikacyjne/komisja-kodyfikacyjna-prawa-cywilnego/ [dostęp 31 lipca 


\section{Rozwiązania proponowane w petycji}

Można zauważyć, że postulaty przedstawione w petycji są częściowo zbliżone do założeń przyjętych przez Komisję Kodyfikacyjną Prawa Cywilnego. W odróżnieniu jednak od Komisji, autorzy petycji nie proponują wprowadzenia opieki z kompetencją do współdecydowania oraz opieki połączonej z umocowaniem do wyłącznego zastępstwa, lecz wyłącznie opiekę asystencyjną oraz opiekę z reprezentacją „równoległą”. Wydaje się jednak, że rozwiązania proponowane w petycji mogą niedostatecznie chronić interesy osoby objętej opieką, jej rodziny, bliskich oraz innych uczestników obrotu prawnego, ponieważ żaden z zaproponowanych środków nie zapobiega np. zaciąganiu niekorzystnych zobowiązań lub dokonywaniu takich rozporządzeń. W razie sporu w każdym wypadku osoba, która ma w tym interes prawny, musiałaby - powołując się na art. 82 k.c. - na podstawie różnych środków dowodowych wykazać, że oświadczenie zostało złożone w stanie wyłączającym świadome albo swobodne powzięcie decyzji i wyrażenie woli, a $\mathrm{z}$ tego powodu oświadczenie to, jak również konstytuowana przez nie czynność prawna - są nieważne z mocy prawa. Natomiast jeśli opiekunowi przysługiwałoby uprawnienie do wyłącznej reprezentacji albo uprawnienie do współdecydowania, o nieważności czynności prawnej przesądzałaby już sama treść wyroku sądu o ustanowieniu opiekuna (a w wypadku opieki z uprawnieniem do współdecydowania także brak zgody opiekuna). Trudności tych nie eliminowałoby także wprowadzenie proponowanych w petycji regulacji umożliwiających unieważnienie czynności prawnej przez sąd wówczas, gdy: a) czynność prawna pociąga za sobą rażące pokrzywdzenie danej osoby lub jej najbliższych; b) osoba ta w chwili dokonywania czynności nie była zdolna do pokierowania swoim postępowaniem oraz rozpoznania jego znaczenia. Dlatego wydaje się, że w niektórych przypadkach - oprócz zaproponowanych w petycji środków opiekuńczych - ustawodawstwo powinno przewidywać możliwość zastosowania środków substytucyjnych (polegających na tym, że osoba sprawująca pieczę podejmuje czynności zamiast podopiecznego lub wraz z nim, współdecydując o jego sprawach).

\section{Wnioski}

Reforma instytucji ubezwłasnowolnienia jest pożądana ze względu na potrzebę wypełnienia zobowiązań międzynarodowych. Prace nad zmianami były podejmowane przez Komisję Kodyfikacyjną Prawa Cywilnego, lecz wraz z jej rozwiązaniem zostały przerwane. Zastąpienie ubezwłasnowolnienia opieką asystencyjną oraz opieką z reprezentacją „równoległą” (tak jak zaproponowano w petycji) może być rozwiązaniem niedostatecznie chroniącym interesy osoby objętej opie-

2019 r.]; D. Mróz, Krytycznie wobec postulatu, op. cit., s. 20; M. Balwicka-Szczyrba, A. Sylwestrzak, Instytucja ubezwłasnowolnienia, op. cit., s. 166. 
ką, jej rodziny, bliskich oraz innych uczestników obrotu prawnego. Wydaje się, że w niektórych wypadkach - oprócz tych środków - ustawodawstwo powinno przewidywać możliwość zastosowania środków substytucyjnych (polegających na tym, że osoba sprawująca pieczę podejmuje czynności zamiast podopiecznego lub wraz z nim, współdecydując o jego sprawach). W razie podjęcia prac nad nowelizacją niewątpliwie warto byłoby rozważyć wprowadzenie obligatoryjnej okresowej weryfikacji istnienia podstaw do stosowania środka opiekuńczego. Jednak zakres tego obowiązku i sposób jego realizacji należałoby określić dopiero po wyborze środków opiekuńczych i ustaleniu materialnoprawnych przesłanek ich stosowania. Z uwagi na to, że ubezwłasnowolnienie wywołuje skutki prawne nie tylko w zakresie prawa cywilnego, ale również w obszarze innych gałęzi prawa, realizacja postulatów przedstawionych w petycji wymagałaby zmian systemowych.

\section{Bibliografia}

Balwicka-Szczyrba M., Sylwestrzak A., Instytucja ubezwłasnowolnienia w perspektywie unormowań Konstytucji RP oraz Konwencji ONZ o prawach osób niepełnosprawnych, „Gdańskie Studia Prawnicze” 2018, t. XL.

Domański M., Ubezwłasnowolnienie w prawie polskim a wybrane standardy międzynarodowej ochrony praw człowieka, „Prawo w Działaniu. Sprawy Cywilne” 2014, nr 17.

Goździewicz G., Zieliński T., Art. 22 [w:] Kodeks pracy. Komentarz, red. L. Florek, 2017, LEX.

Kociucki L., Niektóre problemy nowelizacji polskiego prawa o ubezwłasnowolnieniu, „Studia Prawnicze" 2013, nr 2.

Księżak P., Art. 13, art. 14, art. 19 [w:] Kodeks cywilny. Komentarz, red. K. Osajda, 2019, Legalis.

Mróz D., Krytycznie wobec postulatu zniesienia ubezwłasnowolnienia w kontekście harmonizacji polskiego prawa cywilnego z Konwencja ONZ o prawach osób niepełnosprawnych, „Acta Iuris Stetinensis” 2018 nr 4, https://doi.org/10.18276/ais.2018.24-01.

Rybski R., Konstytucyjny status osób ubezwłasnowolnionych, Warszawa 2015.

Szeroczyńska M., Ubezwłasnowolnienie i alternatywne formy pomocy w realizowaniu zdolności do czynności prawnych osób z niepetnosprawnościa intelektualną, $w$ regulacjach międzynarodowych oraz w prawie obcym, na przykładzie Estonii, Niemiec, Szwecji, Wielkiej Brytanii i Kanady (stanu Manitoba) [w:] Jeśli nie ubezwłasnowolnienie, to co? Prawne formy wsparcia osób z niepetnosprawnościq intelektualną, red. K. Kędziora, Warszawa 2012.

Zima-Parjaszewska M., Artykuł 12 Konwencji ONZ o prawach osób z niepetnosprawnościami a ubezwłasnowolnienie w Polsce, „Studia Prawnicze” 2013, nr 2. 
Jolanta Waszczuk-Napiórkowska

\title{
Ocena petycji w sprawie zmiany ustawy o bezpieczeństwie żywności i żywienia ${ }^{1}$
}

\author{
Evaluation of a petition regarding the amendment of the Act on Food \\ Safety and Nutrition
}

\begin{abstract}
The authors of the petition postulate an amendment to the act by introducing a ban on the production and sale in Poland of food products containing carcinogenic palm oil. In the opinion of the author, the postulate to introduce a total ban on the production and sale of food products containing palm oil in the Republic of Poland seems too far-reaching. However, it is worth to consider introducing rules that would contribute to limiting the content of this oil in food products.

Keywords: petition, health, food

Autorzy petycji postulują nowelizację ustawy poprzez wprowadzenie zakazu produkcji i sprzedaży na terytorium Polski produktów spożywczych zawierających rakotwórczy olej palmowy. Zdaniem autorki opinii postulat wprowadzenia całkowitego zakazu produkcji i sprzedaży produktów spożywczych zawierających olej palmowy na terenie Rzeczypospolitej Polskiej wydaje się zbyt daleko idący. Warto rozważyć jednak wprowadzenie przepisów, które przyczyniłyby się do ograniczenia zawartości tego oleju w produktach spożywczych.
\end{abstract}

Słowa kluczowe: petycja, zdrowie, żywność

Doktor nauk prawnych, adiunkt •

Uniwersytet Kardynała Stefana Wyszyńskiego w Warszawie, Wydział Prawa i Administracji, Katedra Prawa Cywilnego i Prawa Prywatnego Międzynarodowego, WARSZAWA, POLSKA . j.waszczuk@uksw.edu.pl • https://orcid.org/0000-0002-5407-4836

\section{Treść i cel petycji}

Przedmiotem petycji jest żądanie znowelizowania ustawy z 25 sierpnia $2006 \mathrm{r}$. o bezpieczeństwie żywności i żywienia (t.j. Dz.U. 2019, poz. 1252) przez wprowadzenie zakazu produkcji i sprzedaży na terytorium Polski produktów spożywczych zawierających rakotwórczy olej palmowy.

W uzasadnieniu petycji podniesiono, że olej palmowy poddawany jest rafinacji oraz utwardzaniu, a podczas podgrzewania oleju do temperatury ponad $200^{\circ} \mathrm{C}$ powstają szkodliwe dla zdrowia estry kwasów tłuszczowych glicydolu

1 Opinia prawna na temat petycji (BKSP-145-586/19) w sprawie zmiany ustawy o bezpieczeństwie żywności i żywienia sporządzona 18 grudnia 2019 r. na zlecenie przewodniczącego Komisji do Spraw Petycji; BAS-WAP 1904/19. 
(GE) oraz estry kwasów tłuszczowych 3-monochloropropanediolu (3-MCPD) oraz 2-monochloropropanediolu (2-MCPD).

Autor petycji przywołuje zalecenie Komisji Europejskiej (2014/661/UE) o monitorowaniu występowania w żywności 2- i 3-monochloropropano-1,2-diolu (2- i 3-MCPD), estrów kwasów tłuszczowych 2- i 3-MCPD oraz estrów glicydowych kwasów tłuszczowych jako składnikach potencjalnie rakotwórczych dla ludzi i wymagających monitorowania przez państwa członkowskie oraz oświadczenie Europejskiego Urzędu ds. Bezpieczeństwa Żywności (European Food Safety Authority, EFSA) o zanieczyszczeniu żywności zawierającej olej roślinny i kładzie nacisk na rakotwórcze GE, 3-MCPD oraz 2-MCPD w oleju palmowym.

\section{Czy petycja mieści się w zakresie zadań i kompetencji adresata petycji (art. 2 ust. 3 ustawy o petycjach)?}

Petycja dotyczy zmiany ustawy przez Sejm. Zgodnie z art. 95 ust. 1 Konstytucji RP władzę ustawodawczą w Rzeczypospolitej Polskiej sprawują Sejm i Senat. Natomiast stosownie do art. 118 ust. 1 Konstytucji inicjatywa ustawodawcza przysługuje m.in. posłom. Artykuł 32 ust. 2 regulaminu Sejmu, w związku $\mathrm{z}$ art. 112 Konstytucji, precyzuje, że poselskie projekty ustaw mogą być wnoszone przez komisje sejmowe lub grupę co najmniej 15 posłów podpisujących projekt.

Uwzględniając powyższe, należy uznać, że petycja mieści się w zakresie zadań i kompetencji Sejmu.

\section{Wymogi formalne ustawy o petycjach}

Petycja spełnia wymogi formalne określone w art. 4 ust. 1 i 2 ustawy o petycjach (t.j. Dz.U. 2018, poz. 870).

\section{Kwestie, które ekspert uznaje za istotne w związku z petycją}

Zgodnie z zaleceniem Komisji (2014/661/UE) z 10 września 2014 r. w sprawie monitorowania występowania w żywności 2- i 3-monochloropropano-1,2-diolu (2- i 3-MCPD), estrów kwasów tłuszczowych 2- i 3-MCPD oraz estrów glicydowych kwasów tłuszczowych (Dz.Urz. UE L 271/95): Państwa członkowskie powinny, przy aktywnym udziale podmiotów prowadzacych przedsiębiorstwa spożywcze i podmiotów działających na rynku pasz, prowadzić monitorowanie występowania 2 i 3-MCPD, estrów kwasów tłuszczowych 2 i 3-MCPD oraz estrów glicydowych kwasów tłuszczowych (pkt 1). Ponadto: Państwa członkowskie powinny zapewnić regularne dostarczanie wyników analiz (co sześć miesięcy) do EFSA w ustalonym 
przez EFSA formacie przekazywania danych zgodnie z wytycznymi EFSA w sprawie standardu opisu próbek (SSD) dla żywności i paszy oraz dodatkowymi szczególnymi wymaganiami EFSA dotyczącymi sprawozdawczości (pkt 5).

Europejski Urząd ds. Bezpieczeństwa Żywności w 2016. wydał raport o wpływie na zdrowie niektórych składników żywności pochodzenia tłuszczowego (EFSA CONTAM Panel, 2016. Risks for human health related to the presence of 3- and 2-monochloropropanediol (MCPD), and their fatty acid esters, and glycidyl fatty acid esters in food. EFSA Journal 2016;14(5):4426²), w którym stwierdzono, że olej palmowy (i inne tłuszcze palmowe) zawiera najwyższe wśród tłuszczów roślinnych stężenia estrów MCPD (monochloropropanodioli) oraz estrów glicydowych kwasów tłuszczowych. Powstają one w procesie produkcji tłuszczu, zwłaszcza rafinacji oleju prowadzonej w temperaturze powyżej $200{ }^{\circ} \mathrm{C}$. Należy podkreślić, że w stanowisku tym EFSA nie zakazuje stosowania oleju palmowego. Natomiast na podstawie opinii EFSA Komisja Europejska podjęła działania w celu ustanowienia najwyższych dopuszczalnych poziomów dla tych zanieczyszczeń w żywności. W rozporządzeniu Komisji (UE) 2018/290 z 26 lutego 2018 r. zmieniającym rozporządzenie (WE) nr 1881/2006 w odniesieniu do najwyższych dopuszczalnych poziomów estrów glicydowych kwasów tłuszczowych w olejach i tłuszczach roślinnych, preparatach do początkowego żywienia niemowląt, preparatach do dalszego żywienia niemowląt i żywności specjalnego przeznaczenia medycznego dla niemowląt i małych dzieci (Dz.Urz. UE L 55/27) wprowadzono wymagania dla estrów glicydolu. Najniższe wartości ustanowiono w preparatach do żywienia niemowląt i małych dzieci w celu ochrony tej szczególnie wrażliwej grupy konsumentów oraz w olejach i tłuszczach roślinnych. Natomiast kwestię estrów 3-monochloropropano-1,2-diolu (3-MCPD) i kwasów tłuszczowych, estrów glicydowych kwasów tłuszczowych, nadchloranu i akryloamidu unormowano w świeżo wydanym rozporządzeniu wykonawczym Komisji (UE) 2019/2093 z 29 listopada 2019 r. zmieniającym rozporządzenie (WE) nr 333/2007 w odniesieniu do analizy estrów 3-monochloropropano-1,2-diolu (3-MCPD) i kwasów tłuszczowych, estrów glicydowych kwasów tłuszczowych, nadchloranu i akryloamidu (Dz.Urz. UE L 317/96).

Powyższe przepisy prawne przyczynią się niewątpliwie do ograniczania stosowania oleju palmowego przez przetwórców. Ponadto część firm decyduje się na wyeliminowanie tego składnika w produktach ze względu na negatywne opinie medialne dotyczące jego właściwości żywieniowych oraz wpływu upraw na środowisko ${ }^{3}$.

2 Https://efsa.onlinelibrary.wiley.com/doi/epdf/10.2903/j.efsa.2016.4426 [dostęp 17 grudnia 2019 r.].

3 Zob. pismo Ministra Rolnictwa i Rozwoju Wsi w sprawie interpelacji nr 28814 z 7 lutego 2019 r. (znak: PJ.jn.058.2.2019), http://orka2.sejm.gov.pl/INT8.nsf/klucz/ ATTB9BJK6/\%24FILE/i28814-o1.pdf [dostęp 17 grudnia 2019 r.]. 
W świetle obowiązujących przepisów należy podkreślić, że każdy konsument dokonujący wyboru produktu spożywczego może zapoznać się z informacjami o tym produkcie, w tym m.in. o użytych do jego wytworzenia składnikach. Wymóg podawania tych informacji wynika $\mathrm{z}$ rozporządzenia Parlamentu Europejskiego i Rady (UE) nr 1169/2011 z 25 października 2011 r. w sprawie przekazywania konsumentom informacji na temat żywności, zmiany rozporządzeń Parlamentu Europejskiego i Rady (WE) nr 1924/2006 i (WE) nr 1925/2006 oraz uchylenia dyrektywy Komisji 87/250/EWG, dyrektywy Rady 90/496/EWG, dyrektywy Komisji 1999/10/WE, dyrektywy 2000/13/WE Parlamentu Europejskiego i Rady, dyrektyw Komisji 2002/67/WE i 2008/5/WE oraz rozporządzenia Komisji (WE) nr 608/2004 w sprawie przekazywania konsumentom informacji na temat żywności (Dz.Urz. UE L 304 z 22 listopada 2011 r., s. 18). Zgodnie z pkt 8 w załączniku VII do omawianego rozporządzenia użyty w produkcji olej lub tłuszcz roślinny musi być w wykazie składników środka spożywczego podany z określeniem rośliny, z której pochodzi. Wymóg ten wprowadzony $\mathrm{w}$ trakcie prac nad projektem tego rozporządzenia w Parlamencie Europejskim był uzasadniony właśnie koniecznością dokładnej identyfikacji oleju palmowego w związku z coraz powszechniejszym stosowaniem go w produkcji środków spożywczych oraz jego ekstensywnym pozyskiwaniem mającym negatywny wpływ na środowisko naturalne. Wprowadzenie obowiązku identyfikacji w oznakowaniu środka spożywczego źródła pochodzenia oleju/ tłuszczu zapewniło konsumentowi możliwość wyboru pomiędzy produktami ten olej zawierającymi a produktami, w wytworzeniu których nie użyto tego składnika.

Warto podkreślić, że olej palmowy stosowany jest często w produkcie w połączeniu z innymi tłuszczami (np. z olejem rzepakowym, słonecznikowym, sojowym); nie jest on głównym składnikiem tłuszczowym, a jego dodatek ma jedynie znaczenie technologiczne/funkcjonalne (np. zapewnienie odpowiedniej konsystencji). Z tego też względu czytając etykietę produktu, należy zwrócić uwagę nie tylko na obecność oleju palmowego w składzie produktu, ale też na kolejność, w jakiej wymieniane są składniki (wymieniane są w kolejności malejącego udziału w masie produktu) oraz ewentualne ekologiczne pochodzenie oleju z upraw certyfikowanych ${ }^{4}$.

Obowiązujące przepisy Unii Europejskiej nie zakazują produkcji i sprzedaży produktów spożywczych zawierających olej palmowy, lecz określają wymogi jego wykorzystania w tych produktach. Postulat wprowadzenia całkowitego zakazu produkcji i sprzedaży produktów spożywczych zawierających olej palmowy na terenie Rzeczypospolitej Polskiej wydaje się zbyt daleko idący ${ }^{5}$. Przede

4 Ibidem.

5 Z informacji zamieszczonej przez Centrum Prawa Żywnościowego wynika, że podjęte działania legislacyjne na Ukrainie w celu wprowadzenia całkowitego zakazu 
wszystkim warto wskazać, że surowy olej palmowy, to stały olej roślinny, który jest wytwarzany z miąższu lub nasion olejowca gwinejskiego i zawiera całkiem sporo wartości odżywczych - antyoksydanty, witaminę E i beta-karoten. Naturalny, nieuwodorniony olej palmowy używany w normalniej diecie nie ma negatywnego wpływu na zdrowie ${ }^{6}$. Negatywny wpływ na zdrowie ma wyłącznie olej palmowy, który był poddany procesowi rafinacji w temperaturach powyżej 200 stopni. Wprowadzenie całkowitego zakazu produkcji i sprzedaży produktów spożywczych zawierających olej palmowy mogłoby budzić zastrzeżenia także w tym kontekście, że w krajowym obrocie jest dopuszczony obrót innymi produktami, które niewątpliwie są szkodliwe dla zdrowia (np. alkohol, papierosy). Ponadto postulowane unormowanie mogłoby niekorzystnie wpłynąć na stosunki handlowe między Polską a innymi państwami.

Niezależnie od powyższych argumentów można wskazać, że ustawodawca może rozważyć wprowadzenie unormowania, które ograniczy stosowanie oleju palmowego w artykułach spożywczych. Warto w tym miejscu nadmienić, że ciekawe rozwiązanie przyjęto we Francji, gdzie wprowadzono podatek od oleju palmowego w celu zachęcenia przemysłu do zastąpienia oleju palmowego innymi tłuszczami, które są mniej szkodliwe dla zdrowia i środowiska ${ }^{7}$.

\section{Wnioski}

Podsumowując, należy stwierdzić, że postulat wprowadzenia całkowitego zakazu produkcji i sprzedaży produktów spożywczych zawierających olej palmowy na terenie Rzeczypospolitej Polskiej wydaje się zbyt daleko idący. Mając jednak na względzie to, że produkty spożywcze często zawierają szkodliwy dla zdrowia rafinowany olej palmowy, warto rozważyć wprowadzenie przepisów, które przyczyniłyby się do ograniczenia zawartości tego oleju w produktach spożywczych.

stosowania oleju palmowego przy produkcji żywności wywołują dużo kontrowersji. Pojawiają się głosy, że nowa ustawa przyczyni się do ograniczenia handlu między państwami UE a Ukrainą, co z kolei negatywnie wpłynie na gospodarkę ukraińską, https://www.foodfakty.pl/zakaz-oleju-palmowego-na-ukrainie [dostęp 17 grudnia 2019 r.].

6 A. Feliga, Olej palmowy - 4 największe mity zdrowotne. Olej palmowy jednak nie taki $z \nmid y$ ?, https://polki.pl/dieta-i-fitness/zdrowe-odzywianie,olej-palmowy-4-najwieksze-mity,10409511,artykul.html [dostęp 17 grudnia 2019 r.].

7 B. Bonardi, Il Senato francese ripropone la tassa sullolio di palma: conosciuta come la tassa Nutella. Lolio tropicale fa male alla salute e all'ambiente, https://ilfattoalimentare. it/tassa-sull-olio-di-palma-francia.html [dostęp 17 grudnia 2019 r.]. 


\section{Bibliografia}

Bonardi B., Il Senato francese ripropone la tassa sullolio di palma: conosciuta come la tassa Nutella. Lolio tropicale fa male alla salute e allambiente, https://ilfattoalimentare.it/ tassa-sull-olio-di-palma-francia.html.

Feliga A., Olej palmowy - 4 największe mity zdrowotne. Olej palmowy jednak nie taki $z \nmid y$ ?, https://polki.pl/dieta-i-fitness/zdrowe-odzywianie,olej-palmowy-4-najwieksze-mity,10409511,artykul.html. 


\title{
Ocena rządowego projektu ustawy o zmianie ustawy o Państwowej Inspekcji Sanitarnej ${ }^{1}$
}

\author{
Evaluation of the governmental Bill on Amending the Act \\ on the State Sanitary Inspection
}

According to the author, the exclusion of the possibility of a head of commune to request action by the sanitary inspection, postulated in the bill, may raise doubts from the point of view of sanitary safety on the territory of a commune. The bill assumes a transfer to the Act of a normative content of regulations of the Ministry of the Interior and Administration and the Military Sanitary Inspection regarding the State Sanitary Inspection. In the author's opinion, including provisions containing such normative content does not seem appropriate. He presents comments regarding the drafting of provisions granting inspection bodies the power to issue administrative decisions.

Keywords: bill, State Sanitary Inspection, Sejm

Zdaniem autorki postulowane w projekcie wyłączenie możliwości wnioskowania przez wójta gminy o podjęcie działań przez inspekcję sanitarną może budzić wątpliwości z punktu widzenia bezpieczeństwa sanitarnego na terenie gminy. Projekt zakłada bowiem przeniesienie do ustawy treści normatywnej rozporządzeń Ministerstwa Spraw Wewnętrznych i Administracji oraz Wojskowej Inspekcji Sanitarnej dotyczących Państwowej Inspekcji Sanitarnej. W ocenie autorki umieszczenie przepisów zawierających taką treść normatywną nie wydaje się właściwe. Przedstawia ona uwagi do redakcji przepisów przyznających organom inspekcji kompetencje do wydawania decyzji administracyjnych.

Słowa kluczowe: projekt ustawy, Państwowa Inspekcja Sanitarna, Sejm

Doktor nauk prawnych, ekspert ds. legislacji Biura Analiz Sejmowych •

Kancelaria Sejmu, Biuro Analiz Sejmowych, Wydział Analiz Prawnych, Zespół Prawa

Publicznego, WARSZAWA, POLSKA •

beata.binkowska-artowicz@sejm.gov.pl•https://orcid.org/0000-0002-9172-5458

\section{Przedmiot opinii}

Przedmiotem opinii jest analiza prawna rządowego projektu ustawy o zmianie ustawy o Państwowej Inspekcji Sanitarnej (druk sejmowy nr 46); dalej: projekt lub ustawa zmieniająca.

Projekt obejmuje:

1 Opinia prawna na temat rządowego projektu ustawy o zmianie ustawy o Państwowej Inspekcji Sanitarnej (druk sejmowy nr 46) sporządzona 18 grudnia 2019 r. na zlecenie przewodniczącego Komisji Zdrowia; BAS-WAP 191/19. 
- zmianę ustawy z 14 marca 1985 r. o Państwowej Inspekcji Sanitarnej (art. 1 projektu), dotyczącą między innymi:

- wprowadzenia kompetencji dla Głównego Inspektora Sanitarnego oraz państwowego wojewódzkiego inspektora sanitarnego do powoływania odpowiednio państwowego wojewódzkiego inspektora sanitarnego oraz państwowego powiatowego inspektora sanitarnego,

- wprowadzenia wiążących poleceń i wytycznych wydawanych przez Głównego Inspektora Sanitarnego organom Państwowej Inspekcji Sanitarnej,

- zmiany szczebla administracji zespolonej powiatowego inspektora sanitarnego (który staje się organem rządowej administracji zespolonej w województwie),

- wprowadzenia obowiązku składania przez inspektorów sanitarnych oświadczeń o stanie majątkowym do organu powołującego (w miejsce dotychczasowego organu administracji rządowej w powiecie lub województwie),

- wprowadzenia obowiązku składania przez inspektorów sanitarnych Ministerstwa Spraw Wewnętrznych i Administracji oświadczeń majątkowych oraz uzyskania zgody Głównego Inspektora Sanitarnego Ministerstwa Spraw Wewnętrznych i Administracji na wykonywanie dodatkowych zajęć zarobkowych,

- przeniesienia treści normatywnej zawartej w rozporządzeniach dotyczących Państwowej Inspekcji Sanitarnej Ministerstwa Spraw Wewnętrznych i Administracji oraz Wojskowej Inspekcji Sanitarnej.

- przepis przejściowy dotyczący państwowych inspektorów sanitarnych powołanych przed wejściem w życie projektu (art. 2 projektu),

- przepis przejściowy dotyczący ważności statutów i regulaminów organizacyjnych stacji sanitarno-epidemiologicznych (art. 3 projektu),

- przepis przejściowy dotyczący sposobu zakończenia postępowań kontrolnych i administracyjnych będących w toku (art. 4 projektu).

Ustawa zmieniająca wchodzi w życie z dniem 1 marca 2020 r. (art. 5 projektu).

\section{Uwagi do projektu ustawy}

1. Zastrzeżenia budzi propozycja uchylenia art. 12a ust. 3b ustawy zmienianej. Zgodnie z obecnie obowiązującą treścią powyższego przepisu: Wójt (burmistrz, prezydent miasta) w przypadkach bezpośredniego zagrożenia bezpieczeństwa sanitarnego na terenie gminy, a w szczególności zagrożenia życia lub zdrowia ludzi, może wystapić do właściwego państwowego powiatowego inspektora sanitarnego

2 T.j. Dz.U. 2019, poz. 59, dalej: ustawa o PIS lub ustawa zmieniana. 
z wnioskiem o podjęcie działań zmierzających do usunięcia tego zagrożenia. Uchylenie powyższego przepisu oznacza pozbawienie gminnej administracji samorządowej uprawnienia do zainicjowania działań inspekcji sanitarnej.

Z uzasadnienia do projektu (s. 8) wynika, że: [p]rzepisy te [art. 12a ust. 3a i 3 b ustawy zmienianej - dopisek B.B.-A.] wymagaja uchylenia ze względu na uprawnienia organów Państwowej Inspekcji Sanitarnej, które w razie stwierdzenia naruszenia wymagań higienicznych i zdrowotnych nakazuja, $w$ drodze decyzji administracyjnych, usunięcie w ustalonym terminie stwierdzonych uchybień. Zatem to organ Państwowej Inspekcji Sanitarnej ma uprawnienia do egzekwowania usunięcia zagrożenia i zapewnienia należytego stanu bezpieczeństwa sanitarnego. Należy w tym miejscu zaznaczyć, że uprawnienie wójta do złożenia wniosku o podjęcie działań przez organ Państwowej Inspekcji Sanitarnej nie pozostaje w sprzeczności z uprawnieniem tego organu do egzekwowania usunięcia zagrożenia, co więcej, realizacja przez wójta uprawnienia z art. 13a ust. 3b ustawy zmienianej może przyczyniać się do sprawnej realizacji uprawnienia inspekcji sanitarnej z art. 27 ust. 1 ustawy zmienianej, czyli wydania decyzji nakazującej usunięcie uchybień.

W związku z powyższym dostrzeżenia również wymaga, że do zadań własnych gminy należy m.in. utrzymanie czystości i porządku w gminie (art. 3 ust. 1 ustawy z 13 września 1996 r. o utrzymaniu czystości i porządku w gminach, t.j. Dz.U. 2019, poz. 2010). Oznacza to, że przy wykonywaniu kompetencji przyznanych ustawą o utrzymaniu czystości i porządku w gminach (np. podczas nadzorowania gospodarowania odpadami komunalnymi - art. 3 ust. 2 pkt 4 powyższej ustawy) organ gminy może uzyskać wiedzę o okolicznościach mających jednoznacznie negatywny wpływ na bezpieczeństwo sanitarne lokalnej wspólnoty. Konsekwentnie, uchylenie art. 12a ust. 3b ustawy zmienianej może prowadzić do obniżenia poziomu bezpieczeństwa sanitarnego na terenie konkretnej gminy. Ryzyko to wydaje się istotne również dlatego, że z uwagi na organizację administracji zespolonej (jaką jest inspekcja sanitarna) obszarem właściwości miejscowej jednego inspektora sanitarnego jest powiat, czyli jednostka samorządu terytorialnego obejmująca wiele (do kilkunastu) gmin.

2. Projekt zakłada przeniesienie do ustawy zmienianej treści normatywnej rozporządzenia Ministra Spraw Wewnętrznych i Administracji z 26 lutego 2019 r. w sprawie wykonywania zadań przez Państwową Inspekcję Sanitarną Ministerstwa Spraw Wewnętrznych i Administracji (Dz.U. poz. 411), (projektowane art. 22a-22l ustawy zmienianej) oraz rozporządzenia Ministra Obrony Narodowej z 14 czerwca 2002 r. w sprawie organizacji oraz warunków i trybu wykonywania zadań przez Wojskową Inspekcję Sanitarną (Dz.U. nr 97, poz. 872, ze zm.), (projektowane art. 22m-22w ustawy zmienianej).

Proponowana zmiana wydaje się jednak nieczytelna. Projektowane przepisy dotyczące materii odnoszącej się do dwóch inspekcji szczególnych zostały umieszczone w rozdziale 2 ustawy zmienianej - Organizacja Państwowej In- 
spekcji Sanitarnej. Umiejscowienie projektowanych przepisów w tym rozdziale może wskazywać, że inspekcje szczególne, czyli Państwowa Inspekcja Sanitarna Ministerstwa Spraw Wewnętrznych i Administracji oraz Wojskowa Inspekcja Sanitarna, stanowią jednostki organizacyjne Państwowej Inspekcji Sanitarnej podlegającej ministrowi właściwemu do spraw zdrowia (art. 7 ust. 1 ustawy zmienianej), podczas gdy z treści przepisów wynika expressis verbis, że pierwsza $\mathrm{z}$ wymienionych inspekcji szczególnych podlega ministrowi właściwemu do spraw wewnętrznych (projektowany art. 22a ust. 3), a Wojskowa Inspekcja Sanitarna podlega Ministrowi Obrony Narodowej (projektowany art. 22m ust. 3).

Ponadto w rozdziale 2 ustawy zmienianej obok organizacji inspekcji szczególnych umieszczone zostały przepisy dotyczące uprawnień tych inspekcji, podczas gdy materia uprawnień Państwowej Inspekcji Sanitarnej została uregulowana w rozdziale 3 ustawy zmienianej. Nie wydaje się właściwe połączenie dwóch różnych zakresów normatywnych (organizacji oraz uprawnień inspekcji) w jednej jednostce systematyki aktu prawnego (rozdziale 2 ustawy zmienianej).

3. W projektowanym art. 22i ustawy zmieniającej zawarto następujący przepis: Państwowy inspektor sanitarny Ministerstwa Spraw Wewnętrznych i Administracji lub upoważniony pracownik Państwowej Inspekcji Sanitarnej Ministerstwa Spraw Wewnętrznych i Administracji w zwiazku $z$ wykonywaniem zadań, ma prawo do: $[\ldots]$ nakazania, $w$ drodze decyzji, usunięcia $w$ określonym terminie stwierdzonych uchybień higienicznych i zdrowotnych (pkt 5); wydania niezbędnych ze względu na ochrone zdrowia i życia ludzkiego decyzji o unieruchomieniu obiektu, zakładu pracy, jego części (stanowiska pracy lub urządzenia), wyłączeniu z eksploatacji środka transportu, wycofaniu z obrotu środka spożywczego, przedmiotu użytku lub innego wyrobu mogącego mieć wplyw na zdrowie ludzi albo o podjęciu lub zaprzestaniu innych działań, jeżeli naruszenie wymagań higienicznych i zdrowotnych spowodowało bezpośrednie zagrożenie życia lub zdrowia na terenie obiektów jednostek i podmiotów określonych $w$ art. $22 a$ ust. 1 i 2, lub $w$ stosunku do osób, o których mowa $w$ art. $22 a$ ust. 2; decyzje $w$ tych sprawach podlegaja natychmiastowemu wykonaniu (pkt 6).

Analogiczna konstrukcja przepisu została zastosowana wart. 22t pkt 5 i 6 ustawy zmieniającej w odniesieniu do wojskowych inspektorów sanitarnych.

Powyższe rozwiązanie legislacyjne wydaje się wadliwe, ponieważ budzi wątpliwości co do treści normy prawnej w nim zawartej. Użycie przez projektodawcę w części wspólnej projektowanego przepisu art. 22i wyrażenia „ma prawo do" sugeruje przyznanie inspektorowi uprawnienia, czyli możliwości skorzystania $\mathrm{z}$ przysługującego prawa. Wyrażenie takie jest stosowane np. w przypadku enumeracji uprawnień kontrolnych, co nie budzi wątpliwości. Jednakże w treści pkt 5 i 6 omawianego artykułu projektodawca umieścił kompetencje do wydania decyzji administracyjnych. Wydanie decyzji administracyjnej stanowi natomiast władcze rozstrzygnięcie o obowiązku strony postępowania (adresata decyzji). Nie jest więc ono uprawnieniem organu, ale jego obowiązkiem w sytuacji, 
w której spełnione zostaną prawnomaterialne przesłanki do wydania decyzji (np. stwierdzenie uchybienia higienicznego).

W związku z powyższym należałoby rozważyć przeredagowanie omawianych przepisów np. na wzór art. 27 ustawy zmienianej, zgodnie z którym: $W$ razie stwierdzenia naruszenia wymagań higienicznych $i$ zdrowotnych, państwowy inspektor sanitarny nakazuje, $w$ drodze decyzji, usunięcie $w$ ustalonym terminie stwierdzonych uchybień (ust. 1). Jeżeli naruszenie wymagań, o których mowa w ust. 1, spowodowało bezpośrednie zagrożenie życia lub zdrowia ludzi, państwowy inspektor sanitarny nakazuje unieruchomienie zakładu pracy lub jego czesści (...) (ust. 2).

4. Projekt wprowadza obowiązek składania przez państwowych inspektorów sanitarnych MSWiA oświadczeń majątkowych, o których mowa w art. 10 ustawy z 21 sierpnia 1997 r. o ograniczeniu prowadzenia działalności gospodarczej przez osoby pełniące funkcje publiczne, a także obowiązek uzyskania przez państwowego inspektora sanitarnego MSWiA zgody Głównego Inspektora Sanitarnego MSWiA na wykonywanie dodatkowych zajęć zarobkowych (art. 22e ustawy zmienianej). Omawianą zmianę należy ocenić jako korzystną w kontekście regulacji antykorupcyjnych, zwłaszcza że projektowane przepisy zawierają rozwiązania analogiczne do obowiązujących art. 13 ust. 3-5 i art. 13a ustawy zmienianej, dotyczących inspektorów sanitarnych. Warto zauważyć, że w odniesieniu do organów Wojskowej Inspekcji Sanitarnej wprowadzenie analogicznych regulacji byłoby zbędne, ponieważ osoby pełniące funkcje tych organów zobligowane są do spełnienia wymagań przewidzianych dla żołnierzy zawodowych - w tym również do przestrzegania zakazu podejmowania pracy zarobkowej i prowadzenia działalności gospodarczej (art. 56 ustawy z 11 września 2003 r. o służbie wojskowej żołnierzy zawodowych, t.j. Dz.U. 2019, poz. 330) oraz do przestrzegania obowiązku składania oświadczeń majątkowych do Ministerstwa Obrony Narodowej (art. 58 powołanej wyżej ustawy).

5. Wprowadzenie wymogów odnoszących się do stanowisk Głównego Inspektora Sanitarnego Ministerstwa Spraw Wewnętrznych i Administracji (art. 22d ust. 1 ustawy zmienianej) oraz Głównego Inspektora Sanitarnego Wojska Polskiego (art. 20o ust. 2 ustawy zmienianej) należy ocenić pozytywnie. Analogicznie również pozytywnie należy ocenić wprowadzenie wymogów w odniesieniu do stanowisk państwowego inspektora sanitarnego MSWiA (art. 22d ust. 3 ustawy zmienianej) i komendanta oraz wojskowego inspektora sanitarnego wojskowego ośrodka medycyny prewencyjnej (art. 22o ust. 3 ustawy zmienianej). Wymogów takich nie zawierało żadne $\mathrm{z}$ rozporządzeń wydanych na podstawie obecnie obowiązujących art. 20 i 20a ustawy zmienianej. Określenie kwalifikacji do wykonywania zadań szczególnych inspekcji sanitarnych poprzez odwołanie do obowiązujących przepisów ustawy zmienianej (art. 13 tej ustawy) nie budzi wątpliwości.

6. Objęcie Służby Kontrwywiadu Wojskowego i Służby Wywiadu Wojskowego właściwością rzeczową Wojskowej Inspekcji Sanitarnej należy ocenić pozy- 
tywnie (projektowany art. 22m ustawy zmienianej). Dotychczas służby te nie były objęte właściwością szczególnych inspekcji sanitarnych (nie zostały wymienione $\mathrm{w}$ żadnym z rozporządzeń wydanych na podstawie obowiązujących art. 20 i 20a ustawy zmienianej), jednak z uwagi na specyfikę i zakres zadań tych służb zaproponowana regulacja wydaje się zasadna.

7. $\mathrm{W}$ art. $8 \mathrm{a}$ ust. 3 ustawy zmienianej projektodawca zwiększa kompetencje kierownicze Głównego Inspektora Sanitarnego, wprowadzając możliwość wydawania inspektorom sanitarnym poleceń podjęcia określonych czynności zapobiegawczych lub kontrolnych oraz żądania od nich informacji w tym zakresie, jak również zaleceń i wytycznych określających sposób postępowania w trakcie realizacji zadań. Zmianę tę należy ocenić pozytywnie, ponieważ umożliwia wykonywanie nadzoru przez centralny organ administracji rządowej w zakresie zdrowia publicznego.

8. Projektodawca przewidział, że ustawa zmieniająca wejdzie w życie $\mathrm{z}$ dniem 1 marca 2020 r. Z uwagi na niemożność określenia czasu trwania procedury legislacyjnej dotyczącej omawianego aktu prawnego brak możliwości oceny, czy zaproponowana vacatio legis jest wystarczająca.

\section{Podsumowanie}

Rządowy projekt ustawy o zmianie ustawy o Państwowej Inspekcji Sanitarnej może być przedmiotem dalszych prac legislacyjnych.

Wyłączenie możliwości wnioskowania przez wójta gminy o podjęcie działań przez inspekcję sanitarną może budzić wątpliwości z punktu widzenia bezpieczeństwa sanitarnego na terenie gminy.

Projekt zakłada przeniesienie do ustawy treści normatywnej rozporządzeń dotyczących organizacji oraz uprawnień Państwowej Inspekcji Sanitarnej Ministerstwa Spraw Wewnętrznych i Administracji oraz Wojskowej Inspekcji Sanitarnej. Umieszczenie przepisów zawierających powyższą treść normatywną w rozdziale „Organizacja Państwowej Inspekcji Sanitarnej” nie wydaje się właściwe.

Redakcja przepisów przyznających organom inspekcji szczególne kompetencje do wydawania decyzji administracyjnych budzi wątpliwości co do treści norm prawnych zawartych w tych przepisach. 
Magdalena Szczepańska

\title{
Ocena poselskiego projektu nowelizacji ustawy o emeryturach i rentach z Funduszu Ubezpieczeń Społecznych ${ }^{1}$
}

\author{
Assessment of the Deputies' Bill on Amending the Act on Pensions \\ from the Social Insurance Fund
}

\begin{abstract}
The proposed amendment contains regulations specifying the burden of proof in proceedings conducted by the pension body in relation to persons who acquired a benefit under the Act on Retirement Provision of Miners and Their Families. In the author's opinion, the acceptance of the proposed solution only in relation to the group of insured persons indicated in the bill raises doubts in the light of the constitutional principle of equality due to the fact that a similar situation regarding the calculation of pensions applies to other insured persons who acquired benefits under the Act on Retirement Provision of Employees and Their Families.
\end{abstract}

Keywords: pensions, miners, bill, social insurance

Projektowana nowelizacja zawiera regulacje określające ciężar dowodu w postępowaniach prowadzonych przez organ rentowy w stosunku do osób, które nabyły świadczenie na podstawie ustawy o zaopatrzeniu emerytalnymi górników i ich rodzin. W ocenie autorki przyjęcie zaproponowanego rozwiązania jedynie w stosunku do wskazanej w projekcie grupy ubezpieczonych budzi wątpliwości w świetle konstytucyjnej zasady równości ze względu na fakt, że w analogicznej sytuacji w zakresie przeliczania emerytury znajdują się inni ubezpieczeni, którzy nabyli świadczenia na podstawie ustawy o zaopatrzeniu emerytalnym pracowników i ich rodzin.

Słowa kluczowe: emerytury i renty, górnicy, projekt ustawy, ubezpieczenie społeczne

Doktor hab. nauk prawnych, adiunkt -

Uniwersytet Warszawski, Wydział Prawa i Administracji, kierownik Katedry Prawa

Ubezpieczeń, WARSZAWA, POLSKA •

magdalena.szczepanska@sejm.gov.pl • https://orcid.org/0000-0003-1040-5792

\section{Przedmiot projektu}

Projekt zakłada wprowadzenie regulacji prawnej, której podstawowym celem jest modyfikacja przepisów określających ciężar dowodu w postępowaniach prowadzonych przez organ rentowy w stosunku do osób, które nabyły świadczenie na podstawie ustawy z 1 lutego 1983 r. o zaopatrzeniu emerytalnymi górników i ich rodzin (Dz.U. 1995, poz. 154, ze zm.; dalej: ustawa o zaopatrzeniu emerytalnym

1 Ocena prawna poselskiego projektu ustawy o zmianie ustawy o emeryturach i rentach z Funduszu Ubezpieczeń Społecznych (druk sejmowy nr 3756) sporządzona 20 sierpnia 2019 r. na zlecenie zastępcy Szefa Kancelarii Sejmu; BAS-WAP 1670/19. 
górników). W projekcie ustawy przewidziano nową regulację określającą, że w stosunku do osób składających wniosek o ponowne obliczenie wysokości renty i emerytury, którym przysługiwało świadczenie emerytalne na podstawie ustawy o zaopatrzeniu emerytalnym górników i których świadczenia zostały ustalone przed dniem 31 grudnia 1998 r., organ rentowy przeprowadza postępowanie na podstawie dowodów znanych organowi z urzędu. Zawarto również propozycję regulacji, że w tym przypadku nie stosuje się przepisu art. 116 ust. 5. W projekcie określono również konsekwencje braku możliwości jednoznacznego ustalenia wysokości emerytury. Zaproponowano regulację, przewidującą, że jeżeli po przeprowadzeniu postępowania, o którym mowa w ust. 1, ujawnione dowody nie pozwalają na jednoznaczne ustalenie wskaźnika wysokości podstawy emerytury, przyjmuje się średnią wartość wynagrodzeń osoby składającej wniosek z roku wskazanego przez wnioskodawcę, uwzględniając przy tym składniki wynagrodzenia, od których nie były naliczane składki na ubezpieczenia rentowe i emerytalne.

Projektodawcy wskazali, że uzasadnieniem dla wprowadzenia projektowanych zmian jest zróżnicowanie pozycji ubezpieczonych, którzy nabyli prawo do świadczeń emerytalnych i rentowych na podstawie ustawy o zaopatrzeniu emerytalnym górników. Przepisy te zostały uchylone z dniem 31 grudnia 1998 r. przez art. 195 ust. 6 ustawy o emeryturach i rentach z Funduszu Ubezpieczeń Społecznych (t.j. Dz.U. 2018, poz. 1270, ze zm.; dalej: ustawa o emeryturach i rentach z FUS). W uzasadnieniu odniesiono się do możliwości złożenia wniosku o ponowne obliczenie wysokości emerytury górniczej na podstawie art. 110a ustawy o emeryturach i rentach z FUS i wskazano, że praktyka ta jest iluzoryczna $\mathrm{z}$ uwagi na fakt, że to od świadczeniobiorców wymaga się dostarczenia dokumentacji płacowej, na której podstawie organ emerytalny ma dokonać ponownego przeliczenia świadczenia. Ubezpieczeni w większości nie dysponują taką dokumentacją, gdyż zakłady pracy rzadko wydawały takie dokumenty, a dokumentacja płacowa zgromadzona $\mathrm{w}$ publicznym zasobie archiwalnym jest $\mathrm{z}$ wielu przyczyn niekompletna. $W$ związku z powyższym zasadna i konieczna jest odpowiednia interwencja ustawodawcy w tym zakresie, właśnie $w$ postaci modyfikacji przepisów ustawy $z$ dnia 17 grudnia 1998 r. o rentach i emeryturach $z$ Funduszu Ubezpieczeń Społecznych. W opinii projektodawców przedstawione zmiany powinny ułatwić ponowne obliczanie emerytur górniczych świadczeniobiorcom i uzyskanie świadczeń we właściwej wysokości.

W uzasadnieniu wskazano, że kwestia regulowana w niniejszym projekcie może dotyczyć grupy do 10000 osób, a jej skutki finansowe dla budżetu Funduszu Ubezpieczeń Społecznych należy szacować na 240 mln złotych w skali roku.

\section{Adresaci projektu}

Punktem odniesienia dla obszaru normowania projektowanej ustawy o zmianie ustawy o emeryturach i rentach z FUS są przede wszystkim emeryci, którym 
przysługiwało świadczenie emerytalne na podstawie ustawy o zaopatrzeniu emerytalnym górników i których świadczenia zostały ustalone przed dniem 31 grudnia 1998 r. Projektowana ustawa dotyczyć będzie również ZUS, na który ma zostać nałożony obowiązek przeprowadzania postępowania na podstawie dowodów znanych organowi z urzędu (w obecnym stanie prawnym przedmiotową dokumentację jest zobowiązany dostarczyć organowi rentowemu ubezpieczony).

\section{Ocena skutków prawnych przyjęcia projektu}

1. Projektowana regulacja wpłynie na poprawę sytuacji prawnej ubezpieczonych, którzy nabyli prawo do świadczeń emerytalnych i rentowych na podstawie ustawy o zaopatrzeniu emerytalnym górników, ponieważ przeniesie ciężar dowodu w zakresie ustalenia wysokości świadczeń emerytalnych z ubezpieczonych na organ rentowy. W obecnym stanie prawnym obowiązek dostarczenia przez ubezpieczonego dowodów uzasadniających prawo do świadczeń z ubezpieczeń społecznych oraz ich wysokość został nałożony przez ustawodawcę w art. 116 ust. 5 ustawy o emeryturach i rentach z FUS oraz art. 80 ustawy z 13 października 1998 r. o systemie ubezpieczeń społecznych (t.j. Dz.U. 2019, poz. 300, ze zm.), jak również w art. 232 ustawy z 17 listopada 1964 r. - Kodeks postępowania cywilnego (t.j. Dz.U. 2018, poz. 1360). Nałożenie takiego obowiązku na ZUS wiąże się ze znacznym nakładem pracy, który musiałby w takiej sytuacji wykonać organ rentowy.

W ciągu ostatnich kilkudziesięciu lat wystąpił problem dotyczący wszystkich ubezpieczonych, polegający na tym, że regulacje określające sposób wyliczania emerytury, w szczególności okres zatrudnienia ubezpieczonego uwzględniany w formule wymiaru emerytury, nie były w pełni kompatybilne z przepisami dotyczącymi obowiązku przechowywania dokumentacji przez pracodawcę. Do roku 1991 okresy przechowywania dokumentacji płacowej odpowiadały długości okresu, który stanowił podstawę ustalania wymiaru emerytury i renty. Rozporządzenie Ministra Finansów z 15 stycznia 1991 r. w sprawie zasad prowadzenia rachunkowości (Dz.U. nr 10, poz. 35) w związku z wydłużeniem tego okresu analogicznie dostosowywało okres przechowywania tej dokumentacji. Następnie wprowadzono szczegółowe regulacje: rozporządzenie Ministra Pracy i Polityki Socjalnej z 28 maja 1996 r. w sprawie zakresu prowadzenia przez pracodawców dokumentacji w sprawach związanych ze stosunkiem pracy oraz sposobu prowadzenia akt osobowych pracownika (Dz.U. nr 62, poz. 286) oraz art. 125a pkt 4 ustawy o emeryturach i rentach z FUS. Obecnie istnieje obowiązek przechowywania dokumentacji płacowej przez 50 lat. W związku z powyższym należy zwrócić uwagę, że problem braku możliwości przeliczenia emerytury, ze względu na obowiązujące przepisy prawa, które mogło spowodować zniszczenie dokumentacji płacowej, może dotyczyć wszystkich ubezpieczonych, którzy nabyli świadczenia na podsta- 
wie ustawy z 14 grudnia 1982 r. o zaopatrzeniu emerytalnym pracowników i ich rodzin (Dz.U. nr 40, poz. 267, ze zm.), a nie tylko ubezpieczonych, którzy nabyli prawo do świadczeń emerytalnych i rentowych na podstawie ustawy z 1 lutego 1983 r. o zaopatrzeniu emerytalnym górników i ich rodzin. W konsekwencji przyjęcie zaproponowanego rozwiązania jedynie w stosunku do wskazanej w projekcie grupy ubezpieczonych budzi wątpliwości w świetle zasady równości wskazanej w art. 32 Konstytucji RP. Nie ma racjonalnych przesłanek uzasadniających wprowadzenie tego rodzaju rozwiązania prawnego jedynie dla wybranej grupy ubezpieczonych w sytuacji, gdy w analogicznej sytuacji prawnej znajduje się szerszy krąg emerytów uzyskujących świadczenia na podstawie reguł powszechnych wynikających $z$ art. 110a ustawy o emeryturach i rentach z FUS. Przepis ten przewiduje, że wysokość emerytury oblicza się ponownie od podstawy wymiaru ustalonej w sposób określony w art. 15, z uwzględnieniem art. 110 ust. 3, jeżeli do jej obliczenia wskazano podstawę wymiaru składki na ubezpieczenie społeczne lub ubezpieczenia emerytalne i rentowe na podstawie przepisów prawa polskiego przypadającą w całości lub w części po przyznaniu świadczenia, a wskaźnik wysokości podstawy wymiaru przed zastosowaniem ograniczenia, o którym mowa w art. 15 ust. 5, jest wyższy niż $250 \%$. Dotyczy on wszystkich osób objętych zakresem podmiotowym ustawy o emeryturach i rentach z FUS. Mechanizm ten ma zastosowanie $\mathrm{w}$ sytuacji spełnienia warunku kontynuowania podlegającego ubezpieczeniu zatrudnienia po nabyciu prawa do emerytury ${ }^{2}$.

W obecnym stanie prawnym generalna instytucja przeliczenia wysokości świadczenia określona $\mathrm{w}$ art. 109-111 ustawy o emeryturach i rentach z FUS umożliwia zwiększenie emerytury lub renty $\mathrm{w}$ wyniku uwzględnienia $\mathrm{w}$ podstawie wymiaru świadczenia okresów ubezpieczenia przypadających zarówno przed, jak i po przyznaniu emerytury/renty. Artykuł 110a dotyczy jednego ze wskazanych przez ustawodawcę przypadków ponownego obliczania wysokości emerytury. Podstawową zasadą obowiązującą przy zastosowaniu tej instytucji jest reguła, że do przeliczenia świadczenia nie można wykorzystać danych o uzyskiwanych dochodach, które nie wpływają w sposób pewny, lecz tylko przybliżony lub prawdopodobny, na ustalenie podstawy obliczenia wysokości emerytur i rent, jak np. przyjęcie hipotetycznej i uśrednionej wielkości premii ubezpieczonego $\mathrm{w}$ wyniku jej porównania $\mathrm{z}$ premiami wypłaconymi innym pracowni$\mathrm{kom}^{3}$. Od dnia 1 stycznia 2009 r. - na mocy art. 2 ustawy z 4 września 2008 r.

2 Zob. wyrok SA w Łodzi z 29 marca 2018 r., sygn. akt III AUa 319/17, LEX nr 2490978, a także Emerytury i renty $z$ FUS. Emerytury pomostowe. Okresowe emerytury kapitałowe. Komentarz do trzech ustaw emerytalnych, red. K. Antonów, LEX, komentarz do art. 109, art. 110, art. 110(a), art. 111 ustawy o emeryturach i rentach z Funduszu Ubezpieczeń Społecznych.

3 Zob. wyrok SN z 4 lipca 2007 r., sygn. akt I UK 36/07, LEX nr 390123, oraz wyroki SA: w Warszawie z 20 czerwca 2007 r., sygn. akt III AUa 482/07, OSA 2009, nr 1, poz. 1; we Wrocławiu z 29 sierpnia 2012 r., sygn. akt III AUa 233/12, LEX nr 1216267. 
o zmianie ustawy o emeryturach i rentach z Funduszu Ubezpieczeń Społecznych (Dz.U. nr 192, poz. 1180) możliwe stało się przeliczanie świadczeń z uwzględnieniem minimalnego wynagrodzenia za okresy, w których ubezpieczony pozostawał w stosunku pracy, lecz nie mógł ustalić podstawy wymiaru składek ze względu na brak dokumentacji płacowej ${ }^{4}$.

2. W projekcie ustawy wprowadzono odstępstwo od zasady nieuwzględniania przy ustalaniu wysokości wyliczonej ponownie emerytury dochodów nieudokumentowanych i zaproponowano konstrukcję przyjęcia dochodów estymowanych na podstawie danych istniejących w przypadku braku środków dowodowych. Przyjęcie takiej regulacji budzi wątpliwości w świetle obecnie stosowanych reguł. Zaproponowano regulację przewidującą, że jeżeli po przeprowadzeniu postępowania, o którym mowa w ust. 1, ujawnione dowody nie pozwalają na jednoznaczne ustalenie wskaźnika wysokości podstawy emerytury, przyjmuje się średnią wartość wynagrodzeń osoby składającej wniosek z roku wskazanego przez wnioskodawcę, uwzględniając przy tym składniki wynagrodzenia, od których nie były naliczane składki na ubezpieczenia rentowe i emerytalne. Tego rodzaju norma byłaby bardzo korzystna dla tej grupy emerytów w dwóch aspektach. Po pierwsze, mogliby oni mieć przeliczone świadczenie na podstawie wybranego przez siebie relatywnie krótkiego okresu - 1 roku (obecnie zasadą jest okres 10 lat z ostatnich dwudziestu lub 20 z całego okresu kariery zawodowej) najprawdopodobniej o najwyższych dochodach. Po drugie, pozostała grupa emerytów, uzyskująca świadczenia emerytalne na zasadach powszechnych, może mieć ewentualnie uwzględnione dochody na poziomie wynagrodzenia minimalnego. Natomiast w przypadku przyjęcia projektowanego rozwiązania nie będzie miał do nich zastosowania korzystniejszy mechanizm wyboru jednego roku z najwyższymi przychodami, ponieważ został on przewidziany tylko dla osób, które nabyły świadczenie na podstawie ustawy z 1 lutego 1983 r. o zaopatrzeniu emerytalnymi górników i ich rodzin.

Przyjęcie zaproponowanego rozwiązania jedynie w stosunku do wskazanej w projekcie grupy ubezpieczonych budzi wątpliwości w świetle zasady równości wskazanej w art. 32 Konstytucji.

\section{Podsumowanie}

Analizowany projekt przewiduje wprowadzenie nowej regulacji prawnej, której podstawowym celem jest modyfikacja przepisów określających ciężar dowodu $\mathrm{w}$ postępowaniach prowadzonych przez organ rentowy w stosunku do osób, które nabyły świadczenie na podstawie ustawy z 1 lutego 1983 r. o zaopatrzeniu emerytalnym górników i ich rodzin. Projektowana ustawa zawiera uregulowanie

4 Emerytury i renty z FUS. Emerytury pomostowe, op. cit. 
$\mathrm{w}$ tej kwestii oraz normę przewidującą procedurę stosowaną w przypadku braku dokumentacji. Wejście w życie przedmiotowej ustawy poprawiłoby sytuację prawną wymienionej grupy ubezpieczonych w zakresie ponownego ustalania wysokości emerytury. Projektodawcy ustawy wskazali jako źródło finansowania kosztów realizacji przedmiotowej ustawy Fundusz Ubezpieczeń Społecznych, a ze względu na jego deficyt w konsekwencji byłby to budżet państwa. Ponieważ w analogicznej sytuacji w zakresie przeliczania emerytury znajdują się również ubezpieczeni, którzy nabyli świadczenia na podstawie ustawy z 14 grudnia 1982 r. o zaopatrzeniu emerytalnym pracowników i ich rodzin, przyjęcie zaproponowanego rozwiązania jedynie w stosunku do wskazanej w projekcie grupy ubezpieczonych budzi wątpliwości w świetle zasady równości wskazanej w art. 32 Konstytucji.

\section{Bibliografia}

Emerytury i renty z FUS. Emerytury pomostowe. Okresowe emerytury kapitałowe. Komentarz do trzech ustaw emerytalnych, red. K. Antonów, LEX. 
Robert Jastrzębski

\title{
Ocena projektu nowelizacji ustaw: o stosunku Państwa do Muzułmańskiego Związku Religijnego w RP oraz o stosunku Państwa do Karaimskiego Związku Religijnego w RP ${ }^{1}$
}

\author{
Assessment of the Bill on Amending the Following Acts: on the State's \\ Attitude Towards the Muslim Religious Union in the Republic of Poland \\ and on the State's Attitude Towards the Karaim Religious Union in the \\ Republic of Poland
}

\begin{abstract}
The amendment to both acts, formally force since 1936, concerns the adaptation of their contents to the geographical area of the Polish state, which has been changed after the Second World War The amendment has no practical legal significance. In the author's opinion, one should strive to adopt two separate religious statutes on the basis of current legal regulations, rather than introducing changes regarding replacing geographical terms and names of state bodies.
\end{abstract}

Keywords: government administration, Islam, minority, bill, religion

Nowelizacja obydwu nadal formalnie obowiązujących ustaw z 1936 r. w zasadzie dotyczy dostosowania ich treści do obszaru geograficznego państwa polskiego, który uległ zmianie po drugiej wojnie światowej. Ich nowelizacja nie ma w praktyce istotnego znaczenia prawnego. W opinii autora należy raczej dążyć do uchwalenia dwóch osobnych ustaw wyznaniowych na podstawie obowiązujących regulacji prawnych, niż wprowadzać zmiany polegające na zastąpieniu nazw geograficznych oraz nazw organów państwowych.

Słowa kluczowe: administracja rządowa, islam, mniejszości, projekt ustawy, wyznanie

Doktor hab. nauk prawnych, profesor UW -

Uniwersytet Warszawski, Wydział Prawa i Administracji, kierownik Zakładu Historii Administracji, kierownik Pracowni Prawa Polskiego XX wieku, WARSZAWA, POLSKA robert.jastrzebski@sejm.gov.pl • https://orcid.org/0000-0002-7265-0614

\section{Przedmiot opinii}

Przedmiotem opinii prawnej jest nowelizacja ustaw:

- z 21 kwietnia 1936 r. o stosunku Państwa do Muzułmańskiego Związku Religijnego w Rzeczypospolitej Polskiej, Dz.U. nr 30, poz. 240, ze zm.,

1 Ocena skutków prawnych projektu ustawy o zmianie ustawy o stosunku Państwa do Muzulmańskiego Związku Religijnego w Rzeczypospolitej Polskiej oraz ustawy o stosunku Państwa do Karaimskiego Związku Religijnego w Rzeczypospolitej Polskiej sporządzona 31 stycznia 2020 r. na zlecenie zastępcy Szefa Kancelarii Sejmu; BAS-WAP 137/20. 
- z 21 kwietnia 1936 r. o stosunku Państwa do Karaimskiego Związku Religijnego w Rzeczypospolitej Polskiej, Dz.U. nr 30, poz. 241, ze zm.

\section{Uzasadnienie}

Na wstępie należy zaznaczyć, że nowelizowane ustawy pochodzą z okresu II Rzeczypospolitej, co oznacza, że zostały wydane w innej rzeczywistości prawnoustrojowej. Wówczas bowiem obowiązywała ustawa konstytucyjna z 23 kwietnia 1935 r. (Dz.U. nr 30, poz. 227), która uchyliła ustawę z 17 marca 1921 r. - Konstytucja Rzeczypospolitej Polskiej (Dz.U. nr 44, poz. 267, zm.; Dz.U. 1926, nr 78, poz. 442), przy czym nadal, na podstawie art. 81 przepisów przechodnich do ustawy konstytucyjnej z 23 kwietnia 1935 r., obowiązywały art. 99, 109-118 oraz 120 ustawy z 17 marca 1921 r. - Konstytucja Rzeczypospolitej Polskiej. Wśród nieuchylonych artykułów znalazły się przepisy, dotyczące wolności sumienia i wyznania, Kościoła rzymskokatolickiego, kościołów mniejszości religijnych, w tym innych związków religijnych. W związku z tym istotne znaczenie ma art. 115 ustawy z 17 marca 1921 r. Konstytucja Rzeczypospolitej Polskiej, zgodnie z którym: Kościoły mniejszości religijnych $i$ inne prawnie uznane zwiazki religijne rządza się same własnemi ustawami, których uznania Państwo nie odmówi, o ile nie zawieraja postanowień, sprzecznych z prawem. Stosunek Państwa do tych Kościołów i wyznań będzie ustalany $w$ drodze ustawowej po porozumieniu się $z$ ich prawnemi reprezentacjami ${ }^{2}$.

Po drugiej wojnie światowej ówczesna tzw. władza ludowa w Manifeście Polskiego Komitetu Wyzwolenia Narodowego z 22 lipca 1944 r. (załącznik do Dz.U. nr 1, s. 1) uznała że Krajowa Rada Narodowa oraz Polski Komitet Wyzwolenia Narodowego działają: na podstawie Konstytucji z 17 marca 1921 roku, jedynie obowiązującej konstytucji legalnej, uchwalonej prawnie, przy czym miały obowiązywać podstawowe założenia tej konstytucji, aż do zwołania Sejmu Ustawodawczego, wybranego w pięcioprzymiotnikowych wyborach, który miał uchwalić, jako wyraziciel woli narodu, nową konstytucję. Warto zwrócić uwagę, że w manifeście uznano, że emigracyjny „rząd” w Londynie i jego delegatura w Kraju jest władza samozwańczą, władzq nielegalną oraz opiera się na bezprawnej faszystowskiej konstytucji z kwietnia 1935 roku³.

2 Zob. J. Osuchowski, Prawo wyznaniowe Rzeczypospolitej Polskiej 1918-1939 (węzłowe zagadnienia), Warszawa 1967, s. 226 i n.; K. Krasowski, Zwiazki wyznaniowe w II Rzeczypospolitej. Studium historycznoprawne, Warszawa-Poznań 1988, s. 51-61; W. Wysoczański, M. Pietrzak, Prawo kościołów i związków wyznaniowych nierzymskokatolickich $w$ Polsce, Warszawa 1997, s. 14 i n.

3 Zob. K. Działocha, J. Trzciński, Zagadnienie obowiązywania Konstytucji Marcowej w Polsce Ludowej 1944-1952, Wrocław-Warszawa-Kraków-Gdańsk 1977; K. Działocha, Rola Konstytucji marcowej w prawie państwowym Polski Ludowej, „Acta Universitatis Wratislaviensis. Przegląd Prawa i Administracji” 1976, t. VII. 
Po zwołaniu Sejmu Ustawodawczego została uchwalona ustawa konstytucyjna z 19 lutego 1947 r. o ustroju i zakresie działania najwyższych organów Rzeczypospolitej Polskiej (Dz.U. nr 18, poz. 71), która w art. 1 określiła źródła ówczesnego prawa konstytucyjnego, wymieniając w pierwszej kolejności podstawowe założenia Konstytucji z 17 marca 1921 r. W ten sposób nadal obowiązywały, w zakresie formalnym, regulacje o charakterze konstytucyjnym, które dotyczyły zagadnień wyznaniowych w państwie polskim. Następnie została uchwalona Konstytucja Polskiej Rzeczypospolitej Ludowej z 22 lipca 1952 r. (Dz.U. nr 33, poz. 232), zgodnie z jej art. 70 kościoły i inne związki wyznaniowe mogły swobodnie wypełniać swoje funkcje religijne, a zasady stosunku państwa do kościoła oraz sytuację prawną i majątkową związków wyznaniowych miały określać ustawy (art. 82, Konstytucji Polskiej Rzeczypospolitej Ludowej z 22 lipca 1952 r., Dz.U. 1976, nr 7, poz. 36).

Po zmianach polityczno-gospodarczo-społecznych przełomu lat 80. i 90. XX wieku została uchwalona ustawa konstytucyjna z 17 października 1992 r. o wzajemnych stosunkach między władzą ustawodawczą i wykonawczą Rzeczypospolitej Polskiej oraz o samorządzie terytorialnym (Dz.U. nr 84, poz. 426), która uchyliła postanowienia Konstytucji Polskiej Rzeczypospolitej Ludowej z 22 lipca 1952 r., pozostawiając jednak nadal jako obowiązujący jej rozdział 8 „Podstawowe prawa i obowiązki obywateli”, w tym art. 82, który dotyczył zagadnień wyznaniowych. Ustawa konstytucyjna z 17 października 1992 r. o wzajemnych stosunkach między władzą ustawodawczą i wykonawczą Rzeczypospolitej Polskiej oraz o samorządzie terytorialnym została uchylona na podstawie art. 242 Konstytucji Rzeczypospolitej Polskiej z 2 kwietnia 1997 r. (Dz.U. nr 78, poz. 483, ze zm.), czego konsekwencją była utrata mocy obowiązującej postanowień Konstytucji Polskiej Rzeczypospolitej Ludowej z 22 lipca 1952 r. m.in. z zakresu prawa wyznaniowego.

Wynika z tego, że obecnie obowiązują postanowienia Konstytucji Rzeczypospolitej Polskiej z 2 kwietnia 1997 r., w szczególności art. 25, na podstawie którego obowiązuje zasada równouprawnienia oraz autonomii kościołów i związków wyznaniowych. $Z$ punktu widzenia przedmiotowej opinii istotne znaczenie ma ust. 5 tego artykułu, zgodnie z którym stosunki między Rzecząpospolitą Polską a innymi kościołami oraz związkami wyznaniowymi określają ustawy uchwalone na podstawie umów zawartych przez Radę Ministrów z ich właściwymi przedstawicielami.

Należy zaznaczyć, że odrębne oraz bilateralne kształtowanie stosunków państwa polskiego z określonymi kościołami oraz związkami wyznaniowym sięga tradycją właśnie okresu II Rzeczypospolitej, a przyjęte wówczas ustawy ich dotyczące formalnie obowiązywały po drugiej wojnie światowej, w tym niektóre obowiązują do dziś4. Zaliczyć do nich należy m.in. ustawy z: 21 kwietnia 1936 r.

4 Zob. M. Olszówka, Komentarz do art. 25 [w:] Konstytucja RP, t. I, Komentarz. Art. 1-86, red. M. Safjan, L. Bosek, Warszawa 2016, s. 679-683. 
o stosunku Państwa do Muzułmańskiego Związku Religijnego w Rzeczypospolitej Polskiej oraz 21 kwietnia 1936 r. o stosunku Państwa do Karaimskiego Związku Religijnego w Rzeczypospolitej Polskiej. W związku z uchwaleniem tych dwóch ustaw zostały wydane, na ich podstawie, odpowiednio dwa rozporządzenia Rady Ministrów z 26 sierpnia 1936 r.: o uznaniu Statutu Muzułmańskiego Związku Religijnego w Rzeczypospolitej Polskiej (Dz.U. nr 72, poz. 517) oraz o uznaniu Statutu Karaimskiego Związku Religijnego w Rzeczypospolitej Polskiej (Dz.U. nr 72, poz. 518). Warto zaznaczyć, że obydwa rozporządzenia, zgodnie z Internetowym Systemem Aktów Prawnych, są uznane za nadal obowiązujące.

Nowelizowane ustawy, jak zaznaczono na wstępie, zostały wydane w innej rzeczywistości prawnoustrojowej, a także obowiązywały przede wszystkim na obszarze ówczesnego państwa polskiego, który współcześnie znajduje się na terenie innych państw, tzn. Republiki Litewskiej, Republiki Białoruskiej oraz Republiki Ukraińskiej. Wynikało to z rozmieszczenia etnicznego i, co za tym idzie, wyznaniowego ludności II Rzeczypospolitej. Według szacunków z drugiej połowy lat 30. XX wieku ludność wyznania muzułmańskiego, pochodzenia tatarskiego, liczyła około 15 tys. i zamieszkiwała głównie województwo wileńskie, nowogródzkie, białostockie i Warszawę. Ludność zaś wyznania karaimskiego stanowiła około 1500 osób i obejmowała cztery gminy w: Trokach, Wilnie, Łucku oraz Haliczu 5 .

Należy podkreślić, że obydwie nowelizowane ustawy mają podobny niejako „bliźniaczy charakter”, jak stwierdził bowiem Jakub Sawicki: Ustawa karaimska jest bliźniacza siostra ustawy muzułmańskiej nie tylko pod względem równoczesności jej wniesienia do Sejmu, jej uchwalenia i jej ogłoszenia w Dzienniku Ustaw, ale przede wszystkim pod względem konstrukcji prawnej, ujęcia i sformułowania poszczególnych zagadnień i unormowania stosunku państwa do tego związu religijnego ${ }^{6}$.

Ponadto istotne znaczenie $\mathrm{w}$ przedmiotowej sprawie ma ukształtowany w II Rzeczypospolitej oraz po drugiej wojnie światowej nadzór państwa nad funkcjonowaniem związków wyznaniowych. W pierwszym okresie był on związany z wyróżnianiem, w zakresie pojęcia samorządu, osobnej kategorii samorządu wyznaniowego. Nauka ówczesnego prawa administracyjnego dzieliła dychotomicznie samorząd na terytorialny (komunalny, powszechny) oraz nieterytorialny (specjalny). Ten ostatni, według Zdzisława Grelowskiego, obejmował publiczno-prawne związki o charakterze przymusowym, których kompetencji podlegały ściśle określone sfery działalności (zawodowa, gospodarcza, kulturalna, wyzna-

5 Zob. „Mały Rocznik Statystyczny” 1936, s. 248; H. Świątkowski, Wyznania religijne w Polsce ze szczególnym uwzględnieniem ich stanu prawnego, Warszawa 1937, s. 120 139; J. Sawicki, Studia nad położeniem prawnym mniejszości religijnych w państwie polskim, Warszawa 1937, s. 180-208; K. Krasowski, Związki wyznaniowe w II Rzeczypospolitej, op. cit., s. 196-206.

6 J. Sawicki, Studia nad położeniem prawnym mniejszości, op. cit., s. 200. 
niowa, narodowościowa) pewnej kategorii osób, a które na równi z organami samorządu terytorialnego wykonywały w sposób władczy zdecentralizowaną część administracji państwowej. Do związków samorządu wyznaniowego zaliczano m.in. Muzułmański Związek Religijny oraz Karaimski Związek Religijny ${ }^{7}$.

Nadzór nad działalnością obydwu związków wyznaniowych sprawował ówczesny Minister Wyznań Religijnych i Oświecenia Publicznego oraz właściwy wojewoda. Warto zaznaczyć, że wybór muftiego, zgodnie z art. 9 ustawy z 21 kwietnia 1936 r. o stosunku Państwa do Muzułmańskiego Związku Religijnego w Rzeczypospolitej Polskiej, podlegał i podlega zatwierdzeniu Prezydenta Rzeczypospolitej, tak samo zresztą jak wybór hachana, na podstawie art. 9 ustawy z 21 kwietnia 1936 r. o stosunku Państwa do Karaimskiego Związku Religijnego w Rzeczypospolitej Polskiej.

Po drugiej wojnie światowej została utrzymana formalnie moc obowiązująca aktów ustawodawczych z okresu II Rzeczypospolitej, w tym wymienionych wyżej ustaw wyznaniowych z 1936 r., które były i są publikowane jako powszechnie obowiązujące źródła prawa wyznaniowego".

Do 1950 r. administracja wyznaniowa należała do atrybucji Ministra Administracji Publicznej, który zastąpił Kierownika Resortu Administracji Publicznej (zob. ustawa z 21 lipca 1944 r. o utworzeniu Polskiego Komitetu Wyzwolenia Narodowego, Dz.U. nr 1, poz. 1; ustawa z 31 grudnia 1944 r. o powołaniu Rządu Tymczasowego Rzeczypospolitej Polskiej, Dz.U. nr 19, poz. 99). Urząd Ministra Administracji Publicznej zniosła ustawa z 19 kwietnia 1950 r. o zmianie organizacji naczelnych władz państwowych w zakresie gospodarki komunalnej i administracji publicznej (Dz.U. nr 19, poz. 156). Zgodnie z art. 4 tej ustawy został utworzony Urząd do Spraw Wyznań, który podlegał Prezesowi Rady Ministrów. Na jego czele stał dyrektor, powoływany i odwoływany przez Prezesa Rady Ministrów. Organami terenowymi administracji wyznaniowej byli wojewodowie, w tym prezydenci miast. Funkcjonowanie urzędu początkowo regulowała uchwała Rady Ministrów z 27 maja 1950 r. w sprawie tymczasowego statutu Urzędu do Spraw Wyznań (Monitor Polski nr A-78, poz. 905) ${ }^{10}$.

7 Z. Grelowski, Samorząd specjalny. Gospodarczy - zawodowy - wyznaniowy wedtug obowiązujących ustaw w Polsce, Katowice 1947, s. 5, 65, 121, 133-134

8 Zob. M. Pietrzak, Prawo wyznaniowe, Warszawa 2013, s. 140-143; K. Krasowski, Związki wyznaniowe w II Rzeczypospolitej, op. cit., 200-202, 205-206.

9 Zob. M. Pietrzak, Prawo wyznaniowe, op. cit., s. 224-225; Położenie prawne kościołów i związków wyznaniowych w Polskiej Rzeczypospolitej Ludowej. Zbiór przepisów i dokumentów w/g stanu na dzień 1 października 1960 r., Warszawa 1960, s. 269-308; Prawo wyznaniowe, wprowadzenie i oprac. W. Uruszczak, Kraków 1997, s. 307-316, 360-367.

10 Zob. H. Świątkowski, Wyznaniowe prawo państwowe. Problematyka prawna wolności sumienia w PRL, Warszawa 1962, s. 127; M. Pietrzak, Prawo wyznaniowe, op. cit., s. 207-209. 
Zmiany w zakresie nadzoru nad związkami wyznaniowymi były związane z wejściem w życie ustawy z 17 maja 1989 r. o gwarancjach wolności sumienia i wyznania (Dz.U. nr 29, poz. 155, tj. Dz.U. 2017, poz. 1153) ${ }^{11}$, a następnie z ustawą z 23 listopada 1989 r. zmieniającą ustawę o zmianach $\mathrm{w}$ organizacji oraz zakresie działania niektórych naczelnych i centralnych organów administracji państwowej (Dz.U. nr 64, poz. 387). Zgodnie z ostatnią z wymienionych ustaw do zakresu działania Urzędu Rady Ministrów przeszły zadania należące dotychczas do Urzędu do Spraw Wyznań, przy czym Minister Szef Urzędu Rady Ministrów miał realizować zadania przewidziane w odrębnych ustawach dla Ministra Kierownika Urzędu do Spraw Wyznań oraz dla Dyrektora Urzędu do Spraw Wyznań. Następnie, na podstawie ustawy z 8 sierpnia 1996 r. - Przepisy wprowadzające ustawy reformujące funkcjonowanie gospodarki i administracji publicznej (Dz.U. nr 106, poz. 497), na Ministra Spraw Wewnętrznych i Administracji przeszły zadania i kompetencje zniesionego urzędu Ministra Szefa Urzędu Rady Ministrów.

Omówiona, w dużym skrócie, administracja wyznaniowa w państwie polskim miała i ma wpływ na status prawny dwóch wyznań, które są przedmiotem niniejszej opinii prawnej. Warto jednak zaznaczyć, że po drugiej wojnie światowej weszły w życie nowe statuty obydwu związków wyznaniowych, mimo że nadal, o czym była mowa wyżej, obowiązują - przynajmniej formalnie - dwa rozporządzenia Rady Ministrów z 26 sierpnia 1936 r., tj. o uznaniu Statutu Muzułmańskiego Związku Religijnego w Rzeczypospolitej Polskiej oraz o uznaniu Statutu Karaimskiego Związku Religijnego w Rzeczypospolitej Polskiej, które zawierają dwa załączniki dotyczące statutu poszczególnych wyznań.

Następnie, w dniu 12 stycznia 1969 r. został uchwalony nowy statut pierwszego z wyżej wymienionych związków religijnych przez Wszechpolski Kongres Muzułmański, przy czym obecnie obowiązuje statut uchwalony 28 lutego $2009 \mathrm{r}$. przez XVII Nadzwyczajny Wszechpolski Kongres Muzułmańskiego Związku Religijnego w Rzeczypospolitej Polskiej, ze zmianami uchwalonymi 15 marca 2014 r. przez XIX Nadzwyczajny Wszechpolski Kongres Muzułmańskiego Związku Religijnego w Rzeczypospolitej Polskiej ${ }^{12}$. Statut zaś drugiego związku wyznaniowego został uchwalony przez Krajowy Zjazd Delegatów Dżymatów 18 marca $1973 \mathrm{r}$. i zatwierdzony w dniu 10 maja 1974 r. przez Urząd do Spraw Wyznańn ${ }^{13}$.

11 Zob. W. Wysoczański, M. Pietrzak, Prawo kościołów, op. cit., s. 27 i n.; M. Pietrzak, Prawo wyznaniowe, op. cit., s. 210 i n.

12 Zob. Mniejszości wyznaniowe w Polsce. Prawo wewnętrzne (statutowe), wprowadzenie, zbiór statutów, oprac. R. Brożyniak, M. Winiarczyk-Kossakowska, Warszawa 2014, s. 79-91; strona internetowa: mzr.pl.

13 Zob. W. Wysoczański, M. Pietrzak, Prawo kościołów, op. cit., s. 381-387, 388-395 (Statut Muzułmańskiego Związku Religijnego w Polskiej Rzeczypospolitej Ludowej z 12 stycznia 1969 r.), s. 397-405, 406-413 (Statut Karaimskiego Związku Religijnego 
Po dłuższym wstępie, który był konieczny w analizowanej sprawie, należy przedstawić proponowane zmiany projektu ustawy o zmianie ustawy o stosunku państwa do Muzułmańskiego Związku Religijnego w Rzeczypospolitej Polskiej oraz ustawy o stosunku państwa do Karaimskiego Związku Religijnego w Rzeczypospolitej Polskiej. Zmiany te w zasadzie dotyczą dostosowania treści obydwu ustaw do granic współczesnego państwa polskiego, którego obszar uległ zmianie po drugiej wojnie światowej. W przypadku pierwszej z ustaw chodzi w zasadzie o zastąpienie wyrazów „miasto Wilno” wyrazem „Białystok” oraz wyrazy „Wojewoda Wileński” wyrazami „Wojewoda Podlaski”, w drugiej zaś wyrazy „miasto Wilno” wyrazami „miasto stołeczne Warszawa” oraz wyrazy „Wojewoda Wileński” wyrazami „Wojewoda Mazowiecki”.

Proponowane zmiany, w opinii Komisji do Spraw Petycji Sejmu RP, mają na celu potwierdzić istniejący stan faktyczny, dotyczący siedzib obydwu związków wyznaniowych, oraz przypisać określone w ustawach wyznaniowych zadania odpowiednio Wojewodzie Podlaskiemu oraz Wojewodzie Mazowieckiemu. Warto zaznaczyć, że wnioskodawca, przedkładając projekt ustawy, miał świadomość, że stosowanie większości przepisów zmienianych ustaw rodzi poważne trudności, gdyż są to regulacje: archaiczne, charakterystyczne dla przedwojennego systemu zwierzchnictwa państwa nad Kościołami i związkami wyznaniowym, charakteryzujące się przyznaniem państwu szeregu uprawnień nadzorczych wobec związków wyznaniowych i, co istotne, [p]rzepisów tych nie można pogodzić z konstytucyjna zasada rozdziału państwa od Kościołów i związków wyznaniowych. Ponadto: ma też świadomość, że $w$ tych okolicznościach właściwym rozwiązaniem byłoby opracowanie nowych projektów ustaw - co jednak z uwagi na wątpliwości prawne i złożoność takiego procesu może być zadaniem bardzo trudnym i czasochłonnym (uzasadnienie projektu, s. 1). Zasadniczym skutkiem społecznym i prawnym wprowadzonych zmian legislacyjnych ma być, zdaniem wnioskodawcy, poprawa spójności i przejrzystości systemu prawnego.

Należy jednak zaznaczyć, że proponowane zmiany ustaw wyznaniowych dotyczą regulacji, które w praktyce nie obowiązywały po drugiej wojnie światowej. W szczególności chodzi o statuty obydwu wyznań religijnych, które zostały zmienione przez Urząd do Spraw Wyznań, mimo że formalnie nadal obowiązują dwa rozporządzenia Rady Ministrów z 26 sierpnia 1936 r. zawierające odnośne statuty, wydane na podstawie tych dwóch ustaw z 21 kwietnia 1936 r. Oczywiście współcześnie ma miejsce proces ożywionej działalności Muzułmańskiego Związku Wyznaniowego, zwłaszcza na obszarze województwa podlaskiego ${ }^{14}$. Natomiast funkcjonowanie Karaimskiego Związku Wyznaniowego, którego li-

w Polskiej Rzeczypospolitej Ludowej z 18 marca 1973 r.); Mniejszości wyznaniowe w Polsce, op. cit., s. 92-97.

14 Zob. P. Borecki, Status prawny muzułmanów we wspótczesnej Polsce, „Prawo i Religia” 2007, t. 1. 
czebność w 1997 r. była szacowana na około 150 osób, ma obecnie charakter marginalny ${ }^{15}$.

W ten sposób współcześnie ma miejsce sui generis chaos legislacyjny, dotyczący obowiązywania prawa państwowego w stosunku do tych wyznań w państwie polskim. Dotyczy on przede wszystkim pierwszego z wyżej wymienionych wyznań, tj. Muzułmańskiego Związku Wyznaniowego, którego działalność w zasadzie nie podlega żadnemu nadzorowi państwowemu. Stan ten został pogłębiony po wejściu w życie Konstytucji Rzeczypospolitej Polskiej z 1997 r., zgodnie bowiem $\mathrm{z}$ wymienionym wyżej jej art. 25 ust. 5 stosunki między państwem polskim a innymi kościołami oraz związkami wyznaniowymi mają określać ustawy uchwalone na podstawie umów zawartych przez Radę Ministrów z ich właściwymi przedstawicielami. W doktrynie prawa wyznaniowego dominuje pogląd, że wymóg zawarcia takiej umowy dotyczy także nowelizacji ustawy partykularnej niezależnie od daty jej uchwalenia, przy czym nie jest on obligatoryjny w przypadku nowelizacji niemodyfikujących materialnie wzajemnych stosunków stron, tzn. państwa polskiego oraz kościoła, w tym związku wyznaniowego ${ }^{16}$.

Wynika z tego, że współcześnie obowiązują w zasadzie tylko formalnie ustawy z 21 kwietnia 1936 r., tj. o stosunku Państwa do Muzułmańskiego Związku Religijnego w Rzeczypospolitej Polskiej oraz o stosunku Państwa do Karaimskiego Związku Religijnego w Rzeczypospolitej Polskiej. W związku z tym nowelizacja ich nie ma w praktyce istotnego znaczenia prawnego. Dlatego należy raczej dążyć do uchwalenia dwóch osobnych ustaw wyznaniowych, zgodnie z obowiązującymi regulacjami prawnymi, niż wprowadzać zmiany, polegające na zastąpieniu nazw geograficznych oraz organów państwowych, które będą dostosowane do zmiany granic państwa polskiego po drugiej wojnie światowej.

\section{Podsumowanie}

- Po drugiej wojnie światowej została utrzymana formalnie moc obowiązująca ustaw z 21 kwietnia 1936 r. o stosunku Państwa do Muzułmańskiego Związku Religijnego w Rzeczypospolitej Polskiej oraz o stosunku Państwa do Karaimskiego Związku Religijnego w Rzeczypospolitej Polskiej.

- Nowelizacja obydwu ustaw w zasadzie dotyczy dostosowania ich treści do obszaru geograficznego państwa polskiego, który uległ zmianie po drugiej wojnie światowej.

- Zgodnie z art. 25 Konstytucji z 1997 r. obowiązuje zasada równouprawnienia oraz autonomii kościołów i związków wyznaniowych, przy czym stosunki mię-

15 Zob. W. Wysoczański, M. Pietrzak, Prawo kościołów, op. cit., s. 399.

16 Zob. M. Olszówka, Komentarz do art. 25, op. cit., s. 683; M. Olszówka, Wpływ Konstytucji RP z 1997 r. na system źródeł prawa wyznaniowego, Warszawa 2016, s. 260 i n. 
dzy Rzecząpospolitą Polską a innymi kościołami oraz związkami wyznaniowymi określają ustawy uchwalone na podstawie umów zawartych przez Radę Ministrów z ich właściwymi przedstawicielami.

- Nowelizacja ustaw nie ma w praktyce istotnego znaczenia prawnego i, co za tym idzie, należy raczej dążyć do uchwalenia dwóch osobnych ustaw wyznaniowych, zgodnie z obowiązującymi regulacjami prawnymi niż wprowadzać zmiany, polegające na zastąpieniu nazw geograficznych oraz organów państwowych, które będą dostosowane do zmiany granic państwa polskiego po drugiej wojnie światowej.

\section{Bibliografia}

Borecki P., Status prawny muzułmanów we wspótczesnej Polsce, „Prawo i Religia” 2007, t. 1.

Działocha K., Rola Konstytucji marcowej w prawie państwowym Polski Ludowej, „Acta Universitatis Wratislaviensis. Przegląd Prawa i Administracji” 1976, t. VII.

Działocha K., Trzciński J., Zagadnienie obowiązywania Konstytucji Marcowej w Polsce Ludowej 1944-1952, Wrocław-Warszawa-Kraków-Gdańsk 1977.

Grelowski Z., Samorzad specjalny. Gospodarczy - zawodowy - wyznaniowy wedtug obowiązujących ustaw w Polsce, Katowice 1947.

Krasowski K., Związki wyznaniowe w II Rzeczypospolitej. Studium historycznoprawne, Warszawa-Poznań 1988.

Mniejszości wyznaniowe w Polsce. Prawo wewnętrzne (statutowe), wprowadzenie, zbiór statutów, oprac. R. Brożyniak, M. Winiarczyk-Kossakowska, Warszawa 2014.

Olszówka M., Komentarz do art. 25 [w:] Konstytucja RP, t. I, Komentarz. Art. 1-86, red. M. Safjan, L. Bosek, Warszawa 2016.

Olszówka M., Wpływ Konstytucji RP z 1997 r. na system źródeł prawa wyznaniowego, Warszawa 2016.

Osuchowski J., Prawo wyznaniowe Rzeczypospolitej Polskiej 1918-1939 (węzłowe zagadnienia), Warszawa 1967.

Pietrzak M., Prawo wyznaniowe, Warszawa 2013.

Położenie prawne kościołów i związków wyznaniowych w Polskiej Rzeczypospolitej Ludowej. Zbiór przepisów i dokumentów w/g stanu na dzień 1 października 1960 r., Warszawa 1960.

Prawo wyznaniowe, wprowadzenie i oprac. W. Uruszczak, Kraków 1997.

Sawicki J., Studia nad położeniem prawnym mniejszości religijnych $w$ państwie polskim, Warszawa 1937.

Świątkowski H., Wyznania religijne w Polsce ze szczególnym uwzględnieniem ich stanu prawnego, Warszawa 1937.

Świątkowski H., Wyznaniowe prawo państwowe. Problematyka prawna wolności sumienia w PRL, Warszawa 1962.

Wysoczański W., Pietrzak M., Prawo kościołów i związków wyznaniowych nierzymskokatolickich w Polsce, Warszawa 1997. 
Henryk Dzwonkowski

\title{
Ocena skutków regulacji zawartych w poselskim projekcie ustawy Karta Praw Podatnika'
}

\author{
Impact assessment of regulations contained in the Deputies' Bill \\ on the Taxpayers' Rights Charter
}

\begin{abstract}
In the opinion of the author, the draft provisions duplicate the existing regulations in the field of taxpayer's rights arising from the Constitution of the Republic of Poland and the Tax Ordinance. However, the implementation of the goal assumed by sponsors of the bill is desirable and would certainly meet with a positive public perception. The author emphasizes that an alternative solution could be the development of an act constituting an exhaustive set of taxpayers' rights and the corresponding obligations of tax authorities, on a legal basis arising from the Constitution or laws.
\end{abstract}

Keywords: constitution, taxpayer, bill

Zdaniem autora opinii projektowane przepisy stanowią powielenie dotychczas obowiązujących regulacji w zakresie praw podatnika, wynikających z Konstytucji RP oraz ustawy o ordynacji podatkowej. Jednak realizacja celu zakładanego przez projektodawcę jest pożądana i z pewnością spotkałaby się z pozytywnym odbiorem społecznym. Autor podkreśla, że alternatywnym rozwiązaniem mogłoby być opracowanie aktu stanowiącego wyczerpujący zbiór praw podatników oraz odpowiadających im obowiązków organów podatkowych, na podstawie prawnej wynikającej z Konstytucji lub ustaw.

Słowa kluczowe: konstytucja, podatnik, projekt ustawy

Doktor hab. nauk prawnych, profesor U $ヒ$ -

Uniwersytet Łódzki, Wydział Prawa i Administracji, ŁÓDŹ, POLSKA •

hdzwonkowski@poltax.pl • https://orcid.org/0000000271103029

\section{Zakres przedmiotowy ustawy}

Projekt przewiduje wprowadzenie do polskiego porządku prawnego nowej instytucji, jaką jest Karta Praw Podatnika (dalej: Karta). Projekt tożsamej treści był również zgłaszany w poprzedniej kadencji Sejmu, jednakże nie został uchwalony przed jej zakończeniem (zob. druk nr 3458/VIII kad.).

Proponowana Karta Praw Podatnika określa w sposób zwięzły, choć nie do końca precyzyjny (co zostanie opisane w dalszej części opinii) podstawowe prawa podatników, a także stanowiące ich korelat - obowiązki organów podatkowych.

1 Ocena skutków regulacji zawartych w poselskim projekcie ustawy Karta Praw Podatnika (druk nr 137) sporządzona 9 stycznia 2020 r. na zlecenie zastępcy Szefa Kancelarii Sejmu; BAS 248/19. 
Innymi słowy, Karta stanowić ma ujęte w jednym akcie prawnym kompendium wiedzy na temat praw przysługujących podatnikowi i odpowiadających im obowiązkach organów podatkowych. Przy czym zakresem podmiotowym obejmuje również inne podmioty, których prawa i obowiązki są regulowane przepisami prawa podatkowego, zwłaszcza płatników, inkasentów, osoby trzecie odpowiedzialne za zaległości podatkowe oraz następców prawnych.

Projekt dotyczy przede wszystkim sektora finansów publicznych oraz spraw społecznych.

\section{Podmioty, na które oddziałuje akt}

Projekt dotyczy takich podmiotów, jak: podatnicy, a także inne podmioty, których prawa i obowiązki są regulowane przepisami prawa podatkowego, w tym: płatników, inkasentów, osób trzecich odpowiedzialnych za zaległości podatkowe, następców prawnych, a także pełnomocników tych podmiotów (tj. doradców podatkowych, adwokatów, radców prawnych), oraz organów administracji podatkowej (także samorządowych organów podatkowych), sądów administracyjnych, Rzecznika Praw Obywatelskich, ministra właściwego do spraw finansów publicznych, organów stanowiących jednostek samorządu terytorialnego.

\section{Celowość wprowadzenia aktu}

Cele projektu zostały określone w jego preambule. Wedle jej treści ma on realizować dwa zasadnicze założenia. Po pierwsze, zapewnić należytą ochronę praw podatników przez odpowiednie wyważenie interesu publicznego i prywatnego w prawie podatkowym. Po drugie, projekt ma służyć zwiększaniu świadomości społecznej co do istnienia i zakresu praw podatnika.

W ocenie autorów projektu dotychczasowy brak w polskim porządku prawnym Karty Praw Podatnika stanowi przejaw nienadążania za najlepszymi praktykami światowymi. Konieczność przyjęcia Karty motywowana jest również tym, że zmiany w prawie podatkowym, niekiedy godzące $\mathrm{w}$ prawa podatnika oraz spotykane naruszenia praw podatnika w procesie stosowania prawa, skutkują potrzebą wprowadzenia Karty jako nowego instrumentu wzmacniającego ochronę tych praw, zarówno na etapie tworzenia, jak i stosowania prawa podatkowego. Projekt ma ponadto łagodzić skutki istniejącej nierównowagi między pozycją podatnika oraz organu podatkowego (będącego gospodarzem postępowania podatkowego), a także zwiększać zaufanie podatnika do państwa.

$\mathrm{W}$ istocie Karta ma do odegrania rolę porządkującą, wzmacniającą oraz edukacyjną. W swej krótkiej formie ma za zadanie ułatwić podatnikom, zwłaszcza tym niekorzystającym z usług profesjonalnych pełnomocników, odnalezienie 
i powołanie konkretnej podstawy prawnej właściwej dla ochrony ich praw. Regulacje wynikające z projektu mają za zadanie wzmocnić ochronę praw podatnika poprzez ich usystematyzowanie $\mathrm{w}$ formie zasad prawa podatkowego. Założeniem jest, by normy zapisane w Karcie były stosowane łącznie z innymi normami albo bezpośrednio i samodzielnie. Pełnić mają zatem funkcję urzeczywistniającą oraz poszerzającą zakres ochrony praw zagwarantowanych w obszarze prawa podatkowego.

Regulacja nie stanowi efektu zaleceń Unii Europejskiej. Na gruncie międzynarodowym podejmowano próby sformułowania uniwersalnych katalogów praw podatnika, jednakże nie mają one charakteru wiążącego. Cel ustawy jest konkretny, natomiast trudno mierzalny.

\section{Planowane środki (narzędzia i działania) realizacji celów}

Projektodawcy proponują wprowadzenie Karty Praw Podatnika w formie odrębnego dokumentu, mającego charakter normatywny (ustawa). Argumentując konieczność przyjęcia projektu w formie ustawy, wskazano, że siła oddziaływania na praktykę stosowania prawa podatkowego będzie istotnie wyższa niż w przypadku przyjęcia innego dokumentu o charakterze deklaratoryjnym wydanym przez organy administracji podatkowej. Jako świadczący o tym przykład podano opublikowaną przez Ministerstwo Finansów w 2018 r. informację Uprawnienia i obowiązki podatników $w^{2}$, stanowiącą swoisty zbiór praw podatnika, która - ze względu na swój niewiążący charakter - ma marginalne znaczenie dla praktyki stosowania prawa podatkowego i niemalże nie funkcjonuje $\mathrm{w}$ świadomości podatników. Dlatego też, w ocenie projektodawcy, najlepszym rozwiązaniem ma być przyjęcie formy ustawy, ale znacznie krótszej i napisanej prostszym językiem niż inne akty prawne $\mathrm{z}$ zakresu prawa podatkowego, tj. bardziej przystępnym i zrozumiałym dla przeciętnego podatnika.

Zwiększaniu świadomości i popularyzacji Karty Praw Podatnika sprzyjać ma również wynikający z art. 2 ust 2 projektu obowiązek doręczenia każdemu podatnikowi (a także innemu podmiotowi, którego prawa i obowiązki są regulowane przepisami prawa podatkowego) egzemplarza Karty przy wszczęciu postępowania podatkowego, kontroli podatkowej oraz kontroli celno-skarbowej, jak również jej publikacja na stronach internetowych organów podatkowych.

Proponuje się również przyjęcie mechanizmów, które mają pozwolić na monitorowanie zakresu naruszeń praw podatników przez organy podatkowe oraz przekazywania tych informacji właściwym instytucjom i organom (również tym, które bezpośrednio odpowiedzialne są za jakość stanowionego prawa podatkowego).

2 Https://www.podatki.gov.pl/abc-podatkow/uprawnienia-i-obowiazki-podatnika/ [dostęp 8 stycznia 2020 r.] 
Alternatywą dla proponowanego rozwiązania są obowiązujące dzisiaj regulacje normujące prawa podatnika i odpowiadające im obowiązki organów podatkowych, które mają charakter bardziej rozproszony, ponieważ wynikają tak z Konstytucji, jak i ustawy - Ordynacja podatkowa. Alternatywę zaś dla zaproponowanej ustawowej formy omawianej Karty mógłby stanowić dokument o charakterze deklaratoryjnym, który przybrałby postać np. broszury informacyjnej czy deklaracji, w treści której określone i opisane byłyby prawa podatników oraz odpowiadające im obowiązki organów podatkowych wraz z powołaniem właściwej podstawy prawnej znajdującej się w obowiązujących przepisach Konstytucji oraz Ordynacji podatkowej. Broszura - podobnie jak w proponowanym w projekcie rozwiązaniu - mogłaby być przesyłana na etapie wszczęcia postępowania podatkowego, kontroli podatkowej czy kontroli celno-skarbowej podatnikowi (oraz innym podmiotom wymienionym w projekcie), co przyczyniałoby się w sposób bezpośredni do poszerzenia świadomości podatników co do przysługujących im praw oraz do realizacji celów projektu. Takie rozwiązanie wymagałoby również nowelizacji ustawy - Ordynacja podatkowa w zakresie, w jakim projekt co do niektórych wymienionych w Karcie praw przewiduje bardziej korzystne niż dotychczasowe rozwiązania. Kolejno, wysoce pożądanym rozwiązaniem (w miejsce mnożenia regulacji prawnych) mogłoby być także położenie zdecydowanego nacisku na kształcenie i edukowanie pracowników aparatu skarbowego odpowiedzialnych bezpośrednio za stosowanie przepisów prawa podatkowego, mające na celu podniesienie kultury administrowania, jak również prowadzenie kampanii informacyjnych w celu zwiększenia świadomości prawnej podatników, co do przysługujących im praw i obowiązków ciążących na właściwych organach.

\section{Ocena kosztów i korzyści}

\section{Skutki prawne}

Pozytywnie należy ocenić projektowane rozszerzenie zakresu podmiotowego ochrony praw podatników także na innych uczestników postępowania podatkowego, w tym płatników, inkasentów, osoby trzecie odpowiedzialne za zaległości podatkowe oraz następców prawnych.

Pewne wątpliwości może budzić jednakże przyjęta przez projektodawcę forma ustanowienia Karty Praw Podatnika w drodze ustawy, a to z uwagi na obowiązujące $\mathrm{w}$ zakresie zasad techniki prawodawczej postanowienia rozporządzenia Prezesa Rady Ministrów z 20 czerwca 2002 r. w sprawie „Zasad techniki prawodawczej” (t.j. Dz.U. 2016, poz. 283; dalej: rozporządzenie). Stosownie do postanowień $₫ 4$ ust. 1 przywołanego rozporządzenia: ustawa nie może powtarzać przepisów zamieszczonych w innych ustawach. Tymczasem zaproponowana przez projektodawcę Karta w części (zwłaszcza w zakresie, w jakim stanowi właśnie o prawach podatników i odpowiadających im obowiązkach organów podatko- 
wych), stanowi odzwierciedlenie obowiązujących na dziś w tej materii regulacji prawnych, zamieszczonych przede wszystkim w ustawie - Ordynacja podatkowa. Przykładowo wskazać można, że:

- obowiązujący art. $121 \$ 1$ Ordynacji podatkowej stanowi, że: Postępowanie podatkowe powinno być prowadzone $w$ sposób budzący zaufanie do organów podatkowych, zaś odpowiadający jego treści art. 13 ust. 2 projektu ma przyjąć brzmienie: Organy podatkowe i sady rozstrzygając sprawę podatkowa maja obowiązek działać w sposób budzący zaufanie, kierując się zasadami bezstronności i równego traktowania,

- obowiązujący art. $125 \$ 1$ Ordynacji podatkowej stanowi, że: Organy podatkowe powinny działać w sprawie wnikliwie i szybko, postugując się możliwie najprostszymi środkami prowadzacymi do jej załatwienia, zaś odpowiadający jego treści art. 14 ust. 1 projektu ma otrzymać brzmienie: Organy podatkowe mają obowiązek działać w sprawie wnikliwie i szybko, dążac do ograniczenia kosztów własnych i kosztów podatnika,

- obowiązujący art. 2a Ordynacji podatkowej stanowi, że: Niedające się usunąć watpliwości co do treści przepisów prawa podatkowego rozstrzyga się na korzyść podatnika, zaś odpowiadający mu art. 6 ust. 4 projektu ma otrzymać brzmienie: Niedające się usunać wątpliwości co do treści normy prawa podatkowego rozstrzyga się na korzyść podatnika.

$\mathrm{Z}$ uzasadnienia projektu można wywnioskować, że takie działanie było zabiegiem celowym, ponieważ: podstawowym zadaniem proponowanej karty nie jest przyznanie podatnikom nowych praw, bo te wynikaja już z Konstytucji, a także $z$ ustaw szczególowych prawa proceduralnego i materialnego. Karta ma zadanie wzmocnić ochronę tych praw, poprzez usystematyzowanie ich $w$ formie zasad systemu prawa podatkowego (uzasadnienie projektu, s. 11). Normy przyjęte przez projektodawcę, jako wyrażone w prawie pozytywnym, mają cechować się szczególną doniosłością dla systemu prawa podatkowego jako całości, poszczególnych jego części i instytucji. Projektodawca, argumentując o konieczności przyjęcia Karty w formie ustawy, wskazał, że: siła oddziaływania na praktykę stosowania prawa podatkowego karty o charakterze normatywnym będzie z pewnościa większa, niż gdyby poprzestać na dokumencie deklaratywnym pochodzacym od administracji podatkowej (uzasadnienie projektu, s. 9). Należy jednak zauważyć, że powielanie treści niektórych przepisów Ordynacji podatkowej może paradoksalnie nastręczać trudności także samym podatnikom oraz ich pełnomocnikom, w tym sensie, że $\mathrm{w}$ trakcie sporu $\mathrm{z}$ organem podatkowym konieczne będzie powołanie się na treść obu przepisów prawnych, tj. wynikających z ustawy - Ordynacja podatkowa oraz pomocniczo - opiniowanej ustawy, często o analogicznej treści (okoliczność ta nabierze szczególnego znaczenia zwłaszcza na etapie składania skargi kasacyjnej). Dodatkowym utrudnieniem może być również okoliczność, że w opiniowanym brzmieniu Karty część jej postanowień w sposób nie do koń- 
ca precyzyjny odzwierciedla treść przepisów ustawy, co może utwierdzić podatnika w przekonaniu o istnieniu normy prawnej bardziej korzystnej dla niego niż wynikająca z przepisów obowiązującego prawa. Powyższe obrazuje np. treść art. 21 Karty, w świetle której wniesienie środka zaskarżenia nie może pogarszać sytuacji podatnika w postępowaniu administracyjnym i sądowym w sprawach podatkowych, podczas gdy art. 234 Ordynacji podatkowej przewiduje wyjątki od zasady zakazu reformationis in peius. W konsekwencji, w razie uchwalenia Karty, w obrocie prawnym zaistniałyby dwa niezgodne ze sobą przepisy rangi ustawowej. W związku z powyższym w Karcie powinny zostać poczynione stosowne zastrzeżenia, aby podatnik był świadom, że dla ustalenia zakresu swoich praw winien dokonać wykładni przepisów Karty oraz ustawy - Ordynacja podatkowa.

Ponadto nie ma wątpliwości, że uchwalenie Karty w formie ustawowej sprzyjać będzie wzrostowi świadomości podatników co do przysługujących im praw, natomiast w żadnej mierze nie zagwarantuje wzrostu kultury administrowania przez organy podatkowe. W tej materii: z uwagi na charakter tych praw właściwa płaszczyzna ich ochrony jest sfera pozaprawna, gdzie należy podejmować działania w zakresie wzrostu świadomości i kultury prawnej wśród pracowników aparatu skarbowego i podatników $w^{3}$. Tym samym, zapewnienie poszanowania praw podatników i obowiązków ciążących na organach podatkowych możliwe byłoby dzięki prowadzeniu działań szkoleniowych i edukacyjnych wśród podmiotów bezpośrednio odpowiedzialnych za stosowanie prawa podatkowego bądź realizację zaproponowanego wyżej alternatywnego rozwiązania. Wydaje się bowiem, że problemem nie jest brak normatywnego katalogu praw podatników (te wynikają już bowiem z ustawy oraz Konstytucji RP), ale brak świadomości podatników oraz stosowanie prawa przez organy podatkowe w sposób prowadzący niejednokrotnie do ich naruszenia.

W odniesieniu do powyższych wątpliwości należy wskazać jednak, że, po pierwsze, Karta w projektowanym kształcie nie stanowi jedynie powielenia treści niektórych przepisów Ordynacji podatkowej (a tym samym praw przysługujących podatnikom), ale spełnia również inne zadania, które projektodawca przed nią postawił. Przede wszystkim w przyjętej formie prowadzi do usystematyzowania praw podatników oraz obowiązków organów podatkowych i powoduje, że stają się one bardziej czytelne i dostępne dla stron postępowania podatkowego. Ponadto projektowane przepisy uszczegóławiają dotychczasowe przepisy, a niekiedy także rozszerzają ich zakres, co pozytywnie wpływa na wzmocnienie pozycji podatnika jako słabszej strony postępowania (zob. art. 9 ust. 3 projektu, który stanowi, że na korzyść podatnika należy rozstrzygać także niedające usunąć się wątpliwości co do stanu faktycznego).

3 H. Dzwonkowski, M. Duda, J. Gorąca, Zakres i treść istniejącej i pożądanej ochrony praw podatnika (ustalenia de lege lata i postulaty de lege ferenda) [w:] Dylematy reformy systemu podatkowego w Polsce, red. H. Dzwonkowski, J. Kulicki, Warszawa 2016, s. 308. 
Po drugie zaś, należy zwrócić uwagę na charakter przywołanych wcześniej zasad techniki prawodawczej. W orzecznictwie Trybunału Konstytucyjnego wskazuje się, że istota znaczenia zasad techniki prawodawczej sprowadza się do tego, iż stanowią one: prakseologiczny kanon, który powinien być respektowany przez ustawodawce demokratycznego państwa prawnego $o^{4}$. Jak trafnie wskazuje się w literaturze przedmiotu, mimo że zasady te są w Polsce zawarte w akcie normatywnym, to nie stanowią klasycznych dyrektyw o charakterze normatywnym, ale raczej zbiór wytycznych, czyli reguł wskazujących, jak poprawnie konstruować akty normatywne ${ }^{5}$. Nie przewidziano bowiem za ich naruszenie jakichkolwiek sankcji. Innymi słowy, odstępstwo od przewidzianych w przywołanym rozporządzeniu zasad uzasadnione może być brakiem ich wiążącego charakteru i jako takie - nie sprzeciwia się w sposób bezwzględny uchwaleniu omawianego projektu w proponowanych kształcie, choć stanowi ich naruszenie skutkujące istotnym obniżeniem poziomu legislacji.

Powyższe oznacza, że mimo wątpliwości, jakie mogą powstać co do zgodności projektu z rozporządzeniem regulującym zasady techniki prawodawczej, pozytywnie należy ocenić cel, jaki mu przyświeca. Istotnym założeniem jest bowiem, by Karta stanowiła swoiste kompendium wiedzy na temat praw podatnika i odpowiadających im obowiązków organów podatkowych oraz by przyczyniała się do wzrostu świadomości prawnej podatników oraz innych wskazanych w projekcie podmiotów, nie wprowadzając ich jednocześnie w błąd co do obowiązującego stanu prawnego.

W odniesieniu zaś do projektowanego art. 27 należy wskazać, że przewiduje on obowiązek przekazywania przez samorządowe organy podatkowe corocznych sprawozdań o przestrzeganiu praw podatnika na rzecz organów stanowiących jednostek samorządu terytorialnego, jednak $\mathrm{z}$ omawianego projektu nie wynika jakoby informacje te - poza ich gromadzeniem - miały jakiekolwiek potencjalne możliwości wywarcia wpływu na proces legislacyjny i ewentualne zmiany w prawie. W projekcie nie uregulowano bowiem dalszych losów tych sprawozdań, poza wskazaniem, że są one przekazywane organowi stanowiącemu jednostki samorządu terytorialnego i przez niego gromadzone.

\section{Skutki społeczne}

Projekt $\mathrm{z}$ dużym prawdopodobieństwem spotka się z pozytywnym odbiorem społecznym, może wpłynąć na zwiększenie świadomości podatników (oraz innych uczestników postępowania podatkowego) co do przysługujących im w toku tego postępowania praw, a ponadto może w sposób pozytywny wpływać na wzrost zaufania podatników do działań organów podatkowych.

4 Zob. wyrok TK z 21 marca 2001 r., sygn. akt K 24/00, OTK ZU 2001, nr 3, poz. 51.

5 S. Wronkowska, O meandrach skuteczności nowych zasad techniki prawodawczej, „Przegląd Legislacyjny” 2004, nr 4, s. 11. 
Biorąc pod uwagę polskie doświadczenia, świadomość prawną polskich podatników oraz stan polskiego prawa podatkowego, zdefiniowanie omawianego katalogu praw podatników w postaci Karty ma swoje uzasadnienie i zostanie w sposób przychylny przyjęty przez społeczeństwo. Jednakże w przypadku rozbieżności pomiędzy treścią przepisów ustawy - Ordynacja podatkowa (na co wskazano również przy opisie „Skutków prawnych” projektu) a treścią Karty mogą jednak wprowadzać podatnika w błąd, co może skutkować obniżeniem poziomu zaufania podatnika do państwa i stanowionego przezeń prawa.

\section{Skutki administracyjno-organizacyjne}

Projekt może wpłynąć na zwiększenie liczby obowiązków ciążących między innymi na:

- sądach administracyjnych - w zakresie, w jakim przewiduje on obowiązek informowania ministra właściwego do spraw finansów publicznych o każdym dostrzeżonym rażącym naruszeniu praw podatnika przez organy podatkowe (art. 25 projektu),

- ministrze właściwym do spraw finansów publicznych - w zakresie, w jakim przewiduje on obowiązek gromadzenia oraz analizy informacji przekazywanych przez sądy administracyjne (art. 25 projektu) i pełnomocników (z art. 17 ust. 3 projektu) oraz składania Sejmowi corocznego sprawozdania o przestrzeganiu praw podatnika,

- Rzeczniku Praw Obywatelskich - w zakresie, w jakim przewiduje on obowiązek gromadzenia oraz analizy danych przekazywanych przez pełnomocników dotyczących rażącego naruszenia praw podatników (art. 17 ust. 3 projektu) oraz możliwość realizacji uprawnień przewidzianych w art. 28 projektu, zakładających m.in. możliwość formułowania ocen, wniosków i rekomendacji, a także żądania wyjaśnień od organów podatkowych,

- samorządowych organach podatkowych - w zakresie, w jakim przewiduje on obowiązek składania organowi stanowiącemu jednostki samorządu terytorialnego sprawozdania o przestrzeganiu praw podatnika,

- organach stanowiących jednostek samorządu terytorialnego - w zakresie, w jakim przewiduje on obowiązek gromadzenia sprawozdań o przestrzeganiu praw podatnika,

- organach administracji podatkowej - w zakresie, w jakim przewiduje on obowiązek przesyłania podatnikom (i innym podmiotom wymienionym w projekcie) egzemplarza Karty przy wszczęciu postępowania podatkowego, kontroli podatkowej oraz kontroli celno-skarbowej.

Powyższe oznacza, że realizacja wskazanych obowiązków może wiązać się dla tych podmiotów z koniecznością reorganizacji pracy dotychczas zatrudnianych pracowników lub - w zależności od liczby i zakresu dostrzeżonych rażących naruszeń praw podatników - w ostateczności także z koniecznością zatrudnienia 
dodatkowego pracownika do obsługi zadań wynikających z projektu bądź pokrycia kosztów związanych np. ze zleceniem podmiotowi zewnętrznemu opracowania sprawozdania o przestrzeganiu praw podatnika.

\section{Skutki finansowe}

W opiniowanym projekcie zaproponowano, by w celu wzrostu świadomości podatników (i innych wymienionych tam podmiotów) co do przysługujących im praw zobligować organy podatkowe, by każdorazowo na etapie wszczęcia postępowania podatkowego, kontroli podatkowej oraz kontroli celno-skarbowej przesyłały im egzemplarz Karty. Projektodawca nie wskazał jednak, jakie koszty dla budżetu państwa może pociągnąć takie rozwiązanie, niemniej można oczekiwać, że nie będą one stanowily istotnego obciążenia dla budżetu państwa.

Można również spodziewać się, że pewne obciążenia po stronie budżetowej mogłyby również (o ile w praktyce będzie to konieczne - co jest na obecnym etapie trudne do przewidzenia i zależne od ilości zgłaszanych w przyszłości naruszeń praw podatników) wiązać się z koniecznością zatrudnienia dodatkowych pracowników, w celu zagwarantowania realizacji zadań wynikających z przyjęcia projektu.

\section{Podsumowanie - ogólna ocena projektu}

W obliczu stosunkowo niskiej kultury administrowania przez organy podatkowe odpowiedzialne za przestrzeganie i poszanowanie praw podatników zasadne jest podejmowanie wszelkich kroków zmierzających do, po pierwsze, zwiększenia świadomości podatników co do przysługujących im praw, po drugie zaś, do wzrostu tej kultury u podmiotów stosujących prawo. Wątpliwości budzi natomiast proponowana przez projektodawców forma Karty (forma ustawowa) $\mathrm{z}$ uwagi na zastrzeżenia poczynione w opisie skutków prawnych projektu. Warto zatem rozważyć alternatywne rozwiązania w postaci np. przyjęcia aktu o charakterze deklaratoryjnym, stanowiącym zbiór praw podatników i odpowiadających im uprawnień organów podatkowych (wraz z podaniem odpowiedniej podstawy prawnej), który - tak jak w proponowanym rozwiązaniu byłby przesyłany do podatnika (i innych podmiotów) każdorazowo na etapie wszczęcia postępowania podatkowego, kontroli podatkowej lub kontroli celno-skarbowej, oraz dokonanie odpowiedniej nowelizacji ustawy - Ordynacja podatkowa. Ostatecznie należy również ocenić, że realizacja celu zakładanego przez projektodawcę jest wysoce pożądana. Z pewnością spotkałaby się z pozytywnym odbiorem społecznym i mogła w sposób bezpośredni przyczynić się do wzrostu zaufania podatników do organów stosujących prawo podatkowe. 


\section{Bibliografia}

Dzwonkowski H., Duda M., Gorąca J., Zakres i treść istniejącej i pożądanej ochrony praw podatnika (ustalenia de lege lata i postulaty de lege ferenda) [w:] Dylematy reformy systemu podatkowego w Polsce, red. H. Dzwonkowski, J. Kulicki, Warszawa 2016.

Wronkowska S., O meandrach skuteczności nowych zasad techniki prawodawczej, „Przegląd Legislacyjny" 2004, nr 4. 
Jacek Kulicki

\title{
Ocena zasad opodatkowania podatkiem od nieruchomości gruntów, budynków i budowli należących do spółdzielni mieszkaniowej ${ }^{1}$
}

\author{
Assessment of the principles of real estate tax on land, buildings and \\ structures belonging to a housing cooperative
}

A housing cooperative that owns a real estate or a construction object and a perpetual usufructuary of land is a taxpayer regarding the real estate tax, except that it is paid according to different rates. In case of land and buildings related to business operations, the tax is calculated at higher rates. In the author's opinion, the statutory phrase "buildings related to conducting business activities" should be understood as a fact of an actual use of a residential building for such activities. Keywords: tax, premise, housing cooperative

Spółdzielnia mieszkaniowa będąca właścicielem nieruchomości lub obiektów budowlanych oraz użytkownikiem wieczystym gruntów jest podatnikiem podatku od nieruchomości, z tym że podatek ten opłacany jest według różnych stawek. W przypadku gruntów i budynków związanych z prowadzeniem działalności gospodarczej podatek wyliczany jest według wyższych stawek. W ocenie autora przez ustawowy zwrot „budynki związane z prowadzeniem działalności gospodarczej" należy rozumieć okoliczność polegającą na faktycznym wykorzystywaniu części budynku mieszkalnego na prowadzenie takiej działalności.

Słowa kluczowe: podatek, lokal, spółdzielnia mieszkaniowa

Doktor nauk prawnych, ekspert ds. finansów publicznych Biura Analiz Sejmowych • Kancelaria Sejmu, Wydział Analiz Społecznych i Ekonomicznych, Zespół Studiów Ekonomicznych, WARSZAWA, POLSKA • jacek.kulicki@sejm.gov.pl • https://orcid.org/0000-0003-2631-6428

\section{Przedmiot opinii}

Przedmiotem opinii jest odpowiedź na następujące pytania:

- „czy - w świetle obowiązujących przepisów - nieruchomości należące do spółdzielni mieszkaniowej, związane z działalnością gospodarczą, podlegają opodatkowaniu podatkiem od nieruchomości?",

1 Opinia prawna na temat zasad opodatkowania podatkiem od nieruchomości gruntów, budynków i budowli należących do spółdzielni mieszkaniowej sporządzona 8 sierpnia 2019 r. na zlecenie posła Klubu Parlamentarnego Platforma Obywatelska - Koalicja Obywatelska; BAS-WASiE 1636/19. 
- „czy powyższy stan rzeczy odnosi się również do nieruchomości, które służą obsłudze lokali mieszkalnych, tak należących do spółdzielców, jak i wynajmowanych na cele mieszkaniowe przez najemców, czy również tych posiadanych przez spółdzielnię, które służą zaspokojeniu potrzeb mieszkaniowych oraz innych potrzeb (m.in. lokale restauracyjne, sklepy, działki rekreacyjne)?”.

\section{Analiza kwestii sformułowanych w pytaniach}

Obowiązek podatkowy w podatku od nieruchomości kształtuje ustawa z 12 stycznia 1991 r. o podatkach i opłatach lokalnych (t.j. Dz.U. 2019, poz. 1170, ze zm.; dalej: u.p.lok.).

Zgodnie $\mathrm{z}$ art. 2 ust. 1 u.p.lok. opodatkowaniu tym podatkiem podlegają grunty (pkt 1), budynki lub ich części (pkt 2) oraz budowle lub ich części związane $\mathrm{z}$ prowadzeniem działalności gospodarczej (pkt 3).

Zgodnie $\mathrm{z}$ art. 3 ust. 1 u.p.lok. podatnikami tego podatku są osoby fizyczne, osoby prawne oraz jednostki organizacyjne nieposiadające osobowości prawnej, będące ${ }^{2}$ :

- właścicielami nieruchomości lub obiektów budowlanych ${ }^{3}$,

- posiadaczami samoistnymi nieruchomości lub obiektów budowlanych,

- użytkownikami wieczystymi gruntów.

Jeżeli nieruchomość lub obiekt budowlany stanowi współwłasność lub znajduje się w posiadaniu dwóch lub więcej podmiotów, to - zgodnie z art. 3 ust. 4 u.p.lok. - stanowi odrębny przedmiot opodatkowania, a obowiązek podatkowy od nieruchomości lub obiektu budowlanego ciąży (z pewnymi zastrzeżeniami,

2 Poza wymienionymi przypadkami obowiązek podatkowy ciąży również na podmiotach będących posiadaczami nieruchomości lub ich części albo obiektów budowlanych lub ich części, stanowiących własność Skarbu Państwa lub jednostki samorządu terytorialnego, jeżeli posiadanie: a) wynika z umowy zawartej z właścicielem, Krajowym Ośrodkiem Wsparcia Rolnictwa lub z innego tytułu prawnego, z wyjątkiem posiadania przez osoby fizyczne lokali mieszkalnych niestanowiących odrębnych nieruchomości, b) jest bez tytułu prawnego. Zgodnie z art. 3 ust. 2 u.p.lok. obowiązek podatkowy dotyczący w tym przypadku przedmiotów opodatkowania wchodzących w skład Zasobu Własności Rolnej Skarbu Państwa lub będących w zarządzie Państwowego Gospodarstwa Leśnego Lasy Państwowe ciąży odpowiednio na jednostkach organizacyjnych Krajowego Ośrodka Wsparcia Rolnictwa i jednostkach organizacyjnych Lasów Państwowych, faktycznie władających nieruchomościami lub obiektami budowlanymi.

3 Zgodnie $\mathrm{z}$ art. 3 ust. 3 u.p.lok. w związku z art. 3 ust. 1 pkt 1 u.p.lok., jeżeli przedmiot opodatkowania znajduje się w posiadaniu samoistnym, obowiązek podatkowy w zakresie podatku od nieruchomości ciąży na posiadaczu samoistnym. 
zob. art. 3 ust. 4a-6 u.p.lok.) solidarnie na wszystkich współwłaścicielach lub posiadaczach.

Jeśli wyodrębniono własność lokali, obowiązek podatkowy w zakresie podatku od nieruchomości od gruntu oraz od części budynku stanowiących nieruchomość wspólną w rozumieniu art. 3 ustawy o własności lokali ${ }^{4}$ ciąży na właścicielach w zakresie odpowiadającym ich udziałowi w nieruchomości wspólnej (art. 3 ust. 5 u.p.lok.).

Podstawę opodatkowania podatkiem od nieruchomości stanowi:

- dla gruntów - powierzchnia (art. 4 ust. 1 pkt 1 u.p.lok.),

- dla budynków lub ich części - powierzchnia użytkowa (art. 4 ust. 1 pkt 2 i ust. 2 u.p.lok.),

- dla budowli lub ich części związanych z prowadzeniem działalności gospodarczej - wartość, o której mowa w przepisach o podatkach dochodowych ${ }^{5}$, ustalona na dzień 1 stycznia roku podatkowego, stanowiąca podstawę obliczania amortyzacji w tym roku, niepomniejszona o odpisy amortyzacyjne, a w przypadku budowli całkowicie zamortyzowanych - ich wartość z dnia 1 stycznia roku, w którym dokonano ostatniego odpisu amortyzacyjnego (art. 4 ust. 1 pkt 3 i ust. $4-9$ u.p.lok.).

Stawki podatku od nieruchomości określa w drodze uchwały rada gminy, przy czym stawki te nie mogą być wyższe od stawek maksymalnych wynikających $\mathrm{z}$ art. 5 ust. 1 u.p.lok.

Zgodnie $\mathrm{z}$ art. 1a ust. 1 u.p.lok. ustawodawca dla celów podatku od nieruchomości uznaje za:

4 Ustawa z 24 czerwca 1994 r., t.j. Dz.U. 2019, poz. 737. Zgodnie z art. 3 ust. 1 tej ustawy w razie wyodrębnienia własności lokali właścicielowi lokalu przysługuje udział w nieruchomości wspólnej jako prawo związane z własnością lokali, przy czym nie można żądać zniesienia współwłasności nieruchomości wspólnej, dopóki trwa odrębna własność lokali. Nieruchomość wspólną stanowi grunt oraz części budynku i urządzenia, które nie służą wyłącznie do użytku właścicieli lokali (zob. art. 3 ust. 2), zaś udział właściciela lokalu wyodrębnionego w nieruchomości wspólnej odpowiada stosunkowi powierzchni użytkowej lokalu wraz z powierzchnią pomieszczeń przynależnych do łącznej powierzchni użytkowej wszystkich lokali wraz z pomieszczeniami do nich przynależnymi (art. 3 ust. 3). Jeżeli nieruchomość, z której wyodrębnia się własność lokali, stanowi grunt zabudowany kilkoma budynkami, udział właściciela lokalu wyodrębnionego w nieruchomości wspólnej odpowiada stosunkowi powierzchni użytkowej lokalu wraz z powierzchnią pomieszczeń przynależnych do łącznej powierzchni użytkowej wszystkich lokali wraz z pomieszczeniami do nich przynależnymi (art. 3 ust. 5).

5 Zob. art. 16g ustawy z 15 lutego 1992 r. o podatku dochodowym od osób prawnych (t.j. Dz.U. 2019, poz. 865, ze zm.) oraz art. 22g ustawy z 26 lipca 1991 r. o podatku dochodowym od osób fizycznych (t.j. Dz.U. 2018, poz. 1509, ze zm.). 
- budynek - obiekt budowlany w rozumieniu przepisów prawa budowlanego ${ }^{6}$, który jest trwale związany z gruntem, wydzielony z przestrzeni za pomocą przegród budowlanych oraz posiada fundamenty i dach (pkt 1),

- budowlę - obiekt budowlany w rozumieniu przepisów prawa budowlanego niebędący budynkiem lub obiektem małej architektury, a także urządzenie budowlane w rozumieniu przepisów prawa budowlanego związane $\mathrm{z}$ obiektem budowlanym, które zapewnia możliwość użytkowania obiektu zgodnie $z$ jego przeznaczeniem (pkt 2$)^{7}$,

- grunty, budynki i budowle związane z prowadzeniem działalności gospodarczej - grunty, budynki i budowle będące w posiadaniu przedsiębiorcy lub innego podmiotu prowadzącego działalność gospodarczą (pkt 3), z tym że zgodnie z art. 1a ust. 2a pkt 1 u.p.lok. - nie zalicza się do nich m.in. budynków mieszkalnych oraz gruntów związanych z tymi budynkami,

- działalność gospodarczą - działalność, o której mowa w ustawie z 6 marca 2018 r. - Prawo przedsiębiorców (t.j. Dz.U. 2019, poz. 1292) ${ }^{8}$, z tym że za działalność gospodarczą w rozumieniu ustawy o podatkach i opłatach lokalnych nie uważa się: a) działalności rolniczej lub leśnej, b) wynajmu turystom pokoi gościnnych w budynkach mieszkalnych znajdujących się na obszarach wiejskich przez osoby ze stałym miejscem pobytu w gminie położonej na tym terenie, jeżeli liczba pokoi przeznaczonych do wynajęcia nie przekracza 5, c)

$6 \quad$ Ustawa z 7 lipca 1994 r. - Prawo budowlane, t.j. Dz.U. 2019, poz. 1186, ze zm.

7 Zgodnie z art. 3 pkt 3 ustawy - Prawo budowlane za budowlę uznawany jest każdy obiekt budowlany niebędący budynkiem lub obiektem małej architektury, jak: obiekty liniowe, lotniska, mosty, wiadukty, estakady, tunele, przepusty, sieci techniczne, wolno stojące maszty antenowe, wolno stojące trwale związane $\mathrm{z}$ gruntem tablice reklamowe i urządzenia reklamowe, budowle ziemne, obronne (fortyfikacje), ochronne, hydrotechniczne, zbiorniki, wolno stojące instalacje przemysłowe lub urządzenia techniczne, oczyszczalnie ścieków, składowiska odpadów, stacje uzdatniania wody, konstrukcje oporowe, nadziemne i podziemne przejścia dla pieszych, sieci uzbrojenia terenu, budowle sportowe, cmentarze, pomniki, a także części budowlane urządzeń technicznych (kotłów, pieców przemysłowych, elektrowni jądrowych, elektrowni wiatrowych i innych urządzeń) oraz fundamenty pod maszyny i urządzenia jako odrębne pod względem technicznym części przedmiotów składających się na całość użytkową. Zgodnie z art. 3 pkt 3a ustawy - Prawo budowlane obiektem liniowym jest obiekt budowlany, którego charakterystycznym parametrem jest długość, w szczególności droga wraz ze zjazdami, linia kolejowa, wodociąg, kanał, gazociąg, ciepłociąg, rurociąg, linia i trakcja elektroenergetyczna, linia kablowa nadziemna i, umieszczona bezpośrednio w ziemi, podziemna, wał przeciwpowodziowy oraz kanalizacja kablowa, przy czym kable w niej zainstalowane nie stanowią obiektu budowlanego lub jego części ani urządzenia budowlanego.

8 Zgodnie z art. 3 ustawy - Prawo przedsiębiorców działalnością gospodarczą jest zorganizowana działalność zarobkowa, wykonywana we własnym imieniu i w sposób ciągły. 
sprzedaży przetworzonych w sposób inny niż przemysłowy produktów roślinnych lub zwierzęcych $\mathrm{w}$ warunkach określonych $\mathrm{w}$ art. 20 ust. 1c ustawy o podatku dochodowym od osób fizycznych.

Jak wynika z przywołanych przepisów obowiązek podatkowy w podatku od nieruchomości ciąży na każdej osobie fizycznej, osobie prawnej lub jednostce organizacyjnej nieposiadającej osobowości prawnej będącej właścicielem lub posiadaczem samoistnym nieruchomości lub obiektów budowlanych, użytkownikiem wieczystym gruntów lub posiadaczem nieruchomości lub ich części albo obiektów budowlanych lub ich części, stanowiących własność Skarbu Państwa lub jednostki samorządu terytorialnego w warunkach określonych w art. 3 ust. 1 pkt 4 u.p.lok.

Zgodnie z art. $1 \$ 1$ ustawy z 16 września 1982 r. - Prawo spółdzielcze (t.j. Dz.U. 2018, poz. 1285, ze zm.; dalej: u.pr.sp.), spółdzielnia jest dobrowolnym zrzeszeniem nieograniczonej liczby osób, o zmiennym składzie osobowym i zmiennym funduszu udziałowym, które w interesie swoich członków prowadzi wspólną działalność gospodarczą. Jednocześnie, zgodnie z art. $1 \S 2$ tej ustawy spółdzielnia może prowadzić działalność społeczną i oświatowo-kulturalną na rzecz swoich członków i ich środowiska.

Zgodnie z art. $11 \S 1$ u.pr. sp. spółdzielnia nabywa osobowość prawną z chwilą wpisania jej do Krajowego Rejestru Sądowego.

Spółdzielnie należą więc do osób prawnych, na których ciąży obowiązek podatkowy w podatku od nieruchomości w zakresie określonym w ustawie o podatkach i opłatach lokalnych, prowadzących działalność gospodarczą na podstawie ustawy - Prawo spółdzielcze, innych ustaw i zarejestrowanego statutu.

Do spółdzielni mieszkaniowych zastosowanie mają - obok Prawa spółdzielczego - przepisy ustawy z 15 grudnia 2000 r. o spółdzielniach mieszkaniowych (t.j. Dz.U. 2018, poz. 845, ze zm.; dalej: u.sp.m.).

Celem spółdzielni mieszkaniowej jest zaspokajanie potrzeb mieszkaniowych i innych potrzeb członków oraz ich rodzin, przez dostarczanie członkom samodzielnych lokali mieszkalnych lub domów jednorodzinnych, a także lokali o innym przeznaczeniu (art. 1 ust. 1 u.sp.m.). Przedmiotem działalności spółdzielni mieszkaniowej może być (art. 1 ust. 2 u.sp.m.):

- budowanie lub nabywanie budynków w celu ustanowienia na rzecz członków spółdzielczych lokatorskich praw do znajdujących się w tych budynkach lokali mieszkalnych,

- budowanie lub nabywanie budynków w celu ustanowienia na rzecz członków odrębnej własności znajdujących się w tych budynkach lokali mieszkalnych lub lokali o innym przeznaczeniu, a także ułamkowego udziału we współwłasności w garażach wielostanowiskowych,

- budowanie lub nabywanie domów jednorodzinnych w celu przeniesienia na rzecz członków własności tych domów, 
- udzielanie pomocy członkom w budowie przez nich budynków mieszkalnych lub domów jednorodzinnych,

- budowanie lub nabywanie budynków w celu wynajmowania lub sprzedaży znajdujących się w tych budynkach lokali mieszkalnych lub lokali o innym przeznaczeniu.

Zgodnie z art. 1 ust. 3 u.sp.m. spółdzielnia ma obowiązek zarządzania nieruchomościami stanowiącymi jej mienie lub nabyte na podstawie ustawy mienie jej członków. Co istotne, statut spółdzielni określa, którą działalność spośród tych działalności (wymienionych przez ustawodawcę w art. 1 ust. 2 i 3 u.sp.m.) prowadzi spółdzielnia.

Spółdzielnia może również zarządzać nieruchomością niestanowiącą jej mienia lub mienia jej członków na podstawie umowy zawartej z właścicielem (współwłaścicielami) tej nieruchomości (art. 1 ust. 5 u.sp.m.). Może także prowadzić inną działalność gospodarczą na zasadach określonych w odrębnych przepisach i w statucie, jeżeli działalność ta związana jest bezpośrednio z realizacją celu założenia spółdzielni mieszkaniowej, a więc zaspokajania potrzeb mieszkaniowych i innych potrzeb członków oraz ich rodzin, przez dostarczanie członkom samodzielnych lokali mieszkalnych lub domów jednorodzinnych, a także lokali o innym przeznaczeniu (art. 1 ust. 6 u.sp.m.).

Analiza przywołanych przepisów Prawa spółdzielczego i ustawy o spółdzielniach mieszkaniowych wskazuje jednoznacznie, że spółdzielnia mieszkaniowa jest dobrowolnym zrzeszeniem nieograniczonej liczby osób, o zmiennym składzie osobowym i zmiennym funduszu udziałowym, które w interesie swoich członków prowadzi wspólną działalność gospodarczą, której celem jest zaspokajanie potrzeb mieszkaniowych i innych potrzeb członków oraz ich rodzin, przez dostarczanie członkom samodzielnych lokali mieszkalnych lub domów jednorodzinnych, a także lokali o innym przeznaczeniu (art. $1 \$ 1$ u.pr.sp. i art. 1 ust. 1 u.sp.m.). Przedmiotem tej działalności może być zarówno budowa, jak i nabywanie budynków w celach wskazanych w art. 1 ust. 2 u.sp.m., zarządzanie nieruchomościami stanowiącymi jej mienie lub nabytym na podstawie ustawy mieniem jej członków (art. 1 ust. 3 u.sp.m.), jak też zarządzanie nieruchomością niestanowiącą jej mienia lub mienia jej członków (art. 1 ust. 5 u.sp.m.) oraz prowadzenie innej działalności gospodarczej (art. 1 ust. 6 u.sp.m.). Spółdzielnia może również prowadzić działalność społeczną i oświatowo-kulturalną na rzecz swoich członków i ich środowiska (art. $1 \$ 2$ u.pr.sp.).

Spółdzielnia mieszkaniowa jest więc podmiotem prowadzącym działalność gospodarczą, co nie powinno budzić wątpliwości w świetle przytoczonych regulacji prawnych oraz orzecznictwa sądowego9.

9 Zob. m.in. również uchwały: SN z 11 lipca 2014 r., sygn. akt III CZP 33/14, http://www. sn.pl/sites/orzecznictwo/Orzeczenia3/III\%20CZP\%2033-14.pdf [dostęp 2 sierpnia 
Działalność gospodarczą spółdzielni mieszkaniowych różnicować można według różnych kryteriów, wyróżniając działalność skierowaną do członków i ich rodzin (na zaspokajanie ich potrzeb) i podmiotów zewnętrznych, działalność obligatoryjną (np. zarządzanie nieruchomościami stanowiącymi jej mienie lub nabytym na podstawie ustawy mieniem jej członków) i fakultatywną (np. zarządzanie nieruchomością niestanowiącą jej mienia lub mienia jej członków), czy też inwestycyjną (budowa lub nabywanie budynków) i związaną z bieżącym zarządzaniem mieniem spółdzielni i jej członków oraz dotyczącą budynków mieszkalnych i gruntów związanych z tymi budynkami i pozostałych budynków, budowli i gruntów.

W każdym przypadku spółdzielnia mieszkaniowa będąca właścicielem lub posiadaczem samoistnym nieruchomości lub obiektów budowlanych oraz użytkownikiem wieczystym gruntów jest podatnikiem podatku od nieruchomości. Podatek ten opłacany jest jednak według różnych stawek, w zależności od tego, czy przedmiotem opodatkowania są budynki mieszkalne oraz grunty związane $\mathrm{z}$ tymi budynkami, o których mowa $\mathrm{w}$ art. 1a ust. 2a pkt 1 u.p.lok., czy też nieruchomości i budowle kwalifikowane są do gruntów, budynków i budowli związanych $\mathrm{z}$ prowadzeniem działalności gospodarczej, zgodnie $\mathrm{z}$ art. 1a ust. 1 pkt 3 u.p.lok.

W pierwszym przypadku - budynków mieszkalnych oraz gruntów związanych z tymi budynkami - podatek opłacany jest według stawek wynikających $\mathrm{z}$ art. 5 ust. 1 pkt 1 lit. c u.p.lok. ${ }^{10}$, a więc dla gruntów pozostałych (w przypadku gruntów) oraz z art. 5 ust. 1 pkt 2 lit. a u.p.lok. ${ }^{11}$, a więc dla budynków mieszkalnych (w przypadku budynków mieszkalnych lub ich części) lub art. 5 ust. 1 pkt 2 lit. e u.p.lok. ${ }^{12}$, a więc dla budynków pozostałych (w przypadku części niemieszkalnych budynku mieszkalnego wielorodzinnego, stanowiących przedmiot odrębnej własności ${ }^{13}$.

W drugim przypadku - gruntów, budynków i budowli związanych z prowadzeniem działalności gospodarczej - podatek opłacany jest według stawek wyni-

2019 r.] oraz NSA z 27 lutego 2012 r., sygn. akt II FPS 4/11, http://orzeczenia.nsa.gov. $\mathrm{pl} /$ cbo/query [dostęp 2 sierpnia $2019 \mathrm{r}$.].

10 Obecnie maksymalna stawka nie może przekroczyć 0,49 zł od $1 \mathrm{~m}^{2}$. Zob. pkt 1 lit. a tiret trzecie obwieszczenia Ministra Finansów z 25 lipca 2018 r. w sprawie górnych granic stawek kwotowych podatków i opłat lokalnych na rok 2019 (MP poz. 745; dalej: ob.MF).

11 Obecnie maksymalna stawka nie może przekroczyć 0,79 zł od $1 \mathrm{~m}^{2}$, pkt 1 lit. b tiret pierwsze ob.MF.

12 Obecnie maksymalna stawka nie może przekroczyć 7,90 zł od $1 \mathrm{~m}^{2}$. Zob. pkt 1 lit. b tiret piąte ob.MF.

13 Zob. w odniesieniu do garaży uchwałę NSA z 27 lutego 2012 r., sygn. akt II FPS 4/11, http://orzeczenia.nsa.gov.pl/cbo/query [dostęp 2 sierpnia 2019 r.]. 
kających z art. 5 ust. 1 pkt 1 lit. a u.p.lok. ${ }^{14}$ (w przypadku gruntów), art. 5 ust. 1 pkt 2 lit. b u.p.lok. ${ }^{15}$ (w przypadku budynków niemieszkalnych oraz budynków mieszkalnych lub ich części zajętych na prowadzenie działalności gospodarczej) oraz art. 5 ust. 1 pkt 3 u.p.lok. ${ }^{16}$ (w przypadku budowli).

Jak wynika z ugruntowanej linii orzeczniczej sądów administracyjnych ustawowy zwrot „budynki związane z prowadzeniem działalności gospodarczej”: należy rozumieć jako okoliczność faktyczna polegajaca na rzeczywistym wykorzystywaniu (zajęciu) określonej części budynku mieszkalnego na prowadzenie działalności gospodarczej, tj. prowadzeniu w tej części budynku (np. w lokalu użytkowym) działalności gospodarczej w rozumieniu art. 1 a ust. 1 pkt 4 u.p.o.l. [ustawa o podatkach i opłatach lokalnych - dopisek J.K.] Za „zajęte na prowadzenie działalności gospodarczej" nie będa mogły być uznane natomiast te części budynku, które sa wykorzystywane (zajęte) na cele mieszkalne, nawet wówczas, gdy ich oddanie przez spółdzielnię (lub innego właściciela będącego przedsiębiorca) do korzystania osobom trzecim dla zaspokojenia ich potrzeb mieszkaniowych (zajęcie na cele mieszkalne), nastąiło w ramach gospodarczej działalności spółdzielni mieszkaniowej, jak również innego przedsiębiorcy (np. w drodze komercyjnego najmu lokalu mieszkalnego). [...] (Z) redakcji wskazanych unormowań nie wynika, by intencja ustawodawcy było objęcie powierzchni lokalu mieszkalnego (wykorzystywanego faktycznie tylko na cel mieszkalny) podatkiem przewidzianym dla budynków lub ich części związanych z prowadzeniem działalności gospodarczej, a to z tego powodu, że lokal taki został udostępniony członkowi spółdzielni mieszkaniowej, która obligatoryjnie zajmuje się jego zarządem, lub wynajęty najemcy przez podmiot prowadzacy działalność gospodarcza, polegająca na wynajmie lokali mieszkalnych. W konsekwencji zasadne staje się [...] stwierdzenie, że opodatkowanie będących w posiadaniu spółdzielni mieszkaniowej budynków, kwalifikowanych jako mieszkalne (jednorodzinne, dwurodzinne lub wielorodzinne), a to według stawek podatku od nieruchomości właściwych dla budynków związanych z prowadzeniem działalności gospodarczej, uzależnione jest od tego, czy budynki te lub ich czesści zostały zajęte na prowadzenie działalności gospodarczej w przedstawionym wyżej rozumieniu. Stosowanie przy tym najwyższych stawek podatkowych dotyczy tylko zajętej na ten cel powierzchni użytkowej budynku mieszkalnego ${ }^{17}$.

14 Obecnie maksymalna stawka nie może przekroczyć $0,93 \mathrm{zł} \mathrm{od} 1 \mathrm{~m}^{2}$. Zob. pkt 1 lit. a tiret pierwsze ob.MF.

15 Obecnie maksymalna stawka nie może przekroczyć $23,47 \mathrm{zł}$ od $1 \mathrm{~m}^{2}$. Zob. pkt 1 lit. b tiret drugie ob.MF.

16 Stawka podatku wynosi $2 \%$ wartości budowli przyjętej dla celów odpisów umorzeniowych w podatku dochodowym.

17 Wyrok WSA w Opolu z 16 listopada 2016 r., sygn. akt I SA/Op 370/16. Zob. również uchwałę NSA z 27 lutego 2012 r., sygn. akt II FPS 4/11, oraz wyroki NSA z: 15 stycznia 2013 r., sygn. akt II FSK 933/11; 18 grudnia 2013 r., sygn. akt II FSK 2767/11; 28 lipca 2016 r., sygn. akt II FSK 1795/14; 2 grudnia 2016 r., sygn. akt II FSK 3208/14; 
W orzecznictwie sądów administracyjnych ugruntowany jest również pogląd, że: przez grunty zwiąane $z$ budynkami mieszkalnymi należy rozumieć nie tylko grunty, na których taki obiekt budowlany został posadowiony, ale również grunty doń przylegające, zapewniające właściwe korzystanie z tego budynku, niezbędna obsługe budynku oraz jego mieszkańców, $w$ tym $w$ zakresie odpowiedniego skomunikowania, zabezpieczenia porzadku, rekreacji (np. chodniki, drogi dojazdowe, skwery, place dla dzieci) oraz zaspokojenia innych niezbędnych potrzeb zwiazanych z korzystaniem z powierzchni mieszkaniowej budynku ${ }^{18}$. Pojęcie "grunt związany” jest szersze niż "grunt pod.... Również WSA w Lublinie w wyroku z 3 grudnia 2008 r., sygn. akt I SA/Lu 529/08, stwierdził, że prawidłowa wykładnia art. 1a ust. 1 pkt 3 u.p.o.l. (obecnie art. 1a ust. 2 a pkt 1) nie pozwala utożsamiać „gruntów związanych z budynkami” z "gruntami pod budynkami” ${ }^{19}$. W powołanym już wyroku II FSK 933/11 NSA stwierdził, że: w przypadku wyodrębnienia $w$ wielorodzinnym budynku mieszkalnym samodzielnych lokali mieszkalnych, stanowiacych odrębne nieruchomości, w rozumieniu art. 2 ust. 1 i 2 ustawy z dnia 24 czerwca 1994 r. o własności lokali (Dz. U. z 2000 r. Nr 80, poz. 903 ze zm.), do lokali takich moga przynależeć, jako ich czesści składowe, pomieszczenia, choćby nawet do niego bezpośrednio nie przylegały lub były położone $w$ granicach nieruchomości gruntowej poza budynkiem, w którym wyodrębniono dany lokal, a w szczególności: piwnica, strych, komórka, garaż, zwane "pomieszczeniami przynależnymi" (art. 2 ust. 4 ustawy o własności lokali). Istotne jest, że podobne funkcje, tj. zwiazane z zaspokajaniem potrzeb mieszkaniowych, moga spetniać obiekty budowlane (zarówno obiekty małej architektury jak i budowle), położone w obrębie gruntów związanych z budynkiem mieszkalnym, a niestanowiące przynależności konkretnego lokalu mieszkalnego, lecz służace zaspokajaniu potrzeb mieszkaniowych ogółu mieszkańców budynku. Biorąc pod uwagę przedstawione rozważania, uwzględniające wykładnię systemowa polegająca na ustaleniu znaczenia przepisów prawnych ze względu na ich lokalizację $w$ strukturze źródeł prawa oraz powiazania, jakie występuja pomiędzy rozmaitymi aktami normatywnymi, Sąd w składzie rozpoznajacym te sprawe podziela pogląd wyrażony w powołanym już powyżej wyroku NSA $w$ sprawie II FSK 2420/13, aprobujacego w tym zakresie stanowisko zajęte wcześniej w wyroku II FSK 933/11, że opodatkowanie podatkiem od nieruchomości nie dotyczy te ż budowli zlokalizowanych na gruntach, które należy traktować jako związane z budynkami mieszkalnymi w przedstawionym wyżej znaczeniu, nawet

10 listopada 2015 r., sygn. akt II FSJK 2420/13, http://orzeczenia.nsa.gov.pl/cbo/query [dostęp 2 sierpnia 2019 r.]. Zob. także interpretacje indywidualne: Prezydenta Miasta Poznania z 23 listopada 2017 r. (nr 67), http://bip.poznan.pl/bip/podatek-od-nieruchomosci-osoby-prawne,p,14319,14320,14321.html [dostęp 2 sierpnia 2019 r.] oraz Prezydenta Miasta Gdańska z 9 maja 2017 r., nr WBMiP III.3120.2017.ZT, https:// www.gdansk.pl/download/2017-07/93174.pdf [dostęp 2 sierpnia 2019 r.].

18 Wyrok NSA z 15 stycznia 2013 r., sygn. akt II FSK 933/11.

19 Także wyrok NSA z 20 maja 2008 r., sygn. akt II FSK 425/07. 
jeżeli nie stanowią części składowej lokali mieszkalnych, ale których przeznaczenie wiąże się z realizacja potrzeb mieszkaniowych $i$ nie sa one wykorzystywane dla prowadzenia działalności gospodarczej. Takie też stanowisko zają WSA w Gliwicach w wyroku z 22 kwietnia 2013 r., sygn. akt I SA/Gl 982/12, uznając, że jeżeli budowla jest zlokalizowana na gruncie zwiąanym z budynkiem mieszkalnym, a przeznaczenie tej budowli wiąże się z realizacja potrzeb mieszkaniowych, to nie podlega ta budowla opodatkowaniu podatkiem od nieruchomości przewidzianym dla budowli związanych z prowadzeniem działalności gospodarczej, a określonej jako przedmiot podatku od nieruchomości $w$ art. 2 ust. 1 pkt 3 u.p.o.l. W kontekście regulacji zamieszczonej w art. 2 ust. 1 pkt 3 u.p.lok. oznacza to, że w ogóle nie podlega opodatkowaniu ${ }^{20}$.

Odpowiedzi na pytania

- (Odpowiedź na pytanie pierwsze) Nieruchomości należące do spółdzielni mieszkaniowej, związane z działalnością gospodarczą podlegają opodatkowaniu podatkiem od nieruchomości, z tym że do nieruchomości związanych z działalnością gospodarczą nie zalicza się budynków mieszkalnych oraz gruntów (wraz z posadowioną na nich infrastrukturą towarzyszącą) związanych z tymi budynkami, a więc grunty, na których taki obiekt budowlany został posadowiony, a także grunty doń przylegające, zapewniające właściwe korzystanie z tego budynku, niezbędną obsługę budynku oraz jego mieszkańców. W przypadku nieruchomości związanych z działalnością gospodarczą stosowane są wyższe stawki podatku od nieruchomości (wynikające w przypadku gruntów $-\mathrm{z}$ art. 5 ust. 1 pkt 1 lit. a u.p.lok., w przypadku budynków - z art. 5 ust. 1 pkt 2 lit. b, w przypadku budowli z - art. 5 ust. 1 pkt 3 u.p.lok.), zaś w przypadku budynków mieszkalnych oraz gruntów z nimi związanych niższe stawki podatku od nieruchomości (wynikające: w przypadku gruntów $\mathrm{z}$ art. 5 ust. 1 pkt 1 lit. c u.p.lok., w przypadku budynków mieszkalnych lub ich części - z art. 5 ust. 1 pkt 2 lit. a u.p.lok. lub art. 5 ust. 1 pkt 2 lit. e u.p.lok.);

- (odpowiedź na pytanie drugie) Opodatkowaniu podatkiem od nieruchomości podlegają również nieruchomości, które służa obsłudze lokali mieszkalnych, tak należących do spółdzielców, jak $i$ wynajmowanych $i$ wykorzystywanych na cele mieszkaniowe przez najemców, czy również tych posiadanych przez spótdzielnię, które służ zaspokajaniu potrzeb mieszkaniowych oraz innych potrzeb (m.in. lokale restauracyjne, sklepy, działki rekreacyjne), z tym że - podobnie jak w przypadku odpowiedzi na pytanie pierwsze - należy zauważyć, że inna stawka podatku (niższa) będzie w przypadku budynków mieszkalnych (ich części) oraz gruntów związanych z tymi budynkami (art. 5 ust. 1 pkt 1 lit. c, pkt 2 lit. a i e u.p.lok.), inna (wyższa) w przypadku lokali wynajmowanych na inne cele - działalność gospodarczą (art. 5 ust. 1 pkt 1 lit. a, pkt 2 lit. b i pkt 3 u.p.lok.).

20 Ibidem. 
Na zakończenie tej analizy warto również podnieść kwestię jednoznaczności obowiązujących przepisów ustawy o podatkach i opłatach lokalnych w zakresie opodatkowania budowli usytuowanych na gruntach związanych $\mathrm{z}$ budynkami mieszkalnymi. Zgodnie $\mathrm{z}$ art. 1a ust. 2a pkt 1 u.p.lok. do gruntów, budynków i budowli związanych z działalnością gospodarczą, a więc takich, od których podatek pobierany jest według wyższych stawek, nie zalicza się budynków mieszkalnych oraz gruntów związanych z tymi budynkami. W orzecznictwie administracyjnym pojawia się pogląd, biorący za podstawę wykładnię literalną (gramatyczną) przepisów podatkowych, że przepis ten (art. 1a ust. 2a pkt 1 u.p.lok.) wyłącza z kategorii gruntów, budynków i budowli związanych z działalnością gospodarczą jedynie budynki mieszkalne i grunty związane z tymi budynkami, nie wyłącza zaś budowli na takich gruntach posadowionych, co oznacza, że budowle takie traktowane są zawsze jako związane z działalnością gospodarczą i opodatkowane według stawek określonych dla działalności gospodarczejej (art. 5 ust. 1 pkt 3 u.p.lok.). Takiemu stanowisku sprzeciwia się orzecznictwo sądów administracyjnych, które uznaje, że w tym wypadku wykładnia gramatyczna nie pozwala na prawidłowe odczytanie normy prawnej i stwierdza, że: przez grunty związane z budynkami mieszkalnymi należy rozumieć nie tylko grunty, na których taki obiekt budowlany został posadowiony, ale również grunty doń przylegające, zapewniające wtaściwe korzystanie z tego budynku, niezbędna obstugę budynku oraz jego mieszkańców, $w$ tym $w$ zakresie odpowiedniego skomunikowania, zabezpieczenia porzadku, rekreacji (np. chodniki, drogi dojazdowe, skwery, place dla dzieci) oraz zaspokojenia innych niezbędnych potrzeb zwiazanych $z$ korzystaniem z powierzchni mieszkaniowej budynku ${ }^{22}$. W tym kontekście w części wyroków wskazuje się potrzebę interwencji ustawodawcy w kierunku zapewnienia większej jednoznaczności i określoności przedmiotu opodatkowania podatkiem od nieruchomości.

\section{Podsumowanie}

- W każdym wypadku spółdzielnia mieszkaniowa będąca właścicielem lub posiadaczem samoistnym nieruchomości lub obiektów budowlanych oraz użytkownikiem wieczystym gruntów jest podatnikiem podatku od nieruchomości, z tym że podatek ten opłacany jest według różnych stawek, w zależności od tego, czy przedmiotem opodatkowania są budynki mieszkalne oraz grunty zwią-

${ }^{21}$ Zob. np. przywołane już wcześniej: wyrok WSA w Opolu z 16 listopada 2016 r., sygn. akt I SA/Op 370/16, oraz interpretacje indywidualne: Prezydenta Miasta Poznania z 23 listopada 2017 r. (nr 67) i Prezydenta Miasta Gdańska z 9 maja 2017 r., nr WBMiP III.3120.2017.ZT.

22 Zob. przywołane wcześniej wyroki. 
zane z tymi budynkami, o których mowa w art. 1a ust. 2a pkt 1 u.p.lok., czy też nieruchomości i budowle kwalifikowane są do gruntów, budynków i budowli związanych z prowadzeniem działalności gospodarczej, zgodnie $\mathrm{z}$ art. la ust. 1 pkt 3 u.p.lok.

- W przypadku budynków mieszkalnych oraz gruntów związanych z tymi budynkami podatek opłacany jest według stawek niższych, wynikających z art. 5 ust. 1 pkt 1 lit. c, pkt 2 lit. a lub lit. e u.p.lok., zaś w przypadku gruntów, budynków i budowli związanych z prowadzeniem działalności gospodarczej podatek opłacany jest według stawek wyższych, wynikających $z$ art. 5 ust. 1 pkt 1 lit. a, pkt 2 lit. b i pkt 3 u.p.lok.

- Przez ustawowy zwrot „budynki związane z prowadzeniem działalności gospodarczej” należy - zgodnie z orzecznictwem sądowoadministracyjnym - rozumieć okoliczność faktyczną, polegającą na rzeczywistym wykorzystywaniu (zajęciu) określonej części budynku mieszkalnego na prowadzenie działalności gospodarczej, tj. prowadzeniu w tej części budynku (np. w lokalu użytkowym) działalności gospodarczej w rozumieniu art. 1a ust. 1 pkt 4 u.p.lok.

- W orzecznictwie sądów administracyjnych ugruntowany jest pogląd, że przez grunty związane z budynkami mieszkalnymi należy rozumieć nie tylko grunty, na których taki obiekt budowlany został posadowiony, ale również grunty doń przylegające, zapewniające właściwe korzystanie z tego budynku, niezbędną obsługę budynku oraz jego mieszkańców, w tym w zakresie odpowiedniego skomunikowania, zabezpieczenia porządku, rekreacji (np. chodniki, drogi dojazdowe, skwery, place dla dzieci) oraz zaspokojenia innych niezbędnych potrzeb związanych z korzystaniem z powierzchni mieszkaniowej budynku. 
2

OPINIE BAS

D

WSPÓŁPRACA

MIĘDZYNARODOWA

KANCELARII SEJMU 

Paweł Bachmat

\title{
Wykonywanie pracy przez skazanego'
}

\author{
Performance of labour by the convicted person
}

According to the author of the opinion, in the Polish criminal law system such a role is played by the penalty of restriction of liberty. In the catalogue of penalties it holds a second rank in terms of severity. The author emphasizes that the penalty of restriction of liberty may consist of performing unpaid, controlled work for social purposes. On the other hand, the penalty of restriction of liberty may consist of deducting a part of remuneration for ordinary work and transferring this amount to funding a social purpose indicated by a court.

Keywords: ECPRD, labour, prisoners

Zdaniem autora opinii w polskim systemie prawa karnego rolę taką odgrywa kara ograniczenia wolności. W katalogu kar zajmuje ona drugie miejsce pod względem dotkliwości. Autor podkreśla, że kara ograniczenia wolności może polegać na wykonywaniu nieodpłatnej, kontrolowanej pracy na cele społeczne. Z drugiej strony kara ograniczenia wolności może polegać na potrącaniu części wynagrodzenia za zwykłą pracę i przekazaniu tej kwoty na cel społeczny wskazany przez sąd.

Słowa Kluczowa: ECPRD, praca, więźniowie

Asystent w Instytucie Wymiaru Sprawiedliwości • Instytut Wymiaru Sprawiedliwości, WARSZAWA, POLSKA •

pawel.bachmat@sejm.gov.pl • https://orcid.org/0000-0003-3511-5425

In response to ECPRD Request No. 4162 regarding the issue of so called hard labour the Bureau of Research provides the following information. However, at the beginning it should be stipulated that the term hard work can be misleading. In the information presented here, the term hard work will be understood in accordance with the meaning given to it in ECPRD: 1) as a kind of punishment imposed on the perpetrator of the crime or 2) a particular circumstance accompanying the execution of a prison sentence.

1 Hard labour as a penalty (ECPRD request no. 4162) - informacja sporządzona 18 września 2019 r. w ramach współpracy w Europejskim Centrum Badań Parlamentarnych i Dokumentacji (The European Centre for Parliamentary Research and Documentation); BAS-WAP 1782/19.4) s. 179 
- 1. Can someone who has committed a crime be sentenced to community service as a penalty? Community service refers to non-salaried work for a certain number of hours which the convicted person has to carry out in his or her spare time.

In the Polish criminal law system, this role is played by the penalty of restriction of liberty. In the catalog of penalties specified in the Polish Penal Code, it ranks second in terms of severity. In accordance with art. 32 of the Penal Code, the catalog of penalties that the court may impose on the perpetrator of the crime is as follows:

1) fine;

2) restriction of liberty;

3) imprisonment;

4) 25 years imprisonment;

5) life imprisonment.

The order of these penalties is not accidental. The legislator defined it in such a way that it began the catalog of penalties with the mildest penalty (fine). The penalty of restriction of liberty is therefore the second penalty in terms of severity.

The penalty of restriction of liberty may be exercised in three ways (art. 34 $\$ 1 \mathrm{a}-1 \mathrm{~b}$, art. $35 \$ 1-2$ of the Penal Code). The choice of a particular form of execution of a this penalty in relation to a specific offender belongs to the court which decides this matter in the judgment.

First of all, the penalty of restriction of liberty may consist of performing unpaid, controlled work for social purposes. Such work is performed from 20 to 40 hours on a monthly basis. It should be recognized that this form is the closest to the community service model, to which reference is made in ECPRD Request (criterion for performing unpaid work).

Secondly, the penalty of restriction of liberty may consist of deducting from $10 \%$ to $25 \%$ of remuneration for work on a monthly basis for the social purpose indicated by the court. A deduction of remuneration for work may be imposed on the employed person. During the period for which the deduction has been imposed, the convict may not terminate the employment relationship without the court's consent.

Thirdly, the execution of a restriction of liberty may be complex. Then the convicted person is obliged to perform unpaid, controlled work for social purposes in one place, and moreover, from his remuneration for work in another place is deducted from $10 \%$ to $25 \%$ on a monthly basis for social purposes.

The Penal Code stipulates that the penalty of restriction of liberty generally lasts for one month up to 2 years. It is measured in months and years. However, a special act of law may specify a different duration of this penalty (Article $34 \$ 1$ of the Penal Code). 
It should be added that while executing the penalty of restriction of liberty, regardless of the form of exercising it, the convicted person is obliged to: 1) not to change the place of permanent residence, 2) provide explanations regarding the course of serving the sentence (art. $34 \S 2$ of the Penal Code).

In addition, when imposing a penalty of restriction of liberty, the court may impose additional obligations on the convict from the list below (art. $34 \S 3$ of the Penal Code):

1) payment of a cash benefit to the Fund for Victim Aid and Post-penitentiary Assistance,

2) apologizing to the victim,

3) performance of his obligation to provide for the maintenance of another person (maintenance obligation),

4) performing gainful employment, studying or preparing for a profession,

5) refraining from alcohol abuse or using other intoxicants,

6) undergoing addiction therapy,

7) to undergo therapy, in particular psychotherapy or psychoeducation,

8) participation in corrective and educational actions,

9) refraining from staying in certain environments or places,

10) refraining from contacting the victim or other people in a certain way or approaching the victim or other people.

The Penal Code stipulates that the time and manner of performance of these additional obligations are determined by the court after hearing the convict, and the imposition of the obligation mentioned in points 6 and 7 requires the convict's consent.

- 2. Is there any possibility, within the framework of serving a prison sentence, to force prisoners to perform hard labour? If so, what type of labour is it? Hard labour refers to labour that is carried out in conjunction with deprivation of liberty and which the convicted person is required to carry out. The work in question should be nonsalaried.

According to the model for employing convicts adopted in the polish Executive Penal $\mathrm{Code}^{2}$, a person sentenced to imprisonment may perform work while serving a sentence. Therefore, the Executive Penal Code provides that convicts are guaranteed work, but as far as possible. The convicted person is employed on the basis of a referral to work or the convicted person is allowed to perform gainful employment under an employment contract, mandate contract, contract for specific work, contract of outwork or other legal basis (article $120 \$ 1$ and 2 of the Executive Penal Code). However, in this situation the rule is that the work

2 The Executive Penal Code of the 6th June 1997, Journal of Laws 2019, item 676, consolidation act as amended). 
performed by the convict is payable. The principles of remuneration for work are established in an agreement concluded by the director of the prison or in a contract concluded by the convict. When referring a convicted person to administrative and order work in the penal institution, the remuneration for work is determined by the director of this institution (Article $123 \$ 1$ of the Executive Penal Code).

An exception to this model is the situation when the convicted person performs work without remuneration (art. 123a of the Executive Penal Code). This mainly applies to:

- cleaning and auxiliary works performed for the benefit of organizational units of the Prison Service,

- as well as work for social purposes for: 1) local government, 2) entities for which the commune, poviat or voivodship body is a founding body, 3) state or local government organizational units, 4) commercial law companies with exclusive participation of the Treasury or commune, poviat or province

It should be emphasized that the convicted person carries out these types of work on his own initiative or with written consent. In addition, unpaid work may not exceed 90 hours on a monthly basis.

Moreover, the convicted person may work for free for institutions or organizations representing the local community, and in educational establishments, youth educational centers, youth sociotherapy centers, medical entities within the meaning of the provisions on medical activity, social assistance organizational units, foundations, associations and other public institutions or organizations that provide charity. Then a written consent or application for permission to perform such work is also required. It is directed to the Director of the penitentiary institution.

Also for the purpose of apprenticeship to perform work in the future, a convict, with his written consent, may be allowed to perform unpaid work in prison establishments, for a period not longer than 3 months.

In each case cited above rewards may be awarded to the convict for unpaid work. 
\begin{tabular}{l|l}
2 & \\
& OPINIE BAS
\end{tabular}

SPRAWY POSELSKIE 

Agnieszka Tomaszewska

\title{
Ocena możliwości łączenia mandatu posła ze statusem komandytariusza w spółce komandytowej ${ }^{1}$
}

\author{
Assessment of the possibility of combining a Deputy's mandate \\ with the status of a limited partner in a limited partnership
}

\begin{abstract}
In the opinion of the author, there are no obstacles to combine the mandate of a Deputy with the status of a limited partner in a limited partnership, in case, in addition to the Deputy the company is to include another limited partner (natural person) and the limited liability company as a general partner, and in a limited liability company the Deputy will neither be a partner, nor will perform any functions related to decision making, and such a limited partnership will be represented only by the general partner.
\end{abstract}

Keywords: limited partnership, Deputy, mandate

\begin{abstract}
W ocenie autorki opinii brak jest przeszkód do łączenia mandatu posła ze statusem komandytariusza w spółce komandytowej, kiedy w skład spółki oprócz posła ma wejść jeszcze jeden komandytariusz (osoba fizyczna) oraz spółka z o.o. jako komplementariusz, a w spółce z o.o. poseł nie będzie wspólnikiem ani nie będzie pełnił żadnych funkcji związanych z podejmowaniem decyzji, zaś tę spółkę komandytową będzie reprezentował wyłącznie komplementariusz.
\end{abstract}

Słowa kluczowe: spółka komandytowa, poseł, mandat

Ekspert ds. legislacji Biura Analiz Sejmowych •

Kancelaria Sejmu, Biuro Analiz Sejmowych, Wydział Analiz Prawnych, Zespół Prawa

Prywatnego, WARSZAWA, POLSKA .

agnieszka.tomaszewska@sejm.gov.pl • https://orcid.org/0000-0001-9524-8671

\section{Przedmiot opinii}

Opinia dotyczy odpowiedzi na pytanie o możliwość łączenia mandatu posła ze statusem komandytariusza w spółce komandytowej. Chodzi o wyjaśnienie sytuacji, w której poseł może się znaleźć: $w$ skład spółki oprócz mnie wejdzie jeszcze jeden komandytariusz (osoba fizyczna) oraz spótka z o.o. jako komplementariusz. $W$ spółce $z$ o.o. nie będę wspólnikiem ani nie będę pełnił żadnych funkcji (nie będę ani członkiem zarzadu ani prokurentem) i nie będę miał żadnego wplywu na podejmowane przez komplementariusza decyzje. Ponadto spótkę komandytową będzie

1 Opinia prawna $w$ sprawie możliwości łączenia mandatu posła ze statusem komandytariusza w spółce komandytowej sporządzona 3 lutego 2020 r. na zlecenie posła Koalicyjnego Klubu Parlamentarnego Lewicy (Razem, Sojusz Lewicy Demokratycznej, Wiosna Roberta Biedronia); BAS-WAP 328/19. 
reprezentował wyłacznie komplementariusz. Komandytariusze nie będa upowaznieni do jej reprezentowania. Nie będę także prokurentem spółki komandytowej.

Opinia uwzględnienia stan prawny na dzień 19 grudnia $2019 \mathrm{r}$.

W opinii uwzględniono postanowienia następujących aktów prawnych:

- ustawa z 9 maja 1996 r. o wykonywaniu mandatu posła i senatora, t.j. Dz.U. 2018, poz. 1799; dalej: u.w.m.p.s.,

- ustawa z 15 września 2000 r. - Kodeks spółek handlowych, t.j. Dz.U. 2019, poz. 505, ze zm.; dalej: k.s.h.,

- ustawa z 6 marca 2018 r. - Prawo przedsiębiorców, t.j. Dz.U. 2019, poz. 1292; dale: u.p.p.);

- ustawa z 21 sierpnia 1997 r. o ograniczeniu prowadzenia działalności gospodarczej przez osoby pełniące funkcje publiczne, t.j. Dz.U. 2017, poz. 1393, ze zm.; dalej: ustawa o ograniczeniu prowadzenia działalności gospodarczej przez osoby pełniące funkcje publiczne,

- ustawa z 5 czerwca 1998 r. o samorządzie województwa, t.j. Dz.U. 2019, poz. 512, ze zm.; dalej: u.s.w.

\section{Uzasadnienie}

Spółka komandytowa jest spółką osobową (art. $4 \$ 1$ k.s.h.; art. 102 k.s.h.), w której nie występuje kapitał zakładowy. Spółka osobowa, mimo że nie ma osobowości prawnej, została wyposażona w zdolność prawną i może we własnym imieniu nabywać prawa, zaciągać zobowiązania, pozywać i być pozywana (art. 8 $\$ 1$ k.s.h.). Spółka komandytowa ma na celu prowadzenie przedsiębiorstwa pod własną firmą, w której wobec wierzycieli za zobowiązania spółki co najmniej jeden wspólnik odpowiada bez ograniczenia (komplementariusz), a odpowiedzialność co najmniej jednego wspólnika (komandytariusza) jest ograniczona (art. 102 k.s.h.). Spółka komandytowa nie ma organów takich jak zarząd czy rada nadzorcza.

Dopuszczalność łączenia mandatu posła ze statusem komandytariusza spółki komandytowej należy ocenić na tle art. 34 ust. 1 i 2 u.w.m.p.s., tj. przepisów formułujących nakazy niepołączalności materialnej. Zgodnie z ust. 1 tego artykułu: [p] osłowie i senatorowie nie moga prowadzić działalności gospodarczej na własny rachunek lub wspólnie z innymi osobami z wykorzystaniem mienia państwowego lub komunalnego, a także zarządzać taka działalnościa lub być przedstawicielem czy pełnomocnikiem $w$ prowadzeniu takiej działalności. Z kolei ust. 2 przewiduje, że: [p]osłowie i senatorowie nie moga być członkami władz zarządzajacych lub kontrolnych i rewizyjnych ani petnomocnikami handlowymi przedsiębiorców $z$ udziałem państwowych lub komunalnych osób prawnych lub przedsiębiorców, w których uczestnicza takie osoby. Wybór lub powołanie posła lub senatora do tych władz jest $z$ mocy prawa nieważny. 
Ponieważ w przypadku spółki komandytowej nie można mówić o występowaniu władz zarządzających lub kontrolnych i rewizyjnych ${ }^{2}$, aktywność posła w spółce komandytowej powinna być oceniana przede wszystkim z perspektywy art. 34 ust. 1 u.w.m.p.s. Mając powyższe na uwadze, należy w pierwszej kolejności ustalić, jaki jest status komandytariusza spółki komandytowej i czy może być on uznany za osobę „prowadzącą działalność gospodarczą na własny rachunek lub wspólnie z innymi osobami” lub „zarządzającą taką działalnością” oraz czy może on wykonywać czynności jako przedstawiciel czy też pełnomocnik.

Co do zasady uczestnictwo komandytariusza w spółce komandytowej ma charakter bierny. To komplementariusz jest wspólnikiem aktywnym, prowadzącym sprawy spółki i reprezentującym spółkę na zewnątrz. Natomiast zgodnie $\mathrm{z}$ art. $123 \$ 1$ k.s.h.: [k]omandytariusz uczestniczy w zysku spółki proporcjonalnie do jego wkładu rzeczywiście wniesionego do spółki, chyba że umowa spółki stanowi inaczej. Z kolei w art. $121 \$ 1$ k.s.h. wskazano, że: [k]omandytariusz nie ma prawa ani obowiązku prowadzenia spraw spółki, chyba że umowa spółki stanowi inaczej. Ponadto przepisy ustawowe wprowadzają ograniczenia dotyczące możliwości reprezentowania spółki przez komandytariusza. Zgodnie z art. 117 k.s.h.: [s]półkę reprezentuja komplementariusze, których z mocy umowy spółki albo prawomocnego orzeczenia sadu nie pozbawiono prawa reprezentowania spółki. Jak stanowi art. $118 \$ 1$ k.s.h.: [k]omandytariusz może reprezentować spółkę jedynie jako pełnomocnik. Z powyższego wynika zatem, że, co prawda, komandytariusz może reprezentować spółkę komandytową jako jej pełnomocnik (lub prokurent art. $109^{1} \$ 1$ k.c. $\left.^{3}\right)$, to, co do zasady jednak, spółka komandytowa jest reprezentowana przez komplementariusza, który uprawnienie do reprezentacji nabywa z mocy prawa z chwilą uzyskania statusu wspólnika-komplementariusza.

Zgodnie $\mathrm{z}$ art. 3 u.p.p.: [d] ziałalnościa gospodarcza jest zorganizowana działalność zarobkowa, wykonywana we własnym imieniu i w sposób ciagły. Przy czym dla oceny, czy dana aktywność jest działalnością gospodarczą, kluczowe znaczenie ma to, czy faktycznie wykonywana aktywność spełnia - określone w art. 3 u.p.p. materialne przesłanki uznania jej za działalność gospodarczą. Z kolei jak stanowi art. 4 ust. 1-2 u.p.p.: [p]rzedsiębiorca jest osoba fizyczna, osoba prawna lub jednostka organizacyjna niebędaca osoba prawna, której odrębna ustawa przyznaje zdolność prawna, wykonująca działalność gospodarcza, a także wspólnicy spółki cywilnej w zakresie wykonywanej przez nich działalności gospodarczej. Na grun-

2 R. Dubowski, Opinia prawna w sprawie łaczenia mandatu posła łaczenia mandatu $z$ etatem i działalnościa gospodarcza (poset-elekt Aleksander Miszalski), opinia z 7 listopada 2019 r., BAS-WAP 2184/19.

3 Prokura jest petnomocnictwem udzielonym przez przedsiębiorce podlegającego obowiązkowi wpisu do Centralnej Ewidencji i Informacji o Działalności Gospodarczej albo do rejestru przedsiębiorców Krajowego Rejestru Sądowego, które obejmuje umocowanie do czynności sądowych i pozasądowych, jakie sq zwiazane z prowadzeniem przedsiębiorstwa. 
cie tych przepisów przedsiębiorcą jest więc spółka osobowa, która jest jednostką organizacyjną mającą zdolność prawną, a nie jej wspólnik. Jedynie w przypadku spółki cywilnej za przedsiębiorców należy uznać wspólników, a nie samą spółkę. Należy zatem uznać, że komandytariusz nie jest przedsiębiorcą i nie prowadzi działalności gospodarczej ani samodzielnie, ani wspólnie z innymi osobami.

Biorąc pod uwagę powyższe, wydaje się, że zakwalifikowanie uczestnictwa w spółce osobowej jako „prowadzenie działalności gospodarczej wspólnie z innymi osobami”, na gruncie art. 34 ust. 1 u.w.m.p.s., może budzić wątpliwości. W literaturze przedmiotu podkreśla się, że: wspólne z innymi osobami prowadzenie działalności gospodarczej to $w$ aktualnych warunkach nic innego, jak prowadzenie działalności $w$ formie spółki cywilnej. ${ }^{4}$ Co więcej: nie może być mowy o wspólnym prowadzeniu działalności gospodarczej przez wspólników, np. w spółkach osobowych, jawnej w szczególności. To spótka prowadzi działalność gospodarcza na własny rachunek jako przedsiębiorca. Jest to konsekwencja przyjęcia podmiotowości prawnej podmiotów ustawowych (jednostek nieposiadających osobowości prawnej) $)^{5}$. Wskazuje się, że: [o] prowadzeniu przez posła lub senatora działalności gospodarczej „wspólnie” z innymi osobami nie można też mówić wówczas, gdy poseł lub senator jest wspólnikiem handlowej spółki osobowej, tj. spółki jawnej, komandytowej, partnerskiej lub komandytowo-akcyjnej, a więc gdy poseł lub senator działa $w$ ramach wspomnianej spółki w charakterze wspólnika [...] Nie wolno [...] zapominać, że działalność wspomnianych wspólników handlowej spółki osobowej jest $w$ pełni zarachowana na rzecz danej spółki $i w$ sensie prawnym jest ona działalnościa tej właśnie spółki. Realizując de facto czynności składające się na prowadzenie działalności gospodarczej, wspólnicy handlowej spółki osobowej nie stają się bynajmniej podmiotami praw i obowiązków wynikających z tej działalności, gdyż punktem zarachowania dla tychże praw i obowiązków jest sama handlowa spółka osobowa, w której ci wspólnicy uczestniczą ${ }^{6}$. Co więcej, podkreśla się, że: [s]wojej własnej działalności gospodarczej w znaczeniu normatywnym nie prowadzi tym bardziej taki wspólnik handlowej spółki osobowej, który nie jest uprawniony do jej reprezentacji, a więc który nie dokonuje w obrocie żadnych czynności prawnych za spółkę. Zakaz prowadzenia działalności gospodarczej „wspólnie z innymi osobami” występuje także w przepisach antykorupcyjnych dotyczących m.in. członków

4 A. Kidyba, Interpretacja art. 34 ust. 1 ustawy o wykonywaniu mandatu [w:] Status posła, cz. II, Wybór ekspertyz prawnych do rodziału 5 ustawy z 9 maja 1996 r. o wykonywaniu mandatu posła i senatora (Dz.U. z 2003 r. Nr 221, poz. 2199, ze zm.), Warszawa 2007, s. 305.

5 Ibidem, s. 306.

6 M. Szydło, Zakaz łączenia mandatu parlamentarnego. Studium prawne, WarszawaPoznań 2012, s. 222-223; zob. także W. Odrowąż-Sypniewski, Prowadzenie przez posła działalności gospodarczej (rolniczej) na terenach dzierżawionych od Skarbu Państwa [w:] Status posła w opiniach Biura Analiz Sejmowych (2007-2015), t. II, cz. 2, red. I. Galińska-Rączy, Warszawa 2015, s. 203. 
organów jednostek samorządu terytorialnego ${ }^{7}$. Przedstawiona wyżej wykładania jest przyjmowana także na gruncie tych przepisów ${ }^{8}$. Biorąc pod uwagę powyższe, należy zatem uznać, że działalność gospodarcza realizowana przez wspólników handlowej spółki osobowej jest działalnością gospodarczą prowadzoną przez samą spółkę, a nie działalnością gospodarczą wspólników. Tym samym fakt uczestniczenia w spółce komandytowej nie oznacza prowadzenia działalności gospodarczej w znaczeniu przyjmowanym na gruncie art. 34 ust. 1 u.w.m.p.s.

Inna kwestią jest natomiast to, czy aktywność posła komandytariusza w spółce komandytowej może zostać zakwalifikowana jako „zarządzanie” działalnością gospodarczą. W piśmiennictwie wskazuje się, że pojęcie "zarządzanie”: będąc często utożsamiane z pojęciem "kierowanie”, oznacza podejmowanie działań, których rodzaj jest mocno zdeterminowany i uwarunkowany przedmiotem zarzadu, a które działania polegaja na spowodowaniu funkcjonowania m.in. określonych rzeczy (obiektów, przedsiębiorstw) zgodnie z celem wyznaczonym przez zarzadzającego lub też wytyczonym przez tego, kto ustanowił (wyznaczyt) zarzadzającego i jest identyfikowane $z$ działalnością operacyjna, wykonywana bardzo często przez osoby „funkcyjne" (dyrektorów, kierowników, menadżerów) ${ }^{9}$. Można byłoby zatem mówić o naruszeniu zakazu zawartego w art. 34 ust 1 u.w.m.p.s. w sytuacji, kiedy poseł będący wspólnikiem handlowej spółki osobowej byłby jednocześnie uprawniony do prowadzenia spraw tej spółki. Jak wskazano powyżej, w przypadku spółki komandytowej, co do zasady dotyczy to komplementariusza. Komandytariusz nie ma prawa ani obowiązku prowadzenia spraw spółki, chyba że umowa spółki stanowi inaczej (art. $121 \$ 1$ k.s.h.). Jeżeli więc umowa spółki nie zawiera odmiennych postanowień, komandytariusz nie zarządza działalnością gospodarczą tej spółki.

Z informacji, które znalazły się u podstaw niniejszej opinii, wynika, po pierwsze, że nie będzie on wspólnikiem, ani też nie będzie pełnił żadnych funkcji (jako członek zarządu, prokurent) w spółce z o.o. będącej komplementariuszem spółki komandytowej i nie będzie miał żadnego wpływu na podejmowane przez komplementariusza decyzje. Ponadto nie będzie występował jako osoba uprawniona do reprezentacji spółki komandytowej (jako pełnomocnik), ani nie będzie jej prokurentem. W sytuacji takiej wydaje się, że nie może być on zakwalifikowany jako osoba zarządzająca działalnością gospodarczą na gruncie art. 34 ust. 1 u.w.m.p.s.

7 Zob. np. art. 4 pkt 6 ustawy o ograniczeniu prowadzenia działalności gospodarczej przez osoby pełniące funkcje publiczne oraz art. $27 \mathrm{~b}$ u.s.w.

8 S. Płażek, Art. $27 b$ ust. 1 [w:] Komentarz do ustawy o samorządzie województwa, red. P. Chmielnicki, Warszawa 2005, s. 193. Należy jednak odnotować, że w literaturze formułowany jest także pogląd odmienny, zob. np. P. Feczko, Petnienie funkcji wójta przez komandytariusza, „Samorząd Terytorialny” 2007, nr 1-2, s. 59-66; K. Święch, K. Kozłowski, Ograniczenia prowadzenia działalności gospodarczej przez członków organów jednostek samorządu terytorialnego, „Samorząd Terytorialny” 2003, nr 12, s. 28.

9 M. Szydło, Zakaz łączenia, op. cit., s. 230, i powołana tam literatura. 
Ponieważ zgodnie z art. $118 \$ 1$ k.s.h. komandytariusz spółki komandytowej może reprezentować spółkę jako pełnomocnik, potencjalnie poseł mógłby być objęty zarówno zakazem z art. 34 ust. 1, jak i art. 34 ust. 2 u.w.m.p.s. Biorąc jednak pod uwagę zastrzeżenie, że poseł nie będzie upoważniony do reprezentowania spółki jako pełnomocnik ani nie będzie występować w charakterze prokurenta, powyższe kwestie wydają się irrelewantne.

\section{Podsumowanie}

W przedstawionym we wstępie opinii stanie faktycznym brak jest przeszkód do łączenia mandatu posła ze statusem komandytariusza w spółce komandytowej.

\section{Bibliografia}

Feczko P., Pełnienie funkcji wójta przez komandytariusza, „Samorząd Terytorialny” 2007, nr $1-2$.

Kidyba A., Interpretacja art. 34 ust. 1 ustawy o wykonywaniu mandatu [w:] Status posła, cz. II, Wybór ekspertyz prawnych do rozdziału 5 ustawy z 9 maja 1996 r. o wykonywaniu mandatu posła i senatora (Dz.U. z 2003 r. Nr 221, poz. 2199, ze zm.), Warszawa 2007.

Odrowąż-Sypniewski W., Prowadzenie przez posła działalności gospodarczej (rolniczej) na terenach dzierżawionych od Skarbu Państwa [w:] Status posła w opiniach Biura Analiz Sejmowych (2007-2015), t. II, cz. 2, red. Galińska-Rączy, Warszawa 2015.

Płażek S., Art. 27b ust. 1 [w:] Komentarz do ustawy o samorządzie województwa, red. P. Chmielnicki, Warszawa 2005.

Szydło M., Zakaz łączenia mandatu parlamentarnego. Studium prawne, Warszawa-Poznań 2012.

Święch K., Kozłowski K., Ograniczenia prowadzenia działalności gospodarczej przez członków organów jednostek samorządu terytorialnego, „Samorząd Terytorialny” 2003, nr 12. 
Joanna M. Karolczak

\title{
Ocena możliwości łączenia mandatu posła z funkcją inkasenta podatkowego ${ }^{1}$
}

\author{
Assessment of the possibility of combining a Deputy's mandate \\ with the function of a tax collector
}

\begin{abstract}
In the opinion of the author, the occupation and income resulting from the function of a tax collector should be indicated in the Register of Benefits and the statement regarding the financial status. If the village administrator collected taxes as a part of his business activity, he would have to cease from performing such activity. An additional occupation in the form of tax collection by a village administrator does not affect the Deputy's salary.
\end{abstract}

Keywords: incompatibility of a mandate, Deputy, soltys [rural administrative unit leader]

\begin{abstract}
Zdaniem autorki opinii zajęcie i dochody wynikające z funkcji inkasenta podatków powinny być wykazane w Rejestrze Korzyści oraz oświadczeniu majątkowym. Gdyby sołtys pobierał podatki w ramach prowadzonej przez siebie działalności gospodarczej, musiałby zaprzestać takiej działalności. Zajęcie dodatkowe w postaci pobierania podatków przez posła sołtysa nie ma wpływu na uposażenia poselskie.
\end{abstract}

Słowa kluczowe: niepołączalność mandatu, poseł, sołtys

Radca prawny, ekspert ds. legislacji Biura Analiz Sejmowych •

Kancelaria Sejmu, Biuro Analiz Sejmowych, Wydział Analiz Prawnych, Zespół Prawa

Prywatnego, WARSZAWA, POLSKA -

joanna.karolczak@sejm.gov.pl • https://orcid.org/0000-0002-5421-4683

\section{Przedmiot opinii}

Przedmiotem opinii jest odpowiedź na pytanie dotyczące "możliwości łączenia mandatu posła $\mathrm{z}$ funkcją inkasenta podatkowego, wykonywanego przez sołtysa. Uprawnienie jest nadane przez radę gminy. Poseł uzyskuje z tego tytułu kwartalne dochody wyliczane procentowo od wysokości wpłat, tzn. w granicach kilkunastu tysięcy złotych rocznie. Czy jest możliwe dalsze wykonywanie funkcji? Czy ten dochód należy zgłosić i w jakiej formie?”.

Opinia została przygotowana $\mathrm{z}$ uwzględnieniem postanowień:

- ustawy z 8 marca 1990 r. o samorządzie gminnym, t.j. Dz.U. 2019, poz. 506, dalej: u.s.gm.,

1 Opinia prawna w sprawie możliwości łączenia mandatu posła z funkcja inkasenta podatkowego sporządzona 4 grudnia 2019 r. na zlecenie posła Klubu Parlamentarnego Prawo i Sprawiedliwość; BAS-WAP 2233/19. 
- ustawy z 29 sierpnia 1997 r. - Ordynacja podatkowa, Dz.U. 2019, poz. 900, ze zm.,

- ustawy z 12 stycznia 1991 r. o podatkach i opłatach lokalnych, t.j. Dz.U. 2019, poz. 1170, ze zm.,

- ustawy z 15 listopada 1984 r. o podatku rolnym, t.j. Dz.U. 2019, poz. 1256, ze $\mathrm{zm}$.,

- ustawy z 30 października 2002 r. o podatku leśnym, t.j. Dz.U. 2019, poz. 888, ze zm.,

- ustawy z 9 maja 1996 r. o wykonywaniu mandatu posła i senatora, t.j. Dz.U. 2019, poz. 1799; dalej: ustawa o wykonywaniu mandatu,

- uchwały nr 26 Prezydium Sejmu z 25 września 2001 r. w sprawie szczegółowych zasad i trybu wypłacania uposażenia poselskiego oraz odprawy parlamentarnej, dalej: uchwała nr 26, według stanu prawnego na dzień 4 grudnia 2019 r.

\section{Uzasadnienie}

Zgodnie z art. 36 ust. 1 u.s.gm. sołtys jest organem wykonawczym w sołectwie, jednostce pomocniczej gminy. Do jego zadań należy wykonywanie uchwał zebrania wiejskiego, a także zadań wynikających z uchwał rad gminy (np. inkasowanie podatków i opłat lokalnych) oraz z przepisów prawa. Sołtysi są często inkasentami podatków rolnego, leśnego i od nieruchomości od osób fizycznych. Zgodnie z art. 9 Ordynacji podatkowej inkasentem jest osoba fizyczna, osoba prawna lub jednostka organizacyjna niemająca osobowości prawnej, obowiązana do pobrania od podatnika podatku i wpłacenia go we właściwym terminie organowi podatkowemu.

Inkasenci mogą otrzymywać wynagrodzenie prowizyjne za inkaso. Zgodnie bowiem $z$ art. $28 \$ 4$ Ordynacji podatkowej rada gminy, rada powiatu oraz sejmik województwa mogą ustalać wynagrodzenie dla płatników lub inkasentów z tytułu poboru podatków stanowiących dochody, odpowiednio, budżetu gminy, powiatu lub województwa. W myśl art. 6 ust. 12 ustawy o podatkach i opłatach lokalnych rada gminy może zarządzać pobór podatku od nieruchomości od osób fizycznych w drodze inkasa oraz wyznaczać inkasentów i określać wysokość wynagrodzenia za inkaso. Podobnie, zgodnie z art. $6 \mathrm{~b}$ ustawy o podatku rolnym, rada gminy może zarządzać pobór podatku rolnego od osób fizycznych w drodze inkasa oraz określać inkasentów i wysokość wynagrodzenia za inkaso. Analogiczny przepis obowiązuje w ustawie o podatku leśnym - zgodnie $\mathrm{z}$ art. 6 ust. 8 tej ustawy rada gminy, w drodze uchwały, może zarządzić pobór podatku leśnego od osób wymienionych w ust. 2 w drodze inkasa oraz wyznaczyć inkasentów i określić wysokość wynagrodzenia za inkaso.

Powyższe zajęcie należy uznać za „zajęcie dodatkowe” w rozumieniu art. 33 ust. 1 ustawy o wykonywaniu mandatu, wymagające powiadomienia Marszałka 
Sejmu. Jest to także zajęcie zarobkowe. Za zajęcie zarobkowe uznane powinno być bowiem każde zajęcie, które wiąże się z uzyskaniem wynagrodzenia, zapłaty lub też innych korzyści majątkowych i winno eksponować przede wszystkim zarobek lub cel zarobkowy. Termin „zajęcie zarobkowe” powinien być rozumiany szeroko i obejmować wszelkie formy zatrudnienia połączone z uzyskiwaniem dochodów, czyli działalność gospodarczą, stosunek pracy, stosunek służbowy oraz każdy rodzaj umowy cywilnoprawnej ${ }^{2}$. Zajęcie zarobkowe to zajęcie, za które przysługuje wynagrodzenie, a konieczność wypłaty wynagrodzenia może wynikać z przepisów, zawartej umowy lub ogólnie przyjętych zwyczajów3.

Zajęcie polegające na pobieraniu podatków nie koliduje z normami wyrażonym w art. 30 ust. 1 ustawy o wykonywaniu mandatu. Natomiast zajęcie to może naruszać art. 34 ust. 1 ustawy o wykonywaniu mandatu, jeśli jest wykonywane w ramach działalności gospodarczej.

W orzecznictwie Naczelnego Sądu Administracyjnego, wydanym na tle analogicznych przepisów dotyczących radnych, przyjmuje się, że wypłacone zarządzanemu przez radnego podmiotowi gospodarczemu wynagrodzenie $z$ tytułu dokonywania czynności inkasa $\mathrm{w}$ imieniu gminy jest kwalifikowane jako prowadzenie przez radnego działalności z wykorzystaniem mienia komunalnego ${ }^{4}$. Sam fakt pobrania wynagrodzenia ze środków budżetowych gminy jest równoznaczny $\mathrm{z}$ korzystaniem $\mathrm{z}$ mienia gminnego. Uzyskiwanie przez podmiot zarządzany przez radnego wynagrodzenia za wykonane usługi powoduje, że można mówić o „konflikcie interesów” uzasadniających zastosowanie przepisu art. $24 \mathrm{f}$ u.s.gm. ${ }^{5}$. Wynagrodzenie za usługi wykonywane na rzecz gminy (jednostki komunalnej) i wypłacone usługodawcy $\mathrm{z}$ budżetu gminy mieści się w pojęciu prowadzenia działalności gospodarczej na własny rachunek lub wspólnie z innymi osobami $\mathrm{z}$ wykorzystaniem mienia komunalnego. Mienie komunalne obejmuje wszak aktywa, które stanowią nie tylko nieruchomości gruntowe oraz budynki i budowle (majątek trwały), ale także środki pieniężne. Taki sposób rozumienia mienia komunalnego wynika $\mathrm{z}$ art. 43 u.s.gm., zgodnie z którym mieniem komunalnym jest własność i inne prawa majątkowe należące do poszczególnych gmin i ich związków oraz mienie innych gminnych osób prawnych, w tym przedsiębiorstw. Usługodawca realizujący świadczenie w ramach działalności gospodarczej, przez sam fakt pobrania wynagrodzenia ze środków budżetowych - korzysta z mienia

2 Wyrok Wojewódzkiego Sądu Administracyjnego w Poznaniu z 8 października 1015 r., sygn. akt IV SA/Po 467/15, LEX nr 1933084.

3 Wyrok Wojewódzkiego Sądu Administracyjnego w Szczecinie z 25 stycznia 2017 r., sygn. akt II SA/Sz 1395/16, Legalis 1602100.

4 Wyrok Naczelnego Sądu Administracyjnego z 24 listopada 2014 r., sygn. akt II OSK 2892/14, Legalis 1327857.

5 Wyrok Wojewódzkiego Sądu Administracyjnego w Opolu z 14 listopada 2017 r., sygn. akt II SA/Op 490/17, Legalis 1697895. 
gminnego. Jest to zatem działalność prowadzona $\mathrm{z}$ wykorzystaniem mienia komunalnego ${ }^{6}$.

Ponieważ art. 34 ust. 1 ustawy o wykonywaniu mandatu zakazuje prowadzenia działalności gospodarczej z wykorzystaniem mienia komunalnego, to sołtys nie może dokonywać omawianego pobierania podatków w ramach wykonywanej przez siebie działalności gospodarczej.

Jeśli powyższe zajęcie nie jest prowadzone w ramach działalności gospodarczej, to wątpliwość może budzić kwestia wpływu dochodów z tego zajęcia na uposażenie. Zgodnie $\mathrm{z}$ art. 25 ust. 3 ustawy o wykonywaniu mandatu uposażenie nie przysługuje tylko posłowi, który nie korzysta z urlopu bezpłatnego albo prowadzi działalność gospodarczą samodzielnie lub wspólnie z innymi osobami, albo nie zawiesił prawa do emerytury lub renty, $\mathrm{z}$ zastrzeżeniem ust. 3a.

Wypełniając wniosek w sprawie wypłaty uposażenia poselskiego, będący załącznikiem nr 1 do uchwały nr 26 Prezydium Sejmu, poseł oświadcza, że spełnia warunki określone w ustawie o wykonywaniu mandatu posła i senatora do pobierania uposażenia poselskiego bowiem:

- nie pozostaje w stosunku pracy z żadnym pracodawcą,

- pozostaje w stosunku pracy i u każdego pracodawcy korzysta z urlopu bezpłatnego,

- nie prowadzi działalności gospodarczej,

- zawiesił prowadzenie działalności gospodarczej,

- nie pobiera emerytury ani renty,

- zawiesił prawo do emerytury/renty,

- pobiera emeryturę na podstawie:

a) ustawy z 17 grudnia 1998 r. o emeryturach i rentach z Funduszu Ubezpieczeń Społecznych lub ustawy z 20 grudnia 1990 r. o ubezpieczeniu społecznym rolników i ukończył 60 lat (dotyczy kobiet)/65 lat (dotyczy mężczyzn),

a) ustawy z 10 grudnia 1993 r. o zaopatrzeniu emerytalnym żołnierzy zawodowych oraz ich rodzin albo ustawy z 18 lutego 1994 r. o zaopatrzeniu emerytalnym funkcjonariuszy Policji, Agencji Bezpieczeństwa Wewnętrznego, Agencji Wywiadu, Służby Kontrwywiadu Wojskowego, Służby Wywiadu Wojskowego, Centralnego Biura Antykorupcyjnego, Straży Granicznej, Służby Ochrony Państwa, Państwowej Straży Pożarnej, Służby Celno-Skarbowej i Służby Więziennej oraz ich rodzin i emerytura stanowi 75\% podstawy jej wymiaru bez uwzględnienia podwyższenia z tytułu inwalidztwa pozostającego w związku ze służbą.

$6 \quad$ Wyrok Naczelnego Sądu Administracyjnego z 3 sierpnia 2017 r., sygn. akt II OSK 765/17, Legalis 1672981. 
Poseł będący sołtysem, którą to funkcję sprawuje się społecznie ${ }^{7}$, i będący jednocześnie inkasentem, może zgodnie z prawdą złożyć oświadczenie o treści wskazanej w załączniku nr 1 (o ile nie prowadzi działalności gospodarczej).

Dochód z inkasa zostanie uwzględniony w oświadczeniu majątkowym, składanym za dany rok. Omawiane zajęcie winno być także wykazane w Rejestrze Korzyści, bowiem zgodnie z art. 35a ust. 3 pkt 1 ustawy o wykonywaniu mandatu, do Rejestru należy zgłaszać informacje: o wszystkich stanowiskach i zajęciach wykonywanych zarówno $w$ administracji publicznej, jak $i w$ instytucjach prywatnych, z tytułu których pobiera się wynagrodzenie, oraz pracy zawodowej wykonywanej na własny rachunek.

\section{Podsumowanie}

- Zajęcie wykonywane przez sołtysa jest „zajęciem dodatkowym” w rozumieniu art. 33 ustawy o wykonywaniu mandatu posła i senatora.

- Zajęcie i dochody wynikające $z$ funkcji inkasenta podatków powinny być wykazane w Rejestrze Korzyści oraz oświadczeniu majątkowym.

- W orzecznictwie sądowoadministracyjnym przyjmuje się, że wypłacone podmiotowi gospodarczemu wynagrodzenie z tytułu dokonywania czynności inkasa w imieniu gminy, jest kwalifikowane jako prowadzenie działalności z wykorzystaniem mienia komunalnego. Gdyby więc sołtys pobierał podatki w ramach prowadzonej przez siebie działalności gospodarczej, musiałby zaprzestać takiej działalności, bowiem art. 34 ust. 1 ustawy o wykonywaniu mandatu zakazuje prowadzenia działalności gospodarczej z wykorzystaniem mienia komunalnego. - W świetle nowego w tej kadencji Sejmu brzmienia załączników do uchwały nr 26 Prezydium Sejmu zajęcie dodatkowe w postaci pobierania podatków przez sołtysa nie ma wpływu na uposażenia poselskie.

7 Zob. wyrok NSA z 3 stycznia 1995 r., sygn. akt II SA 1825/94, LEX nr 10671, oraz z 17 sierpnia 1995 r., sygn. akt II SA 1592/95, LEX nr 24079. Mogą oni natomiast mieć prawo do diety i zwrotu kosztów podróży służbowych (art. 37b u.s.gm.). 
Irena Galińska-Rączy

\title{
Ocena możliwości łączenia mandatu posła z funkcją dyrektora SP ZOZ Sanatorium Uzdrowiskowego MSWiA ${ }^{1}$
}

\author{
Assessment of the possibility of combining the mandate of a Deputy \\ with the function of a director of the SP ZOZ Sanatorium of the Ministry \\ of the Internal Affairs and Administration
}

\begin{abstract}
The author of the opinion states that in order to avoid the consequences of violating the substantive incompatibility of a Deputy's mandate, it is advisable to take an unpaid leave by the director of the Health Resort Sanatorium of the Ministry of Internal Affairs and Administration, as he manages an entity being a state legal person conducting a business activity with the use of state property, what is contrary to the provisions of the Act on the Exercise of the Mandate of a Deputy or Senator.
\end{abstract}

Keywords: director, Deputy, mandate

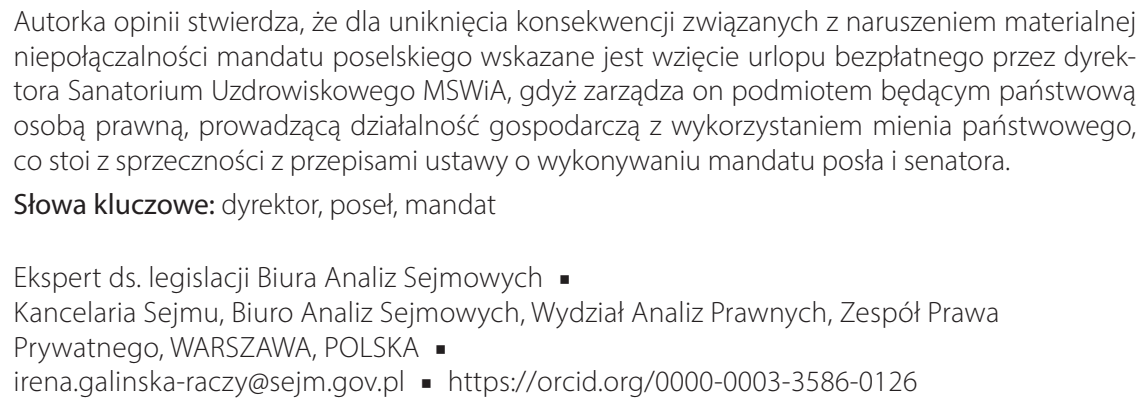

Autorka opinii stwierdza, że dla uniknięcia konsekwencji związanych z naruszeniem materialnej niepołączalności mandatu poselskiego wskazane jest wzięcie urlopu bezpłatnego przez dyrektora Sanatorium Uzdrowiskowego MSWiA, gdyż zarządza on podmiotem będącym państwową osobą prawną, prowadzącą działalność gospodarczą z wykorzystaniem mienia państwowego, co stoi z sprzeczności z przepisami ustawy o wykonywaniu mandatu posła i senatora.

Słowa kluczowe: dyrektor, poseł, mandat

Ekspert ds. legislacji Biura Analiz Sejmowych •

Kancelaria Sejmu, Biuro Analiz Sejmowych, Wydział Analiz Prawnych, Zespół Prawa

Prywatnego, WARSZAWA, POLSKA -

irena.galinska-raczy@sejm.gov.pl • https://orcid.org/0000-0003-3586-0126

\section{Przedmiot opinii}

Przedmiotem niniejszej opinii prawnej jest odpowiedź na następujące pytanie: „czy mogę łączyć mandat posła ze sprawowaniem funkcji dyrektora SP ZOZ Sanatorium Uzdrowiskowego MSWiA w Wraz z pytaniem, w celu uzyskania opinii co do konkretnego stanu faktycznego, przedstawiono: statut tego podmiotu, wydruk z KRS oraz kopię aktu notarialnego z 1 października 2019 r., na podstawie którego doszło do przeniesienia włas-

1 Opinia prawna $w$ sprawie możliwości łączenia mandatu poselskiego $z$ funkcja dyrektora SP ZOZ Sanatorium Uzdrowiskowego MSWiA w sporządzona 29 października 2019 r. na zlecenie dyrektora Biura Analiz Sejmowych; BAS-WAP 2000/19. 
ności dwóch nieruchomości Skarbu Państwa (pozostających w odpłatnym zarządzie Ministerstwa Spraw Wewnętrznych) na rzecz Sanatorium jako państwowej osoby prawnej (na podstawie art. 51 ust. 2 ustawy z 21 sierpnia 1997 r. o gospodarce nieruchomościami, Dz.U. 2018, poz. 2204, ze zm.). Poseł elekt wyraził zamiar łączenia funkcji dyrektora tej jednostki z mandatem posła „w formule niezawodowej", czyli sprawowania mandatu bez korzystania z tzw. poselskiego urlopu bezpłatnego.

Odnosząc się do powyższej wątpliwości, należy przeanalizować status prawny SP ZOZ Sanatorium Uzdrowiskowego MSWiA w

oraz dyrektora tej jednostki, mając na względzie zakaz bezwzględnej niepołączalności formalnej (art. 103 ust. 1 Konstytucji) oraz niepołączalności materialnej (wynikający z art. 34 ustawy z 9 maja 1996 r. o wykonywaniu mandatu posła i senatora; dalej: u.w.m.p.s.).

\section{Status prawny SP ZOZ Sanatorium Uzdrowiskowego MSWiA}

Samodzielny Publiczny Zakład Opieki Zdrowotnej Sanatorium Uzdrowiskowe MSWiA w , dalej: Sanatorium lub Sanatorium MSWiA, jest podmiotem leczniczym niebędącym przedsiębiorcą, o którym mowa w art. 2 ust. 1 pkt 4 w związku z art. 4 ust. 1 pkt 2 ustawy z 15 kwietnia 2011 r. o działalności leczniczej (Dz.U. 2018, poz. 2190, ze zm.).

Podmiot ten został utworzony przez ministra właściwego do spraw wewnętrznych i wyposażony w osobowość prawną (zarządzenie nr 11 Ministra Spraw Wewnętrznych i Administracji z 23 marca 2017 r. w sprawie nadania statutu Samodzielnemu Publicznemu Zakładowi Opieki Zdrowotnej Sanatorium Uzdrowiskowemu Ministerstwa Spraw Wewnętrznych i Administracji w

(Dz.Urz. MSWiA 2017, poz. 11, zm.

Dz.Urz. MSWiA 2018, poz. 35).

Sanatorium należy do jednostek nadzorowanych przez Ministra Spraw Wewnętrznych i Administracji [podmiot ten został wymieniony w zał. nr II do obwieszczenia Ministra Spraw Wewnętrznych i Administracji z 27 września 2018 r. w sprawie wykazu jednostek organizacyjnych podległych Ministrowi Spraw Wewnętrznych i Administracji lub przez niego nadzorowanych; M.P. 2018, poz. 965].

\section{Niepołączalność formalna}

1. Artykuł 103 ust. 1 Konstytucji stanowi, że mandatu posła nie można łączyć m.in. $\mathrm{z}$ zatrudnieniem $\mathrm{w}$ administracji rządowej oraz że zakaz ten nie dotyczy członków Rady Ministrów i sekretarzy stanu w administracji rządowej. Konsty- 
tucyjne pojęcie „administracja rządowa” budzi znaczne wątpliwości interpretacyjne. W związku z tymi wątpliwościami Biuro Analiz Sejmowych sporządziło opracowanie pt. Zasady oceny sytuacji prawnej posła $w$ związku z niepołaczalnościa jego mandatu ${ }^{2}$. W Zasadach wskazano dwa kluczowe kryteria oceny, które muszą być spełnione jednocześnie, aby uznać, że dany podmiot należy do administracji rządowej. W opracowaniu tym stwierdzono: administracja rzadowa to podmioty, które podlegaja kierownictwu Rady Ministrów w rozumieniu art. 146 ust. 3 Konstytucji (należy przez to rozumieć ich zależność osobowa lub zależność służbowa względem Rady Ministrów) oraz nie maja osobowości prawnej.

Pierwsze z kryteriów, tj. podległość Radzie Ministrów, wynika wprost z przepisów Konstytucji (art. 146 ust. 3). Drugie zaś powstało w wyniku następującej interpretacji ustawy zasadniczej: [n] a gruncie regulacji konstytucyjnej wyposażenie podmiotu administrującego w taką osobowość (przyznanie mu prawa do dysponowania - we własnym imieniu i na własny rachunek - odrębnym od Skarbu Państwa majatkiem, czyli prawami podmiotowymi o charakterze prywatnoprawnym), stanowi wyraz samodzielności tego podmiotu względem pozostałej części aparatu administracyjnego państwa (por. art. 165 Konstytucji). Taka gwarantowana prawnie i chroniona sadownie samodzielność jest uznawana z kolei za przejaw decentralizacji administracji publicznej, a zatem uchylenia hierarchicznej więzi, która określa relacje między podmiotami znajdujacymi się $w$ ramach tej samej struktury administracyjnej. Przyjmując te założenia, należy uznać, że podmioty administrujące - które mają osobowość prawną odrębną względem osobowości prawnej Skarbu Państwa lub też osobowości prawnej gminy, powiatu, samorząu województwa dysponuja ustawowymi gwarancjami samodzielności względem odpowiednio: administracji rzadowej albo administracji samorzadu terytorialnego, i z tego powodu nie moga zostać uznane za części składowe ich struktury organizacyjnej.

Przyjęte kryterium osobowości prawnej może budzić wątpliwości interpretacyjne ${ }^{4}$, jednakże prezentowane od 2011 r. stanowisko Biura Analiz Sejmowych

\footnotetext{
„Zeszyty Prawnicze” 2011, nr 3(31).

Ibidem, s. 204, 205.
}

4 Wątpliwości te były podnoszone m.in. przez J. Jagielskiego w ekspertyzie Łączenie mandatu posła $z$ wykonywaniem pracy nauczyciela $w$ samorządowej szkole podstawowej, opublikowanej w zbiorze Status posła w opiniach Biura Analiz Sejmowych (20072015), t. II, cz. 2, red. I. Galińska-Rączy, Warszawa 2015. Według J. Jagielskiego: Osobowość prawna stanowi cechę (przymiot) podmiotu, skutkujacca przede wszystkim w sferze prywatnoprawnej (cywilnoprawnej), a nie na płaszczyźnie publicznoprawnej. Wyraża ona samodzielność tego podmiotu w pierwszym rzędzie w stosunkach cywilnoprawnych, a nie w zakresie samodzielności w sferze prawa publicznego (administracyjnego), która mierzona jest kwota praw i obowiązków oraz zadań $i$ kompetencji o charakterze prawnoadministracyjnym. Choć oczywiście osobowość prawna w jakimś stopniu utwierdza też samodzielność i podmiotowość prawnoadministracyjna (jak np. w przypadku jednostek samorządu terytorialnego, tj. gminy, powiatu czy województwa). Wśród pod- 
(opracowane w omawianych Zasadach) w zakresie osobowości prawnej jako negatywnej przesłanki warunkującej stosowanie art. 103 ust. 1 ustawy zasadniczej zostało podtrzymane $\mathrm{w}$ referacie Prawne ograniczenia publicznej, zawodowej i gospodarczej działalności posłów ${ }^{5}$. W związku z tym wyposażenie jakiegoś podmiotu w osobowość prawną, zdaniem Biura Analiz Sejmowych, uniemożliwia stosowanie zakazu wynikającego z art. 103 ust. 1 Konstytucji RP.

2. Pierwszym zagadnieniem, jakie należy rozważyć, jest stwierdzenie, czy podmiot leczniczy może być uznany za podmiot pozostający w systemie administracji. Dopiero po odpowiedzi pozytywnej, należy rozważyć, czy jest to administracja rządowa, o której mowa w art. 103 Konstytucji RP.

W opinii M. Szydło pojęcie ,administracja” występujące w art. 103 ust. 1 zdanie pierwsze Konstytucji RP powinno być6: pojmowane $w$ znaczeniu podmiotowo-przedmiotowym i obejmować te podmioty (organy, struktury, jednostki organizacyjne), które zostały powołane do życia przez ustawodawce $w$ tym celu, aby wykonywać administracje publiczna $w$ znaczeniu przedmiotowym, $w$ tym takize (a niekiedy nawet wyłacznie) $w$ formach niewładczych ${ }^{7}$. Autor ten zalicza do pod-

miotów administrujących, a więc tych, które składają się na administrację w interesującym nas organizacyjnym ustrojowym sensie sa podmioty nie posiadające ze swej istoty osobowości prawnej, jak organy administracyjne czy urzędy administracyjne (zarówno administracji rządowej, jak i samorządowej), a także podmioty wyposażone $w$ tę osobowość, a których przynależność do kategorii administracji nie budzi na ogół wątpliwości, jak m.in. zakłady administracyjne czy agencje rządowe (te ostatnie przynależa do administracji rzadowej). Ekspertyza ta została powołana w opinii I. Galińskiej-Rączy Czy podjęcie pracy na stanowisku dyrektora ośrodka kultury (samorządowej instytucji kultury) nie będzie kolidować z pełnieniem mandatu posła (opinia publikowana w tym zbiorze).

Podobne stanowisko w tej kwestii zajmuje m.in. M. Stahl w odniesieniu do kategorii „podmioty administrujące” [w:] System prawa administracyjnego, t. 6, Podmioty administrujące, red. R. Hauser, Warszawa 2011, s. 18-23, która powołuje np. J. Zimmermanna (autor ten zalicza do podmiotów administrujących m.in. „kierowników państwowych osób prawnych” oraz agencje rządowe), P. Radziewicz, Decentralizacja jako pojęcie prawne, „Kwartalnik Prawa Publicznego” 2005, nr 1-2, oraz M. Szydło, Zakaz łączenia mandatu parlamentarnego. Studium prawne, Warszawa 2012, s. 87-88.

5 Z. Cieślik, Prawne ograniczenia publicznej, zawodowej i gospodarczej działalności posłów [w:] Seminarium dla nowo wybranych posłów IX kadencji, Warszawa 2019.

${ }_{6}$ Autor wskazuje wyrok Trybunału Konstytucyjnego z 28 czerwca 2000 r. w sprawie o sygn. akt K 25/99, w którym Trybunał, powołując się na doktrynę prawa administracyjnego, stwierdził: [...] $w$ doktrynie prawa administracyjnego pod pojęciem „administracji publicznej” rozumie się przejęte przez państwo i realizowane przez jego zawisłe organy, a także przez organy samorzadu terytorialnego, zaspokajanie zbiorowych $i$ indywidualnych potrzeb obywateli, wynikajacych ze wspólżycia ludzi w społecznościach, M. Miemiec [w:] Prawo administracyjne, red. J. Boć, Wrocław 1997, s. 14.

7 M. Szydło, Zakaz łączenia, op. cit., s. 87. 
miotów administracji publicznej (administracji rządowej i samorządu terytorialnego) rozmaite zakłady administracyjne, a więc samodzielne podmioty, które zostały powołane do wykonywania zadań publicznych (najczęściej w sferze tzw. administracji świadczącej), którym przydzielono zespół środków osobowych oraz rzeczowych, a wśród nich wymienia: szkoły, instytucje kultury i podmioty lecznicze ${ }^{8}$. Zakłady publiczne (administracyjne), będac powoływane zawsze do wykonywania pewnych zadań z zakresu przedmiotowo pojmowanej administracji (chociażby w ochronie zdrowia, oświaty i kultury), należa do niejako klasycznych elementów administracji publicznej, stanowiąc nieodzowny składnik tejże administracji ${ }^{9}$.

Dla rozważanej kwestii istotny wydaje się pogląd prezentowany w doktrynie na temat podmiotów administracji świadczącej (do których należą m.in. samodzielne publiczne zakłady opieki zdrowotnej; dalej: sp zoz)): Zakład opieki zdrowotnej jest wyodrębnionym organizacyjnie zespołem osób i środków majątkowych utworzonym i utrzymywanym w celu udzielania świadczeń ochrony zdrowia. Podstawe jego działania stanowi art. 68 Konstytucji RP. Przepis ten ma podwójny charakter. Z jednej strony, normuje prawa podmiotowe określonych osób do ochrony zdrowia, przyjmując, że użytkownikiem zakładów opieki zdrowotnej może być każdy człowiek. Z drugiej strony, ten przepis wskazuje obowiazek działania władz publicznych w zakresie ochrony zdrowia. Nakaz taki czyni ochronę zdrowia funkcja publiczna. Konsekwencja takiego stanu prawnego jest przyznanie zakładowi opieki zdrowotnej przymiotu zakładu publicznego ze względu na funkcje publiczna, jaka jest ochrona zdrowia.

W takim ujęciu, o publicznym charakterze zakładów opieki zdrowotnej nie decyduje publiczny charakter podmiotów, które je tworza, ale rodzaj świadczonych usług. Zakład opieki zdrowotnej może być utworzony zarówno przez podmioty publiczne (np. minister, jednostka samorzadu terytorialnego), jak i niepubliczne (np. pracodawca, spółka niemająca osobowości prawnej, osoba fizyczna). Moga to być zarówno podmioty wyposażone w osobowość prawnq (np. jednostka samorzadu terytorialnego, stowarzyszenie, inne osoby prawne), jak i podmioty wyposażone jedynie w podmiotowość administracyjnoprawna (np. minister, wojewoda).

Publiczny charakter zakładów opieki zdrowotnej wymaga poddania ich władztwu administracji publicznej, odpowiedzialnej za prawidłowa realizacje ochrony $z$ drowia. W pierwszej kolejności przejawia się to $w$ reglamentacji procedury tworzenia i likwidacji zakładów opieki zdrowotnej ${ }^{10}$.

Ibidem, s. 156.

$9 \quad$ M. Szydło zalicza np. do administracji samorządu terytorialnego zakłady publiczne (administracyjne), takie jak podmioty utworze i prowadzone przez jednostki samorządu terytorialnego, w tym również podmioty lecznicze działające w formie spółki kapitałowej, ibidem, s. 157.

10 Z. Czarnik, J. Posłuszny [w:] System prawa administracyjnego, t. 6, Podmioty administrujące, red. R. Hauser, Warszawa 2011, s. 460-461. 
3. J. Jagielski, analizując pojęcie "administracja samorządu terytorialnego" (wynikające $\mathrm{z}$ art. 30 u.w.m.p.s.), przyjmuje, że: [...] na gruncie doktrynalnym podmioty majace status np. zakładów administracyjnych (np. szkoła, przedszkole, zakład opieki zdrowotnej itp.) traktowane sa jako podmioty administrujace na równi $z$ organami $i$ urzędami administracyjnymi $z$ kolei zaś np. przedsiębiorstwa komunalne czy inne podmioty włączane sa także do tejże kategorii podmiotów administrujacych, o ile wyposażone sa w funkcje i zadania ze sfery administracji (pojmowanej przedmiotowo), przy czym to właczenie określane jest zwykle miarami funkcji zleconych administracji. Niewatpliwie więc „samorządowe jednostki organizacyjne" maja przynajmniej w części właściwości podmiotów administrujących ${ }^{11}$. Pogląd ten należy odnieść również do sp zoz-ów, dla których organem założycielskim jest organ administracji rządowej - a tak jest w wypadku przedmiotowego Sanatorium MSWiA.

Sanatorium można zaliczać do jednostek administracji wykonujących funkcję administracji niewładczo-świadczącej, czyli administracji będącej wytwórca usług $i$ świadczeń $w$ sferze zaspokajania potrzeb powstających $w$ wielkich zbiorowościach ludzkich ${ }^{12}$.

$\mathrm{W}$ odniesieniu do administracji samorządu terytorialnego $\mathrm{w}$ literaturze zwraca się uwagę na fakt, że zmieniła się ogólna formuła kompetencyjna (zadaniowa) współczesnego samorządu terytorialnego. Do zadań samorządu należą m.in. sprawy związane z infrastrukturą techniczną (np. drogi, wodociągi, komunikacja publiczna) oraz infrastrukturą społeczną (np. szkoły, ochrona zdrowia, opieka społeczna) $)^{13}$.

W doktrynie uznaje się, że współczesna administracja publiczna składa się z systemu organów oraz innych podmiotów publicznych powołanych do wykonywania zadań $\mathrm{z}$ zakresu tej administracji, przy czym podmioty publiczne tworzą aparat administracyjny ${ }^{14}$. W skład tego aparatu wchodzą: organy administracji publicznej (którymi w przypadku samorządu terytorialnego są organy stanowiące, kontrolne i wykonawcze samorządu terytorialnego), państwowe i sa-

11 J. Jagielski, Łączenie wykonywania mandatu posła, op. cit., s. 398-399.

12 Tak M. Stahl, Pojęcie administracji, jej cechy i funkcje [w:] Prawo administracyjne, pojęcia, instytucje, zasady $w$ teorii i orzecznictwie, red. M. Stahl, Warszawa 2009. Autorka powołując się na literaturę, zwraca uwagę na coraz bardziej znaczącą rolę takiej administracji: Szczególna rolę zaczęła odgrywać funkcja zaspokajania podstawowych potrzeb bytowych ludzi, zwłaszcza $w$ miastach, i organizowania usług $w$ dziedzinie infrastruktury komunalnej, oświaty, kultury, w sferze socjalnej. [...] Administracja, która dotychczas była głównie gwarantka porządku prawnego oraz spokoju i bezpieczeństwa publicznego, stała się głównym organizatorem usług publicznych, zobowiązanym do tworzenia odpowiedniej bazy materialnej i świadczenia tych ustug.

13 Z. Niewiadomski [w:] Prawo administracyjne, red. Z. Niewiadomski, Warszawa 2011.

14 R. Michalska-Badziak, Podmioty administrujące [w:] Prawo administracyjne, pojęcia, instytucje, zasady w teorii i orzecznictwie, red. M. Stahl, Warszawa 2009, s. 251-252. 
morządowe jednostki organizacyjne oraz instytucje publiczne. Wedle omawianego systemu administracji publicznej należą do niej m.in. zakłady publiczne ${ }^{15}$, do których zalicza się np. sp zoz-y. Zakłady publiczne (dawniej zakłady administracyjne) są bowiem definiowane jako podmioty wykonujące zadania administracji publicznej w sferze ochrony zdrowia, pomocy społecznej, oświaty i kultury ${ }^{16}$. Zakłady administracyjne (zakłady publiczne) mogą działać jako osoby prawne (w takiej formie działają np. podmioty lecznicze - sp zoz-y - w tym Sanatorium MSWiA będące szczególnym rodzajem takich podmiotów, oraz instytucje kultury), jednostki budżetowe lub zakłady budżetowe ${ }^{17}$.

Z powyższego wynika, że Sanatorium MSWiA jako sp zoz wykonuje administrację publiczną w znaczeniu przedmiotowym (tj. organizatorską działalność państwa, polegającą na zaspokajaniu potrzeb społeczeństwa w zakresie ochrony zdrowia), wykonując przy tym funkcję ustanowioną konstytucyjnie, jaką jest ochrona zdrowia. W myśl przepisów ustawy o działach administracji rządowej minister właściwy do spraw zdrowia kieruje działem „Zdrowie”, który obejmuje m.in. sprawy ochrony zdrowia i zasad organizacji opieki zdrowotnej, sprawy nadzoru nad produktami leczniczymi i wyrobami medycznymi, sprawy organizacji i nadzoru nad systemem Państwowe Ratownictwo Medyczne oraz sprawy zawodów medycznych (art. 33 ust. 1 ustawy o działach administracji rządowej). Minister kierujący działem „Zdrowie” jest właściwy we wszystkich sprawach z zakresu administracji rządowej określonych przez ustawę o działach administracji rządowej jako mieszczących się w dziale „Zdrowie” (art. 4 ust. 2 ustawy o działach administracji rządowej).

4. Powyższe stanowisko należy uzupełnić, mając na względzie szczególny charakter Sanatorium MSWiA, którego cele i zadania polegają m.in. na organizowaniu i prowadzeniu turnusów w zakresie rehabilitacji leczniczej służb mundurowych, medycznym zabezpieczeniu wykonywanych przez ministra spraw wewnętrznych zadań obronnych, medycznym zabezpieczeniu działań służb podległych ministrowi właściwemu do spraw wewnętrznych oraz wykonywaniu zadań nałożonych przez tego ministra ( $\$ 7$ pkt 3, 7-9 statutu). Z zadań tych wynika, że placówka ta m.in. udziela świadczeń, które wykraczają poza formułę

15 Gospodarka komunalna może być prowadzona w ramach takich form organizacyjnoprawnych, jak np. zakłady administracyjne („komunalne zakłady użyteczności publicznej”), do których zalicza się m.in. instytucje kultury czy ochrony zdrowia, C. Banasiński, M. Kulesza, Ustawa o gospodarce komunalnej. Komentarz, Warszawa 2002, komentarz do art. 2.

16 R. Michalska-Badziak, Podmioty administrujace, op. cit., s. 251-252 oraz 260. A. Wiktorowska [w:] Prawo administracyjne, red. M. Wierzbowski, Warszawa 2011, mówi o jednostkach organizacyjnych powoływanych przez organy administracji do różnego rodzaju zadań z zakresu świadczeń typu opieka społeczna, zdrowotna, oświata.

17 I. Lipowicz [w:] Prawo administracyjne, red. Z. Niewiadomski, Warszawa 2011, s. $208 \mathrm{i} \mathrm{n.}$ 
„zaspokajania zbiorowych i indywidualnych potrzeb obywateli”, ponieważ działa również na rzecz służb, które podlegają ministrowi, oraz że wykonuje ona inne zadania (polecenia) nakładane przez ten organ administracji rządowej.

Zgodnie z ustawą 4 września 1997 r. o działach administracji rządowej (Dz.U. 2019, poz. 945): 1. Dział sprawy wewnętrzne obejmuje m.in. sprawy: 1) ochrony bezpieczeństwa i porządku publicznego; 2) ochrony granicy Państwa, kontroli ruchu granicznego i cudzoziemców oraz koordynacji działań zwiąanych z polityka migracyjna państwa; 3) zarzadzania kryzysowego; 4) obrony cywilnej; 5) ochrony przeciwpożarowej, zaś minister ds. wewnętrznych sprawuje nadzór nad działalnościa Policji, Straży Granicznej, Państwowej Straży Pożarnej, Obrony Cywilnej Kraju, Szefa Urzędu do Spraw Cudzoziemców, Krajowego Centrum Informacji Kryminalnej oraz Stużby Ochrony Państwa ${ }^{18}$.

Nieodzowne jest również powołanie art. 146 ust. 4 pkt 7 Konstytucji, zgodnie z którym: W zakresie i na zasadach określonych $w$ Konstytucji i ustawach Rada Ministrów w szczególności: [...] zapewnia bezpieczeństwo wewnętrzne państwa oraz porzadek publiczny ${ }^{19}$.

Zadania określone w powyższy sposób przez Konstytucję RP, jakie ma realizować Rada Ministrów, a dokładnie m.in. minister właściwy ds. wewnętrznych w ramach wyodrębnionego działu administracji rządowej, wskazują na pozostawanie Sanatorium MSWiA (jako podmiotu utworzonego i nadzorowanego przez tego ministra) $\mathrm{w}$ systemie organizacyjno-funkcjonalnym poddanym kierownictwu Rady Ministrów. Sanatorium działa bowiem w obszarze zadań i spraw, które ustawowo podlegają ministrowi właściwemu ds. zdrowia oraz ministrowi właściwemu ds. wewnętrznych.

5. Badając wypełnienie przesłanki „kierownictwa Rady Ministrów” warunkującej zaliczenie Sanatorium MSWiA do administracji rządowej, należy przywołać argument prawny wskazujący na podległość służbową tego podmiotu ministrowi ds. wewnętrznych, jaka wynika z nadzoru sprawowanego przez tego ministra nad tą placówką z obwieszczenia Ministra Spraw Wewnętrznych i Administracji z 27 września 2018 r. w sprawie wykazu jednostek organizacyjnych podległych Ministrowi Spraw Wewnętrznych i Administracji lub przez niego nadzorowanych.

18 Na podstawie rozporządzenia Prezesa Rady Ministrów z 14 sierpnia 2019 r. w sprawie szczegółowego zakresu działania Ministra Spraw Wewnętrznych i Administracji (Dz.U. poz. 1540) organami podległymi temu ministrowi są m.in.: Komendant Główny Policji, Komendant Główny Straży Granicznej, Komendant Główny Państwowej Straży Pożarnej, Komendant Służby Ochrony Państwa, Szef Obrony Cywilnej Kraju.

19 W komentarzu do tego przepisu D. Dudek [w:] Konstytucja RP, t. II, Komentarz. Art. 87-243, red. M. Safjan, L. Bosek, Warszawa 2016, stwierdza: Zapewnienie ochrony bezpieczeństwa i porządku publicznego stanowi konstytucyjna powinność wielu organów władzy (por. D. Dudek, "Konstytucyjne podstawy ochrony bezpieczeństwa”, s. 44 i n.), jednak niewątpliwie powierzoną w szczególny sposób rządowi. 
We wcześniejszych opiniach BAS nadzór sprawowany przez ministra stanowił przesłankę do uznania zatrudnienia na stanowisku Komendanta Głównego Ochotniczych Hufców Pracy ${ }^{20}$ oraz zatrudnienia w Państwowym Gospodarstwie Leśnym „Lasy Państwowe” jako zatrudnienia w administracji rządowej ${ }^{21}$.

6. Analizując aspekt pozostawania Sanatorium w ramach kierownictwa sprawowanego wobec tego podmiotu przez ministra ds. wewnętrznych (poza nadzorem ustalonym expressis verbis w obwieszczeniu Ministra Spraw Wewnętrznych i Administracji z 27 września 2018 r. w sprawie wykazu jednostek organizacyjnych podległych Ministrowi Spraw Wewnętrznych i Administracji lub przez niego nadzorowanych), należy stwierdzić, że istotne znaczenie ma przy tym fakt, że minister spraw wewnętrznych tworzy ten podmiot, może go również zlikwidować oraz nadaje mu statut.

W Zasadach oceny sytuacji prawnej posła $w$ związku z niepołączalnościa jego mandatu zwrócono uwagę na m.in. na podległość w sensie zależności osobowej (lub służbowej) podmiotów zależnych od kierownictwa rządowego (o którym mowa w art. 146 ust. 3 Konstytucji).

O występowaniu owych zależności (organizacyjnych, funkcjonalnych i personalnych) świadczą następujące postanowienia statutu Sanatorium MSWiA:

- Zastępcy kierownika Sanatorium i główny księgowy moga zostać zatrudnieni po zatwierdzeniu kandydatur przez ministra właściwego do spraw wewnętrznych (\$10 ust. 3),

- Do zadań rady społecznej należy:

1) przedstawianie ministrowi właściwemu do spraw wewnętrznych wniosków i opinii $w$ sprawach:

a) zbycia, oddania $w$ dzierżawę, najem, użytkowanie oraz użyczenie aktywów trwałych Sanatorium,

b) zakupu lub przyjęcia darowizny nowej aparatury i sprzętu medycznego przez Sanatorium,

20 E. Gierach w: Uzupetnienie notatki na temat oceny poprawności formalnej oświadczenia o rezygnacji z funkcji i stanowisk objętych niepołączalnością bezwzględna złożonego przez Posła AS z 6 listopada 2015 r. nr BAS WAUiP 2286(11)/15, niepubl., stwierdziła, że: W myśl art. 11 ust. 1 i 2 ustawy z dnia 20 kwietnia 2004 r. o promocji zatrudnienia i instytucjach rynku pracy (t.j. Dz.U. z 2015 poz. 149 ze zm.) stanowiq one państwowa jednostkę budżetowa, nadzorowana przez ministra właściwego do spraw pracy. W konsekwencji przynależa do sfery centralnej administracji rządowej, co potwierdzit Trybunału Konstytucyjny w wyroku $z$ dnia 25 listopada 2002 r. (sygn. akt K 34/01).

${ }^{21}$ J. Jagielski, Problem zaliczania Państwowego Gospodarstwa Leśnego „Lasy Państwowe” do kategorii „administracja rządowa” [w:] Status posła, cz. II, red. I. Galińska-Rączy, Warszawa 2007, s. 186, uznał nadzór ministra nad PGL „Lasy Państwowe” za pozostawanie $w$ organizacyjnych związkach $z$ organem administracji rządowej (art. 4 ust. 4 ustawy o lasach stanowi, że nadzór nad PGL LP sprawuje minister właściwy do spraw środowiska). 
c) zwiazanych z przekształceniem lub likwidacja, rozszerzeniem lub ograniczeniem działalności Sanatorium,

d) przyznawania kierownikowi nagród;

e) rozwiazania stosunku pracy lub umowy cywilnoprawnej o zarządzanie Sanatorium $z$ kierownikiem $-z$ własnej inicjatywy lub na wniosek ministra właściwego do spraw wewnętrznych (\$14),

- Od uchwaly rady społecznej kierownikowi przysługuje odwołanie do ministra właściwego do spraw wewnętrznych (\$15),

- Spory wynikłe między kierownikiem a rada społeczna rozstrzyga minister właściwy do spraw wewnętrznych ( $\$ 16)$,

- 2. Minister właściwy do spraw wewnętrznych zatwierdza sprawozdanie finansowe.

3. Minister właściwy do spraw wewnętrznych dokonuje wyboru firmy audytorskiej do przeprowadzenia badania sprawozdania finansowego.

4. Minister właściwy do spraw wewnętrznych zatwierdza propozycję kierownika dotyczaca podziału zysku oraz sposobu pokrycia straty (\$19),

- Sanatorium jest obowiązane uzyskać zgodę ministra właściwego do spraw wewnętrznych w szczególności na:

1) zbycie, oddanie $w$ dzierżawę, najem, użytkowanie oraz użyczenie aktywów trwalych Sanatorium;

2) zmiany związane z rozszerzeniem lub ograniczeniem działalności Sanatorium;

3) zaciagnięcie kredytu lub pożyczki przez Sanatorium;

4) zakup lub przyjęcie darowizny nowej aparatury i sprzętu medycznego powyżej jednostkowej wartości poczatkowej wynoszacej $20000 \mathrm{zk}$;

5) nabycie na rzecz Sanatorium aktywów trwałych o jednostkowej wartości przekraczajacej $50000 \mathrm{zk}$;

6) zawieranie umów zlecenia na czas dłuższy niż 12 miesięcy oraz umów zlecenia i umów o dzieło, których wartość przekracza 100000 zł w roku, z wyłączeniem umów w zakresie udzielania świadczeń zdrowotnych;

7) prowadzenie działalności innej niż działalność lecznicza;

8) zmiane wierzyciela Sanatorium (\$21).

Według M. Szydło „kierowanie” w rozumieniu art. 146 ust. 3 Konstytucji RP oznacza sprawowanie przez Radę Ministrów nadzoru hierarchicznego nad danym podmiotem administracji (RM jest organem nadrzędnym a dany podmiot ma status podmiotu podległego $)^{22}$. W opinii tego autora chodzi nie tylko o kierownictwo bezpośrednie $\mathrm{RM}$, ale również o kierownictwo pośrednie sprawowane przez poszczególnych ministrów (a nawet organy lub jednostki podległe lub nadzorowane przez poszczególnych ministrów).

22 M. Szydło, Zakaz łączenia, op. cit., s. 87. 
7. Mimo że Sanatorium MSWiA może być kwalifikowane jako podmiot podlegający kierownictwu Rady Ministrów w rozumieniu art. 146 ust. 3 Konstytucji, ze względu na wyposażenie w osobowość prawną nie spełnia jednej z przesłanek przyjętych przez Biuro Analiz Sejmowych (ustalonych w Zasadach oceny sytuacji prawnej posła $w$ związku z niepołaczalnościa jego mandatu ${ }^{23}$ ) umożliwiających stosowanie zakazu z art. 103 ust. 1 Konstytucji RP.

Jak stwierdzono wcześniej, stanowisko zaprezentowane w Zasadach przez Biuro Analiz Sejmowych w zakresie osobowości prawnej jako negatywnej przesłanki warunkującej stosowanie art. 103 ust. 1 ustawy zasadniczej zostało podtrzymane w referacie Prawne ograniczenia publicznej, zawodowej i gospodarczej działalności posłów opublikowanym w zbiorze Seminarium dla nowo wybranych posłów IX kadencji, Wydawnictwo Sejmowe, Warszawa 2019.

\section{Niepołączalność materialna}

1. W $\$ 10$ statutu Sanatorium MSWiA zawarto następujące postanowienie: Kierownik kieruje Sanatorium i reprezentuje Sanatorium na zewnątrz. Postanowienie to oznacza, że dyrektor tej placówki m.in. kieruje (zarządza) działalnością gospodarczą prowadzoną przez Sanatorium.

O prowadzeniu działalności gospodarczej przez Sanatorium świadczą $\$ 20^{24}$ oraz $₫ 22^{25}$ statutu. Potwierdzeniem, że podmiot ten prowadzi działalność gospodarczą jest punkt II regulaminu organizacyjnego Sanatorium (z 28 lutego

23 W opracowaniu przyjęto, że: administracja rządowa to podmioty, które podlegają kierownictwu Rady Ministrów w rozumieniu art. 146 ust. 3 Konstytucji (należy przez to rozumieć ich zależność osobową lub zależność stużbowa względem Rady Ministrów) oraz nie maja osobowości prawnej, „Zeszyty Prawnicze” 2011, nr 3(31).

$24 \$ 20.1$. Sanatorium jest utrzymywane ze środków finansowych pochodzacych $z$ realizacji umów o udzielanie świadczeń zdrowotnych zawieranych $z$ :

1) publicznymi i niepublicznymi dysponentami środków finansowych na ochronę zdrowia;

2) osobami fizycznymi.

2. Sanatorium może uzyskiwać środki finansowe zgodnie $z$ art. 55 ustawy $z$ dnia 15 kwietnia 2011 r. o działalności leczniczej.

Przepis art. 55 ust. 1 pkt 2 daje jednoznaczną wskazówkę co do tego, że sp zoz może także prowadzić inną działalność niż tylko udzielanie świadczeń zdrowotnych.

25 \$22. Sanatorium prowadzi wydzielona działalność inna niż działalność lecznicza $w$ zakresie:

1) oddawania w najem lub dzierżawę aktywów trwałych, zbędnych na cele działalności statutowej Sanatorium;

2) działalności hotelowej i rekreacyjnej;

3) sprzedaży positków;

4) prowadzenia parkingu. 
2019 r.), w którym stwierdzono: Wykonywanie działalności gospodarczej innej niż działalność lecznicza, pod warunkiem, że działalność ta nie jest uciążliwa dla pacjenta lub przebiegu leczenia (postanowienie to nawiązuje do art. 13 ustawy o działalności leczniczej ${ }^{26}$ ).

Ponadto w regulaminie mowa o: „pobieraniu opłat za usługi komercyjne”, a także o „sporządzaniu ofert leczniczych oraz komercyjnych, kalkulacji cen usług hotelarsko-leczniczych” oraz o „pozyskiwaniu nowych klientów”.

W związku z tym, że Sanatorium jako państwowa osoba prawna prowadzi działalność gospodarczą, wykorzystując przy tym mienie państwowe (art. $44^{1} \$ 1$ k.c.), w rozważanym stanie faktycznym znajdzie zastosowanie ograniczenie $z$ art. 34 ust. 1 ustawy o wykonywaniu mandatu posła i senatora. Zgodnie $\mathrm{z}$ tym przepisem posłowie nie mogą m.in. zarządzać działalnością gospodarczą z wykorzystaniem mienia państwowego lub komunalnego.

$\mathrm{Na}$ możliwość stosowania art. 34 ust. 1 u.w.m.p.s. w przypadku pełnienia przez posła funkcji kierownika sp zoz zwrócono uwage w dotychczasowych opiniach Biura Analiz Sejmowych ${ }^{27}$. W opinii prawnej przygotowanej dla Komisji Regulaminowej i Spraw Poselskich ${ }^{28}$ stwierdzono: W ustawie o działalności leczniczej ustawodawca przesadził, że samodzielne publiczne zakłady opieki zdrowotnej nie maja statusu przedsiębiorców, nie rozstrzygną jednak, czy podmioty lecznicze prowadza działalność gospodarczą.

W wyroku z dnia 21 listopada 2014 r. [sygn. akt II OSK 2769/14 - dopisek I.G.-R.], Naczelny Sąd Administracyjny (dalej: NSA) przyjąt, że zakwalifikowanie przez ustawodawce $w$ art. 2 ust. 1 pkt 4 ustawy o działalności leczniczej samodzielnych publicznych zakładów opieki zdrowotnej do kategorii podmiotów leczniczych nieprowadzacych działalności gospodarczej wyklucza „możliwość zaliczenia podmiotu leczniczego, działajacego $w$ formie samodzielnego publicznego zakładu opieki zdrowotnej, do kategorii przedsiębiorców w rozumieniu przepisów ustawy o swobodzie działalności gospodarczej". W wyroku z dnia 22 lipca 2014 r. [sygn. akt II UK 192/13 - dopisek I.G.-R.] Sąd Najwyższy (dalej: SN) uznał, że ze wzglę-

26 Art. 13. W miejscu udzielania świadczeń zdrowotnych:

1) nie moga być świadczone usługi pogrzebowe oraz prowadzona ich reklama;

2) może być wykonywana działalność inna niż działalność lecznicza, pod warunkiem, że nie jest uciążliwa:

a) dla pacjenta lub przebiegu leczenia,

b) dla przebiegu leczenia - w przypadku jednostki wojskowej.

27 Tak: M. Szydło, Dopuszczalność łączenia mandatu posła ze stanowiskiem kierownika (dyrektora) samodzielnego publicznego zakładu opieki zdrowotnej [w:] Status posła w opiniach Biura Analiz Sejmowych (2007-2015), t. II, cz. 2, red. I. Galińska-Rączy, Warszawa 2015, s. 139-144.

28 P. Sobolewski, Opinia prawna w sprawie dopuszczalności łączenia przez posła MZ mandatu posła z pełnieniem funkcji dyrektora Śląskiego Centrum Chorób Serca, BAS-WAL 396/15, niepubl. 
du na brzmienie art. 2 ust. 1 pkt 4 ustawy o działalności leczniczej, samodzielne publiczne zakłady opieki zdrowotnej nie mają statusu przedsiębiorców.

$W$ przywołanych wyrokach NSA i SN trafnie stwierdzity, że brzmienie art. 2 ust. 1 pkt 4 ustawy o działalności leczniczej rozstrzyga, że samodzielne zakłady opieki zdrowotnej nie maja statusu przedsiębiorców, dlatego nie znajduja do nich zastosowania przepisy adresowane do przedsiębiorców np. art. 10 ustawy o swobodzie działalności gospodarczej. Należy jednak podkreślić, że pojęcia przedsiębiorcy i podmiotu prowadzącego działalność nie sa pojęciami tożsamymi. Pojęcie działalności gospodarczej zdefiniowane jest w ustawie z dnia 2 lipca 2004 r. o swobodzie działalności gospodarczej [t.j. Dz.U. 2015, poz. 584, ze zm. - dopisek I.G.-R.]. Według wskazanego artykułu działalnościa gospodarcza jest zarobkowa działalność wytwórcza, budowlana, handlowa, usługowa oraz poszukiwanie, rozpoznawanie $i$ wydobywanie kopalin ze złóż, a także działalność zawodowa, wykonywana $w$ sposób zorganizowany i ciagty. Przedsiębiorcami, w rozumieniu art. 4 ust. 1 ustawy o swobodzie działalności gospodarczej, moga być osoby fizyczne, osoby prawne i jednostki organizacyjne niebędace osobami prawnymi, którym odrębna ustawa przyznaje zdolność prawna - wykonujące we własnym imieniu działalność gospodarcza. Według art. 4 ust. 2 ustawy o swobodzie działalności gospodarczej za przedsiębiorców uznaje się także wspólników spółki cywilnej w zakresie wykonywanej przez nich działalności gospodarczej. Gdyby pojęcia „przedsiębiorcy” i "podmiotu prowadzacego działalność gospodarcza” stanowity synonimy posługiwanie się przez ustawodawcę dwoma różnymi terminami w jednym akcie prawnym byłoby nieracjonalne. W piśmiennictwie od dawna trafnie zwraca sie uwage, że rozstrzygnięcie przez ustawodawcę wprost $w$ przepisie, że określony podmiot nie jest przedsiębiorca nie oznacza, że podmiot ten nie prowadzi działalności gospodarczej ${ }^{29}$.

2. Należy przyjmować, że z uwagi na art. 2 ust. 1 pkt 4 ustawy o działalności leczniczej oraz powołaną interpretację tego przepisu przez NSA (wedle której samodzielne zakłady opieki zdrowotnej nie mają statusu przedsiębiorców) ${ }^{30}$, do omawianego stanu faktycznego nie znajdzie zastosowania art. 34 ust. 2 u.w.m.p.s.

3. W analizowanym przypadku możliwe jest skorzystanie przez posła z urlopu bezpłatnego na podstawie art. 29 u.w.m.p.s. Urlop „poselski”, tak jak urlop bezpłatny ( $\mathrm{z}$ art. 174 Kodeksu pracy), jest przerwą w wykonywaniu pracy, w trakcie której pracownik nie wykonuje żadnych czynności i działań związanych z zakresem jego obowiązków pracowniczych. Nie wykonując swoich obowiązków pracowniczych, poseł nie będzie mógł być uznany za osobę „zarządzającą” działalnością gospodarczą w rozumieniu art. 34 ust. 1. Należy przy tym zastrzec, że

29 M. Szydło, Osoby wykonujące wolne zawody prawnicze jako przedsiębiorcy, „Przegląd Sejmowy" 2004, nr 2, s. 22.

30 Patrz również glosa G. Glanowskiego do wyroku SN z 22 lipca 2014 r. sygn. akt III UK 192/13 (PUG 2015). 
jeżeli poseł w okresie korzystania z urlopu bezpłatnego nie przerwałby świadczenia swojej pracy u danego pracodawcy i nadal de facto wykonywał tam czynności dające się scharakteryzować jako „zarządzanie” działalnością gospodarczą w rozumieniu art. 34 ust. 1 u.w.m.p.s., to wówczas, mimo formalnego trwania urlopu bezpłatnego, aktywność posła musiałaby być oceniana zgodnie z jej materialną treścią (i istotą), wywołując ryzyko naruszenia zakazu z art. 34 ust. 1 ustawy ${ }^{31}$.

\section{Podsumowanie}

1. Przedstawiona analiza podstaw prawnych utworzenia i funkcjonowania Sanatorium MSWiA (a zwłaszcza aspekt zależności od ministra właściwego ds. wewnętrznych) wskazuje, że podmiot ten można zaliczać do tzw. administracji świadczącej podlegającej kierownictwu Rady Ministrów, ale jednocześnie placówka ta, posiadając osobowość prawną, nie spełnia jednego z kryteriów określonych w Zasadach oceny sytuacji prawnej posła w związku z niepołaczalnościa jego mandatu" ${ }^{\prime 2}$ umożliwiających stosowanie zakazu z art. 103 ust. 1 Konstytucji.

W związku z tym, kierując się powyższymi Zasadami, należy uznać, że pozostawanie dyrektorem SP ZOZ Sanatorium Uzdrowiskowe MSWiA w nie jest zatrudnieniem w administracji rządowej w rozumieniu art. 103 ust. 1 ustawy zasadniczej. Poseł pełniąc tę funkcję, nie pozostaje w niepołączalności bezwzględnej (czyli nie znajduje wobec niego zastosowania art. $247 \$ 1$ pkt 5 Kodeksu wyborczego $\left.{ }^{33}\right)$.

31 M. Szydło, Urlop bezpłatny jako okoliczność przerywająca „zarządzanie działalnościa gospodarcza" w rozumieniu art. 34 ust. 1 ustawy o wykonywaniu mandatu posła i senatora[w:] Status posła w opiniach Biura Analiz Sejmowych (2007-2015), t. II, cz. 2, red. I. Galińska-Rączy, Warszawa 2015, s. 114 i n.

32 Zasady te zostały powtórzone przez Z. Cieślika w artykule Prawne ograniczenia publicznej, zawodowej i gospodarczej działalności posłów opublikowanym w zbiorze Seminarium dla nowo wybranych posłów IX kadencji, Wydawnictwo Sejmowe, Warszawa 2019.

33 Zgodnie z art. $247 \$ 1$ pkt 5 Kodeksu wyborczego wygaśnięcie mandatu posła następuje w przypadku zajmowania w dniu wyborów stanowiska lub funkcji, których stosownie do przepisów Konstytucji Rzeczypospolitej Polskiej albo ustaw nie można łączyć z mandatem posła.

Art. $247 \$ 3$ Kodeksu wyborczego stanowi, że wygaśnięcie mandatu posła zajmującego w dniu wyborów stanowisko lub funkcję, o których mowa w $\$ 1$ pkt 5 , następuje, jeżeli nie złoży on Marszałkowi Sejmu, w terminie 14 dni od dnia ogłoszenia przez Państwową Komisję Wyborczą w Dzienniku Ustaw Rzeczypospolitej Polskiej wyników wyborów do Sejmu, oświadczenia o złożeniu rezygnacji z zajmowanego stanowiska lub pełnionej funkcji. 
2. W rozważanym stanie faktycznym znajdzie jednakże zastosowanie zakaz wynikający z art. 34 ust. 1 u.w.m.p.s. (zakaz zarządzania działalnością gospodarczą z wykorzystaniem mienia państwowego), ponieważ SP ZOZ Sanatorium Uzdrowiskowe MSWiA w prowadzi działalność gospodarczą z wykorzystaniem mienia państwowego. Dla uniknięcia konsekwencji związanych $\mathrm{z}$ naruszeniem materialnej niepołączalności mandatu poselskiego wynikającej z art. 34 ust. 1 ustawy o wykonywaniu mandatu posła i senatora wystarczający będzie urlop bezpłatny. W rozważanym stanie faktycznym nie znajdzie zastosowania art. 34 ust. 2 tej ustawy (wymagający rezygnacji z funkcji).

\section{Bibliografia}

Cieślik Z., Prawne ograniczenia publicznej, zawodowej i gospodarczej działalności posłów [w:] Seminarium dla nowo wybranych posłów IX kadencji, Warszawa 2019.

Czarnik Z., Posłuszny J. [w:] System prawa administracyjnego, t. 6, Podmioty administrujace, red. R. Hauser, Warszawa 2011.

Dudek D. [w:] Konstytucja RP, t. II, Komentarz. Art. 87-243, red. M. Safjan, L. Bosek, Warszawa 2016.

Galińska-Rączy I., Czy podjęcie pracy na stanowisku dyrektora ośrodka kultury (samorzadowej instytucji kultury) nie będzie kolidować z petnieniem mandatu posła [w] Status posła w opiniach Biura Analiz Sejmowych (2007-2015), t. II, cz. 2, red. I. Galińska-Rączy, Warszawa 2015.

Jagielski J., Łączenie mandatu posła $z$ wykonywaniem pracy nauczyciela w samorządowej szkole podstawowej [w] Status posła w opiniach Biura Analiz Sejmowych (2007-2015), t. II, cz. 2, red. I. Galińska-Rączy, Warszawa 2015.

Jagielski J., Problem zaliczania Państwowego Gospodarstwa Leśnego „Lasy Państwowe” do kategorii „administracja rządowa” [w:] Status posła, cz. II, red. I. Galińska-Rączy, Warszawa 2007.

Lipowicz I. [w:] Prawo administracyjne, red. Z. Niewiadomski, Warszawa 2011.

Michalska-Badziak R., Podmioty administrujace [w:] Prawo administracyjne, pojęcia, instytucje, zasady w teorii i orzecznictwie, red. M. Stahl, Warszawa 2009.

Niewiadomski Z. [w:] Prawo administracyjne, red. Z. Niewiadomski, Warszawa 2011.

Radziewicz P., Decentralizacja jako pojęcie prawne, „Kwartalnik Prawa Publicznego” 2005, nr 1-2.

Stahl M. [w:] System prawa administracyjnego, t. 6, Podmioty administrujace, red. R. Hauser, Warszawa 2011.

Stahl M., Pojęcie administracji, jej cechy i funkcje [w:] Prawo administracyjne, pojęcia, instytucje, zasady w teorii i orzecznictwie, red. M. Stahl, Warszawa 2009.

Szydło M., Dopuszczalność łączenia mandatu posła ze stanowiskiem kierownika (dyrektora) samodzielnego publicznego zakładu opieki zdrowotnej [w:] Status posła w opiniach Biura Analiz Sejmowych (2007-2015), t. II, cz. 2, red. I. Galińska-Rączy, Warszawa 2015. 
Szydło M., Osoby wykonujące wolne zawody prawnicze jako przedsiębiorcy, „Przegląd Sejmowy" 2004, nr 2.

Szydło M., Urlop bezpłatny jako okoliczność przerywająca „zarządzanie działalnościa gospodarcza" w rozumieniu art. 34 ust. 1 ustawy o wykonywaniu mandatu posła i senatora[w:] Status posła w opiniach Biura Analiz Sejmowych (2007-2015), t. II, cz. 2, red. I. Galińska-Rączy, Warszawa 2015.

Szydło M., Zakaz łączenia mandatu parlamentarnego. Studium prawne, Warszawa-Poznań 2012.

Wiktorowska A. [w:] Prawo administracyjne, red. M. Wierzbowski, Warszawa 2011. 


\author{
Adam Karczmarek*, Paweł Kościelny**
}

\title{
Ocena możliwości łączenia mandatu posła z zatrudnieniem na stanowisku dyrektora Centrum Kultury i Bibliotek ${ }^{1}$
}

Assessment of the possibility of combining the mandate of a Deputy with employment as the director of the Centre for Culture and Libraries

\begin{abstract}
In the opinion of the authors, employment as the director of the Centre for Culture and Libraries is not covered by the principle of incompatibility, the violation of which results in the expiry of the Deputy's mandate. However, it is not permissible to combine a Deputy's mandate with employment on such a post due to a prohibition resulting from the provisions of the Act on the Exercise of the Mandate of a Deputy and Senator. In the event of not resigning from that post, the Deputy will lose it by law three months after taking the Deputy's oath.
\end{abstract}

Keywords: director, Deputy, mandate

Zdaniem autorów opinii zatrudnienie na stanowisku dyrektora Centrum Kultury i Bibliotek nie jest objęte nakazem niepołączalności, którego naruszenie skutkuje wygaśnięciem mandatu poselskiego. Nie jest jednak dopuszczalne łączenie mandatu posła z zatrudnieniem na takim stanowisku ze względu na zakaz wynikający z przepisów ustawy o wykonywaniu mandatu posła i senatora. W razie niezrzeczenia się stanowiska poseł utraci je z mocy prawa po upływie trzech miesięcy od dnia złożenia ślubowania.

Słowa kluczowe: dyrektor, poseł, mandat

* Doktor nauk prawnych, wykładowca akademicki Uniwersytet Kardynała Stefana Wyszyńskiego w Warszawie, Wydział Prawa i Administracji, Katedra Publicznego Prawa Gospodarczego, WARSZAWA, POLSKA • adam.karczmarek@sejm.gov.pl • https://orcid.org/0000-0002-1475-6322

** Ekspert ds. legislacji Biura Analiz Sejmowych • Kancelaria Sejmu, Biuro Analiz Sejmowych, Wydział Analiz Prawnych, Zespół Prawa Publicznego, WARSZAWA, POLSKA • pawel.koscielny@sejm.gov.pl•https://orcid.org/0000-0002-4070-5107

\section{Przedmiot opinii}

Przedmiotem opinii prawnej jest odpowiedź na pytanie o dopuszczalność łączenia mandatu posła $\mathrm{z}$ zatrudnieniem na stanowisku dyrektora Centrum Kultury i Bibliotek Gminy , tj. samorządowej instytucji kultury.

1 Opinia prawna dotyczaca zagadnienia łączenia mandatu posła z zatrudnieniem na stanowisku Dyrektora Centrum Kultury i Bibliotek Gminy sporządzona 31 października 2019 r. na zlecenie zastępcy Szefa Kancelarii Sejmu; BAS-WAP-2189/19. Paweł Kościelny opracował pkt III.1-2 opinii. 
Opinia uwzględnia stan prawny na dzień 30 października 2019 r.

Opinia przygotowana została $\mathrm{z}$ uwzględnieniem następujących aktów prawnych:

- ustawa z 9 maja 1996 r. o wykonywaniu mandatu posła i senatora, t.j. Dz.U. 2018, poz. 1799; dalej: u.w.m.p.s.,

- ustawa z 25 października 1991 r. o organizowaniu i prowadzeniu działalności kulturalnej, t.j. Dz.U. 2018, poz. 1983, ze zm.; dalej: u.o.p.d.k.,

- ustawa z 27 czerwca 1997 r. o bibliotekach, t.j. Dz.U. 2019, poz. 1479,

- ustawa z 8 marca 1990 r. o samorządzie gminnym, t.j. Dz.U. 2019, poz. 506, ze zm.

\section{Uzasadnienie prawne}

\section{Funkcjonowanie Centrum Kultury i Bibliotek Gminy stan faktyczny}

Zgodnie ze Statutem Centrum Kultury i Bibliotek Gminy placówka ta powstała z połączenia Gminnej Biblioteki Publicznej Gminy oraz Centrum Animacji Kulturalnej Gminy _ i jest samorządową instytucją kultury, działającą na podstawie przepisów ustawy o organizowaniu i prowadzeniu działalności kulturalnej i ustawy o bibliotekach; organizatorem dla Centrum jest Gmina (pkt 1, 2, $3 \mathrm{w}$ rozdziale 1 statutu Centrum). Według pkt $1 \mathrm{w}$ rozdziale 3 statutu Centrum podmiotem tym kieruje dyrektor, który zarządza całokształtem jego działalności. Dyrektora powołuje i odwołuje wójt Gminy (pkt $2 \mathrm{w}$ rozdziale 3 statutu Centrum).

Ponadto zgodnie z treścią pkt $10 \mathrm{w}$ rozdziale 4 statutu Centrum placówka ta: może prowadzić działalność gospodarcza, z której przychody przekazywane sa wyłacznie na realizacje jego celów statutowych. Według informacji otrzymanych wraz z przedstawionym we wstępie pytaniem Centrum faktycznie prowadzi działalność gospodarczą (m.in. oddając w najem lub dzierżawę lokale, pomieszczenia, hale, boiska i place, jak również prowadząc basen). Przychody z działalności gospodarczej Centrum są przeznaczane wyłącznie na realizację jego celów statutowych.

Stosownie do przepisów ustawy o organizowaniu i prowadzeniu działalności kulturalnej domy kultury i biblioteki stanowią formę organizacyjną działalności kulturalnej, a na podstawie art. 14 ust. 1 tej ustawy uzyskują osobowość prawną i mogą rozpocząć działalność z chwilą wpisu do rejestru prowadzonego przez organizatora.

Zgodnie zaś z art. 10 ustawy o bibliotekach: biblioteka może stanowić samodzielna jednostke organizacyjna albo wchodzić w skład innej jednostki (przepis art. 2 ustawy o bibliotekach stanowi, że: $w$ zakresie nieuregulowanym ustawa do 
bibliotek stosuje się odpowiednio przepisy o organizowaniu i prowadzeniu działalności kulturalnej).

\section{Niepołączalność mandatu poselskiego wynikająca z art. 30 u.w.m.p.s.}

Na wstępie należy zaznaczyć, że zatrudnienie na stanowisku dyrektora Centrum

Kultury i Bibliotek Gminy nie jest objęte nakazem niepołączalności, którego naruszenie skutkuje wygaśnięciem mandatu poselskiego.

W analizowanym przypadku należy rozważyć zastosowanie przepisu art. 30 ust. 1 u.w.m.p.s., który wprowadza tzw. względną (zawieszającą) niepołączalność mandatu parlamentarnego w odniesieniu do zatrudnienia, m.in. w administracji samorządu terytorialnego. W świetle stanowiska Biura Analiz Sejmowych opracowanego w 2011 r., dotyczącego kwestii niepołączalności mandatu poselskiego (Zasady oceny sytuacji prawnej posła $w$ związku z niepołaczalnościa jego mandatu ${ }^{2}$ ) poseł, który podejmuje zatrudnienie w charakterze dyrektora samorządowej instytucji kultury jako jednostki mającej osobowość prawną, nie podlega zakazowi ustanowionemu w art. 30 ust. 1 u.w.m.p.s.

\section{Niepołączalność mandatu poselskiego wynikająca z art. 34 u.w.m.p.s.}

Spośród przepisów ustanawiających zakazy łączenia mandatu poselskiego z funkcjami, zatrudnieniem bądź działalnością należy przeanalizować w niniejszym przypadku przepis art. 34 u.w.m.p.s.

Zgodnie $\mathrm{z}$ art. 34 ust. 1 in fine u.w.m.p.s. posłowie i senatorowie nie moga „zarządzać” działalnością gospodarczą prowadzoną z wykorzystaniem mienia państwowego lub komunalnego ${ }^{3}$. Pojęcie „zarządzać” nie zostało zdefiniowane w ustawie o wykonywaniu mandatu posła i senatora, a więc należy odwołać się do definicji używanej w języku potocznym. „Zarządzać” znaczy wykonywać czynności administracyjne, sprawować nad czymś zarząd, kierować czymśs. [...] Zarządzanie obejmuje więc działanie na cudzy rachunek, występowanie w cudzym imieniu, ale także kierowanie określona działalnością, podejmowanie $w$ ramach tej działalności samodzielnych decyzji. [...] Z kierowaniem tym wiąże się możliwość samodzielnego decydowania o wszelkich kwestiach związanych z prowadzo-

2 Opracowanie zbiorowe, „Zeszyty Prawnicze BAS” 2011, nr 3(31), http://orka.sejm. gov.pl/WydBAS.nsf/0/E967697A0A81219BC1257A31002F0392/\$file/Strony\%20 od\%20ZP_3(31)-14.pdf [dostęp 31 października 2019 r.].

3 Przepis art. 34 ust. 1 u.w.m.p.s. in extenso stanowi: posłowie i senatorowie nie moga prowadzić działalności gospodarczej na własny rachunek lub wspólnie z innymi osobami z wykorzystaniem mienia państwowego lub komunalnego, a także zarzadzać taka działalnością lub być przedstawicielem czy pełnomocnikiem w prowadzeniu takiej działalności.

4 Słownik języka polskiego, t. 3, red. M. Szymczak, Warszawa 1981, s. 954. Podaję za: J. Jagoda [w:] Ustawa o samorządzie powiatowym. Komentarz, red. B. Dolnicki, Kraków 2005. 
ną działalnościa, w tym zwłaszcza o sposobach pozyskiwania dochodów, formach działalności, przeznaczeniu środków stanowiących dochód itd. ${ }^{5}$. Jednocześnie w literaturze prawniczej wskazuje się, że „zarządzanie” działalnością gospodarczą, o którym mowa w art. 34 ust. 1 in fine u.w.m.p.s., to: osobiste, bezpośrednie i rzeczywiste podejmowanie wszelkich działań faktycznych i prawnych ukierunkowanych na zapewnienie ekonomicznego powodzenia (i ekonomicznej efektywności) określonej działalności gospodarczej (własnej lub cudzej), zwłaszcza poprzez załatwianie bieżacych $i$ codziennych spraw związanych $z$ tą działalnościa, jej ochrone oraz poprzez decydowanie o jej rozwoju i inwestycjach ${ }^{6}$. M. Szydło wśród najbardziej typowych sytuacji, w których można mówić o „zarządzaniu działalnością gospodarczą", wskazuje m.in. na sytuacje, gdy:

- poseł lub senator zawarł tzw. umowę menedżerską z określonym podmiotem prawa prowadzacym działalność gospodarcza, na mocy której zobowiązał się do zarządzania tym ostatnim podmiotem i jego działalnościa gospodarcza, czyniąc to przy tym na rachunek tego podmiotu $i$ z reguły $w$ jego imieniu;

- poset lub senator jest pracownikiem określonego podmiotu prowadzacego działalność, zajmujac przy tym w tym podmiocie takie stanowisko, które daje możliwość podejmowania decyzji dotyczących bieżacego prowadzenia spraw związanych $z$ działalnościa wspomnianego podmiotu, w tym m.in. decyzji inwestycyjnych, zakupowych itp.; chodzi tu zatem o zatrudnienie posła lub senatora na samodzielnym stanowisku kierowniczym $w$ danym podmiocie (np. kierownik wydziału lub innego podobnego pionu organizacyjnego), na którym można podejmować w miarę samodzielne decyzje zarzadcze, nawet jeżeli decyzje te sa w oczywisty sposób koordynowane i uzgadniane $w$ ramach całości danego podmiotu, $w$ tym również z innymi osobami mającymi swój własny zakres kompetencji odnośnie do zarzadzania danym podmiotem ${ }^{7}$.

Jednocześnie należy zwrócić uwagę, że w art. 34 ust. 1 u.w.m.p.s. mowa o zarządzeniu „działalnością gospodarczą”. W myśl zdecydowanej większości poglądów prezentowanych w literaturze prawniczej definicja „działalności gospodarczej” zawarta w art. 3 ustawy - Prawo przedsiębiorców ma charakter uniwersalny i należy ją stosować, interpretując m.in. omawiany art. 34 u.w.m.p.s. Z definicji tej wynika, że ustawodawca podał cechy, jakimi musi charakteryzować się dana działalność, aby mogła zostać uznana za gospodarczą. Tymi cechami są (muszą być one spełnione łącznie): zarobkowy charakter działalności, zorganizowany sposób jej wykonywania, ciągłość działalności.

Jak wskazano w informacji dołączonej do pytania sformułowanego na wstępie opinii, Centrum Kultury i Bibliotek Gminy _ faktycznie prowadzi dzia-

5 Ibidem.

6 M. Szydło, Zakaz łączenia mandatu parlamentarnego. Studium prawne, WarszawaPoznań 2012, s. 232.

7 Ibidem, s. 236. 
łalność gospodarczą, choć przychody z działalności gospodarczej Centrum są przeznaczane wyłącznie na realizację jego celów statutowych. Jak jednak wynika z orzecznictwa - gospodarczego celu działalności nie niweczy fakt, że dochód z jej prowadzenia jest przeznaczony na działalność statutową ${ }^{8}$.

Pewne ograniczenie co do możliwości zakwalifikowania działalności Centrum jako działalności gospodarczej wynika z przepisu art. 3 ust. 2 u.o.p.d.k., zgodnie z którym: działalność kulturalna określona $w$ art. 1 ust. 1 nie stanowi działalności gospodarczej w rozumieniu odrębnych przepisów (przepis art. 1 ust. 1 określa, że: działalność kulturalna $w$ rozumieniu niniejszej ustawy polega na tworzeniu, upowszechnianiu i ochronie kultury). W analizowanym przypadku wyłączenie to nie znajdzie jednak w pełni zastosowania, ponieważ wynajmowanie przez Centrum lokali, boisk, czy prowadzenie basenu nie da się zakwalifikować jako działalności kulturalnej. Konkludując, należy ocenić, że Centrum Kultury i Bibliotek Gminy poza działalnością kulturalną prowadzi także działalność gospodarczą.

Biorąc pod uwagę treść statutu Centrum (Centrum kieruje Dyrektor, który zarządza całokształtem jego działalności i reprezentuje Centrum na zewnątrz pkt $1 \mathrm{w}$ rozdziale 3 statutu Centrum), a także powyższe uwagi na temat rozumienia pojęcia „zarządzanie”, należy ocenić, że dyrektor Centrum zarządza działalnością gospodarczą w rozumieniu art. 34 ust. 1 u.w.m.p.s. W konsekwencji, na podstawie przepisu art. 34 ust. 1 u.w.m.p.s., należy stwierdzić, że nie jest dopuszczalne łączenie funkcji dyrektora Centrum Kultury i Bibliotek Gminy $\mathrm{z}$ wykonywaniem mandatu poselskiego.

W analizowanym $\mathrm{w}$ niniejszej opinii przypadku należy także wziąć pod uwagę zastosowanie przepisu art. 34 ust. 2 u.w.m.p.s., w myśl którego: posłowie i senatorowie nie moga być członkami władz zarzadzających lub kontrolnych i rewizyjnych ani pełnomocnikami handlowymi przedsiębiorców z udziałem państwowych lub komunalnych osób prawnych lub przedsiębiorców, w których uczestnicza takie osoby. Wybór lub powołanie posła lub senatora do tych władz jest z mocy prawa nieważny. Natomiast zgodnie z art. 34 ust. 3 u.w.m.p.s., jeżeli wybór lub powołanie, o którym mowa w ust. 2, miało miejsce przed rozpoczęciem wykonywania mandatu, poset i senator jest obowiązany zrzec się stanowiska lub funkcji. W razie niezrzeczenia się stanowiska lub funkcji, poseł i senator traci je z mocy prawa po upływie trzech miesięcy od dnia złożenia ślubowania, o którym mowa wart. 2.

Należy ocenić, że Centrum Kultury i Bibliotek Gminy jest przedsiębiorcą (prowadzi działalność gospodarczą), o którym mowa w art. 34 ust. 2 u.w.m.p.s., tzn. jest przedsiębiorcą, w którym uczestniczy komunalna osoba prawna, tj. gmina. W przypadku samorządowej instytucji kultury, analizowanym w niniejszej opinii, uczestnictwo (partycypacja) gminy wyraża się m.in. przez to, że jednostka samorządu terytorialnego:

8 Zob. np. wyrok Naczelnego Sądu Administracyjnego z 12 stycznia 2006 r., sygn. akt II OSK 787/05. 
- tworzy samorządową instytucję kultury (art. 9 ust. 1 oraz art. 11 ust. 1 u.o.p.d.k.),

- zapewnia instytucji kultury środki niezbędne do rozpoczęcia i prowadzenia działalności kulturalnej oraz do utrzymania obiektu, w którym ta działalność jest prowadzona (art. 12 u.o.p.d.k.),

- nadaje statut (art. 13 ust. 1 u.o.p.d.k.),

- powołuje dyrektora (art. 15 ust. 1 u.o.p.d.k.),

- przed powołaniem dyrektora zawiera $\mathrm{z}$ nim odrębną umowę $\mathrm{w}$ formie pisemnej, w której strony określają warunki organizacyjno-finansowe działalności instytucji kultury oraz program jej działania (art. 15 ust. 5 u.o.p.d.k.),

- może powierzyć zarządzanie instytucją kultury osobie fizycznej lub prawnej (art. 15 a ust. 1 u.o.p.d.k.),

- przejmuje zobowiązania i wierzytelności likwidowanej instytucji kultury (art. 25 u.o.p.d.k.),

- zabezpiecza mienie likwidowanej instytucji (art. 26 ust. 2 u.o.p.d.k.),

- może przekazać odpłatnie lub w wyjątkowych przypadkach nieodpłatnie składniki mienia zlikwidowanej instytucji kultury osobie prawnej lub fizycznej w celu prowadzenia działalności kulturalnej (art. 26 ust. 1 u.o.p.d.k.).

\section{Podsumowanie}

Podsumowując, należy ocenić, że w świetle przepisu art. 34 ust. 2 u.w.m.p.s. nie jest dopuszczalne łączenie mandatu posła $z$ zatrudnieniem na stanowisku dyrektora Centrum Kultury i Bibliotek Gminy . W analizowanym w niniejszej opinii przypadku zastosowanie znajdzie więc przytoczony wyżej przepis art. 34 ust. 3 u.w.m.p.s.

Zgodnie $\mathrm{z}$ art. 34 ust. 5 u.w.m.p.s. naruszenie przez posła zakazu z art. 34 ust. 1-3 u.w.m.p.s. skutkowałoby odpowiedzialnością regulaminową (zwrócenie posłowi uwagi, udzielenie upomnienia, udzielenie nagany).

\section{Bibliografia}

Jagoda J. [w:] Ustawa o samorządzie powiatowym. Komentarz, red. B. Dolnicki, Kraków 2005.

Słownik języka polskiego, t. 3, red. M. Szymczak, Warszawa 1981.

Szydło M., Zakaz łączenia mandatu parlamentarnego. Studium prawne, Warszawa-Poznań 2012. 

\begin{tabular}{l|l}
2 & OPINIE BAS
\end{tabular}

VARIA 

Ewelina Gierach

\title{
Interpelacje i zapytania radnych ${ }^{1}$
}

\author{
Interpellations and councillors' questions
}

In the opinion of the author of the opinion, a communal council may include in a communal stat-
utes issues related to interpellations and questions submitted by councillors. The provisions of the
statutes in this respect may not repeat or modify the provisions of the Act on Communal Self-gov-
ernment, in particular the statutes of the commune may not provide for any other form of submis-
sion of these documents than a written one. There are no legal obstacles to including in the agenda
of a session of the communal council an item concerning the information on the number of sub-
mitted interpellations and questions by councillors, their contents and the answers given to them.

Keywords: communal council, interpellation, councillor

Zdaniem autorki opinii rada gminy w statucie może uregulować kwestie związane z interpelacjami i zapytaniami radnych. Postanowienia statutu w tym zakresie nie mogą powtarzać ani modyfikować przepisów ustawy o samorządzie gminnym, w szczególności w statucie gminy nie można przewidzieć innej niż pisemna forma wnoszenia tych dokumentów. Brak jest przeszkód prawnych dla wprowadzenia do porządku obrad sesji rady gminy punktu, w ramach którego przewidziane jest złożenie informacji o liczbie złożonych interpelacji i zapytań radnych, ich treści oraz udzielonych na nie odpowiedziach.

Słowa kluczowe: rada gminy, interpelacja, radny

Doktor nauk prawnych, adiunkt -

Uniwersytet Kardynała Stefana Wyszyńskiego w Warszawie, Wydział Prawa i Administracji,

Katedra Prawa Konstytucyjnego, WARSZAWA, POLSKA •

ewelina.gierach@sejm.gov.pl • https://orcid.org/0000-0002-2689-786X

\section{Przedmiot opinii}

Przedmiotem opinii jest odpowiedź na następujące pytania:

- czy wprowadzenie na sesję rady gminy punktu „interpelacje i zapytania radnych", podczas którego radni mogliby odczytywać interpelacje i zapytania, a następnie składać je u przewodniczącego rady, jest niezgodne z ustawą z 8 marca 1990 r. o samorządzie gminnym?,

- czy umieszczanie powyższego punktu w ramach porządku obrad rady gminy jest złamaniem ustawy z 8 marca 1990 r. o samorządzie gminnym?,

- czy jakakolwiek inna ustawa zabrania wpisania punktu „interpelacje i zapytania radnych" do porządku obrad sesji rady gminy.

1 Opinia prawna dotyczaca interpelacji $i$ zapytań radnych sporządzona 25 czerwca 2019 r. na zlecenie posła niezrzeszonego; BAS-WAKiU 1032/19. 


\section{Analiza szczegółowa}

W myśl art. 24 ust. 3 ustawy z 8 marca 1990 r. o samorządzie gminnym (t.j. Dz.U. 2019, poz. 506): w sprawach dotyczacych gminy radni moga kierować interpelacje i zapytania do wójta. Ustęp 4 tego przepisu zastrzega, że interpelacja: dotyczy spraw o istotnym znaczeniu dla gminy. Interpelacja powinna zawierać krótkie przedstawienie stanu faktycznego będącego jej przedmiotem oraz wynikajace z niej pytania. Zapytania zaś: składa się w sprawach dotyczacych aktualnych problemów gminy, a także $w$ celu uzyskania informacji o konkretnym stanie faktycznym (art. 24 ust. 5). Interpelacje i zapytania składane są na piśmie do przewodniczącego rady, który przekazuje je niezwłocznie wójtowi. Wójt, lub osoba przez niego wyznaczona, jest zobowiązany udzielić odpowiedzi na piśmie nie później niż w terminie 14 dni od dnia otrzymania interpelacji lub zapytania (art. 24 ust. 6). Treść interpelacji i zapytań oraz udzielonych odpowiedzi podawana jest do publicznej wiadomości poprzez niezwłoczną publikację w Biuletynie Informacji Publicznej i na stronie internetowej gminy oraz $\mathrm{w}$ inny sposób zwyczajowo przyjęty (art. 24 ust. 7). Interpelacje, jak również zapytania poselskie stanowią uprawnienia kontrolne wobec wójta jako organu wykonawczego. Uregulowanie tych instytucji na poziomie ustawowym do niedawna było domeną wyłącznie regulacji statutowych, bowiem dokonało się na mocy przepisów ustawy z 11 stycznia 2018 r. o zmianie niektórych ustaw w celu zwiększenia udziału obywateli w procesie wybierania, funkcjonowania i kontrolowania niektórych organów publicznych (Dz.U. poz. 130, ze zm.).

Zgodnie $\mathrm{z}$ art. 22 ust. 1 ustawy o samorządzie gminnym organizację wewnętrzną oraz tryb pracy organów gminy określa statut gminy. Rada gminy, ustalając statut gminy, nie jest jednak w pełni swobodna i nie ma dowolności w zakresie ustalania treści tego dokumentu. Statut bowiem, jako akt prawa miejscowego, nie może regulować materii należącej do przepisów aktów wyższego rzędu i nie może być z nimi sprzeczny. Odnosząc się do postawionych we wstępie pytań, należy zauważyć, że jakkolwiek rada gminy w statucie może uregulować kwestie związane $z$ interpelacjami i zapytaniami radnych, postanowienia statutu w tym zakresie nie mogą powtarzać ani modyfikować przepisów ustawy o samorządzie gminnym. Mając zatem na względzie uregulowania tej ustawy, należy zaznaczyć, że jedyną dopuszczalną formą składania interpelacji jest forma pisemna, w tym także forma elektroniczna ${ }^{2}$. Zatem w statucie danej gminy nie można przewidzieć innych postaci wnoszenia tych dokumentów, np. w formie ustnej do protokołu. Nie jest możliwe zarówno uzależnienie skutecznego przedłożenia interpelacji bądź zapytania od odczytania ich na sesji rady, jak też ustanowienie warunku, aby w trakcie sesji udzielane były odpowiedzi na interpelacje i zapyta-

2 Zob. P. Sitniewski, Jawność obrad organów stanowiących - nowe obowiązki samorzadów, „Informacja w Administracji Publicznej” 2019, nr 1, s. 36 i n. 
nia zgłoszone na poprzednich sesjach. Takie uregulowania statutowe stanowią niedozwoloną modyfikację art. 24 ust. 6 ustawy o samorządzie gminnym, zgodnie z którym interpelacje i zapytania składane są na piśmie do przewodniczącego rady, zaś wójt, bądź osoba przez niego wyznaczona, jest zobowiązany udzielić odpowiedzi na piśmie $e^{3}$. Interpelacje i zapytania mogą być bowiem składane podczas sesji, jak również w okresie między sesjami. Treść interpelacji i zapytań oraz udzielonych na nie odpowiedzi objęta jest ustawowym obowiązkiem publikacji. Obowiązkowo interpelacje i zapytania upublicznia się na stronie Biuletynu Informacji Publicznej jednostki samorządu terytorialnego oraz na stronie internetowej, jeżeli taką dana jednostka prowadzi. Formą fakultatywną upublicznienia są wszelkie formy zwyczajowo przyjęte. Publikacja ma następować niezwłocznie. Upublicznienie treści interpelacji i zapytań nie może być uzależnione od odbycia sesji organu stanowiącego ani od udzielenia przez organ wykonawczy odpowiedzi na nie. Obowiązek publikacji interpelacji i zapytań oraz udzielonych odpowiedzi niewątpliwie wymaga poszanowania ochrony danych osobowych i innych informacji prawnie chronionych. Właściwa publikacja na stronie internetowej treści interpelacji i zapytań wymaga często zatem przeprowadzenia procesu anonimizacji treści dokumentów, co niemożliwe jest w przypadku uprzedniego ich odczytywania podczas sesji rady.

W mojej ocenie brak jest natomiast przeszkód prawnych dla wprowadzenia do porządku obrad sesji rady gminy punktu „interpelacje i zapytania radnych”, w ramach którego przewidziane jest złożenie informacji przez wójta lub osobę przez niego upoważnioną o liczbie złożonych interpelacji i zapytań, ich treści oraz udzielonych na nie odpowiedziach. Taki punkt obrad może mieć jednak charakter wyłącznie informacyjny i sprawozdawczy i nie może stanowić substytutu wywiązywania się z ustawowych obowiązków publikacji treści interpelacji i zapytań oraz odpowiedzi na nie ${ }^{4}$.

\section{Podsumowanie}

- Jakkolwiek rada gminy w statucie może uregulować kwestie związane z interpelacjami i zapytaniami radnych, postanowienia statutu $\mathrm{w}$ tym zakresie nie mogą powtarzać ani modyfikować przepisów ustawy o samorządzie gminnym. W szczególności w statucie danej gminy nie można przewidzieć innej niż

3 Zob. rozstrzygnięcie nadzorcze Wojewody Wielkopolskiego z 28 listopada 2018 r., KN I.4131.1.618.2018.16, Dz.Urz.Woj.Wlkp. 2018 nr 217, poz. 9391; rozstrzygnięcie nadzorcze Wojewody Zachodniopomorskiego z 6 grudnia 2018 r., P 1.4131.378.2018. AS, Dz.Urz.Woj.Zach. 2018, nr 217, poz. 5701.

4 Tak również: rozstrzygnięcie nadzorcze Wojewody Wielkopolskiego z 28 listopada 2018 r., KN I.4131.1.618.2018.16. 
pisemna forma wnoszenia tych dokumentów, np. w formie ustnej do protokołu. Nie jest możliwe zarówno uzależnienie skutecznego przedłożenia interpelacji bądź zapytania od odczytania ich na sesji rady, jak też ustanowienie warunku, aby w trakcie sesji udzielane były odpowiedzi na interpelacje i zapytania zgłoszone na poprzednich sesjach.

- Brak jest przeszkód prawnych dla wprowadzenia do porządku obrad sesji rady gminy punktu „interpelacje i zapytania radnych”, w ramach którego przewidziane jest złożenie informacji przez wójta lub osobę przez niego upoważnioną o liczbie złożonych interpelacji i zapytań, ich treści oraz udzielonych na nie odpowiedziach.

\section{Bibliografia}

Sitniewski P., Jawność obrad organów stanowiących - nowe obowiązki samorządów, „Informacja w Administracji Publicznej” 2019, nr 1. 
Kamila Groszkowska

\title{
Skład osobowy komisji rewizyjnej w sejmiku województwa, radzie powiatu i radzie gminy oraz konflikt interesów w samorządzie terytorialnym ${ }^{1}$
}

\author{
Composition of an audit committee in a voivodeship sejmik (regional \\ parliament), district council and municipal council, as well as conflicts \\ of interest in local government
}

Statutory provisions regulating the functioning of local government do not include a prohibition regarding assuming the function of a member of an audit committee by a person married to a person holding the function of a head of commune, mayor, starost (head of a district board) or marshal of a voivodeship. Main regulations concerning counteracting conflicts of interest in a local government unit concern the prohibition of combining public functions, restrictions on taking up economic or commercial activities outside the sphere of public administration and exclusion of a councillor from voting, if a vote concerns his legal interest.

Keywords: audit committee, conflicts of interest, local government

Przepisy ustaw regulujących funkcjonowanie samorządu terytorialnego nie zawierają zakazu objęcia funkcji członka komisji rewizyjnej przez osobę pozostającą w związku małżeńskim z osobą pełniącą funkcję wójta, burmistrza, starosty lub marszałka województwa. Główne uregulowania w zakresie przeciwdziałania konfliktowi interesów w jednostce samorządu terytorialnego dotyczą zakazu łączenia funkcji publicznych, ograniczenia podejmowania działalności gospodarczej lub zarobkowej poza sferą administracji publicznej oraz wyłączenie radnego z udziału w głosowaniu, jeżeli dotyczy ono jego interesu prawnego.

Słowa kluczowe: komisja rewizyjna, konflikt interesów, samorząd terytorialny

Ekspert ds. międzynarodowych Biura Analiz Sejmowych •

Kancelaria Sejmu, Wydział Analiz Prawa Międzynarodowego i Zagranicznych Systemów Prawnych, Zespół Studiów nad Zagranicznymi Systemami Prawnymi, WARSZAWA, POLSKA • kamila.groszkowska@sejm.gov.pl • https://orcid.org/0000-0002-8618-1302

\section{Przedmiot opinii}

Przedmiotem opinii jest rozwiązanie kwestii dotyczącej składu osobowego komisji rewizyjnej w jednostkach samorządu terytorialnego. Służyć temu ma odpowiedź na następujące pytania:

1 Opinia prawna na temat składu osobowego komisji rewizyjnej w sejmiku województwa, radzie powiatu i radzie gminy oraz [na temat] konfliktu interesów w samorządzie terytorialnym sporządzona 30 stycznia 2020 r. na zlecenie posła Klubu Parlamentarnego Platforma Obywatelska - Koalicja Obywatelska; BAS-WAP 38/20. 
- czy członkiem komisji rewizyjnej rady gminy/ powiatu/sejmiku województwa może być małżonek osoby pełniącej funkcję wójta/ burmistrza/ starosty/ marszałka województwa (casus gminy Namysłów, woj. opolskie)?,

- w sytuacji dopuszczalności wyżej opisanej sytuacji, z jakimi ograniczeniami wiąże się pełnienie funkcji członka komisji rewizyjnej?,

- czy przepisy regulujące funkcjonowanie samorządu terytorialnego chronią przed zaistnieniem konfliktu interesów, tj. czy konflikt interesów jest w samorządzie terytorialnym kategorią etyczną czy prawną?

Opinia została przygotowana $\mathrm{z}$ uwzględnieniem przepisów następujących aktów prawnych:

- ustawa z 5 czerwca 1998 r. o samorządzie województwa, t.j. Dz.U. 2019, poz. 512, ze zm.; dalej: u.s.woj.,

- ustawa z 5 czerwca 1998 r. o samorządzie powiatowym, t.j. Dz.U. 2019, poz. 511, ze zm.; dalej: u.s.pow.,

- ustawa z 8 marca 1990 r. o samorządzie gminnym, t.j. Dz.U. 2019, poz. 506, ze zm.; dalej: u.s.gm.

- Kodeks wyborczy z 5 stycznia 2011 r., Dz.U. 2019, poz. 684, ze zm.

Biuro Analiz Sejmowych nie dokonuje oceny prawnej konkretnych stanów prawnych w kontekście prowadzenia sporów sądowych. Statutowym zadaniem BAS jest prowadzenie działalności w zakresie zapewniania doradztwa naukowego na rzecz Sejmu i jego organów, co w przypadku posłów wyraża się we wspieraniu ich działalności związanej z toczącymi się pracami legislacyjnymi oraz z realizacją praw i obowiązków wynikających ze sprawowania mandatu. Ten zakres działalności BAS obejmuje także przygotowywanie informacji oraz opinii na temat stosowania obowiązującego prawa.

Opracowywane dla posłów analizy i opinie nie stanowią jednak rozstrzygnięć w sprawach indywidualnych, dotyczących konkretnych stanów faktycznych i prawnych, ale koncentrują się na zagadnieniach abstrakcyjnych lub zgeneralizowanych. Poniżej przedstawione zostaną ogólne zasady oraz przepisy, które mogą znaleźć zastosowanie w odpowiedzi na postawione we wstępie opinii pytania.

\section{Uzasadnienie prawne}

\section{Uwagi ogólne}

Komisja rewizyjna w jednostkach samorządu terytorialnego jest organem pełniącym funkcje kontrolne. W samorządzie województwa jest to kontrola nad działalnością zarządu województwa i wojewódzkich samorządowych jednostek organizacyjnych (art. 30 ust. 1 u.s.woj.), w samorządzie powiatowym nad działalnością zarządu oraz powiatowych jednostek organizacyjnych (art. 16 ust. 1 u.s.pow.), 
a w samorządzie gminnym nad działalnością wójta, gminnych jednostek organizacyjnych oraz jednostek pomocniczych gminy (art. 18a ust. 1 u.s.gm.). Komisje rewizyjne są obligatoryjnie powoływane przez sejmik województwa (art. 30 ust. 1 u.s.woj.), radę powiatu (art. 16 ust. 1 u.s.pow.) lub radę gminy (art. 18a ust. 1 u.s.gm.) w celu realizowania funkcji kontrolnej. Do podstawowych zadań komisji rewizyjnych należą opiniowanie wykonania budżetu oraz występowanie $\mathrm{z}$ wnioskiem $\mathrm{w}$ sprawie udzielenia lub nieudzielenia absolutorium zarządowi (art. 30 ust. 3 u.s.woj., art. 16 ust. 3 u.s.pow., art. 18a ust. 3 u.s.gm.). Komisja rewizyjna nie ma własnych uprawnień decyzyjnych, działa jako organ wyspecjalizowany, wykonujący zadania w ramach funkcji kontrolnej przyznanej przez ustawodawcę sejmikowi województwa (art. 16 ust. 1 u.s.woj.), radzie powiatu (art. 9 ust. 1 u.s.pow.) i radzie gminy (art. 15 u.s.gm.). Zgodnie z interpretacją Wojewódzkiego Sądu Administracyjnego (WSA) w Bydgoszczy w wyroku z 21 listopada $2008 \mathrm{r}^{2}$. art. 18a ust. 1 u.s.gm. nie wyklucza możliwości wykonywania kontroli bezpośrednio przez radę gminy, a komisja rewizyjna jest powoływana w celu zapewnienia odpowiedniej sprawności tej kontroli. Jednocześnie, zdaniem sądu, istnienie obowiązku powołania komisji rewizyjnej nie może prowadzić do stwierdzenia, że komisja ta wykonuje funkcję kontrolną zamiast rady.

\section{Skład osobowy komisji rewizyjnej}

Analizowane akty prawne nie regulują bezpośrednio możliwości objęcia funkcji członka komisji rewizyjnej w jednostce samorządu terytorialnego przez małżonka osoby zajmującej stanowisko wójta, burmistrza, starosty lub marszałka, zawierają natomiast pewne wytyczne w zakresie składu osobowego komisji. Zgodnie z art. 30 ust. 2 u.s.woj. w skład komisji rewizyjnej wchodzą radni, w tym przedstawiciele wszystkich klubów. Przepis ten zawiera zakaz łączenia członkostwa w komisji z funkcją marszałka województwa, przewodniczącego oraz wiceprzewodniczącego sejmiku oraz radnych będących członkami zarządu województwa. Podobnie uregulowany został skład komisji rewizyjnej w radzie powiatu. Zgodnie $\mathrm{z}$ art. 16 ust. 2 u.s.pow. w skład komisji rewizyjnej wchodzą radni, w tym przedstawiciele wszystkich klubów, $\mathrm{z}$ wyjątkiem radnych pełniących funkcje przewodniczącego lub wiceprzewodniczących rady powiatu oraz będących członkami zarządu. Ustawa o samorządzie gminnym zawiera analogiczny przepis, tj. art. 18a ust. 2, zgodnie z którym w skład komisji rewizyjnej wchodzą radni, w tym przedstawiciele wszystkich klubów, z wyjątkiem radnych pełniących funkcje przewodniczącego i wiceprzewodniczących. Zakaz łączenia stanowisk nie został w ustawie rozszerzony na małżonków lub członków rodziny ww. osób.

$\mathrm{Z}$ analizowanych przepisów wynika, że w skład komisji rewizyjnej muszą wchodzić radni, tj. osoby wybrane w powszechnych wyborach samorządowych,

2 Wyrok WSA w Bydgoszczy z 25 listopada 2008 r., sygn. akt II SA/BD 711/08, Legalis nr 149998. 
przy czym każdy klub radnych musi mieć w komisji swojego przedstawiciela. Ustawodawca nie precyzuje składu ilościowego komisji rewizyjnej, nakłada natomiast na sejmik województwa, radę powiatu i radę gminy obowiązek zapewnienia, by każdy klub radnych był w komisji reprezentowany. Wymóg ustalenia odpowiedniego składu osobowego jest również podkreślany $\mathrm{w}$ orzecznictwie sądów administracyjnych. Zgodnie z wyrokiem WSA w Olsztynie z 30 czerwca $2011 \mathrm{r}^{3}$ ustawa nie przewiduje odstępstw od zasady uczestnictwa przedstawicieli wszystkich klubów w komisji rewizyjnej i dopóki nie można stworzyć komisji z przedstawicieli wszystkich klubów, organ ten nie może w ogóle zostać utworzony. Podobnie Naczelny Sąd Administracyjny (NSA) w wyroku z 27 czerwca 2013 r. ${ }^{4}$ podtrzymał obowiązek powoływania komisji rewizyjnej w składzie określonym ustawowo, to znaczy w składzie, w którym znajdą się przedstawiciele wszystkich klubów. NSA podkreślił, że: ratio legis takiego rozwiązania wynika z uznania doniosłości funkcji kontrolnej komisji rewizyjnej i potrzeby zapewnienia politycznym reprezentacjom radnych (klubom) realnej możliwości - w ramach demokratycznych procedur - sprawowania kontroli m.in. $w$ tak istotnym zakresie jak wykonanie budżetu i wnioskowanie o udzielenie lub nieudzielenie zarzadowi absolutorium czy opiniowanie wniosku o odwołanie starosty.

Warto zauważyć, że sejmik czy rada nie są związane kandydaturami zaproponowanymi przez kluby radnych. Powołanie komisji rewizyjnej jest ustawowym obowiązkiem sejmiku województwa (art. 30 ust. 1 u.s.woj.), rady powiatu (art. 16 ust. 1 u.s.pow.) i rady gminy (art. 18a ust. 1 u.s.gm.), a uchwała o powołaniu składu osobowego komisji ma charakter konstytutywny, co oznacza, że członkami komisji rewizyjnej zostają tylko ci radni, których wybrał sejmik lub $\mathrm{rada}^{5}$. Zgodnie z wyrokiem NSA z 10 stycznia $2012 \mathrm{r}^{6}:$ rada gminy nie jest [...] związana kandydatura przedstawiona przez klub. Jeżeli jednak na danej sesji rady nie można podjać uchwały w sprawie wyboru członków komisji rewizyjnej, próbę wyboru należy ponowić na kolejnej sesji, zaś organy gminy oraz kluby radnych winny dążý do wypracowania konsensusu w sprawie wyboru konkretnego kandydata. W przeciwnym razie brak obligatoryjnego wewnętrznego organu gminy może doprowadzić do zainicjowania procedury ustanowienia zarząu komisarycznego $w$ trybie art. 97 ustawy o samorzadzie gminnym. Podobnie w wyroku z 8 grudnia 2011 r. $^{7}$ NSA orzekł, że: okoliczność, że rada gminy ma powołać komisje rewizyjna o określonym składzie nie oznacza, że pozbawiona jest swobody wyboru przedstawicieli klubów. Komisja rewizyjna jest organem, za pomocą którego realizo-

3 Wyrok WSA w Olsztynie z 30 czerwca 2011 r., sygn. akt II SA/Ol 296/11, Legalis nr 385633.

4 Wyrok NSA z 27 czerwca 2013 r., sygn. akt II OSK 325/13, Legalis nr 734961.,

5 Ustawa o samorządzie województwa. Komentarz, red. S. Gajewski, A. Jakubowski, Warszawa 2019, komentarz do art. 30.

$6 \quad$ Wyrok NSA z 10 stycznia 2012 r., sygn. akt II OSK 2351/11, Legalis nr 491291.

7 Wyrok NSA z 8 grudnia 2011 r., sygn. akt II OSK 2380/11, Legalis nr 825587. 
wana jest funkcja kontrolna, w związku z czym jej członkowie mają cieszyć się zaufaniem radnych zasiadających w sejmiku lub w radzie. W konsekwencji sejmik lub rada muszą mieć możliwość wpływu na skład osobowy komisji rewizyj$n j^{8}$. W przypadku gdy kandydat zaproponowany przez klub radnych wzbudza uzasadnione wątpliwości np. co do jego stronniczości lub braku obiektywizmu, sejmik lub rada może odrzucić jego kandydaturę lub odwołać ze składu już powołanej komisji rewizyjnej w zwykłym przewidzianym statutem trybie podejmowania uchwał . Pozostawanie w związku małżeńskim z np. wójtem lub marszałkiem województwa może być okolicznością przesądzającą o odrzuceniu takiej kandydatury do komisji rewizyjnej przez radę lub sejmik.

Ponadto, zgodnie z wyrokiem NSA z 9 maja 2013 r. $^{10}$, komisja rewizyjna powinna zostać powołana przez radę lub sejmik z pominięciem przedstawiciela klubu radnych, jeżeli klub nie korzysta ze swojego ustawowego prawa i odmawia wskazania swojego przedstawiciela do komisji. NSA określił, że wykładnia przepisów ustawy musi: uwzględniać cele, jakie zakładat ustawodawca, wprowadzając wymóg wybierania do składu komisji rewizyjnej przedstawicieli wszystkich klubów i nie może prowadzić, poprzez uznanie każdej uchwaty niespetniajacej tego wymogu za sprzeczna z prawem, do skutków przez tego ustawodawce nieprzewidzianych i niepożądanych.

Szczegółowe postanowienia w zakresie zasad i trybu działania komisji rewizyjnej powinny zostać uregulowane w statucie jednostki samorządu terytorialnego. Zgodnie z art. 28 ust. 2 u.s.woj. statut województwa określa przedmiot działania, zakres zadań, zasady dotyczące składu, organizację wewnętrzną i tryb pracy komisji powoływanych przez sejmik województwa. Podobnie w przypadku powiatu, zgodnie $\mathrm{z}$ art. 19 u.s.pow., organizację wewnętrzną oraz tryb pracy rady i komisji powoływanych przez radę, a także zasady tworzenia klubów radnych, określa statut. Również statut gminy określa zasady i tryb działania komisji rewizyjnej (art. 18a ust. 5 u.s.gm.). Zgodnie z orzecznictwem NSA statut jest wyrazem autonomii w zakresie regulacji funkcjonowania samorządu i należy go traktować jako integralną część ustrojowego prawa samorządu ${ }^{11}$. W statucie mogą zostać unormowane wszystkie kwestie ustrojowe nieokreślone szczegółowo w ustawach, o ile nie są sprzeczne z przepisami prawa. W konsekwencji statut powinien określać procedury dotyczące trybu pracy komisji rewizyjnej, sposobu jej powoływania oraz zasady kreowania składu osobowego. W wyroku z 10 stycznia 2012 r. $^{12}$ NSA potwierdził, że postanowienia dotyczące składu osobowego komisji rewizyjnej mogą zostać zawarte w statucie.

8 Zob. wyrok WSA w Lublinie z 15 września 2005 r., sygn. akt III SA/Lu 257/05, Legalis nr 159908.

9 Ustawa o samorządzie województwa, red. S. Gajewski, A. Jakubowski, op. cit.

10 Wyrok NSA z 9 maja 2013 r., sygn. akt II OSK 778/13, Legalis nr 722429.

11 Zob. wyrok NSA z 8 lutego 2005 r., sygn. akt OSK 1122/04, Legalis nr 73238.

12 Wyrok NSA z 10 stycznia 2012 r.,sygn. akt II OSK 2351/11, Legalis nr 491291. 
W zakresie możliwości ograniczenia funkcji poszczególnych członków komisji rewizyjnej ze względu na stronniczość czy brak obiektywizmu w literaturze przedmiotu i orzecznictwie nie ma jednolitego stanowiska. WSA w Olsztynie wyroku z 26 kwietnia 2016 r $^{13}$. orzekł, że pojęcia „interesowności” i „stronniczości” nie pojawiają się w ustawie regulującej funkcjonowanie rady powiatu. Sąd stwierdził, że: $w$ sytuacji wyboru radnego do składu komisji nie sa możliwe jakiekolwiek, nawet czasowe wyłaczenia od udziału w jej pracach ani na mocy decyzji przewodniczącego komisji, ani też uchwały rady, chyba, że rada podejmie decyzje o zmianie składu osobowego komisji, bądz komisji rewizyjnej. Jednocześnie autorzy komentarza do art. 16 u.s.pow. wskazali, że statuty niektórych powiatów i gmin zawierają zapisy określające zasady ograniczania i wyłączania członków komisji z prac komisji, a stanowisko WSA w Olsztynie uznali za radykalne ${ }^{14}$. Ich zdaniem zawarcie w statucie jednostki samorządu terytorialnego ograniczeń o charakterze obiektywnym, np. w zakresie ograniczenia prawa radnego do udziału w pracach zespołów kontrolnych ze względu na pozostawanie w związku małżeńskim z pracownikiem kontrolowanego podmiotu, powinno zostać uznane za dopuszczalne w granicach prawa ${ }^{15}$.

\section{Konflikt interesów}

Konflikt interesów można zdefiniować ogólnie jako występującą rzeczywiście lub mogącą wystąpić sprzeczność między obowiązkami wynikającymi z pełnienia funkcji publicznej a interesami prywatnymi, podczas gdy realizacja tego interesu prawnego mogłaby godzić w dobro publiczne lub negatywnie wpływać na realizowanie obowiązków służbowych ${ }^{16}$. W ustawach określających funkcjonowanie samorządu terytorialnego ustawodawca wprowadził regulacje mające na celu zapobiegać powstawaniu konfliktowi interesów oraz służyć transparentności działań samorządu. Pierwszym ograniczeniem jest zasada niepołączalności formalnej, tj. zakaz łączenia funkcji publicznych. Zgodnie z art. 25b u.s.gm. funkcji radnego nie można łączyć $\mathrm{z}$ :

- mandatem posła,

- mandatem senatora,

- funkcją wojewody,

- funkcją wicewojewody,

- mandatem radnego gminnego dowolnej gminy,

- mandatem radnego powiatowego dowolnego powiatu,

13 Wyrok WSA w Olsztynie z 26 kwietnia 2016 r., sygn. akt II SA/Ol 364/16, Legalis nr 1484571.

14 Ustawa o samorzadzie powiatowym. Komentarz, red. P. Drembkowski, Warszawa 2019, komentarz do art. 16.

15 Ibidem.

16 Konflikt interesów w polskiej administracji rządowej - prawo, praktyka, postawy urzędników, Fundacja im. Stefana Batorego, Warszawa 2014, s. 9. 
- mandatem radnego wojewódzkiego dowolnego województwa,

- funkcją wójta innej gminy,

- funkcją członka zarządu jakiegokolwiek powiatu,

- funkcją członka zarządu jakiegokolwiek województwa.

Ponadto, zgodnie z art. 27 u.s.gm., radny nie może pełnić funkcji wójta i jego zastępcy w gminie, w której uzyskał mandat. Sankcją za naruszenie przepisów o niepołączalności jest wygaśnięcie mandatu radnego (art. $383 \$ 1$ pkt 5 Kodeksu wyborczego). Analogiczny zakaz łączenia funkcji publicznych zawarty jest w art. 21 ust. 8 u.s.pow. oraz w art. 23 ust. 4 u.s.woj.

Ustawodawca przewidział również ograniczenia dotyczące podejmowania działalności gospodarczej lub zarobkowej poza sferą administracji publicznej. Radny nie może być w związku z tym zatrudniony w urzędzie gminy, starostwie powiatowym lub urzędzie marszałkowskim, w którym uzyskał mandat (art. 24a u.s.gm., art. 23 u.s.pow., art. 25 u.s.woj.), a w przypadku pozostawania w takim stosunku pracy przed objęciem mandatu jest zobowiązany do złożenia wniosku o urlop bezpłatny. Zgodnie z art. 24d u.s.gm. wójt nie może powierzyć radnemu gminy, w której radny uzyskał mandat, wykonywania pracy na podstawie umowy cywilnoprawnej (analogicznie art. 23 ust. 5 u.s.pow. i art. 25 ust. 4 u.s.woj.). Ustawy zawierają także zakaz podejmowania przez radnych dodatkowych zajęć lub otrzymywania darowizn mogących podważyć zaufanie wyborców do wykonywania mandatu (art. 24e u.s.gm., art. 25a u.s.pow. i art. 27a u.s.woj.). Radni nie mogą również prowadzić działalności gospodarczej na własny rachunek lub wspólnie z innymi osobami z wykorzystaniem mienia jednostki samorządu terytorialnego, w której radny uzyskał mandat, a także zarządzać taką działalnością lub być przedstawicielem czy pełnomocnikiem w prowadzeniu takiej działalności (art. 24f u.s.gm., art. 25b u.s.pow. i art. 27b u.s.woj.).

Kolejnym ograniczeniem w przedmiocie zapobiegania konfliktowi interesów jest wyłączenie radnego $\mathrm{z}$ udziału w głosowaniu w radzie lub w komisji, jeżeli dotyczy ono jego interesu prawnego (art. 25a u.s.gm. i analogicznie art. 21 ust. 7 u.s.pow. oraz art. 24 ust. 2 u.s.woj.). Celem przepisu jest wyeliminowanie sytuacji, gdy radny w głosowaniu będzie kierował się interesem własnym a nie dobrem wspólnym jednostki samorządu terytorialnego. Zgodnie z interpretacją NSA zakaz ten dotyczy wszelkich aktów podejmowanych przez radę gminy (analogicznie radę powiatu i sejmik województwa) lub komisję, a więc również tzw. uchwał intencyjnych rady oraz wszelkich uchwał komisji, które nie mają charakteru prawotwórczego ${ }^{17}$. NSA w wyroku z 9 kwietnia 2013 r. zdefiniował interes prawny jako: osobisty, konkretny i aktualny prawnie chroniony interes, który może być realizowany na podstawie określonego przepisu, bezpośrednio wiążacy się $z$ indywidualnie i prawnie chroniona sytuacją strony. Istnieje on więc wówczas, gdy istnieje

17 Wyrok NSA z 11 stycznia 2012 r., sygn. akt I OSK 2006/11, Legalis nr 418286. 
związek o charakterze materialnoprawnym między obowiązujaca norma prawa administracyjnego, a sytuacja prawna konkretnego podmiotu prawa, polegajaca na tym, że akt stosowania tej normy może mieć wpływ na sytuacje tego podmiotu na gruncie administracyjnoprawnym. Pojęcie interesu prawnego jest interpretowane szeroko, może on wynikać zarówno z przepisów ustrojowych, przepisów prawa materialnego (cywilnego, administracyjnego, karnego, gospodarczego czy prawa pracy) i przepisów prawa procesowego ${ }^{18}$. Interes prawny należy także odróżnić od interesu faktycznego, gdy radny jest bezpośrednio zainteresowany rozstrzygnięciem danej sprawy, nie może jednak tego zainteresowania poprzeć przepisami prawa, mającymi stanowić podstawę skierowanego żądania w zakresie podjęcia stosownych czynności przez organ administracji. W myśl art. 25a u.s.gm. radny podlega wyłączeniu nawet wtedy, gdy jego interes prawny jest zbieżny z interesem gminy.

Artykuł 21 ust. 7 u.s.pow. ma szerszy zakres, odnosi się bowiem do wszystkich głosowań dotyczących interesu prawnego radnego (nie tylko w radzie i w komisjach jak w przypadków radnych gminnych), natomiast zakres wyłączenia w art. 24 ust. 2 u.s.woj. został ograniczony tylko do spraw majątkowych.

\section{Podsumowanie}

- Przepisy ustaw regulujących funkcjonowanie samorządu terytorialnego nie zawierają zakazu objęcia funkcji członka komisji rewizyjnej ze względu na pozostawanie w związku małżeńskim z osobą pełniącą funkcję wójta, burmistrza, starosty lub marszałka województwa.

- Skład osobowy komisji rewizyjnej w jednostce samorządu terytorialnego jest powoływany odpowiednio przez sejmik województwa, radę powiatu lub radę gminy na podstawie kandydatur przedstawianych przez kluby radnych. Każdy klub radnych musi mieć w komisji rewizyjnej swojego przedstawiciela, przy czym sejmik województwa, rada powiatu lub rada gminy nie są związane tymi kandydaturami i mogą je odrzucić np. ze względu na brak obiektywizmu kandydata.

- Szczegółowe postanowienia w zakresie funkcjonowania i powoływania składu osobowego komisji rewizyjnej mogą zostać określone w statucie jednostki samorządu terytorialnego.

- Główne uregulowania w zakresie przeciwdziałania konfliktowi interesów w jednostce samorządu terytorialnego dotyczą zakazu łączenia funkcji publicznych, ograniczenia podejmowania działalności gospodarczej lub zarobkowej poza sferą administracji publicznej oraz wyłączenie radnego z udziału w głosowaniu, jeżeli dotyczy ono jego interesu prawnego.

18 Wyrok WSA w Lublinie z 20 listopada 2007 r., sygn. akt III SA/Lu 414/07, Legalis nr 173008. 


\section{Bibliografia}

Konflikt interesów w polskiej administracji rządowej - prawo, praktyka, postawy urzędników, Fundacja im. Stefana Batorego, Warszawa 2014.

Ustawa o samorzadzie gminnym [w:] Ustawy samorzadowe. Komentarz, red. S. Gajewski, A. Jakubowski, Warszawa 2018.

Ustawa o samorzadzie powiatowym. Komentarz, red. P. Drembkowski, Warszawa 2019.

Ustawa o samorządzie województwa. Komentarz, red. S. Gajewski, A. Jakubowski, Warszawa 2019. 
Małgorzata Bajor-Stachańczyk

\title{
Możliwość wyboru metody ustalania opłaty za gospodarowanie odpadami komunalnymi ${ }^{1}$
}

\author{
Choosing the method for determining the communal waste \\ management fee
}

The Act on Maintaining Cleanliness and Order in Communes provides the basis for choosing the method of determining the fee based on several criteria. It also states that a communal council may apply various criteria differentiating the rates of payment. According to the current case law of the Supreme Administrative Court, the communal council has no right to introduce an additional criterion - within the chosen method of determining the fee - i.e. a division of households into categories depending on the number of tenants. Though, it cannot be excluded that there is a possibility to differentiate the fee calculated as a product of the number of tenants in the given real estate and the sum of the fee when applying the number of tenants as a criterion of differentiation. It has to be stressed that the stance of acceptance of such differentiation may be questioned by supervisory authorities.

Keywords: commune, waste, fee

Ustawa o utrzymaniu czystości i porządku w gminach daje podstawę do wyboru metody ustalenia opłaty według kilku kryteriów. Postanawia również, że rada gminy może stosować łącznie kilka kryteriów różnicujących stawki opłaty. Zgodnie z aktualnym orzecznictwem Naczelnego Sądu Administracyjnego brak upoważnienia dla rady gminy do wprowadzenia dodatkowego kryterium - w ramach wybranej metody ustalania opłaty - jakim jest podział gospodarstw domowych na kategorie zależne od liczby osób w nich zamieszkujących. Nie można natomiast wykluczyć możliwości zróżnicowania opłaty stanowiącej iloczyn liczby mieszkańców danej nieruchomości i stawki opłaty przy zastosowaniu liczby mieszkańców jako kryterium zróżnicowania. Należy jednak podkreślić, że stanowisko dopuszczające zróżnicowanie stawki z uwzględnieniem tego kryterium może być kwestionowane przez organy nadzoru.

Słowa kluczowe: gmina, odpady, opłaty

Ekspert ds. legislacji Biura Analiz Sejmowych •

Kancelaria Sejmu, Biuro Analiz Sejmowych, Wydział Analiz Prawnych, Zespół Prawa

Publicznego, WARSZAWA, POLSKA .

malgorzata.bajor-stachanczyk@sejm.gov.pl • https://orcid.org/0000-0003-0952-281X

\section{Przedmiot opinii}

W opinii przedstawiono odpowiedź na pytanie o ocenę dopuszczalności, na gruncie przepisów ustawy z 13 września 1996 r. o utrzymaniu czystości i porząd-

1 Opinia prawna w sprawie możliwości wyboru metody ustalania opłaty za gospodarowanie odpadami komunalnymi sporządzona 24 lutego 2020 r. na zlecenie posła Klubu Parlamentarnego Klub Parlamentarny Koalicja Obywatelska - Platforma Obywatelska, Nowoczesna, Inicjatywa Polska, Zieloni; BAS-WAP 244/20. 
ku w gminach, wyboru metody ustalania opłaty za gospodarowanie odpadami komunalnymi uzależnionej od liczby mieszkańców zamieszkujących daną nieruchomość przy uwzględnieniu założenia, że za każdą kolejną osobę zamieszkującą daną nieruchomość naliczana będzie niższa opłata, przy czym pojęcie „nieruchomość” w przypadku zabudowy wielorodzinnej (wielolokalowej) rozumiane będzie jako lokal mieszkalny. Należy podkreślić, że interpretacja przepisów w tym zakresie jest zróżnicowana i sprzeczna.

W niniejszej opinii uwzględniono stan prawny na dzień jej sporządzenia następujących postanowień:

- ustawy z 13 września 1996 r. o utrzymaniu czystości i porządku w gminach, t.j. Dz.U. 2019, poz. 2010, ze zm.; dalej: ustawa albo u.c.p.g.,

- ustawy z 8 marca 1990 r. o samorządzie gminnym, t.j. Dz.U. 2019, poz. 506, ze zm.; dalej: u.s.gm.

\section{Uzasadnienie}

Zadania gminy oraz obowiązki właścicieli nieruchomości dotyczące utrzymania czystości i porządku, w tym zasady ustalania opłat ponoszonych za gospodarowanie odpadami komunalnymi, reguluje ustawa o utrzymaniu czystości i porządku w gminach. Zgodnie z jej przepisami gminy są obowiązane do zorganizowania odbierania odpadów komunalnych od właścicieli nieruchomości, na których zamieszkują mieszkańcy (art. $6 c$ ust. 1 u.c.p.g.), a właściciele nieruchomości są obowiązani ponosić na rzecz gminy, na terenie której są położone ich nieruchomości, opłatę za gospodarowanie odpadami komunalnymi (art. $6 \mathrm{~h}$ u.c.p.g.). $\mathrm{W}$ art. $6 \mathrm{j}$ ustawa przewiduje różne metody ustalania opłaty za gospodarowanie odpadami komunalnymi w przypadku nieruchomości, o której mowa w art. $6 \mathrm{c}$ ust. 1. Pierwszą metodę wskazuje art. 6j ust. 1, zgodnie z którym opłata za gospodarowanie odpadami komunalnymi stanowi iloczyn:

- liczby mieszkańców zamieszkujących daną nieruchomość lub

- ilości zużytej wody z danej nieruchomości, lub

- powierzchni lokalu mieszkalnego

oraz stawki opłaty ustalonej na podstawie art. $6 \mathrm{k}$ ust. 1 u.c.p.g.

Drugą metodę reguluje art. $6 \mathrm{j}$ ust. 2, który wskazuje, że rada gminy może uchwalić jedną stawkę opłaty za gospodarowanie odpadami komunalnymi od gospodarstwa domowego.

Wyboru metody ustalenia opłaty za gospodarowanie odpadami komunalnymi spośród metod określonych w art. 6j ust. 1 i 2 u.c.p.g., ustalenia stawki takiej opłaty oraz ustalenia stawki opłaty za pojemnik lub worek o określonej pojemności, przeznaczony do zbierania odpadów komunalnych na terenie nieruchomości, dokonuje rada gminy w drodze uchwały (art. 6k ust. 1 ustawy). Uchwała rady 
gminy zawierająca wskazane regulacje jest aktem prawa miejscowego w rozumieniu art. 40 ust. 1 u.s.gm. Przy wydawaniu takiej uchwały rada ma obowiązek uwzględnić: liczbę mieszkańców zamieszkujących daną gminę, ilość wytwarzanych na terenie gminy odpadów komunalnych, koszty funkcjonowania systemu gospodarowania odpadami komunalnymi oraz przypadki, w których właściciele nieruchomości wytwarzają odpady nieregularnie, w szczególności to, że na niektórych nieruchomościach odpady komunalne powstają sezonowo. Ustawa dopuszcza stosowanie więcej niż jednej metody ustalenia opłat na obszarze gminy.

Zgodnie $z$ art 6 j ust. 1 u.c.p.g. opłata stanowi iloczyn stawki ustalonej na podstawie art. 6k ust. 1 oraz wybranej zmiennej (liczba mieszkańców, ilość zużytej wody, powierzchnia lokalu). Metoda ta (czy też, według niektórych, trzy metody) przewiduje więc ustalenie jednej stawki za gospodarowanie odpadami, a następnie uzależnienie wysokości opłat od okoliczności wskazanych w pkt 1-3 (art. 6j ust. 1). Z kolei art. 6j ust. 2 pozwala na uchwalenie jednej stawki opłaty za gospodarowanie odpadami komunalnymi od gospodarstwa domowego, bez względu na liczebność takiego gospodarstwa. Regulację tę uzupełnia art. 6j ust. 2a ustawy, który daje podstawę do zróżnicowania stawki opłaty w zależności od powierzchni lokalu mieszkalnego, liczby mieszkańców zamieszkujących nieruchomość, odbierania odpadów z terenów wiejskich lub miejskich, a także od rodzaju zabudowy. Postanawia również, że rada gminy może też stosować łącznie różne kryteria różnicujące stawki opłaty.

Powstaje w związku z tym pytanie, czy możliwość różnicowania stawek opłat za gospodarowanie odpadami komunalnymi wyrażona przez ustawodawcę w art. 6j ust. 2 u.c.p.g. dotyczy obu metod. W razie odpowiedzi twierdzącej, dopuszczalna byłaby koncepcja różnicowania stawki ze względu na liczbę osób stanowiących dane gospodarstwo domowe. Taki sposób rozumienia przepisu art. 6 j ust. 2a zdanie drugie jest jednak kwestionowany przez organy nadzoru oraz sądy administracyjne ${ }^{2}$. Zgodnie $z$ tym stanowiskiem ustawodawca w pierwszej kolejności uregulował w art. 6j ust. 1 i 2 u.c.p.g. metody ustalania opłat za gospodarowanie odpadami komunalnymi, a następnie wprowadził możliwość zróżnicowania stawki opłaty, ale z zawartych w tej regulacji sformułowań wynika, że odnosi się ona jedynie do metody wskazanej w art. 6j ust. 1, za pomocą kryteriów wskazanych w art. 6j ust. 2a ustawy. W konsekwencji możliwość różnicowania stawek opłat za gospodarowanie odpadami komunalnymi wyrażona przez ustawodawcę w art. 6j ust. 2a u.c.p.g. nie dotyczyłaby metody od gospodarstwa domowego. Takie stanowisko zaprezentował w szczególności Naczelny Sąd Administracyjny (NSA) w wyroku z 6 maja 2016 r., w sprawie o sygn akt II FSK 16/16. NSA podkreślił, że ze sformułowania art. 6j ust. 2a u.c.p.g. wyni-

2 Zob. uchwała Regionalnej Izby Obrachunkowej we Wrocławiu z 17 stycznia 2018 r., 5/2018; wyrok Wojewódzkiego Sądu Administracyjnego w Łodzi z 29 listopada 2016 r., sygn akt I SA/Łd 856/16, Legalis. 
ka, iż możliwość zróżnicowania stawki odnosi się tylko do niektórych parametrów obliczania opłaty, takich jak liczba mieszkańców czy powierzchnia lokalu, a więc tych, o których mowa $w$ art. $6 \mathrm{j}$ ust. 1 u.c.p.g., nie odnosi się natomiast do metody uregulowanej w art. 6j ust. 2. Zdaniem NSA z żadnego przepisu prawa nie wynika upoważnienie dla rady gminy do wprowadzenia w ramach metody wymienionej w art. 6j ust. 2 u.c.p.g. dodatkowego kryterium, jakim jest podział gospodarstw domowych na kategorie zależne od liczby osób w nich zamieszkujących i zróżnicowanie na tej podstawie wysokości stawki opłaty.

Cytowany wyrok stanowił odejście od linii orzeczniczej NSA, zgodnie z którą, przy zastosowaniu wykładni celowościowej i funkcjonalnej, takie zróżnicowanie uznawano za dopuszczalne ${ }^{3}$. NSA uzasadnił to odejście zmianą przepisów ustawy ${ }^{4}$, a konkretnie zmianą przez ustawodawcę treści art. 6k ust. 4 ustawy, który w brzmieniu obowiązującym do dnia 31 stycznia 2015 r., umożliwiał radzie gminy, określającej warunki opłat zgodnie z metodą, o której mowa w art. 6j ust. 1 i 2 u.c.p.g., różnicowanie stawki opłat, wprowadzanie zwolnień przedmiotowych, ustanawianie dopłaty dla właścicieli nieruchomości, o których mowa w art. $6 \mathrm{c}$ ust. 1, spełniających ustalone przez nią kryteria, lub określanie szczegółowo zasady ustalania tych opłat.

Wnioskując z przedstawionego wyżej stanowiska NSA, koncepcja zróżnicowania opłat ze względu na liczbę osób stanowiących dane gospodarstwo domowe nie jest dopuszczalna. Pytanie przedstawione we wstępie opinii dotyczy jednak wyboru metody ustalania opłaty za gospodarowanie odpadami komunalnymi uzależnionej od liczby mieszkańców zamieszkujących daną nieruchomość w taki sposób, że za każdą kolejną osobę zamieszkującą daną nieruchomość naliczana będzie niższa opłata, przy czym pojęcie „nieruchomość” w przypadku zabudowy wielorodzinnej (wielolokalowej) rozumiane będzie jako lokal mieszkalny. Taka metoda ustalenia opłaty odwoływałaby się nie do pojęcia gospodarstwa domowego, ale do metody wskazanej w art. 6j ust. 1 pkt 1 u.c.p.g. W powołanym wyroku NSA w sprawie o sygn. akt II FSK 16/16 zaznaczył, że możliwość zróżnicowania stawki opłaty, o której mowa w art. 6j ust. 2a u.c.p.g., odnosi się tylko do metody wskazanej w art. 6j ust. 1 u.c.p.g. oraz, że nie można utożsamiać pojęcia „liczby mieszkańców zamieszkujących daną nieruchomość” z pojęciem "gospodarstwa domowego". NSA nie odniósł się wprost do możliwości zróżnicowania opłaty na podstawie kryterium liczby mieszkańców, wskazanego w art. 6j ust. 2a u.c.p.g. przy wyborze metody wskazanej w art. 6j ust. 1, niemniej wydaje się, że taka koncepcja byłaby uprawniona. Art. 6j ust. 2a ustawy, który daje podstawę do

3 Zob. wyrok NSA z 22 stycznia 2016 r., sygn. akt II FSK 3231/15, Legalis; wyrok Wojewódzkiego Sądu Administracyjnego w Rzeszowie z 9 lipca 2015 r., sygn. akt I SA/Rz 499/15, Legalis.

4 Zmiana art. 6k została dokonana nowelizacją z 28 listopada 2014 r., obowiązującą od dnia 1 lutego 2015 r., Dz.U. 2015, poz. 87. 
zróżnicowania stawki opłaty w zależności od powierzchni lokalu mieszkalnego, liczby mieszkańców zamieszkujących nieruchomość, odbierania odpadów z terenów wiejskich lub miejskich, a także od rodzaju zabudowy odnosi się, zgodnie ze stanowiskiem NSA, do metody określonej w art. 6j ust. 1. Postanawia również, że rada gminy może również stosować łącznie różne kryteria różnicujące stawki opłaty. Należy jednak podkreślić, że stanowisko dopuszczające takie zróżnicowanie może być kwestionowane jako rozwiązanie regulujące sposób ustalenia opłaty odmiennie niż wynika to z przepisów ustawy ${ }^{5}$.

\section{Podsumowanie}

- Na podstawie art. 6j ust. 1 pkt 1 u.c.p.g. jedną z metod ustalenia opłaty za gospodarowanie odpadami komunalnymi jest metoda, w której opłata stanowi iloczyn liczby mieszkańców zamieszkujących daną nieruchomość lub ilości zużytej wody z danej nieruchomości, lub powierzchni lokalu mieszkalnego oraz stawki opłaty ustalonej na podstawie art. 6k ust. 1 u.c.p.g. Inną metodą jest możliwość ustalenia jednej stawki opłaty za gospodarowanie odpadami komunalnymi od gospodarstwa domowego (art. 6 j ust. 2 u.c.p.g.).

- Artykuł 6j ust. 2a u.c.p.g. daje podstawę do zróżnicowania stawki opłaty w zależności od powierzchni lokalu mieszkalnego, liczby mieszkańców zamieszkujących nieruchomość, odbierania odpadów z terenów wiejskich lub miejskich, a także od rodzaju zabudowy. Postanawia również, że rada gminy może też stosować łącznie różne kryteria różnicujące stawki opłaty.

- Zgodnie z aktualnym orzecznictwem NSA brak upoważnienia dla rady gminy do wprowadzenia $w$ ramach metody wymienionej w art. 6j ust. 2 u.c.p.g. dodatkowego kryterium, jakim jest podział gospodarstw domowych na kategorie zależne od liczby osób w nich zamieszkujących i zróżnicowanie na tej podstawie wysokości stawki opłaty.

- Wydaje się, że nie można wykluczyć możliwości zróżnicowania opłaty, o której mowa w art. 6j ust. 1 pkt 1 u.c.p.g., czyli opłaty stanowiącej iloczyn liczby mieszkańców danej nieruchomości i stawki opłaty przy zastosowaniu liczby mieszkańców jako kryterium zróżnicowania stawki (art. 6ust. 2a u.c.p.g.). Należy jednak podkreślić, że stanowisko dopuszczające takie zróżnicowanie może być kwestionowane przez organy nadzoru.

5 Zob. uchwała nr 11/2019 r. Regionalnej Izby Obrachunkowej we Wrocławiu z 30 października 2019 r., https://bip.wroclaw.rio.gov.pl/dokumenty/uchwaly/2019/1111905 052.pdf. 


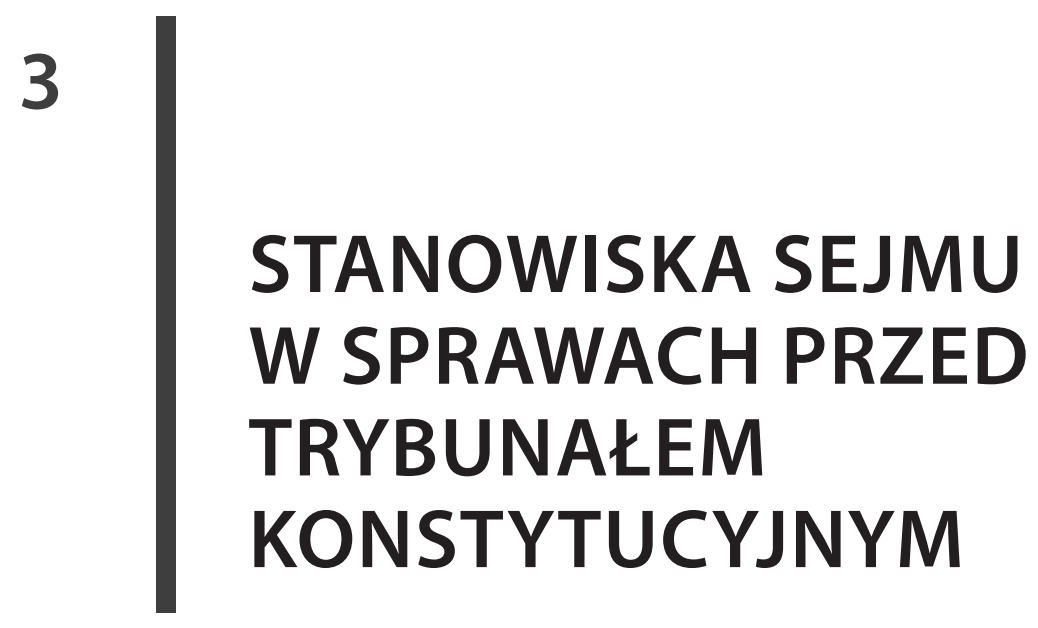





\title{
Ocena zgodności z Konstytucją przepisów ustawy - Kodeks cywilny (problem retroaktywności uchwał) ${ }^{1}$
}

\author{
Assessment of conformity to the Constitution of provisions of the Civil \\ Code (issues related to the retroactivity of resolutions)
}

\begin{abstract}
The subject of the assessment contained in the position of the Sejm before the Constitutional Tribunal are provisions of the Civil Code in relation to the doubts of a regional court, whether the application for a court enforcement clause for a bank enforcement title does not interrupt the limitation period for a claim covered by that title against a transferee who is not a bank. In the author's opinion, the interpretation of the questioned provisions in the process of applying the law, and in particular the limitation of a retroactive effect of interpretation, is vested in courts and it is difficult to conclude that the assessment of the constitutionality of the questioned provisions by the Constitutional Tribunal determined the resolution of the case pending before the court that submitted the question of law. In view of the doubts regarding the admissibility of the question of law, the Sejm should request that the proceedings be discontinued.
\end{abstract}

Keywords: Civil Code, Constitutional Tribunal

Przedmiotem oceny zawartej w stanowisku Sejmu przed Trybunałem Konstytucyjnym są przepisy Kodeksu cywilnego w związku z wątpliwością sądu okręgowego, czy wniosek o nadanie sądowej klauzuli wykonalności bankowemu tytułowi egzekucyjnemu nie przerywa biegu przedawnienia roszczenia objętego tym tytułem wobec cesjonariusza niebędącego bankiem. W opinii autorki interpretacja zaskarżonych przepisów w procesie stosowania prawa, a w szczególności ograniczenie skutku retroaktywnego wykładni, leży w gestii sądów i trudno uznać, że od oceny konstytucyjności kwestionowanych przepisów przez TK zależy rozstrzygnięcie sprawy toczącej się przed sądem pytającym. Wobec podniesionych wątpliwości co do dopuszczalności pytania prawnego, Sejm powinien wnieść o umorzenie postępowania.

Słowa kluczowe: Kodeks cywilny, Trybunał Konstytucyjny

Doktor hab. nauk prawnych, adiunkt -

Uniwersytet Warmińsko-Mazurski w Olsztynie, Wydział Prawa i Administracji, Katedra

Prawa Konstytucyjnego i Nauki o Państwie, OLSZTYN, POLSKA •

staran@uwm.edu.pl • https://orcid.org/0000-0002-2118-3761

Na podstawie art. 69 ust. 2 w związku z art. 42 pkt 3 ustawy z 30 listopada 2016 r. o organizacji i trybie postępowania przed Trybunałem Konstytucyjnym (Dz. U. poz. 2072, ze zm.), w imieniu Sejmu Rzeczypospolitej Polskiej przedkładam wyjaśnienia w sprawie pytania prawnego Sądu Okręgowego w Poznaniu Wydział II Cywilny Odwoławczy z 14 grudnia 2018 r. (sygn. akt P 7/19), jed-

$1 \quad$ Sprawa dot. pytania prawnego (sygn. akt P 7/19), dotyczaca kodeksu cywilnego - projekt sporządzony 6 sierpnia 2019 r.; BAS-WAKU 1026/19. 
nocześnie wnosząc o umorzenie postępowania na podstawie art. 59 ust. 1 pkt 2 ustawy z 30 listopada 2016 r. o organizacji i trybie postępowania przed Trybunałem Konstytucyjnym ze względu na niedopuszczalność wydania wyroku.

\section{Uzasadnienie}

\section{Przedmiot kontroli}

W dniu 22 maja 2019 r. do Kancelarii Sejmu wpłynęło zawiadomienie Prezes Trybunału Konstytucyjnego o wszczęciu postępowania przed Trybunałem Konstytucyjnym w sprawie pytania prawnego Sądu Okręgowego w Poznaniu Wydział II Cywilny Odwoławczy z 14 grudnia 2018 r. (sygn. akt P 7/19).

Przedmiotem kontroli są: art. $123 \$ 1$ pkt 1 i art. $509 \$ 2$ ustawy z 23 kwietnia 1964 r. Kodeks cywilny (t.j. Dz. U. 2018, poz. 1025, ze zm.; dalej: k.c.). Kwestionowane przepisy odpowiednio stanowią: „Bieg przedawnienia przerywa się: [...] przez każdą czynność przed sądem lub innym organem powołanym do rozpoznawania spraw lub egzekwowania roszczeń danego rodzaju albo przed sądem polubownym, przedsięwziętą bezpośrednio w celu dochodzenia lub ustalenia albo zaspokojenia lub zabezpieczenia roszczenia” (art. $123 \$ 1$ pkt 1 k.c.) oraz „Wraz z wierzytelnością przechodzą na nabywcę wszelkie związane z nią prawa, w szczególności roszczenie o zaległe odsetki” (art. $509 \$ 2$ k.c.).

\section{Stan faktyczny i zarzuty sądu pytającego}

Pozwem skierowanym do Sądu Rejonowego w Pile powód (dalej: sekurytyzacyjny fundusz, fundusz) domagał się zasądzenia od pozwanego (dalej: dłużnik) kwoty 14 002,89 zł. Od nakazu zapłaty wydanego 2 sierpnia 2016 r. pozwany wniósł sprzeciw, podnosząc między innymi zarzut przedawnienia roszczenia. Sąd Rejonowy w Pile wyrokiem z 14 grudnia 2016 r. oddalił powództwo. Sąd ustalił, że 30 grudnia 2010 r. bank zawarł z pozwanym umowę pożyczki. Pozwany nie spłacał rat pożyczki. Wobec tego bank wypowiedział umowę i wystawił bankowy tytuł egzekucyjny (dalej: b.t.e.). Postanowieniem z 19 listopada 2013 r. Sąd Rejonowy w Pile w sprawie o sygn. akt [...] nadał sądową klauzulę wykonalności bankowemu tytułowi egzekucyjnemu numer [...] z 29 października 2013 r. wystawionemu przez bank. Postanowieniem z 10 czerwca 2014 r. komornik sądowy umorzył postępowanie prowadzone przeciwko pozwanemu z powodu bezskuteczności egzekucji. Następnie 7 maja 2015 r. została zawarta umowa przelewu wierzytelności pomiędzy bankiem a funduszem. Zgodnie z art. 509 k.c. wierzyciel może bez zgody dłużnika przenieść wierzytelność na osobę trzecią (przelew), chyba że sprzeciwiałoby się to ustawie, zastrzeżeniu umownemu albo właściwości zobowiązania. Pozwany nie kwestionował ważności umowy przelewu, nie budziła ona też wątpliwości sądu. Sąd pierwszej instancji przyjął, że roszczenie uległo przedawnieniu 13 września 2015 r., ponieważ zgodnie z uchwałą Sądu 
Najwyższego z 29 czerwca 2016 r. (sygn. akt III CZP 29/16) nabywca wierzytelności niebędący bankiem nie może powoływać się na przerwę biegu przedawnienia spowodowaną wszczęciem postępowania egzekucyjnego na podstawie bankowego tytułu egzekucyjnego zaopatrzonego w klauzulę wykonalności.

Powód wniósł apelację od wyroku sądu pierwszej instancji. Sąd Okręgowy w Poznaniu postanowieniem z 1 czerwca 2017 r. przedstawił Sądowi Najwyższemu następujące zagadnienie prawne: „Czy nabywca wierzytelności niebędący bankiem może powoływać się na przerwę biegu przedawnienia spowodowaną złożeniem wniosku o nadanie klauzuli wykonalności bankowemu tytułowi egzekucyjnemu?". Sąd Najwyższy odmówił podjęcia uchwały z powodu rozstrzygnięcia powyższego zagadnienia w uchwałach z: 29 czerwca 2016 r. (sygn. akt III CZP 29/16) i 9 czerwca 2017 r. (sygn. akt III CZP 17/17).

Sąd pytający powziął wątpliwość, czy „art. $123 \$ 1$ pkt 2 k.c. stosowany w związku z art. $509 \$ 2$ k.c. w zakresie, w jakim stanowi, że po uchyleniu art. 96 ust. 1 i art. 97 ust. 1 prawa bankowego (na skutek wyroku Trybunału Konstytucyjnego z dnia 14 kwietnia 2015 roku, sygn. P 45/12) wniosek o nadanie sądowej klauzuli wykonalności bankowemu tytułowi egzekucyjnemu nie przerywa biegu przedawnienia roszczenia objętego tym tytułem wobec cesjonariusza niebędącego bankiem, jest zgodny z art. 2, art. 20, art. 21, art. 22, art. 31 ust. 3, art. 32 i art. 64 Konstytucji Rzeczpospolitej Polskiej?”.

2. Zdaniem sądu pytającego zaskarżone przepisy naruszają: art. 2 (zasada zaufania obywateli do państwa i prawa, zasada przyzwoitej legislacji, zasada lex retro non agit), art. 20 i art. 22 (wolność działalności gospodarczej i przesłanki jej ograniczenia), art. 21 (zasada ochrony własności i podstawy konstytucyjne wywłaszczenia), art. 31 ust. 3 (zasada proporcjonalności), art. 32 ust. 1 i 2 (zasada równości) oraz art. 64 ust. 1 i 2 (ochrona prawa własności).

3. Zaskarżone przepisy odnoszą się do zagadnienia przerwania biegu terminu przedawnienia roszczeń. Problem konstytucyjny wiąże się zaś z utrwaloną od 2016 r. linią orzeczniczą SN, który stoi na stanowisku, że: „przerwanie biegu przedawnienia na skutek wniosku o nadanie sądowej klauzuli wykonalności jest związane tylko z podmiotami uczestniczącymi w tym postępowaniu i na podstawie tego tytułu, w granicach ukształtowanych klauzulą wykonalności. Powód, jako nabywca wierzytelności niebędący bankiem, nabył wprawdzie wierzytelność tożsamą z wierzytelnością [...] Banku, lecz nie wszedł w sytuację prawną zbywcy wywołaną przerwaniem biegu przedawnienia i jego rozpoczęciem" (pytanie prawne).

Normie wywiedzionej przez Sąd Najwyższy z treści art. $123 \$ 1$ pkt 1 k.c. w związku z art. 509 k.c. zarzuca się naruszenie kilku przepisów konstytucyjnych. Po pierwsze, w ocenie sądu pytającego, jest ona niezgodna z zasadą zaufania obywateli do państwa i stanowionego przez nie prawa, przyzwoitej legislacji oraz zakazu retroakcji prawa (art. 2 Konstytucji), ponieważ: „Przed 29 czerwca 2016 r. (tj. przed uchwałą SN wydaną w sprawie III CZP 29/16) istniejące przepisy ni- 
gdy nie były interpretowane w ten sposób, jak czyni to obecnie Sąd Najwyższy. O utracie skutków przerwy biegu przedawnienia z chwilą cesji wierzytelności na rzecz podmiotu niebędącego bankiem, nie miały świadomości nie tylko banki i nabywcy wierzytelności, ale i sami dłużnicy, którzy z bankiem czynności bankowej dokonywali. Przy przyjęciu kwestionowanej treści przepisów prawa, wynikającej z utrwalonej wykładni Sądu Najwyższego, w wielu przypadkach - bez uwzględnienia czynności banku dokonanych w trybie art. 123 k.c. - termin przedawnienia minął i w istocie strony umowy przelewu dokonywały cesji wierzytelności przedawnionej nie mając o tym świadomości i bez możliwości podjęcia przez nie obrony swych praw, ewentualnie uwzględnienia tej cechy wierzytelności przy ustalaniu warunków zawarcia umów cesji. Przeciwnie, zarówno bank, jak i nabywca wierzytelności niebędący bankiem, mieli świadomość tego, że zgodnie z art. 123 k.c. złożenie o nadanie klauzuli wykonalności na bankowy tytuł egzekucyjny oraz skierowanie roszczenia do egzekucji, to zdarzenia, które wywołują skutek materialnoprawny, a więc przerywa bieg przedawnienia. Wprawdzie zdarzenie to jest związane z czynnością konkretnego, aktualnego na daną chwilę wierzyciela, ale dotyczy określonej wierzytelności i stan nieprzedawnienia staje się nierozłączną cechą wierzytelności, a nie wierzyciela" (pytanie prawne). Treść zaskarżonych przepisów, ukształtowana orzecznictwem SN, zaskoczyła zatem wierzycieli, którzy nie mogli się do tego przygotować, i stała się dla nich pułapką.

Po drugie, sąd pytający dostrzega „naruszenie zasady wolności działalności gospodarczej (art. 22 Konstytucji), w powiązaniu z zasadą proporcjonalności ograniczania konstytucyjnych wolności i praw (art. 31 ust. 3 Konstytucji)”, gdyż przyjęta przez SN wykładnia zakwestionowanych przepisów uniemożliwia „cesjonariuszom niebędącym bankiem [...] realizację praw wynikających z umów cesji zawartych legalnie i skutecznie, i co do wierzytelności będących w dacie zawarcia umowy cesji wierzytelnościami nieprzedawnionymi. Także w tym miejscu podkreślić trzeba, że zasada wolności gospodarczej może być ograniczona przez ustawę i tylko ze względu na ważny interes społeczny" (pytanie prawne).

Po trzecie, w ocenie inicjatora postępowania wskazane przepisy Kodeksu cywilnego są sprzeczne z: zasadą ochrony własności (art. 64 Konstytucji), zasadą ochrony praw nabytych (art. 2 Konstytucji), a także konstytucyjnymi przesłankami wywłaszczenia (art. 21 Konstytucji) i zasadą proporcjonalności (art. 31 ust. 3 Konstytucji), gdyż: „podmiotowe ograniczenie prawa do korzystania z przerwy przedawnienia tak dalece ogranicza prawa wynikające $\mathrm{z}$ umowy cesji, że w skutkach jest równoważne z pozbawieniem - lub co najmniej istotnym ograniczeniem dotkniętych tym ograniczeniem nabywców wierzytelności. Sąd Najwyższy, choć wyraźnie nie pozbawił cesjonariusza niebędącego bankiem całości praw z cesji, to jednak w taki sposób zaingerował w ich treść, że uniemożliwia czynienie z nabytych praw użytku zgodnie z ich gospodarczym przeznaczeniem. Naruszenia zasady ochrony własności należy dopatrywać się również w arbitralności wprowadzonego ograniczenia praw wynikających z przerwy 
[biegu terminu] przedawnienia i nieproporcjonalnym wkroczeniu w sferę majątkową przedsiębiorcy” (pytanie prawne). A ponadto: „Naruszenie zasady wynikającej z art. 21 ust. 2 Konstytucji w powiązaniu z zasadą ochrony własności (art. 22 Konstytucji) uzasadnić należy tym, że wykładnia Sądu Najwyższego, polegająca na odjęciu cesjonariuszom niebędącym bankiem uprawnienia do korzystania z przerwy [biegu terminu] przedawnienia, spowodowanej wnioskiem banku o nadanie sądowej klauzuli wykonalności na bankowy tytuł egzekucyjny, nie została dokonana $\mathrm{w}$ celu ochrony dobra publicznego - a przynajmniej taki cel nie został przez Sąd Najwyższy wprost wskazany. Jeżeli nawet zamiarem Sądu Najwyższego była ochrona dobra publicznego poprzez ograniczenie praw cesjonariuszy niebędących bankiem, to nastąpiło to bez przyznania odpowiedniego odszkodowania podmiotom, które zostały pozbawione swych praw w związku $\mathrm{z}$ realizacją tego celu" (pytanie prawne).

Po czwarte, według sądu pytającego zaskarżone normy prawne są niezgodne $\mathrm{Z}$ „zasadą równości wobec prawa (art. 32 Konstytucji) w powiązaniu z zasadą solidarności partnerów społecznych (art. 20 Konstytucji)”. „Na podstawie zastosowanej przez Sąd Najwyższy wykładni dochodzi bowiem do nieuprawnionego zróżnicowania sytuacji prawnej cesjonariuszy będących bankiem od tych, którzy przymiotu «bycia bankiem» nie posiadają. Mianowicie zupełnie nie wiadomo dlaczego cesjonariusz będący bankiem korzysta z przerwy przedawnienia na skutek czynności cedenta, a dlaczego cesjonariusz niebędący bankiem nie. Przecież cechą wspólną dla nich obu jest to, że korzystają z czynności swojego poprzednika prawnego i z jego własnego (jak to wyeksponował Sąd Najwyższy) przywileju do wystawienia bankowego tytułu egzekucyjnego, ale tego bte [bankowy tytuł egzekucyjny - uwaga D.L.-S.] już nie ma, tymczasem Sąd Najwyższy znalazł nowy przywilej dla cesjonariusza będącego bankiem. W tej sytuacji dochodzi również do naruszenia zasady równości rozumianej jako równe prawa wszystkich podmiotów gospodarczych funkcjonujących na rynku usług" (pytanie prawne).

\section{Analiza formalna}

1. W myśl art. 193 Konstytucji każdy sąd może przedstawić Trybunałowi Konstytucyjnemu pytanie prawne co do zgodności aktu normatywnego z Konstytucją, ratyfikowanymi umowami międzynarodowymi lub ustawą, jeżeli od odpowiedzi na to pytanie zależy rozstrzygnięcie sprawy toczącej się przed sądem.

Pytanie prawne, aby mogło skutecznie zainicjować kontrolę konkretną, musi spełniać łącznie trzy przesłanki. Przesłanka pierwsza, podmiotowa, oznacza, że z pytaniem prawnym może wystąpić jedynie sąd, rozumiany jako państwowy organ władzy sądowniczej. Przesłanka druga, przedmiotowa, polega na tym, iż podstawą pytania prawnego może być tylko zarzut niezgodności aktu normatywnego z Konstytucją lub z innym aktem hierarchicznie wyższym, przy czym zastrzeżenia co do konstytucyjności tego aktu muszą być tak istotne, że zacho- 
dzi potrzeba ich wyjaśnienia przez Trybunał Konstytucyjny. Przesłanka trzecia, funkcjonalna, pozwala na wystąpienie z pytaniem prawnym tylko wtedy, gdy od odpowiedzi na nie zależy rozstrzygnięcie w konkretnej sprawie sądowej (zob. np. wyrok TK z 2 grudnia 2008 r., sygn. akt P 48/07). Z tą ostatnią przesłanką Sejm wiąże swoje wątpliwości formalnoprawne, które uniemożliwiają rozpatrzenie pytania prawnego przez Trybunał Konstytucyjny.

2. Stawiane przez sąd pytający zarzuty niekonstytucyjności zaskarżonych przepisów nie wiążą się z ich literalnym brzmieniem, które zostało ustalone wraz z wejściem w życie Kodeksu cywilnego, ale znaczeniem ustalonym przez orzecznictwo SN. Zaskarżone przepisy nie uległy zmianie w warstwie werbalnej w drodze procedury ustawodawczej. Uległo natomiast zmianie ich rozumienie, dostosowujące się do nowej rzeczywistości prawnej, jak podnosi sąd pytający, ukształtowanej wyrokiem TK w sprawie b.t.e. Uchwałą z 29 czerwca 2016 r., sygn. akt III CZP 29/16, i uchwałą z 9 czerwca 2017 r., sygn. akt III CZP 17/17, SN przyjął, że: „na poziomie ogólnym nie ulega wątpliwości, iż skutki przerwy biegu przedawnienia wywołanej przez zbywcę wierzytelności odnoszą się z zasady także do cesjonariusza. Nabywa on wierzytelność w takim kształcie, w jakim przysługiwała ona zbywcy, także pod względem stanu jej przedawnienia [...]. Jeżeli podstawę przerwy biegu przedawnienia stanowiła czynność związana z b.t.e. skutki tej przerwy powinny zostać uzależnione od charakteru podmiotu, który nabył wierzytelność. Może on powołać się na przerwanie biegu przedawnienia przez cedenta jedynie wówczas, gdy sam mógłby posłużyć się w obrocie b.t.e. Przemawiają za tym stanowiskiem zarówno względy konstrukcyjne, jak i aksjologiczne, zasadnicze założenie, że bankowy tytuł w tym egzekucyjny, będąc szczególnym przywilejem, dostępnym jedynie wybranej grupie wierzycieli, nie może być stosowany w nadmiernie szerokich granicach, tj. służyć także innym podmiotom, którym ustawodawca nie przyznał możliwości posłużenia się tym instrumentem. Założenie to wzmacnia także argumentacja konstytucyjna, oparta na uznaniu przez Trybunał Konstytucyjny regulacji b.t.e. za sprzeczną z konstytucją (wyrok TK z 14 kwietnia 2015 r., sygn. P 45/12, Dz. U. 2015, poz. 559). Orzeczenie to stanowi dodatkowy, silny argument za ujmowaniem wszelkich skutków b.t.e. w wąskich granicach i ochronie tym samym w możliwie szerokim zakresie wartości konstytucyjnych, na które powołał się Trybunał". Powyżej zarysowana linia orzecznicza istotnie modyfikuje i pogarsza, jak wskazuje sąd pytający, sytuację prawną funduszu, który dotychczas „korzystał” z przerwania biegu przedawnienia dokonanego przez cedenta. Powyższa norma, ukształtowana w drodze orzecznictwa SN, nadała nowe znaczenie zaskarżonym przepisom. To nowe znaczenie leży u podstaw pytania prawnego. Sąd Okręgowy w Poznaniu upatruje w nim naruszenia zasady lex retro non agit. Pozostałe zaś zarzuty niekonstytucyjności mają charakter akcesoryjny wobec naruszenia tej fundamentalnej dla porządku prawnego zasady, mającej swoje źródło normatywne w art. 2 Konstytucji. Innymi słowy, przywołane wyżej orzeczenia SN i zaprezentowana w nich 
wykładnia zaskarżonych przepisów wywołały skutek retroaktywny, pozbawiając fundusz praw majątkowych.

3. Zaskarżone przepisy odnoszą się do dwóch instytucji prawa prywatnego, dobrze rozpoznanych i opisanych $\mathrm{w}$ doktrynie prawa i orzecznictwie sądowym, tj. przedawnienia roszczeń i cesji wierzytelności. Dotychczas nie budziły one, co warto podkreślić, poważnych wątpliwości konstytucyjnych.

Przedawnienie jest instytucją ugruntowaną w prawie cywilnym, mającą swoje źródło w prawie rzymskim. Jak wskazuje się w piśmiennictwie: „Przedawnienie wiązało się i wciąż się wiąże $\mathrm{z}$ ograniczeniem w czasie praktycznych możliwości dochodzenia roszczenia przy udziale profesjonalnych organów szeroko pojętego wymiaru sprawiedliwości" (J. Kuźmicka-Sulikowska, Idea przedawnienia i jej realizacja w polskim kodeksie cywilnym, Wrocław 2015, s. 56). Określa ono skutki upływu czasu na zaskarżalność wierzytelności. Na wstępie należy zauważyć, że instytucja przedawnienia jako taka nie jest bezpośrednim przedmiotem regulacji konstytucyjnych, jednakże konsekwencje wynikające z jej ukształtowania w systemie prawnym mogą mieć istotny wpływ na skuteczność ochrony praw podmiotowych, a wśród nich także i tych, które korzystają bezpośrednio z gwarancji konstytucyjnych.

Trybunał Konstytucyjny stoi na stanowisku, zgodnie z którym wprowadzenie do systemu prawnego tej instytucji, jak również nadanie jej konkretnego kształtu, w tym określenie terminu przedawnienia, pozostaje w sferze uznania ustawodawcy (zob. wyroki TK z: 23 maja 2005 r., sygn. akt SK 44/04; 25 maja 2004 r., sygn. akt SK 44/03). Przy tym sprzeczne z zasadami państwa prawnego byłoby, zdaniem TK, twierdzenie o istnieniu prawa podmiotowego do niewykonania ciążącego na dłużniku zobowiązania. Oczekiwanie na przedawnienie nie powinno wypierać obowiązku wywiązania się z zaciągniętych zobowiązań (zob. np. wyroki TK z: 16 kwietnia 2002 r., sygn. akt SK 23/01; 21 czerwca 2011 r., sygn. akt P 26/10). Z kolei w wyroku z 15 maja 2019 r. (sygn. akt SK 31/17) sąd konstytucyjny dodał, że: „Obowiązkiem dłużnika jest spłata kredytu (pożyczki), nie zaś uchylanie się od wykonania umowy przez dążenie do przedawnienia roszczenia bądź przerzucenie odpowiedzialności na właścicieli nieruchomości niebędących dłużnikami osobistymi. Przepisy ustawy z dnia 23 kwietnia 1964 r. - Kodeks cywilny (tj. Dz. U. z 2018 r. poz. 1025, ze zm.), regulujące wykonywanie zobowiązań i skutki ich niewykonania nakierowane są przede wszystkim na ochronę praw wierzyciela".

Podstawowym przepisem dla analizowanej instytucji jest art. $117 \$ 1$ k.c., w myśl którego: „Z zastrzeżeniem wyjątków w ustawie przewidzianych, roszczenia majątkowe ulegają przedawnieniu". Ustawodawca określa skutki upływu czasu dla zobowiązania, stanowiąc: „Po upływie terminu przedawnienia ten, przeciwko komu przysługuje roszczenie, może uchylić się od jego zaspokojenia, chyba że zrzeka się korzystania z zarzutu przedawnienia" (art. $117 \$ 2$ k.c.). Ponadto Kodeks cywilny określa długość okresu przedawnienia. Zasadą jest, że 
termin przedawnienia wynosi sześć lat (do 9 lipca 2018 r. wynosił 10 lat, został bowiem skrócony ustawą z 3 kwietnia 2018 r. o zmianie ustawy - Kodeks cywilny oraz niektórych innych ustaw, Dz. U. poz. 1104), a dla roszczeń o świadczenia okresowe oraz roszczeń związanych z prowadzeniem działalności gospodarczejtrzy lata (art. 118 k.c.). Przepisy szczegółowe mogą odmiennie określać terminy przedawnienia.

Zgodnie z regulacją kodeksową zasadniczo bieg terminu przedawnienia rozpoczyna się od dnia, w którym roszczenie stało się wymagalne. Jeżeli wymagalność roszczenia zależy od podjęcia określonej czynności przez uprawnionego, bieg terminu rozpoczyna się od dnia, w którym roszczenie stałoby się wymagalne, gdyby uprawniony podjął czynność w najwcześniej możliwym terminie (art. $120 \$ 1$ k.c.). Przez wymagalność roszczenia należy rozumieć taki stan, w którym wierzyciel może żądać od dłużnika spełnienia świadczenia, a dłużnik zobowiązany jest to świadczenie spełnić (zob. uchwała SN z 12 lutego 1991 r., sygn. akt III CRN 500/90).

Zaskarżony przepis art. $123 \$ 1$ pkt 1 k.c. odnosi się do przerwy biegu przedawnienia. Bieg terminu przedawnienia przerywa się, zgodnie $z$ art. $123 \$ 1$ pkt 1 k.c., przez każdą czynność przed sądem lub innym organem powołanym do rozpoznawania spraw lub egzekwowania roszczeń danego rodzaju albo przed sądem polubownym, przedsięwziętą bezpośrednio w celu dochodzenia lub ustalenia albo zaspokojenia lub zabezpieczenia roszczenia. Jak podnosi się w doktrynie prawa: „W okresie przedawnienia uprawniony jest zobowiązany podjąć stosowne kroki w celu zaspokojenia swego roszczenia. Ustawodawca premiuje zachowania zmierzające $\mathrm{w}$ tym kierunku przerwą biegu przedawnienia, której istota polega na przywróceniu uprawnionemu stanu, jaki istniał w dniu, w którym jego roszczenie stało się wymagalne. Okres przedawnienia, który dotąd upłynął, uważany jest za niebyły, co wynika wprost z art. $124 \$ 1$ KC” (B. Kordasiewicz, Problematyka dawności [w:] System prawa prywatnego, t. II, Prawo cywilne - część ogólna, red. Z. Radwański, A. Olejniczak, 2019, Legalis, nb. 136).

Na marginesie należy zaznaczyć, że w doktrynie i orzecznictwie sądowym pojawiły się wątpliwości czy nadanie b.t.e. klauzuli wykonalności przerywa bieg przedawnienia. Stan niepewności został autorytatywnie rozwiązany rozstrzygnięciem Sądu Najwyższego, który przyjął, że: „,[w]niosek o nadanie klauzuli wykonalności bankowemu tytułowi egzekucyjnemu przerywa bieg przedawnienia” (uchwała SN z 16 stycznia 2004 r., sygn. akt III CZP 101/03). Jakkolwiek wystawienie bankowego tytułu egzekucyjnego nie jest objęte hipotezą art. $123 \$ 1$ pkt 1 k.c. i tym samym nie powoduje przerwania biegu przedawnienia (nie jest ono bowiem, jak tego żąda wymieniony przepis, czynnością podjętą przed sądem lub innym organem powołanym do rozpoznawania spraw lub egzekwowania roszczeń danego rodzaju ani przed sądem polubownym), to cechy takie spełnia wniosek o nadanie b.t.e. klauzuli wykonalności przez sąd. Do takiego wniosku skłoniła SN m.in. okoliczność, że roszczenia z tytułu umowy kredytu przedaw- 
niają się po upływie trzech lat. „W takiej sytuacji odmowa uznania przerwania biegu przedawnienia przez złożenie wniosku o nadanie klauzuli wykonalności bankowemu tytułowi egzekucyjnemu i będący następstwem tej odmowy bieg przedawnienia roszczenia $\mathrm{w}$ toku postępowania klauzulowego, wydłużającego się nieraz na skutek wniesienia środka odwoławczego oraz wniosku o zwolnienie od opłaty zażaleniowej, musiałyby nierzadko prowadzić do stwierdzenia przedawnienia się roszczenia jeszcze przed uzyskaniem przez bank możliwości złożenia wniosku o wszczęcie egzekucji. Wymaga podkreślenia, że w takich przypadkach bank korzystający z rozwiązania przewidzianego w art. 96-98 pr. Bank [ustawy - Prawo bankowe - dopisek D.L.-S]. nie miałby możliwości przerwania przedawnienia w żadnym okresie jego biegu" (ibidem). Sąd Najwyższy podkreślił, że u podstaw takiej wykładni przepisu nie leżą przywileje bankowe, których źródłem jest bankowy tytuł egzekucyjny.

Przenosząc powyższe na grunt sprawy zawisłej przed TK, trzeba stwierdzić, że pierwotny wierzyciel, tj. bank, podejmował czynności zmierzające do dochodzenia roszczenia. Po pierwsze, wystawił b.t.e., a następnie wystąpił o klauzulę wykonalności, która została nadana postanowieniem z 19 listopada 2013 r. Po drugie, przystąpił do dochodzenia wierzytelności na drodze postępowania egzekucyjnego, które postanowieniem z 10 czerwca 2014 r. komornik umorzył z powodu bezskuteczności egzekucji. Po trzecie, czynności podejmowane przez wierzyciela doprowadziły (skutecznie) do przerwania biegu przedawnienia.

4. Bank-wierzyciel zbył wierzytelność funduszowi sekurytyzacyjnemu. Zgodnie z art. 92a ust. 1 pkt 1 ustawy z 29 sierpnia 1997 r. - Prawo bankowe (t.j. Dz. U. 2018, poz. 2187, ze zm.; dalej: p.b.): „Bank może zawrzeć z towarzystwem funduszy inwestycyjnych tworzącym fundusz sekurytyzacyjny albo z funduszem sekurytyzacyjnym: [...] umowę przelewu wierzytelności”. Z kolei ustawa z 27 maja 2004 r. o funduszach inwestycyjnych i zarządzaniu alternatywnymi funduszami inwestycyjnymi (t.j. Dz. U. 2018, poz. 1355, ze zm.; dalej: u.f.i.) reguluje funkcjonowanie funduszy sekurytyzacyjnych. Fundusze podlegają nadzorowi Komisji Nadzoru Finansowego. Fundusz sekurytyzacyjny jest szczególnym typem funduszu inwestycyjnego zamkniętego, co oznacza, że możliwość uczestnictwa w funduszu dotyczy wąskiego kręgu podmiotów, co do zasady inwestorów instytucjonalnych, a w ograniczonym stopniu osób fizycznych. Fundusz sekurytyzacyjny może być utworzony jedynie przez towarzystwo funduszy inwestycyjnych, które nadaje mu statut. Towarzystwo to jest równocześnie upoważnione do zarządzania funduszem oraz reprezentowania funduszu wobec osób trzecich. Ustawa o funduszach inwestycyjnych dopuszcza również, po uzyskaniu zezwolenia Komisji Nadzoru Finansowego, zarządzanie sekurytyzowanymi wierzytelnościami funduszu przez podmiot inny niż towarzystwo funduszy inwestycyjnych (art. 192 u.f.i.). Fundusze te mogą być tworzone jako standaryzowane albo niestandaryzowane (art. 183 ust. 2 u.f.i.). Fundusz sekurytyzacyjny emituje certyfikaty inwestycyjne i w ten sposób gromadzi środki na zakup wierzytelności albo 
zakup praw do świadczeń z określonych wierzytelności (art. 183 ust. 1 u.f.i.; zob. wyrok TK z 11 lipca 2011 r., sygn. akt K 1/10).

W Polsce nie ma legalnej definicji sekurytyzacji. W naukach ekonomicznych opisuje ono „operację o charakterze gospodarczym, polegającą na emisji papierów wartościowych, której podstawą jest zespół określonych, odpowiednio wyselekcjonowanych wierzytelności. To konkurencyjna w stosunku do kredytowania forma finansowania przedsiębiorców oraz często także podmiotów publicznych, polegająca na wprowadzeniu do obrotu papierów wartościowych. Dzięki dokonanej emisji papierów wartościowych podmiot inicjujący cały proces sekurytyzacji pozyskuje określoną kwotę, która zasila go finansowo, a następnie odkupuje owe papiery ze środków uzyskanych $\mathrm{z}$ wyodrębnionego uprzednio zbioru wierzytelności, który stanowi ekonomiczną bazę operacji sekurytyzacji” (W. Szydło, Cywilnoprawne aspekty umowy cesji wierzytelności oraz umowy o subpartycypację zawieranych $w$ procesie sekurytyzacji wierzytelności, „Przegląd Prawa i Administracji” 2015, t. CIII, s. 319). Z kolei analiza obowiązujących rozwiązań prawnych pozwala uznać sekurytyzację za: „proces polegający na zarządzaniu aktywami, $\mathrm{w}$ ramach którego inicjator sekurytyzacji (aranżer), tj. podmiot, któremu przysługują określone wierzytelności, dokonuje wyodrębnienia stosownej puli wierzytelności oraz zawiera następnie z podmiotem emisyjnym - spółką kapitałową lub funduszem sekurytyzacyjnym - cywilnoprawną umowę cesji wierzytelności bądź też umowę subpartycypacji, który, dokonując następnie emisji określonych papierów wartościowych (rodzaj ich zależy przede wszystkim od charakteru prawnego tego podmiotu; mogą to być na przykład obligacje lub certyfikaty inwestycyjne), zaspokaja roszczenia $z$ wyemitowanych przez siebie papierów ze środków, które w sensie ekonomicznym pochodzą od dłużników wyodrębnionej uprzednio puli wierzytelności" (ibidem, s. 320).

Punktem istotnym w procesie sekurytyzacji jest umowa przelewu wierzytelności (cesja), do której mają zastosowanie przepisy Kodeksu cywilnego, w tym zaskarżony art. 509 k.c. W myśl tego przepisu wierzyciel może bez zgody dłużnika przenieść wierzytelność na osobę trzecią (przelew), chyba że sprzeciwiałoby się to ustawie, zastrzeżeniu umownemu albo właściwości zobowiązania. Wraz z wierzytelnością przechodzą na nabywcę wszelkie związane z nią prawa, w szczególności roszczenie o zaległe odsetki. W nauce prawa oraz orzecznictwie podnosi się, że przedmiotem analizowanej umowy może być każda wierzytelność, bez względu na źródło jej powstania. „Wyjątki w tym zakresie wynikać mogą z ustawy, zastrzeżenia umownego albo z właściwości zobowiązania. [...] kompetencja do przeniesienia wierzytelności na inny podmiot ma charakter zasady, wyjątki od niej nie mogą być interpretowane rozszerzająco (exceptiones non sunt extendendae). Patrząc na problem $\mathrm{z}$ innej perspektywy, za godną akceptacji należy uznać dyrektywę wykładni in dubio pro favorem cedendo" (W. Mularski [w:] Kodeks cywilny, t. II, Komentarz. Art. 353-626, red. M. Gutowski, 2019, Legalis, art. 509, nb. 31). 
W doktrynie prawa i orzecznictwie sądowym utorował sobie drogę pogląd, zgodnie z którym należy zwrotowi temu nadawać szerokie i funkcjonalne rozumienie (np. wyrok SN z 11 sierpnia 2005 r., sygn. akt V CK 74/05). Cesja wierzytelności obejmuje wszelkie prawa, nawet te które nie mają charakteru wierzytelności, a które zabezpieczają lub ułatwiają realizację wierzytelności głównej (W. Mularski [w:] Kodeks cywilny, op. cit.). Do takich uprawnień zalicza się uprawnienia prawnokształtujące, zarzuty, roszczenia z tytułu kar umownych. „Niekiedy mówi się w tym kontekście o uprawnieniach związanych funkcjonalnie z wierzytelnością główną, rozumiejąc przez to uprawnienia, których realizacja warunkuje spełnienie świadczenia zaspokajającego roszczenie główne [...] Można chyba nawet metaforycznie mówić o «wstąpieniu w wierzytelność» czy «wejściu w sytuację prawną cedenta» (tego ostatniego sformułowania używa wyrok SN z 25.5.2016 r., V CSK 579/15, Legalis)” (W. Mularski [w:] Kodeks cywilny, op. cit., nb. 34).

Analizując tę konstrukcję, należy odnieść się do zasady niepogarszania przez przelew sytuacji dłużnika. „Przelew w zasadzie nie może prowadzić, poza zmianą podmiotu uprawnionego, do zmiany treści stosunku zobowiązaniowego. W szczególności, przelew nie może pogarszać sytuacji prawnej dłużnika [...]. Daje on bowiem dłużnikowi kompetencję do podniesienia przeciwko cesjonariuszowi tych wszystkich zarzutów, które przysługiwały mu wcześniej wobec cedenta, nie odnosząc się do zakresu cedowanej wierzytelności” W. Mularski [w:] Kodeks cywilny, op. cit., art. 513, nb. 34).

Zaskarżone przepisy, co wynika z przeprowadzonej rekonstrukcji ich znaczenia, pozbawione były treści, z którymi sąd pytający wiąże zarzut niekonstytucyjności. Powszechnie przyjmowano, zarówno w doktrynie prawa, jak i w orzecznictwie sądowym, że cesjonariusz wstępuje w uprawnienia cedenta, co obejmowało również czynności, których skutkiem było przerwanie biegu przedawnienia. Sąd Najwyższy dokonał zmiany wykładni zakwestionowanych przepisów. Z tą zmianą wiąże się problem konstytucyjny, podnoszony przez sąd pytający.

5. Problem konstytucyjny, który diagnozuje sąd pytający, dotyczy w pierwszej kolejności zagadnienia retroaktywności orzeczeń sądów kształtujących sposób interpretacji przepisów prawa. „Skutki przyjęcia w orzecznictwie określonej wykładni pewnego przepisu nierzadko niewiele różnią się od skutków zmiany normatywnej” (M. Kłoda, Zastosowanie zasad prawa międzyczasowego prywatnego do skutków zmiany wykładni przyjętej w orzecznictwie, „Państwo i Prawo” 2014, z. 2, s. 34). Zagadnienie to jest mało rozpoznane w doktrynie prawa i wywołuje poważne kontrowersje (zob. np. W. Mularski, Orzecznictwo retroaktywne. Szkic problematyki ( w świetle wybranych przykładów), „Forum Prawnicze” 2017, nr 2). Problem retroaktywności $\mathrm{w}$ procesie stosowania prawa dostrzega również SN. „W wyroku z 28.1.2009 r., IV CSK 333/08, Legalis, z 8.7.2011 r., IV CSK 532/10, Legalis oraz z 16.2.2012 r., IV CSK 229/11, Legalis, SN stwierdził że dokonywana przez sądy ocena zdarzeń prawnych powinna następować z uwzględnieniem wy- 
kładni przepisów przyjmowanej przez doktrynę i orzecznictwo w chwili zajścia zdarzenia prawnego, a nie w chwili orzekania" (P. Sobolewski [w:] Kodeks cywilny. Komentarz, red. K. Osajda, 2019, Legalis, art. 3, nb. 3). Tytułem przykładu można wskazać kilka wypowiedzi Sądu Najwyższego.

Przede wszystkim „Podstawę do tych rozważań daje głoszony w literaturze oraz orzecznictwie Trybunału Konstytucyjnego pogląd, że gdy występowały rozbieżności interpretacyjne w praktyce funkcjonowania prawa - w zachowaniach podmiotów zobowiązanych do przestrzegania norm prawnych oraz w działaniach organów powołanych do ich stosowania - istnieje możliwość ograniczenia wstecznego stosowania ustalonej interpretacji przepisu (uchwała Trybunału Konstytucyjnego z 7 marca 1995 r., W 9/94, OTK Zb.Urz. 1995, nr 1 poz. 20). Do rozważań tych skłania także wnikliwa, zasługująca w pełni na akceptację, analiza dokonana przez sędziów Sądu Najwyższego w uzasadnieniach zdań odrębnych do uchwały pełnego składu Sądu Najwyższego z dnia 14 listopada 2007 r., BSA I-4110-5/07 (OSNC 2008, nr 4, poz. 42). Z tych względów Sąd Najwyższy stwierdza, że dokonana w uchwale wykładnia ma zastosowanie na przyszłość, od dnia jej podjęcia” (uchwała SN z 5 czerwca 2008 r., sygn. akt III CZP 142/07).

Ponadto „[p]odniesiony w skardze kasacyjnej problem dotyczy w istocie zagadnienia wpływu nowej interpretacji przepisu prawa na toczące się postępowanie [...]. W doktrynie wysunięty został pogląd, że w odniesieniu do szczególnych orzeczeń sądowych, związanych na przykład z ogólną zasadą pewności prawa (L. Morawski, Wykładnia w orzecznictwie sądów, Toruń 2002, s. 30) sąd może wziąć pod uwagę wszystkie okoliczności i określić datę, od której ustalenie interpretacyjne będzie wywierać skutki, inaczej niż od daty wejścia w życie przepisu [...]. Europejski Trybunał Sprawiedliwości w Luksemburgu, między innymi w sprawie nr 43/57 Gabrielle Defrenne (Defrenne II) przeciwko Societe Anonyme Belge De Navigation Aerienne Sabena w wyroku z dnia 8 kwietnia 1976 r., przewidział możliwość ograniczenia skutków wykładni określonego przepisu w czasie, gdy powoływanie się na nową, poprawną wykładnię przepisu prowadziłoby do rozstrzygnięć naruszających inne ważne wartości chronione prawem (P. Dąbrowska, Obowiązywanie w czasie wyroków wstępnych ETS, „Przegląd Sądowy” 2002, nr 7-8, s. 53, wyrok Sądu Najwyższego z dnia 8 lutego 2008 r. I CSK 549/07) [...]. W przypadku zwykłych orzeczeń sądowych zdarzają się również sytuacje, w których wykładnia przepisów ze względu na rozbieżności w doktrynie i orzecznictwie może dawać różne rezultaty. Należy zatem dopuścić możliwość ograniczenia wstecznego stosowania nowej interpretacji przepisu, skoro występowały usprawiedliwione różnice stanowisk w orzecznictwie sądów i przemawia za tym wzgląd na inne wartości chronione przez porządek prawny" (wyrok SN z 9 stycznia 2009 r., sygn. akt I CSK 284/08).

Nadto „[r]ozpatrując problem wpływu zmiany wykładni na ocenę czynności zdziałanych w okresie, kiedy przyjmowane było inne rozumienie danego przepisu i czynność dokonana została z zachowaniem reguł wówczas ocenianych jako 
prawidłowe i gwarantujące skuteczność, Sąd Najwyższy w uzasadnieniu wyroku z dnia 8 lipca 2011 r. (IV CSK 532/10) zwrócił uwagę, że na funkcjonującą normę prawną składa się zarówno treść przepisu, jak i jego rozumienie w praktyce stosowania prawa. Zmiana dotychczasowej wykładni przepisu i jego nowe rozumienie podlega zasadzie lex retro non agit, ponieważ tworzy w istocie nową treść normy prawnej. Zmieniona interpretacja nie powinna prowadzić do nieważności lub bezskuteczności czynności prawnych dokonanych w czasie, gdy obowiązywało inne rozumienie przepisu, a czynność zdziałana została z jego poszanowaniem. Sąd Najwyższy wskazał, że reguła przyjmująca działanie nowej wykładni na przyszłość dominuje w orzecznictwie Europejskiego Trybunału Sprawiedliwości i Europejskiego Trybunału Praw Człowieka. Swoją ocenę wsparł przykładowo przytoczonymi judykatami obydwu Trybunałów. Odwołał się także do analogicznych poglądów wyrażanych przez Trybunał Konstytucyjny i przytaczanej przezeń argumentacji, że nadawanie mocy wstecznej nowej wykładni przepisu prawa, na podstawie którego doszło do nabycia określonego prawa, godzi w zasadę pewności prawa, zaufania $\mathrm{w}$ stosunkach między obywatelem a państwem oraz $\mathrm{w}$ zasadę ochrony praw nabytych (przede wszystkim wyrok Trybunału Konstytucyjnego z dnia 14 czerwca 2000 r. P 3/00, OTK 2000/5/138, zawierający także omówienie wcześniejszego orzecznictwa Trybunału). Wprawdzie powołana argumentacja odnosi się głównie do zmiany treści prawa wynikających z interwencji legislacyjnych, jednakże opiera się na poszanowaniu wartości, które zagrożone zostają również wówczas, kiedy zmiana treści prawa jest wynikiem przyjęcia odmiennych koncepcji interpretacyjnych. Także w orzecznictwie Sądu Najwyższego przeważa stanowisko, że pewność prawa wymaga, by w razie późniejszej zmiany przepisu prawa lub jego rozumienia, respektowane były czynności prawne podejmowane pod rządami poprzednio obowiązującego prawa i jego wykładni (np. wyrok z dnia 26 lipca 1991 r., I PRN 34/91, uchwałę składu siedmiu sędziów z dnia 19 maja 2009 r., III CZP 139/08, OSNC 2009/11/144 oraz wyrok z dnia 12 lutego 2010 r. I CSK 328/09, OSNC 2010/9/130 i cytowane tam orzecznictwo)" (wyrok SN z 16 lutego 2012 r., sygn. akt IV CSK 229/11).

6. Konfrontując powyższe ustalenia $\mathrm{z}$ istotą pytania prawnego, należy jeszcze raz powtórzyć, że, po pierwsze, nie nastąpiła zmiana formalna zaskarżonych przepisów. Ustawodawca nie ingerował w ich treść. Po drugie, przepisy nie wywoływały rozbieżności $\mathrm{w}$ orzecznictwie sądów powszechnych $\mathrm{w}$ zakresie przedawnienia wierzytelności zbytych przez banki. Po trzecie, w drodze utrwalonej wykładni SN nadano zaskarżonym przepisom nowe znaczenie, obowiązujące od 2016 r. Po czwarte, SN akceptuje stanowisko, że pewność prawa wymaga, by w razie późniejszej zmiany rozumienia przepisów, respektowane były czynności prawne podejmowane pod rządami poprzednio obowiązującego prawa i jego wykładni. Po szóste i najważniejsze, sąd pytający może ograniczyć, stosując wykładnię w zgodzie z Konstytucją, retroaktywny skutek zaskarżonych norm prawnych, będący efektem nowej linii orzeczniczej SN. Problem konstytucyjny pojawił się, 
jak sam wskazuje Sąd Okręgowy, na płaszczyźnie stosowania prawa i nie dotyczy sensu stricto płaszczyzny stanowienia prawa. Podejmując przedmiotowe uchwały, które zapadły w sprawach cesji wierzytelności bankowych, SN nie wyłączył bezpośrednio retroaktywnego skutku wykładni. Niemniej analiza rozstrzygnięć zapadłych w innych sprawach wskazuje, że SN jest w pełni świadomy, że zmiana dotychczasowej wykładni przepisu i jego nowe rozumienie podlega zasadzie lex retro non agit, ponieważ tworzy w istocie nową treść normy prawnej. A ponadto „[z]mieniona interpretacja nie powinna prowadzić do nieważności lub bezskuteczności czynności prawnych dokonanych w czasie, gdy obowiązywało inne rozumienie przepisu, a czynność zdziałana została z jego poszanowaniem" (wyrok SN z: 26 lipca 1991 r., sygn. akt I PRN 34/91; 12 lutego 2010 r., sygn. akt I CSK 328/09, uchwała SN z 19 maja 2009 r., sygn. akt III CZP 139/08; wyrok Sądu Rejonowego w Ostrowi Mazowieckiej I Wydział Cywilny z 18 listopada 2015 r., sygn. akt I C 498/15).

Trzeba mieć także świadomość, że z punktu widzenia rudymentarnych zasad demokratycznego państwa prawnego utrzymywany w systemie mechanizm cesji wierzytelności bankowej, o którym mowa w art. 92a prawa bankowego, prowadzi de facto do kreacji pozornego prawa majątkowego, które powstając, staje się od razu nieskuteczne, gdyż podlega w tym samym momencie przedawnieniu (nieprzedawnione wobec cedenta i z chwilą zawarcia umowy przelewu staje się przedawnione wobec cesjonariusza). Zdaniem TK tego rodzaju koncepcja kreacji swoistego nudum ius wprowadza w błąd ewentualnych beneficjentów prawa, tworząc złudzenie istnienia na danym odcinku skutecznych instrumentów ochrony prawnej (wyrok TK z 1 września 2006 r., sygn. akt SK 14/05).

Mając powyższe na uwadze, interpretacja zaskarżonych przepisów w procesie stosowania prawa, a w szczególności ograniczenie skutku retroaktywnego wykładni leżą w gestii sądów, w których dyspozycji pozostają takie instrumenty, jak wykładnia w zgodzie z Konstytucją. W tym stanie rzeczy trudno uznać, że od oceny konstytucyjności kwestionowanych przepisów przez TK zależy rozstrzygnięcie sprawy toczącej się przed sądem pytającym w rozumieniu art. 193 Konstytucji. Wobec podniesionych wątpliwości co do dopuszczalności pytania prawnego, Sejm wnosi o umorzenie postępowania na podstawie art. 59 ust. 1 pkt 2 ustawy z 30 listopada 2016 r. o organizacji i trybie postępowania przed Trybunałem Konstytucyjnym (Dz. U. poz. 2072, ze zm.).

\section{Bibliografia}

Dąbrowska P., Obowiązywanie w czasie wyroków wstępnych ETS, „Przegląd Sądowy” 2002, nr 7-8.

Kłoda M., Zastosowanie zasad prawa międzyczasowego prywatnego do skutków zmiany wykładni przyjętej w orzecznictwie, „Państwo i Prawo” 2014, z. 2. 
Kordasiewicz B., Problematyka dawności [w:] System prawa prywatnego, t. II, Prawo cywilne - część ogólna, red. Z. Radwański, A. Olejniczak, 2019, Legalis.

Kuźmicka-Sulikowska J., Idea przedawnienia i jej realizacja w polskim kodeksie cywilnym, Wrocław 2015.

Morawski L., Wykładnia w orzecznictwie sądów, Toruń 2002.

Mularski W. [w:] Kodeks cywilny, t. II, Komentarz. Art. 353-626, red. M. Gutowski, 2019, Legalis.

Mularski W., Orzecznictwo retroaktywne. Szkic problematyki ( $w$ świetle wybranych przykładów), „Forum Prawnicze” 2017, nr 2.

Sobolewski P. [w:] Kodeks cywilny. Komentarz, red. K. Osajda, 2019, Legalis.

Szydło W., Cywilnoprawne aspekty umowy cesji wierzytelności oraz umowy o subpartycypację zawieranych $w$ procesie sekurytyzacji wierzytelności, „Przegląd Prawa i Administracji” 2015, t. CIII. 


\title{
Ocena zgodności z Konstytucją przepisów ustawy o gospodarce nieruchomościami oraz ustawy o szczególnych zasadach przygotowania i realizacji inwestycji w zakresie dróg publicznych ${ }^{1}$
}

\author{
Assessment of conformity to the Constitution of provisions of the Act \\ on Real Estate Management and the Act on Specific Principles for the \\ Preparation and Realisation of Investments Regarding Public Roads
}

\begin{abstract}
The subject of the assessed constitutional complaint is the problem of the lack of standards specifying the procedure for returning property that has not been finally used for public purposes in the event of deprivation of property rights on the basis of the special road statute. The applicants point out, inter alia, that the diversity of the legal situation of former owners of the expropriated property and owners of property taken over as a result of the decision to authorize road construction works violates the principle of equality before the law and the prohibition of discrimination in political, economic or social life. It was applied that the questioned provision of the Act on Specific Principles for the Preparation and Realisation of Investments Regarding Public Roads, to the extent that it excludes the possibility of an appropriate application of the provisions of the Act on Real Estate Management to real estate taken over under the former of these acts, does not conform to the Constitution.
\end{abstract}

Keywords: public roads, real estate, Constitutional Tribunal

Przedmiotem ocenianej skargi konstytucyjnej jest problem braku norm określających procedurę zwrotu nieruchomości ostatecznie niewykorzystywanej na cele publiczne w sytuacji pozbawienia prawa własności na podstawie specustawy drogowej. Skarżący wskazują m.in., że zróżnicowanie sytuacji prawnej byłych właścicieli nieruchomości wywłaszczonych i właścicieli nieruchomości przejętych wskutek wydania decyzji o zezwoleniu na realizację inwestycji drogowej narusza zasadę równości wobec prawa oraz zakazu dyskryminacji w życiu politycznym, gospodarczym czy społecznym. Wniesiono o stwierdzenie, że przepis ustawy o szczególnych zasadach przygotowania i realizacji inwestycji w zakresie dróg publicznych w zakresie, w jakim wyłącza możliwość odpowiedniego stosowania wskazanych przepisów ustawy o gospodarce nieruchomościami do nieruchomości przejętych na podstawie pierwszej z ustaw, jest niezgodny z Konstytucją.

Słowa kluczowe: drogi publiczne, nieruchomość, Trybunał Konstytucyjny

Doktor hab. nauk prawnych, prof. UMK -

Uniwersytet Mikołaja Kopernika w Toruniu, Wydział Prawa i Administracji, Katedra Teorii

Prawa i Państwa, TORUŃ, POLSKA •

karol.dobrzeniecki@umk.pl • https://orcid.org/0000-0002-6364-9793

$1 \quad$ Sprawa dot. skargi konstytucyjnej A $R$ iT $R$ $z 4$ lutego 2019 r. (sygn. akt SK 37/19) dotyczącej ustawy $z$ dnia 21 sierpnia 1997 r. o gospodarce nieruchomościami oraz ustawy z dnia 10 kwietnia 2003 r. o szczególnych zasadach przygotowania i realizacji inwestycji w zakresie dróg publicznych, sygn. akt SK 37/19, projekt sporządzony 6 grudnia 2019 r.; BAS-WAKU 1575/19. 
Na podstawie art. 69 ust. 2 w związku z art. 42 pkt 3 ustawy z 30 listopada 2016 r. o organizacji i trybie postępowania przed Trybunałem Konstytucyjnym (Dz. U. poz. 2072, ze zm.), w imieniu Sejmu Rzeczypospolitej Polskiej przedkładam wyjaśnienia w sprawie skargi konstytucyjnej A $\mathrm{R}$ i $\mathrm{T}$ R z 4 lutego 2019 r. (sygn. akt SK 37/19), jednocześnie wnosząc o stwierdzenie, że art. 23 ustawy z 10 kwietnia 2003 r. o szczególnych zasadach przygotowania i realizacji inwestycji w zakresie dróg publicznych (t.j. Dz. U. 2018, poz. 1969) w zakresie, w jakim wyłącza możliwość odpowiedniego stosowania przepisów rozdziału 6 działu III ustawy z 21 sierpnia 1997 r. o gospodarce nieruchomościami (t.j. Dz. U. 2018, poz. 2204, ze zm.) do nieruchomości przejętych na podstawie ustawy o szczególnych zasadach przygotowania i realizacji inwestycji w zakresie dróg publicznych jest niezgodny z art. 21 ust. 2 w związku $\mathrm{z}$ art. 32 ust. 1 i art. 64 ust. 2 Konstytucji.

W pozostałym zakresie wnoszę o umorzenie postępowania na podstawie art. 59 ust. 1 pkt 2 ustawy o organizacji i trybie postępowania przed Trybunałem Konstytucyjnym ze względu na niedopuszczalność wydania wyroku.

\section{Uzasadnienie}

\section{Stan faktyczny i przebieg postępowania}

1. Skarga konstytucyjna została wniesiona w związku z następującym stanem faktycznym. Skarżący byli właścicielami nieruchomości położonej w przy ul. o powierzchni $\mathrm{m}^{2}$ (dalej: przejęta nieruchomość). Przedmiotowa nieruchomość przeszła na własność Miasta na mocy prawa, w związku z wydaniem decyzji Prezydenta z _ czerwca 2009 r. o ustaleniu lokalizacji drogi powiatowej dla inwestycji polegającej na

utrzymana w mocy decyzją Wojewody . Decyzja ta została

Dnia listopada 2014 r. skarżący złożyli wniosek o zwrot części ( $\left.\mathrm{m}^{2}\right)$ przejętej nieruchomości, argumentując, że część ta stała się zbędna dla realizacji celu, dla którego nastąpiło wywłaszczenie, oraz, że organ zamierza wykorzystać przedmiotową nieruchomość na inny cel. Starosta $\quad$ decyzją z lipca 2015 r. orzekł o umorzeniu postępowania w przedmiocie zwrotu wnioskowanej nieruchomości. Po rozpatrzeniu odwołania skarżących Wojewoda decyzją z $\quad$ września 2015 r. uchylił decyzję Starosty i orzekł o odmowie zwrotu przejętej nieruchomości. Organ odwoławczy podzielił stanowisko organu pierwszego stopnia, że przejęta nieruchomość nie stała się zbędna na cel wywłaszczenia w rozumieniu art. 137 ust. 1 ustawy z 21 sierpnia 1997 r. o gospodarce nieruchomościami (t.j. Dz. U. 2018, poz. 2204, ze zm.; dalej: u.g.n.). Budowa została rozpoczęta przed upływem siedmiu lat od dnia, w którym decyzja o wywłaszczeniu stała się ostateczna i nie upłynęło dziesięć lat wymaga- 
nych dla zakończenia inwestycji liczonych od dnia, w którym decyzja o wywłaszczeniu stała się ostateczna. W ocenie organu skarżący mogą skutecznie ubiegać się o zwrot wywłaszczonego gruntu dopiero po upływie terminu określonego w art. 137 ust. 1 pkt 2 u.g.n. Wojewoda uznał, że ustalenie braku tzw. zbędności wywłaszczonego gruntu dla realizacji celu wywłaszczenia przemawia za wydaniem decyzji o odmowie zwrotu wywłaszczonej nieruchomości na podstawie art. $138 \$ 1$ pkt 2 Kodeksu postępowania administracyjnego.

Skarżący wnieśli skargę na powyższą decyzję do Wojewódzkiego Sądu Administracyjnego w , który wyrokiem z marca 2016 r. uchylił zaskarżoną decyzję oraz decyzję Starosty $\quad$ z lipca 2015 r. Sąd uznał, że w sytuacji, w której cel wywłaszczenia został w sposób bezsporny zrealizowany w całości wyłącznie na części wywłaszczonej działki, a w odniesieniu do pozostałej części nie podjęto $\mathrm{w}$ siedmioletnim terminie, przewidzianym w art. 137 ust. 1 pkt 1 u.g.n., żadnych działań inwestycyjnych, ta część nieruchomości nie pozostaje w realnym związku funkcjonalnym $\mathrm{z}$ inwestycją zrealizowaną na części zagospodarowanej. Jeżeli beneficjent wywłaszczenia nie jest w stanie wykazać, że niezagospodarowana część działki jest konieczna do realizacji jakiegokolwiek składnika celu wywłaszczenia, dopuszczalne byłoby uznanie, że w stosunku do tej części nieruchomości nie został zachowany siedmioletni termin z powołanego artykułu. Powyższe otwierałoby drogę do zwrotu tej części nieruchomości. Sąd zastrzegł przy tym, że chodzi wyłącznie o takie stany faktyczne, które charakteryzują się oczywistym brakiem możliwości realizacji jakiegokolwiek składnika celu wywłaszczenia na niezagospodarowanej części działki w związku z kompletną realizacją tego celu na innej części działki. Sytuacji tej nie można mylić z taką, w której beneficjent wywłaszczenia nie zaplanował zagospodarowania poszczególnych części wywłaszczonej działki jednocześnie, a w pewnej kolejności.

Miasto wniosło skargę kasacyjną do Naczelnego Sądu Administracyjnego (dalej: NSA). Zaskarżonemu wyrokowi zarzuciło naruszenie przepisów prawa materialnego tj. art. 136 ust. 3 zdanie $1 \mathrm{w}$ związku z art. 137 ust. 1 u.g.n. poprzez wadliwą interpretację i w konsekwencji niewłaściwe zastosowanie, polegające na przyjęciu, że w konkretnym stanie faktycznym zaistniała szczególna sytuacja, nakazująca organom administracyjnym badanie przesłanek zwrotu wywłaszczonej nieruchomości, mimo że do czasu rozpoznawania sprawy o zwrot wywłaszczonej nieruchomości nie minął 7-letni okres przewidziany w art. 137 ust. 1 pkt 1 u.g.n., liczony od wywłaszczenia nieruchomości, a przewidziany na rozpoczęcie prac zmierzających do realizacji celu, na jaki nieruchomość została wywłaszczona.

Naczelny Sąd Administracyjny wyrokiem z $\quad$ września 2018 r. uchylił zaskarżone orzeczenie i oddalił skargę skarżących na decyzję Wojewody

. W uzasadnieniu Sąd wskazał, że podstawą prawną przejęcia nieruchomości była ustawa z 10 kwietnia 2003 r. o szczególnych zasadach przygotowania 
i realizacji inwestycji w zakresie dróg publicznych (t.j. Dz. U. 2018, poz. 1474, ze zm.; dalej: specustawa drogowa). Ustawa ta ma szczególny charakter wynikający z jej celu, którym jest stworzenie warunków prawnych umożliwiających sprawną i szybką realizację inwestycji drogowych, w związku z czym przewidziany w niej został uproszczony tryb przejmowania nieruchomości niezbędnych na ten cel. W ocenie NSA ustawa w żadnym z przepisów nie reguluje kwestii związanych ze zwrotem lub alternatywnym wykorzystaniem nieruchomości bądź ich części, które nie zostały wykorzystane na realizację inwestycji drogowej. Nie zawiera też bezpośredniego odesłania do ustawy o gospodarce nieruchomościami w zakresie stosowania przepisów tej ustawy stanowiących o zwrocie nieruchomości, jak również odesłania generalnego do przepisów ustawy o gospodarce nieruchomościami - w sprawach nieuregulowanych w specustawie drogowej. Specustawa drogowa w art. 23 stanowi, że w sprawach „nieuregulowanych w niniejszym rozdziale" stosuje się przepisy ustawy o gospodarce nieruchomościami. W rozdziale trzecim, noszącym tytuł „Nabywanie nieruchomości pod drogi” ustawodawca nie unormował zasad i trybu zwrotu nieruchomości wywłaszczonej na podstawie przepisów omawianej specustawy. Tym samym, zdaniem NSA, nie można, na podstawie wskazanego przepisu art. 23, do nieruchomości nabytych na podstawie specustawy drogowej zastosować art. 136 u.g.n. regulującego kwestię zwrotu wywłaszczonych nieruchomości. Naczelny Sąd Administracyjny wskazuje, że, co prawda, przejęcie nieruchomości w trybie art. 12 specustawy drogowej nosi znamiona wywłaszczenia - dokonywane jest na wniosek podmiotu publicznoprawnego, na realizację celu publicznego, polega na pozbawieniu praw do nieruchomości i odbywa się za odszkodowaniem, jednakże nie przesądza to o możliwości zastosowania do takiej nieruchomości przepisów ustawy o gospodarce nieruchomościami dotyczących zwrotu wywłaszczonych nieruchomości, bowiem instytucja taka zarezerwowana jest dla gruntów wywłaszczonych w trybie przepisów ustawy o gospodarce nieruchomościami, a także przejętych lub nabytych na podstawie aktów prawnych wymienionych w art. 216 u.g.n. Wyliczenie zawarte $\mathrm{w}$ art. 216 u.g.n. ma charakter zamknięty. Niedopuszczalne jest zatem i z tej przyczyny stosowanie przepisów o zwrocie do nieruchomości przejętych przez Skarb Państwa na podstawie przepisów innych niż wymienione w art. 216 u.g.n. W wyliczeniu tym brak ustawy z 10 kwietnia 2003 r. o szczególnych zasadach przygotowania i realizacji inwestycji w zakresie dróg publicznych. Nie jest zatem możliwe orzeczenie na podstawie przepisów działu III rozdziału 6 u.g.n. o zwrocie nieruchomości przejętych decyzją o lokalizacji drogi.

Dnia 4 lutego 2019 r. skarżący wnieśli skargę konstytucyjną, a 23 kwietnia 2019 r. pismo, w którym uzupełnili jej braki formalne, zgodnie z wezwaniem Trybunału (dalej: uzupełnienie skargi).

W piśmie procesowym z 2 października 2019 r. Rzecznik Praw Obywatelskich zajął stanowisko, w którym opowiedział się za uznaniem niekonstytucyjności art. 216 ust. 1 u.g.n. oraz art. 23 specustawy drogowej w zakresie, w jakim 
przepisy te wykluczają bądź wyłączają odpowiednie zastosowanie przepisów rozdziału 6 działu III u.g.n. do nieruchomości nabytych przez Skarb Państwa na podstawie specustawy drogowej.

\section{Przedmiot kontroli}

1. Przedmiotem postępowania wskazanym w skardze jest badanie zgodności:

- art. 216 ust. 1 u.g.n. w zakresie, w jakim wyklucza on odpowiednie stosowanie przepisów rozdziału 6 działu III u.g.n. do nieruchomości nabytych przez Skarb Państwa na podstawie specustawy drogowej, z art. 2, art. 64 ust. 1 i 3, art. 32 ust. 1 i 2 i art. 31 ust. 3 Konstytucji,

- art. 23 specustawy drogowej w zakresie, w jakim ogranicza on odesłanie do przepisów ustawy o gospodarce nieruchomościami tylko do spraw nieuregulowanych w rozdziale 3 specustawy drogowej, z art. 2 i art. 31 ust. 1 i 2 Konstytucji.

2. Zaskarżone przepisy mają następujące brzmienie.

Art. 216 ust. 1. u.g.n.: „Przepisy rozdziału 6 działu III niniejszej ustawy stosuje się odpowiednio do nieruchomości przejętych lub nabytych na rzecz Skarbu Państwa na podstawie art. 6 lub art. 47 ustawy z dnia 12 marca 1958 r. o zasadach i trybie wywłaszczania nieruchomości (Dz. U. z 1974 r. poz. 64 oraz z 1982 r. poz. 79), ustawy z dnia 22 maja 1958 r. o terenach dla budownictwa domów jednorodzinnych w miastach i osiedlach (Dz. U. poz. 138, z 1961 r. poz. 47 i 159 oraz z 1972 r. poz. 192), ustawy z 31 stycznia 1961 r. o terenach budowlanych na obszarach wsi (Dz. U. z 1969 r. poz. 216, 1972, poz. 312 oraz z 1985 r. poz. 99), art. 22 ustawy z 14 lipca 1961 r. o gospodarce terenami w miastach i osiedlach (Dz. U. z 1969 r. poz. 159, z 1972 r. poz. 193 oraz 1974, r. poz. 84), ustawy z dnia 6 lipca 1972 r. o terenach budownictwa jednorodzinnego i zagrodowego oraz o podziale nieruchomości w miastach i osiedlach (Dz. U. poz. 192, $1973 \mathrm{r}$. poz. 282 oraz z 1985 r. poz. 99) oraz do nieruchomości wywłaszczonych na rzecz państwowych i spółdzielczych przedsiębiorstw gospodarki rolnej, jak również do gruntów wywłaszczonych na podstawie odrębnych przepisów w związku z potrzebami Tatrzańskiego Parku Narodowego”.

Art. 23 specustawy drogowej: „W sprawach nieuregulowanych w niniejszym rozdziale stosuje się przepisy ustawy o gospodarce nieruchomościami”.

3. Wobec sformułowania skargi konstytucyjnej w sposób zakresowy należy przytoczyć również treść kluczowych przepisów tego rozdziału u.g.n., na który wskazują skarżący. Rozdział 6 działu III (pt. „Zwrot wywłaszczonych nieruchomości”) zawiera uregulowania stanowiące podstawę prawną do żądania przez poprzedniego właściciela zwrotu nieruchomości zbędnych oraz określające przesłanki uznania wywłaszczonej nieruchomości za zbędną na cel określony w decyzji o wywłaszczeniu; są to w szczególności art. 136 ust. 3 i art. 137 u.g.n.

Przepisy te stanowią: 
Art. 136 ust. 3 u.g.n.: „Poprzedni właściciel lub jego spadkobierca mogą żądać zwrotu wywłaszczonej nieruchomości lub udziału w tej nieruchomości albo części wywłaszczonej nieruchomości lub udziału w tej części, jeżeli, stosownie do przepisu art. 137, nieruchomość lub jej część stała się zbędna na cel określony w decyzji o wywłaszczeniu. Z wnioskiem o zwrot występuje się do starosty, wykonującego zadanie z zakresu administracji rządowej, który zawiadamia o tym właściwy organ gospodarujący zasobem nieruchomości. Warunkiem zwrotu wywłaszczonej nieruchomości lub udziału w tej nieruchomości albo części wywłaszczonej nieruchomości lub udziału w tej części jest zwrot przez poprzedniego właściciela lub jego spadkobiercę odszkodowania lub nieruchomości zamiennej stosownie do art. 140".

Art. 137 u.g.n.: „1. Nieruchomość uznaje się za zbędną na cel określony w decyzji o wywłaszczeniu, jeżeli:

1) pomimo upływu 7 lat od dnia, w którym decyzja o wywłaszczeniu stała się ostateczna, nie rozpoczęto prac związanych $\mathrm{z}$ realizacją tego celu albo

2) pomimo upływu 10 lat od dnia, w którym decyzja o wywłaszczeniu stała się ostateczna, cel ten nie został zrealizowany.

2. Jeżeli w przypadku, o którym mowa w ust. 1 pkt 2, cel wywłaszczenia został zrealizowany tylko na części wywłaszczonej nieruchomości, zwrotowi podlega pozostała część”.

\section{Zarzuty skarżących}

1. Skarżący łączą z wydaniem wyroku NSA z września 2018 r. (sygn. akt. IOSK 2491/16) naruszenie następujących praw i zasad konstytucyjnych: zasady zaufania do państwa i stanowionego przez nie prawa, zasady sprawiedliwości społecznej oraz zasady ochrony praw nabytych (art. 2 Konstytucji), prawa do własności, innych praw majątkowych oraz prawa dziedziczenia (art. 64 ust. 1-3 Konstytucji), zasady równości i zakazu dyskryminacji (art. 32 ust. 1 i 2 Konstytucji), zasady ochrony własności i prawa dziedziczenia (art. 21 ust. 1 i 2 Konstytucji), zasady proporcjonalności, zasady ograniczenia praw tylko w drodze ustawy i w sposób wskazany w ustawie (art. 31 ust. 3 Konstytucji).

2. Zasadniczym problemem konstytucyjnym ujętym w skardze jest: „problem braku norm określających procedurę zwrotu nieruchomości ostatecznie niewykorzystywanej na cele publiczne w sytuacji pozbawienia prawa własności na podstawie specustawy drogowej. W konsekwencji dochodzi do zróżnicowania sytuacji podmiotów w świetle prawa, sprzecznego z konstytucyjnym nakazem równego traktowania w sytuacji podobnej, a czynnikiem przyjętym przez ustawodawcę za okoliczność uzasadniającą zróżnicowanie pozostaje charakter celu publicznego" (uzupełnienie skargi, s. 11). Skarżący podnoszą, że: „nieujęcie przez Ustawodawcę w dyspozycji art. 216 u.g.n. zwrotu nieruchomości wywłaszczonych na podstawie ustawy z dnia 10 kwietnia 2003 r. o szczególnych zasadach przygotowania i realizacji inwestycji w zakresie dróg publicznych oraz nieure- 
gulowanie wprost przez Ustawodawcę instytucji zwrotu nieruchomości w samej ustawie drogowej powoduje powstanie swoistej próżni, która w ostatecznym rozrachunku powoduje pogwałcenie praw i wolności konstytucyjnych" (uzupełnienie skargi, s. 12).

„Kwestionowane przepisy stanowią niezgodne z art. 32 Konstytucji różnicowanie sytuacji prawnej obywateli - de facto w zależności od celu na jaki jest pożytkowana wywłaszczana nieruchomość. [...] istotne dla rozstrzygnięcia czy dane podmioty powinny być potraktowane podobnie pozostaje określenie, czy ich sytuacja jest podobna. I tak, za okoliczność przesądzającą o podobnej sytuacji w przypadku wywłaszczenia nieruchomości należy uznać sam fakt pozbawienia nieruchomości na cele publiczne za rekompensatą majątkową" (uzupełnienie skargi, s. 13).

Skarżący uważają, że „przyjęty model wywłaszczenia na podstawie specustawy drogowej, de facto petryfikujący przysługiwanie uprawnień właścicielskich Skarbowi Państwa oraz nieprzewidujący w tym zakresie możliwości zwrotu pozostaje sprzeczny z przesłanką konieczności ograniczenia" (uzupełnienie skargi, s. 14). W skardze pojawia się stwierdzenie, że „obywatel, kierując się zasadą zaufania do państwa i tworzonego przez niego prawa może oczekiwać, że w przypadku zbędności wywłaszczonej nieruchomości na cele publiczne będzie mógł domagać się jej zwrotu, a przyjęcie innego rozwiązania przez ustawodawcę narusza wskazane reguły konstytucyjne" (uzupełnienie skargi, s. 16).

Skarżący wskazują też, że przepis art. 216 u.g.n. poprzez zróżnicowanie sytuacji prawnej byłych właścicieli nieruchomości wywłaszczonych i właścicieli nieruchomości przejętych wskutek wydania decyzji o zezwoleniu na realizację inwestycji drogowej narusza zasadę równości wobec prawa oraz zakazu dyskryminacji w życiu politycznym, gospodarczym czy społecznym. Wymienione instytucje są do siebie podobne: „obie prowadzą do pozbawienia własności nieruchomości dotychczasowego właściciela, w obu przypadkach pozbawienie własności następuje na cel publiczny i zarówno w jednym, jak i w drugim przypadku odbywa się to za odszkodowaniem. Jedyna różnica jaka występuje to skutki ekspropriacyjne (przy decyzji wywłaszczeniowej mają charakter bezpośredni, przy decyzji o zezwoleniu - pośredni). Ta różnica nie ma jednak istotnego znaczenia, gdyż skutki te powstają na podstawie decyzji administracyjnej i to przesądza o tym, że mamy do czynienia z instytucją wywłaszczenia sensu stricto".

\section{Analiza formalnoprawna}

1. Zgodnie z art. 79 ust. 1 Konstytucji, każdy, czyje prawo lub wolność konstytucyjna zostały naruszone, może wnieść skargę konstytucyjną w sprawie zgodności z Konstytucją ustawy lub innego aktu normatywnego, na podstawie którego sąd lub organ administracji publicznej orzekł ostatecznie o jego wolnościach lub prawach albo o jego obowiązkach określonych w Konstytucji. Skarga konstytucyjna może zostać złożona po wyczerpaniu drogi prawnej, o ile droga ta jest przewi- 
dziana, w ciągu 3 miesięcy od doręczenia skarżącemu prawomocnego wyroku, ostatecznej decyzji lub innego ostatecznego rozstrzygnięcia (art. 77 ust. 1 ustawy $\mathrm{z}$ dnia 30 listopada 2016 r. o organizacji i trybie postępowania przed Trybunałem Konstytucyjnym; Dz. U. poz. 2072, ze zm.; dalej: ustawa o TK).

2. W orzecznictwie Trybunału ugruntowany jest pogląd, że pozytywnie zakończone wstępne badanie skargi konstytucyjnej i przekazanie jej do merytorycznego rozpoznania nie zwalnia składu orzekającego od badania - na każdym etapie postępowania - czy w sprawie nie zachodzi ujemna przesłanka procesowa, pociągająca za sobą konieczność umorzenia postępowania (zob. postanowienia TK z: 21 listopada 2001 r., sygn. akt K 31/01; 20 marca 2002 r., sygn. akt K 42/01; 27 stycznia 2004 r., sygn. akt SK 50/03; 16 marca 2005 r., sygn. akt SK 41/03; 12 października 2011 r., sygn. akt SK 22/10; 11 września 2012 r., sygn. SK 19/12; 10 marca 2015 r., sygn. akt SK 65/13; 13 grudnia 2016 r., sygn. akt SK 16/15). Dopiero szczegółowa analiza okoliczności sprawy, prowadzona na etapie merytorycznego rozpoznania skargi konstytucyjnej, pozwala ostatecznie ustalić, czy skarga spełnia wymogi wynikające z art. 79 ust. 1 Konstytucji oraz z art. 53 ust. 1 ustawy o TK. Trybunał na obecnym etapie postępowania nie jest związany wynikami wstępnej kontroli ujętymi w postanowieniu TK o nadaniu skardze biegu. Jeśli wydanie orzeczenia byłoby niedopuszczalne ze względu na niespełnienie wymogów skargi konstytucyjnej, konieczne jest umorzenie postępowania (zob. postanowienie TK z 22 marca 2016 r., sygn. akt SK 6/15). Mając powyższe na uwadze, w pierwszej kolejności Sejm odniesie się do formalnoprawnych przesłanek merytorycznego rozpoznania skargi.

3. Sposób sformułowania przez skarżących skargi skłania do wstępnego rozstrzygnięcia kwestii, czy zawisły przed Trybunałem problem konstytucyjny stanowi przypadek pominięcia legislacyjnego, które może być przedmiotem badania konstytucyjności, czy też jest zaniechaniem ustawodawcy. To ostatnie pozostaje poza kognicją Trybunału Konstytucyjnego. Skarżący expressis verbis opowiadają się za pierwszą ewentualnością.

4. Rozróżnienie na pominięcie i zaniechanie legislacyjne pojawiło się w orzecznictwie Trybunału Konstytucyjnego jeszcze przed wejściem w życie obecnej Konstytucji (zob. orzeczenie z 3 grudnia 1996 r., sygn. akt K 25/95, oraz wyrok z 6 maja 1998 r., sygn. akt K 37/97, podtrzymujący tę linię orzecznictwa po uchwaleniu Konstytucji z 1997 r.). Jest ono powszechnie stosowane także w najnowszych judykatach TK (zob. podsumowanie dotychczasowego orzecznictwa w wyrokach TK z: 13 czerwca 2011 r., sygn. akt SK 41/09, i 6 listopada 2012 r., sygn. akt K 21/11, w postanowieniu z 19 października 2018 r, sygn. akt SK 11/17).

Zaniechanie ustawodawcze występuje w sytuacji, gdy ustawodawca w ogóle nie ustanowił określonych regulacji prawnych, których wprowadzenie do systemu prawnego jest - zdaniem podmiotu inicjującego kontrolę - konieczne z punktu widzenia Konstytucji. Trybunał Konstytucyjny konsekwentnie przyjmuje, że nie posiada kognicji do orzekania w sprawach tego rodzaju (zob. przy- 
kładowo postanowienie TK z 11 grudnia 2002 r., sygn. akt SK 17/02), gdyż w innym wypadku wcieliłby się w rolę prawodawcy. Trybunał zaznacza w ten sposób, że jego rolą „nie jest zastępowanie ustawodawcy w sytuacji, gdy zaniechał on uregulowania jakiegoś zagadnienia, nawet gdy obowiązek tego uregulowania został ustanowiony w Konstytucji” (postanowienie TK z 8 września 2004 r., sygn. akt SK 55/03, oraz wyroki TK z: 8 września 2005 r., sygn. akt P 17/04; 27 listopada 2007 r., sygn. akt SK 39/06; 10 marca 2009 r., sygn. akt P 80/08).

W świetle art. 188 Konstytucji, rolą Trybunału Konstytucyjnego jest przede wszystkim badanie istniejących norm prawnych, czyli tego, co prawodawca unormował. Ze względu na założenie zupełności systemu prawa oraz konieczność zapewnienia skuteczności przepisów konstytucyjnych, dopuszczalne jest także kontrolowanie przez Trybunał Konstytucyjny, czy w badanych aktach prawnych nie brakuje pewnych elementów koniecznych z punktu widzenia Konstytucji, a więc tego, czego ustawodawca nie unormował, choć był do tego zobowiązany przez ustawę zasadniczą (zob. orzeczenie TK z 3 grudnia 1996 r., sygn. akt K 25/95). Pominięcie ustawodawcze, rozumiane jako wprowadzenie regulacji niepełnej, jest poddawane przez Trybunał ocenie zgodności z Konstytucją. Możliwość orzekania przez Trybunał Konstytucyjny o tego typu wadliwości regulacyjnej jest, co do zasady, niekwestionowana (zob. przykładowo wyrok TK z 3 kwietnia 2006 r., sygn. akt SK 46/05, i powoływane tam wcześniejsze orzecznictwo).

„Granice między zaniechaniami prawodawczymi a pominięciami prawodawczymi są dość płynne (wyr. pełnego składu TK z 24.11.2010 r., K 32/09, OTK-A 2010, Nr 9, poz. 108), co wynika z braku jednoznacznego kryterium pozwalającego oddzielić te dwie sytuacje (P. Tuleja, Zaniechanie ustawodawcze, s. 397-398). W orzecznictwie wskazuje się dwa kryteria. Z jednej strony TK odmawia wydania merytorycznego rozstrzygnięcia, gdy brak unormowania wiąże się ze «świadomym» pozostawieniem przez ustawodawcę określonej kwestii poza uregulowaniem prawnym (post. z 16.6.2009 r., SK 12/07, OTK-A 2009, Nr 6, poz. 95; zob. także K. Gonera, E. Łętowska, Artykuł 190, s. 4-5 oraz M. Safjan, Odpowiedzialność odszkodowawcza, s. 57), TK uznaje zaś za dopuszczalną kontrolę stanu prawnego, w którym niekonstytucyjny skutek jest «następstwem przypadkowej konfiguracji przesłanek normowania w ustawodawstwie zwykłym» (wyr. TK z 9.6.2003 r., SK 5/03, OTK-A 2006, Nr 6, poz. 50)” (L. Bosek, M. Wild, Komentarz do art. 79 Konstytucji [w:] Konstytucja RP, t. I, Komentarz. Art. 1-86, red. M. Safjan, L. Bosek, 2016, Legalis, nb. 55-58).

5. Pominięcia prawodawcze mogą polegać na brakach proceduralnych (np. niezapewnieniu sądowej ochrony praw konstytucyjnych - zob. wyrok z 22 października 2013 r., sygn. akt SK 14/13), albo - co w praktyce jest bardziej kontrowersyjne - materialnoprawnych, np. zbyt wąskiego i arbitralnego zakreślenia przesłanek realizacji praw konstytucyjnych - zob. wyrok z 16 grudnia 2009 r., sygn. akt K 49/07. Pominięcie takie może być badane przez Trybunał - jednak tylko wtedy, gdy na poziomie Konstytucji istnieje „norma o treści odpowiada- 
jącej normie pominiętej w ustawie kontrolowanej" (postanowienie z 1 marca 2010 r., sygn. akt SK 29/08), czyli w danym obszarze obowiązuje konstytucyjny nakaz uregulowania kwestii pominiętych w określony sposób.

„Pomocniczym kryterium stosowanym niekiedy do odróżnienia zaniechania od pominięcia ustawodawczego jest przesłanka celowego i świadomego działania prawodawcy (ustawodawcy): jeżeli dane rozwiązanie zostało w zamierzony sposób pozostawione poza zakresem regulacji, należy je kwalifikować jako zaniechanie ustawodawcze (por. np. wyrok z 8 września 2005 r., sygn. P 17/04, OTK ZU nr 8/A/2005, poz. 90). Wystąpienie pominięć prawodawczych jest natomiast bardziej prawdopodobne $\mathrm{w}$ wypadku regulacji sprawiających wrażenie przypadkowych (np. pozostawionych z poprzedniej wersji przepisu), absurdalnych albo oczywiście dysfunkcjonalnych (por. np. wyrok z 13 listopada 2007 r., sygn. P 42/06, OTK ZU nr 10/A/2007, poz. 123)" (postanowienie TK z 2 grudnia 2014 r., sygn. akt SK 7/14).

W przypadku art. 23 specustawy drogowej nie sposób mówić o zamierzonym działaniu ustawodawcy, sytuacji, gdy aktualnie przyjmowana wykładnia tego przepisu w zakresie objętym skargą jest efektem ubocznym zmiany jego otoczenia normatywnego. Analiza formalna przedmiotu zaskarżenie prowadzi do wniosku, że zawisły przed Trybunałem problem konstytucyjny nie stanowi przypadku intencjonalnego zaniechania ustawodawczego, więc $\mathrm{z}$ tego powodu Sejm nie wnosi o umorzenia postępowania.

6. Akcentowana w art. 79 ust. 1 Konstytucji zależność między przedmiotem skargi konstytucyjnej a jednostkowym orzeczeniem wydanym wobec skarżących przesądza o ich legitymacji do wystąpienia $\mathrm{z}$ tym środkiem ochrony praw i wolności, a jednocześnie nadaje skardze konstytucyjnej niezbędny - w świetle założeń wyrażonych w przywołanym przepisie - charakter środka inicjowania tzw. konkretnej kontroli prawa przed Trybunałem Konstytucyjnym. Analizując problem podstawy prawnej ostatecznego orzeczenia wydanego wobec skarżących, należy zwrócić uwagę na to, że za taką podstawę mogą być uznane tylko te przepisy, które wyrażają normy prawne bezpośrednio określające sytuację prawną skarżących w chwili wydania ostatecznego orzeczenia. Konieczną przesłanką skargi jest więc wykazanie związku między kwestionowanym unormowaniem a ostatecznym orzeczeniem, z którego wydaniem skarżący wiąże zarzut naruszenia jego praw (zob. przykładowo postanowienia TK z: 15 lipca 2002 r., sygn. akt Ts 5/02; 19 października 2004 r., sygn. akt SK 13/03). Ponadto, przepisy wskazane przez inicjatorów postępowania, będąc podstawą ostatecznego orzeczenia sądu, powinny jednocześnie stanowić bezpośrednie źródło naruszenia jego konstytucyjnych wolności lub praw (dotyczyć go osobiście). Naruszenie musi mieć charakter osobisty i aktualny (rzeczywisty), a nie potencjalny, czyli możliwy do wyobrażenia w realiach innych niż sytuacja faktyczna i prawna skarżącego (zob. przykładowo postanowienia TK z: 17 marca 1998 r., sygn. akt Ts 11/97; 19 października 2004 r., sygn. akt SK 13/03; 9 lipca 2012 r., sygn. akt SK 19/10). 
Powyższy związek bywa wyjaśniany w nieco bardziej rozwiniętej formule w ten sposób, że: „Po pierwsze, przepisy kwestionowane za pomocą skargi konstytucyjnej stanowić winny normatywną podstawę ostatecznego orzeczenia wydanego wobec skarżącego w sprawie, w związku z którą wniesiona została skarga konstytucyjna do Trybunału. Po drugie, to w treści tych przepisów tkwić winna bezpośrednia przyczyna zaistniałego naruszenia konstytucyjnych praw lub wolności skarżącego. Po trzecie wreszcie, naruszenie to wywołane być winno wydaniem przez sąd lub organ administracji publicznej orzeczenia opartego na przepisach stanowiących przedmiot skargi konstytucyjnej" (postanowienie TK z 12 stycznia 2012 r., sygn. akt Ts 84/09; zob. także wyrok TK z 18 października 2011 r., sygn. akt SK 39/09). Innymi słowy, dopuszczalność skargi konstytucyjnej zależy - co do zasady - także od tego, czy w wyniku zastosowania aktu normatywnego pogorszyła się sytuacja prawna skarżącego w kontekście jego konstytucyjnych praw i wolności (zob. Z. Czeszejko-Sochacki, Formy naruszenia konstytucyjnych wolności lub praw [w:] Skarga konstytucyjna, red. J. Trzciński, Warszawa 2000, s. 75; L. Jamróz, Skarga konstytucyjna. Wstępne rozpoznanie, Białystok 2011, s. 192). Powinien on to wykazać w ramach spełnienia wymogu „uprawdopodobnienia naruszenia", które uzasadnia udzielenie ochrony w trybie skargi konstytucyjnej.

7. Wątpliwości Sejmu budzi kwestia występowania zależności między przedmiotem skargi konstytucyjnej, tj. art. 216 ust. 1 u.g.n., a orzeczeniem wydanym wobec skarżących, która to zależność przesądzałaby o legitymacji skarżących do wystąpienia $\mathrm{z}$ tym środkiem ochrony praw i wolności. Zaskarżony przepis nie stanowi bowiem normatywnej podstawy ostatecznego orzeczenia wydanego wobec skarżących w sprawie, w związku z którą wniesiona została skarga konstytucyjna do Trybunału.

Naczelny Sąd Administracyjny wyrokiem z 12 września 2018 r. przesądził, że „podstawą prawną przejęcia nieruchomości była specustawa drogowa. Ustawa ta ma szczególny charakter wynikający z jej celu, którym jest stworzenie warunków prawnych umożliwiających sprawną i szybką realizację inwestycji drogowych, w związku z czym przewiduje ona uproszczony tryb przejmowania nieruchomości niezbędnych na ten cel. [...] Specustawa drogowa normuje proces inwestycyjny w zakresie dróg publicznych. Dlatego stanowi akt szczególny w stosunku do ustawy o gospodarce nieruchomościami (por. Marian Wolanin, Ustawa o szczególnych zasadach przygotowania i realizacji inwestycji w zakresie dróg publicznych, C.H. Beck 2009, s. 286). Ustawa ta w żadnym z przepisów nie reguluje kwestii związanych ze zwrotem lub alternatywnym wykorzystaniem nieruchomości bądź ich części, które nie zostały wykorzystane na realizację inwestycji drogowej. Nie zawiera też bezpośredniego odesłania do ustawy o gospodarce nieruchomościami w zakresie stosowania przepisów tej ustawy o zwrocie nieruchomości, jak również odesłania generalnego do przepisów ustawy o gospodarce nieruchomościami - w sprawach nieuregulowanych w ustawie (specustawie drogowej)". Artykuł 23 specustawy drogowej, który w sprawach nieuregulowanych 
w jej rozdziale 3 nakazuje stosować przepisy ustawy o gospodarce nieruchomościami, Naczelny Sąd Administracyjny zinterpretował w ten sposób, że na jego mocy przepisy ustawy o gospodarce nieruchomościami mają zastosowanie tylko do stanów faktycznych związanych z nabywaniem nieruchomości pod drogi i tylko w tym zakresie, gdy dana okoliczność faktyczna nie może być poddana regulacji specustawy drogowej. „W rozdziale tym ustawodawca nie unormował zasad i trybu zwrotu nieruchomości wywłaszczonych na podstawie przepisów omawianej specustawy. Tym samym nie można na podstawie wskazanego wyżej art. 23 do nieruchomości nabytych na podstawie specustawy drogowej zastosować art. 136 u.g.n. regulującego kwestię zwrotu wywłaszczonych nieruchomości” (wyrok Naczelnego Sądu Administracyjnego z 12 września 2018 r.).

Z treści uzasadnienia wyroku wynika jednoznacznie, że powodem odmowy zastosowania przez sąd art. 136 u.g.n. i n. do przejętej nieruchomości, a w konsekwencji oddalenie skargi skarżących była treść art. 23 specustawy drogowej, a nie fakt, że w wyliczeniu $\mathrm{z}$ art. 216 u.g.n. aktów prawnych, do których mają zastosowanie przepisy ustawy o gospodarce nieruchomościami o zwrocie wywłaszczonych nieruchomości, nie występuje specustawa drogowa. To w treści art. 23 specustawy tkwi bezpośrednia przyczyna wydania wyroku NSA z 12 września 2018 r., z którym skarżący wiążą skutek w postaci naruszenia ich konstytucyjnych praw. Jedynie ten przepis może być wskazany jako przepis właściwy do wykazania zarzutu pominięcia ustawodawczego i to on powinien stanowić w sprawie przedmiot zaskarżenia.

Wykładni art. 216 u.g.n. dokonał TK w uzasadnieniu wyroku z 23 września 2014 r. (sygn. akt SK 7/13) na gruncie rozpatrywania podobnej sprawy. Trybunał uznał, że przepis ten: „jest przepisem przejściowym, reguluje odpowiednie stosowanie przepisów rozdziału 6 działu III u.g.n. do nieruchomości przejętych lub nabytych na podstawie nieobowiązującej już ustawy. Zasady zwrotu nieruchomości wywłaszczonych w oparciu o obecnie obowiązujące przepisy ustawy o gospodarce nieruchomościami wytycza wprost art. 136 ust. 3 u.g.n.”. Podobny sposób interpretacji tego artykułu przyjmowali zgodnie uczestnicy postępowania, tj. Rzecznik Praw Obywatelskich, Sejm i Prokurator Generalny. Stwierdzenia TK co do charakteru art. 216 u.g.n. mają znaczenie w rozpatrywanym przypadku. Wynika $\mathrm{z}$ nich bowiem, że art. 216 jako przepis przejściowy dotyczy jedynie ustaw, które utraciły moc obowiązującą przez wejściem w życie ustawy o gospodarce nieruchomościami, podczas gdy zasady zwrotu nieruchomości przejmowanych na podstawie obowiązujących przepisów ustawy o gospodarce nieruchomościami określa art. 136 i n. tej ustawy. Ponieważ specustawa weszła w życie po wejściu w życie ustawy o gospodarce nieruchomościami, a ponadto jest aktem wciąż obowiązującym, kwestia zwrotu przejętych na jej podstawie nieruchomości mogłaby hipotetycznie być rozstrzygana przez przepisy rozdziału 6 działu III u.g.n. na mocy odesłania $z$ art. 23 specustawy, a nie art. 216 u.g.n., który, jako przepis przejściowy pełni inną funkcję. 
Mając powyższe na względzie, Sejm wnosi na podstawie art. 59 ust. 1 pkt 2 ustawy o TK o umorzenie postępowania w zakresie badania konstytucyjności art. 216 ust. 1 u.g.n. z uwagi na niedopuszczalność wydania wyroku.

8. Zarzutowi pominięcia ustawodawczego w odniesieniu do art. 23 specustawy drogowej nadano w skardze brzmienie: „w zakresie w jakim ogranicza on odesłanie do przepisów ustawy o gospodarce nieruchomościami tylko co do spraw nieuregulowanych w rozdziale 3 specustawy drogowej”. Biorąc pod uwage treść uzasadnienia skargi oraz jej uzupełnienia, należy dokonać korekty zakresu zaskarżenia. W istocie intencją skarżących było podważanie konstytucyjności wyłączenia przez wskazany przepis możliwości odpowiedniego stosowania przepisów rozdziału 6 działu III u.g.n. do nieruchomości przejętych na podstawie specustawy drogowej. Argumentacja zawarta w skardze nie obejmuje kwestii wyłączenia stosowania ustawy o gospodarce nieruchomościami do jakichkolwiek innych kwestii. Zdaniem skarżących powinni oni mieć prawo do zwrotu nieruchomości przejętej i ostatecznie niewykorzystywanej na cele publiczne w sytuacji pozbawienia prawa własności na podstawie specustawy drogowej. Tak skonstruowany zarzut może stać się przedmiotem konstytucyjnej kontroli, jako zarzut pominięcia ustawodawczego, które polega na „zbyt wąskim określeniu zakresu zastosowania normy prawnej" (wyrok TK z 30 października 2012 r., sygn. akt SK 20/11).

9. Zarzut ten wymaga również skonfrontowania z przywołanymi przez skarżących wzorcami kontroli. Skarżący jako wzorce kontroli wskazali w petitum skargi art. 2 i art. 31 ust. 1 i 2 Konstytucji. W jej uzasadnieniu sprecyzowane zostało, które zasady wywodzone z art. 2 Konstytucji miały zostać naruszone: zasada zaufania do państwa i stanowionego przez nie prawa, zasada sprawiedliwości społecznej, zasada ochrony praw nabytych.

Przepisy ustawy o TK nakładają na podmioty uprawnione do złożenia skargi do sądu konstytucyjnego obowiązki, w tym wymóg uzasadnienia postawionego zarzutu, z powołaniem dowodów na jego poparcie (art. 53 ust. 1 pkt 3 ustawy o TK). W swoim wcześniejszym orzecznictwie, które zachowuje pełną aktualność na tle obowiązującego stanu prawnego, Trybunał Konstytucyjny podkreślał, że: „[...] uzasadnienie zarzutów powinno opierać się na przedstawieniu we wniosku takiej argumentacji, która uprawdopodobni ewentualną niekonstytucyjność kwestionowanych przepisów. W szczególności argumentacja taka nie może opierać się jedynie na odczuciach czy wyobrażeniach wnioskodawcy, ale powinna być poparta merytorycznym uzasadnieniem, mogącym uwzględniać m.in. wcześniejsze orzecznictwo TK, praktykę stosowania prawa czy dorobek doktryny" (postanowienie TK z 6 listopada 2007 r., sygn. akt Tw 41/05; zob. także postanowienia TK z: 12 sierpnia 2005 r., sygn. akt Tw 23/05; 29 sierpnia 2006 r., sygn. akt Tw 14/06). Samo werbalne sformułowanie zarzutu czy też wskazanie, że kwestionowany przepis jest sprzeczny $\mathrm{z}$ innym przepisem aktu hierarchicznie wyższego, nie może więc zostać uznane za uzasadnienie zarzutu w sensie pro- 
cesowym. Zgodnie z art. 67 ustawy o TK Trybunał Konstytucyjny jest bowiem związany treścią oraz granicami rozpatrywanego wniosku, pytania prawnego lub skargi. Tym samym, nie może on - wychodząc poza granice określone w piśmie inicjującym postępowanie - wyręczać inicjatora tego postępowania w doborze argumentacji adekwatnej do podnoszonych wątpliwości. Brak odpowiedniego uzasadnienia zarzutu niezgodności danego przepisu z przywołanymi wzorcami kontroli stanowi o uchybieniu przez wnioskodawcę ustawowej powinności określonej w art. 53 ust. 1 pkt 3 ustawy o TK [na tle poprzednio obowiązującego art. 32 ust. 1 pkt 4 ustawy z dnia 1 sierpnia 1997 r. o Trybunale Konstytucyjnym (Dz. U. 1997, nr 102, poz. 643, ze zm.; dalej: ustawa o TK z 1997 r.; por. przykładowo postanowienie TK z 15 października 2009 r., sygn. akt P 120/08] powoduje brak możliwości jego rozpatrzenia przez sąd konstytucyjny i konieczność umorzenia postępowania ze względu na niedopuszczalność wydania wyroku (art. 59 ust. 1 pkt 2 ustawy o TK).

Skarżący nie przedstawili jakiegokolwiek argumentu na rzecz tezy o niezgodności zakwestionowanej normy prawnej z zasadą sprawiedliwości społecznej oraz zaufania obywateli do państwa i stanowionego przez nie prawa oraz art. 31 ust. 1 i 2 Konstytucji. Z tej racji Sejm wnosi o umorzenie postępowania w zakresie kontroli zgodności art. 23 specustawy drogowej z zasadami sprawiedliwości społecznej oraz zaufania obywateli do państwa i stanowionego przez nie prawa wynikającymi z art. 2 Konstytucji, a także w zakresie kontroli zgodności tego artykułu $\mathrm{z}$ art. 31 ust. 1-2 Konstytucji.

10. Zasada falsa demonstratio non nocet odnosi się nie tylko do ustalania przedmiotu kontroli, lecz także ustalania wzorców konstytucyjnych przywołanych przez skarżącą. Mając to na uwadze, Sejm stwierdza, że analiza argumentacji przedstawionej w rozpatrywanej skardze prowadzi do wniosku, że właściwym wzorcem kontroli w sprawie jest art. 21 ust. 2 (warunki dopuszczalności wywłaszczenia) w związku z art. 32 ust. 1 i art. 64 ust. 2 Konstytucji (zasada równości odnoszona do własności i innych praw majątkowych).

\section{Wzorce kontroli}

1. Zgodnie z art. 21 ust. 2 Konstytucji wywłaszczenie jest dopuszczalne jedynie wówczas, gdy jest dokonywane na cele publiczne i za słusznym odszkodowaniem.

Trybunał Konstytucyjny w sprawie o sygn. P 5/99 (wyrok z 14 marca 2000 r.) uznał, że: „normatywną podstawą dla określenia zakresu art. 21 ust. 2 Konstytucji, winny być przede wszystkim postanowienia konstytucyjne, nie zaś uregulowania zawarte w ustawach zwykłych". W tym samym wyroku przesądził, że pojęcie „wywłaszczenie” zawarte w art. 21 ust. 2 Konstytucji powinno być rozumiane szeroko, jako „wszelkie pozbawienie własności [...] bez względu na formę”, wskazując, że ujęcie to wychodzi swoim zakresem poza ramy wyznaczone konstrukcją ukształtowaną na gruncie przepisów ustawy o gospodarce nieruchomościami. Z kolei w wyroku z 9 grudnia 2008 r. (sygn. K 61/07) Trybunał dokonał następu- 
jącej interpretacji: „wywłaszczenie jest wyjątkową, szczególną formą ingerencji w sferę własności, dopuszczalną w wypadkach, gdy w grę wchodzi cel publiczny. Łączy się ono z ograniczeniem lub odjęciem w całości prawa własności w drodze aktu indywidualnego, dotyczącego konkretnej nieruchomości, na rzecz konkretnego podmiotu. Polega ono na nabyciu przez Państwo własności nieruchomości lub innego prawa do nieruchomości, będącej własnością podmiotu niepaństwowego, w drodze ściśle sformalizowanego postępowania administracyjnego połączonego z jednoczesnym wypłaceniem wywłaszczonemu odszkodowania określonego przez przepisy wywłaszczeniowe [...] wywłaszczenie powinno być stosowane tylko w sytuacjach koniecznych, uzasadnionych celami publicznymi, których nie można zrealizować za pomocą innych środków prawnych. Cel (interes) publiczny winien być przy tym rozumiany wyłącznie jako dobro ogółu, czyli całego społeczeństwa lub społeczności regionalnej”.

Podsumowując dotychczasową doktrynę, Trybunał sformułował następującą definicję konstytucyjnego pojęcia wywłaszczenia w wyroku z 23 września 2014 r. (sygn. akt SK 7/12). Obejmuje ono stany spełniające łącznie następujące warunki:

„- wywłaszczenie jest szczególną formą ingerencji w sferę własności, dopuszczalną jedynie gdy w grę wchodzi cel publiczny, którego nie można zrealizować za pomocą innych środków prawnych,

- wywłaszczenie następuje zawsze z inicjatywy podmiotu publicznego, na rzecz którego przechodzi własność lub inne prawo majątkowe,

- wywłaszczenie następuje aktem indywidualnym, obejmującym konkretną nieruchomość, na rzecz konkretnego podmiotu, w postępowaniu administracyjnym,

- wywłaszczenie następuje na rzecz podmiotu publicznego wbrew woli właściciela prywatnego i polega na ograniczeniu bądź odjęciu w całości prawa własności lub innego prawa majątkowego,

- cel (interes) publiczny należy rozumieć wyłącznie jako dobro ogółu, czyli całego narodu lub społeczności regionalnej, a wywłaszczenie następuje w interesie uwłaszczanego podmiotu publicznego (bezpośrednio) oraz w interesie całego narodu lub społeczności regionalnej (pośrednio),

- wywłaszczenie połączone jest z jednoczesnym wypłaceniem wywłaszczonemu słusznego odszkodowania, określonego przez przepisy wywłaszczeniowe”.

W tym miejscu należy również przypomnieć, że Trybunał nadaje rangę konstytucyjną zasadzie zwrotu wywłaszczonej nieruchomości, która nie została użyta na cel publiczny stanowiący przesłankę wywłaszczenia (zob. wyroki TK z: 24 października 2001 r., sygn. akt SK 22/01; 3 kwietnia 2008 r., sygn. akt K 6/05). Jak wskazał sąd konstytucyjny w wyroku z 24 października 2001 r. (sygn. akt SK 22/01), po wejściu w życie Konstytucji z 1997 r. zasadę zwrotu należy traktować jako oczywistą konsekwencję art. 21 ust. 2 Konstytucji, który - dopuszczając wywłaszczenie ,jedynie na cele publiczne” - tworzy nierozerwalny związek pomiędzy określeniem tych celów w decyzji o wywłaszczeniu i faktycznym sposo- 
bem użycia wywłaszczonej rzeczy (teza ta została następnie powtórzona m.in. w wyrokach TK z: 3 kwietnia 2008 r., sygn. akt K 6/05; 13 grudnia 2012 r., sygn. akt P 12/11; 13 marca 2014 r., sygn. akt P 38/11; 23 września 2014 r., sygn. akt SK 7/13). W wyroku z 13 grudnia 2012 r. (sygn. akt P 12/11) Trybunał stwierdził: „Jeżeli [...] cel publiczny, na który wywłaszczono nieruchomość, nie jest realizowany, albo wywłaszczona nieruchomość nie jest konieczna na ten cel publiczny, wówczas nie istnieje nie tylko konstytucyjna legitymacja ingerencji we własność prywatną, ale również prawna podstawa (przyczyna) nabycia własności przez podmiot publiczny. W tej sytuacji gwarancje prawa własności wynikające $\mathrm{z}$ art. 21 ust. 1 Konstytucji odzyskują swoją moc ochronną. Pozycja prawna i interes podmiotu publicznego osiągnięte przez takie wywłaszczenie muszą z powrotem ustąpić przed konstytucyjnie chronioną pozycją prawną obywatela. Dalsze pozostawienie własności w domenie własności publicznej nie ma konstytucyjnego uzasadnienia. Zatrzymując w tej sytuacji wywłaszczoną nieruchomość państwo osiągałoby korzyści majątkowe kosztem swoich obywateli. Tymczasem instytucja wywłaszczenia nie może prowadzić do przysporzenia wywłaszczycielowi korzyści zarobkowych lub fiskalnych, dopóki nie zostanie zrealizowany cel wywłaszczenia. Z tych przyczyn z konstytucyjnej gwarancji ochrony prawa własności wynika prawo powrotnego nabycia nieruchomości przez jej poprzedniego właściciela, jeżeli nie zrealizowano na niej pierwotnego celu wywłaszczenia” (podobnie w wyroku TK z 13 marca 2014 r., sygn. akt P 38/11). O „prawie do zwrotu wywłaszczonej nieruchomości” mowa była także w wyrokach o sygn. akt SK 7/13 i SK 26/14. To z tego względu art. 21 ust. 2 Konstytucji jest traktowany jako dopuszczalny wzorzec $\mathrm{w}$ postępowaniach zainicjowanych skargami konstytucyjnymi. Podsumowania swojego orzecznictwa w zakresie prawa żądania zwrotu wywłaszczonej nieruchomości zbędnej na cel publiczny dokonał sąd konstytucyjny w wyroku z 14 lipca 2015 r. (sygn. akt SK 26/14). Jak stwierdził tam Trybunał: „treść konstytucyjnie chronionego prawa do zwrotu wywłaszczonych nieruchomości jest determinowana przez następujące okoliczności: Po pierwsze, «obowiązująca regulacja konstytucyjna pozostawia ustawodawcy szeroką swobodę normowania zasad zwrotu nieruchomości wywłaszczonych. Obowiązek dopuszczenia w ustawodawstwie zwrotu nieruchomości w określonych sytuacjach nie zawsze musi oznaczać obowiązek dokonania zwrotu. [...] Istotne znaczenie dla sposobu ukształtowania prawa do uzyskania zwrotu wywłaszczonej nieruchomości ma ponadto czynnik czasu i konieczność zapewnienia trwałości ukształtowanych stosunków i sytuacji prawnych» (wyrok o sygn. SK 43/07, tezy powtórzone m.in. w wyroku o sygn. SK 7/13). Po drugie, roszczenia w tym zakresie aktualizują się wyłącznie w sytuacji, gdy na nieruchomości nie zrealizowano celu wywłaszczenia. Okoliczność tę należy oceniać według stanu w okresie przypadającym bezpośrednio po wywłaszczeniu - niepodobna bowiem przyjąć, że cel wywłaszczenia określa trwałe przeznaczenie nieruchomości (por. wyrok o sygn. P 12/11, a także wyroki o sygn. P 38/11 i SK 7/13). Po trzecie, prawo 
do zwrotu wywłaszczonych nieruchomości na tle art. 21 ust. 2 Konstytucji ma stosunkowo szeroki zakres przedmiotowy: może dotyczyć nie tylko prawa własności, ale również prawa użytkowania wieczystego oraz ograniczonych praw rzeczowych (por. zwłaszcza wyrok o sygn. K 6/05, którego ustalenia zostały utrzymane m.in. w wyroku o sygn. SK 7/13). Po czwarte, ochrona gwarantowana przez art. 21 ust. 2 Konstytucji w omawianym zakresie jest ograniczona pod względem czasowym. Prawo do zwrotu co do zasady przysługuje tylko w odniesieniu do nieruchomości odjętych właścicielom na podstawie «ustawodawstwa wywłaszczeniowego» uchwalonego pod rządami obecnej Konstytucji (por. wyroki o sygn. SK 22/01 i SK 7/13). Możliwość żądania restytucji nieruchomości wywłaszczonych na podstawie przepisów szczególnych w okresie PRL Trybunał Konstytucyjny oceniał ad casum przede wszystkim z punktu widzenia zasady równego poszanowania prawa majątkowych, a postępowania te kończyły się różnym wynikiem (por. wyroki o sygn. SK 22/01, SK 43/07 i SK 9/08)”.

2. Stosownie do art. 32 ust. 1 Konstytucji: „Wszyscy są wobec prawa równi. Wszyscy mają prawo do równego traktowania przez władze publiczne”. Wyrażona $\mathrm{w}$ przywołanym przepisie zasada równości wobec prawa (oraz równego traktowania przez władze publiczne) jest rozumiana w orzecznictwie Trybunału Konstytucyjnego jako zakaz tworzenia takiego prawa, które różnicowałoby sytuację prawną podmiotów charakteryzujących się daną cechą istotną (relewantną) w równym stopniu (zob. np. wyrok TK z 7 czerwca 2004 r., sygn. akt P 4/03). Zasada równości może doznać naruszenia, jeśli sytuacje „podobne” zostały przez prawo potraktowane odmiennie. Przy czym odmienność potraktowania sytuacji podobnych może być w niektórych przypadkach usprawiedliwiona, jeśli pozostaje w bezpośrednim związku z celem i zasadniczą treścią przepisów, w których zawarta jest kontrolowana norma oraz służy realizacji tego celu i treści; waga interesu, któremu ma służyć różnicowanie sytuacji adresatów normy pozostaje w odpowiedniej proporcji do wagi interesów, które zostaną naruszone w wyniku nierównego potraktowania podmiotów podobnych; wiąże się z innymi wartościami, zasadami czy normami konstytucyjnymi, uzasadniającymi odmienne potraktowanie podmiotów podobnych. Jednocześnie z zasady równości wynika także akceptacja „różnego traktowania przez prawo różnych podmiotów (adresatów norm prawnych), bo równe traktowanie przez prawo tych samych podmiotów pod pewnym względem oznacza z reguły różne traktowanie tych samych podmiotów pod innym względem" (tak orzeczenia TK z: 9 marca 1988 r., sygn. akt U 7/87; 20 grudnia 1994 r., sygn. akt K 8/94; wyroki TK z: 22 lutego 2005 r., sygn. akt K 10/04, oraz 23 marca 2006 r., sygn. akt K 4/06). Dopuszczalność lub zakaz różnego traktowania poszczególnych kategorii podmiotów w zbliżonych przypadkach zależy w związku z tym od istnienia lub nieistnienia wspólnej „cechy relewantnej”. Ustalenie, co może być taką cechą, zależy przede wszystkim od rodzaju stosunków prawnych, które mają być przedmiotem regulacji (A. Kulig [w:] Prawo konstytucyjne, red. P. Sarnecki, Warszawa 2014, s. 157, nb 186). 
Okoliczności decydujące o istnieniu lub nieistnieniu wspólnej cechy relewantnej mogą mieć zarówno charakter faktyczny, jak i charakter prawny. Orzecznictwo TK jest w tym zakresie szczególnie bogate. TK uznał np. że o braku istnienia wspólnej cechy relewantnej między ofiarami różnych zdarzeń losowych mogą decydować znaczne rozmiary szkód spowodowane przez określone zdarzenie pozwalające na wprowadzenie szczególnej legislacji dotyczącej ofiar takiego zdarzenia (zob. wyrok TK z 6 marca 2001 r., sygn. akt K 30/00). O braku istnienia wspólnej cechy relewantnej może także decydować publiczny lub prywatny status podmiotów traktowanych przez ustawodawcę w odmienny sposób (zob. wyrok TK z 12 listopada 2001 r., sygn. akt P 2/01). Za okoliczność usprawiedliwiającą odmienne traktowanie określonej kategorii podmiotów w odniesieniu do wysokości rozliczenia ulgi podatkowej TK uznał fakt posiadania przez tę kategorię podmiotów udziału we współwłasności nieruchomości, na której realizowane są inwestycje (zob. wyrok TK z 9 maja 2005 r., sygn. akt SK 14/04). Trybunał zauważył jednocześnie, że: „[u]stawodawcy przysługuje przy tym swoboda co do określenia cechy relewantnej, według której dokonywane jest zróżnicowanie sytuacji prawnej poszczególnych adresatów. Przyjmować należy domniemanie, że ustawodawca działa w tej mierze zgodnie z Konstytucją, a więc sam dobór cech relewantnych, jak i przeprowadzane na ich podstawie klasyfikacje korzystają z domniemania konstytucyjności". TK podzielił także w pełni pogląd, zgodnie $\mathrm{z}$ którym rozumienie zasady równości może być różne w zależności od dziedziny stosunków, jakich dotyczy regulacja prawna, wskazując, że im słabsza konstytucyjna ranga lub ochrona wolności, prawa albo innej konstytucyjnej wartości, do której odnosi się normatywne zróżnicowanie traktowania, tym większa swoboda pozostawiona jest ustawodawcy do stosowania takich cech relewantnych, które wprowadzają to zróżnicowanie, i tym łatwiej należy akceptować odmienne traktowanie sytuacji w zasadzie podobnych (zob. wyroki TK z: 9 maja 2005 r., sygn. akt SK 14/04; 23 października 2006, sygn. akt SK 42/04; 27 marca 2007 r., sygn. akt SK 9/05; 19 grudnia 2007 r., sygn. akt K 52/05; 11 lipca 2013 r., sygn. akt SK 16/12).

$\mathrm{W}$ orzecznictwie TK dominuje pogląd, że zasada równości nie może być wyłączną podstawą skargi konstytucyjnej. Powoływanie się przez skarżącego na naruszenie zasady równości jest możliwe tylko $\mathrm{w}$ związku $\mathrm{z}$ naruszeniem innych praw i wolności zagwarantowanych w Konstytucji. Czyli „jeżeli te normy lub działania [władz publicznych - dopisek K.D.] nie mają odniesienia do konkretnych, określonych w Konstytucji wolności i praw [skarżącego], prawo do równego traktowania nie ma w pełni charakteru prawa konstytucyjnego, a to sprawia, że nie może być ono chronione za pomocą skargi konstytucyjnej" (postanowienie TK z 24 października 2001 r., sygn. akt SK 10/01).

3. Wyrażona w art. 64 ust. 2 Konstytucji zasada równej ochrony własności i innych praw majątkowych stanowi szczególną postać ogólnej zasady równości przewidzianej w art. 32 Konstytucji. Orzecznictwo Trybunału Konstytucyjnego 
wskazuje, że istotą tej zasady jest zakaz różnicowania ochrony praw majątkowych ze względu na charakter podmiotu danego prawa (zob. wyroki TK z: 25 lutego 1999 r., sygn. akt K 23/98; 28 października 2003 r., sygn. akt P 3/03; 15 września 2009 r., sygn. akt P 33/07). Gwarancja równej ochrony praw majątkowych nie może być utożsamiana $\mathrm{z}$ identycznością intensywności ochrony udzielanej poszczególnym kategoriom praw majątkowych. Równość bowiem należy odnosić jedynie do praw majątkowych należących do tej samej kategorii. Nie jest natomiast dopuszczalne rozumienie równości jako przypisanie tych samych gwarancji ochronnych prawom majątkowym, które należą do różnorodnych typów praw majątkowych, choćby nawet zbliżone było ich ujęcie funkcjonalne (zob. wyroki TK z: 2 czerwca 1999 r., sygn. akt K 34/98; 28 października 2003 r., sygn. akt P 3/03; 17 marca 2008 r., sygn. akt K 32/05; 11 maja 2010 r., sygn. akt SK 50/08).

Artykuł 64 ust. 2 Konstytucji powinien być interpretowany w związku $\mathrm{z}$ art. 32 Konstytucji, bo zapewnienie równej dla wszystkich ochrony prawnej jest elementem równego traktowania przez władze publiczne. Nakaz równej ochrony praw majątkowych tej samej kategorii nie jest absolutny. Jeżeli można wykazać, że zróżnicowanie ochrony spełnia wymóg relewantności, proporcjonalności i powiązania $z$ innymi normami, zasadami lub wartościami konstytucyjnymi, to zróżnicowanie staje się dopuszczalne.

Trybunał Konstytucyjny zwraca uwagę, że wymóg „równości ochrony” sformułowany przez ten artykuł Konstytucji oznacza przede wszystkim niedopuszczalność materialnoprawnego zróżnicowania „statusu” własności i innych praw majątkowych (zob. wyrok TK z 16 marca 2004 r., sygn. akt K 22/03). Z drugiej strony Trybunał Konstytucyjny wielokrotnie wskazywał, że art. 64 ust. 2 Konstytucji nie tylko nawiązuje do zasady równości, ale też daje wyraz ogólnemu stwierdzeniu, że wszystkie prawa majątkowe muszą podlegać ochronie prawnej (zob. wyroki TK z: 13 kwietnia 1999 r., sygn. akt K 36/98; 2 czerwca 1999 r., sygn. akt K 34/98, oraz 14 marca 2006 r., sygn. akt SK 4/05). Z kolei w wyroku z 12 grudnia 2005 r. (sygn. akt SK 20/04). Trybunał stwierdził, że: „[o]chrona prawa majątkowego, o której mowa w art. 64 ust. 2 Konstytucji, nie oznacza gwarancji określonej treści prawa majątkowego. W orzecznictwie Trybunału prezentowany jest pogląd, że na gruncie art. 64 ust. 2 Konstytucji można wskazać dwa aspekty ochrony konstytucyjnej praw majątkowych z punktu widzenia podmiotowego: po pierwsze, ochroną taką objęty jest każdy, komu przysługuje prawo majątkowe, bez względu na posiadane cechy osobowe czy inne szczególne przymioty; po drugie, ochrona praw podmiotowych musi być równa dla wszystkich tych podmiotów. Oznacza to, że ustawodawca, tworząc określone prawa majątkowe i mając szeroką swobodę w kreowaniu ich treści, musi liczyć się z koniecznością respektowania zasad wskazanych w art. 64 Konstytucji” (analogicznie TK w wyroku z 24 lutego 2009 r., sygn. akt SK 34/07). W wyroku z 28 października 2003 r. (sygn. akt P 3/03) Trybunał przyjął, że art. 64 ust. 2 Konstytucji: „dopełnia regulację zawartą w art. 21 ust. 1 oraz art. 64 ust. 1, nawiązując - w perspektywie kon- 
stytucyjnej regulacji ochrony własności - do ogólnej normy art. 32 ust. 1 zd. 1 Konstytucji [...]”. Zasada równości oznacza bowiem: „nakaz jednakowego traktowania podmiotów równych i podobnego traktowania podmiotów podobnych. Istotą zaś art. 64 ust. 2 Konstytucji (zob. wyrok TK z 25 lutego 1999 r., sygn. akt K 23/98 [...] jest podkreślenie, że ochrona własności i innych praw majątkowych nie może być różnicowana $\mathrm{z}$ uwagi na charakter podmiotu danego prawa [...]. Wyalienowanie od elementów podmiotowych ma zapewnić obiektywizację nakazu zapewnienia równej ochrony własności (innych praw majątkowych)”. Ochrona własności i innych praw majątkowych nie ma charakteru absolutnego, a jej ograniczenia są dopuszczalne z zachowaniem warunków przewidzianych w art. 31 ust. 3 oraz art. 64 ust. 2 i ust. 3 Konstytucji, tj. na podstawie ustawy i z poszanowaniem zasad równości oraz proporcjonalności.

\section{Analiza zgodności}

1. Uwzględniając dokonaną w części III stanowiska korektę przedmiotu zaskarżenia, należy przyjąć, że zasadniczym zarzutem podniesionym przez skarżących jest zarzut pominięcia prawodawczego, sformułowany na tle uregulowanego w art. 23 specustawy drogowej odesłania do rozdziału 6 działu III u.g.n. w zakresie prawa żądania zwrotu części nieruchomości przejętej na podstawie specustawy drogowej, jeżeli ta część okazała się zbędna dla realizacji celu publicznego. Pominięciem ustawodawczym jest m.in. sytuacja, gdy ustawodawca unormował jakąś dziedzinę stosunków społecznych, ale dokonał tego w sposób niepełny z perspektywy norm konstytucyjnych. W orzecznictwie Trybunału ukształtowało się przekonanie, że w razie dokonania regulacji częściowej o niepełnym charakterze możliwe jest zakwestionowanie zakresu takiej regulacji, w szczególności rozważenie jej połączalności z zasadą równości. W przypadku aktu ustawodawczego wydanego i obowiązującego, Trybunał Konstytucyjny ma kompetencję do oceny jego konstytucyjności z tego punktu widzenia, czy w jego przepisach nie brakuje unormowań, bez których, ze względu na naturę objętej aktem regulacji, może on budzić wątpliwości natury konstytucyjnej. Zarzut niekonstytucyjności może więc dotyczyć zarówno tego, co ustawodawca $w$ danym akcie unormował, jak i tego co $\mathrm{w}$ akcie tym pominął, choć postępując zgodnie z Konstytucją powinien był unormować. $\mathrm{W}$ takim wypadku Trybunał rozstrzyga zatem, czy w przepisach obowiązującego aktu normatywnego nie brakuje unormowań istotnych w kontekście standardów ustawy zasadniczej (postanowienie TK z 14 lipca 2009 r., sygn. akt SK 2/08; zob. też wyroki TK z: 6 maja 1998 r., sygn. akt K 37/97; 9 października 2001 r., sygn. akt SK 8/00; 16 listopada 2004 r., sygn. akt P 19/03). Ustawodawcy przysługuje wprawdzie swoboda wyboru stosunków społecznych, podlegających regulacji w danej ustawie oraz swoboda w zakresie sposobu unormowania tych stosunków. Jednakże, jeśli ustawodawca podjął decyzje dotyczące zakresu i sposobu regulacji ustawowej, winna być ona dokonana z poszanowaniem wymogów konstytucyjnych (zob. wyrok TK z 19 maja 2011 r., sygn. akt SK 9/08). 
2. Ratio specustawy drogowej było stworzenie warunków prawnych umożliwiających sprawną i szybką realizację inwestycji drogowych, m.in. poprzez uproszczony tryb przejmowania nieruchomości niezbędnych na ten cel. Ustawa ta $\mathrm{w}$ żadnym z przepisów nie reguluje kwestii związanych ze zwrotem lub alternatywnym wykorzystaniem nieruchomości bądź ich części, które nie zostały wykorzystane na realizację inwestycji drogowej. Nie zawiera też bezpośredniego odesłania do ustawy o gospodarce nieruchomościami w zakresie unormowanych w tej ustawie reguł dotyczących zwrotu nieruchomości, jak również odesłania generalnego do przepisów ustawy o gospodarce nieruchomościami w sprawach w specustawie nieuregulowanych.

Odesłanie zawarte w art. 23 specustawy ogranicza się do spraw nieuregulowanych w rozdziale, w którym przepis ten jest zawarty - rozdziale 3 „Nabywanie nieruchomości pod drogi”. Tym samym odesłanie znajduje zastosowanie jedynie wówczas, gdy dana okoliczność faktyczna nie została uregulowana w tej jednostce systematyzacyjnej ustawy i ma związek z jej przedmiotem. Wobec faktu, że w rozdziale 3 brak jest regulacji określających zasady i tryb zwrotu nieruchomości przejętych na podstawie przepisów specustawy drogowej, sądy administracyjne odmawiają stosowania art. 136 i n. u.g.n. do nieruchomości nabytych na podstawie specustawy drogowej. Jednocześnie zastrzegają, jak to uczynił NSA w sprawie skarżących, że przejęcie nieruchomości w trybie art. 12 specustawy drogowej nosi znamiona wywłaszczenia w znaczeniu konstytucyjnym. Zbyt wąski zakres odesłania $\mathrm{z}$ art. 23 jest więc przyczyną niedopuszczalności zwrotu na podstawie przepisów działu III rozdziału 6 u.g.n. nieruchomości przejętych wskutek wydania decyzji o lokalizacji drogi publicznej.

Taki sposób interpretacji art. 23 jest powszechnie podzielany w orzecznictwie sądów administracyjnych i w doktrynie. W wyroku NSA z 25 maja 2016 r. (sygn. akt I OSK 1975/14) sąd uznał, że: „przepis ten zawiera normę o charakterze odsyłającym, zgodnie z którą do spraw nieuregulowanych w rozdziale 3 ustawy «Nabywanie nieruchomości pod drogi» stosuje się przepisy ustawy o gospodarce nieruchomościami. Zdaniem składu orzekającego w niniejszej sprawie, przepis ten odsyła do wszystkich przepisów GospNierU [ustawy o gospodarce nieruchomościami - dopisek K.D.], jednak zakres odesłania winien uwzględniać cel regulacji, do której ma mieć zastosowanie. Treść powyższego przepisu wyraźnie wskazuje, iż przepisy GospNierU mają zastosowanie tylko do stanów faktycznych związanych $\mathrm{z}$ nabywaniem nieruchomości pod drogi i tylko w tym zakresie gdy dana okoliczność faktyczna nie może być poddana regulacji ustawy o szczególnych zasadach przygotowania i realizacji inwestycji w zakresie dróg publicznych. [...] Nie można na podstawie wskazanego wyżej art. 23 u.z.r.i.d. [specustawy drogowej - dopisek K.D.] do nieruchomości nabytych na podstawie omawianej ustawy zastosować art. 136 GospNierU regulującego kwestię zwrotu wywłaszczonych nieruchomości. Art. 136 GospNierU wskazuje, że nieruchomość wywłaszczona na rzecz Skarbu Państwa podlega zwrotowi poprzedniemu właścicie- 
lowi lub jego spadkobiercy, jeżeli stała się zbędna na cel, jaki określono w decyzji o wywłaszczeniu. Przepis powyższy odnosi się do przypadków wywłaszczenia nieruchomości na podstawie GospNierU. Ponadto w art. 216 GospNierU ustawodawca rozszerzył stosowanie przepisów dotyczących zwrotu nieruchomości o nieruchomości nabyte i przejęte na rzecz Skarbu Państwa lub nabyte na rzecz Skarbu Państwa albo gminy, na podstawie enumeratywnie wymienionych w tym artykule przepisów prawa”. W związku z powyższym sądy wykluczyły, aby w drodze wykładni sądowej rozszerzać stosowanie instytucji zwrotu nieruchomości na nieruchomości, które nie zostały wywłaszczone (zob. zgodne w tym zakresie orzecznictwo: wyrok NSA z 5 lutego 2015 r., sygn. akt I OSK 1225/13, wyrok NSA z 18 marca 2015 r. sygn. akt I OSK 1698/13, wyrok WSA w Krakowie z 22 kwietnia 2010 r., sygn. akt II SA/KR 181/10, a także poglądy nauki: M. Wolanin, Ustawa o szczególnych zasadach przygotowania i realizacji inwestycji w zakresie dróg publicznych, Warszawa 2009, s. 286).

3. Sejm stoi na stanowisku, że rozstrzygany problem konstytucyjny, a więc kwestia zgodności art. 23 specustawy drogowej we wskazanym zakresie z przedstawionymi wyżej wzorcami konstytucyjnymi musi zostać poprzedzona ustaleniem, czy przejęcie nieruchomości na podstawie specustawy drogowej powoduje skutki tożsame z konstytucyjnym pojęciem wywłaszczenia.

W pierwotnym brzmieniu specustawa drogowa regulowała szczególny przypadek postępowania wywłaszczeniowego. Wywłaszczenie następowało na podstawie decyzji o wywłaszczeniu nieruchomości wydawanej na podstawie art. 15. Artykuł ten obowiązywał do 16 grudnia 2006 r. Wówczas został uchylony przez ustawę z 18 października 2006 r. o zmianie ustawy o szczególnych zasadach przygotowania i realizacji inwestycji w zakresie dróg krajowych oraz o zmianie niektórych innych ustaw (Dz. U. nr 220, poz. 1601). Do tego momentu regulacja miała charakter szczególny względem ustawy o gospodarce nieruchomościami, a w nieuregulowanym $\mathrm{w}$ art. 15 zakresie odsyłała do ustawy o gospodarce nieruchomościami za pośrednictwem art. 23. Jeden i drugi przepis umiejscowiony był w tym samym rozdziale 3 . Odesłanie dotyczyło m.in. kwestii zwrotu nieruchomości niewykorzystanych na cel publiczny określony w decyzji o wywłaszczeniu.

Przywołana ustawa nowelizująca specustawę drogową z 16 grudnia $2006 \mathrm{r}$. wprowadziła rozwiązanie prawne, zgodnie z którym nieruchomość przechodziła na własność publiczną (zostawała przejęta) z mocy prawa (a nie na podstawie decyzji) w granicach linii rozgraniczającej pas drogowy, z chwilą, gdy decyzja o ustaleniu lokalizacji drogi stawała się ostateczna (art. 12 ust. 4). Mechanizm przejmowania prywatnej nieruchomości z mocy prawa został utrzymany po wejściu w życie kolejnej nowelizacji specustawy drogowej, tj. ustawy z 25 lipca 2008 r. o zmianie ustawy o szczególnych zasadach przygotowania i realizacji inwestycji w zakresie dróg publicznych oraz o zmianie niektórych innych ustaw (Dz. U. nr 154, poz. 958). Skutek taki następował wraz z uzyskaniem statusu decyzji ostatecznej przez decyzję o zezwoleniu na realizację inwestycji drogowej: 
„Nieruchomości lub ich części, o których mowa w art. 11f ust. 1 pkt 6, stają się z mocy prawa: 1) własnością Skarbu Państwa w odniesieniu do dróg krajowych, 2) własnością odpowiednich jednostek samorządu terytorialnego w odniesieniu do dróg wojewódzkich, powiatowych i gminnych - z dniem, w którym decyzja o zezwoleniu na realizację inwestycji drogowej stała się ostateczna" (znowelizowany art. 12 ust. 4 w brzmieniu obowiązującym od 10 września 2008 r.). Po wskazanych nowelizacjach art. 12 specustawy drogowej z lat 2006 i 2008 sądownictwo administracyjne stanęło na stanowisku, że nie jest już dopuszczalne traktowanie przewidzianego w tym przepisie trybu nabycia własności nieruchomości jako wywłaszczenia, a w konsekwencji stosowania do przejętych nieruchomości przepisów ustawy o gospodarce nieruchomościami o zwrocie nieruchomości niewykorzystanych na cel publiczny.

Wobec tak ukształtowanej normy prawnej, która została zakwestionowana w skardze konstytucyjnej, Sejm zajmuje następujące stanowisko. W ocenie Sejmu przejęcie nieruchomości w trybie art. 12 ust. 4 specustawy drogowej mieści się w konstytucyjnym pojęciu wywłaszczenia określonym w art. 21 ust. 2 ustawy zasadniczej. Dokonywane jest ono na wniosek podmiotu publicznoprawnego na realizację celu publicznego, polega na pozbawieniu praw do nieruchomości i odbywa się za odszkodowaniem. Irrelewantny z punktu widzenia Konstytucji jest tryb jego dokonania - tj. utrata własności z mocy prawa, a nie na podstawie decyzji administracyjnej - przesądza w aktualnym stanie prawnym o niemożliwości zastosowania do takiej nieruchomości przepisów ustawy o gospodarce nieruchomościami dotyczących zwrotu nieruchomości niewykorzystanych na cel publiczny. W konsekwencji osoby wywłaszczone w rozumieniu konstytucyjnym nie mają możliwości skorzystania z przyznanych im przez ustawę zasadniczą gwarancji ochrony ich praw. Z uwagi na treść art. 23 specustawy drogowej taka ewentualność jest przewidziana jedynie dla gruntów wywłaszczonych w trybie przepisów ustawy o gospodarce nieruchomościami, a także przejętych lub nabytych na podstawie aktów prawnych wymienionych w art. 216 u.g.n.

„TK przyjmuje istnienie swojej kognicji, gdy badane unormowanie nie odnosi się do wszystkich przypadków, do których zgodnie z zasadami konstytucyjnymi powinno się odnosić. Jak trafnie zauważono, w takiej sytuacji «pozytywny wynik badania kognicji zawsze jest jednocześnie dowodem niekonstytucyjności poddanego kontroli pominięcia legislacyjnego» (zob. zd. odrębne sędzi M. Pyziak-Szafnickiej do wyr. TK z 13.6.2011 r., SK 41/09, OTK-A 2011, Nr 5, poz. 40)” (L. Bosek, M. Wild, Komentarz do art. 79 [w:] Konstytucja RP, t. I, Komentarz, Art. 1-86, red. M. Safjan, L. Bosek, Warszawa 2016, nb. 55-58). W ocenie Sejmu na tle regulacji art. 23 specustawy drogowej zasadny jest zarzut niekonstytucyjnego pominięcia legislacyjnego, polegającego na braku normy odsyłającej do odpowiedniego stosowania przepisów o zwrocie wywłaszczonych nieruchomości do nieruchomości przejętych na podstawie specustawy drogowej. W orzeczni- 
ctwie Trybunału Konstytucyjnego wyraźnie wyartykułowana została konstytucyjna zasada zwrotu nieruchomości zbędnej na cele wywłaszczenia, stanowiąca konsekwencję a contrario normy art. 21 ust. 2 Konstytucji (zob. wyroki TK: z 3 kwietnia 2008 r., sygn. akt K 6/05; z 13 grudnia 2012 r., sygn. akt P 12/11; z 12 grudnia 2017 r., sygn. akt SK 39/15). Obowiązkiem ustawodawcy jest wprowadzenie regulacji dopuszczającej zwrot nieruchomości, gdy nie zostanie ona wykorzystana na cel publiczny, który był przesłanką jej wywłaszczenia. W przypadku art. 23 nie można mówić o zaniechaniu ustawodawczym, a więc o świadomym nieuregulowaniu oznaczonej materii z zakresu stosunków społeczno-gospodarczych. Pominięcie ustawodawcze rozumiane jest jako wprowadzenie regulacji niepełnej. Trybunał, dopuszczając możliwość oceny konstytucyjności pominięć prawodawczych, wskazuje, że $\mathrm{w}$ ramach kontroli konstytucyjności oceniana jest zawsze pełna treść normatywna kwestionowanego przepisu. Dopuszczalne jest zatem badanie również braków pewnych elementów normatywnych, koniecznych z punktu widzenia regulacji konstytucyjnej (zob. przykładowo orzeczenie TK z 3 grudnia 1996 r., sygn. akt K 25/95, oraz wyrok TK z 8 września 2005 r., sygn. akt P 17/04). Określona regulacja może być uznana za zawierającą unormowanie niepełne w sytuacji, gdy z punktu widzenia zasad konstytucyjnych ma zbyt wąski zakres zastosowania albo pomija treści istotne z punktu widzenia przedmiotu i celu tej regulacji (zob. postanowienie TK z 29 listopada 2010 r., sygn. akt P 45/09). Aktualna treść art. 23 specustawy drogowej została pozostawiona $\mathrm{w}$ niezmienionym brzmieniu mimo zmiany jej otoczenia normatywnego, co w ocenie Sejmu stanowi niezamierzone, a konstytucyjnie wadliwe pominięcie ustawodawcze. Zakres odesłania do ustawy o gospodarce nieruchomościami jest niepełny (zbyt wąski) w stosunku do nakazu wynikającego z normy konstytucyjnej, jaką można dekodować $\mathrm{z}$ art. 21 ust. 2 Konstytucji. W myśl tej normy, nieruchomości przejęte przez Skarb Państwa lub jednostkę samorządu terytorialnego dla realizacji celu publicznego w okolicznościach świadczących o istnieniu tzw. przymusu wywłaszczeniowego, a więc w sytuacji, w której nie można mówić o w pełni swobodnym kształtowaniu i wyrażeniu woli dotychczasowego właściciela nieruchomości, powinny zostać mu zwrócone, jeżeli nie doszło do realizacji tego celu.

Sejm wnosi o stwierdzenie, że art. 23 specustawy drogowej w zakresie, w jakim wyłącza on możliwość odpowiedniego stosowania przepisów rozdziału 6 działu III ustawy z 21 sierpnia 1997 r. o gospodarce nieruchomościami (t.j. Dz. U. 2018, poz. 2204, ze zm.) do nieruchomości przejętych na podstawie ustawy o szczególnych zasadach przygotowania i realizacji inwestycji w zakresie dróg publicznych jest niezgodny $z$ art. 21 ust. 2 Konstytucji.

4. Kolejny zarzut dotyczy naruszenia przez zaskarżony przepis zasady równości i równej ochrony praw majątkowych (art. 32 ust. 1 i art. 64 ust. 2 Konstytucji). Punktem wyjścia do weryfikacji, czy doszło do naruszenia praw skarżących jest ugruntowany w orzecznictwie TK pogląd, że zgodnie z przywołanymi zasadami 
wszystkie podmioty charakteryzujące się daną cechą relewantną w równym stopniu, mają być traktowane równo, bez zróżnicowań zarówno dyskryminujących, jak i faworyzujących (zob. orzeczenie TK z 9 marca 1988 r., sygn. akt U 7/87). Rodzi to obowiązek ustawodawcy, by przyznając jednostkom uprawnienia, nie określał kręgu beneficjentów w sposób arbitralny, ale kierował się określoną cechą, którą można uznać za istotną (zob. wyrok TK z 7 kwietnia 2003 r., sygn. akt $\mathrm{P}$ 7/02). Odstąpienie od zasady równego traktowania (także w odniesieniu do równiej ochrony prawa własności i innych praw majątkowych) jest możliwe, jeżeli kryterium zróżnicowania jest merytorycznie uzasadnione i sprawiedliwe, a nie dowolne albo wręcz przypadkowe. W ocenie Sejmu z taką sytuacją mamy do czynienia w sprawie.

Za cechę relewantną, opisującą sytuację podmiotów prawa, należy uznać przejęcie własności nieruchomości (wywłaszczenie w ujęciu konstytucyjnym) na cel publiczny i niezrealizowanie tego celu w określonym czasie. Dwie grupy podmiotów, które znalazły się w takiej sytuacji, zostały potraktowane odmiennie w zależności od formy przejęcia własności. Jedna grupa, której własność została wywłaszczona na podstawie decyzji wywłaszczeniowej, ma prawo żądać zwrotu niewykorzystanej na cel publiczny nieruchomości, zaś druga grupa, której własność przeszła na podmiot publiczny z mocy prawa, jako dalszy skutek wydania decyzji o zezwoleniu na realizację inwestycji drogowej, takiej możliwości jest pozbawiona.

W ocenie Sejmu kryterium różnicowania nie pozostaje w racjonalnym związku z celem i treścią zaskarżonego przepisu, gdyż jedna i druga uregulowana sytuacja dotyczy odjęcia własności na cel publiczny. Ponieważ nie sposób stwierdzić, jakiemu celowi to zróżnicowanie miałoby służyć, nie można również ustalić, czy pozostaje ono w odpowiedniej proporcji do wagi interesów, które zostaną naruszone w wyniku wprowadzonego różnicowania. Niewątpliwie jednak kryterium różnicowania nie znajduje uzasadnienia w innych wartościach, zasadach czy normach konstytucyjnych, które uzasadniałyby odmienne traktowanie podmiotów podobnych. Analizując kontekst systemowy zmian prawa, w związku z którym doszło do opisywanej nierówności, nie sposób stwierdzić, by była to celowa, intencjonalna decyzja ustawodawcy. W istocie stanowiła ona „efekt uboczny” zmian przepisów inwestycyjnych o charakterze technicznym, która doprowadziła do ukształtowania się w orzecznictwie sądowym nowej normy prawnej zakazującej zwrotu niewykorzystanych nieruchomości.

Mając powyższe na względzie, Sejm wnosi o stwierdzenie, że art. 23 specustawy drogowej w zakresie, w jakim wyłącza on możliwość odpowiedniego stosowania przepisów rozdziału 6 działu III ustawy z 21 sierpnia 1997 r. o gospodarce nieruchomościami (t.j. Dz. U. 2018, poz. 2204, ze zm.) do nieruchomości przejętych na podstawie ustawy o szczególnych zasadach przygotowania i realizacji inwestycji w zakresie dróg publicznych jest niezgodny z art. 64 ust. 2 w związku $\mathrm{z}$ art. 32 ust. 1 Konstytucji. 


\section{Bibliografia}

Bosek L., Wild M., Komentarz do art. 79 Konstytucji [w:] Konstytucja RP, t. I, Komentarz. Art. 1-86, red. M. Safjan, L. Bosek, 2016, Legalis.

Czeszejko-Sochacki Z., Formy naruszenia konstytucyjnych wolności lub praw [w:] Skarga konstytucyjna, red. J. Trzciński, Warszawa 2000.

Jamróz L., Skarga konstytucyjna. Wstępne rozpoznanie, Białystok 2011.

Kulig A. [w:] Prawo konstytucyjne, red. P. Sarnecki, Warszawa 2014.

Wolanin M., Ustawa o szczególnych zasadach przygotowania i realizacji inwestycji w zakresie dróg publicznych, Warszawa 2009. 
